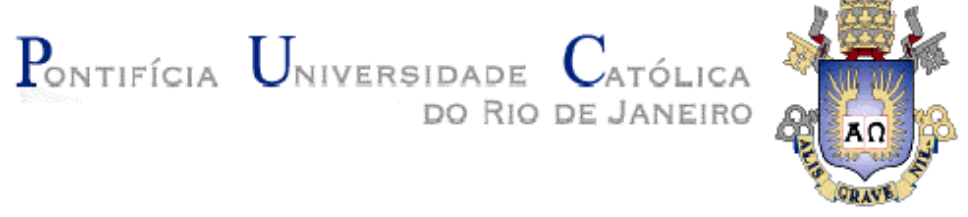

Sérgio Cândido de Oscar

\title{
O ENSINO MÉDIO NA REDE ESTADUAL MINEIRA: UM ESTUDO SOBRE A ABRANGÊNCIA DAS POLÍTICAS EDUCACIONAIS ESTADUAIS
}

Tese de Doutorado

Tese apresentada como requisito parcial para obtenção do grau de Doutor pelo Programa de Pósgraduação em Educação do Departamento de Educação do Centro de Teologia e Ciências Humanas da PUC-Rio.

Orientadora: Prof ${ }^{a}$.Fátima Cristina de M. Alves 
Sérgio Cândido de Oscar

O ENSINO MÉDIO NA REDE ESTADUAL MINEIRA: UM ESTUDO SOBRE A ABRANGÊNCIA DAS POLÍTICAS EDUCACIONAIS ESTADUAIS

Tese apresentada como requisito parcial para obtenção do grau de Doutor pelo Programa de Pósgraduação em Educação do Departamento de Educação do Centro de Teologia e Ciências Humanas da PUC-Rio. Aprovada pela Comissão Examinadora abaixo assinada.

Prof ${ }^{\text {. Fátima Cristina de Mendonça Alves }}$

Orientadora

Departamento de Educação - PUC-Rio

Profa. Alícia Maria Catalano de Bonamino

Departamento de Educação - PUC-Rio

Profª. Rosaly Hermengarda Lima Brandão (Zaia Brandão)

Departamento de Educação - PUC-Rio

Profa. Mariane Campelo Koslinski

UFRJ

Prof ${ }^{\text {. Hustana Maria Vargas }}$

UFRJ

Profa Denise Berruezo Portinari

Coordenadora Setorial do Centro de Teologia e Ciências Humanas

PUC-Rio

Rio de Janeiro, 27 de março de 2014. 
Todos os direitos reservados. É proibida a reprodução total ou parcial do trabalho sem autorização da universidade, da autora e da orientadora.

\section{Sérgio Cândido de Oscar}

Licenciado e Bacharel em Geografia pela UFJF em 1999. Mestre em Educação pela Universidade Católica de Petrópolis em 2006. Professor da rede municipal de Juiz de Fora desde 2002. De 2005 a 2006 foi professor da Universidade Salgado de Oliveira - JF nos cursos de Graduação em Geografia e Turismo. Desde 2008 é coordenador e pesquisador da Rede de Pesquisa e Formação em Educação - REPEd realizando pesquisas sobre temas relacionados à política educacional, avaliação, equidade e desigualdades educacionais.

Ficha Catalográfica

Oscar, Sérgio Cândido de

O ensino médio na rede estadual mineira: um estudo sobre a abrangência das políticas educacionais estaduais / Sérgio Cândido de Oscar ; orientadora: Fátima Alves. - 2014.

318 f. : il. (color.) ; $30 \mathrm{~cm}$

Tese (doutorado)-Pontifícia Universidade Católica do Rio de Janeiro, Departamento de Educação, 2014. Inclui bibliografia

1. Educação - Teses. 2. Abrangência. 3. Políticas educacionais. 4. Regressão logística. 5. Ensino Médio. 6. Minas Gerais. I. Alves, Fátima Cristina de Mendonça. II. Pontifícia Universidade Católica do Rio de Janeiro. Departamento de Educação. III. Título. 


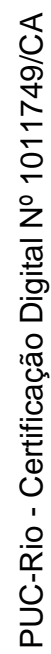

Para Juliana. 


\section{Agradecimentos}

Mais do que um esforço individual, este trabalho é fruto de significativas contribuições recebidas durante esta pesquisa. Assim, agradeço a todos e todas que de alguma forma me proporcionaram oportunidades de compartilhar conhecimentos e experiências ao longo desta trajetória, em especial:

A minha orientadora, Fátima Alves, por sua preciosa orientação, pelo compartilhamento de suas ideias e pela confiança.

Aos professores que compõem a banca examinadora pela atenciosa análise e debate acadêmico.

Aos professores do Departamento de Educação da PUC-Rio.

A equipe de avaliação da SEE-MG, em especial ao Sérgio Costa pelo apoio no acesso às bases de dados que foram fundamentais para a realização desta pesquisa. Ao amigo Zhang Yi Ling pelo apoio na revisão das análises estatísticas aqui realizadas.

Aos amigos do Centro Herval e CESU, em especial ao Gabriel pelo apoio na elaboração dos horários e na minha liberação para assistir as aulas na PUC.

A todos os colegas do programa de pós-graduação em Educação da PUC-Rio, em especial a Adailda, André e Larissa.

Ao pessoal da Secretaria do Departamento, em especial a Nancy Ferreira pelo apoio mais direto.

A minha família pelo apoio incondicional e pela compreensão de me ver mais ausente nos últimos anos.

Obrigado! 


\section{Resumo}

Oscar, Sérgio Cândido de; Alves, Fátima Cristina de Mendonça. O ensino médio na rede estadual mineira: Um estudo sobre a abrangência das políticas educacionais estaduais. Rio de Janeiro, 2014. 318p. Tese de Doutorado - Departamento de Educação, Pontifícia Universidade Católica do Rio de Janeiro.

Este trabalho investiga a abrangência das políticas educacionais voltadas para o Ensino Médio da rede pública estadual de Minas Gerais no período de 2007 a 2010, período este que correspondente ao "choque de gestão" implementado pelo governador Aécio Neves. Considerando o desempenho médio dos estudantes por município nas avaliações em larga escala promovidas pelo governo estadual, aspectos sócio demográficos dos municípios mineiros e características intrínsecas das Superintendências Regionais de Ensino - SRE medidas pelo índice de complexidade das superintendências - ICS, inicialmente o estudo traz referências e discute conceitos sobre políticas educacionais e abrangência das políticas educacionais, apresentando os principais indicadores sociais e demográficos dos municípios mineiros e mapeando as políticas educacionais implementadas no período analisado. Em seguida, investiga-se a relação entre a abrangência das políticas educacionais voltadas para o Ensino Médio e os indicadores sócio demográficos municipais. O resultado da estimação do modelo mostrou que embora o governo mineiro tenha implementado um conjunto variado de projetos e programas, a análise da abrangência destes programas revelou a inexistência de um planejamento integrado, sugerindo que os programas e projetos propostos foram elaborados de forma centralizada, não levando em consideração as reais demandas educacionais das escolas e as características sociais e demográficas dos municípios mineiros. Com relação à abrangência das políticas implementadas, verificou-se que as mesmas foram implementadas de forma pulverizada e com pouca unidade entre si, não chegando a constituir uma política educacional global de Estado. O trabalho também revelou a partir da análise do desempenho médio dos estudantes do $3^{\circ}$ ano do ensino médio que a desigualdade educacional existente entre os municípios manteve-se inalterada ao longo do período. 


\section{Palavras-chave}

Abrangência; Políticas Educacionais; Regressão logística; Ensino Médio; Minas Gerais. 


\section{Abstract}

Oscar, Sérgio Cândido de; Alves, Fátima Cristina de Mendonça (Advisor). Public high school education in the State of Minas Gerais: a study on the scope of the state educational policies. Rio de Janeiro, 2014. 318p. PhD Thesis. Departamento de Educação, Pontifícia Universidade Católica do Rio de Janeiro.

This work investigates the scope of the education policies for the public high school education of the state of Minas Gerais from 2007 to 2010. This period corresponds to the "Management Shock" introduced by governor Aécio Neves. The study regards the average performance of the students per municipality in the large scale evaluations promoted by the state government, demographic aspects and intrinsic characteristics of the municipalities of the Regional Office of Education, assessed by the rate of complexity of the offices. At first, the study brings references and discusses concepts on education politics and their scope, presenting the main social and demographic indicators of the municipalities as well as mapping the education politics implemented in the period studied. Then, the relation between the scope of the education politics for the high school education and the demographic municipal indicators is investigated. The estimation results of the model showed that the analysis of the scope of these programs revealed the non-existence of an integrated planning, although the government of Minas Gerais had implemented a varied set of projects and programs. This suggests that the programs and proposed projects were prepared in a centralized way, not taking into account the real education demands of the schools and the social and demographic characteristics of the municipalities. Regarding the scope of the policies implemented, it was found that they were implemented in a scattered form and with little unity among themselves, without being able to provide a general educational state policy. The study also revealed, based on the analysis of the average performance of the 3rd year high school students, that the existing educational inequality between municipalities remained unchanged throughout the period. 


\section{Keywords}

Scope; Educational policies; Logistic regression; High school education; Minas Gerais. 


\section{Sumário}

1. Introdução 18

2. Políticas educacionais: conceitos, classificação e abrangência 28

2.1. Políticas educacionais: finalidades e objetivos 28

2.2. Conceitos de política 31

2.3. Classificação das políticas públicas 33

2.4. A abrangência das políticas educacionais 35

2.5. As políticas sociais e os indicadores sociais e demográficos 39

3. Minas Gerais e seus indicadores sociais, demográficos e 44 educacionais

3.1. Indicadores sócio demográficos, educacionais e a qualidade 46 da educação nos municípios mineiros

3.1.1. População, PIB e renda per capita 48

3.1.2. Índice de desenvolvimento humano municipal (IDH-M) 53

3.1.3. Coeficiente de GINI 55

3.1.4. Índice FIRJAN de desenvolvimento municipal - IFDM 57

3.2. Números do ensino médio no Brasil e em Minas Gerais 58

3.2.1. Acesso 58

3.2.2. Fluxo 62

3.2.3. Desempenho 66

4. Políticas educacionais e Minas Gerais 73

4.1. Políticas educacionais mineira na década de $1990 \quad 74$

4.2. As políticas educacionais do governo Aécio Neves (2003- 80 2010)

4.2.1. Descrição das políticas educacionais 84

4.2.1.1. Programa Escola Viva, Comunidade Ativa 84

4.2.1.2. Plano Global de Desenvolvimento da instituição Escolar 84 $-\mathrm{PDPI}$

4.2.1.3. Programa Livro na Escola 85

4.2.1.4. Currículo Básico Comum para o Ensino Médio - CBC 86

4.2.1.5. Programa Aprofundamento de Estudos 87

4.2.1.6. Programa de Melhoria da Qualidade e Eficiência do 88

Ensino Médio - PRÓMÉDIO

4.2.1.7. Programa de Distribuição da Merenda 88

4.2.1.8. Efetivação de professores sem concurso público - 89

LC100/2007

4.2.1.9. Curso Técnico Normal 90

4.3. Abrangência das políticas educacionais implementadas pela 91

SEE-MG (2006-2010)

4.3.1. Projeto Escolas-Referência - ER 93

4.3.2. Programa de Desenvolvimento Profissional - PDP 94

4.3.3. Programa Educacional de Atenção ao Jovem - PEAS 96 Juventude

4.3.4. Programa de Formação Inicial para o Trabalho - FIT 97

4.3.5. Programa de Educação Profissional - PEP 99 
4.3.6. Programa Poupança Jovem - PJ 100

4.4. Análise da política educacional mineira na gestão Aécio 103 Neves

4.4.1. Análise descritiva 108

4.4.2. Análise das políticas em relação ao desempenho médio 110 dos estudantes

4.4.3. Comparação entre as piores e melhores médias de 122 desempenho

4.5. Abrangência das políticas considerando as características 123 das Superintendências Regionais de Ensino

4.5.1. O papel das Superintendências Regionais de Ensino 123

4.5.2. O desempenho dos estudantes de EM por SER 124

4.5.2.1. Desempenho em Matemática 125

4.5.2.2. Desempenho em Português 128

4.5.3. Índice de complexidade das Superintendências Regionais 132 de Ensino (ICS)

4.5.4. Regressão logística 135

4.5.5. Análise dos resultados da regressão logística 138

4.5.5.1. Regressão logística - Escola Referência (2007-2010) 139

4.5.5.2. Regressão logística - PDP 144

4.5.5.3. Regressão logística - PEAS 147

4.5.5.4. Regressão logística - PEP 151

4.5.5.5. Regressão logística - FIT 156

4.5.5.6. Regressão logística - Poupança Jovem 159

4.5.5.7. Variáveis com maior impacto na abrangência 161

5. Conclusões 164

6. Referências bibliográficas 169

7. Anexos 173

7.1. Análise descritiva da base de dados 173

7.2. Mapas temáticos - desempenho médio 195

7.3. Análise por nota média dos municípios e indicadores sócio 200 demográficos

7.4. Desempenho X Indicadores sócio demográficos - Gráficos e 236 suas respectivas tabelas de freqüência

7.5. Desempenho das escolas contempladas com programas/políticas educacionais X Não contempladas 


\section{Lista de tabelas}

Tabela 1 - Distribuição da população mineira de acordo com 048 porte do município CENSO Demográfico 2010

Tabela 2 - PIB per capita por UF - 2010

Tabela 3 - Número de Escolas-Referência em 2003 e 2007

Tabela 4 - Número de escolas atendidas pelo Poupança Jovem entre 2007 e 2009

Tabela 5 - Foco principal dos programas analisados

Tabela 6 - Desempenho em Matemática por Superintendência de Ensino - 2007 à 2010

Tabela 7 - Desempenho em Português por Superintendência de Ensino - 2007 á 2010

Tabela 8 - ICS por SER - 2007 à 2010

Tabela 9 - Estatística descritiva das variáveis

Tabela 10 - Resultado da regressão logística - ER - 2007 à 139 2010

Tabela 11 - Resultado da regressão logística - PDP - 2007 à 144 2010

Tabela 12 - Resultado da regressão logística - PEAS - 2007 à 147 2010

Tabela 13 - Resultado da regressão logística - PEP - 2007 à 151 2010

Tabela 14 - Resultado da regressão logística - FIT - 2007 à 156 2010

Tabela 15 - Resultado da regressão logística - PJ - 2007 à 2010 


\section{Lista de quadros}

Quadro 1 - Base de dados utilizada na pesquisa 24

Quadro 2 - Programas e projetos educacionais analisados 25

Quadro 3 - Quadro síntese das políticas educacionais 82

implementadas em MG - 2006-2010

Quadro 4 - Programas analisados $\quad 91$

$\begin{array}{ll}\text { Quadro } 5 \text { - Descrição escrita das variáveis } & 137\end{array}$ 


\section{Lista de gráficos}

Gráfico 1 - Número total de matrículas na $3^{\underline{a}}$ série do EM-Rede Estadual de Minas Gerais - 2006-2010

Gráfico 2 - Número de estudantes (\%) com defasagem idadesérie igual ou superior a 2 anos matriculados na $3^{\text {a }}$ série do EM na Rede Estadual de Minas Gerais entre os anos de 2006 e 2010 Gráfico 3 - Porte dos municípios de Mias Gerais - Frequência 2010

Gráfico 4 - Porte dos municípios de Mias Gerais - \% de população por grupo 2010

Gráfico 5 - Percentual de matrículas do EM por dependência administrativa: Brasil (1991 a 2010)

Gráfico 6 - Matrículas do Ensino Médio (Regular e EJA) Minas Gerais Rede Estadual (2002 a 2009)

Gráfico 7 - Taxa de atendimento da população de 15 a 17 anos Minas Gerais e Brasil

Gráfico 8 - Distribuição da população brasileira de 15 a 17 que não frequenta a escola $2^{\circ}$ ano de estudo

Gráfico 9 - Taxas de escolarização bruta e líquida do Ensino Médio Minas Gerais e Brasil - 1996-2009

Gráfico 10 - Ensino Médio. Taxa de aprovação (\%). Escolas Estaduais e Privadas: Brasil (1997 a 2010)

Gráfico 11 - Ensino Médio. Taxa de reprovação e abandono (\%).Escolas Estaduais: Brasil (1997 a 2010)

Gráfico 12 - Taxas de reprovação do Ensino Médio - Rede Estadual - Minas Gerais 2006-2010

Gráfico 13 - Taxas de repetência do Ensino Médio - Rede Estadual - Minas Gerais, 2006-2010

Gráfico 14 - Taxas de abandono de Ensino Médio - Rede Estadual - Minas Gerais, 2006-2010

Gráfico 15 - Número (\%) de concluintes no Ensino Médio: Brasil (1997 a 2010)

Gráfico 16 - Taxas de distorção idade/série do EM - Minas Gerais - Rede Estadual

Gráfico 17 - SAEB. Matemática. Ensino Médio - Escolas

Estaduais e Privadas: Brasil (1995-2009)

Gráfico 18 - SAEB. Língua Portuguesa. EM - Escolas Estaduais e Privadas: Brasil

Gráfico 19 - PROEB $3^{\text {a }}$ ano do EM - Proficiência em Língua Portuguesa em Minas Gerais (2006-2010)

Gráfico 20 - PROEB 3ำ ano do EM - Proficiência em Matemática em Minas Gerais (2006-2010)

Gráfico 21 - Desempenho médio em Português dos estudantes do EM por município de acordo com o porte - MG - 2006 - 2010 Gráfico 22 - Municípios X (\%) de escolas atendidas pelo 
Programa Escolas Referência - ER (2006-2010)97

Gráfico 23 - Municípios X (\%) de escolas atendidas pelo 97

Programa de Desenvolvimento Profissional - PDP

Gráfico 24 - Municípios X (\%) de escolas atendidas pelo 98

Programa de Atenção ao Jovem - PEAS (2006-2009)

Gráfico 25 - Municípios X (\%) de escolas atendidas pelo 100

Programa de Formação Inicial ao Trabalho - FIT (2008-2009)

Gráfico 26 - Municípios X (\%) de escolas atendidas pelo 103

Programa de Educação Profissional - PEP (2007-2010)

Gráfico 27 - Municípios X (\%) de escolas atendidas pelo

Programa Poupança Jovem - PJ (2007-2010)

Gráfico 28 - Média de desempenho em Português dos estudantes nos municípios com $100 \%$ e sem a presença do Programa ER

Gráfico 29 - Média de desempenho em Português dos estudantes nos municípios com $50 \%$ e sem a presença do Programa ER

Gráfico 30 - Média de desempenho em Matemática dos estudantes nos municípios com $100 \%$ e sem a presença do Programa ER

Gráfico 31 - Média de desempenho em Matemática dos estudantes nos municípios com $50 \%$ e sem a presença do Programa ER

Gráfico 32 - Média de desempenho em Português dos estudantes nos municípios com $100 \%$ e sema presença do Programa PDP

Gráfico 33 - Média de desempenho em Português dos estudantes nos municípios com 50\% e sema presença do Programa PDP

Gráfico 34 - Média de desempenho em Matemática dos estudantes nos municípios com $100 \%$ e sema presença do Programa PDP

Gráfico 35 - Média de desempenho em Matemática dos estudantes nos municípios com $50 \%$ e sema presença do Programa PDP

Gráfico 36 - Média de desempenho em Português dos estudantes nos municípios com $100 \%$ e sem a presença do Programa PEAS

Gráfico 37- Média de desempenho em Português dos estudantes nos municípios com $50 \%$ e sem a presença do Programa PEAS

Gráfico 38 - Média de desempenho em Matemática dos estudantes nos municípios com $100 \%$ e sem a presença do Programa PEAS

Gráfico 39 - Média de desempenho em Matemática dos estudantes nos municípios com $50 \%$ e sem a presença do Programa PEAS

Gráfico 40 - Média de desempenho em Português dos estudantes nos municípios com $100 \%$ e sem a presença do Programa FIT

Gráfico 41 - Média de desempenho em Português dos 
estudantes nos municípios com $50 \%$ e sem a presença do Programa FIT

Gráfico 42 - Média de desempenho em Matemática dos estudantes nos municípios com $100 \%$ e sem a presença do Programa FIT

Gráfico 43 - Média de desempenho em Matemática dos estudantes nos municípios com $50 \%$ e sem a presença do Programa FIT

Gráfico 44 - Média de desempenho em Português dos estudantes nos municípios com $100 \%$ e sem a presença do Programa PEP

Gráfico 45 - Média de desempenho em Português dos estudantes nos municípios com $50 \%$ e sem a presença do Programa PEP

Gráfico 46 - Média de desempenho em Matemática dos estudantes nos municípios com $100 \%$ e sem a presença do Programa PJ

Gráfico 47 - Média de desempenho em Matemática dos estudantes nos municípios com $50 \%$ e sem a presença do Programa PJ

Gráfico 48 - Comparação da evolução do desempenho médio em Matemática entre os $1^{\circ}$ e $9^{\circ}$ quartis

Gráfico 49 - Comparação da evolução do desempenho médio em Português entre os $1^{\circ}$ e $9^{\circ}$ quartis

Gráfico 50 - Desempenho por SRE em Matemática - 2007

Gráfico 51 - Desempenho por SRE em Matemática - 2008

Gráfico 52 - Desempenho por SRE em Matemática - 2009

Gráfico 53 - Desempenho por SRE em Matemática - 2010

Gráfico 54 - Desempenho por SER em Português - 2007

Gráfico 55 - Desempenho por SER em Português - 2008

Gráfico 56 - Desempenho por SER em Português - 2009

Gráfico 57 - Desempenho por SER em Português - 2010

Gráfico 58 - Evolução por desempenho em Matemática - SER -

MG - 2007 à 2010

Gráfico 59 - Evolução por desempenho em Português - SER MG - 2007 à 2010

Gráfico 60 - Razão de chances - ER - 2007 à 2010

Gráfico 61 - Razão de chances - PDP - 2007 à 2010

Gráfico 62 - Razão de chances - PEAS - 2007 à 2010

Gráfico 63 - Razão de chances - PEP - 2007 à 2010

Gráfico 64 - Razão de chances - FIT - 2008 à 2010 


\section{Lista de mapas}

Mapa 1 - Minas Gerais - Densidade Demográfica em \% 51

Mapa 2 - Participação no PIB do estado por Macrorregião 52

Mapa 3 - Minas Gerais - IDHM - 2010

Mapa 4 - Minas Gerais - índice de GINI por município - 2010 


\section{1. Introdução}

A proposta deste trabalho é estudar a abrangência das políticas educacionais implementadas no estado de Minas Gerais, por meio dos resultados das avaliações estaduais de proficiência dos estudantes do Ensino Médio - EM, com os indicadores sociais e demográficos dos municípios mineiros e também características das Superintendências Regionais de Ensino - SRE.

A escolha da rede estadual mineira justifica-se pela possibilidade de se analisar o nível de abrangência das diferentes políticas implementadas pelo governo estadual nos diferentes municípios. Assim, aqui foram analisadas as políticas implementadas dentro de um mesmo sistema de ensino (a rede de educação estadual de Minas Gerais), a abrangência dessas políticas entre os municípios e entre as escolas de um mesmo município, bem como as características sociais e demográficas existentes entre os municípios mineiros. Além disso, foi incluída como variável de análise, um índice para medir a complexidade das Superintendências Regionais de Ensino - ICS. Este índice foi criado exclusivamente para as análises realizadas neste trabalho, utilizando dados disponíveis no censo escolar.

Com relação à abrangência das políticas educacionais implementadas no Estado de Minas Gerais nos últimos anos, me chama a atenção o fato de que grande parte delas não apresentou estratégias de continuidade. Em geral, muitas das políticas educacionais implementadas entre os anos de 1990 e 2010, foram descontinuadas após as trocas de governo, corroborando com a ideia de que estas políticas não são estruturadas a partir de um projeto de estado e sim ligadas às estratégias dos governos em que são propostas.

Este é um entrave que ocorre não só em Minas Gerais, mas em todo o país. Cunha (1994) nomeia tais práticas como administração "zigue-zague”. Para o autor, essa é uma prática na qual cada secretário de educação orienta o seu mandato de acordo com um programa próprio (pessoal ou partidário) de gestão do sistema de ensino. Tal programa muda a cada quatro anos, ou mais rapidamente, no caso do secretário não permanecer no cargo durante todo o mandato, o que prejudica a avaliação das políticas educacionais e impede que seus efeitos 
positivos se reproduzam, continuem ou ganhem consistência. Cunha (1994) ainda argumenta que essa descontinuidade torna o campo educacional extremamente vulnerável à disputa político-eleitoral na qual o controle do sistema de ensino representa uma moeda de alto valor, seja para a legitimação dos líderes políticos do momento, seja para a desautorização de seus opositores (ou antecessores).

Outro aspecto que vejo como relevante, embora não exclusivo da rede mineira de educação, refere-se à organização centralizada do sistema de gestão da rede de educação estadual, onde as decisões políticas sempre são tomadas pela Secretaria Estadual de Educação - SEE-MG, na capital do estado, e afetam todo o sistema estadual. Embora existam as Superintendências Regionais de Ensino ${ }^{1}$ SRE que são órgãos intermediários entre a SEE-MG e as escolas, estas possuem autonomia limitada para elaboração e proposição de soluções para questões específicas de suas áreas de responsabilidade. As SRE's possuem atribuições geralmente burocráticas no sentido de fiscalizar o cumprimento das orientações determinadas pelo órgão central. A plena subordinação das SRE's é garantida pela indicação política de seus superintendentes pelo Secretário de Educação do Estado. Esta organização centralizada da instrução pública é acompanhada pelo caráter objetivo e uniforme de programas e projetos que são pensados de maneira única para todo o Estado. Esta é uma questão preocupante, considerando que Minas Gerais é um dos estados mais extensos e populosos do país e que possui uma diversidade social e demográfica singular. Contudo, mesmo com o limitado poder de decisão das SRE's, a análise das mesmas não deixa de ser fundamental, já que as mesmas atendem extensas regiões do estado e são diretamente responsáveis pela implementação das políticas educacionais nos municípios e escolas localizados em seu território de atuação. Esta grande variação de características sociais e demográficas existente entre os municípios me motivou, como já relatado, a incluir na análise da abrangência das políticas educacionais o ICS que considera características intrínsecas das superintendências como o número de municípios atendidos, números de estudantes atendidos, percentual de escolas rurais e percentual de estudantes atendidos no EF.

\footnotetext{
${ }^{1}$ De acordo com as orientações da SEE-MG, as SRE's têm por finalidade exercer em nível regional, as ações de supervisão técnica, orientação normativa, cooperação e de articulação e integração Estado e Município em consonância com as diretrizes e políticas educacionais. A descrição completa das atribuições das SRE's está disponível no site oficial da SEE-MG: http://www.educacao.mg.gov.br/sobre/servicos-18/superintendencias-regionais-de-ensino
} 
Quanto às diferenças econômicas, sociais e demográficas existentes entre os municípios, medidas por indicadores como PIB, IDHM e GINI, busco as relações com as políticas educacionais com o propósito de entender quais são os reflexos dessas diferenças na abrangência das políticas educacionais.

Com isto, é necessário pensar no papel das políticas educacionais em promover não só o acesso e bons resultados, mas também a equidade para o sistema educacional. Franco et. al. (2007) argumentam que os resultados da participação do Brasil em avaliações em larga escala indicam que o nível médio do desempenho de alunos brasileiros quando comparado com resultados de países da Organization for Economic Cooperation and Development (OECD), tem se mostrado bastante baixo, o que é particularmente preocupante no contexto de crescente integração econômica em escala mundial. Os autores ainda destacam que, além de problemas com a qualidade da educação, a sociedade brasileira precisa enfrentar questões relativas à equidade. Investigação da OECD (2004) indica que o Brasil é um dos países nos quais a correlação entre o nível socioeconômico e cultural dos alunos e as condições escolares associadas à eficácia escolar possui maior magnitude. (FRANCO et. al., 2007).

Em Minas Gerais, alguns indicadores demonstram que a equidade também é um desafio a ser enfrentado pela SEE-MG. Mesmo com a implementação de políticas voltadas para a redução da evasão nos últimos anos, a rede pública de educação do estado ainda apresenta números preocupantes em relação ao acesso e ao fluxo dos estudantes do EM. Abaixo, no gráfico 1, verificamos que, entre os anos de 2008 e 2010, o número de estudantes matriculados da $3^{\mathrm{a}}$ série do EM da rede estadual permaneceu estável. 
Gráfico 1 - Número total de matrículas na $3^{\text {a }}$ Série do EM - Rede Estadual de Minas Gerais - 2006 - 2010.

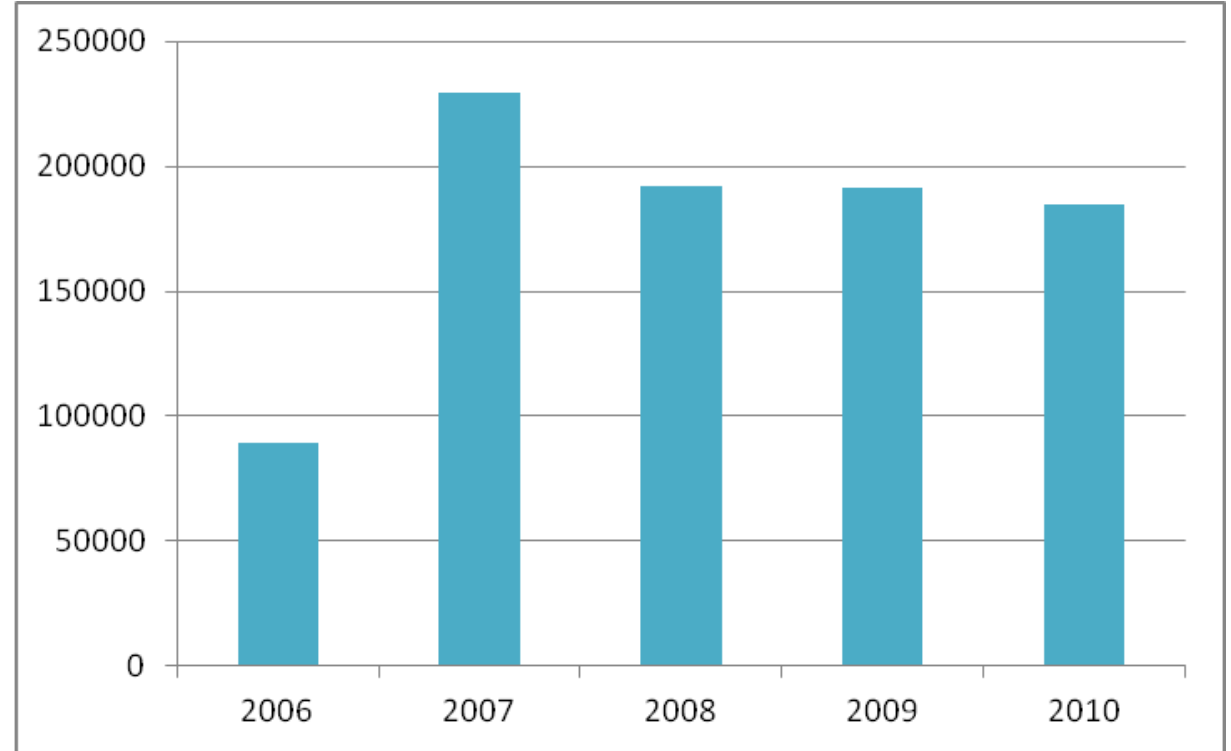

Fonte: Elaborado pelo autor com dados do censo escolar - INEP.

Outra questão que merece atenção é a defasagem idade-série. Fazendo uma comparação entre os municípios com menor distorção idade-série ( $1^{\circ}$ decil $)$ e municípios com maior defasagem $\left(9^{\circ}\right.$ decil), verificamos que, enquanto no primeiro grupo o percentual de estudantes com defasagem está em torno de $30 \%$, o segundo grupo chega a ter $60 \%$ de estudantes com defasagem idade-série.

Podemos verificar que, na comparação entre os municípios com maior e menor distorção idade-série ${ }^{2}$, a desigualdade entre esses municípios partiu de $30 \%$ em 2006, sendo ampliada em 2007 para quase o dobro e em seguida declinando até atingir os 30\% novamente em 2010. Assim, podemos concluir que entre 2006 e 2010 houve uma redução geral da defasagem idade-série; porém a distância entre os "piores" e "melhores" permaneceu inalterada.

\footnotetext{
${ }^{2}$ Esse indicador foi calculado por meio do levantamento do percentual de estudantes com defasagem idade-série igual ou superior a dois anos matriculados na terceira série do EM por município. Em seguida estes municípios foram ordenados de acordo com o percentual de estudantes com defasagem idade-série e divididos em decis.
} 
Gráfico 2 - Número de estudantes (\%) com defasagem idade-série igual ou superior a 2 anos matriculados na terceira série do EM na rede estadual de Minas Gerais entre os anos de 2006 e 2010.

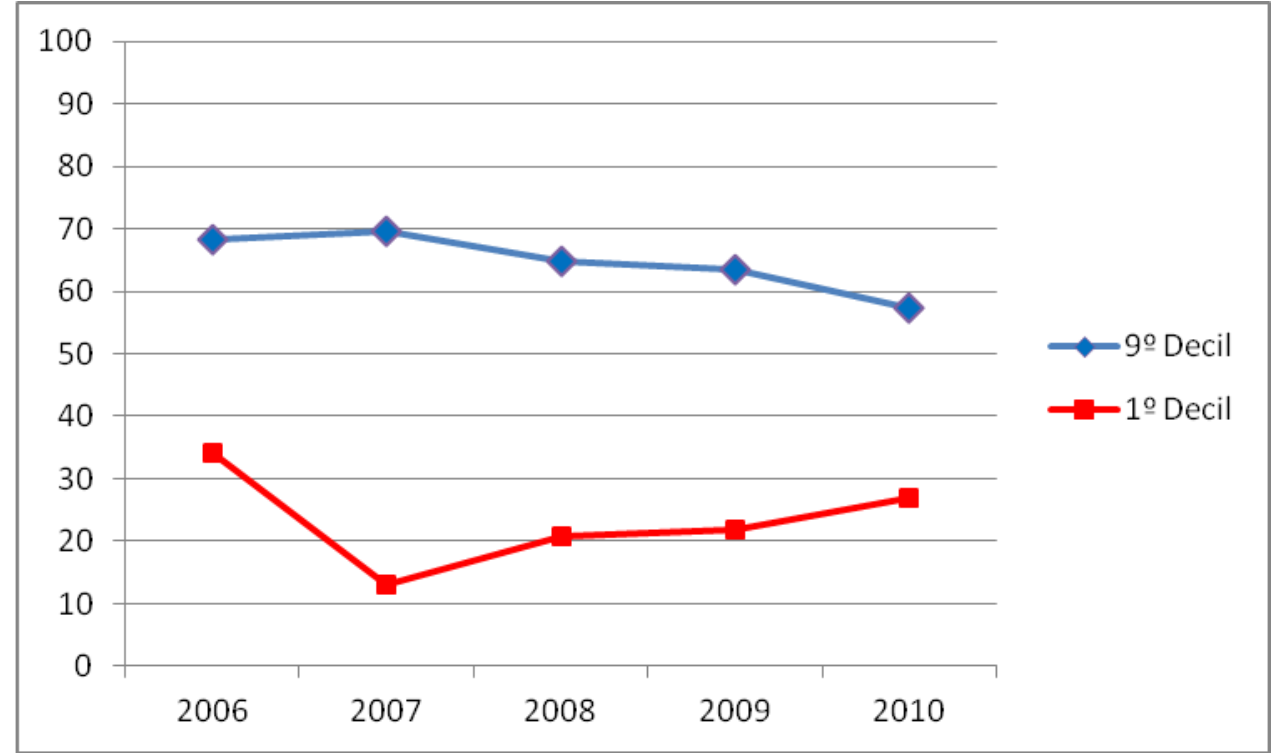

Fonte: Elaborado pelo autor com dados do censo escolar - INEP.

Estes dados reforçam a ideia de que, além da necessidade de avanços na qualidade da educação, a equidade ainda é um desafio para a rede pública de educação de Minas Gerais. Sendo assim, é necessário conhecer as políticas educacionais propostas para a rede mineira nos últimos anos, bem como entender a abrangência destas políticas no Estado. Nesta investigação busco contribuir com a discussão sobre a abrangência das políticas educacionais no Estado de Minas Gerais considerando as diferenças socioeconômicas e demográficas entre os municípios mineiros.

Esses objetivos estão relacionados com as seguintes questões de pesquisa:

1. Como se caracteriza o EM da rede estadual de Minas Gerais? Quais municípios apresentam os melhores indicadores de acesso, fluxo e desempenho? Quais apresentam os piores? Quais municípios apresentaram melhora no acesso, fluxo e desempenho ao longo do período analisado?

2. Quais indicadores sociais e demográficos caracterizam os municípios mineiros? Existe associação entre os indicadores sociais e demográficos dos municípios mineiros e os indicadores educacionais de acesso, fluxo e desempenho médio dos estudantes da $3^{\text {a }}$ série do EM por município?

3. Quais as políticas educacionais (programas/projetos) implementadas pela rede estadual entre os anos de 2007 e 2010? Como essas políticas podem 
ser classificadas? Qual a abrangência das políticas implementadas? Quais indicadores educacionais, sociais e demográficos estão relacionados com a abrangência destas políticas?

Em consonância com a vasta literatura sobre desigualdade, minha hipótese é de que existe associação entre as características sociais e demográficas dos diferentes municípios mineiros e as variáveis educacionais de acesso, fluxo e desempenho. Entretanto, minha principal hipótese é que as políticas educacionais implementadas pela rede estadual de Minas Gerais são experimentais e não são suficientes para atender às reais demandas dos municípios mineiros com relação ao EM.

Considero que as questões de pesquisa aqui propostas são relevantes e podem contribuir com o debate político-educacional em Minas Gerais e no Brasil. A investigação sobre a abrangência das políticas educacionais estaduais e suas relações com as desigualdades sociais, demográficas e educacionais intermunicipais do EM merece atenção por ser um campo ainda pouco pesquisado.

O trabalho também busca atender à necessidade de se ter um mapeamento da situação do EM da rede estadual mineira, realizando um levantamento do que tem sido feito na rede pública de ensino em termos de desenvolvimento de políticas públicas voltadas para este nível de ensino.

Com relação a metodologia, minha proposta é realizar uma análise descritiva dos dados disponíveis em bancos de dados públicos e, em seguida, por meio de regressão logística, identificar quais deles interferem na abrangência das políticas educacionais aqui estudadas. Como já dito, trabalho com dados de proficiência dos estudantes de ensino médio, variáveis socioeconômicas e demográficas dos municípios mineiros, características das Superintendências Regionais de Ensino e também com dados relativos às políticas educacionais (programas e projetos) desenvolvidas pelo Estado durante o período estudado. No entanto, não é meu objetivo analisar os processos inerentes à implementação dessas políticas em seus diferentes níveis ou quais foram seus impactos e efeitos. Centro-me, apenas, em descrever os indicadores educacionais e demográficos nos diferentes municípios mineiros, bem como em mapear a abrangência das politicas educacionais implementadas no estado. 
Para isso, construí a base desta pesquisa a partir de dados públicos, tendo como população alvo os estudantes do $3^{\circ}$ ano do ensino médio das escolas estaduais dos 853 municípios do Estado de Minas Gerais. Os dados referentes ao desempenho dos estudantes são oriundos do Programa de Avaliação da Educação Básica - PROEB que faz parte do Sistema de Avaliação da Educação pública de Minas Gerais - SIMAVE. Considerando que no EM o PROEB avalia apenas os estudantes da $3^{\text {a }}$ série do EM, organizei estes dados pelo desempenho médio dos estudantes por município, ano e disciplina avaliada (matemática e português).

Minha unidade de análise são os municípios mineiros e, portanto, incorporei à base de dados para cada município variáveis sociais e demográficas como o PIB, PIB per capita, População, IFDM e os fatores que o compõe: Emprego \& Renda, Educação, Saúde; o IDHM de 2010, IDHM-Renda de 2010, IDHM-Longevidade de 2010, IDHM-Educação de 2010 e Índice de GINI 2010. As informações sobre as variáveis estão reunidas no Quadro 1.

Quadro 1 - Base de dados utilizada na pesquisa.

\begin{tabular}{|c|c|c|}
\hline \multicolumn{3}{|c|}{ BASES DE DADOS } \\
\hline Categoria & Descrição & Fonte \\
\hline $\begin{array}{l}\text { Proficiência dos } \\
\text { estudantes }\end{array}$ & $\begin{array}{l}\text { Base contendo a nota dos estudantes do } 3^{\circ} \text { Ano do Ensino } \\
\text { Médio da Rede Estadual de Educação do Estado de Minas } \\
\text { Gerais. A base contém as notas obtidas pelos estudantes } \\
\text { no PROEB nos anos de } 2006 \text { à } 2010 \text {. }\end{array}$ & $\begin{array}{l}\text { Secretaria } \\
\text { Estadual de } \\
\text { Educação - MG }\end{array}$ \\
\hline $\begin{array}{l}\text { Políticas Educacionais } \\
\text { (projetos e programas } \\
\text { educacionais } \\
\text { desenvolvidos pelo } \\
\text { governo do Estado de } \\
\text { Minas Gerais) }\end{array}$ & $\begin{array}{l}\text { Base contendo as escolas contempladas com os projetos e } \\
\text { programas desenvolvidos pelo governo do Estado de } \\
\text { Minas Gerais durante os anos de } 2006 \text { à 2010. } \\
\text { Considerando as características dos programas } \\
\text { apresentados no capítulo } 4 \text { e a disponibilidade de dados } \\
\text { fornecidos pela SEE-MG, constam da base os seguintes } \\
\text { programas: 1. Escolas Referência - ER; 2. Programa de } \\
\text { Desenvolvimento Profissional - PDP; 3. Programa de } \\
\text { Atenção ao Jovem - PEAS; 4. Formação Inicial para o } \\
\text { Trabalho - FIT; 5.Programa de Educação Profissional - } \\
\text { PEP e 6. Programa Poupança Jovem. As bases foram } \\
\text { organizadas em categorias dicotômicas, tendo } 1 \text { para as } \\
\text { escolas que participaram do projeto/programa e } 0 \text { para as } \\
\text { que não participaram. }\end{array}$ & $\begin{array}{l}\text { Secretaria } \\
\text { Estadual de } \\
\text { Educação - MG }\end{array}$ \\
\hline $\begin{array}{l}\text { Características das } \\
\text { Superintendências } \\
\text { Regionais de Ensino }\end{array}$ & $\begin{array}{l}\text { Elaboração do Índice de Complexidade das } \\
\text { Superintendências } \\
\text { meio do Censo Educacional Brasileiro. }\end{array}$ & INEP \\
\hline $\begin{array}{l}\text { Características } \\
\text { municipais }\end{array}$ & $\begin{array}{l}\text { Base contendo indicadores de todos os municípios } \\
\text { mineiros relacionados ao desenvolvimento econômico e } \\
\text { social. Foram selecionados os seguintes indicadores: } 1 . \\
\text { População; } 2 \text {. PIB_Per_Capita; 3. Índice de } \\
\text { desenvolvimento Humano; 4. Índice de Gini; 5. Índice de } \\
\text { Desenvolvimento Municipal. }\end{array}$ & $\begin{array}{l}\text { IBGE, FJP, } \\
\text { Firjam }\end{array}$ \\
\hline
\end{tabular}
Fonte: Pesquisa do autor. 
Quanto aos programas e projetos desenvolvidos pela SEE-MG durante o período de estudo, a base de dados foi organizada pelos programas, ano em que funcionaram e municípios em que foram implementados, conforme abaixo o quadro 2 .

\begin{tabular}{c|c}
\hline \multicolumn{2}{c}{ Quadro 2 - Programas e projetos educacionais analisados. } \\
\hline PROGRAMA/PROJETO & ANO \\
\hline Escolas Referência - ER & $2006-2010$ \\
\hline Programa de Desenvolvimento Profissional - PDP & $2006-2010$ \\
\hline Programa de Atenção ao Jovem - PEAS & $2006-2009$ \\
\hline Formação Inicial para o Trabalho - FIT & $2008-2009$ \\
\hline Programa de Educação Profissional - PEP & $2007-2010$ \\
\hline Programa Poupança Jovem & $2007-2010$ \\
\hline
\end{tabular}

Fonte: Pesquisa do autor.

Para responder as questões de pesquisa apresentadas, dividi a metodologia de análise de dados em três fases distintas e complementares:

$1^{a}$ fase: Constituiu-se na pesquisa para obtenção e organização da base de dados. Defini como unidade de análise os municípios mineiros, considerando que estes são as menores unidades com independência administrativa e seus dados sócio demográficos estão disponíveis nas diversas bases de dados públicas. Para isso, todas as variáveis foram organizadas por médias municipais possibilitando a comparação entre os municípios. Em seguida os dados foram ordenados em quantis, o que possibilitou a comparação entre os municípios com melhores e piores indicadores.

$2^{\mathrm{a}}$ fase: Com os dados de proficiência dos estudantes ordenados por municípios, verifiquei a relação entre as notas médias por disciplina, ano e cidade com o padrão comportamental dos índices sociais e demográficos. Para isso utilizei a comparação entre os diferentes quantis.

$3^{\text {a }}$ fase: Nesta etapa, analiso a distribuição das políticas educacionais (projetos e programas) implementadas pelo governo estadual e a correlação das mesmas com as variáveis educacionais e sócio demográficas. Além das variáveis sociais e demográficas, acrescento na análise o Índice de Complexidade das Superintendências - ICS. Como já dito, este índice foi elaborado com o fim de permitir uma análise que considerasse também características intrínsecas de cada Superintendência Regional de Ensino em relação à abrangência das políticas 
educacionais implementadas pela SEE-MG. Nesta análise é considerada a abrangência de cada um dos programas e projetos. Considerando que em um mesmo município existem escolas que foram contempladas e outras que não foram contempladas por um mesmo programa, busco analisar o percentual de escolas contempladas por município, para que seja possível comparar o efeito desses programas na unidade de análise que é o município. Na terceira etapa também realizo, por meio de regressão logística, a verificação das variáveis que influenciam a maior ou menor abrangência das políticas educacionais.

As fases de análise apresentadas geraram um número elevado de gráficos, tabelas e mapas. Assim, optei por apresentar parte das análises no corpo do trabalho. A análise detalhada é apresentada no anexo. A escolha do município como unidade de análise, tornou inviável a realização de pesquisa de campo, já que Minas Gerais possui 853 municípios. Assim, utilizo apenas bases de dados públicas disponibilizadas por órgãos oficiais.

Entretanto, esta mesma condição trouxe como vantagem a possibilidade de realizar análises comparativas a nível municipal com os indicadores sociais e demográficos também disponibilizados pelos órgãos oficiais. Infelizmente, as variáveis disponíveis não permitem elaborar uma imagem completa do percurso educativo desses estudantes, ou seja, não é possível realizar uma análise longitudinal sobre o desenvolvimento educacional dos mesmos, captando, por exemplo, dados sobre o desempenho desses estudantes no ensino fundamental. Esta seria uma análise rica já que, no ensino fundamental, muitos municípios mantêm suas próprias redes educacionais. Um acompanhamento longitudinal permitiria apreender outros efeitos sobre o desenvolvimento desses estudantes, ou seja, verificar como estes estudantes chegaram ao ensino médio, considerando que os mesmos são oriundos de diferentes escolas e redes de ensino. Assim, seria possível verificar as disparidades de desempenho acumuladas por estes estudantes ao longo de suas vidas escolares.

O trabalho está estruturado em cinco capítulos, incluindo esta introdução. No capítulo 2, busco referências para a análise das políticas públicas implementadas, onde apresento as ideias de autores como Bell \& Stevenson (2006) e Arretche (2001) sobre análise de políticas educacionais. Sobre os conceitos de políticas públicas trago as contribuições de Hofling (2001), Secchi 
(2009) e Nudzor (2009). E com relação à abrangência das políticas públicas apresento as ideias de Souza (2007), Arretche (2004) e Costa (2002).

No capítulo 3, apresento os indicadores sociais e demográficos do Estado de Minas Gerais e de seus municípios. No capítulo 4, apresento um histórico das políticas educacionais implementadas no estado de Minas Gerais desde a década de 1990 e, mais detalhadamente, os programas e projetos educacionais implementados no governo Aécio Neves entre os anos de 2006 e 2010. Ainda neste capítulo apresento os principais resultados da análise de regressão e analiso a abrangência da políticas educacionais, apresentando os principais achados da pesquisa. Por fim, no capítulo 5, apresento minhas conclusões. 


\section{2. \\ Políticas educacionais: conceitos, classificação abrangência}

Neste capítulo, busco na literatura especializada argumentos para analisar a abrangência das principais políticas educacionais voltadas para o Ensino Médio e implementadas pela SEE-MG entre os anos de 2006-2010. Considero que a conceituação e classificação das políticas educacionais são a chave para uma melhor compreensão das políticas desenvolvidas em Minas Gerais.

Com isso, vou discutir alguns conceitos que entendo serem importantes para um melhor entendimento e análise das políticas educacionais. Apresento algumas ideias sobre conceitos e a classificação e implementação de políticas educacionais e em seguida falo sobre a literatura a respeito da abrangência das políticas educacionais.

\section{1. Políticas Educacionais: finalidades e objetivos}

As políticas educacionais em países em desenvolvimento, como o Brasil, geralmente são geradas por pressões, vindas do crescimento populacional e das crises fiscais persistentes que exigem que os governos busquem medidas que sejam eficazes no sentido de ampliar o acesso e ao mesmo tempo melhorar os padrões de qualidade da educação. Embora a provisão da educação básica seja uma das tarefas básicas exigidas dos governos de todos os níveis (municipal, estadual e federal), Lima (2009 p.11122) nos alerta que:

É particularmente preocupante o reduzido acesso ao Ensino Médio no Brasil, muito menor que nos demais países latino-americanos em desenvolvimento, embora as estatísticas demonstrem que os concluintes do Ensino Fundamental começam a chegar à terceira etapa da educação básica em número um pouco maior, a cada ano.

O relatório Education at a Glance $^{3}$ de 2013, mostra que os níveis educacionais alcançados pela população brasileira ainda se mantêm abaixo da

\footnotetext{
${ }^{3}$ Panorama da Educação - 2013: Relatório de Indicadores elaborado pela OCDE para oferecer um conjunto comparável de indicadores com a finalidade de medir o estado atual da educação internacional. Os indicadores fornecem informações sobre os recursos humanos e financeiros
} 
média dos membros da Organização para a Cooperação e o Desenvolvimento Econômico (OCDE). Embora tenha havido progresso, o Brasil é o país com menor gasto por aluno nas escolas de ensino médio entre 32 nações com dados analisados pela OCDE. Entre os aspectos positivos apresentados pelo relatório está o crescimento do acesso à educação, mostrando que $57 \%$ da população na faixa de 25 a 34 anos concluiu o EM contra apenas $26 \%$ dos brasileiros de 55 a 64 anos. No entanto, o país continua com a mais baixa taxa de detentores de diploma universitário, ficando em último lugar entre 36 países analisados e corresponde a um terço da média das nações da OCDE (39\%). Entre a população de 25 a 64 anos, apenas $12 \%$ dos brasileiros têm curso superior completo, contra $32 \%$ na média da OCDE.

Nesse sentido, a não universalização do acesso ao Ensino Médio é um indicador que claramente ameaça a eficácia das políticas educacionais voltadas para esse seguimento no Brasil. Além do acesso, variáveis como fluxo e desempenho também são importantes ao se pensar em políticas educacionais. Bell \& Stevenson (2006) argumentam que alguns temas devem ser considerados por serem interligados e comumente identificados no âmbito das políticas educacionais da maioria dos países. Para eles, o capital humano e a cidadania/justiça social estão ligados aos mercados, às escolhas e à avaliação/responsabilização.

Para os autores, o objetivo de uma determinada política educacional destinase a cumprir as finalidades dos temas a que estão ligadas, ou seja, promover mudanças ao longo do tempo de acordo com os discursos dominantes no ambiente sócio-político. No Brasil, podemos constatar que muitas políticas educacionais estão intimamente ligadas às concepções partidárias ou pessoais dos governantes, tornando-as frágeis às transições eleitorais, quando são interrompidas ou abandonadas.

Nesse jogo de poder, as políticas educacionais podem ser contraditórias, como por exemplo, nos casos em que a opção em aumentar a eficiência financeira da máquina estatal e, por consequência, do sistema de ensino, vai de encontro às necessidades de investimento para ampliar a oferta e qualidade da educação.

investidos na educação, como a educação e sistemas de aprendizagem operam e evoluem, e quais são os retornos aos investimentos educacionais. 
Bell \& Stevenson (2006) destacam a necessidade de entender os diferentes contextos em que uma política é implementada como também a necessidade de se distinguir seus objetivos e finalidades e a complexidade de seus processos.

A análise das políticas educacionais permite conhecer os diferentes contextos em que as mesmas são desenvolvidas e implementadas, as instituições envolvidas e as características culturais, sociais e demográficas dos municípios ou localidades atingidas por estas políticas. Além disso, permite a compreensão, por exemplo, da abrangência das políticas educacionais e suas relações com os indicadores sociais e demográficos nos espaços por elas atendidos.

Segundo Arretche (2001) é praticamente impossível um programa público ser implementado inteiramente de acordo como previsto por seus formuladores, uma vez que, na gestão de programas públicos, é grande a distância entre os objetivos e o desenho de programas, além da tradução de tais concepções em intervenções públicas, tal como elas atingem seus beneficiários e provedores. Para a autora:

Esta distância não diz respeito a fatores de ordem moral ou ética, que possam ser atribuídos a interesses escusos de formuladores e implementadores. Na verdade, esta distância é uma contingência da implementação, que pode ser, em grande parte, explicada pelas decisões tomadas por uma cadeia de implementadores, no contexto econômico, político e institucional em que operam. (ARRETCHE, 2001 p. 01).

Neste caso, as vontades, os interesses, as lealdades e as concepções ideológicas dos diversos agentes envolvidos em um programa público dificilmente serão inteiramente coincidentes. Portanto, quanto mais complexo um programa, maior será a variedade de interesses e concepções envolvidos em sua execução e, por consequência, mais fortes serão as tendências à não-convergência.

Arretche (2001) ainda dá destaque para a importância de se ter em mente que a implementação modifica o desenho original das políticas, por ocorrer em um ambiente caracterizado por contínua mutação e que os implementadores é que fazem a política e a fazem segundo suas próprias referências. Nestas circunstâncias, a autora ressalta a necessidade de se investigar a autonomia decisória dos implementadores, suas condições de trabalho e suas disposições em relação à política analisada. (ARRETCHE, 2001).

Considero que os argumentos reunidos até aqui não deixam dúvidas de que a análise de políticas educacionais permite uma ampla possibilidade de caminhos. 
Em resumo, uma análise da implantação de uma política educacional parte do estudo sobre o que os governos fazem, por que fazem e qual a abrangência de seus efeitos. Este último tópico é o ponto chave desta pesquisa, como será detalhado no capítulo 4.

\section{2. \\ Conceitos de Política}

São inúmeras as definições de política pública, mas é fato que as "decisões" e "ações" escolhidas pelo governo e que afetam um grande número de pessoas, tornam-se políticas públicas. No entanto, as políticas não são simplesmente imposições administrativas. Elas são fruto de interações e processos extremamente complexos e para compreender esses processos desde a origem até a implementação em uma determinada sociedade, é preciso considerar aspectos históricos de luta, pressões e conflitos entre os grupos e classes que a constituem. Para Hofling (2001, p.30-31):

$\mathrm{Na}$ análise e avaliação de políticas implementadas por um governo, fatores de diferentes natureza e determinação são importantes. Especialmente quando se focaliza as políticas sociais (usualmente entendidas como as de educação, saúde, previdência, habitação, saneamento etc.) os fatores envolvidos para a aferição de seu "sucesso" ou "fracasso" são complexos, variados, e exigem grande esforço de análise.

Para a autora, estes diferentes aspectos devem estar sempre referidos a um contorno de Estado no interior do qual eles se movimentam. Em sua análise, a autora também destaca a necessidade de se diferenciar Estado e governo na análise de políticas públicas:

Torna-se importante aqui ressaltar a diferenciação entre Estado e governo. Para se adotar uma compreensão sintética compatível com os objetivos deste texto, é possível se considerar Estado como o conjunto de instituições permanentes - como órgãos legislativos, tribunais, exército e outras que não formam um bloco monolítico necessariamente - que possibilitam a ação do governo; e Governo, como o conjunto de programas e projetos que parte da sociedade (políticos, técnicos, organismos da sociedade civil e outros) propõe para a sociedade como um todo, configurando-se a orientação política de um determinado governo que assume e desempenha as funções de Estado por um determinado período. (HOFLING, 2001 p. 31).

Hofling (2001) entende que as políticas públicas devem ser entendidas como o "Estado em ação", considerando que por trás dessas políticas está o Estado implantando um projeto de governo, por meio de programas, projetos e 
ações voltadas para setores específicos da sociedade. De acordo com Secchi (2009) quando falamos de reformas administrativas propostas nas transições de governos, é comum a existência de políticos, funcionários de carreira e empreendedores políticos em geral que tentam manipular a percepção coletiva a respeito das organizações públicas. Segundo o autor, não são raros os esforços de reforma da administração pública que avançam mais em autopromoção e retórica do que em fatos concretos. Para o autor, com o desenvolvimento dos sistemas eleitorais e partidários das sociedades industriais modernas, a retórica tornou-se fundamental nas disputas políticas e na principal forma que os governos têm de apresentar resultados (mesmo que virtuais) que garantam sua sustentação. Por isso, apresentar resultados positivos é vital para qualquer governo. (SECCHI, 2009).

Mesmo com tantas variações conceituais, a maioria dos autores concorda em dois aspectos essenciais: a) que as políticas públicas resultam de decisões tomadas pelos governos e b) que a política é uma questão de alocação autoritária de valores e a demonstração operacional desses valores e intenções.

Nudzor (2009) sugere um "ecletismo teórico" para o entendimento do conceito de política. $\mathrm{O}$ autor argumenta que a definição tradicional vê a política fundamentalmente como um guia, ou seja, um documento que indica as escolhas políticas determinadas pelos políticos. Aos demais atores resta implementá-los para lidar com os problemas na prática. Nudzor (2009) critica esta definição por duas razões principais. Em primeiro lugar, pelo fato desta definição negligenciar o dinamismo sociocultural dos processos políticos. E em segundo lugar, critica esta definição tradicional por seu excesso de determinismo. Isto é, a pré-suposição de que as escolhas e decisões políticas, uma vez documentadas, serão rigorosamente seguidas e que as mudanças políticas desejadas irão ocorrer obrigatoriamente.

Em contraposição ao modelo tradicional, Nudzor (2009) apresenta o modelo de processo, onde a política é compreendida como um processo dinâmico e foca compreender a interação entre os diversos atores, tanto na formulação, articulação, divulgação e interpretação. Para o autor, o conceito de processo presta especial atenção à "agência social do processo político" e, nesse sentido, faz crítica ao seu excesso de concentração no exame que os atores políticos fazem em resposta à política. Para Nudzor (2009) o processo de concepção pode ser criticado por superestimar os efeitos provocados pelos atores do nível micro político, 
esquecendo que são os atores de nível macro que estabelecem as regras básicas para as negociações envolvidas no processo político.

Em sua observação crítica sobre os conceitos tradicional e de processo, Nudzor (2009) sugere a adoção de uma abordagem da teoria composta, defendendo que tanto os modelos de processos como os tradicionais são capazes de complementar um ao outro e, juntos, oferecem maiores insights sobre os processos políticos. Compartilhando das ideias de Nudzor (2009), entendo que as políticas educacionais são emanadas do Estado, como qualquer outra política pública e implicam em escolhas e decisões, que envolvem indivíduos, grupos e instituições. Para os tomadores de decisão as políticas educacionais são ferramentas de resolução de problemas mas, ao mesmo tempo, não são simplesmente controláveis em sua implementação considerando a complexidade de interação dos diferentes contextos e atores envolvidos Bell \& Stevenson (2006). As políticas constroem-se na correlação entre as forças sociais, que se articulam na defesa de seus interesses.

\section{3. \\ Classificação das Políticas públicas}

Para que uma política pública seja capaz de cumprir seus objetivos e trazer as transformações e mudanças propostas em seu escopo, é necessário, entre outras coisas, que os atores envolvidos estejam convencidos e comprometidos com as mudanças propostas. Em outras palavras, teoricamente não deve haver resistência e desacordo para que uma política possa avançar da forma que foi pensada por seus proponentes.

Souza (2010), embora considere a existência de políticas públicas além da ação estatal, adota a visão de que as políticas se identificam na ação do Estado. Para o autor a análise da política pública deve contemplar o conhecimento do tipo de política adotada, classificando-as a partir de critérios que as identifiquem como, por exemplo, se são formais ou institucionais, qual o grau de universalidade e quais são os sujeitos afetados.

$\mathrm{O}$ autor ressalta que a identificação dos tipos, áreas ou grandes categorias de políticas públicas seria grande problema e sua definição seria dada através do impacto sobre a sociedade ou o impacto esperado. Estas ações governamentais 
corresponderiam a arenas reais de poder com suas características próprias, estrutura política etc. (SOUZA, 2010 p. 166).

Lowi (1970) enfatiza a importância da coerção diferenciando os tipos de políticas e acrescenta que a administração é a rotinização da coerção e o Estado o seu aparato. Assim, a classificação das políticas deveria estar ligada às funções do Estado e seria relevante o entendimento sistemático destas, seus tipos e consequências. Os tipos de políticas e de coerção constituiriam indicadores das funções do Estado e toda política seria coerção deliberada. O autor critica o pensamento tecnocrata por subestimar a importância das escolhas feitas, pois excluiria questões sobre o impacto das mesmas sobre os processos e sobre a sociedade amplamente. (LOWI, 1970 p. 314)

Nesse sentido, as políticas também podem ser diferenciadas em função da natureza do seu impacto na sociedade e pelas relações entre os envolvidos em sua formulação, sendo classificadas como: reguladoras, distributivas ou de redistribuição. As políticas regulatórias seriam as que impõem restrições ou limitações sobre o comportamento de indivíduos ou grupos. Por esta razão, as decisões reguladoras envolvem conflito entre dois grupos ou coligação de grupos com um lado impondo o controle sobre o outro.

As políticas redistributivas envolvem esforços deliberados por parte do governo para mudar a distribuição da riqueza, renda, bens ou direitos entre classes, a fim de buscar reduzir a desigualdade entre as mesmas. Essas políticas envolvem redistribuição de dinheiro ou poder (inclusive direitos - ex: política de cotas). Assim, essas políticas raramente agradam o grupo social que paga por essa redistribuição. As políticas distributivas envolvem a distribuição de serviços ou benefícios para um segmento específico ou geral da população (comunidades, grupos, indivíduos, empresas etc.). Na maioria dos casos, aqueles que buscam benefícios não competem diretamente entre si e os seus benefícios não representam um custo direto a qualquer grupo específico, e não geram conflitos, embora os contribuintes paguem por seus custos financeiros.

Souza (2010) ainda destaca que as políticas públicas podem ser distinguidas como políticas simbólicas ou materiais:

Falam de diferenças importantes entre decisões que alocam benefícios tangíveis para pessoas ou grupos de forma direta e decisões que estabelecem regras de autoridade para posteriores alocações, já que podem ter efeitos significativos sobre a distribuição. Analisam os vínculos entre demanda e apoio e o sistema de decisão 
em termos de razão custo-benefício para os tomadores de decisão, ou seja, diríamos que se adota como critério para classificar as políticas públicas ou de custobenefício. Os decisores procurariam otimizar seus custos-benefícios, levando em conta os eleitores, os custos de informação sobre questões substantivas, tempo etc. Como decorrência, falam de dois tipos de políticas, as alocativas (variam ao longo do eixo distributivo-redistributivo, benefícios são diretos, materiais ou simbólicos para indivíduos e grupos) e estruturais (formuladas mais abstratamente e mais ambíguas nos seus efeitos, podem variar entre os resultados regulatórios e autoregulatórios, estabelecem estruturas de autoridade ou regras para alocações posteriores). E a hipótese fundamental, é que o custo maior seria para organizar a coalização sobre uma questão e que, comumente, os resultados das políticas seriam mais estruturais que alocativos. (SOUZA, 2010 p. 166).

Assim, as políticas materiais podem fornecer tanto recursos tangíveis como poder substancial para os seus beneficiários. As políticas simbólicas têm pouco ou nenhum impacto material sobre as pessoas.

As políticas públicas educacionais permanentemente sofrem mutações em um movimento cíclico, embora sempre direcionadas para dar respostas aos problemas da prática. Esse movimento é inevitável, considerando a dinâmica da sociedade brasileira e a necessidade de atender as demandas específicas da educação. Nesse sentido, na análise das políticas é importante compreender a sua abrangência. Embora as pesquisas sobre a abrangência das políticas educacionais ainda seja bastante propedêutica no Brasil, entendo que a proposta de análise desta pesquisa é consistente e coerente para a avaliação das políticas educacionais e, por isso, se constitui em um importante instrumento de pesquisa.

\section{4.}

\section{A abrangência das Políticas Educacionais}

A identificação da abrangência das políticas educacionais contribui para revelar o alcance geográfico da política e/ou programa educacional implementado, como também para revelar o número de pessoas beneficiadas. Contudo, esses dados, quando apresentados isoladamente, não são suficientes. É necessário que eles sejam sempre relacionados ao universo a que a política e/ou programa se destina, ou seja, considerando-se o universo que uma política deve atender, podese analisar se sua abrangência é ampla ou restrita, a partir do \% de municípios ou indivíduos de fato por ela atingidos.

Para Arretche (2004), os estados federativos são encarados como propensos a produzir níveis comparativamente mais baixos de gasto social, bem como menor 
abrangência e cobertura dos programas sociais. Em sua análise, a autora argumenta que o sistema brasileiro de repartição tributária garante receitas sem vinculação de gasto (exceto obrigações constitucionais de gasto em saúde e educação) aos governos subnacionais e, por consequência, produz alta rigidez do orçamento federal. A autora afirma que sistemas tributários e fiscais caracterizados por elevado nível de dependência de transferências fiscais e ausência de vínculo entre quem taxa e quem gasta tendem a produzir baixo compromisso com o equilíbrio fiscal por parte dos governos subnacionais. Com isso, a autoridade do governo federal para induzir as decisões dos governos locais, no sentido de que estas venham a coincidir com as suas próprias prioridades, permanece limitada, uma vez que estes detêm autonomia fiscal e política, tendo, portanto, condições institucionais para não aderir às políticas federais. Arretche (2004, p.19) ainda destaque que:

Adicionalmente, como as transferências fiscais têm limitado efeito equalizador sobre as diferenças interestaduais e intermunicipais de capacidade de gasto, permanece necessária a ação do governo federal para viabilizar patamares básicos de produção de serviços sociais.

Dessa forma, a autora defende que a coordenação federal dos programas sociais se justifica tanto por razões relacionadas à coordenação das decisões dos governos locais quanto para corrigir desigualdades de capacidade de gasto entre Estados e municípios.

Segundo Cardoso \& Jaccoud (2005), estudos desenvolvidos desde meados da década de 1980 vêm enfatizando que a importância do aparato institucional e do gasto público no âmbito das políticas sociais, assim como a abrangência de sua cobertura, justificariam uma análise sob a perspectiva de um sistema de proteção social. Para os autores, o sistema de proteção social brasileiro é insuficiente, incompleto e até mesmo perverso e, mesmo com o progressivo avanço de aspectos importantes das condições de vida no país expressos na melhoria de certos indicadores sociais como expectativa de vida ou mortalidade infantil, a gravidade da situação social reafirma a necessidade do debate sobre esse tema:

A cobertura universal em saúde e no ensino fundamental está, ainda, marcada por públicos segmentados em face da modalidade pública ou privada e da qualidade variável dos serviços oferecidos. As políticas de educação e saúde representam no Brasil os direitos incondicionais da cidadania social. Seus objetivos dizem respeito à presença da desigualdade como problema constitutivo das sociedades modernas, movendo o Estado a garantir a ampliação e a universalização do acesso a alguns 
serviços sociais. E é em torno desta questão que ainda residem seus maiores desafios. (CARDOSO JR \& JACCOUD, 2005 p. 239).

No Brasil, como em outros países em desenvolvimento, a agenda social da década de 1990 foi freada pelas mudanças nas estratégias de desenvolvimento nacional alinhadas à internacionalização da economia. No mesmo período, o país passou por um processo de estabilização econômica, reformas institucionais e consolidação democrática. Com isso, a política pública foi marcada pelo incentivo à centralização, aumento do controle das despesas não financeiras do governo federal, a reforma administrativa do governo federal e governos subnacionais, a privatização das atividades de prestação de serviços públicos, a liberação do comércio externo e outras reformas orientadas para a abertura do mercado interno, e a adoção de políticas focalizadas e de proteção seletiva aos grupos mais vulneráveis aos processos de ajuste no modelo de desenvolvimento. Para Souza (2006, p. 34), este formato ainda guia as políticas públicas:
A partir da influência do que se convencionou chamar de "novo gerencialismo público" e da política fiscal restritiva de gasto, adotada por vários governos, novos formatos foram introduzidos nas políticas públicas, todos voltados para a busca de eficiência. Assim, a eficiência passou a ser vista como o principal objetivo de qualquer política pública, aliada à importância do fator credibilidade e à delegação das políticas públicas para instituições com "independência" política. Estes novos formatos, que guiam hoje o desenho das políticas públicas mais recentes, ainda são pouco incorporados nas pesquisas empíricas.

De acordo com Costa (2002), ao longo da década de 1990, essa agenda foi hegemônica na formulação das políticas nacionais e na decisão governamental para as áreas sociais e formulação de política, como o saneamento, a habitação e a educação. Contudo, para o autor:

Pode-se afirmar que esse novo cenário não permitiu encaminhamento de soluções abrangentes para as políticas sociais, em razão dos pressupostos aceitos para a integração da economia brasileira na globalização. Esses pressupostos levaram negação da agenda universalista em determinadas áreas sociais, a focalização de programas e o constrangimento ao financiamento social. (COSTA, 2002 p. 18).

Com esse argumento, Costa (2002) conclui que as políticas sociais brasileiras vêm contribuindo para a estabilização dos recursos em determinadas áreas sociais em patamares extremamente baixos que resultam na redução em termos absolutos dos gastos sociais em áreas críticas, como assistência social e educação. Nesse sentido, as restrições impostas aos gastos públicos limitaram severamente a capacidade de promover programas sociais mais abrangentes. 
A Constituição Brasileira de 1988, passou a garantir cobertura e o acesso universal aos diversos serviços sociais. Entretanto, com a descentralização do financiamento, não houve uma adequada descentralização das competências entre as esferas subnacionais. No caso da educação, a criação do Fundo de Manutenção e Desenvolvimento do Ensino Fundamental e de Valorização do Magistério (FUNDEF) em 1998 teve como objetivo garantir que o nível mínimo de gastos exigido por lei para a educação tivesse impactos mais significativos sobre o ensino fundamental. Com o FUNDEF, aproximadamente $60 \%$ do total destinado a educação por estados e municípios passou a ser destinado ao ensino fundamental e o rateio de cada fundo estadual foi vinculado ao número de matrículas na rede de ensino fundamental, o que resultou no aumento do número de matrículas municipais.

Estas mudanças trouxeram avanços em termos de direitos sociais, mas também desencadearam, como vimos, um período de intrincado ajustamento aos novos deveres do Estado, à nova distribuição de obrigações entre as esferas públicas e ao contexto econômico e internacional. Costa (2002), Arretche (2004), Cardoso Jr \& Jaccoud (2005) e Souza (2006).

Esse período de ajustamento às novas diretrizes, foi e, de certa forma, ainda é em alguns setores, conturbado pela configuração econômica e ideológica dos anos 1990 e também 2000. Sob o subjugo de instituições internacionais, o Brasil adotou políticas de superávit fiscal, pressionando negativamente a capacidade de gastos sociais. Durante esses anos, sob o argumento de "melhoria da eficiência do gasto público", se disseminou a adoção de programas sociais focalizados no Brasil. Veremos no próximo capítulo que o "Choque de Gestão" implementado pelo governo Aécio Neves, se enquadra perfeitamente nesta definição.

Em princípio, a adoção de políticas focalizadas não prejudica de maneira alguma a adoção de políticas universais, como verificamos em Kerstenetzky (2006, p.564-565):

No presente texto, argumento que a decisão sobre o estilo de política social, se focalizada ou universal, revela-se pouco clara na ausência de uma decisão prévia sobre princípios de justiça social que se quer implementar, fazendo, por exemplo, com que se associe automaticamente, e erradamente a meu ver, a universalização com a garantia de direitos sociais e a focalização com noções residualistas de justiça. Em outras palavras, sugiro que o marco em termos de justiça - por exemplo, justiça de mercado ou, alternativamente, justiça distributiva - é crucial para esclarecer nossas atitudes perante estilos de política social. Uma vez, por exemplo, que se selecione uma concepção de justiça reparatória ou distributiva, a 
escolha do grau de focalização ou universalização em cada programa específico poderá ser transferida ao campo da "tecnologia social", do cálculo da eficiência social relativa, deixando de suscitar maiores paixões, pelo menos no que respeita à equidade. Focalização e universalização apareceriam, então, como métodos alternativos, quando não complementares, de implementação de uma noção de justiça previamente definida.

Para a autora, sem referência a noções de justiça, não haveria uma equivalência imediata entre focalização - "eficiência", e universalização "equidade". Ainda, para a autora, focalização e universalização podem significar, respectivamente, a inclusão ou não de condicionalidades no desenho de políticas sociais específicas, como forma de aumentar sua eficiência relativa - neste segundo sentido, a decisão dependeria, principalmente, da eficiência social relativa das opções em cada caso. (KERSTENETZKY, 2006).

Em países com elevados índices de pobreza, como é o caso do Brasil, esse pode ser um importante instrumento de alívio imediato da pobreza. Contudo, não podemos fechar os olhos para o fato de que houve uma estagnação nos últimos anos, em termos de gastos públicos e de políticas de cunho universal. Uma vez que essas políticas ainda não apresentam níveis de cobertura e qualidade suficientes, a falta de recursos afeta diretamente os resultados pretendidos pelas políticas sociais. Isso porque, muitas dessas políticas ficam aquém dos objetivos pretendidos, como, por exemplo, o caso da oferta de educação de baixa qualidade, que não gera condições para que a população de baixa renda supere sua condição de vulnerabilidade.

É necessário, portanto, um maior - e constante - investimento público nas áreas básicas de proteção social, para que a cobertura se pretenda universal de fato, para que os resultados se tornem satisfatórios e para que os programas sociais sejam mais amplos e coordenados.

\section{5.}

\section{As políticas sociais e os indicadores sociais e demográficos}

O desenvolvimento dos indicadores sociais está ligado à evolução das atividades de planejamento do setor público nas últimas décadas. $\mathrm{O}$ desenvolvimento da área é recente, tendo ganhado corpo científico em meados dos anos 60, com o intuito de acompanhar as transformações sociais e medir o impacto das políticas sociais na sociedade. Para Torres et. al. (2003, p.80): 
Entre outras coisas, as estatísticas constituem instrumento importante para: desenvolver melhor as políticas sociais, permitindo o acompanhamento e a evolução dos processos; aumentar o consenso social sobre as difíceis escolhas diante do sempre presente constrangimento dos recursos; revelar e criar responsabilidades dos diferentes atores envolvidos nesses processos; e incluir na agenda de políticas sociais temas muitas vezes negligenciados no campo de ação de determinada política setorial (como a questão racial, por exemplo).

Entretanto, com a maior divulgação desses dados, ficaram evidentes os desajustes entre o crescimento econômico e a melhoria das condições sociais da população na maioria dos países subdesenvolvidos e em desenvolvimento, onde mesmo com desenvolvimento econômico, ainda persistem altos os níveis de pobreza e desigualdade. No Brasil, este desajuste também ocorreu entre as unidades subnacionais, conforme verificamos em Souza \& Carvalho (1999, p.202):

As desigualdades existentes no Brasil se refletem em profundas diferenças nas condições financeiras, políticas e administrativas das entidades subnacionais e, consequentemente, na sua capacidade de resposta às necessidades e demandas da população.

Assim, indicadores como o PIB per capita, passaram a ser considerados como insuficientes para medir o desenvolvimento social. Nesse sentido, novos instrumentos de mensuração do bem estar e do desenvolvimento social foram desenvolvidos por instituições internacionais como OCDE, Unesco, FAO, OIT, OMS, Unicef, entre outras. Também os sistemas nacionais de produção e divulgação de estatísticas passaram a produzir relatórios sociais aplicando metodologias internacionais. Segundo Jannuzzi (2009), um conjunto de indicadores sociais passou a abordar temáticas sociais específicas, para análise e acompanhamento de políticas ou da mudança social.

Sem dúvidas, o avanço na qualidade dos indicadores sociais deu suporte para o aprimoramento da formulação e implementação de políticas públicas. Com isso, universidades, centros de pesquisa e sistemas de planejamento público passaram a desenvolver instrumentos para quantificação e qualificação da realidade social, alimentando a produção de indicadores sociais que dão subsídio para análise e acompanhamento das políticas e da mudança social.

Como já vimos, com a descentralização administrativa e tributária em favor dos municípios e da institucionalização do processo de planejamento público em âmbito local, informações sociais e demográficas para fins de formulação de políticas públicas municipais vêm apresentando uma demanda crescente no país. 
Municípios, principalmente os de médio e grande porte, passaram a utilizar os indicadores sócio demográficos com o objetivo de justificar o repasse de verbas federais para implementação de programas sociais.

Atualmente, a principal fonte de informação para construção de indicadores municipais no país é o censo demográfico, realizado pelo IBGE. Devido a sua abrangência temática e possibilidades de desagregação espacial, fornecem uma gama variada de informações. Além do censo, também são importantes fontes de indicadores sociais do IBGE os registros administrativos dos ministérios - da Saúde, da Educação e Trabalho - que podem ser também bastante úteis na construção de indicadores sociais. Essa disponibilidade de indicadores sociais relevantes, válidos e confiáveis certamente potencializa as chances de sucesso do processo de formulação e implementação de políticas públicas, oferecendo o mapeamento social e a possibilidade de acompanhamento de políticas/programas e sua abrangência.

Para Jannuzzi (2009), quando os indicadores sociais são utilizados de forma responsável, tornam-se instrumentos de "empoderamento" da sociedade e de controle e direcionamento das atividades do poder público:

No contexto de uma sociedade democrática o processo de planejamento não pode ser conduzido de forma tecnocrática, como se as pressões políticas não fossem legítimas ou como se os interesses divergentes não devessem ser explicitados. O planejamento público é um jogo político legítimo, no qual participam e devem participar técnicos de planejamento e vários outros stakeholders, isto é, outros grupos de pressão interessados na definição das políticas, no governo, na sociedade civil, nas diferentes instâncias da burocracia pública (federal, estadual e municipal). Não é um processo linear, mas permeado por vicissitudes e sujeito a diversos condicionantes políticos-institucionais. (JANNUZZI, 2009 p. 34-35).

Nesta pesquisa, trabalho especificamente com as políticas educacionais implementadas pela SEE-MG durante o segundo mandato do governo Aécio Neves (2006-2010). Assim, me concentro em utilizar indicadores que possam ter associação com os indicadores educacionais municipais. Tanto no Brasil, como em Minas Gerais, houve aumento das taxas de escolarização básica e de alfabetização nas décadas finais do século XX. Porém, no mesmo período, ocorreu aumento das desigualdades sociais e educacionais. Mesmo diante de indicadores positivos para a escolarização dos brasileiros, as desigualdades sociais continuaram aumentando como demonstraram os indicadores divulgados pelos órgãos federais e estaduais de pesquisas estatísticas. Nesse sentido, se faz necessário considerar estes indicadores na análise das políticas educacionais. Para 
Jannuzzi (2005), na formulação e seleção de programas, é necessário utilizar indicadores selecionados a partir dos objetivos norteadores dos programas definidos como prioritários pela agenda político-social vigente. Isso permite um diagnóstico sobre os bolsões de pobreza, as áreas com maior déficit de serviços urbanos e com maior parcela de crianças fora da escola, áreas com maior número de responsáveis sujeitos ao desemprego, etc. Assim, para o autor, nessa etapa se faz necessário definir, a partir da orientação político-governamental, a natureza dos programas, as questões sociais prioritárias a enfrentar e os públicos-alvo a atender:

É nessa fase que os indicadores sintéticos já mencionados podem ter maior aplicação, na medida em que oferecem ao gestor uma medida-síntese das condições de vida, da vulnerabilidade, do desenvolvimento social de municípios, estados ou de outra unidade territorial em que há implementação de programas. O IDHmunicipal foi, por exemplo, o indicador empregado pelo Programa Comunidade Solidária para selecionar os municípios para suas ações, o que certamente representou um avanço em termos de critério técnico-político de priorização. (JANNUZZI, 2005 p. 150).

Como já apresentei, na década de 1990 os indicadores educacionais demonstravam que o sistema educacional brasileiro evoluiu no que se refere a melhoria em relação ao acesso ao ensino fundamental, estando praticamente universalizado de acordo com os dados do censo 2000. Por outro lado, indicadores sociais mostravam resultados negativos em relação à desigualdade e exclusão social e a persistência de problemas como a baixa cobertura do ensino médio, a alta distorção entre a idade e a série adequada cursada pelo jovem e a baixa mobilidade social. Problemas que persistem até hoje.

Nesse sentido, busco nessa pesquisa justamente entender a relação entre os indicadores sociais e demográficos dos municípios mineiros para entender a abrangência das políticas educacionais implementadas no período aqui estudado. Assim, dou prioridade aos indicadores municipais relacionados aos objetivos desta pesquisa.

Com essa revisão, entendo que a teoria aponta para o entendimento de que a formulação de políticas não é uma ação unilateral do estado, mas sim o resultado de um imbricado processo que envolve não somente os aspectos políticos, mas também aspectos econômicos, sociais e ideológicos que, em sua complexidade, se tornam indissociáveis. Nesse sentido, não é possível entender as políticas educacionais como algo estático. Pelo contrário, entendo a ideia de política 
educacional como dinâmica ligada aos discursos, possibilidades, impossibilidades, a teoria e à prática. É necessário ter clareza sobre a realidade dos processos que estão entre os contextos de gênese e implementação de uma política educacional, ou seja, considerar a distância entre o debate, a formulação de políticas, implementação e a real mudança provocada no desempenho dos estudantes, nas escolas e na sociedade como um todo. O próximo passo envolve investigar os indicadores sociais, demográficos e educacionais dos municípios mineiros, o que será tratado nos capítulos a seguir. 


\title{
3. \\ Minas Gerais e seus indicadores sociais, demográfi educacionais.
}

\author{
Minas, são muitas. Porém, poucos são \\ aqueles que conhecem as mil faces das \\ Gerais. (Guimarães Rosa)
}

Minas são muitas, como também muitos são os mineiros como descreveu João Guimarães Rosa em seus contos e romances. Minas Gerais é o segundo Estado mais populoso do país, com uma população superior a 20 milhões de habitantes e o quarto maior em extensão territorial, com $586.528 \mathrm{~km}^{2}$, área superior à da França. Suas dimensões geográficas permitem ao Estado manter fronteiras com Rio de Janeiro, São Paulo, Espírito Santo, Bahia, Goiás e Mato Grosso do Sul ampliando suas conexões culturais e dando à sua população características ímpares.

Para essa pesquisa, é fundamental conhecer as diferenças existentes ao longo do território mineiro. Com o objetivo de estudar a abrangência das políticas educacionais implementadas pelo Estado, apresento aqui as principais características e indicadores sociais e demográficos do Estado e dos municípios mineiros. Como já dito, embora não seja meu objetivo mensurar o efeito das políticas educacionais aqui analisadas, esses indicadores serão utilizados para verificar associações dessas variáveis com o desempenho médio por município dos estudantes do terceiro ano do ensino médio nas avaliações de língua portuguesa e matemática das escolas da rede estadual de Minas Gerais.

Para isso, a seguir descrevo as principais características sociais, econômicas e demográficas do Estado de Minas Gerais e de seus municípios. Podemos constatar nas pesquisas de Amaral (2007), Costa et. al. (2012) e Santos \& Pales (2012), que é fato a existência de importantes disparidades econômicas e sociais entre as regiões e os municípios do Estado de Minas Gerais. Estas disparidades refletem na distribuição de indicadores sociais e demográficos dos municípios mineiros, sendo sensíveis as diferenças regionais Norte-Sul com relação aos níveis social e econômico, sendo que as regiões que apresentam taxas menos favoráveis concentram-se principalmente no norte e nordeste do estado. Em contrapartida, as regiões com maior desenvolvimento estão no Centro-Sul e 
Triângulo Mineiro. As desigualdades geográficas persistem, apesar dos inúmeros programas e ações políticas implementados nos últimos anos com objetivo de promover o avanço das regiões menos desenvolvidas de Minas Gerais.

Nesse sentido, é importante ressaltar que o Estado de Minas Gerais é marcado não só pela diversidade cultural e espacial, mas também pela desigualdade de desenvolvimento entre seus municípios. Analisando os efeitos da descentralização política no Brasil, Souza \& Carvalho dão destaque para a desigualdade entre os municípios:

A diversidade política, econômica e social do Brasil provoca grandes diferenças entre os municípios. Essas diferenças prejudicam os próprios objetivos da descentralização e das reformas, na medida em que a descentralização financeira a favor das esferas subnacionais reduz as possibilidades de ajuda federal e estadual às esferas locais com o objetivo de minimizar os efeitos das referidas desigualdades. (SOUZA\&CARVALHO, 1999 p. 208).

Essa desigualdade é verificada não só nos níveis de desenvolvimento social e humano, mas também nos níveis de desenvolvimento educacional medidos pelas avaliações em larga escala e pelos índices de desenvolvimento da educação existentes no país e no Estado. Outro indicador que está correlacionado com a qualidade educacional são os níveis de qualidade de vida da população. Para Cirino \& Cassuce (2012), avanços na educação no Estado de Minas Gerais poderiam contribuir com a redução da desigualdade entre os municípios mineiros:

A capacidade da qualidade educacional de gerar renda também deve ser levada em consideração no Estado de Minas Gerais, uma vez que este apresenta altos índices de desigualdade de renda e até mesmo dificuldade de gerar renda em determinadas regiões. Um aumento na qualidade da educação poderia elevar a produtividade da mão de obra e, consequentemente, a renda das regiões mais pobres do Estado. (CIRINO \& CASSUCE, 2012 p.2)

É interessante perceber esse paradoxo, ou seja, a educação é considerada uma solução para uma das causas de seu fracasso. Para esses autores, o desenvolvimento econômico das regiões mineiras é desigual bem como seu sistema educacional. Melhorar a qualidade educacional das regiões mais pobres do Estado pode ser uma saída para reduzir as desigualdades socioeconômicas que, como vamos ver ao longo deste capítulo, são muitas. 


\section{1. \\ Indicadores sócio demográficos, educacionais e a qualidade da educação nos município mineiros}

Embora meu foco nessa pesquisa seja o ensino médio nas escolas da rede estadual de Minas Gerais, mantenho como unidade de pesquisa os municípios mineiros tendo como justificativa a possibilidade de nesta unidade trabalhar ao mesmo tempo as médias de proficiência dos estudantes, os indicadores sócio demográficos e também mapear a abrangência das políticas educacionais. É importante lembrar que no Brasil o município é a menor unidade de governo com autoridade para implementar políticas públicas e assim exercer alguma influência nas escolas neles situadas, mesmo no caso das escolas de EM que estão sob a gestão da SEE-MG. Um exemplo dessa influência é o fato de que por força da legislação vigente, a maioria dos municípios possui suas próprias redes de $\mathrm{EF}$, o que significa que no EM a rede estadual de educação absorve estudantes oriundos de centenas de redes municipais de educação. Nesse sentido, conhecer as características municipais por meio das variáveis sociais e demográficas constituise em um importante instrumento para conhecer as diferenças e especificidades dos municípios e regiões mineiras e consequentemente orientar o direcionamento de políticas que atendam as demandas mais específicas dos mesmos. Dessa forma, este estudo considera as características municipais que se correlacionam com a abrangência das políticas educacionais voltadas para o EM no estado de Minas Gerais.

Como já mencionei, a unidade de análise desta pesquisa é o município e esta opção justifica-se pelo fato de ser a menor unidade político-administrativa do país e com isso ser possível ter acesso às variáveis sociais e espaciais de domínio público. Além disso, tendo o município como unidade de análise, é possível realizar comparações e analisar a correlação entre os indicadores de qualidade da educação agregados pela média municipal. Por outro lado, é necessário ressaltar que mesmo trabalhando com uma unidade que agrega informações dos alunos e das escolas, a base de dados que utilizo ainda guarda uma grande quantidade de dados, visto que a rede estadual de educação mineira abrange os 853 (oitocentos e cinquenta e três) municípios do Estado. 
É necessário considerar que o elevado número de municípios de Minas Gerais cria uma condição de desafio para a implementação das políticas públicas educacionais no estado. Contudo, esta é uma das questões que pretendo explorar ao longo desta investigação, já que os números recentes do Instituto Brasileiro de Geografia e Estatística (IBGE) revelam que a desigualdade socioeconômica e demográfica ainda é um desafio para as políticas públicas no Estado.

Com relação aos indicadores educacionais, a situação não é diferente. Conforme estudos da Fundação João Pinheiro - FJP (2011) sobre os dados do censo demográfico de 2010, o contingente de pessoas que frequentavam a escola em 2010 era de $29 \%$ da população do Estado. Dessas pessoas, $80 \%$ frequentavam a rede pública. De acordo com o censo, o nível de ensino mais representativo em Minas Gerais era o fundamental com $50,3 \%$ das pessoas que frequentavam a escola em 2010, seguido do ensino médio, com 18,2\%.

Nesse mesmo estudo, ao comparar os grupos etários que deveriam frequentar os ensinos fundamental e médio em 2010, ou seja, crianças e adolescentes com idades entre 7 e 14 anos e entre 15 e 17 anos, respectivamente, observou-se na última década uma redução no número de estudantes que não frequentavam a escola. Contudo, 16,5\% dos adolescentes ainda estavam fora da escola em Minas Gerais.

Como já vimos, assim como no Brasil e em todos os estados brasileiros, Minas Gerais sofre as consequências de um processo histórico de construção da desigualdade social e demográfica que reflete na distribuição da riqueza e das oportunidades educacionais para a sua população. Essa distribuição desigual torna-se evidente quando analisamos indicadores de população, PIB, renda, Desenvolvimento Humano Municipal, desigualdade ou desenvolvimento municipal. Essa é uma das minhas propostas para este trabalho e para isso vou descrever aqui as principais variáveis que utilizo para analisar as políticas educacionais implementadas em Minas Gerais entre os anos de 2006 e 2010. 


\subsection{1. População, PIB e renda per capita}

Distribuição da população.

No último censo demográfico, realizado no país em 2010, o Estado de Minas Gerais tinha uma população de 19.595.309 de pessoas distribuídas em 853 municípios (IBGE, 2010). Minas Gerais é o Estado brasileiro com maior número de municípios. Além disso, é grande a variação do porte desses municípios. No censo de 2010, 4 de cada 10 mineiros viviam em municípios pequenos, com população de até 50.000 habitantes, sendo que $26,26 \%$ desses habitantes viviam em municípios com até 20.000 habitantes como se verifica na tabela 3. Os municípios de médio porte concentravam 13,48\% da população mineira, 31,30\% viviam em municípios de grande porte e $12,12 \%$ dos habitantes concentravam-se na capital do Estado.

Tabela 1 - Distribuição da população mineira de acordo com o porte do município censo demográfico 2010.

DISTRIBUIÇÃO DA POPULAÇÃO DE MINAS GERAIS DE ACORDO COM O PORTE
DO MUNICÍPIO

\begin{tabular}{l|r|r|r|r}
\hline \multicolumn{1}{c|}{ PORTE DO MUNICÍPIO* } & MUNICíPIOS & \multicolumn{1}{c|}{$\%$} & \multicolumn{1}{c|}{ POPULAÇÃO } & $\%$ \\
\hline $\begin{array}{l}\text { Municípios de Pequeno Porte 1 - população até } \\
\text { 20.000 habitantes. }\end{array}$ & 675 & 79.13 & 5145330 & 26.26 \\
\hline $\begin{array}{l}\text { Municípios de Pequeno Porte 2 - população de 20.001 } \\
\text { a 50.000 habitantes. }\end{array}$ & 112 & 13.13 & 3300894 & 16.84 \\
\hline $\begin{array}{l}\text { Municípios de Médio Porte - população de 50.001 a } \\
\text { 100.000 habitantes. }\end{array}$ & 37 & 4.34 & 2642693 & 13.48 \\
\hline $\begin{array}{l}\text { Municípios de Grande Porte - população de 100.001 } \\
\text { mil a 900.000 habitantes. }\end{array}$ & 28 & 3.28 & 6133262 & 31.30 \\
\hline $\begin{array}{l}\text { Metrópoles - população de mais de 900.000 } \\
\text { habitantes. }\end{array}$ & 1 & 0.12 & 2375151 & 12.12 \\
\hline População total de Minas Gerais & 853 & 100.0 & 19597330 & 100.0 \\
\hline
\end{tabular}

*Classificação dos municípios conforme o número de habitantes (IBGE)

Fonte: Elaborado pelo autor com dados do censo demográfico do IBGE (2010)

Podemos visualizar melhor esses dados nos gráficos abaixo. Além dos municípios de pequeno porte representarem a maioria absoluta em número, a soma da população dos mesmos representa o segundo maior grupo no Estado, ficando atrás apenas da população residente em municípios de grande porte. Este aspecto deve ser levado em consideração já que o porte do município está relacionado ao seu desenvolvimento econômico. 
Gráfico 3 - Porte dos municípios de Minas Gerais - frequência - 2010.

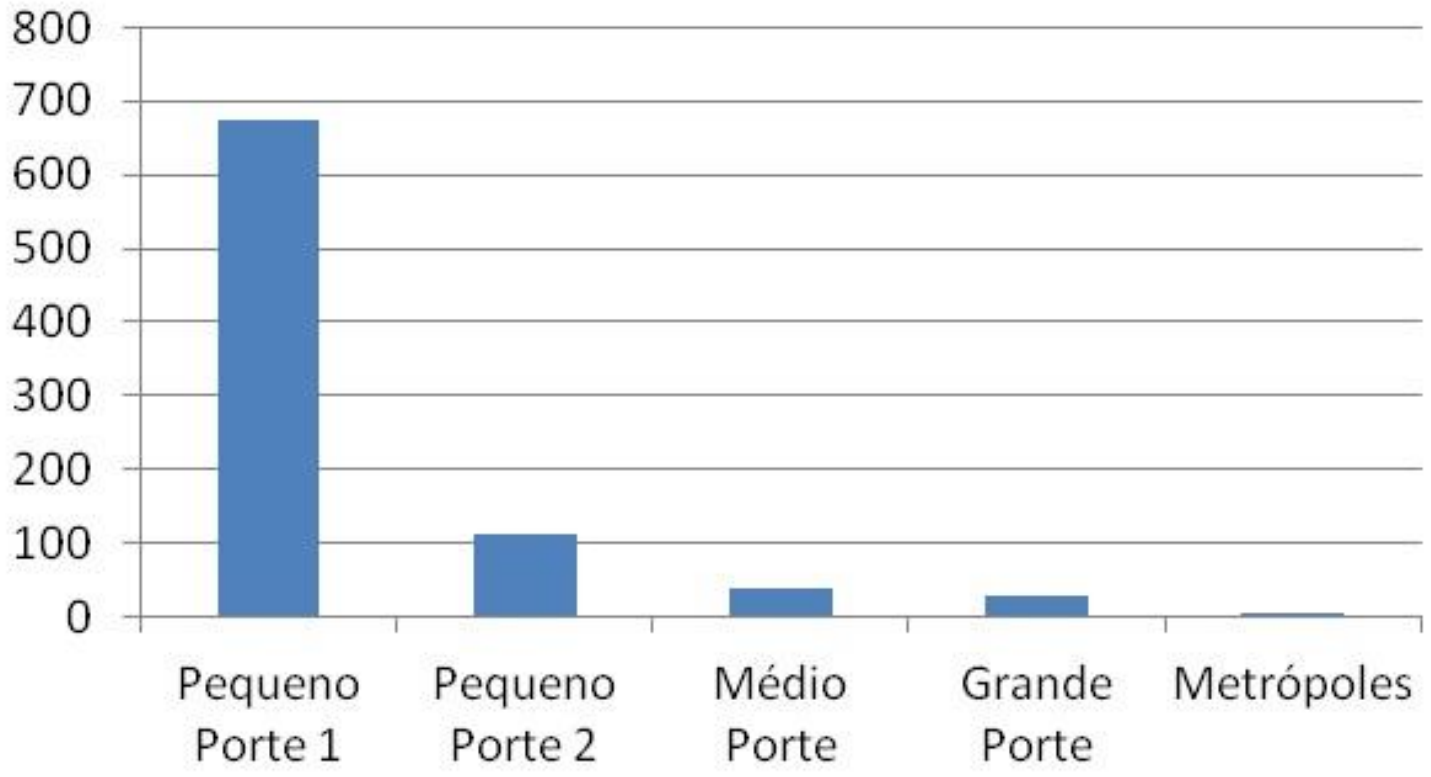

Fonte: Elaborado pelo autor com dados do IBGE - 2010.

Pissaia (2011) ao investigar a implementação da política de municipalização do Ensino Fundamental no estado de São Paulo, verificou que os municípios de pequeno porte apresentaram maiores dificuldades em garantir a gestão de seus sistemas. O autor argumenta que apenas o "principio" norteador de equidade social e educacional, não garante aos municípios de pequeno porte implementação de políticas públicas educacionais que atendam à demanda (quantitativa/qualitativa), as quais impliquem em efetiva autonomia administrativa e pedagógica e que favoreçam a gestão municipal de recursos de forma sustentável e participativa. Para o autor:

A situação estrutural de gestão, a condição financeira e econômica e a autonomia dos Municípios de Pequeno Porte para fazer gestão em prol da qualidade educacional implicaram em elementos chaves no contexto de estratégia de política local na implementação de políticas públicas educacionais. Assim, a municipalização do ensino, se por um lado, poderia propiciar condições concretas de melhoria substancial da qualidade de gestão em educação, por outro, concorreria para a manutenção da vulnerabilidade e à incidência de contínuos e recentes erros e equívocos. (PISSAIA, 2011 p. 3).

Em seu estudo, o autor concluiu que a implementação da política de municipalização do ensino, em municípios de qualquer porte, restrita apenas aos repasses de recursos e ações esporádicas, por vezes desconexas, não promove condições plenas de gestão municipal e melhoria substancial na qualidade da educação nos municípios, em especial nos de pequeno porte. Ainda sobre a 
municipalização da educação no Brasil, Azevedo (2002) constata que "vários estudos demonstram que há correlação entre o tamanho dos municípios e os níveis de pobreza neles encontrados". (AZEVEDO, 2002. p. 62). Isso é um fato que influencia diretamente na capacidade destes municípios investirem nos seus próprios sistemas de educação, aumentando a dependência do sistema estadual e de repasses federais. Além disso, de acordo com Gomes \& Macdowell (2000), a descentralização política, a proliferação de municípios e o aumento dos recursos tributários apropriados pelos municípios, especialmente os de menor tamanho:

Aumentaram os recursos utilizados no pagamento de despesas administrativas (custeios de gabinetes de prefeitos, câmaras de vereadores e administrações municipais), ao mesmo tempo em que reduziram, em termos relativos, o montante de recursos que o setor público (União, estados e municípios) tinha disponíveis para aplicar em programas sociais e em investimentos. (GOMES\&MACDOWELL, 2000 p. 24).

Gráfico 4 - Porte dos municípios de Minas Gerais - \% de População por grupo 2010.

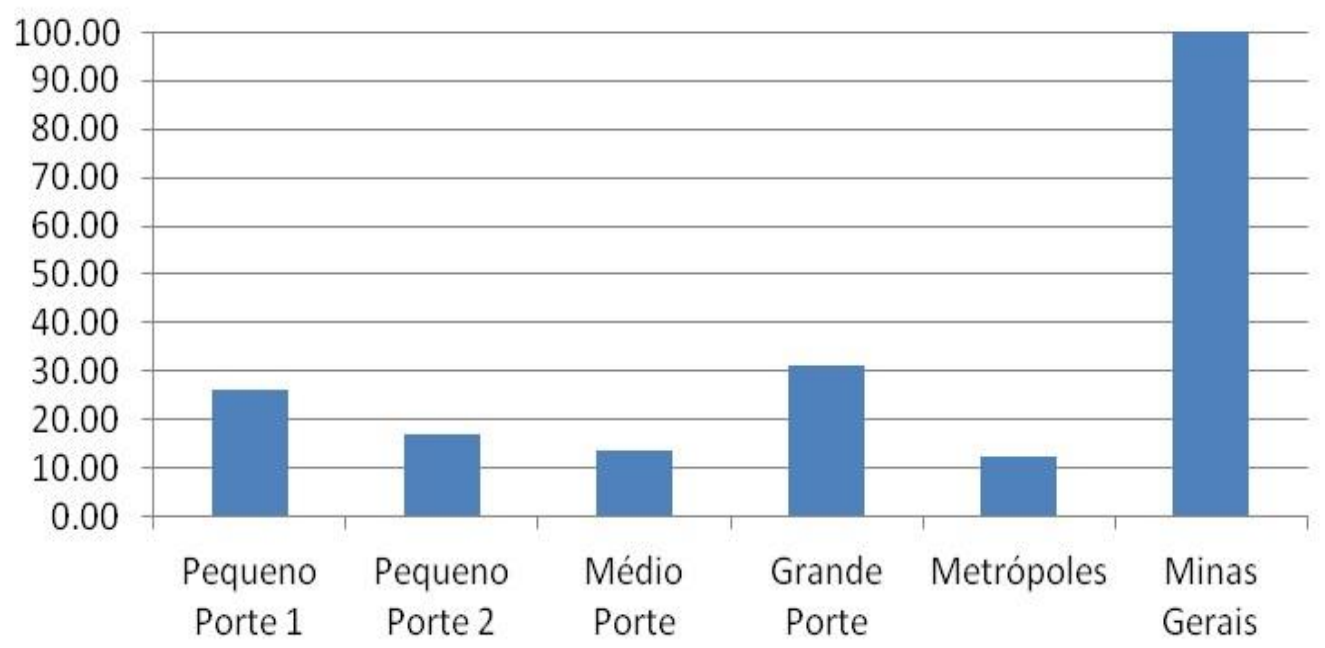

Fonte: Elaborado pelo autor com dados do IBGE - 2010.

Ainda com referência ao porte dos municípios, Vaitsmam et. al. (2006) dão destaque ao fato que a maior parte dos 5.564 municípios brasileiros é de pequeno porte e com capacidade administrativa e gerencial limitada. Segundo os autores é possível encontrar centenas de cenários tecnológicos, conforme a capacidade dos municípios. Com isso, a coleta de informações para alimentar os sistemas gerenciais usados para monitorar os programas requer soluções muito individualizadas para atender prontamente às responsabilidades de cada município. 
Assim, é necessário considerar o porte dos municípios no processo de implementação de políticas públicas educacionais. Especificamente no caso de Minas Gerais, conforme podemos verificar acima nos gráficos 3 e 4, cerca de $80 \%$ dos municípios são de pequeno porte e abrigam aproximadamente $40 \%$ da população do Estado, ou seja, 8 milhões de habitantes.

Para visualização desta desigualdade, apresento no mapa 1 a distribuição da população no estado de Minas Gerais de acordo com o porte do município e percentual de população total concentrado em cada categoria. Com isso podemos verificar que a grande maioria do municípios mineiros é de pequeno porte que, como vimos, juntos (pequeno porte 1 e 2) somam $40 \%$ da população do estado, conforme podemos verificar pelas áreas mais claras do mapa.

Mapa 1 - Minas Gerais - densidade demográfica em \%.

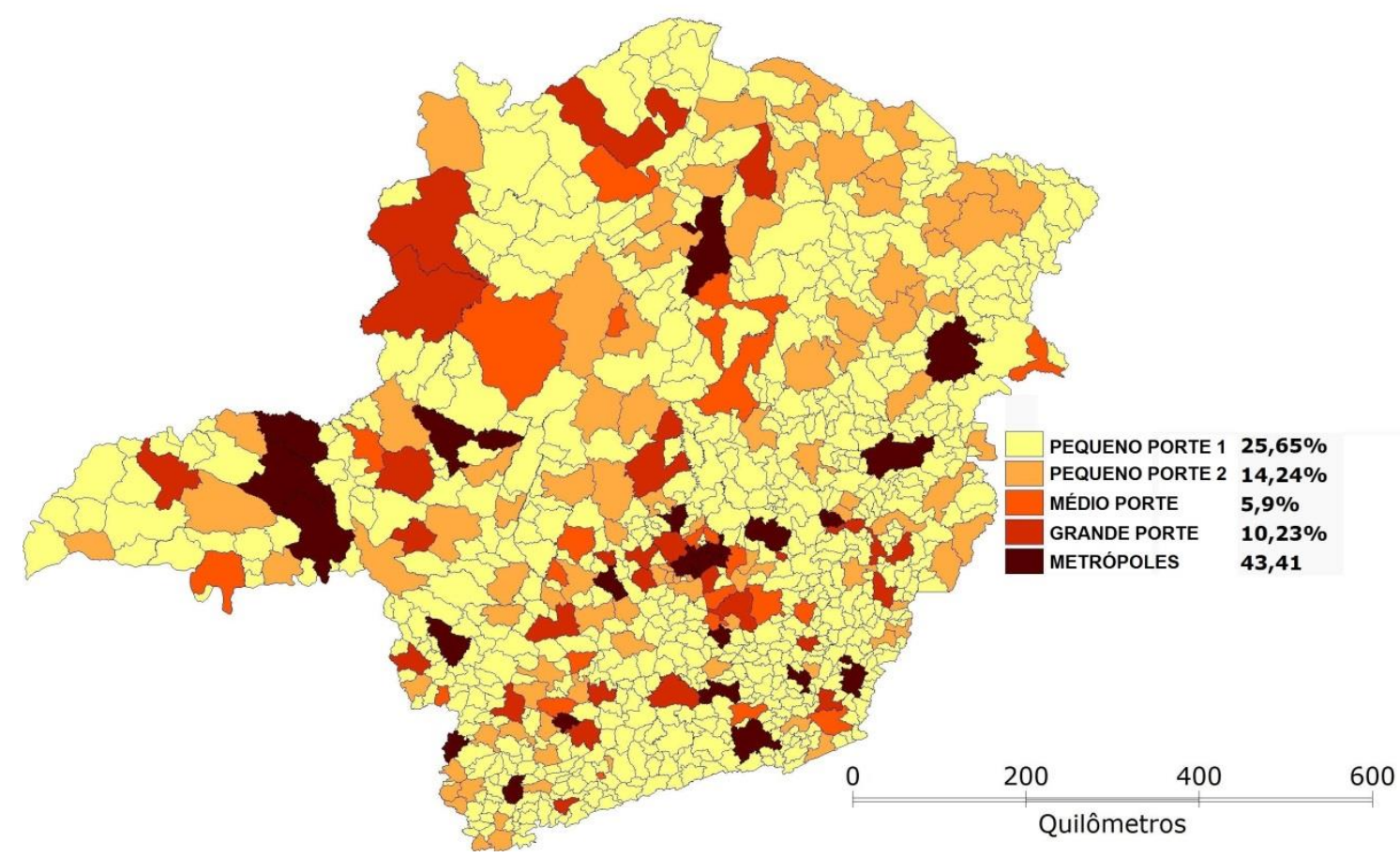

Fonte: Elaborado pelo autor com dados do IBGE/CENSO 2010.

Distribuição de riqueza.

De acordo com o IBGE, o PIB mineiro em 2008 representava 9,37\% do conjunto de riquezas geradas pelo Brasil. Em 2010, houve um crescimento real médio de $10,9 \%$ do PIB mineiro, em relação a 2009, superando em 3,4 pontos percentuais o resultado nacional que era de 7,5\%. Com esses números, o Estado 
de Minas Gerais passou a ser a terceira economia do país, podendo ser comparado a economias de países como Chile, Israel ou República Tcheca.

Mesmo com uma economia de destaque no cenário nacional, Minas Gerais ainda mantém uma distribuição de riqueza bastante desigual, como mostram os dados apresentados abaixo no mapa 2. Juntas, as regiões Central, Sul e Triângulo respondem por cerca de $70 \%$ do Produto Interno Bruto (PIB) mineiro, baseados nos resultados de 2009, que levaram em consideração dez regiões de Minas Gerais. Somente a Região Central, onde estão concentrados os principais complexos mineradores do estado, responde por $45,8 \%$ do PIB mineiro. A Região Metropolitana de Belo Horizonte (RMBH), sozinha, responde por 41,92\% do PIB. Essa irregularidade na distribuição do PIB demonstra o desequilíbrio no desenvolvimento econômico entre os municípios do Estado, e a necessidade de analisar o efeito das políticas voltadas para redução da desigualdade econômica e social.

Mapa 2 - Participação no PIB do estado por macrorregião.

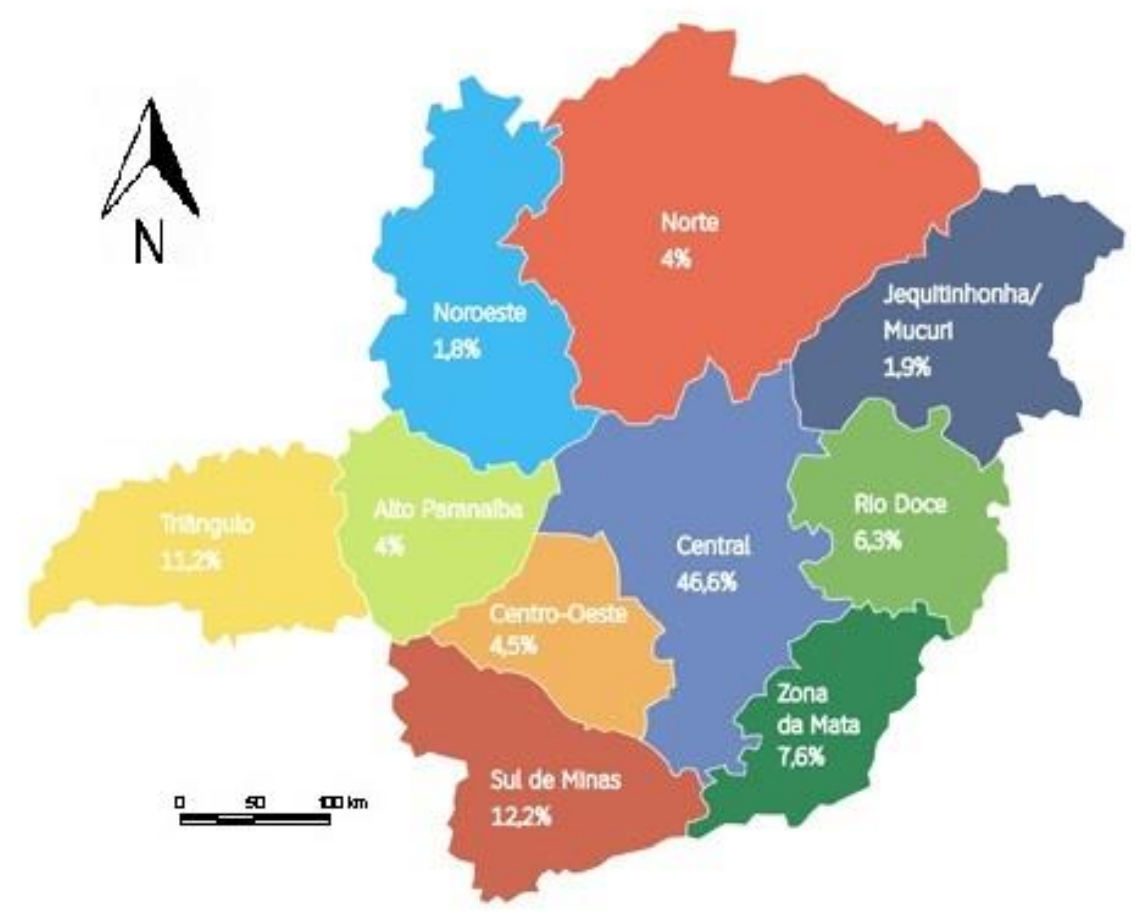

Fonte: IBGE (2009)

Mesmo possuindo o terceiro maior PIB brasileiro, Minas Gerais não possui renda per capita elevada pelo fato de possuir a segunda maior fatia da população total do país $(10,4 \%)$. Isso faz com que Minas Gerais ocupe apenas a nona posição 
com relação ao PIB per capita, como se verifica abaixo na tabela 4. Com isso, Minas acaba tendo uma situação de desvantagem em relação a outros estados com menor PIB. Esta baixa renda per capita também influencia os baixos índices de desenvolvimento humano do Estado.

Tabela 2 - PIB per capita por UF - 2010.

\begin{tabular}{c|c|c}
\hline Posição & Estado & $\begin{array}{c}\text { PIB - per capita } \\
\text { (em R\$) }\end{array}$ \\
\hline 1 & Distrito Federal & 58489 \\
\hline 2 & São Paulo & 30243 \\
\hline 3 & Rio de Janeiro & 25455 \\
\hline 4 & Santa Catarina & 24398 \\
\hline 5 & Rio Grande do Sul & 23606 \\
\hline 6 & Espírito Santo & 23378 \\
\hline 7 & Paraná & 20813 \\
\hline 8 & Mato Grosso & 19644 \\
\hline 9 & Minas Gerais & 17931 \\
\hline
\end{tabular}

\subsection{2. \\ Índice de desenvolvimento humano municipal (IDH-M)}

O Índice do Desenvolvimento Humano- IDH foi elaborado em 1990 pelo paquistanês Mahbub ul Haq com apoio do economista indiano Amartya Sen ganhador do Prêmio Nobel de Economia de 1998. Esse índice tinha como objetivo medir o nível de desenvolvimento humano dos países a partir de indicadores de educação (alfabetização e taxa de matrícula), longevidade (expectativa de vida ao nascer) e renda (PIB per capita), sendo que seus valores variam de 0 (nenhum desenvolvimento humano) a 1 (desenvolvimento humano total). O IDH pode ser utilizado também para analisar ou comparar o desenvolvimento de municípios, passando a ser denominado de IDH-Municipal ou IDH-M, focando nas mesmas dimensões que o IDH país - educação (taxa de alfabetização de pessoas acima de 15 anos e taxa bruta de frequência a escola), longevidade (expectativa de vida) e renda (renda municipal per capita).

Calculados os índices específicos de cada uma das três dimensões: IDHME, para a educação, IDHM-L, para a saúde (longevidade), e IDHM-R, para a renda, são determinados os valores de referência mínimo e máximo de cada 
categoria, que serão equivalentes a 0 e 1 , respectivamente, no cálculo do IDH-M. Por fim, chega-se ao IDH-M de cada município calculando a média aritmética das três dimensões encontradas: somam-se os valores e divide-se o resultado por três (IDHM-E + IDHM-L + IDHM-R / 3).

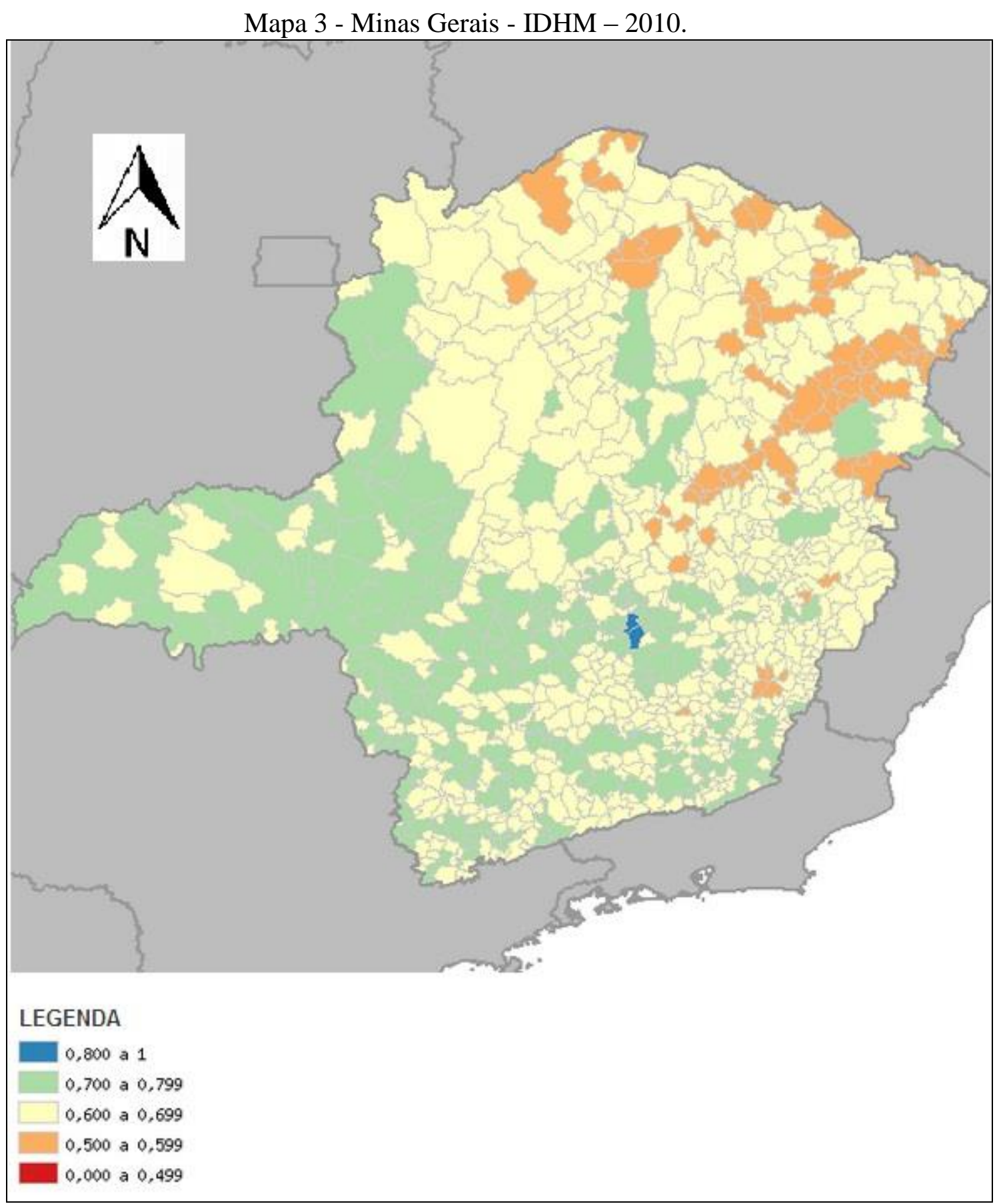

Fonte: Atlas de Desenvolvimento Humano/PNUD (2013)

A primeira medição do IDH dos Estados brasileiros foi elaborada em 1998, com dados fornecidos pelo censo demográfico de 1991, a partir do cálculo 
do IDH-M. Em 1991, Minas Gerais apresentava o IDH-M de 0,478, ocupando a última posição dos Estados do Sudeste Brasileiro, atrás do Rio de Janeiro, São Paulo e Espírito Santo. Naquele ano, Minas Gerais ocupava a $10^{\text {a }}$ colocação no ranking nacional.

Com os dados do censo demográfico de 2000, o PNUD voltou a calcular o IDH-M. Minas Gerais, como os demais Estados, avançou nas três dimensões. O IDH-M de 2000 referente a Minas Gerais alcançou 0,624 e sua posição no ranking nacional subiu para o $8^{\circ}$ lugar, ultrapassando os Estados de Goiás e Espírito Santo.

Em 2013, foram publicados os dados do IDHM-2010 ${ }^{4}$. Todos os estados do Sul e Sudeste apresentaram o IDHM e subíndices superiores aos do Brasil, com exceção de Minas Gerais que, na dimensão Renda apresentou índice de 0,730 contra IDHM Renda do país que foi de 0,739.

Analisando o mapa 3, podemos constatar que, internamente, o Estado de Minas Gerais apresenta grande discrepância. Ainda em 2010, nota-se que, embora a média do IDH-M do Estado tenha evoluído, ainda existe um número expressivo de municípios concentrados principalmente nas regiões Norte e Jequitinhonha com IDH-M abaixo de 0,6. Os municípios com maior desenvolvimento humano estão distribuídos entre as regiões Centro-Sul e Triângulo Mineiro, e apenas a região metropolitana de Belo Horizonte apresenta IDHM superior a 0.8.

\subsection{3. Coeficiente de GINI}

O Índice de GINI é na verdade um índice de concentração, ou seja, uma medida que avalia o grau de desigualdade da distribuição dos rendimentos de uma determinada população. Este índice varia entre 0 que corresponde a uma situação de igualdade perfeita da distribuição de rendimentos, ou seja, quando todos os habitantes da população estudada possuem a mesma renda e 1, que indica a desigualdade máxima, ou concentração máxima de renda, em que apenas um indivíduo ou grupo se apropria de toda a renda da população estudada.

Em seu primeiro relatório sobre desenvolvimento humano para a América Latina e Caribe em que aborda especificamente a distribuição de renda, o

\footnotetext{
${ }^{4}$ Atlas de desenvolvimento Humano do Brasil. Disponível em: http://atlasbrasil.org.br.
} 
Programa das Nações Unidas para o Desenvolvimento (PNUD) constatou que a região continua sendo a mais desigual do planeta.

Mapa 4 - Minas Gerais - Índice de GINI por município - 2010.

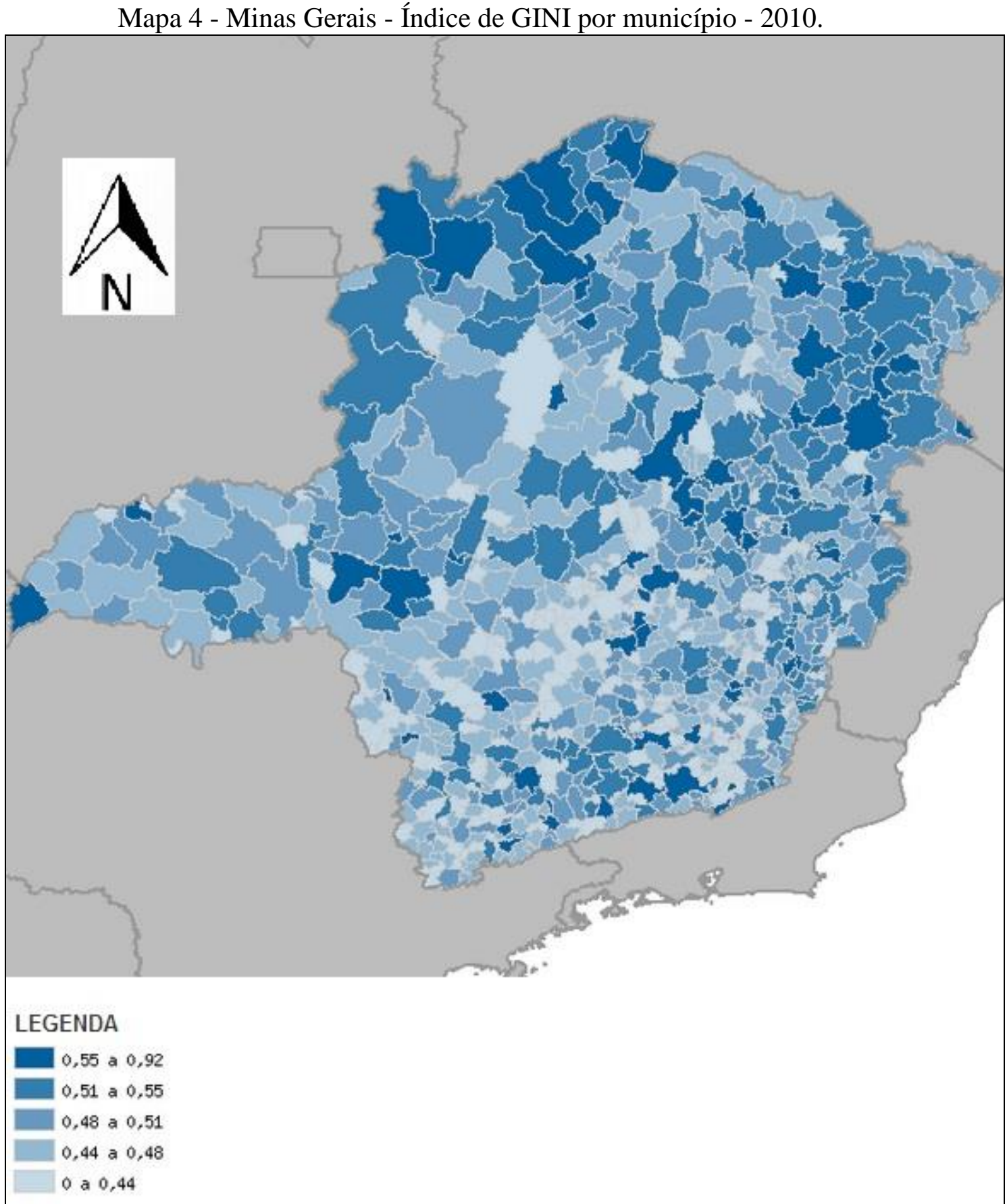

Fonte: Atlas de Desenvolvimento Humano/PNUD (2013)

Dos 15 países do mundo nos quais a distância entre ricos e pobres é maior, 10 estão na América Latina e Caribe. O Brasil tem o terceiro pior Índice de GINI do mundo. A concentração de renda só é pior na Bolívia, Camarões e Madagascar, com 0,60; seguidos de África do Sul, Haiti e Tailândia, com 0,59. O relatório 
considera a renda domiciliar per capita e o último dado disponível em que era possível a comparação internacional. No caso do Brasil, porém, a desigualdade de renda caiu fortemente nos últimos anos e, em 2008, o Índice de GINI estava em 0,515 .

Na região, os países onde há menos desigualdade são Costa Rica, Argentina, Venezuela e Uruguai, com GINI inferior a 0,49. Na média, segundo o PNUD, o Índice de GINI da América Latina e do Caribe é 36\% maior que o dos países do leste asiático e $18 \%$ maior que os da África Subsaariana.

Com relação à desigualdade, constatamos no mapa acima que, em 2010, os municípios com maior desigualdade estavam no norte e nordeste do Estado, enquanto que os municípios menos desiguais aparecem entre o centro e sul do Estado.

\subsection{4. \\ Índice FIRJAN de desenvolvimento municipal - IFDM}

O IFDM é um estudo anual do Sistema FIRJAN $^{5}$ que acompanha o desenvolvimento de todos os municípios brasileiros em três áreas: Emprego e Renda, Educação e Saúde. Este índice é construído a partir de bases estatísticas públicas oficiais, disponibilizadas pelos ministérios do Trabalho, Educação e Saúde.

O IFDM também apresenta o resultado nacional discriminado por unidades da Federação, por meio da divulgação oficial das variáveis componentes do índice por estados e para o país.

Este índice também varia entre 0 e 1 , sendo que quanto mais próximo de 1 , maior o desenvolvimento da localidade. A análise da evolução desse índice permite a verificação do desenvolvimento dos municípios brasileiros e sua correlação com a adoção de políticas municipais.

5 O Sistema FIRJAN reúne cinco organizações com foco no desenvolvimento industrial. São elas: FIRJAN - Federação das Indústrias do Estado do Rio de Janeiro, CIRJ - Centro Industrial do Rio de Janeiro, SESI - Serviço Social da Indústria, SENAI - Serviço Nacional de Aprendizagem Industrial e IEL - Instituto Euvaldo Lodi. 


\section{2.}

\section{Números do ensino médio no Brasil e em Minas Gerais}

\subsection{1.}

Acesso

Aqui apresento alguns números sobre o EM no Brasil e em Minas Gerais. O Censo Escolar, realizado pelo Instituto Nacional de Estudos e Pesquisas Educacionais Anísio Teixeira (INEP) oferece sinopses estatísticas sobre a educação básica e disponibiliza dados preciosos para a pesquisa. Com relação ao acesso, podemos verificar no gráfico 5 que as matrículas apresentaram movimentos de expansão entre 1991 e 2004 (variação de 143\%) e depois uma queda de 9\% até 2007 e em seguida uma estabilização até 2010, conforme dados do INEP. Nesse período, com base nos dados da Pesquisa Nacional por Amostra de Domicílios (PNAD), do Instituto Brasileiro de Geografia e Estatística (IBGE), a taxa líquida de matrícula para a população de 15 a 17 anos passou de 17,3\%, em 1991, para 32,7\%, em 1999, atingindo 44,2\% em 2004 e 50,9\% em 2009 (IBGE, 2010). Mesmo com esse expressivo crescimento, os números demonstram que o acesso ainda é uma questão preocupante, considerando que metade dos jovens dessa faixa etária estão fora do EM por ainda permanecerem no Ensino Fundamental $(34,3 \%)$ ou estarem fora da escola $(14,8 \%)$.

Gráfico 5 - Percentual de matriculas do EM por dependência administrativa: Brasil (1991 a 2010).

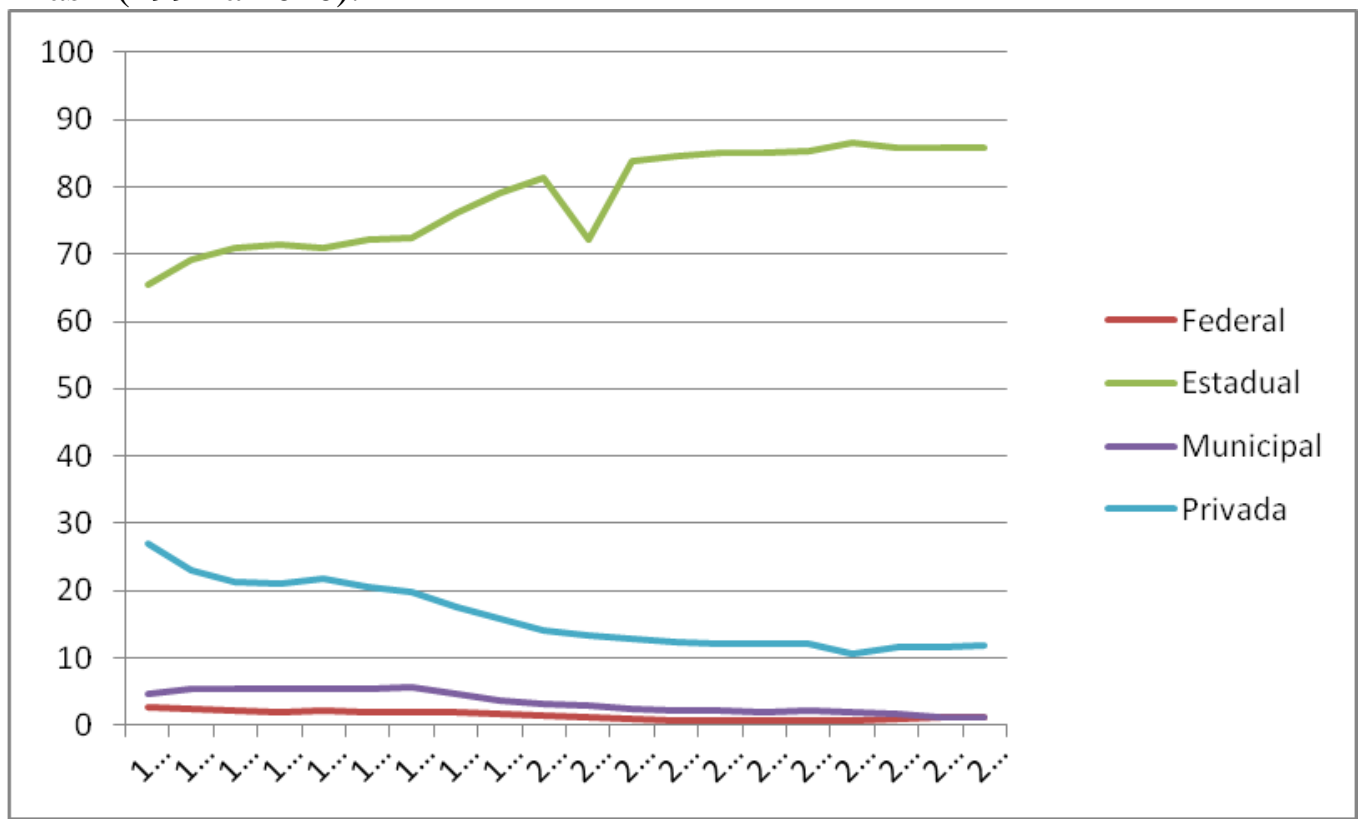

Fonte: MEC/INEP 
No gráfico acima, também podemos constatar que a rede pública ampliou seu atendimento enquanto a rede privada permaneceu com um número de matrículas estável e, por consequência, diminuiu sua participação no percentual total de matrículas no EM. A participação das escolas privadas no total de matrículas diminuiu de 27\% para 11,8\% entre os anos de 1991 e 2010. No âmbito das escolas públicas, as redes estaduais passaram de 65,5\% em 1991 para 85,9\%, em 2010, do total das matrículas, totalizando 97,4\% das matrículas de escolas públicas. Embora o EM legalmente seja responsabilidade do Estado, um reduzido número de municípios ainda mantêm este nível de ensino, principalmente na modalidade Educação de Jovens e Adultos (EJA).

Gráfico 6 - Matriculas do Ensino Médio (Regular e EJA) Minas Gerais Rede Estadual (2002 a 2009).

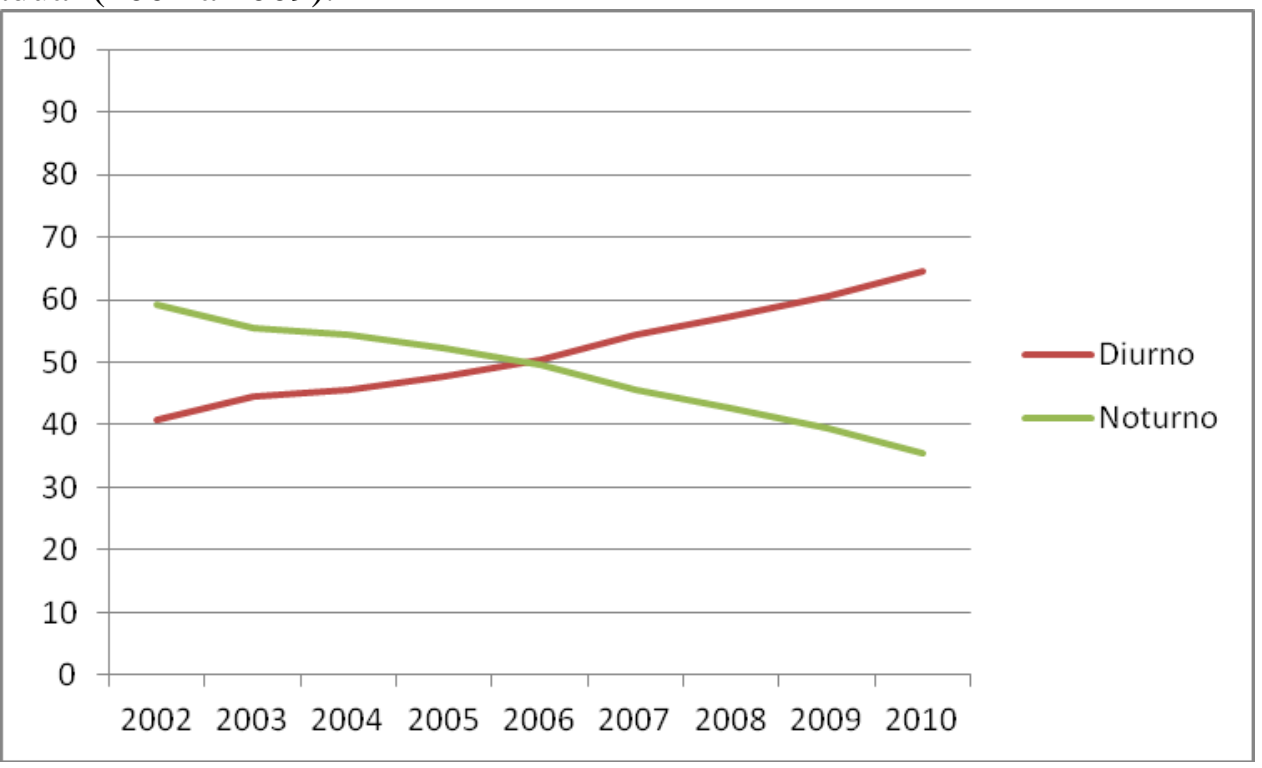

Fonte: Censo Escolar - INEP/MEC

Acima, no gráfico 6, verificamos as matrículas por turno da rede estadual de Minas Gerais. Desde 2002 constata-se um movimento contínuo de crescimento do percentual de matrículas no diurno, que passa de 40,8\% em 2002 para 64,6\% em 2010. Embora uma análise otimista desses números possa identificar uma tendência de melhoria, é preocupante verificar que em oito anos a matrícula total do EM em Minas Gerais tenha decrescido cerca de $7 \%$.

LIMA (2011) analisa que entre os anos 2000 e 2009 a população na faixa etária entre 15 e 17 anos não sofreu alterações significativas e a Taxa de Matrícula 
Líquida (TML) de indivíduos em idade própria aumentou ano a ano ${ }^{6}$. Com isso a capacidade do ensino médio de absorver discentes fora da faixa etária pode ter diminuído. Como consequência, a Taxa de Matrícula Bruta (TMB) cresceu em ritmo muito menor: de $73 \%$ em 2000 para $85,5 \%$ em 2008. Nesse contexto, a taxa de distorção idade-série no ensino médio diminuiu significativamente de 2007 para 2009. Para o autor, a evolução da taxa na $1^{\text {a }}$ série da escolarização secundária (de 44,8\% em 2007 para 38,1\% em 2009) deve ser observada com cuidado: representa, por um lado, que uma quantidade menor de maiores de 15 anos ingressou no ensino médio e, por outro, que muitos adolescentes ainda estão "presos" no ensino fundamental. (LIMA, 2011 p. 281).

Além disso, notamos que, embora a matrícula do noturno esteja diminuindo em 2010, aproximadamente 4 de cada 10 estudantes do EM ainda estudam no turno da noite. GOMES (2011) argumenta que essa distribuição tem impacto considerável na qualidade da educação praticada no Ensino Médio, em face do volume elevado de matrículas noturnas, cujas condições de estudo, do fazer pedagógico e as relações do trabalho docente são extremamente inapropriadas. RODRIGUES (2011), ao pesquisar as oportunidades educacionais do EM no Rio de Janeiro constatou que grande parte das escolas estaduais funcionam em prédios cedidos ou alugados, que frequentemente são utilizados por outras escolas, restando para o EM somente o período noturno. Na maioria dos casos, são prédios de uso múltiplo, sobretudo nas regiões de periferia. Para o autor isso dificulta a relação de pertencimento e coesão institucional de professores e alunos.

Abaixo, o gráfico 7 reforça nossa preocupação com a ineficiência do Ensino Médio em atender não só uma demanda reprimida de jovens acima de 18 anos, mas também no atendimento aos jovens que estão dentro da idade correta. Verificamos que praticamente não existem diferenças entre os números para o Brasil e Minas Gerais com relação às taxas de atendimento à população jovem. $\mathrm{O}$ gráfico demonstra que, no ano de 2009, 15,2\% dos jovens mineiros entre 15 e 17 anos não frequentavam nenhum nível de ensino. Isso denuncia a incapacidade do sistema educacional público em atender a demanda pelo Ensino Médio em Minas Gerais e no Brasil.

\footnotetext{
${ }^{6}$ A TML aumentou de 34,4\% em 2000 para 50,4 em 2008.
} 
Gráfico 7 - Taxa de Atendimento da População de 15 a 17 anos Minas Gerais e Brasil - 1996-2009.

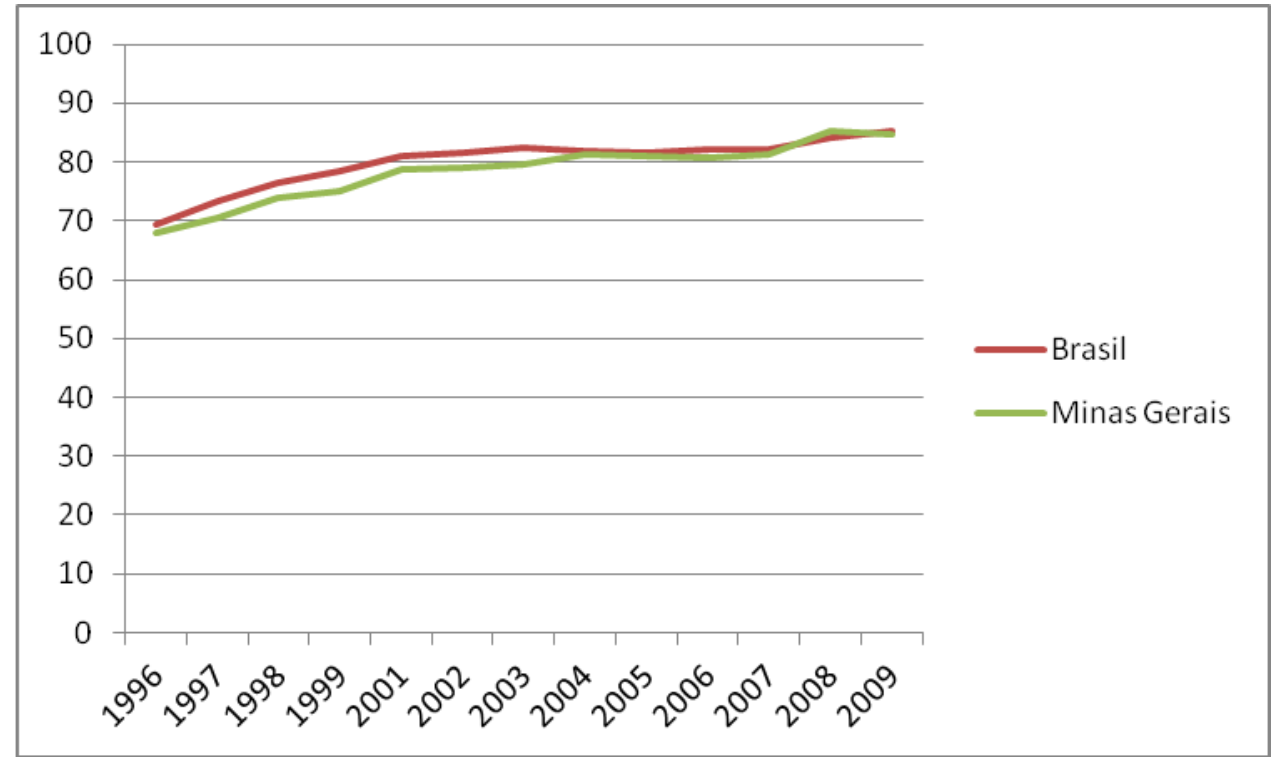

Fonte: PNAD/IBGE.

O gráfico 8 também apresenta números preocupantes. Verificamos que, do total de jovens brasileiros entre 15 e 17 anos que estão fora da escola, 70,3\% deixaram de estudar sem concluir nem mesmo o Ensino Fundamental e 17,6\% sem concluir o EM. Em 2009, dos 15,2\% dos jovens de 15 a 17 anos que não frequentavam escola, apenas $7,4 \%$ trabalhavam e os demais $7,8 \%$ não estudavam nem trabalhavam. Esses números sugerem a ineficácia das políticas públicas para atrair e manter esses jovens na escola.

Gráfico 8 - Distribuição da população brasileira de 15 a 17 que não frequenta a escola segundo anos de estudo.

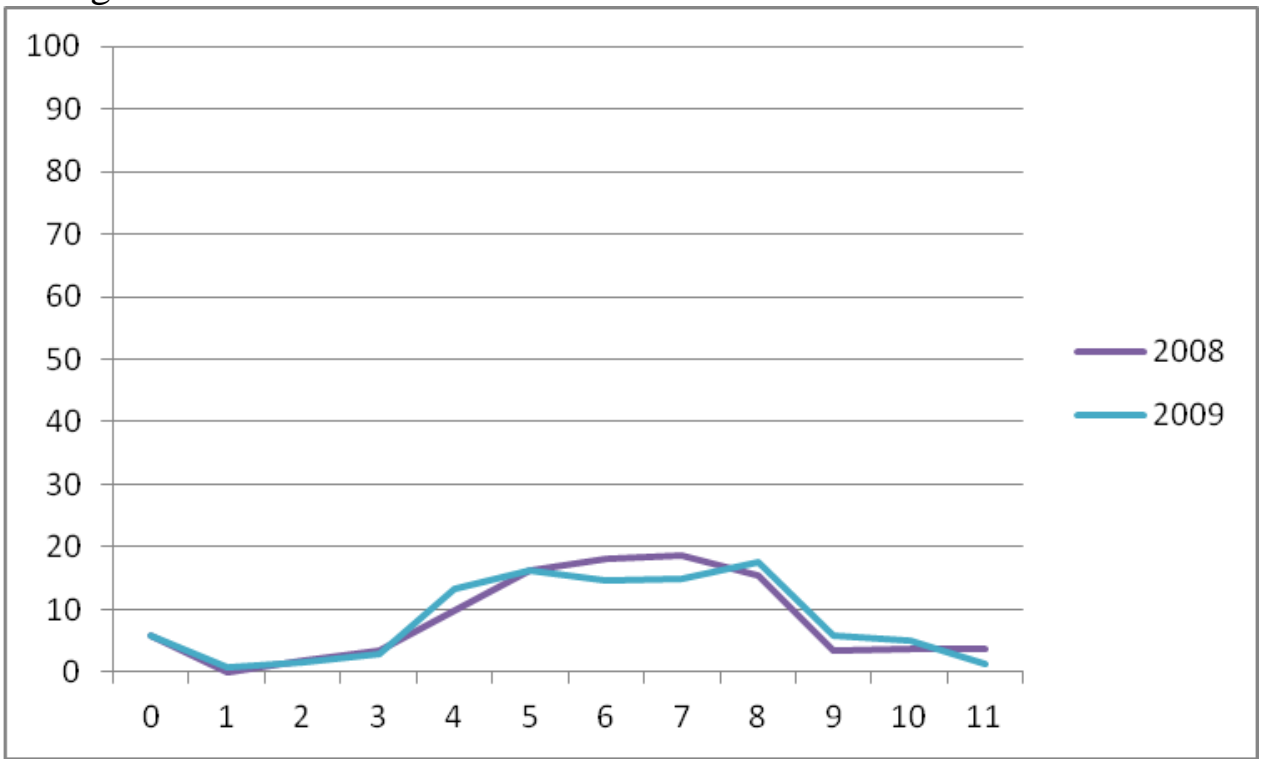

Fonte: PNAD/IBGE. 
Gráfico 9 - Taxas de Escolarização Bruta e Líquida do Ensino Médio Minas Gerais e Brasil - 1996-2009.

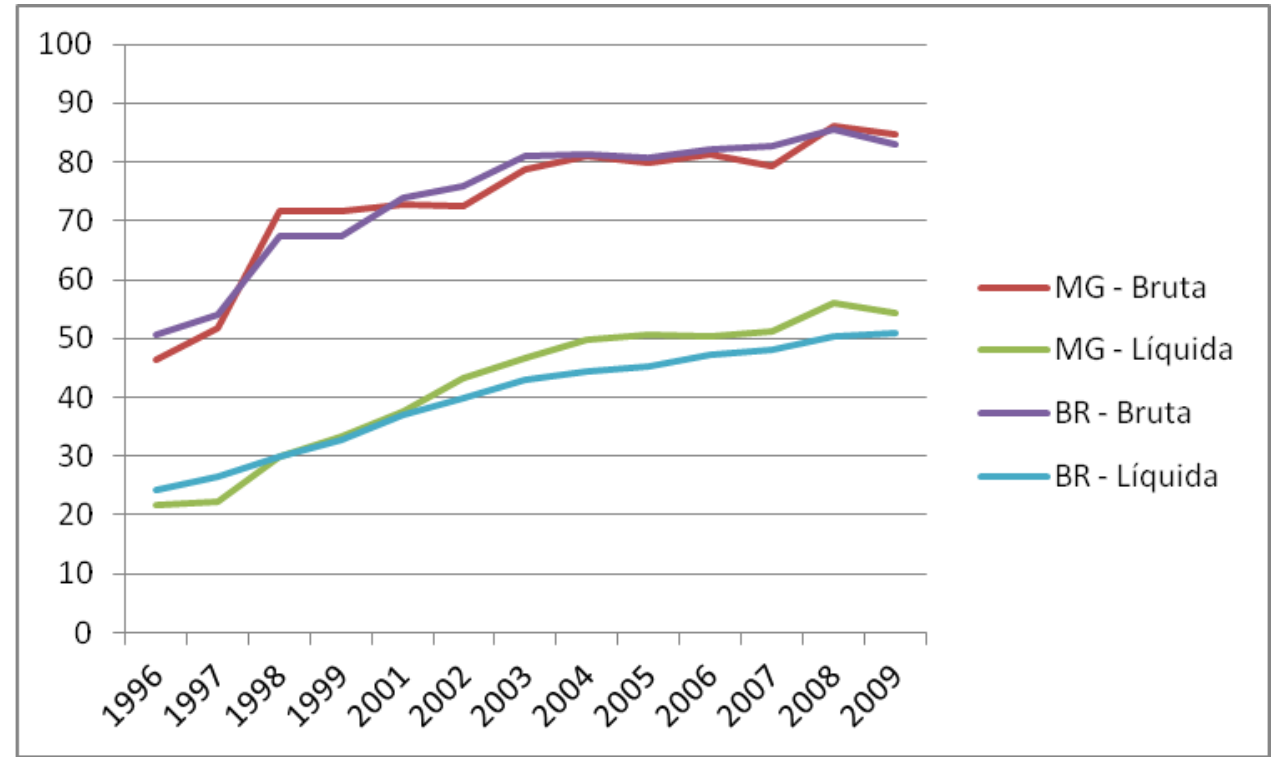

Fonte: PNAD/IBGE.

No gráfico 9, a análise da relação entre as taxas de escolarização bruta e líquida do Estado de Minas Gerais e Brasil, confirma a existência de uma grande demanda reprimida com relação ao EM, ainda existindo um percentual significativo de pessoas acima de 17 anos cursando o EM (30,2\%). Esta demanda também é causada pelos problemas de fluxo acumulados ao longo do EF e também no EM, resultando em uma elevada taxa de distorção idade-série. Em Minas Gerais, para cada 100 pessoas na idade de 15 a 17 anos, 15 estão fora da escola e cerca de 30 ainda estão em outros níveis de ensino.

\subsection{2.}

\section{Fluxo}

As taxas de rendimento são constituídas pelas taxas de aprovação, reprovação e abandono apuradas ao final de cada período letivo. A análise desses números também é de fundamental importância para um diagnóstico da situação do Ensino Médio. No gráfico 10, podemos verificar os contrastes entre as redes públicas e privadas. Com relação às taxas de aprovação, o quadro é de leve declínio na rede estadual entre 1997 e 2010: em média, para cada 10 alunos matriculados, dois não são aprovados, enquanto na rede privada a aprovação está acima de $90 \%$. 
Gráfico 10 - Ensino Médio. Taxa de aprovação (\%). Escolas estaduais e privadas: Brasil (1997 a 2010).

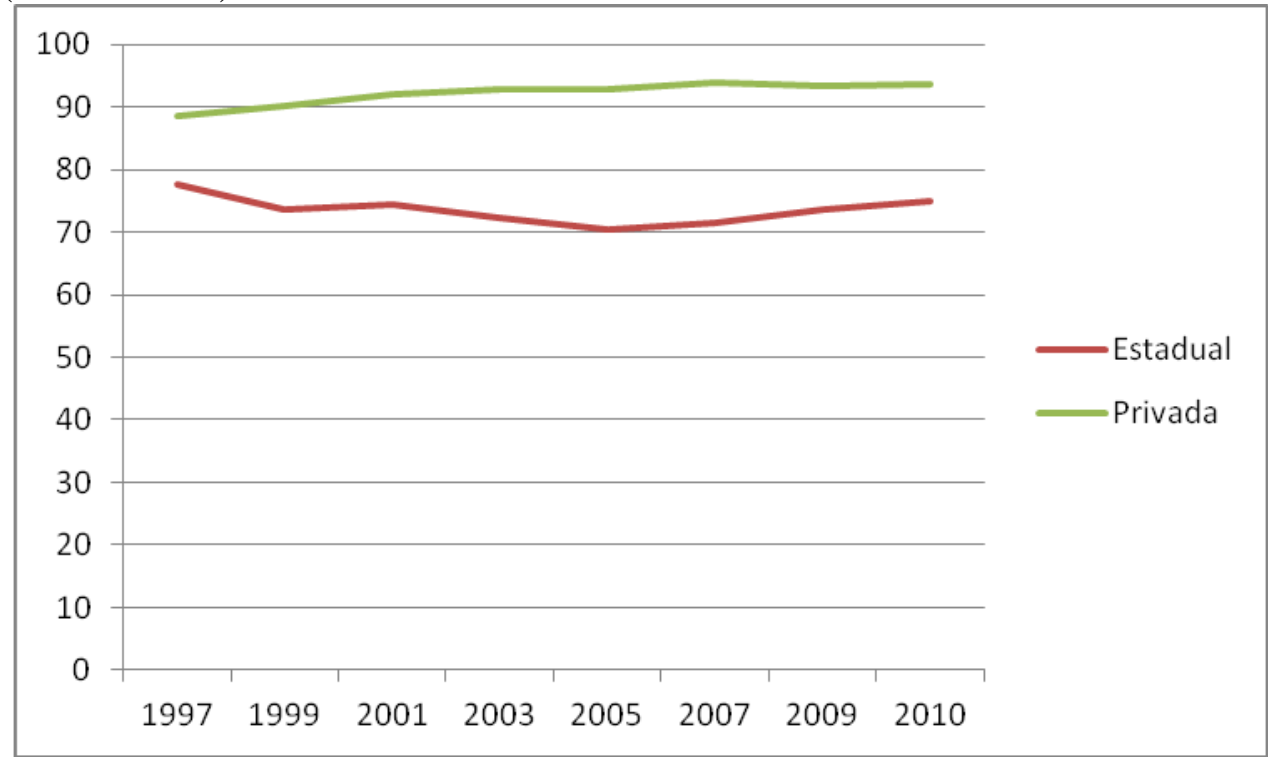

Fonte: MEC/INEP.

Abaixo, no gráfico 11, é possível constatar que, embora apresente uma leve queda, as taxas de abandono mantêm-se acima dos 10\%. Essa estabilidade de abandono mostra a necessidade do desenvolvimento de políticas para a fixação dos jovens na escola.

Gráfico 11 - Ensino Médio. Taxa de reprovação e abandono (\%). Escolas estaduais: Brasil (1997 a 2010).

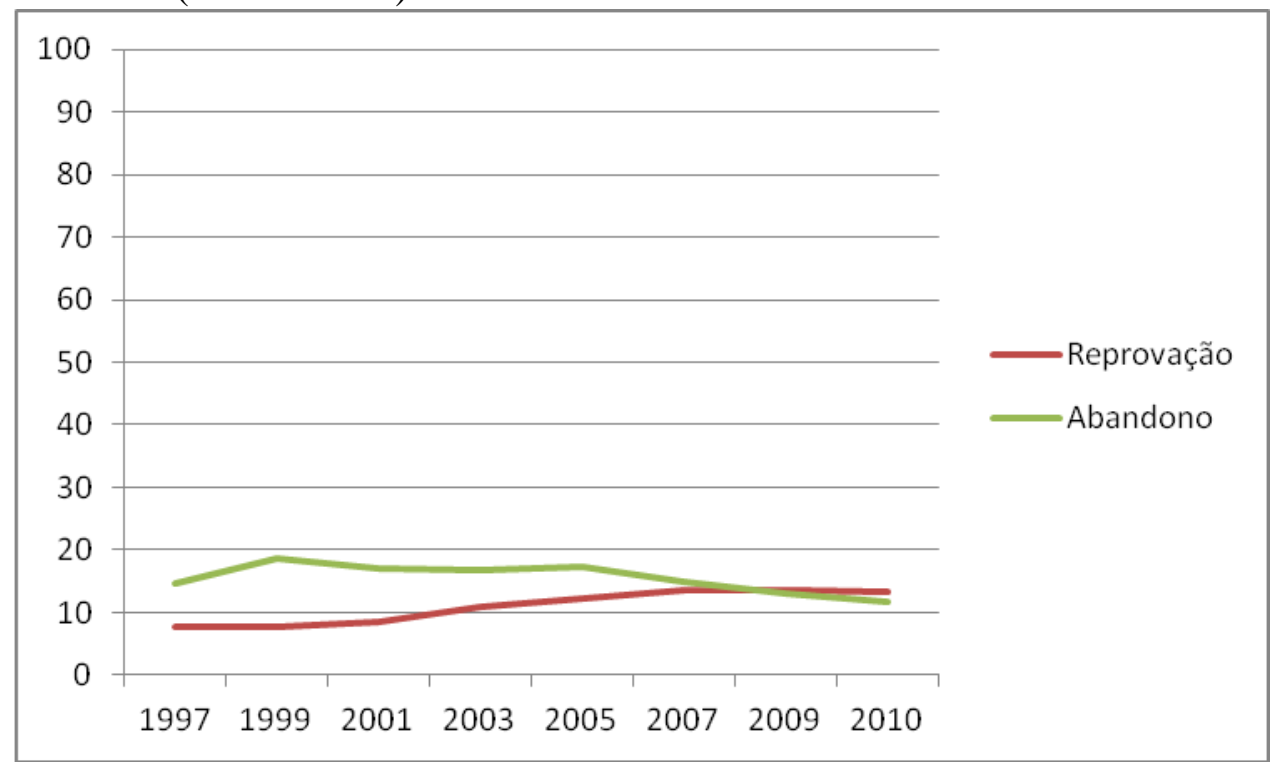

Fonte: MEC/INEP.

Quanto à reprovação, as escolas estaduais apresentam um aumento próximo de 5 pontos percentuais entre 1997 e 2010. 
A seguir, os gráficos 12, 13 e 14 apresentam as taxas de rendimento da rede estadual de Minas Gerais por série entre os anos de 2006 e 2010. Embora as taxas estejam dentro das médias brasileiras, a visualização por série da rede mineira permite verificar que as maiores taxas de repetência e abandono acontecem na primeira série do EM. Tomando como exemplo o ano de 2010, para cada 10 estudantes que entraram na $1^{\text {a }}$ série do EM no estado de Minas Gerais, 1 abandonou e 3 não foram aprovados. Para os demais anos do EM as taxas são elevadas e preocupantes, pois reforçam o atraso educacional. Comparadas ao Brasil, as taxas de abandono em Minas Gerais estão abaixo da média, mas ainda são bastante elevadas e preocupantes.

Gráfico 12 - Taxas de Aprovação do Ensino Médio Rede Estadual - Minas Gerais 2006-2010.

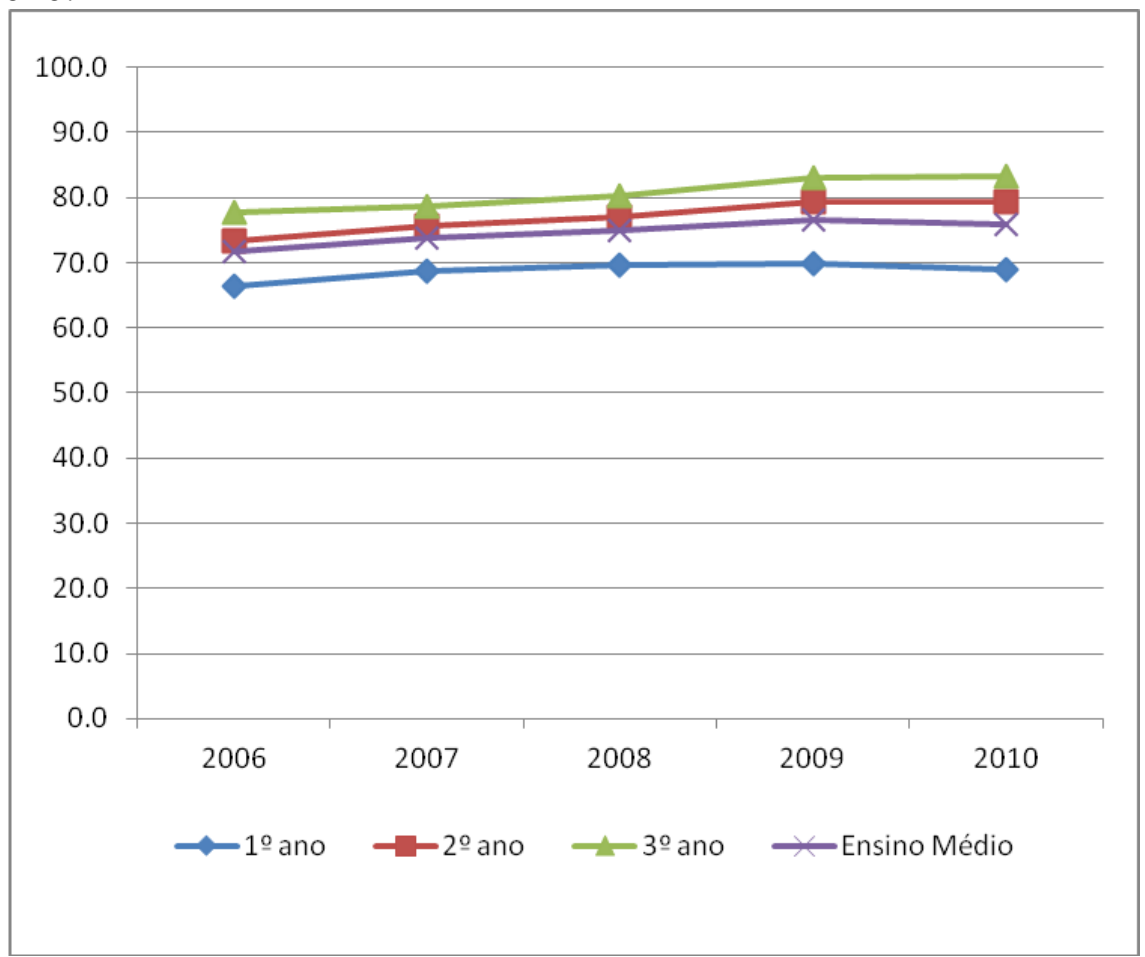

Fonte: PNAD/IBGE. 
Gráfico 13 - Taxas de Abandono do Ensino Médio Rede Estadual - Minas Gerais, 2006-2010.

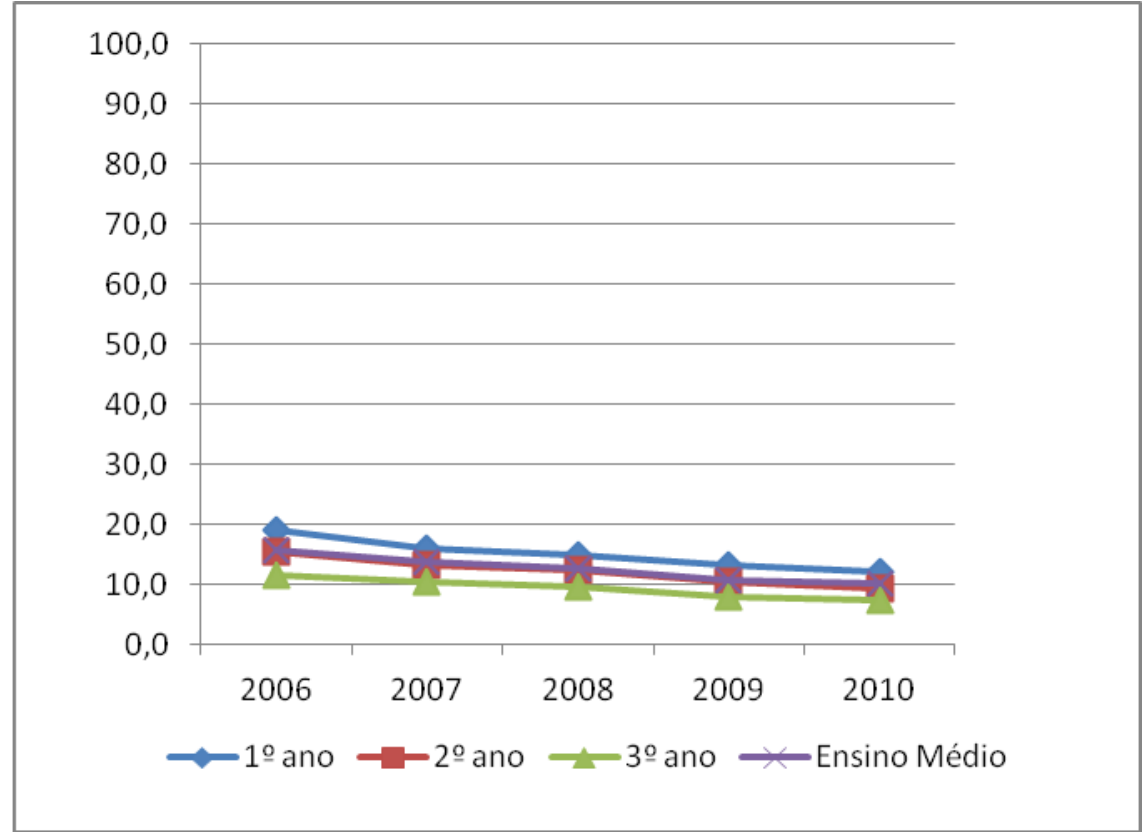

Fonte: PNAD/IBGE.

No gráfico 13, é apresentado o percentual de concluintes no Ensino Médio brasileiro e verifica-se a proporção de concluintes em torno de $21,5 \%$ entre 1997 e 2010. Essa estabilização do número de concluintes pode ser vista como um indício de fluxo com muitas perdas, por evasão e repetência, nas três séries do Ensino Médio, com 1,8 milhões de concluintes, embora tenha havido aumento nas matrículas, como verificamos anteriormente.

Esses números confirmam que um dos grandes desafios em termos de políticas educacionais no Brasil ainda é expandir este número de ingressantes do Ensino Médio através da expansão da taxa de matrícula e/ou da redução das taxas de evasão e abandono. Para tanto, faz-se necessário o entendimento aprofundado da transição dos alunos entre o Ensino Fundamental e o Ensino Médio e as transições entre os anos do Ensino Médio. No gráfico 16, verificamos que, embora nos últimos anos a defasagem idade-série tenha caído, os entraves no rendimento escolar ainda provocam uma elevada distorção no EM da rede estadual de Minas Gerais.

Para Soares (2012), a universalização do acesso ao EM depende da regularização do fluxo no Ensino Fundamental (EF). Em sua pesquisa sobre atraso escolar, o autor constata que alunos que terminam o EF em uma idade mais avançada, tendem a ter dificuldades de continuar seus estudos. 
Gráfico 14 - Número (\%) de concluintes no Ensino Médio: Brasil (1997 a 2010).

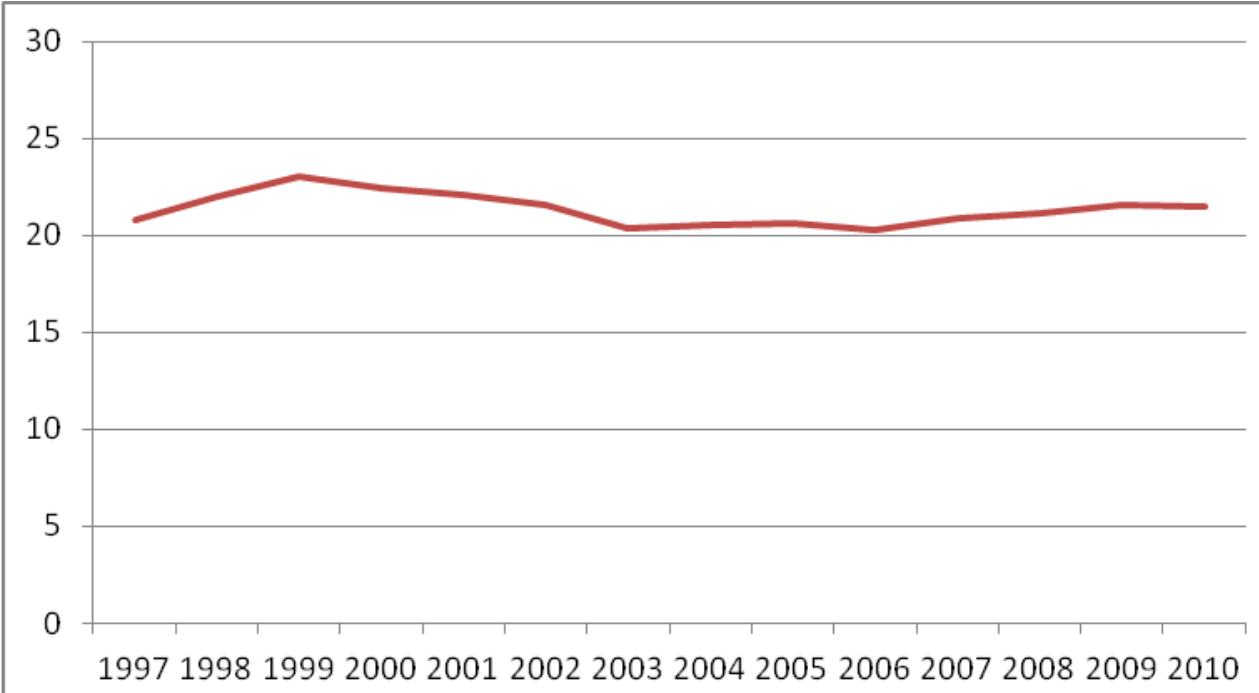

Fonte: Censo Escolar - Inep/MEC

Gráfico 15 - Taxas de Distorção idade/série do EM - Minas Gerais - Rede

Estadual.

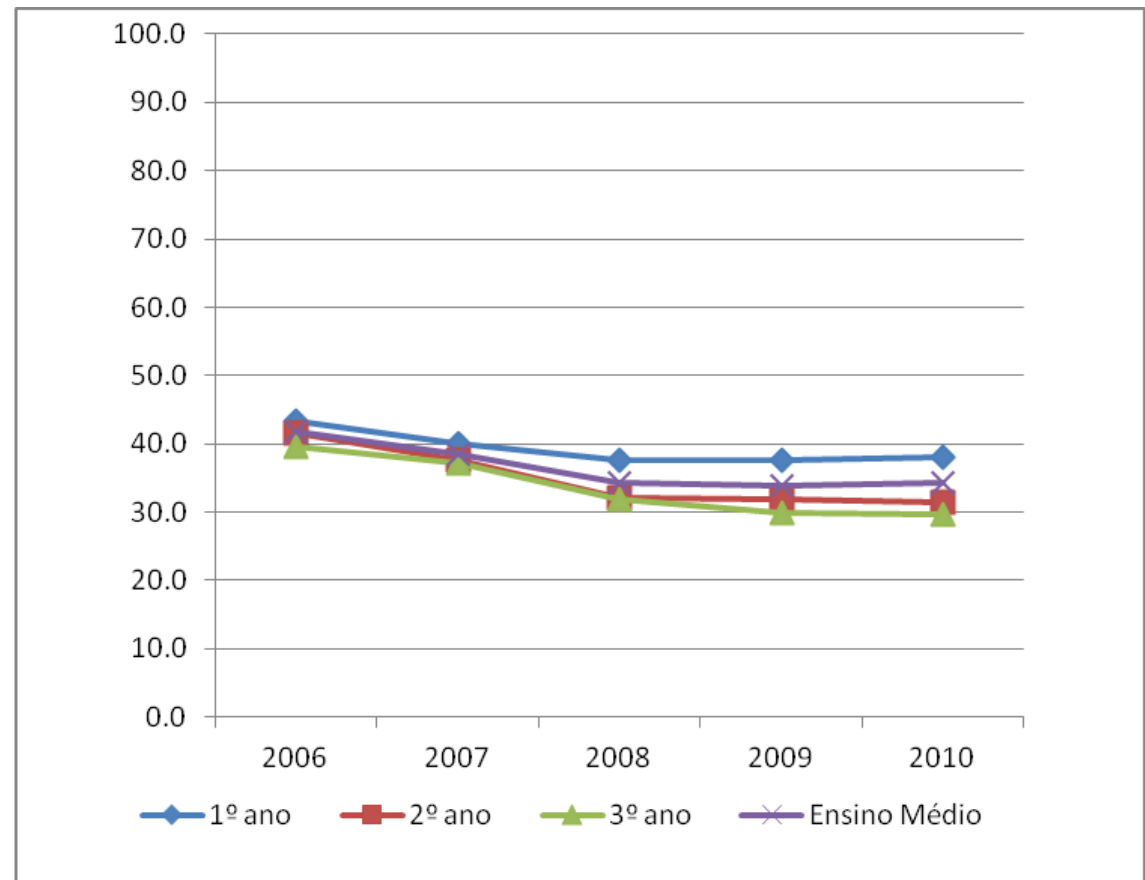

Fonte: Censo Escolar - Inep/MEC

\subsection{3.}

\section{Desempenho}

Bonamino \& Franco (1999) e Alves (2007) apontam que a institucionalização do Sistema Nacional de Avaliação da Educação Básica 
(SAEB) no início dos anos de 1990, constituiu um relevante instrumento de avaliação capaz de produzir informações sobre o desempenho da educação básica em todo o País, abrangendo as diferentes realidades dos sistemas estaduais e municipais de ensino e tornando-se, a partir de 1995, com a adesão de todos os Estados e todas as redes de ensino estaduais, municipais e particulares, um sistema de avaliação da educação nacional.

Alavarse et. al. (2013) reforça que as avaliações externas ganharam proeminência após o desdobramento, em 2005, do SAEB em duas avaliações complementares: a Prova Brasil e a Avaliação Nacional da Educação Básica (ANEB). Segundo os autores, as duas avaliações têm como objeto a avaliação de língua portuguesa e matemática, mediante provas com itens de múltipla escolha aplicadas em alunos da segunda etapa do Ensino Fundamental e $3^{\mathrm{a}}$ série do Ensino Médio. (ALAVARSE et al, 2013. p. 17).

É importante frisar que a Prova Brasil se diferencia do SAEB por ser uma avaliação censitária. Diferentemente do SAEB, onde os resultados são calculados a partir de uma amostra de estudantes, a Prova Brasil conta com a participação de todos os alunos dos 5. ${ }^{\circ}$ ou $9 .^{\circ}$ anos do Ensino Fundamental de todas as escolas urbanas com mais de 20 alunos na etapa de ensino avaliada - exceto em caso de redes ou escolas que se recusam a participar.

Essa abrangência permite à Prova Brasil obter o desempenho dos estudantes em português e em matemática por município e, até mesmo, por escola pública. No caso do SAEB, essas informações são disponíveis apenas para estados, regiões ou para todo o Brasil.

Conforme podemos verificar nos gráficos 17 e 18, o SAEB nos proporciona uma visão do desempenho médio dos estudantes de Ensino Médio, desde 1995. Esses resultados são bienais expressos na Escala de proficiência SAEB. Analisando esses gráficos, verificamos que, para Matemática, a linha tracejada apresenta o nível básico ${ }^{7}$ (em 275 pontos). Assim, podemos constatar que o rendimento médio dos alunos de escolas estaduais está abaixo desse nível desde 1995, ainda que seja considerado um tímido crescimento em 2005. A diferença entre a rede estadual e a rede privada era de 63.7 pontos na escala SAEB em 2009.

\footnotetext{
${ }^{7}$ De acordo com a escala de proficiência do SAEB, os alunos neste nível demonstram conhecimento parcial dos conteúdos, competências e habilidade requeridos para a série escolar em que se encontram.
} 
Para os alunos das escolas privadas, mesmo com uma queda de proficiência a partir de 2003, estes estudantes estão, em média, acima do nível básico. Em Língua Portuguesa, a linha pontilhada que indica o nível básico está em 250 pontos conforme escala SAEB. Os alunos de escolas estaduais ficam um pouco acima do básico e apresentam um movimento de crescimento a partir de 2005, o que reduz a diferença entre eles, pois os alunos de escolas privadas praticamente estabilizaram o desempenho a partir desse momento.

Gráfico 16 - SAEB. Matemática. Ensino Médio - Escolas estaduais e privadas: Brasil (1995-2009).

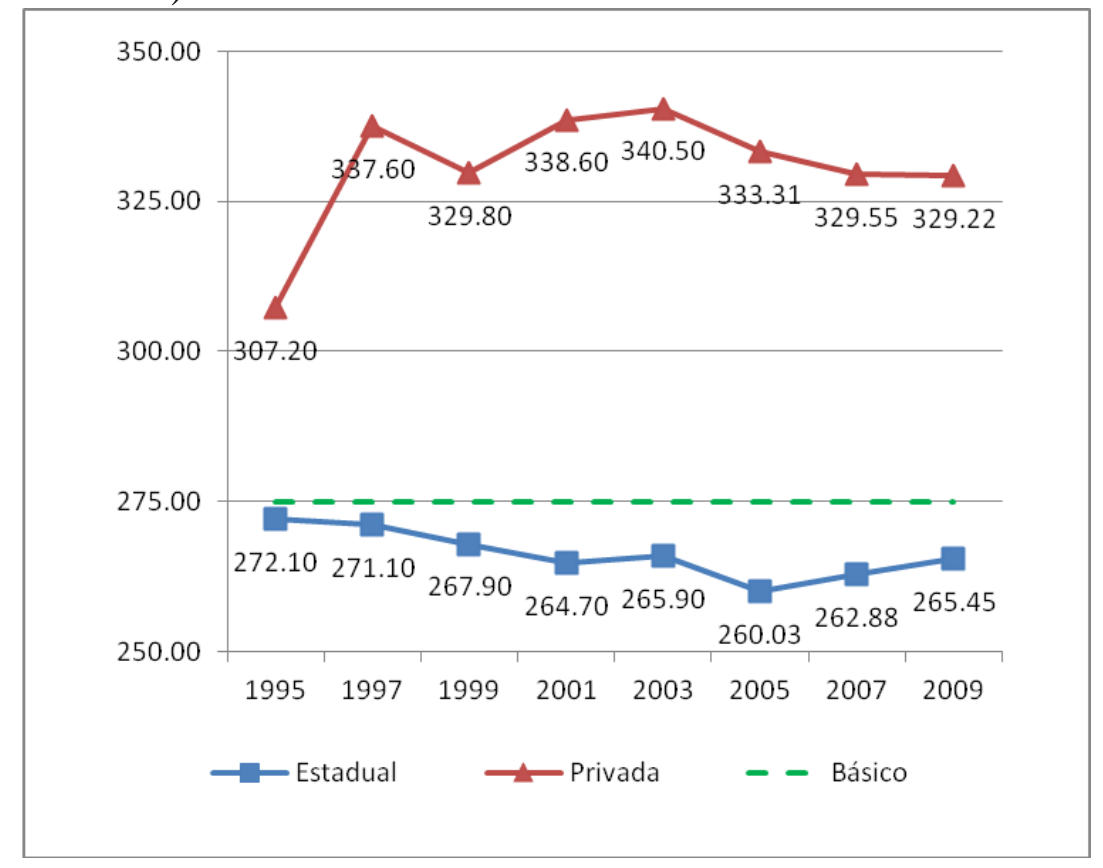

Fonte: SAEB 
Gráfico 17 - SAEB. Língua Portuguesa. EM - Escolas estaduais e privadas: Brasil.

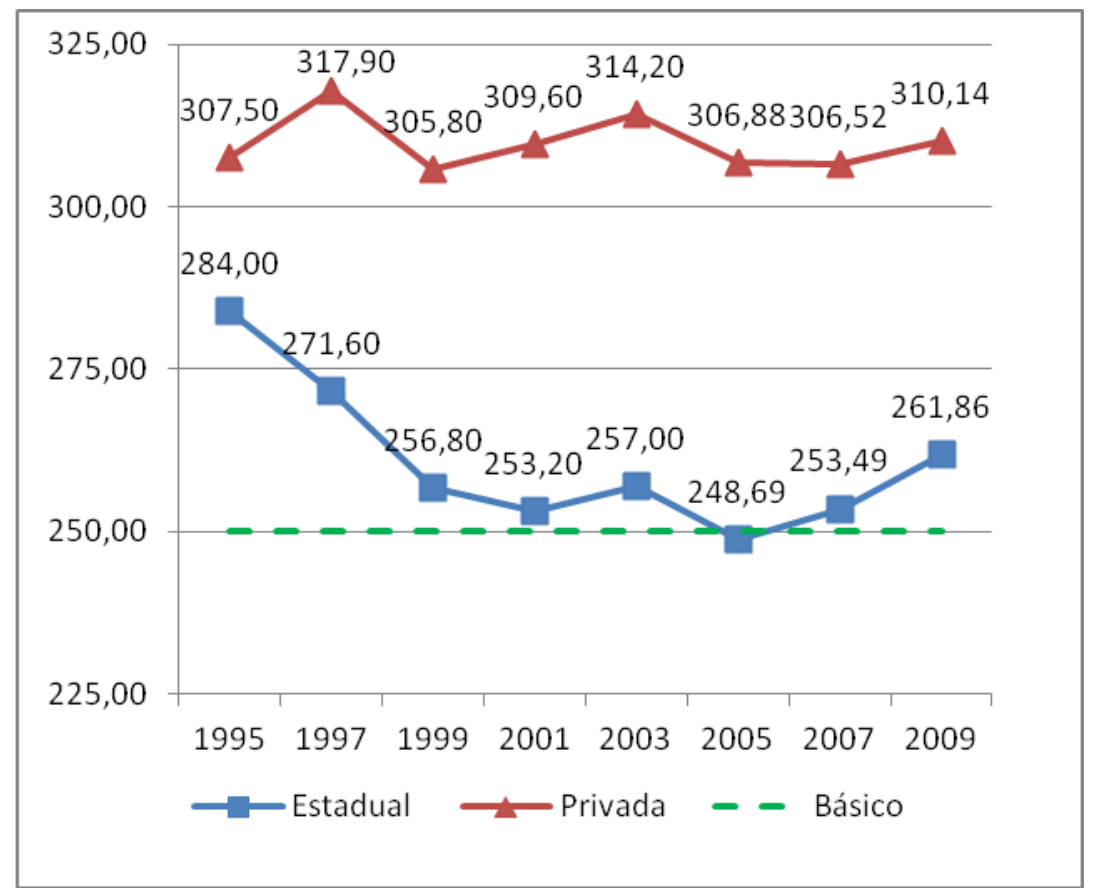

Fonte: SAEB

Estes resultados são extremamente preocupantes, pois demonstram a existência de um grande abismo entre estudantes das redes estadual e privada. A rede estadual, que foi responsável por $85,9 \%$ das matrículas em 2009, no mesmo ano, teve a média dos seus estudantes em matemática quase 10 pontos abaixo do nível considerado como básico na escala SAEB.

No Estado de Minas Gerais um sistema próprio de avaliação das escolas públicas começou a ser desenvolvido a partir de 1992. As avaliações em Minas Gerais foram inicialmente planejadas e realizadas em ciclos de dois anos. Eram avaliações censitárias, incorporando outras informações através de questionários contextuais. Com a implantação da progressão continuada, a partir de 1998, a avaliação passou a ser realizada anualmente. Este sistema de avaliação foi acompanhado de uma proposta formativa de quadros na própria Secretaria. Atualmente, Minas Gerais possui um modelo de avaliação complexo: O SIMAVE. Este sistema é composto por três subprogramas de avaliação: PROALFA — voltado à avaliação dos níveis de alfabetização; PROEB verifica a eficiência e a qualidade do ensino com base no desempenho nas séries 
finais dos blocos de ensino e o PAAE — realiza diagnósticos progressivos da aprendizagem para subsidiar intervenções pedagógicas.

Nos gráficos 19 e 20, verificamos a evolução do desempenho médio dos estudantes da rede estadual de Minas Gerais entre os anos de 2006 e 2010. A escala utilizada pelo SIMAVE é a mesma do SAEB. Em Língua Portuguesa, o desempenho médio desses estudantes ficou dentro da faixa considerada como intermediária, sendo registrada uma melhora de 14,6 pontos na escala de proficiência dentro desse período. Mesmo com essa evolução, em média, os estudantes ainda estão abaixo da faixa considerada como recomendada para o $3^{\circ}$ ano do EM, o que é preocupante, pois como já apresentei, a rede estadual concentra a grande maioria dos estudantes de EM. Em Matemática, o desempenho da rede estadual é pior. Embora também apresente uma progressiva melhora no desempenho entre os anos aqui apresentados, em média, a proficiência em matemática dos alunos do $3^{\circ}$ ano está abaixo do nível intermediário, sendo necessária uma melhoria de 85 pontos na escala para chegar ao nível considerado como recomendável.

Gráfico 18 - PROEB $3^{\circ}$ ANO do EM - Proficiência em Língua Portuguesa em Minas Gerais (2006-2010).

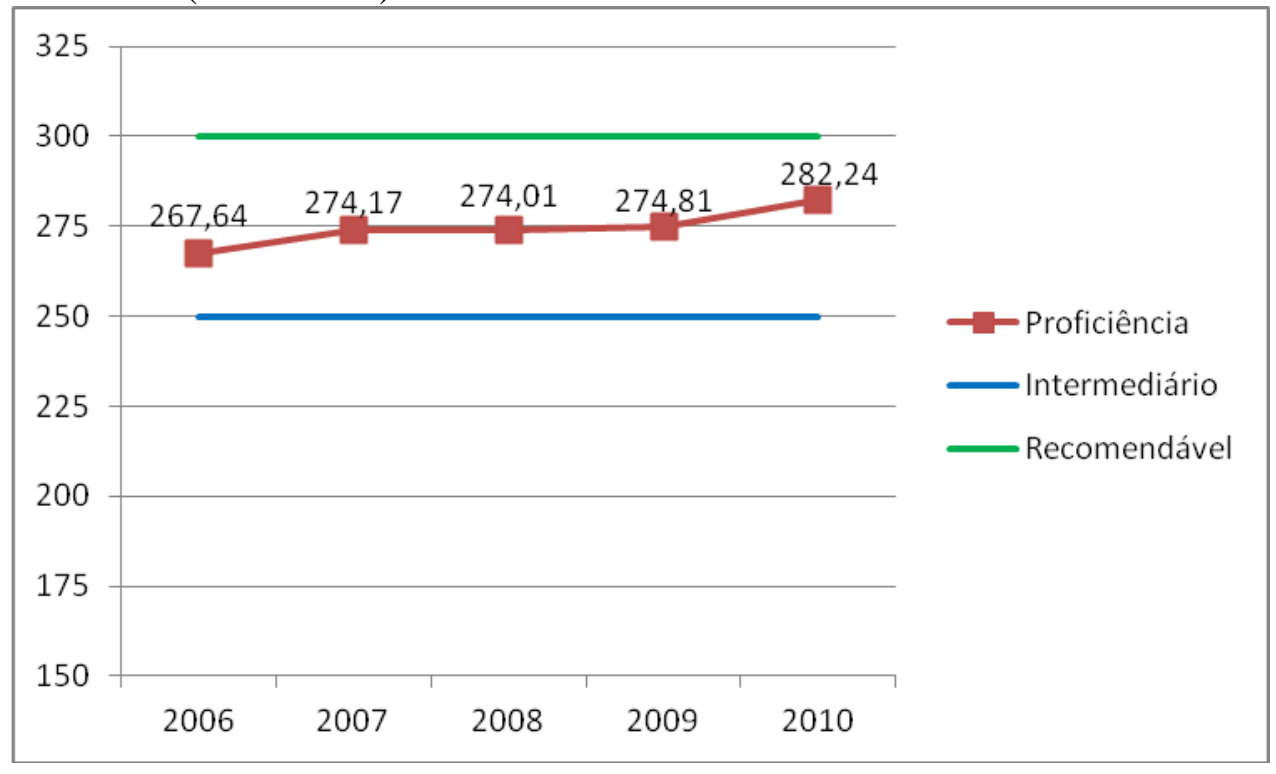

Fonte: PROEB 
Gráfico 19 - PROEB $3^{\circ}$ ANO do EM - Proficiência em Matemática em Minas Gerais (2006-2010).

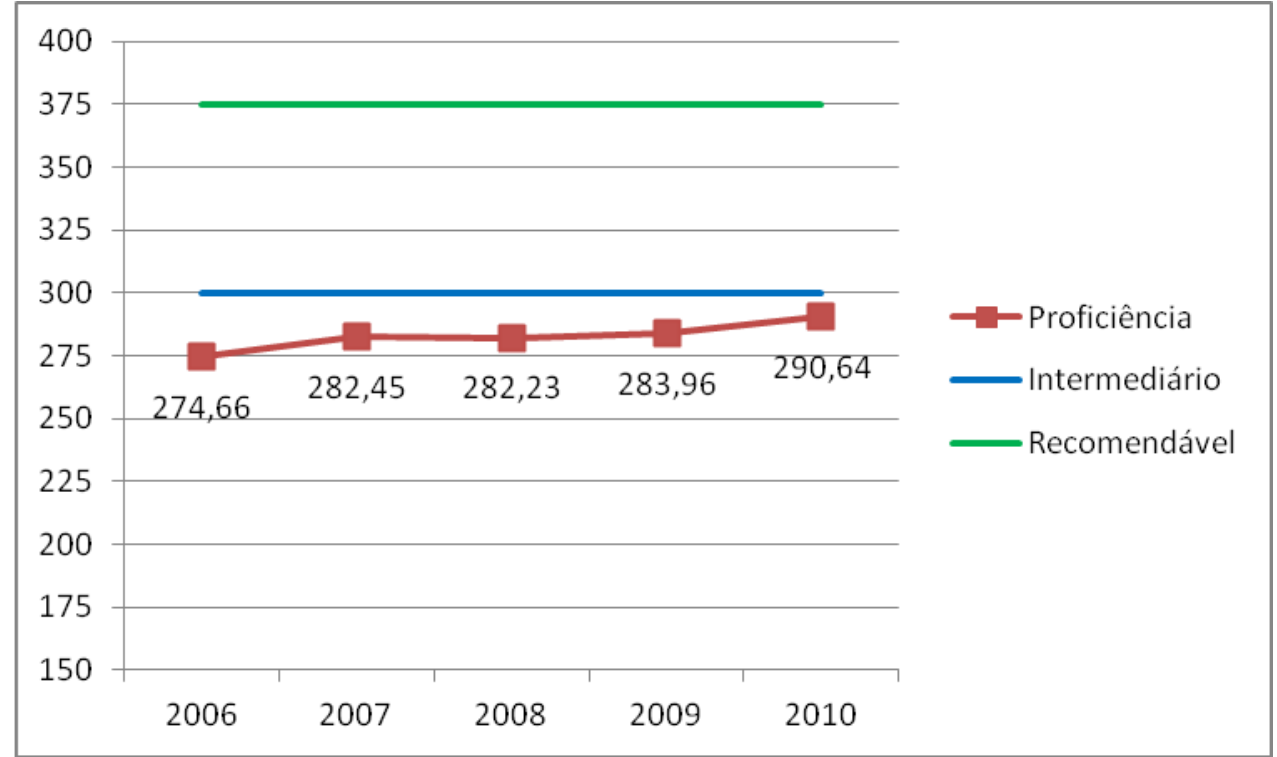

Fonte: PROEB

Neste capítulo apresentei os principais indicadores sociais e demográficos do estado de Minas Gerais e também as variáveis sobre a qualidade do EM no Estado de Minas Gerais. No anexo 4 apresento as análises de correlação dos indicadores sociais e demográficos com os indicadores de desempenho, conforme exemplifico abaixo no gráfico 21 .

Gráfico 20 - Desempenho médio em português dos estudantes do EM por município de acordo com o porte - MG - 2006 - 2010.

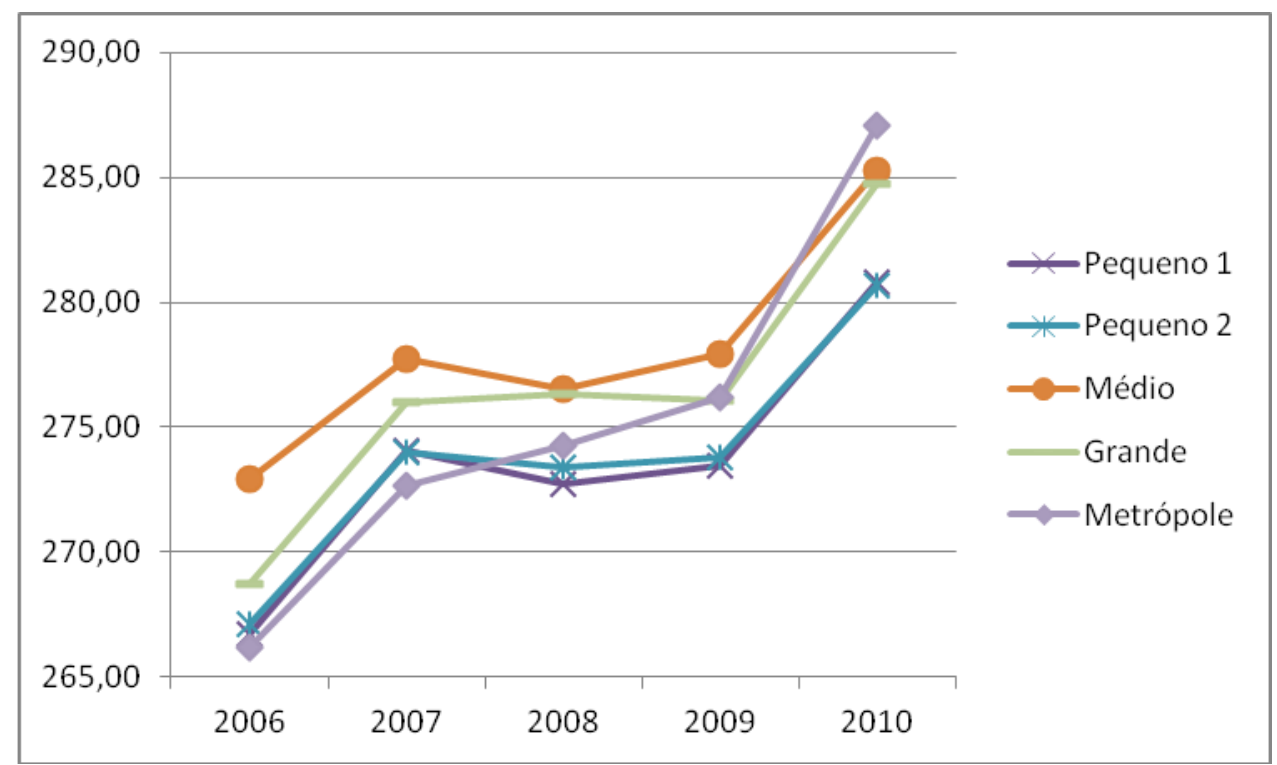

Fonte: Elaborado pelo autor com dados PROEB/IBGE. 
Ao realizar a comparação do desempenho médio dos estudantes pelo porte dos municípios, verificamos que, embora todos os grupos tenham apresentado melhoria no desempenho, é clara a existência de vantagem em todos os anos para os municípios de grande e médio porte em relação aos municípios de pequeno porte, sendo que a desigualdade de desempenho (em torno de 5 pontos na escala de proficiência) se mantêm ao longo do período estudado A região metropolitana apresenta um comportamento discrepante em relação aos demais grupos, realizando um salto de aproximadamente 21 pontos, saindo da pior posição em 2006 para apresentar a melhor média entre os grupos em 2010.

No próximo capítulo, apresento um breve histórico da política educacional do Estado de Minas Gerais nas últimas décadas, no sentido de resgatar informações importantes para a compreensão da atual conjuntura educacional do Estado. Em seguida apresento mais detalhadamente as políticas educacionais do governo Aécio Neves, por meio da análise dos principais projetos e programas desenvolvidos em seu governo e os objetivos de suas políticas. 


\section{4. \\ Políticas Educacionais em Minas Gerais}

Para estudar a abrangência das políticas educacionais desenvolvidas pelo governo mineiro entre os anos de 2006 e 2010 e estudar suas relações com os indicadores sociais, demográficos e de desempenho dos estudantes do ensino médio nos municípios mineiros, é necessário antes conhecer o contexto de alguns dos programas e políticas desenvolvidas antes desse período. Para isso, faço um resgate das políticas educacionais desenvolvidas no estado antes do governo Aécio Neves. Precisamente, destaco as principais políticas educacionais desenvolvidas durante a década de 1990. Esse resgate é importante para compreender melhor a conjuntura em que os programas e projetos educacionais aqui estudados foram pensados e implementados na rede estadual de Minas Gerais.

Inicio assim minha análise a partir das políticas desenvolvidas no estado entre 1991 e 1998 durante os governos Hélio Garcia e Eduardo Azeredo e posteriormente no período compreendido entre os anos de 1999 e 2003 durante o governo Itamar Franco - governador que antecedeu Aécio Neves - onde o foco estava simultaneamente nas ações de fortalecimento da gestão escolar e avaliação do sistema educacional.

Em seguida, descrevo os programas e ações implementados no governo Aécio Neves e, mais detalhadamente, os programas desse governo voltados para o EM, justificando a seleção dos programas que serão analisados com o objetivo de compreender a relação da abrangência dos mesmos com os indicadores sociais e demográficos dos municípios em que foram implementados e também o comportamento do desempenho médio por município dos estudantes do EM entre os anos de 2006 e 2010.

$\mathrm{Na}$ análise sobre abrangência destas políticas educacionais no Estado de Minas Gerais durante a gestão do Governador Aécio Neves, busco como referencial Arretche (2004), Cardoso Jr \& Jaccoud (2005), Bell \& Stevenson (2006) e Souza (2006). Sobre os conceitos de políticas públicas, trago as contribuições de Hofling (2001), Secchi (2009) e Nudzor (2009). E com relação à 
classificação de políticas públicas e os indicadores sociais e demográficos apresento as ideias de Torres (2003), Jannuzzi (2009) e Souza (2010).

\section{1. \\ Política educacional mineira na década de 1990}

No Brasil e em muitos países da América Latina, no período imediatamente posterior ao fim do autoritarismo imposto pelo regime militar, foram introduzidas importantes mudanças nos sistemas educacionais, marcados principalmente pelo processo de descentralização do Estado. A reforma das instituições educacionais ocupou lugar de destaque no contexto geral da reforma do Estado. No entanto, sendo o Brasil uma república federativa onde as políticas públicas são produzidas e implementadas nos diferentes níveis de governo (federal, estadual e municipal), o processo de reforma educacional apresentou características específicas. A educação pública brasileira, especialmente a educação básica que é composta pela educação infantil, ensino fundamental e ensino médio, consolidou sua principal estrutura nas redes estaduais e municipais de ensino. Esta fragmentada estrutura de oferta, presente nos sistemas federativos, provê um sistema que se desenvolve e apresenta resultados bastante diversificados, pois sofre influências das diferentes condições políticas, financeiras e administrativas dos estados e municípios.

Considerando a autonomia dos estados e municípios no desenvolvimento de programas e políticas educacionais, importantes mudanças institucionais ocorreram na educação pública estadual mineira na década de 80 e início da de 90 . Estas mudanças tiveram como objetivo a descentralização do sistema estadual de educação e o fortalecimento da autonomia de funcionamento das escolas, criando espaços para a sua gestão participativa e reduzindo as possibilidades de uso da gestão da educação para fins político-partidários.

Governo Hélio Garcia (1991- 1994)

Em 1991, com a posse de Hélio Garcia no governo de Minas Gerais, iniciase uma ampla reforma do sistema estadual de ensino. O princípio norteador dessa reforma é a descentralização, tendo como argumento a democratização e a busca de eficiência da rede estadual. Assume como Secretário de Educação o diretor da Rede Pitágoras de Ensino (uma Rede privada de educação) Walfrido S. dos Mares Guia Neto, que era assessorado por técnicos do Banco Mundial. 
O novo secretário de educação elege entre seus maiores desafios a resolução de problemas históricos como os elevados índices de repetência e evasão escolar, estabelecendo entre suas metas alcançar um sistema eficiente e produtivo. Para isso, propõe a descentralização das decisões até então concentradas na Secretaria Estadual de Educação - SEE-MG e em suas Delegacias Regionais de Ensino DREs. Essa decisão é apoiada na constituição estadual de 1989, que já previa um modelo de gestão descentralizado e participativo. As escolas mineiras passam a ter autonomia financeira, administrativa e pedagógica. Esta autonomia reflete em maior poder de decisão dos diretores e a instauração dos colegiados com a participação de pais e servidores da escola que passam também a opinar e deliberar sobre a alocação de recursos financeiros, fiscalização de gastos, gerenciamento e movimentação de recursos humanos, avaliação do sistema e elaboração do projeto pedagógico da escola. A escolha do diretor também deixa de ser realizada por meio de indicação política da SEE-MG e passa a ser uma atribuição da comunidade escolar após a avaliação da competência técnica dos candidatos realizada por meio de avaliação de títulos e prova escrita.

Com a nova sistemática de escolha de diretores, a SEE-MG enfrentou a rejeição da associação de diretores e do sindicato de professores, e também dividiu a opinião de parlamentares do mesmo partido, conforme descreve Rocha (2003, p.574):

$\mathrm{Na}$ Assembleia Legislativa, tais posições refletiam-se nas posturas discordantes dos deputados. As posições não se alinhavam perfeitamente segundo as posições partidárias. No interior da maioria dos partidos havia posições antagônicas. Os partidos progressistas, especialmente o Partido dos Trabalhadores, estavam coesos na defesa da mudança, rejeitando, no entanto, a etapa de avaliação técnica. A defesa da eleição de diretores era compartilhada por alguns parlamentares conservadores que também defendiam a realização da avaliação técnica. Do outro lado, a maioria dos parlamentares mais conservadores rejeitava a eleição como critério de recrutamento dos diretores.

Embora o governador e o secretário de educação reconhecessem a forte rejeição à nova sistemática por parte de setores governistas do Legislativo, os mesmos empenharam-se na aprovação do projeto da seleção competitiva e conseguiram aprovar o Projeto de Lei 198/1991. Aprovada a lei que adotava as eleições, a Associação dos Diretores escolares de Minas Gerais - ADEOMG entrou com uma Ação Direta de Inconstitucionalidade no Superior Tribunal Federal e logo após a realização da primeira eleição para diretores saiu uma liminar acatando a inconstitucionalidade da Lei 198/1991. No final de 1996, sai a 
sentença definitiva confirmando a inconstitucionalidade da lei. $\mathrm{O}$ argumento acatado pelo Judiciário foi de que a Constituição Federal confere aos governadores poder para nomear os ocupantes de cargos de confiança comissionados. Contudo, o governo Hélio Garcia continuou adotando informalmente os critérios contemplados pela lei. Os selecionados, porém, não se tornam mais detentores de mandato, podendo ser exonerados, ou mesmo nem empossados, segundo a vontade do governador. Esse poder sobre os diretores foi utilizado por outros governadores para impor regras às escolas posteriormente.

Mesmo assim, nesse período, o sistema mineiro de educação passou a orientar-se por regras que davam espaço para uma participação mais ampla dos setores realmente interessados na educação pública, com a comunidade escolar participando das decisões relacionadas com o destino das escolas e, mesmo que informalmente, começaram a ter o poder de escolher o diretor, passaram a participar das decisões sobre a definição das prioridades de alocação de recursos e da linha pedagógica a ser adotada, através da atuação nas assembleias e colegiados escolares. Com isso, houve uma quebra do controle clientelista de recursos educacionais que historicamente eram utilizados com finalidade eleitoral no estado.

Também nessa gestão, foram dados os primeiros passos para a construção de um sistema de avaliação da qualidade do ensino no estado. A avaliação da escola pública foi eleita como um dos pilares da gestão Hélio Garcia. Para isso, criou-se o Programa de Avaliação Educacional da Escola Pública de Minas Gerais, por meio da resolução nº 6.908, de 18 de janeiro de 1992. Em março do mesmo ano, realizou-se a primeira experiência de avaliação do sistema educacional mineiro, da qual participaram crianças de todas as escolas do Estado. Segundo SOARES (2011, p. 59):

Foi desenvolvido concomitantemente um programa para formação de quadros técnicos em avaliação da Secretaria do Estado da Educação, com cursos específicos oferecidos, tanto no Brasil como também no exterior, com a intenção de ter pessoal capacitado na interpretação e geração de dados com as respostas dadas nas avaliações, bem como nos questionários.

A formação desse corpo técnico na SEE-MG permitiu o crescimento e consolidação desse programa de avaliação ao longo dos anos seguintes.

Também nessa gestão, foi dado ao planejamento do trabalho escolar grande importância. A partir de 1993, por meio de um convênio firmado com o Banco 
Mundial, foi criado o programa denominado PROQUALIDADE. Seguindo princípios da gestão da qualidade total, as escolas elaboraram o Plano de Desenvolvimento (PDE). Nesse documento deveriam estar definidas as ações a serem implementadas num período de, pelo menos, cinco anos. Embora o PROQUALIDADE tenha contribuído na organização das unidades escolares, o excesso de burocracia acabou se tornando um entrave para o desenvolvimento do programa. Silva (2007) ressalta que esta fase ainda foi marcada fortemente por procedimentos burocráticos e ausência de análise e reflexão:

No entanto, o planejamento educacional, por vezes, é tomado como um ato mecânico. Preenchia-se planilhas e formulários de um modelo estereotipado, como exigência de uma burocracia escolar que os arquivava. Assim, com o pressuposto de se procurar a eficiência da instituição escolar, os planos não raramente são definidos a partir de modelos padronizados, o que contribui para manutenção da prática do planejamento como ato mecânico, sem análise e reflexão do contexto e dos sujeitos envolvidos no ato de aprender e ensinar. (SILVA, 2007 p.9)

Para o autor, o processo de planejamento não admite modelos fechados ou prontos. Ele deve ser resultado de uma reflexão sobre o mundo, a relação homem - mundo e a prática pedagógica necessária a determinado momento em uma instituição.

Contudo, com o PROQUALIDADE e com o fortalecimento da gestão do sistema educacional, o planejamento do trabalho escolar passou a receber grande importância na gestão Hélio Garcia. Esperava-se que o projeto pedagógico da escola fosse desenvolvido por meio do trabalho coletivo de seus profissionais a partir de sua realidade.

Governo Eduardo Azeredo (1995 - 1998)

Em 1995, Eduardo Azeredo assume o governo do estado dando continuidade a descentralização e autonomia escolar, transferindo para as escolas funções administrativas e burocráticas como o controle de pessoal, vida funcional dos servidores das escolas, controle da contagem do tempo de serviço e a administração dos recursos repassados às unidades escolares. Em seu governo essas medidas de descentralização e autonomia da educação pública, não foram muito além dessas transferências para as unidades escolares de tarefas e responsabilidades que antes estavam nas mãos dos órgãos centrais e regionais de ensino. Para Silva (2007) esse processo de descentralização foi unilateral:

No processo de implementação das medidas descentralizadoras da Secretaria de Estado da Educação de Minas Gerais, não houve nenhuma discussão mais ampla com os agentes educativos sobre seu significado e dimensões. Não se viabilizaram 
canais, nem houve espaço e tempo para que a comunidade escolar pudesse participar de forma ativa na definição dos rumos e contornos dessa descentralização e autonomia. (SILVA, 2007 p.3)

Em 1997, a nova LDB, Lei Federal n. ${ }^{\circ}$ 9394/96, sancionada pelo Presidente Fernando Henrique Cardoso em dezembro de 1996, estimulou algumas reformas em Minas Gerais. Ainda com Eduardo Azeredo no governo do estado, a SEE-MG anunciou uma "revolução" na educação mineira, promovendo mudanças adequadas à nova LDB e objetivando, segundo a fala oficial, uma melhoria na educação estadual.

Tentando sair na frente das demais unidades federativas, o governo mineiro passou a introduzir reformas educacionais como a municipalização do ensino fundamental, programas de aceleração da educação, programas de capacitação, sistemas de avaliação e sistema de progressão continuada por meio do regime de ciclos. É importante ressaltar que essas reformas implementadas nas escolas estaduais mineiras foram financiadas principalmente pelo Banco Mundial (BIRD) e atendiam recomendações do Fundo Monetário Internacional (FMI).

Com relação ao Ensino Médio, a gestão Azeredo concentrou-se em algumas ações com a finalidade de melhoria na qualidade. Entre essas ações, estava a proposta de que as escolas estaduais deveriam se concentrar na formação propedêutica e na realização de parcerias com a iniciativa privada para oferecimento de cursos técnicos.

Em síntese, o governo Eduardo Azeredo concentrou-se nas políticas educacionais voltadas para o Ensino Fundamental contempladas pelo Programa de Melhoria de Qualidade do Ensino Fundamental - PROQUALIDADE que continha estratégias para conter a evasão e repetência, acelerar a aprendizagem dos alunos, corrigir o fluxo escolar, avaliar a qualidade educacional e integrar os municípios. Esse último objetivo acabou tornando-se um processo de municipalização.

Assim, em 1998, Eduardo Azeredo, com base na nova Lei de Diretrizes e Bases da Educação Nacional (Lei $N^{\circ}$ 9.394/1996) e na aprovação da Lei $N^{\circ}$ 9494/1996, determinou que as escolas estaduais passassem a oferecer, prioritariamente, e em muitos casos, exclusivamente, apenas os anos finais do Ensino Fundamental e o Ensino Médio. Essa medida provocou reações dos governos municipais que alegavam não ter estrutura técnica e financeira para assumir a demanda referente às séries iniciais do ensino fundamental. Com a 
eleição de Itamar Franco, esse processo foi suspenso. No novo governo, um novo modelo de gestão começou a ser implementado, embora alguns dos programas do governo Azeredo tenham continuado.

Governo Itamar Franco (1999 - 2002)

Itamar Franco toma posse em 1999 rompendo com a concepção de planejamento presente no PDE. Em sua gestão, por meio da SEE-MG, houve a valorização do projeto político-pedagógico - PPP da escola e sua articulação com a autonomia e democratização da gestão escolar. O PPP foi rapidamente absorvido pelas escolas e firmou-se como um instrumento para transformação do cotidiano escolar. Partia-se do princípio de que a construção do PPP seria o momento e o espaço para a escola pensar sua prática e estabelecer metas/objetivos com vistas a transformação escolar e melhoria da qualidade de ensino e aprendizagem. Assim, o PPP seria um movimento coletivo e permanente, desde que superasse as obrigações simplesmente burocráticas, conforme verificamos em Silva (2011, p.3):

A construção destes parâmetros (elaborados não necessariamente de forma objetiva e exteriorizada) pelos profissionais da escola, é que estabelecem a dinâmica administrativo-educacional, para além daquilo que é estabelecido burocraticamente pelos sistemas de ensino e pelo currículo.

Além da valorização do PPP, um dos principais projetos do governo Itamar Franco e de seu secretário de Educação Murilo Hingel foi a criação do Projeto Escola Sagarana. Este projeto foi anunciado como uma ação permanente do governo com a finalidade de envolver a comunidade educacional no planejamento e desenvolvimento da educação. Apesar das fortes críticas feitas ao governo anterior, a proposta da Escola Sagarana não alterou radicalmente o que já vinha sendo realizado, deu continuidade a muitos projetos e manteve sempre um discurso crítico quanto aos financiamentos do Banco Mundial. Na gestão seguinte este projeto foi descontinuado.

Outra ação que marcou esse governo foi a efetivação do "Sistema de Avaliação da Educação Pública - SIMAVE. Embora, a avaliação educacional em Minas Gerais tenha tido seus primórdios no início da década de 1990, é no governo Itamar Franco que esse sistema é efetivamente instituído por meio da resolução $\mathrm{n}^{\circ} 14$ de 03 de fevereiro de 2000 e substituída em seguida pela resolução $\mathrm{n}^{\circ} 104$ de 14 de julho do mesmo ano, que instituiu o Programa de Avaliação da Educação Básica - PROEB. Com o objetivo de diagnosticar a 
qualidade da educação das escolas mineiras e dar suporte ao planejamento das políticas educacionais do estado, esse sistema iniciou sua aplicação de exames entre outubro e novembro de 2000 e desde então vem aplicando suas avaliações anualmente nas séries finais dos primeiro e segundo ciclos do ensino fundamental e no terceiro ano do ensino médio.

\section{2. As políticas educacionais do governo Aécio Neves (2003-2010)}

Aécio Neves assume seu primeiro mandato em 2003. Entre suas principais prioridades estava a redução dos gastos públicos para redução da dívida pública do estado. Assim, colocou em prática sua proposta de "choque de gestão" que tinha como objetivo a redução das contas públicas e aumento da eficácia da máquina estatal.

Alegando ter assumido um estado endividado e com acúmulo de déficits orçamentários históricos, manifestava não ter meios para arcar com as principais demandas da população, entre elas a educação de qualidade. Esse discurso justificou sua política de redução de despesas e o foco na reorganização e modernização do modelo de gestão do Estado, buscando apresentar programas e ações mais eficazes para atender as diversas demandas sociais. Para Abrucio (2005), esta medida encaixa-se aos problemas de coordenação intergovernamental, presente nas federações em todo o mundo nos últimos anos. Para o autor:

Há hoje expansão ou, no mínimo, manutenção do Welfare State convivendo com maior escassez relativa de recursos. Tal situação exige melhor desempenho governamental, com fortes pressões por economia (cortar gastos e custos), eficiência (fazer mais com menos) e efetividade (ter impacto sobre as causas dos problemas sociais) - três tópicos que dependem, em países federativos, de maior coordenação entre as esferas político-administrativas na gestão das políticas públicas. (ABRUCIO, 2005 p. 41-42).

Aécio Neves nomeia para o comando da SEE-MG a pedagoga e ex-reitora da UFMG, Professora Vanessa Guimarães. Em abril de 2003, após a realização de um diagnóstico das condições educacionais do estado, a Secretária apresenta um plano de trabalho para os quatro anos do seu primeiro mandato. Nesse documento, totalmente alinhado ao plano global de governo de Aécio Neves, dava prioridade à reforma das estruturas administrativas com o "choque de gestão" e ao conceito 
de crescimento com redistribuição, destacando a necessidade de profissionalização da administração da educação. A partir daí a SEE-MG passa a lançar uma série de programas, projetos e ações com ampla divulgação na mídia, porém com pequena abrangência entre as escolas e municípios. A seguir, com a finalidade de aprofundar o estudo sobre a abrangência destas políticas, apresento um "quadro síntese" das políticas educacionais desenvolvidas no governo Aécio Neves entre os anos de 2006-2010. Neste quadro apresento, além das políticas (programas e projetos) e seus objetivos e o ano de implementação. Em seguida, apresento a descrição destas políticas. 
Quadro 3 - QUADRO SÍNTESE DAS POLÍTICAS EDUCACIONAIS IMPLEMENTADAS EM MG - 2006-2010.

\begin{tabular}{|c|c|c|c|c|}
\hline POLÍTICA & FOCO & OBJETIVO & $\begin{array}{l}\text { ANO DE } \\
\text { IMPLEMENTAÇÃO }\end{array}$ & $\begin{array}{l}\text { BASE DE } \\
\text { DADOS }\end{array}$ \\
\hline Escolas Referência (ER) & $\begin{array}{l}\text { Gestores, } \\
\text { Professores } \\
\text { e Estudantes }\end{array}$ & $\begin{array}{c}\text { Identificar e desenvolver características intrínsecas } \\
\text { das escolas com melhores resultados e transformá- } \\
\text { las posteriormente em centros de referência para as } \\
\text { demais escolas da rede. }\end{array}$ & 2003 & SIM \\
\hline $\begin{array}{l}\text { Escola Viva, comunidade } \\
\text { Ativa }\end{array}$ & Estudantes & $\begin{array}{l}\text { Reformas, construção de quadras de esporte e } \\
\text { introdução de ensino profissionalizante, atividades } \\
\text { culturais e outras oficinas. }\end{array}$ & 2003 & NÃO \\
\hline $\begin{array}{l}\text { Plano Global de } \\
\text { Desenvolvimento da } \\
\text { Instituição escolar - PDPI }\end{array}$ & Gestores & $\begin{array}{l}\text { Ganhar a adesão das escolas que participavam do } \\
\text { programa Escolas Referência para que as mesmas } \\
\text { atingissem os objetivos propostos pela SEE-MG. } \\
\text { Em contrapartida as escolas tinham acesso a } \\
\text { recursos e formas de atendimento específicos. }\end{array}$ & 2004 & SIM \\
\hline $\begin{array}{l}\text { Programa de } \\
\text { Desenvolvimento } \\
\text { profissional - PDP }\end{array}$ & Professores & $\begin{array}{l}\text { Melhorar o desempenho profissional dos } \\
\text { professores do Ensino Fundamental e Médio. }\end{array}$ & 2004 & SIM \\
\hline $\begin{array}{l}\text { Programa Educacional de } \\
\text { Atenção ao Jovem - PEAS } \\
\text { Juventude } \\
\end{array}$ & Estudantes & $\begin{array}{l}\text { Complementar a formação escolar através de ações } \\
\text { de caráter lúdico-educativo com o foco na } \\
\text { integração social dos jovens. }\end{array}$ & 2004 & SIM \\
\hline Programa livro na Escola & Estudantes & $\begin{array}{l}\text { Distribuição de livros didáticos para os estudantes } \\
\text { do EM }\end{array}$ & 2004 & SIM \\
\hline $\begin{array}{l}\text { Currículo Básico Comum } \\
\text { para o EM - CBC }\end{array}$ & $\begin{array}{l}\text { Professores } \\
\text { e Estudantes }\end{array}$ & $\begin{array}{l}\text { Indicar as habilidades e competências que os } \\
\text { estudantes de ensino médio devem adquirir e } \\
\text { desenvolver. }\end{array}$ & 2006 & SIM \\
\hline
\end{tabular}




\begin{tabular}{|c|c|c|c|c|}
\hline POLÍTICA & FOCO & OBJETIVO & $\begin{array}{l}\text { ANO DE } \\
\text { IMPLEMENTAÇÃO } \\
\end{array}$ & \begin{tabular}{|l} 
BASE DE \\
DADOS \\
\end{tabular} \\
\hline $\begin{array}{l}\text { Programa Aprofundamento } \\
\text { de Estudos }\end{array}$ & Estudantes & $\begin{array}{l}\text { Ofertar aulas em turmas de aprofundamento de } \\
\text { estudos em horário extraclasse, com o fim de } \\
\text { consolidar conteúdos estudados em sala de aula. }\end{array}$ & 2006 & NÃO \\
\hline $\begin{array}{l}\text { Programa de Formação } \\
\text { Inicial para o Trabalho - } \\
\text { FIT }\end{array}$ & Estudantes & $\begin{array}{l}\text { Oferecer formação tecnológica adicional para os } \\
\text { estudantes de ensino médio, por meio da formação } \\
\text { de professores que, depois de capacitados, } \\
\text { repassavam o mesmo treinamento, na escola, aos } \\
\text { alunos interessados. }\end{array}$ & 2006 & SIM \\
\hline $\begin{array}{l}\text { Programa de Melhoria da } \\
\text { Qualidade e Eficiência do } \\
\text { EM - PROMÉDIO }\end{array}$ & Estudantes & $\begin{array}{l}\text { Melhorar os indicadores de eficiência do Ensino } \\
\text { Médio, como a ampliação da taxa de conclusão e } \\
\text { redução dos índices de repetência e evasão escolar. }\end{array}$ & 2007 & NÃO \\
\hline $\begin{array}{l}\text { Programa de Distribuição } \\
\text { da Merenda }\end{array}$ & Estudantes & Oferecer merenda aos alunos do Ensino Médio. & 2007 & SIM \\
\hline $\begin{array}{l}\text { Programa de Educação } \\
\text { Profissional - PEP }\end{array}$ & Estudantes & $\begin{array}{l}\text { Expansão da formação profissional técnica de nível } \\
\text { médio. }\end{array}$ & 2007 & SIM \\
\hline $\begin{array}{l}\text { Programa Poupança Jovem } \\
\text { - PJ }\end{array}$ & Estudantes & $\begin{array}{l}\text { Ampliar as taxas de conclusão e reduzir os índices } \\
\text { de repetência e evasão escolar em áreas com } \\
\text { elevados índices de violência e baixo Índice de } \\
\text { Desenvolvimento Humano (IDH). }\end{array}$ & 2007 & SIM \\
\hline $\begin{array}{l}\text { Efetivação de Professores } \\
\text { sem concurso - } \\
\text { LC100/2007 }\end{array}$ & Professores & $\begin{array}{l}\text { Efetivação de } 98 \text { mil professores e funcionários da } \\
\text { SEE-MG que mantinham contratos precários de } \\
\text { trabalho com o estado, garantindo a estabilidade } \\
\text { sem a exigência do concurso público. }\end{array}$ & 2007 & NÃO \\
\hline Curso Técnico Normal & Estudantes & Oferecer a formação Técnica Normal & 2008 & $\mathrm{NÃO}$ \\
\hline
\end{tabular}




\subsection{1. \\ Descrição das políticas educacionais}

A seguir apresento uma descrição dos programas e projetos desenvolvidos pela SEE-MG ao longo da gestão Aécio Neves que, de forma geral, atingiram outros níveis de ensino ou, no caso do EM, foram universais ou a SEE-MG não tinha controle da abrangência dos mesmos, não sendo possível realizar a análise de abrangência das mesmas. Contudo, é importante destacar a existência destas políticas no sentido de possibilitar uma compreensão geral do programa de políticas educacionais implementadas nesse governo.

\subsubsection{1. \\ Programa escola viva, comunidade ativa}

O Programa Escola Viva, Comunidade Ativa, foi um programa de combate à violência escolar e também foi implementado em 2003. Consistia em reformas, construção de quadras de esporte e introdução de ensino profissionalizante, atividades culturais e outras oficinas. Ao todo, foram atendidas apenas 170 escolas da região metropolitana.

\subsubsection{2. \\ Plano Global de desenvolvimento da instituição escolar - PDPI}

O Plano Global de Desenvolvimento da Instituição Escolar - PDPI, foi implantado a partir de 2004. Sua elaboração se deu por solicitação da SEE-MG às escolas participantes do Projeto Escolas-Referência e consistia em um plano de ação comum para atingir os objetivos propostos pela SEE-MG. Em contrapartida, as escolas participantes tinham acesso aos recursos e formas de atendimentos específicos oferecidos pela SEE-MG. Para Silva (2007), esse documento seguia concepções presentes em governos anteriores:

Em boa medida, observa-se que as diretrizes orientadoras do PDPI representaram uma retomada das concepções de planejamento do trabalho escolar presentes nos governos de Eduardo Azeredo (1995-1999) e Hélio Garcia (1991-1994), dentro da perspectiva do gerenciamento da qualidade total, porém sob outro campo terminológico. (SILVA, 2007 p. 14). 
No que concerne ao planejamento do trabalho escolar, a perspectiva apontada pelo governo anterior, Itamar Franco, foi gradualmente substituída pelo PDPI.

A construção do PDPI era orientada pela SEE-MG no sentido de situar a escola no âmbito do mercado atual com todas as suas contradições e problemas (macro situacional), no âmbito do mundo almejado (macro doutrinal) e no âmbito da educação como prática social que busca as transformações no mundo e nos cidadãos.

Para atender essas orientações, as escolas deveriam obrigatoriamente criar alternativas como abertura da escola à comunidade para oferecimento de atividades culturais, científicas, esportivas e recreativas capazes de desenvolver a cidadania e colaborar na preparação dos alunos e comunidade em geral para o trabalho e protagonismo social; ampliação do atendimento escolar com ampliação da duração do ensino fundamental com matrículas desde 6 anos e aumento do número de vagas no ensino médio para atendimento de toda a demanda existente; ampliação da jornada escolar, com a implantação do projeto "Aluno de tempo integral" por meio do atendimento em outro turno a grupos selecionados de alunos que apresentassem necessidade de atendimento adicional; introdução no currículo de qualificação básica para o trabalho, oferecimento de oficinas e cursos de qualificação básica para o trabalho, especialmente para alunos do ensino médio (informática, artesanato, eletricista, bordado, fotografia); melhoria da qualidade de ensino com a incorporação ao currículo de atividades e projetos de enriquecimento curricular como, concursos literários, feiras de cultura, de ciência e tecnologia etc., propiciando descobrir e desenvolver talentos e preparação de alunos para serem monitores na própria escola (trabalho voluntário); apoio ao professor para sua capacitação e apoio à escola para por meio do fortalecimento da direção e do colegiado com a capacitação de gestores e membros do colegiado, estimular a participação da comunidade e a integração escola/comunidade, além de outras atividades prevista no PDPI da escola.

\subsubsection{3. \\ Programa livro na escola}

Também em 2004, a SEE-MG, antecipou-se ao MEC e implantou o programa "Livro na Escola - Mais Fácil Aprender, Mais Fácil Ensinar", voltado para os alunos do ensino médio, adquirindo, com recursos próprios do estado, livros didáticos de Língua Portuguesa, Matemática, Física, Química, Biologia, Geografia e História. Em 2005, 
foram distribuídos os livros de Português e Matemática. No ano seguinte, foram distribuídos livros de Química, Física e Biologia. E, por fim, em 2007, os alunos receberam exemplares de livros de História e Geografia. A partir de 2008, o estado passou a ser contemplado pelo Programa Nacional do Livro Didático para o Ensino Médio - PNLEM e as escolas mineiras de ensino médio passaram a receber livros adquiridos com recursos federais. Ao longo do processo de escolha do livro didático, foram realizados estudos e reuniões para discussão de um Currículo Básico Comum para o Ensino Médio - CBC.

\subsubsection{4.}

\section{Currículo básico comum para o Ensino Médio - CBC}

Por meio do CBC, a SEE-MG indicou as habilidades e competências que os estudantes de ensino médio deveriam adquirir e desenvolver. Nessa orientação, foram estruturados dois níveis, permitindo uma primeira abordagem mais geral $\mathrm{e}$ semiquantitativa no $1^{\circ}$ ano e um tratamento mais quantitativo e aprofundado no $2^{\circ}$ ano. Com isso, a SEE-MG passou a controlar $50 \%$ dos conteúdos e da carga horária do Ensino Médio. Os conteúdos obrigatórios dos CBC passaram a ser utilizados nas avaliações sistêmicas da SEE-MG, que, a partir de 2006, passou a utilizá-los como referencial, avaliando os alunos matriculados nas escolas estaduais da mesma forma, independentemente da região em que viviam.

Para garantir a implantação do CBC nas escolas, foram disponibilizadas versões eletrônicas em um sítio na internet criado para apoiar os educadores. O Centro de Referência Virtual do Professor - CRV. Por meio do CRV, os professores de todas as escolas mineiras passaram a ter acesso ao CBC com a finalidade de unificá-lo em todo estado. Também no sentido de garantir a implementação do CBC a SEE-MG instituiu uma Coordenação Pedagógica, vinculada à Coordenação Executiva do Projeto Escola Referência para acompanhar as escolas na implantação do novo currículo. A Coordenação Pedagógica de Acompanhamento e Avaliação da Implantação do Novo Plano Curricular do Ensino Médio iniciou suas atividades em março de 2006. Para garantir a integração entre as ações do Projeto Escolas-Referência e aquelas voltadas à implantação do novo plano curricular, também foram preparados os técnicos das SRE, garantindo que os outros $50 \%$ da carga horária fossem utilizados para aprofundamento 
dos conteúdos dos CBC e/ou introdução de conteúdos complementares, de acordo com o projeto pedagógico de cada escola.

\subsubsection{5.}

\section{Programa aprofundamento de estudos}

Em 2006, último ano do primeiro mandato do governador Aécio Neves, a SEEMG implantou o programa aprofundamento de estudos para os alunos do $3^{\circ}$ ano do ensino médio das escolas-referência. Esse programa consistia na oferta de aulas em turmas de aprofundamento de estudos em horário extraclasse, com o fim de consolidar conteúdos estudados em sala de aula, dedicando mais tempo para uma melhor preparação, principalmente para aqueles estudantes que pretendiam realizar o ENEM ou vestibular.

Esse programa também foi utilizado como estratégia da SEE-MG para a implementação do Novo Plano Curricular do Ensino Médio e tinha como seu principal objetivo aprofundar os conhecimentos em disciplinas ou conteúdos não consolidados pelos estudantes. A partir de 2007 esse programa passou a ser oferecido às demais escolas da rede que manifestaram interesse. Somente os alunos matriculados nessas escolas podiam participar do projeto. De acordo com dados ${ }^{8}$ fornecidos pela SEE-MG, em 2007, foram beneficiados alunos do $3^{\circ}$ ano do Ensino Médio regularmente matriculados nas escolas pertencentes ao Projeto Escola Referência, quando foram oferecidas 30.000 vagas.

Em 2008, houve expansão para os alunos do $2^{\circ}$ ano do Ensino Médio e alunos do $1^{\circ}$ ano das escolas participantes do Programa Poupança Jovem. Nesse ano, foram oferecidas 40.000 vagas. Em 2009, o programa passou a atender, também, aos alunos do $1^{\circ}$ ano do Ensino Médio das escolas municipais de Uberlândia, quando foram ofertadas 60.000 vagas. Em 2010, foram oferecidas 50.000 vagas para os alunos do $1^{\circ}, 2^{\circ}$ e $3^{\circ}$ anos do Ensino Médio em toda a Rede Estadual de Minas Gerais. Embora esse projeto tenha se ampliado para toda a rede, não foi possível captar seus efeitos para os fins dessa pesquisa, considerando que a participação dos alunos não é universal e se deu por adesão.

\footnotetext{
${ }^{8}$ Dados obtidos por meio do Relatório circunstanciado do Ensino Médio e Profissional de Minas Gerais, 2010 .
} 


\subsubsection{6. \\ Programa de melhoria da qualidade e eficiência do Ensino Médio - PROMÉDIO}

O Governador Aécio Neves foi reeleito em 2006 e a partir de 2007 iniciou seu segundo mandato no governo de Minas Gerais mantendo a professora Vanessa Guimarães à frente da SEE-MG. Logo no início do novo governo, é lançado o Programa de Melhoria da Qualidade e Eficiência do Ensino Médio - PROMÉDIO. Esse programa tinha como meta melhorar os indicadores de eficiência do Ensino Médio, como a ampliação da taxa de conclusão e redução dos índices de repetência e evasão escolar.

Na prática, o PROMÉDIO foi um programa amplo que passou a aglutinar várias ações já praticadas nas escolas-referência e outros programas que já atendiam o ensino médio. Entre as ações que compunham esse programa podemos citar a implementação das novas propostas curriculares, a oferta de merenda para os alunos do turno noturno e a oferta de cursos de qualificação básica para o trabalho. Além disso, também estavam no escopo desse programa a capacitação de professores e a compra de equipamentos didáticos. Assim, o novo programa simplesmente absorveu as ações de antigos programas como o Programa Aprofundamento de Estudos - PAE, o Programa Formação Inicial para o Trabalho - FIT e também de novos programas como o Programa de Educação Profissional (PEP) e outros projetos, programas e ações desenvolvidos no âmbito do Ensino Médio e Profissional em Minas Gerais entre 2003 e 2010.

Com o PROMÉDIO, o projeto escolas-referência passa a ser considerado um projeto complementar e em seguida é absorvido pelos projetos escolas em rede e pelo próprio PROMÉDIO.

\subsubsection{7. \\ Programa de distribuição da merenda}

Também alinhado às propostas do PROMÉDIO, em 2007 foi lançado o Programa de Distribuição da Merenda, com o objetivo de oferecer merenda aos alunos do Ensino Médio noturno em escolas da região do semiárido mineiro (Norte de Minas, Vales do Jequitinhonha e Mucuri) e da região metropolitana de Belo Horizonte. Em 2009, por meio da Medida Provisória n 455 de 28 de janeiro de 2009, que posteriormente foi convertida na LEI No 11.947, de 16 de junho de 2009, a merenda escolar tornou-se obrigatória e foi estendida a todo o universo do Ensino Médio. 


\subsubsection{8. \\ Efetivação de professores sem concurso público - LC100/2007}

Antes do término do ano de 2007, o governador Aécio Neves aprovou na Assembleia Legislativa de Minas Gerais a Lei Complementar 100 - LC100/2007 que se tornou uma das mais polêmicas de seu governo. Essa lei efetivou 98 mil professores e funcionários da SEE-MG que mantinham contratos precários de trabalho com o estado. Com a LC100/2007 o estado de Minas Gerais garantiu a estabilidade sem a exigência do concurso público, mas não garantiu a esses servidores os mesmos direitos dos professores concursados, como o direito de progressão na carreira. Assim, com a efetivação, criou-se uma subcategoria de professores dentro da Rede Estadual de Minas Gerais. Com o elevado número de efetivações sem concurso, a rede passou a comportar uma minoria de professores ingressos por concurso público dividindo a categoria. Com essa divisão as escolas passaram a ter professores "efetivados" e professores "concursados". A categoria perdeu força política e ao mesmo tempo a SEE-MG ganhou maior poder para exigir o cumprimento de suas propostas por ter a simpatia dos professores agraciados com a efetivação.

A medida que era justificada pelo estado como uma forma de corrigir a situação trabalhista de professores e outros profissionais da educação que mantinham vínculos contratuais precários com o estado foi considerada inconstitucional pela justiça estadual e encaminhada ao Supremo Tribunal Federal. Contudo, independente dos resultados jurídicos da LC100/2007, a mesma transformou-se em um sério problema da rede mineira de educação e sua promulgação não deu solução aos mesmos. Como verificamos em Gatti et. al. (2011, p.159):

A condição de contrato temporário de docentes, não conduzindo à estabilidade e à progressão profissional, gera nas redes alguns problemas que mereceriam melhor consideração, pois afetam a própria profissionalização docente, a formação continuada e progressiva de quadros, a formação de equipes nas escolas e, em decorrência, a qualidade do ensino. A precariedade dos contratos de trabalho traz consigo rodízio excessivo de professores, instabilidade das equipes escolares e, até mesmo, desistências da profissão. São questões importantes a serem consideradas pelas políticas relativas aos docentes, dado que interferem diretamente no trabalho cotidiano das escolas, na aprendizagem dos alunos e no seu desenvolvimento, causando também desperdício financeiro no que se refere aos investimentos formativos em serviço.

Pode-se verificar que a LC100/2007 resolveu provisoriamente o problema da estabilidade dos docentes, mas criou um clima de desconfiança para esses educadores que ainda temem a perda do cargo após o julgamento da inconstitucionalidade da lei. 
Além disso, a estabilidade sem acesso a progressão profissional criou na Rede Mineira de Educação dois grupos de profissionais que disputam entre si, dividindo a categoria e fortalecendo a SEE-MG.

\subsubsection{9.}

\section{Curso Técnico Normal}

Em 2008, a SEE-MG passou a ofertar o Curso Técnico Normal na rede estadual de ensino com o objetivo de atender às reivindicações das prefeituras municipais referentes à qualificação dos profissionais em exercício em creches e pré-escolas. Também vinculada ao PEP, a oferta do curso técnico Normal visava a qualificação de profissionais que atuavam em creches e não possuíam a habilitação mínima legalmente definida na Lei de Diretrizes e Bases. Nesse contexto, para atender as exigências da Lei 9.394/96 e da Resolução CNE/CEB no 2/99 a SEE-MG passou a ofertar também o Curso Normal para Professores de Educação Infantil.

Assim, em 2008, foi implantado em 55 escolas o Curso Normal para preparação de professores para atuar na educação infantil. No ano de 2009, esse número elevou-se para 77 escolas com 20,6 mil alunos, sendo 4.326 (quatro mil trezentos e vinte e seis) alunos dos Cursos Técnicos em escolas estaduais e 16.274 (dezesseis mil duzentos e setenta e quatro) alunos do Curso Normal em Nível Médio.

Na primeira fase de implantação do Curso Normal, em 2008, foi autorizado o funcionamento de turmas em escolas estaduais, que tradicionalmente já haviam oferecido o Curso Normal e apresentavam infraestrutura necessária, localizadas no município sede de cada Superintendência Regional de Ensino, envolvendo um total de 55 escolas. Em 2009, na $2^{\text {a }}$ fase de implementação do programa, a proposta inicial tratava de autorização para o funcionamento do Curso Normal em 3 (três) escolas estaduais por Superintendência Regional de Ensino. No entanto, diante da demanda apresentada pelos diversos municípios, a SEE-MG expandiu esse atendimento para 77 escolas distribuídas em todo o Estado. Na $3^{\text {a }}$ fase, em 2010 esse atendimento atingiu o total de 184 escolas estaduais. 


\section{3.}

\section{Abrangência das políticas educacionais implementadas pela SEE-MG (2006-2010)}

Além dos programas acima apresentados, também foram desenvolvidos outros seis programas que foram selecionados para uma análise estatística mais detalhada. Esses programas, diferentemente dos já descritos, apresentam uma distribuição espacial bastante irregular, os quais pretendo estudar com maior cuidado. Ao longo do período analisado, foram levantados quinze programas/projetos que constituíram o pacote de políticas educacionais desenvolvidas no governo Aécio Neves. Entretanto, devido às características destes programas e considerando que o foco desta pesquisa está no Ensino Médio, selecionei os seis programas que serão analisados com relação a abrangência, ou seja, número de municípios contemplados.

Para realizar a análise da abrangência das políticas implementadas por ano, por SRE e por município, organizei a base de dados por \% de escolas contempladas em cada município com os seguintes programas:

Quadro 4 - Programas analisados.

\begin{tabular}{l|c}
\hline \multicolumn{1}{c|}{ INDICADOR } & PERÍODO \\
\hline Escolas Referência - ER & $2007-2010$ \\
\hline Programa de Desenvolvimento Profissional - PDP & $2007-2010$ \\
\hline Programa de Atenção ao Jovem - PEAS & $2007-2009$ \\
\hline Formação Inicial para o Trabalho - FIT & $2008-2009$ \\
\hline Programa de Educação Profissional - PEP & $2007-2010$ \\
\hline Programa Poupança Jovem & $2007-2010$ \\
\hline \multicolumn{2}{c}{ Fonte: Elaborado pelo autor. }
\end{tabular}

A seguir apresento descrição dos programas selecionados e os resultados da análise de abrangência por município dispostos em mapas temáticos e gráficos, organizados por programa. Os resultados apresentam os municípios que foram contemplados ou não pelos programas, considerando $100 \%$ para os municípios que tiveram todas as suas escolas contempladas e 50\% para aqueles que tiveram apenas metade de suas escolas contempladas.

Para isso, criei como parâmetros para essa análise 5 faixas para verificar o número de escolas de EM atendidas em cada município: 0\% (municípios não atendidos pelo programa), $1 \%-25 \%$ ( $1 \%$ a $25 \%$ das escolas dentro de um mesmo município atendidas pelo programa), $26 \%-50 \%$ (26\% a $50 \%$ das escolas dentro de um mesmo município 
atendidas pelo programa), $51 \%$ a $75 \%$ (51\% a $75 \%$ das escolas dentro de um mesmo município atendidas pelo programa) e 100\% (acima de $75 \%$ das escolas dentro de um mesmo município atendidas pelo programa). Em Minas Gerais, os 29 municípios mais populosos somam cerca de 8,5 milhões de habitantes $(43,41 \%$ do total da população), enquanto os 670 menores municípios, ou seja, a maioria dos 853 municípios do estado soma aproximadamente 5 milhões de habitantes (25,65\% da população do estado). É importante pensar nesses números antes de analisar a abrangência das políticas educacionais aqui estudadas, ou seja, entender que a distribuição da população é irregular, bem como a dispersão da mesma pelo Estado. Portanto, é necessário conhecer a população atendida e a população não atendida por estes programas.

Conforme já discutido, para Arretche (1998), a análise e avaliação de políticas sociais deve compreender a configuração dessas políticas, bem como explicitar a sua dimensão, significado, abrangência, funções, efeitos e outros elementos que atribuem forma e significado às mesmas. Nesse sentido, busco me concentrar na análise das políticas educacionais aqui eleitas no sentido de compreender sua abrangência e suas relações com os indicadores sociais e demográficos e também com o desempenho médio por município dos estudantes do $3^{\circ}$ ano do EM.

Para a autora, avaliação se distingue da análise de políticas sociais, pois a análise busca reconstituir as diversas características de uma política, como por exemplo, suas relações entre público e privado, formas de financiamento, as modalidades de prestação de serviços e as possibilidades de desenho institucional que atribuem corpo a uma política social. Analisar uma política social, nessa perspectiva, pressupõe examinar o quadro institucional e os traços constitutivos da política analisada, a fim de observar, examinar e criticá-la. Nessa definição, a análise de políticas sociais busca apreender sua conformação e estrutura, sem se preocupar com seus efeitos e implicações reais. Arreche (1998, p.31) reforça essa ideia:

Ainda que a análise de uma política pública possa atribuir a um determinado desenho institucional alguns resultados prováveis, somente a avaliação desta política poderá atribuir uma relação de causalidade entre um programa x um resultado.

As ideias de Arretche (1998) reforçam os objetivos desta pesquisa, já que me proponho a analisar a abrangência das políticas educacionais implementadas no governo Aécio Neves, e não avaliá-las no sentido de apresentar aqui neste estudo explicações de causalidade entre as políticas e os indicadores educacionais. Entretanto, apresentarei algumas análises que buscam relacionar e comparar indicadores sociais, demográficos e 
educacionais em relação à abrangência dos programas implementados. A identificação da abrangência dos programas é importante no sentido de revelar o alcance da política e/ou programa analisado. Assim, para efeito de análise, esse indicador deve sempre ser relacionado ao universo a que a política e/ou programa deveria se destinar. Na série de gráficos que apresento a seguir é possível verificar a abrangência dos programas em relação ao número de municípios contemplados e, dentro de cada município, o percentual de escolas atendidas.

Para isso, selecionei apenas os programas que atingiram o EM e solicitei à SEEMG a base de dados com informações sobre todas as escolas contempladas por cada um desses programas. Com esse material em mãos, foi possível confeccionar os gráficos que se seguem e realizar a análise da abrangência destas políticas.

\subsection{1. \\ Projeto Escolas-Referência - ER}

Ainda em 2003, a SEE-MG começa a apresentar seus primeiros programas e projetos. O Projeto escolas referência foi um dos primeiros a ser criado. Foram selecionadas 223 escolas, com representantes de todas as regiões do Estado, para compor o projeto. Pretendia-se identificar e desenvolver características intrínsecas dessas escolas e transformá-las posteriormente em centros de referência para as demais escolas da rede. Mais tarde, esse projeto foi expandido e com a abertura de um novo edital foram selecionadas outras 361 escolas, totalizando 584 escolas-referência em 2008. Este número correspondia a $27,90 \%$ das escolas de ensino médio regular da rede estadual mineira como podemos constatar na tabela 4. Ainda em 2008, o projeto foi incorporado pelo Programa de Melhoria da Qualidade e Eficiência do Ensino Médio PROMÉDIO, que tinha como meta melhorar os indicadores de eficiência do Ensino Médio, ampliando a taxa de conclusão e reduzindo os índices de repetência e evasão escolar.

Tabela 3 - Número de escolas-referência em 2003 e 2007. Rede Estadual de Minas Gerais

\begin{tabular}{c|c|c|c|c|c|c|c}
\hline \multicolumn{2}{c|}{$\begin{array}{c}\text { Total de Escolas } \\
\text { da Rede }\end{array}$} & \multicolumn{2}{c|}{$\begin{array}{c}\text { Total de Escolas } \\
\text { com EM Regular }\end{array}$} & \multicolumn{2}{c|}{$\begin{array}{c}\text { Total de Escolas Referência } \\
\text { com EM Regular 2003* }\end{array}$} & \multicolumn{2}{c}{$\begin{array}{c}\text { Total de Escolas Referência } \\
\text { com EM Regular 2007* }\end{array}$} \\
\hline Total & $\%$ & Total & $\%$ & Total & $\%$ & Total & $\%$ \\
\hline 3.982 & 100 & 2.093 & 52.56 & 223 & 10.65 & 584 & 27.90 \\
\hline
\end{tabular}

*Percentual de escolas calculado em relação ao total de escolas com Ensino Médio.

FONTE: Elaborado pelo autor com dados fornecidos pela SEE-MG 
Como verificamos na tabela 5, embora o programa tenha ampliado o número de escolas beneficiadas em mais de $100 \%$ em 2007, sua abrangência total alcançou menos de $30 \%$ do total de escolas com ensino médio no estado.

Gráfico 21 - Municípios x \% de escolas atendidas pelo programa Escolas Referência ER (2006-2010).

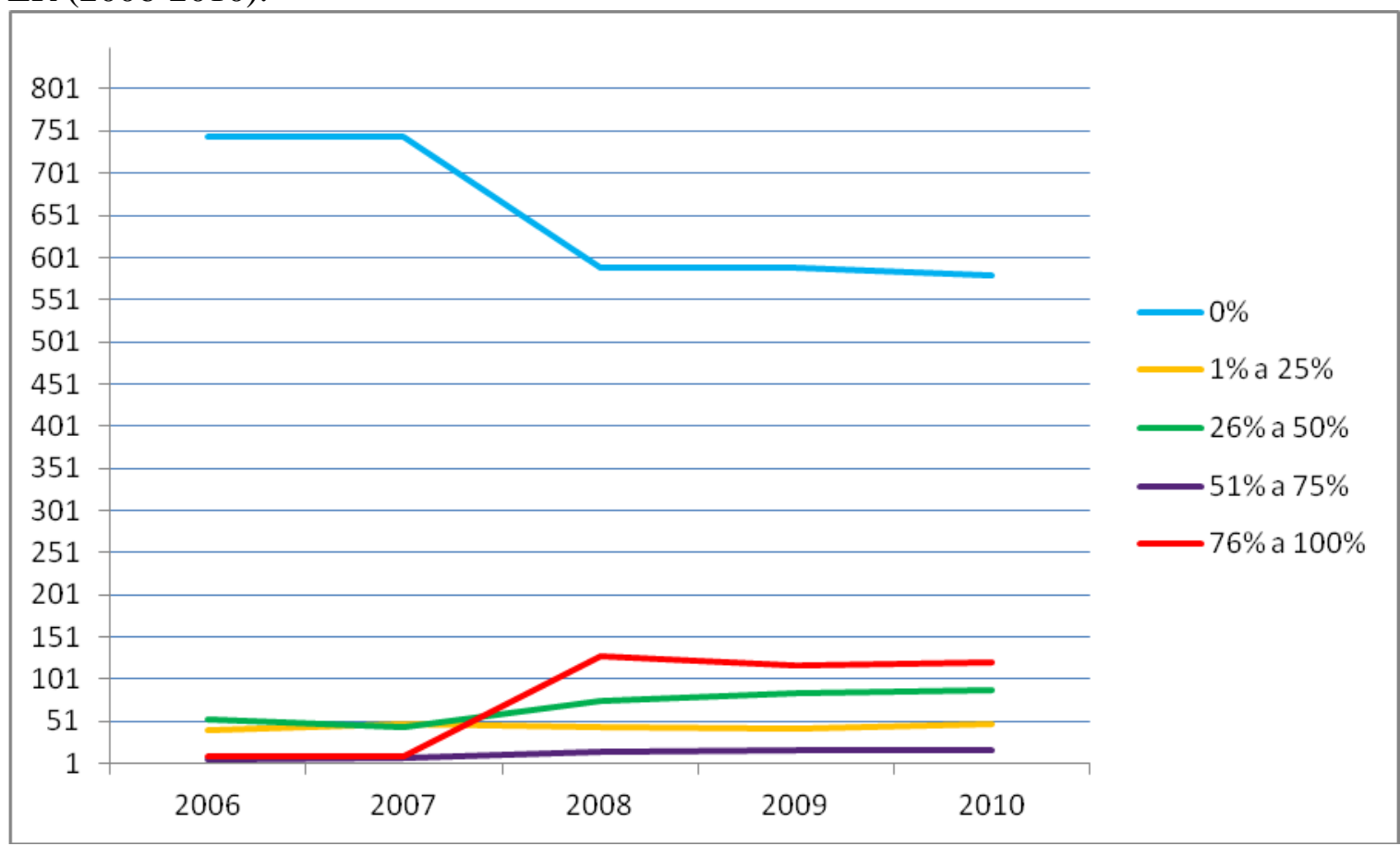

Fonte: Elaborado pelo autor com dados da SEE-MG.

É possível constatar no gráfico 22 que o programa Escolas Referência iniciado em 2006, em seu primeiro ano de implementação atingiu apenas 109 municípios, ampliando sua abrangência apenas a partir de 2009, quando passou a contemplar um número maior de municípios a partir de 2008. Analisando a evolução do programa ER entre os anos de 2006-2010, é possível verificar que sua abrangência foi bastante tímida, visto que em 2010 chegou a apenas 272 municípios, sendo que destes apenas 121 foram contemplados em $100 \%$ de suas escolas.

\subsection{2.}

Programa de desenvolvimento profissional - PDP

Também em 2004 é relançado o Programa de Desenvolvimento Profissional PDP. Este programa que teve sua concepção em 1998, a partir das melhores experiências de formação continuada de professores até então realizadas pela SEE-MG, teve sua implementação interrompida logo após a fase da inscrição de grupos 
participantes, em consequência da descontinuidade administrativa produzida pela mudança de governo, ocorrida em 1999.

Este projeto tinha como foco melhorar o desempenho profissional dos professores do Ensino Fundamental e Médio. O programa foi planejado e executado em etapas, capacitando inicialmente os coordenadores pedagógicos e, em seguida, focando no aperfeiçoamento dos professores. O PDP também era articulado a um Programa de Avaliação de Desempenho Individual. O programa iniciou-se nas escolas participantes do Projeto Escolas-Referência e em 2007 foi estendido às demais escolas.

A metodologia utilizada pelo programa foi a de criação de grupos de desenvolvimento profissional. Esses grupos deveriam articular-se em torno da concepção e execução de projetos determinados pela SEE-MG, que elegeu como tópicos para o aprimoramento profissional o planejamento didático, a gestão de sala de aula, a seleção de recursos e métodos didáticos e a avaliação da aprendizagem. Ao constituir e participar de um Grupo de Desenvolvimento Profissional (GDP), os educadores deveriam compartilhar boas práticas, metodologias e processos didáticopedagógicos. O PDP também serviu como estratégia da SEE-MG para implantação do Currículo Básico Comum (CBC) nas escolas de Ensino Médio.

A partir de 2008, a SEE-MG reconfigurou o PDP, definindo seis áreas temáticas para que suas ações e projetos fossem desenvolvidos: Alfabetização e Letramento, Avaliação Educacional e Institucional, Desenvolvimento do Ensino, Educação Ambiental, Educação Patrimonial, Feiras e Mostras de Cultura, Ciência e Tecnologia. A expansão do programa até o ano de 2009 atingiu 788 GDPs em 425 escolas, envolvendo 8.668 professores.

No gráfico 23, referente ao programa de desenvolvimento profissional - PDP, verifica-se que houve diminuição do número de municípios contemplados, sendo que dos 18 municípios que possuíam o programa em 2007, apenas 2 tinham o programa implementado em 100\% de suas escolas. Nos anos de 2008 e 2009, o programa se expandiu atingindo 178 escolas em 2010. Embora o número de municípios tenha aumentado, apenas 67 municípios contaram com o programa em 100\% de suas escolas e a maioria dos municípios contemplados pelo programa, teve a implementação em menos da metade de suas escolas. 
Gráfico 22 - Municípios x \% de escolas atendidas pelo Programa de Desenvolvimento Profissional - PDP (2006-2010).

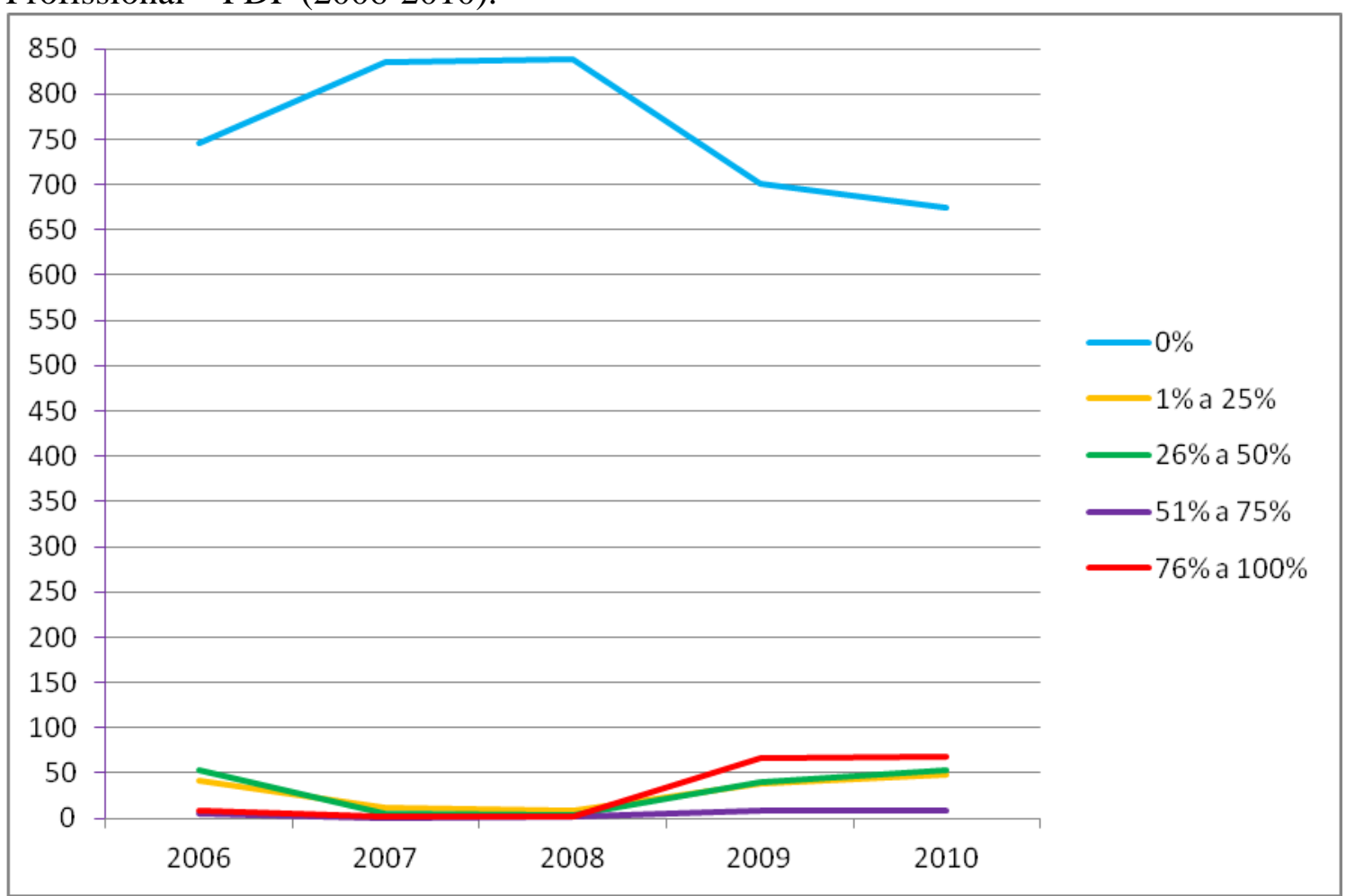

Fonte: Elaborado pelo autor com dados da SEE-MG.

\subsection{3.}

Programa educacional de atenção ao jovem - PEAS JUVENTUDE

No ano de 2004 também é reestruturado o Programa Educacional de Atenção ao Jovem - PEAS Juventude. Este programa passou por uma série de mudanças desde suas origens no "Projeto de Educação Afetivo-Sexual - um novo olhar" (PEAS), implementado em 1994. Em sua concepção original, o programa tinha como objetivo minimizar a vulnerabilidade dos jovens e adolescentes frente a questões como gravidez não planejada, uso indevido de drogas e doenças sexualmente transmissíveis, em especial o HIV/Aids.

Na gestão Aécio Neves, o PEAS Juventude passou a ficar vinculado aos Projetos Estruturadores Escola Viva, Comunidade Ativa e Escolas-Referência. Com isso, o projeto passou a ser dirigido aos alunos do ensino médio público da rede estadual de Minas Gerais com o objetivo de complementar a formação escolar através de ações de caráter lúdico-educativo com o foco na integração social dos jovens. Em 2005, a abrangência do PEAS cresceu para 391 Escolas Estaduais. Em 2006, foram desenvolvidos projetos com temas dirigidos ao "Protagonismo Juvenil" nessas 391 
escolas. Nesse ano, houve ainda a adesão de mais 117 escolas. Em 2007, 491 Escolas Estaduais desenvolveram o Plano Anual PEAS (Estudo e Projeto), ampliando o atendimento para 422 escolas estaduais em 2008 e para 642 escolas em 2009.

Gráfico 23 - Municípios x \% de escolas atendidas pelo Programa de Atenção ao Jovem - PEAS (2006-2009).

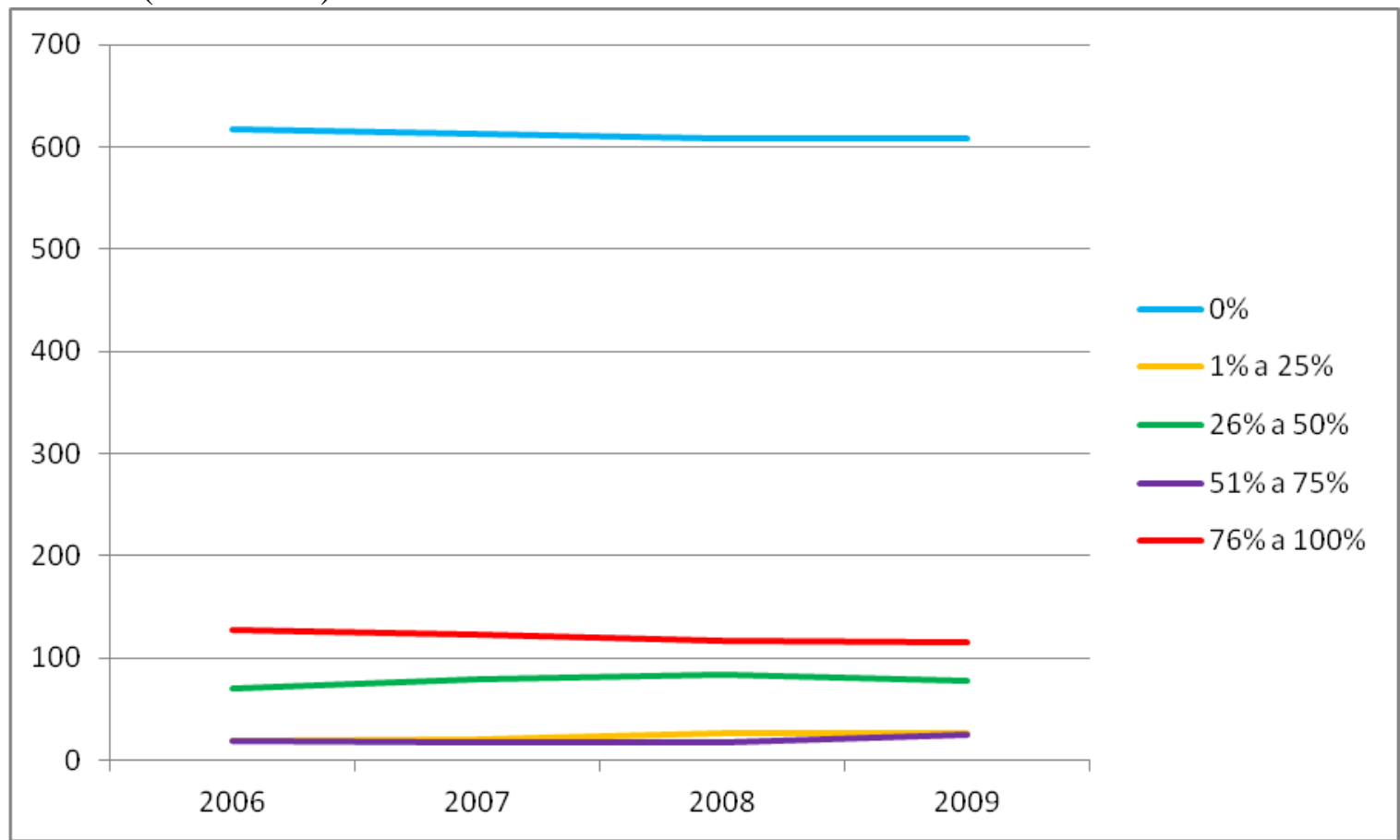

Fonte: Elaborado pelo autor com dados da SEE-MG.

O programa de atenção ao jovem (PEAS-Juventude) funcionou apenas até o ano de 2009. O gráfico 24 apresenta a evolução da abrangência do programa durante o período. Conforme os demais programas, o PEAS também deixou a maioria absoluta dos municípios mineiros sem atendimento. Estendendo sua abrangência para apenas mais dez municípios desde 2006, o programa contemplava 245 municípios em 2009. Entre os municípios contemplados em 2009, apenas 115 tinham todas as suas escolas atendidas pelo programa.

\subsection{4.}

Programa de formação inicial para o trabalho - FIT

Outro programa iniciado em 2006 foi o Programa de Formação Inicial para o Trabalho - FIT. Esse programa consistia em oferecer uma formação tecnológica adicional para os estudantes de ensino médio, por meio da formação de professores que, depois de capacitados, deveriam repassar o mesmo treinamento, na escola, aos alunos 
interessados. Cada curso de formação para os docentes tinha a duração de 180 horas e eram ministrados inicialmente pela equipe dos Núcleos de Tecnologia Educacional NTEs das Superintendências Regionais de Ensino - SREs, sob a coordenação da SEEMG em parceria com o SENAC. Os cursos ministrados aos alunos, pelos professores multiplicadores, tinham a carga horária de 40 horas cada. A SEE-MG também confeccionou material impresso e em CD que foi distribuído aos cursistas.

Foram capacitados educadores em todo o estado, que passaram a ser multiplicadores dos cursos que frequentaram. Esses cursos tinham o objetivo de oferecer formação inicial na área tecnológica, sendo uma opção de formação profissional para os estudantes de ensino médio. Todos os cursos oferecidos relacionavam-se à área de tecnologia e informática, como construção de Web Sites, computação gráfica e sistemas operacionais.

Ao todo, foram formados cerca de 20 mil professores multiplicadores. De 2006 a 2009, 264 mil alunos frequentaram o FIT em 2.089 escolas. Em 2010 foram atendidos cerca de 90 mil alunos. Também foram distribuídas, na $1^{\text {a }}$ etapa do Programa, 21 mil kits com o material didático e 160 mil CDs dos cursos.

Gráfico 24 - Municípios x \% de escolas atendidas pelo Programa de Formação Inicial ao Trabalho - FIT (2008-2009).

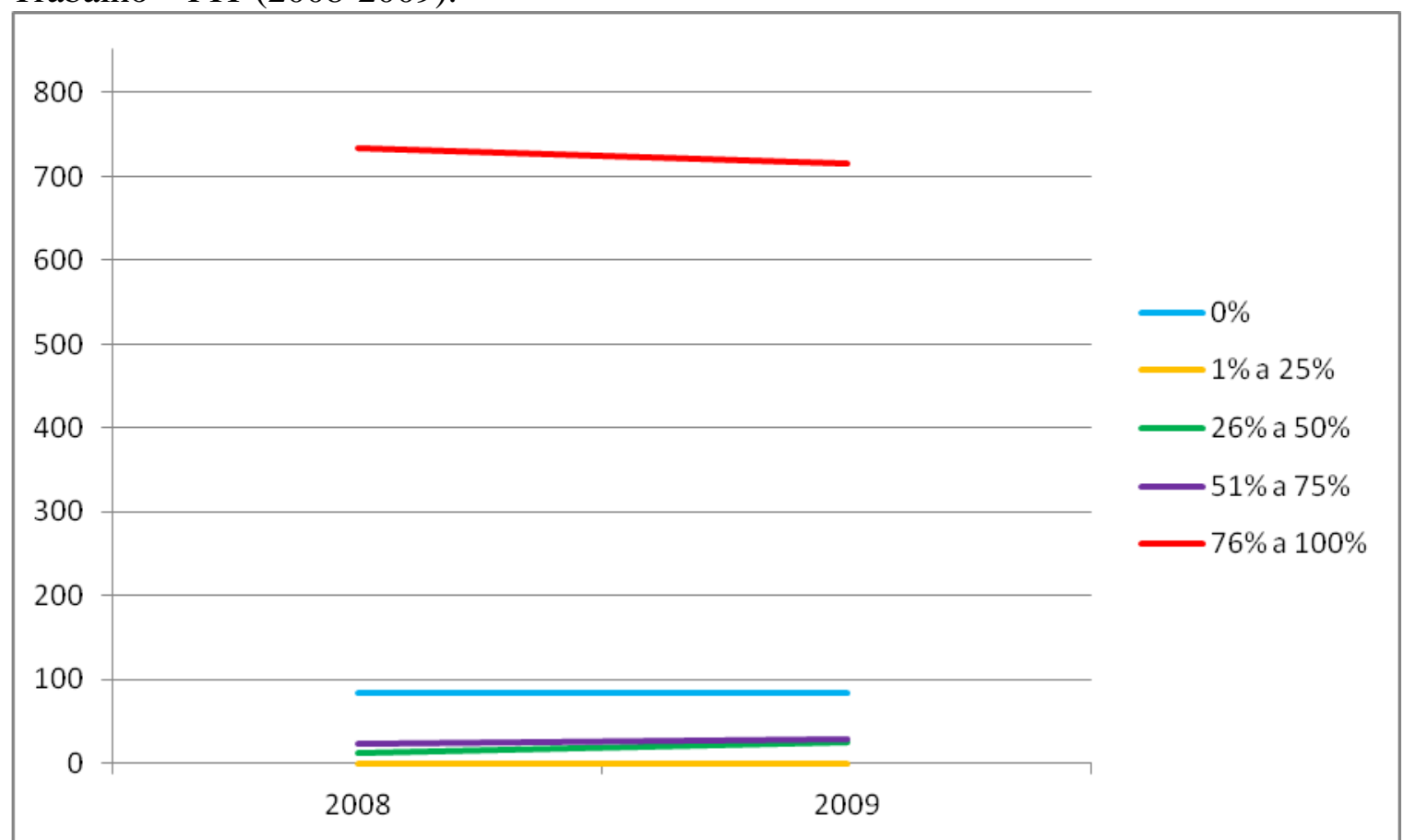

Fonte: Elaborado pelo autor com dados da SEE-MG.

O programa de formação inicial ao trabalho (FIT) que funcionou apenas entre os anos de 2008 e 2009 foi o programa com maior abrangência em relação ao número de 
municípios atendidos. Nos dois anos de funcionamento do programa, foram contemplados 770 municípios, sendo que a maior parte deles teve o programa implementado em $100 \%$ de suas escolas, conforme podemos verificar no gráfico 25 .

\subsection{5. \\ Programa de educação profissional - PEP}

Ainda em 2007 foi publicado o Decreto no 44.632 - Implantação do Programa de Educação Profissional - PEP e a instituição da Rede Mineira de Formação Profissional Técnica em Nível Médio. Em outubro do mesmo ano foi publicado o $1^{\circ}$ Edital do PEP.

Por meio do PEP era gerida a Rede Mineira de Formação Profissional, com o objetivo de permitir a expansão da formação profissional técnica de nível médio em todas as regiões de Minas Gerais. A Rede Mineira de Formação Profissional de Nível Médio compreendia um circuito de instituições envolvidas na formação profissional de nível médio em Minas Gerais. Coordenada pelo PEP, a Rede Mineira de Formação Profissional Técnica de Nível Médio articulava as instituições de ensino.

A Rede foi constituída por escolas estaduais que já ofertavam cursos técnicos, por instituições conveniadas (instituições públicas federais, municipais e privadas, sem fins lucrativos, que oferecem Educação Profissional) e por instituições credenciadas (instituições privadas de Ensino Médio, com ou sem fins lucrativos). Também articularam-se ao PEP os cursos de informática aos alunos do Ensino Médio das escolas estaduais oferecidos pelo FIT.

De acordo com Decreto $n^{\circ}$ 44.632, o PEP destinaria vagas em cursos técnicos, oferecidos pelas instituições credenciadas, aos alunos regularmente matriculados no Ensino Médio da rede estadual de ensino e aos jovens de 18 a 24 anos que já haviam concluído o Ensino Médio. O Decreto n 44.973, de 3 de dezembro de 2008, alterou o texto original, retirando o limite de idade dos participantes que já haviam concluído o Ensino Médio. Ao todo, o programa atendeu 297 municípios selecionados na região metropolitana de Belo Horizonte, nas sedes de SRE, nas sedes de microrregiões, nos municípios com mais de 30 mil habitantes e nos municípios com investimento previsto de mais de 100 milhões de reais, nos quatro anos seguintes ao da implantação da Rede de Formação Profissional.

Em 2008, a SEE-MG lança o Curso de Montagem e Manutenção de Computadores. Esse curso foi implantado em escolas do município sede de cada 
Superintendência Regional de Ensino. A indicação das escolas foi feita pela própria SRE, levando-se em conta as condições de infraestrutura das escolas participantes do Projeto Escolas-Referência existentes no município. Nas escolas escolhidas, foi montado um laboratório de informática para a oferta do curso. O objetivo da oferta desse curso foi capacitar tecnicamente os alunos de Ensino Médio que manifestavam interesse em aprender a montar, fazer manutenção e configurar microcomputadores. $\mathrm{O}$ curso também foi oferecido a alunos de outras escolas, professores, servidores e para a comunidade quando disponível.

Gráfico 25 - Municípios x \% de escolas atendidas pelo Programa de Educação Profissional - PEP (2007-2010).

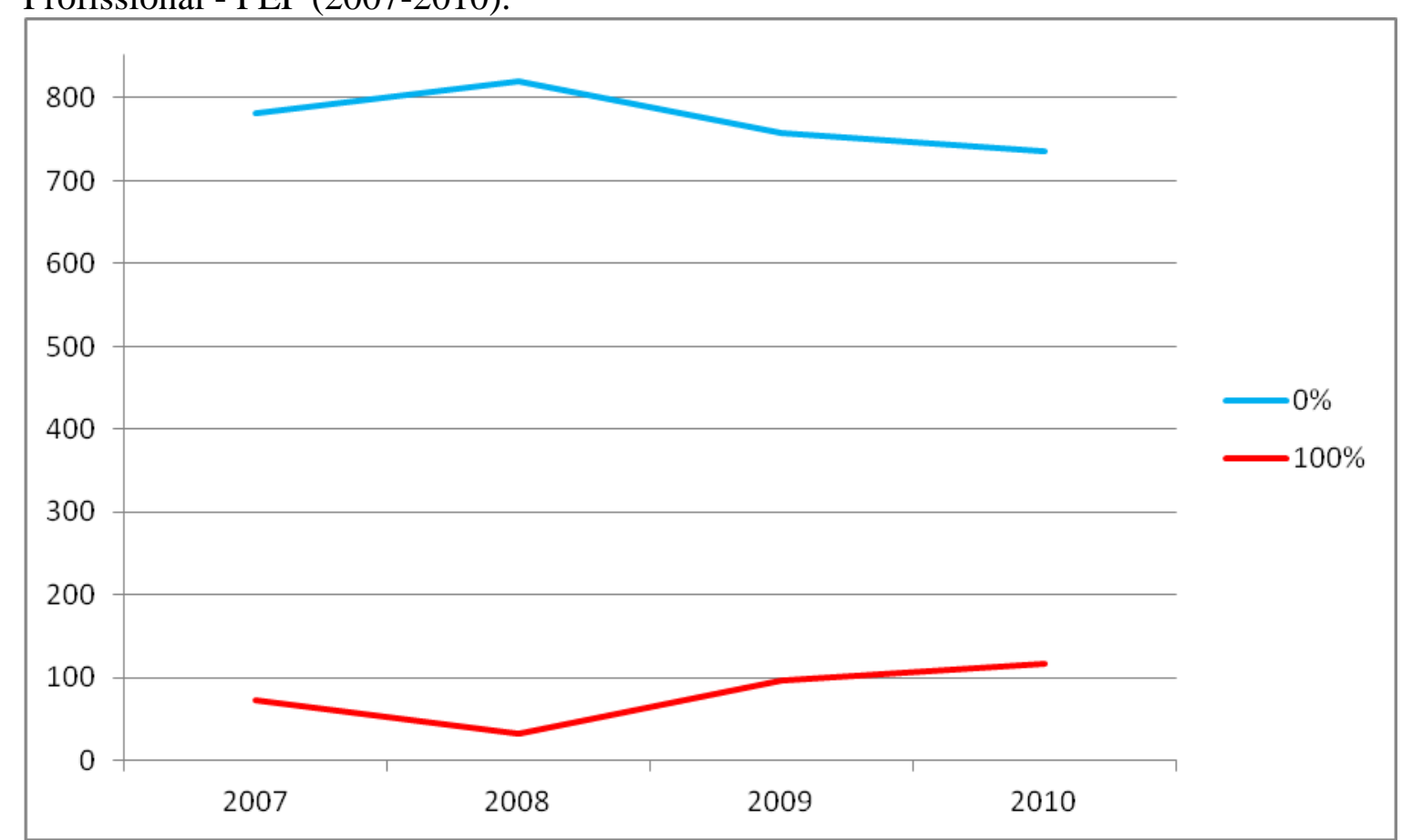

Fonte: Elaborado pelo autor com dados da SEE-MG.

O programa de educação profissional (PEP) teve sua implementação em 2007, contemplando apenas 72 municípios. Conforme podemos verificar no gráfico 26, houve redução dos municípios contemplados em 2008 e expansão do atendimento a partir de 2009, chegando a 117 municípios contemplados no ano de 2010. Entretanto, conforme outros programas, o atendimento foi bastante tímido, deixando de fora 736 municípios.

\subsubsection{Programa poupança jovem - PJ}

Em 2007 tem início o programa Poupança Jovem - PJ que, embora integralmente voltado para estudantes do ensino médio, era coordenado pela Secretaria de Estado de 
Desenvolvimento Social (SEDESE). Ao final dos três anos de curso do EM, o jovem aprovado e concluinte das atividades do programa PJ tinha direito ao saque de uma poupança no valor de $\mathrm{R} \$ 3$ mil. Classificado pela SEE-MG como um programa social de caráter estruturador, o PJ era voltado exclusivamente para estudantes matriculados nas escolas públicas do estado de Minas Gerais. O programa tinha como justificativa atender estudantes residentes em municípios ou regiões com elevadas taxas de evasão escolar, combinadas com violência e baixo Índice de Desenvolvimento Humano (IDH).

Para que o estudante pudesse sacar seu benefício ao final do ensino médio, teria como contrapartida, cumprir durante o período de formação as exigências de frequência determinadas pela SEE-MG, bem como assumir o compromisso de submeter-se ao acompanhamento permanente do seu rendimento escolar e a participação em programas estabelecidos pela SEE-MG. Considerando o tamanho da rede estadual de Minas Gerais e o número total de escolas de ensino médio do estado, o número de escolas contempladas com as bolsas do programa PJ foi bastante tímido como podemos constatar na tabela 6 .

Tabela 4 - Número de escolas atendidas pelo Poupança Jovem entre 2007 e 2009.

\begin{tabular}{c|r|c|r|r|r|r}
\hline \multicolumn{6}{c}{ Poupança Jovem - Número de escolas atendidas } \\
\hline $\begin{array}{c}\text { Total de Escolas com EM } \\
\text { Regular }\end{array}$ & \multicolumn{2}{|c|}{2007} & \multicolumn{2}{|c|}{2008} & \multicolumn{2}{|c}{2009} \\
\cline { 2 - 7 } & \multicolumn{1}{c|}{ Total } & $\%$ & \multicolumn{1}{c}{ Total } & $\%$ & Total & $\%$ \\
\hline 2.093 & 30 & 1.43 & 78 & 3.73 & 177 & 8.46 \\
\hline
\end{tabular}

*Percentual de escolas calculado em relação ao total de escolas com Ensino Médio.

FONTE: Elaborado pelo autor com dados fornecidos pela SEE-MG

Em análise realizada pelo CEDEPLAR - UFMG, coordenada pelo Professor RIOS-NETO em 2011, foram avaliados os resultados do PJ, entre eles, o impacto do programa sobre a proficiência dos estudantes mineiros. Nesse estudo, os resultados obtidos não foram favoráveis ao programa como podemos ver:

Os resultados não são favoráveis ao programa: os alunos participantes do Poupança Jovem em Ribeirão das Neves, Coorte 1, obtiveram notas em português e matemática, significativamente inferiores as dos alunos do grupo controle. Considerando o desviopadrão da curva de proficiência do Proeb 2009 (ver anexo 5.5), este efeito corresponde a 0,476 desvio padrão (matemática) e 0,270 (português). Há a possibilidade de se estar observando um viés de seletividade devido à atrição tanto de alunos de tratamento quanto de controle, mas a estimativa da totalidade de escolas que serviram de base para a amostra, confirma o impacto negativo sobre a proficiência. (CEDEPLAR, 2011 p.39).

Em análise qualitativa apresentada no mesmo estudo, é apontada a necessidade de investimentos em outras áreas como a melhoria da estrutura física das escolas nos 
diferentes municípios, bem como ações da própria escola para melhorar o acesso dos estudantes à infraestrutura existente:

Em muitas escolas, embora os espaços existam, eles não podem ser utilizados pelos alunos, que, em geral, nem mesmo os conhecem. Esta invisibilidade impede aqueles alunos que não têm recursos em casa, tais como livros e computadores, façam seus trabalhos e, eventualmente, se sintam mais motivados para estudar. Neste sentido, a sugestão é de que as escolas planejem, em conjunto com os alunos, melhores formas de utilização do espaço físico. As bibliotecas não só deveriam ficar abertas durante todo o horário de funcionamento das escolas, incluindo o horário noturno, como também deveriam ser melhor equipadas. (CEDEPLAR, 2011 p.41).

Ainda no mesmo relatório, a equipe técnica do CEDEPLAR considerou que o Programa Poupança Jovem pratica a meritocracia ao eleger os jovens do ensino médio como beneficiários:

Claramente, o Poupança Jovem, que se inspirou em uma das ramificações do programa Oportunidades do México, é um programa que pretende induzir o comportamento do jovem e apresenta um conteúdo explícito de estímulo ao mérito, além da introdução de uma noção de planejamento de longo prazo, algo característico da atividade de poupar e investir. Ao focalizar no ensino médio, o programa acaba delimitando um foco menor do que o conjunto de jovens, o que acaba sendo definidor de um benefício para um grupo de mérito, por estar matriculado no ensino médio, embora ainda assim, pela condição geográfica ou de residência, carente e em risco de ver frustrada as suas chances de vida. Neste sentido, é possível dizer que, a despeito das generalizações sobre pobreza e desajuste, na realidade o Poupança Jovem já é meritocrático no seu ponto de partida, a matrícula na primeira série do médio, apresentando um conteúdo mais incentivador deste mérito ao estimular a conclusão do ensino médio. (CEDEPLAR, 2011 p.46).

Mesmo com a baixa eficácia apontada pela pesquisa realizada pela CEDEPAR, o PJ continuou sendo desenvolvido pela SEDESE em parceria com a SEE-MG. Sua abrangência continuou pequena em relação ao total de escolas mineiras e por consequência também um baixo número de municípios foi atendido.

O programa poupança jovem (PJ) foi o programa com o menor percentual de municípios atendidos. Iniciando como um projeto piloto em 2007 com apenas um município, atingiu oito municípios em 2009 e sete municípios em 2010, conforme se pode constatar abaixo no gráfico 27 . 
Gráfico 26 - Municípios x (\%) de escolas atendidas pelo Programa Poupança Jovem PJ (2007-2010).

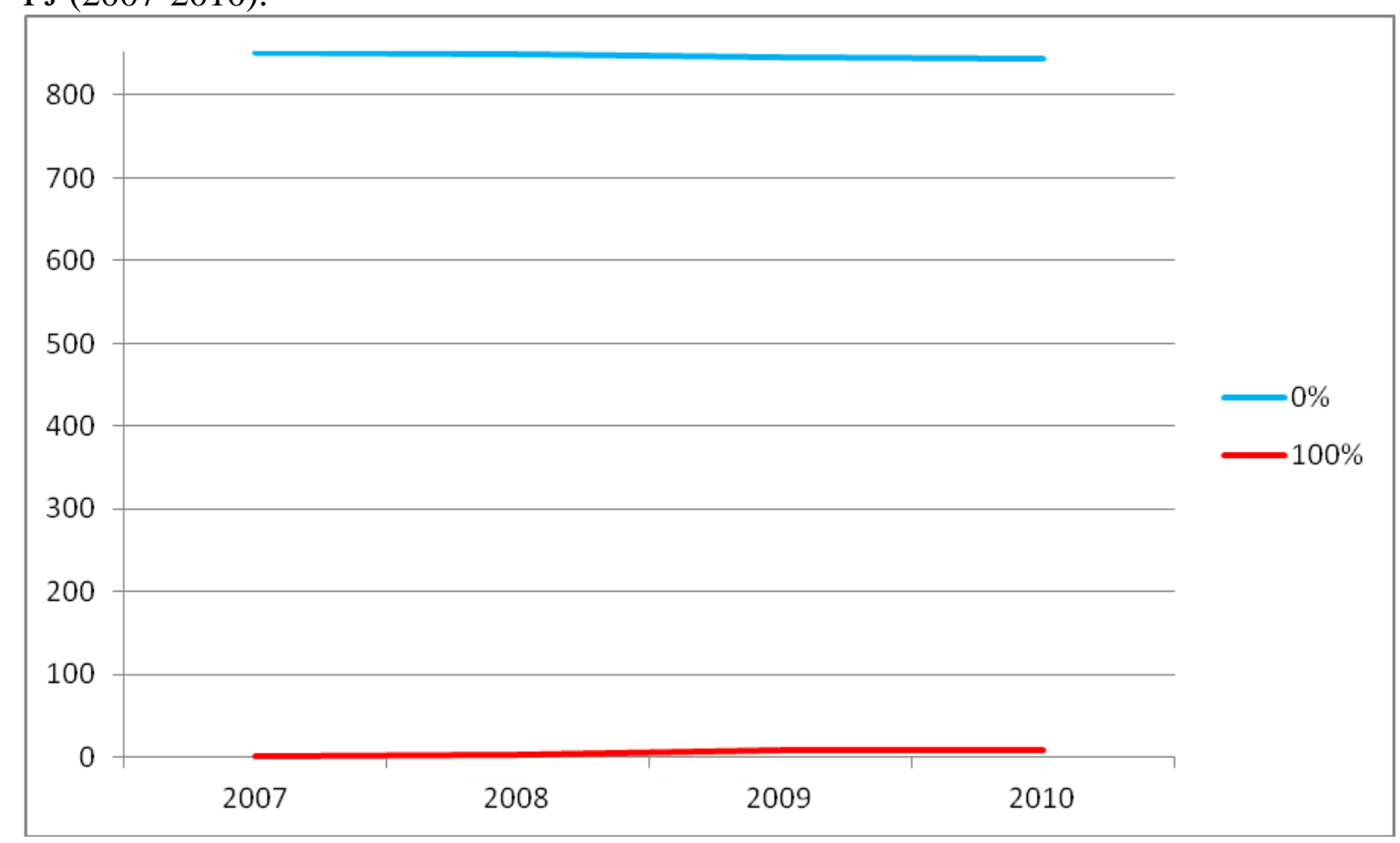

Fonte: Elaborado pelo autor com dados da SEE-MG.

\section{4. \\ Análise da política educacional mineira na gestão Aécio Neves}

Pude constatar na descrição dos programas/projetos aqui apresentados, que as políticas educacionais mineiras implementadas desde a década de 1990 foram marcadas por mudanças e descontinuidade, e isso também se repetiu ao longo da gestão Aécio Neves. Na década de 1990 não existiram políticas educacionais sistêmicas no âmbito do estado de Minas Gerais, sendo que a maior parte dos programas e ações implementados nesse período estavam vinculados a políticas de governo que, na maioria das vezes, foram descontinuadas após os períodos de transição entre os mesmos.

Cunha (1991), analisando a descontinuidade das politicas educacionais, as definiu como políticas que têm um efeito "zigue-zague". Para o autor, este efeito justifica-se pelo eleitoralismo, o experimentalismo pedagógico e o voluntarismo ideológico. O primeiro é caracterizado pelas políticas educacionais que provocam "impacto" capaz de trazer resultados nas urnas. $\mathrm{O}$ experimentalismo pedagógico como resultante do entusiasmo com propostas elaboradas sem bases cientificas anunciadas como redentoras dos problemas educacionais e assumidas apressadamente para o conjunto da rede escolar, antes mesmo de serem suficientemente testadas. Por fim, o voluntarismo 
pedagógico refere-se à atitude generosa de querer acabar com os males da educação escolar e até da sociedade como um todo, no curto espaço de uma administração, ou até em menos tempo.

A descontinuidade das políticas tem com certeza grande influência na vida da escola e de seus profissionais e por isso é importante mapear a abrangência destas políticas bem como o tempo em que vigoraram nos municípios contemplados. Conforme apresentado por Cunha (1991), políticas e ações como, por exemplo, a efetivação de milhares de professores sem a realização de concurso podem estar atreladas a um viés eleitoreiro. No caso dessa política especificamente, os objetivos políticos do governador Aécio Neves foram atingidos, já que o mesmo conseguiu eleger seu sucessor no primeiro turno de 2010 e também ser eleito Senador da república no mesmo ano. Com relação a segunda razão elencada por Cunha (1991), a gestão Aécio Neves demonstrou não se encaixar, já que a grande maioria dos programas e ações propostas não chegou a atender todas as escolas da Rede Estadual Mineira. Na verdade o que se observou foi um efeito contrário, já que grande parte das políticas foi apenas testada e na prática atendeu apenas uma pequena parcela das escolas como já demonstrei, por exemplo, nos programas Escolas-Referência e Poupança Jovem. Quanto ao voluntarismo pedagógico, esse governo também deu sinais de dominar os caminhos para solucionar as mazelas da educação mineira em sua administração, apresentando políticas já formatadas sem estabelecer um diálogo mais amplo e cuidadoso com professores da rede ou pesquisadores do campo da educação. Com base nas estatísticas já apresentadas, constatamos que isso também não aconteceu.

Apropriando-me do referencial teórico já apresentado sobre a abrangência dos programas e ações da SEE-MG durante a gestão Aécio Neves, tomo como base os trabalhos de Arretche (2004), Abrucio (2005) e Souza (2006). Assim, constato que as políticas educacionais implementadas ao longo do governo Aécio Neves estavam perfeitamente adaptadas a ideologia de um "novo gerencialismo público" conforme afirma Souza (2006, p.34):

A partir da influência do que se convencionou chamar de "novo gerencialismo público" e da política fiscal restritiva de gasto, adotada por vários governos, novos formatos foram introduzidos nas políticas públicas, todos voltados para a busca de eficiência. Assim, a eficiência passou a ser vista como o principal objetivo de qualquer política pública, aliada à importância do fator credibilidade e à delegação das políticas públicas para instituições com "independência" política. Estes novos formatos, que guiam hoje o desenho das políticas públicas mais recentes, ainda são pouco incorporados nas pesquisas empíricas. 
Para a autora, a adoção de políticas restritivas de gasto passou a dominar a agenda da maioria dos países, em especial os em desenvolvimento. A partir dessas políticas, o desenho e a execução de políticas públicas, tanto as econômicas como as sociais, ganharam maior visibilidade. Assim, o estado de Minas Gerais, fortemente marcado por uma conjuntura de fragilidade econômica, foi gerido por uma proposta global de governo baseada no choque de gestão que, como já descrito, era constituído por ações de racionalização de processos, modernização de sistemas, reestruturação do aparelho do estado e avaliação de desempenho institucional e individual, com o objetivo de melhorar a qualidade e reduzir os custos dos serviços públicos. Esse choque de gestão foi amplamente noticiado como prioridade governamental por ser essencial para a reestruturação econômica do Estado. Com isso, os investimentos da área social foram marcados pela contenção de gastos, inclusive na educação.

A contenção de gastos públicos para a recuperação econômica do estado pôde ser constatada no texto da maioria dos programas e ações da SEE-MG que tinham como pano de fundo o tema da boa gestão e da adoção de medidas de rápido impacto na área educacional, com eficiência e eficácia, como por exemplo, o Programa de Melhoria da Qualidade e Eficiência do Ensino Médio - PROMÉDIO, que anunciava como meta "melhorar os indicadores de eficiência do Ensino Médio".

Embora o estado não apresente um programa específico para avaliação dos impactos de suas políticas educacionais, os exames de proficiência realizados pelos estudantes, como por exemplo o PROEB, permitem avaliar os estudantes do $3^{\circ}$ ano do EM.

Ao longo da gestão Aécio Neves e mesmo após a sua saída do governo, não foram realizadas muitas pesquisas com o objetivo de estudar as políticas educacionais do seu governo. Um dos trabalhos realizados e que aqui foi apresentado, foi a análise do CEDEPLAR que avaliou o programa Poupança Jovem. Como vimos, este estudo constatou a baixa eficácia deste programa em melhorar o desempenho dos estudantes de ensino médio e também em reduzir desigualdades, já que na análise da equipe avaliadora o fato do programa se concentrar no ensino médio já reforçava a desigualdade, considerando o baixo percentual de estudantes que chegam a esse nível de escolaridade no Estado.

Nessa apresentação dos programas e ações implementados pela SEE-MG durante a gestão Aécio Neves, verifica-se uma grande quantidade de projetos e ações voltadas para o ensino médio, porém não são apresentados instrumentos de acompanhamento dos 
mesmos. O monitoramento dos programas é realizado pela própria equipe gestora do programa. Isso pode dificultar a realização de um diagnóstico imparcial para apontar as possíveis falhas e necessidades de ajuste de cada programa.

Destaco, ainda, outro aspecto que considero fundamental para entender o contexto em que as políticas educacionais do governo Aécio Neves foram implementadas, com relação ao trabalho docente. Dou destaque para a LC100 aprovada pelo governador Aécio Neves em 2007 junto ao Legislativo mineiro. Para Oliveira (2004), os aspectos relacionados às questões trabalhistas ainda são os mais contundentes nas lutas e manifestações dos trabalhadores docentes. Para a autora, isso se explica provavelmente pelo quadro de precarização das condições de trabalho e de remuneração a que esses profissionais se viram submetido nos últimos anos:

Podemos considerar que assim como o trabalho em geral, também o trabalho docente tem sofrido relativa precarização nos aspectos concernentes às relações de emprego. $\mathrm{O}$ aumento dos contratos temporários nas redes públicas de ensino, chegando, em alguns estados, a número correspondente ao de trabalhadores efetivos, o arrocho salarial, o respeito a um piso salarial nacional, a inadequação ou mesmo ausência, em alguns casos, de planos de cargos e salários, a perda de garantias trabalhistas e previdenciárias oriunda dos processos de reforma do Aparelho de Estado têm tornado cada vez mais agudo o quadro de instabilidade e precariedade do emprego no magistério público. (OLIVEIRA, 2004 p. 1140).

Assim, com a aprovação da LC100, estrategicamente o governo mineiro dividiu a categoria criando uma subclasse de profissionais efetivados sem concurso e, com isso, ganhou o apoio desses profissionais que passaram a constituir o grupo majoritário de professores da rede estadual de educação. Estrategicamente com o apoio conquistado, a SEE-MG implementou seus programas com poucos questionamentos da categoria e o governo conseguiu atingir seus objetivos políticos.

Entretanto, nos últimos anos, a LC100/2007 foi contestada juridicamente e atualmente está em processo de julgamento no Supremo Tribunal Federal - STF. Recentemente, uma Ação Direta de Inconstitucionalidade (ADI 4876) ${ }^{9}$ foi proposta ao Supremo Tribunal Federal (STF) pelo procurador-geral da República, Roberto Gurgel, que questiona o artigo $7^{\circ}$ da LC100/2007. Segundo o procurador-geral, "a questão central diz respeito à investidura de milhares de cidadãos em cargos públicos efetivos, sem a realização de concurso público". Tal medida, segundo ele, "caracteriza evidente violação aos princípios republicanos (artigo $1^{\circ}$, cabeça), da isonomia (artigo $5^{\circ}$, cabeça e inciso II), da impessoalidade e da moralidade administrativa (artigo 37,

\footnotetext{
${ }^{9} \mathrm{STF}$ - http://www.stf.jus.br/portal/cms/verNoticiaDetalhe.asp?idConteudo=224553\&tip=UN.
} 
cabeça) e da obrigatoriedade de concurso público (artigo 37, inciso II), todos da Constituição Federal".

Nesse documento, o Procurador revela outra estratégia por trás da LC100/2007. Um dos objetivos dessa lei foi obter para o Estado de Minas Gerais, o Certificado de Regularização Previdenciária (CRP) que, desde 2004, vinha sendo renovado por meio de decisões judiciais de caráter liminar. Com essa regularização o governo de Minas tornou-se apto para firmar convênios com a União e receber verbas federais.

Além de ter acesso as verbas federais, nesse período o governo estadual realizou a negociação de convênios com o BID (US\$ 100 milhões para eletrificação do noroeste e US\$ 10 milhões para o Programa de Aumento de Competitividade das Pequenas Empresas), com o BIRD (US\$ 170 milhões para Políticas de Desenvolvimento) e o Banco Japonês de Cooperação Internacional (US\$ 50 milhões para o Rio Doce).

No momento, os resultados dessa política podem gerar efeitos ainda mais negativos, gerando um clima de instabilidade e nervosismo entre os professores efetivados que correm o risco de perder seus empregos. E, sem dúvida, essa instabilidade dos educadores pode afetar o ambiente escolar.

Outro aspecto percebido é a estratégia de antecipação de políticas nacionais, que mais tarde passaram a ser incorporadas pelo Ministério da Educação, como verificamos no Programa de Distribuição do Livro Didático e da Merenda Escolar. Isso também aconteceu em 2004 com o ensino fundamental de 9 anos. Embora seja uma política definida em lei federal, foi uma das iniciativas mais populares e reconhecidas do governo estadual, principalmente pela população de baixa renda que, com a carência de creches e vagas na educação infantil, passou a levar seus filhos mais cedo para escola.

Nesse sentido, de forma geral, verifica-se que a educação mineira durante a gestão Aécio Neves foi marcada por cortes de gastos sob a ótica do choque de gestão e, por consequência, pela escassez de recursos que levou a SEE-MG à realização de ações e programas pulverizados e pouco abrangentes e que mantêm pouca ou nenhuma unidade entre si. Fica clara a fragilidade das ações ligadas apenas ao plano de governo sem a preocupação de elaborar uma política global de Estado.

A seguir, no item 4.3.1, comento alguns achados da análise descritiva dos dados. Em seguida, no item 4.3.2, analiso a abrangência destas políticas verificando quais municípios foram contemplados por essas políticas e dentro de cada um destes municípios quantas escolas foram atingidas. 


\subsection{1.}

\section{Análise descritiva}

Ao longo do trabalho realizei a descrição dos dados sobre avaliação (matemática e português), ano e município para responder as questões de pesquisa relacionadas à caracterização do desempenho dos estudantes de EM da rede estadual de Minas Gerais e as respectivas médias por municípios. Além disso, verifiquei a evolução dessas médias ao longo do período analisado.

De maneira geral, os resultados indicaram que o desempenho médio dos estudantes foi crescente entre os anos de 2006 e 2010, porém, com a maioria dos estudantes $(68,5 \%)$ ainda na faixa de desempenho baixo segundo os próprios parâmetros do SIMAVE. Um achado interessante nesta análise foi com relação ao turno em que os estudantes estudam. No ano de 2006, 53\% dos estudantes do $3^{\circ}$ Ano do EM avaliados pelo SIMAVE estudavam a noite. Esse número caiu para 40,5\% em 2010. A maior parte dos estudantes com desempenho baixo estudavam no turno da noite e a maioria dos estudantes com desempenho intermediário ou recomendado estudavam no turno da manhã ou tarde, ou seja, os dados confirmam que o desempenho baixo é atribuído aos estudantes do noturno.

Com relação a distribuição espacial da proficiência média dos estudantes, verifiquei que a sitação dos municípios mineiros durante o período analisado não sofreu grandes variações. O desempenho médio dos estudantes por município em ambas as disciplinas avaliadas pelo PROEB em 2006 foi baixo, sendo que a maior parte dos municípios do noroeste, norte e Jequitinhonha apresentaram desempenho médio correspondente ao esperado para estudantes do $9^{\circ}$ ano do ensino fundamental. Nesse ano, 30 municípios não foram avaliados. Dos 853 municípios do Estado, apenas os estudantes de $112(13,1 \%)$ alcançaram o desempenho médio considerado intermediário pelo SIMAVE e em nenhum município mineiro o desempenho médio dos estudantes ficou dentro do parâmetro recomendado para matemática. Na avaliação realizada em 2010, a desigualdade entre o sul e o norte do estado permaneceu. Embora tenha sido registrada melhora no desempenho dos estudantes em ambas as disciplinas, praticamente todo o norte e nordeste do estado concentrava médias de desempenho baixo em ambas as disciplinas. O desempenho intermediário apareceu de forma bastante pulverizada na região centro-sul do estado. 
Considerando as diferenças de desempenho encontradas na análise descritiva dos dados, realizei a comparação entre as notas médias das cidades com seus indicadores sociais e demográficos (População, PIB, PIB per capita, Índice de desenvolvimento Humano e suas divisões, Índice de GINI, e Índice de Desenvolvimento Municipal e suas divisões).

Em seguida, analisei os programas/projetos educacionais implementados pela SEE-MG durante o período de análise. Embora não seja possível afirmar que as variações do desempenho dos estudantes resultem destas políticas, nota-se que os resultados médios dos municípios contemplados em todas as suas escolas pelo programa “Escolas Referência - ER" foi superior aos municípios contemplados em apenas 50\% das escolas e também superior àqueles que não foram contemplados pelo programa. Esses resultados se repetiram em todas as avaliações e anos. Ainda com relação às ER, quando comparado os resultados de desempenho médio por município em português e matemática, verifica-se que nos anos de 2006 e 2007, não houve diferenças relevantes com relação aos municípios não contemplados e também em relação a média geral do estado. Já nos demais anos de 2008 - 2010, observamos um desempenho superior para os municípios $100 \%$ contemplados em relação aos demais grupos.

Os resultados do PDP seguem os mesmo das ER: nos municípios contemplados em $100 \%$ de suas escolas, o desempenho foi superior a todos os outros grupos a partir de 2008. No caso dos municípios contemplados em apenas 50\% de suas escolas, o desempenho em ambas as disciplinas foi em média superior aos demais grupos, porém com uma diferença bem mais tímida. Apenas no ano de 2008, houve resultado discrepante na disciplina de português, já que a média dos municípios contemplados em $50 \%$ de suas escolas ficou abaixo dos demais grupos.

No caso do programa PEAS, temos um bom desempenho em relação aos municípios $100 \%$ contemplados pelo programa, ou seja, o desempenho médio dos estudantes destes municípios ficou acima dos outros grupos e também acima da média geral do estado. Com relação ao grupo de municípios contemplados em apenas $50 \%$ de suas escolas, o desempenho foi superior a média estadual apenas em matemática. Em português este grupo de municípios teve média superior aos municípios não contemplados pelo programa, porém abaixo da média geral do estado, exceto em 2010 quando superou todos os grupos.

Com relação ao PEP, os municípios contemplados pelo programa apresentaram desempenho inferior aos não contemplados em matemática. Já em português, o 
desempenho médio dos municípios contemplados superou os demais grupos, exceto em 2010 quando se verificou um empate entre todos os grupos.

O programa poupança jovem teve resultados piores, ou seja, não houve melhorias nas médias dos municípios contemplados e isso pode ser observado em todos os anos e em ambas as avaliações: as escolas que não adotaram o programa tiveram resultados melhores nessa comparação.

O programa FIT foi oferecido apenas nos anos de 2008 e 2009. Como há divergências de resultados em cada ano, a comparação entre municípios que foram contemplados e não contemplados com o programa não é possível para o ano de 2008. Em matemática, as médias de desempenho dos estudantes dos municípios $100 \%$ contemplados superaram os demais grupos. Já em português, os municípios contemplados ficaram atrás dos demais grupos.

\subsection{2.}

\section{Analise das políticas em relação ao desempenho médio dos estudantes.}

Como vimos na descrição de cada um dos programas apresentados, muitos deles não tinham a proficiência dos estudantes como foco principal de sua ação. Na tabela 7 faço um resumo dos principais objetivos de cada um dos programas aqui analisados.

Tabela 5 - Foco principal dos programas analisados.

\begin{tabular}{c|l|c}
\hline Programa/Projeto & \multicolumn{1}{|c|}{ Objetivos } & Período analisado \\
\hline Escolas Referência - ER & $\begin{array}{l}\text { Melhoria no desempenho dos } \\
\text { estudantes }\end{array}$ & $2006-2010$ \\
\hline $\begin{array}{c}\text { Programa de } \\
\text { Desenvolvimento } \\
\text { Profissional - PDP }\end{array}$ & $\begin{array}{l}\text { Capacitação dos Professores e } \\
\text { melhoria do desempenho dos } \\
\text { estudantes }\end{array}$ & $2006-2010$ \\
\hline $\begin{array}{c}\text { Programa de Atenção ao } \\
\text { Jovem - PEAS }\end{array}$ & $\begin{array}{l}\text { Reduzir Evasão e Melhorar } \\
\text { desempenho dos estudantes }\end{array}$ & $2006-2009$ \\
\hline $\begin{array}{c}\text { Formação Inicial para o } \\
\text { Trabalho - FIT }\end{array}$ & $\begin{array}{l}\text { Reduzir Evasão e oferecer formação } \\
\text { inicial voltada para o mercado de } \\
\text { trabalho para os estudantes }\end{array}$ & $2008-2009$ \\
\hline $\begin{array}{c}\text { Programa de Educação } \\
\text { Profissional - PEP }\end{array}$ & $\begin{array}{l}\text { Reduzir Evasão e oferecer formação } \\
\text { voltada para o mercado de trabalho } \\
\text { para os estudantes }\end{array}$ & $2007-2010$ \\
\hline Programa Poupança Jovem & $\begin{array}{l}\text { Reduzir a Evasão e melhorar o } \\
\text { desempenho dos estudantes }\end{array}$ & $2007-2010$ \\
\hline
\end{tabular}

FONTE: Elaborado pelo autor. 
A seguir apresento uma análise da relação entre o desempenho médio dos estudantes nos municípios que tiveram o programa presente em todas as escolas, e os municípios que não tiveram o programa em nenhuma de suas escolas. O segundo gráfico já representa a comparação das escolas que tiveram metade de suas escolas contempladas com o programa e a outra metade não contemplada ${ }^{10}$.

Como podemos constatar nos gráficos 28 e 29, o desempenho médio em português dos estudantes nos municípios que tiveram o programa implementado em $100 \%$ das suas escolas foi sensivelmente melhor que os municípios com ausência deste programa. A diferença de desempenho médio entre estes dois grupos chegou a aproximadamente 15 pontos em 2010. Mesmo os municípios contemplados com o programa ER em apenas 50\% de suas escolas apresentaram desempenho médio dos estudantes superior em relação aos municípios que não foram contemplados.

Nos gráficos 30 e 31, é possível verificar que em matemática o comportamento das médias dos municípios contemplados em $100 \%$ de suas escolas foi similar ao de português, ficando acima da média estadual. No caso dos municípios contemplados com apenas $50 \%$ de suas escolas esse desempenho, tanto em matemática como em português se mantiveram acima da média do estado.

Gráfico 27 - Média de desempenho em português dos estudantes nos Municípios com $100 \%$ e sem a presença do Programa ER.

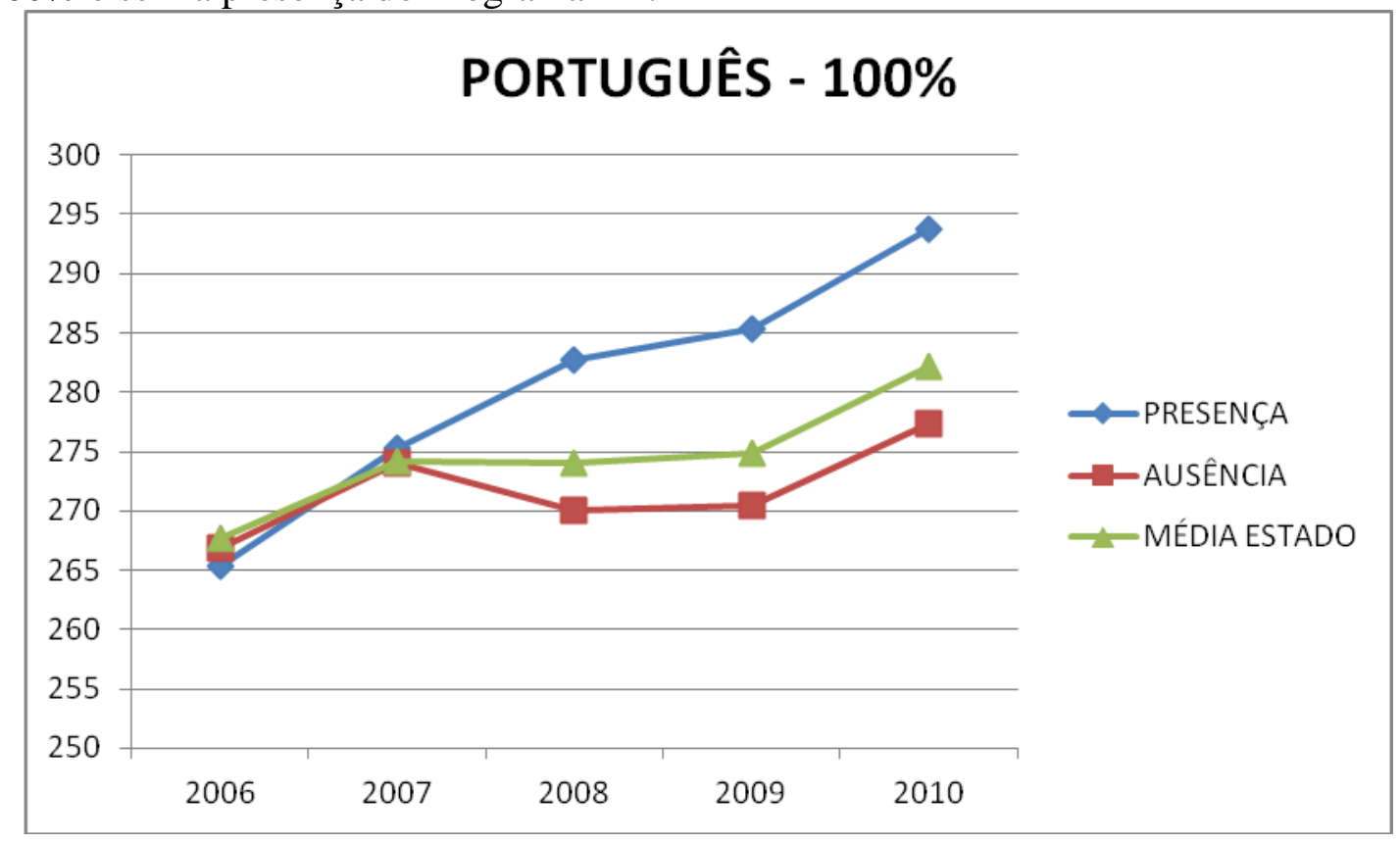

Fonte: Elaborado pelo autor com dados fornecidos pela SEE-MG.

\footnotetext{
${ }^{10}$ A análise aqui realizada é descritiva, uma vez que a comparação é feita entre municípios diferentes e não estão sendo consideradas características específicas como grupo de controle. Portanto, não é possível afirmar a existência de relação de causalidade entre as políticas e o desempenho dos estudantes.
} 
Gráfico 28 - Média de desempenho em português dos estudantes nos Municípios com $50 \%$ e sem a presença do Programa ER.

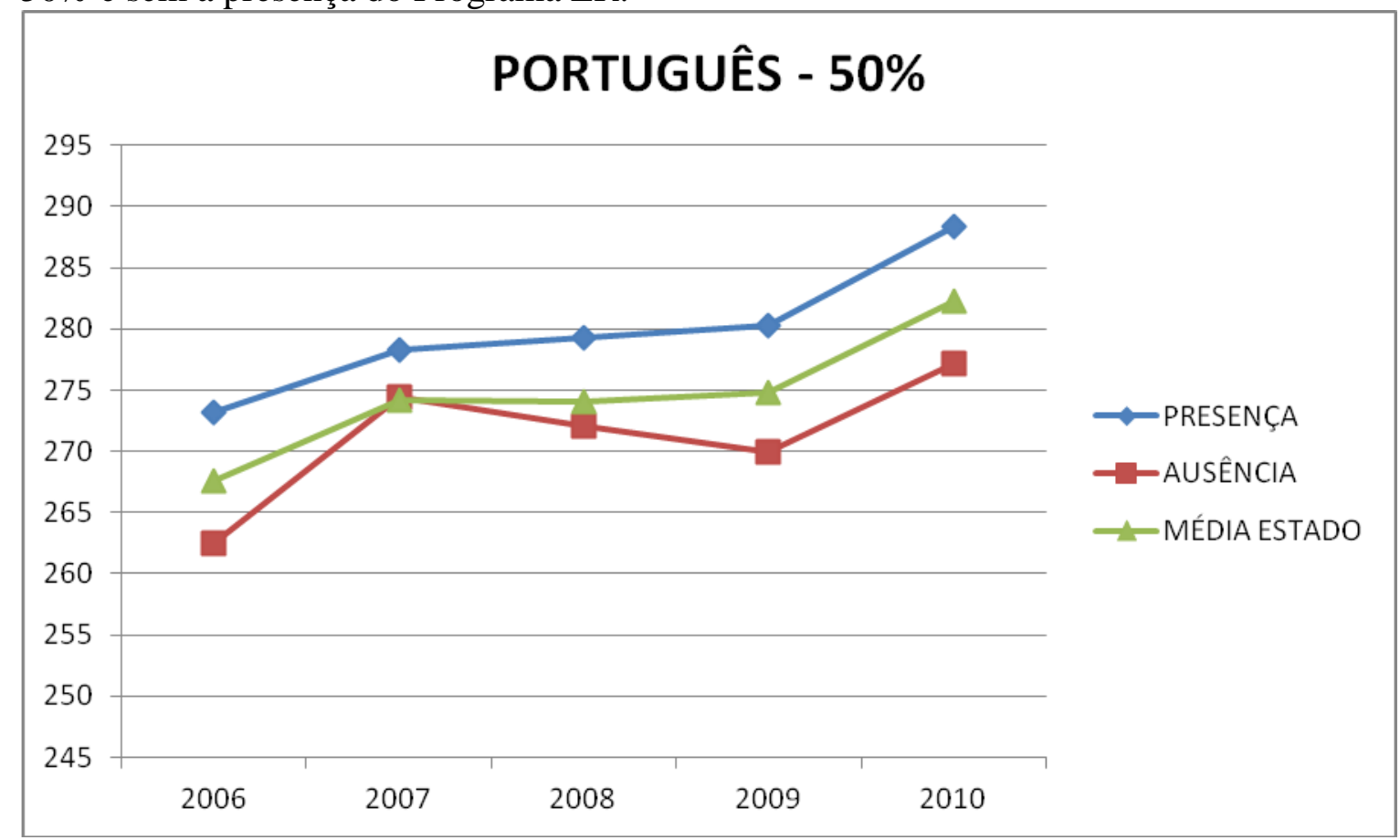

Fonte: Elaborado pelo autor com dados fornecidos pela SEE-MG.

Gráfico 29 - Média de desempenho em matemáticas dos estudantes nos Municípios com $100 \%$ e sem a presença do Programa ER.

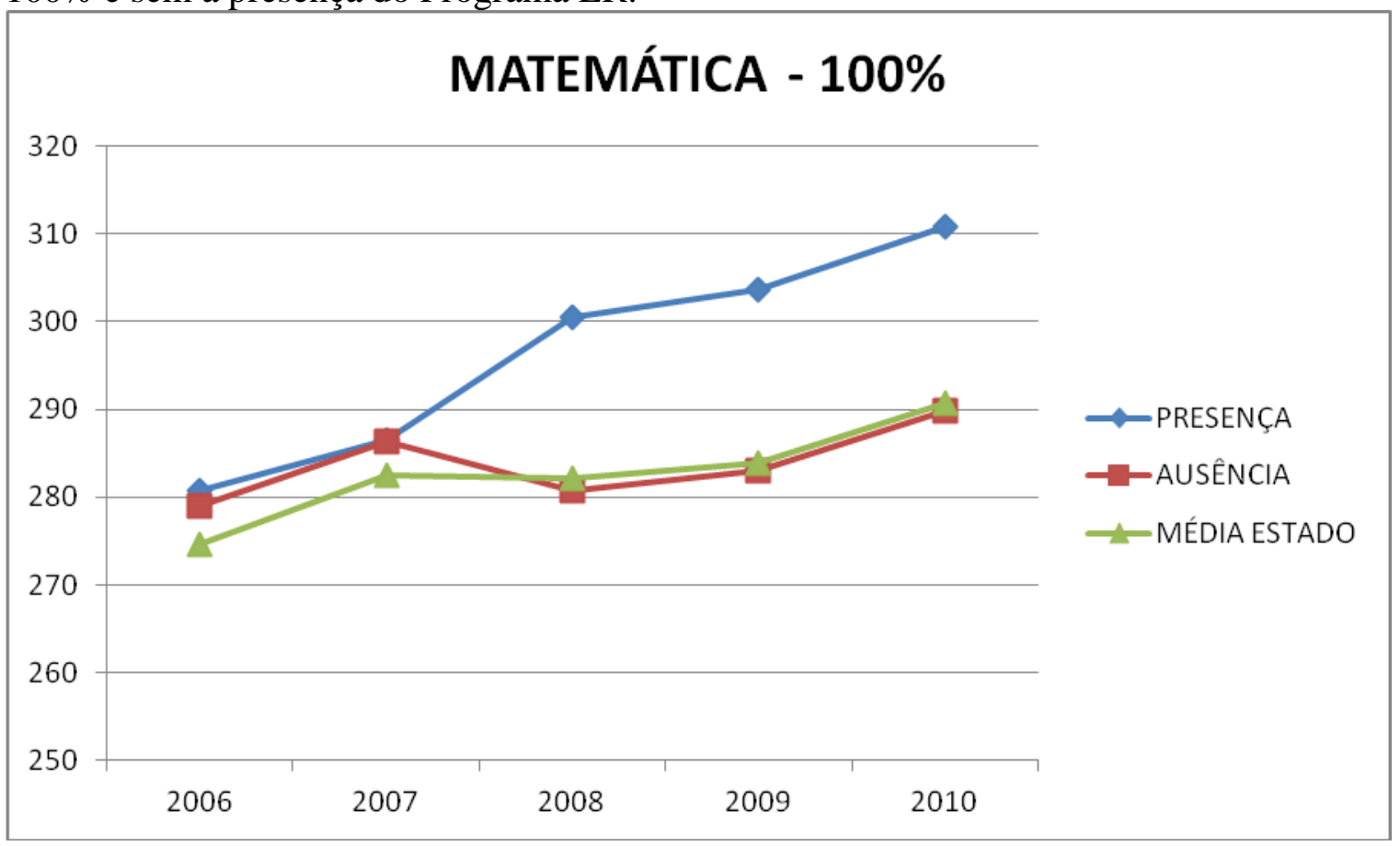

Fonte: Elaborado pelo autor com dados fornecidos pela SEE-MG. 
Gráfico 30 - Média de desempenho em matemáticas dos estudantes nos Municípios com $50 \%$ e sem a presença do Programa ER.

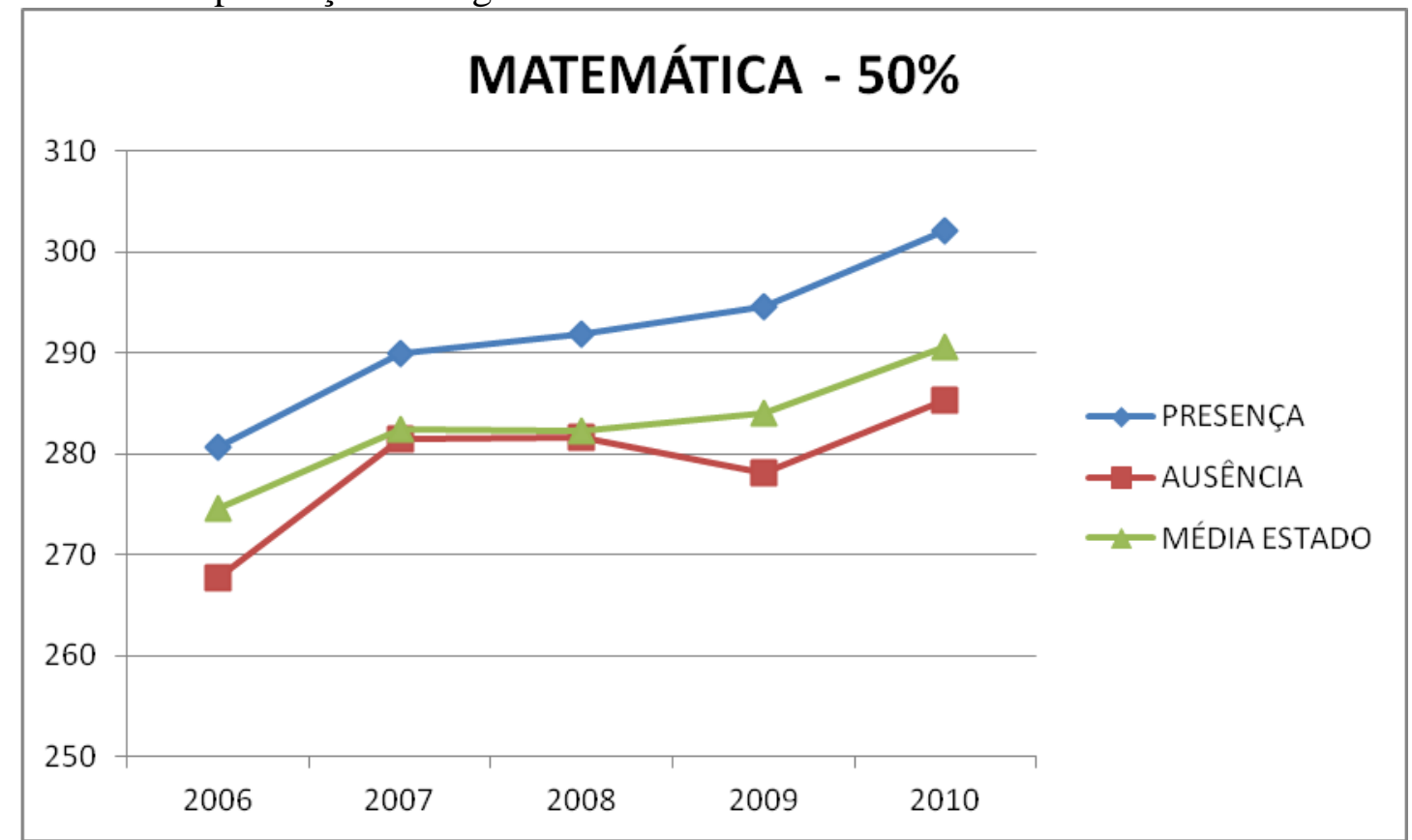

Fonte: Elaborado pelo autor com dados fornecidos pela SEE-MG.

Com relação ao PDP, o desempenho médio dos estudantes também foi superior nos municípios que tiveram o programa implementado em $100 \%$ de suas escolas. No entanto, os municípios onde o programa foi implementado em apenas 50\% das escolas apresentou diferenças mais tímidas.

Gráfico 31 - Média de desempenho em português dos estudantes nos Municípios com $100 \%$ e sem a presença do Programa PDP.

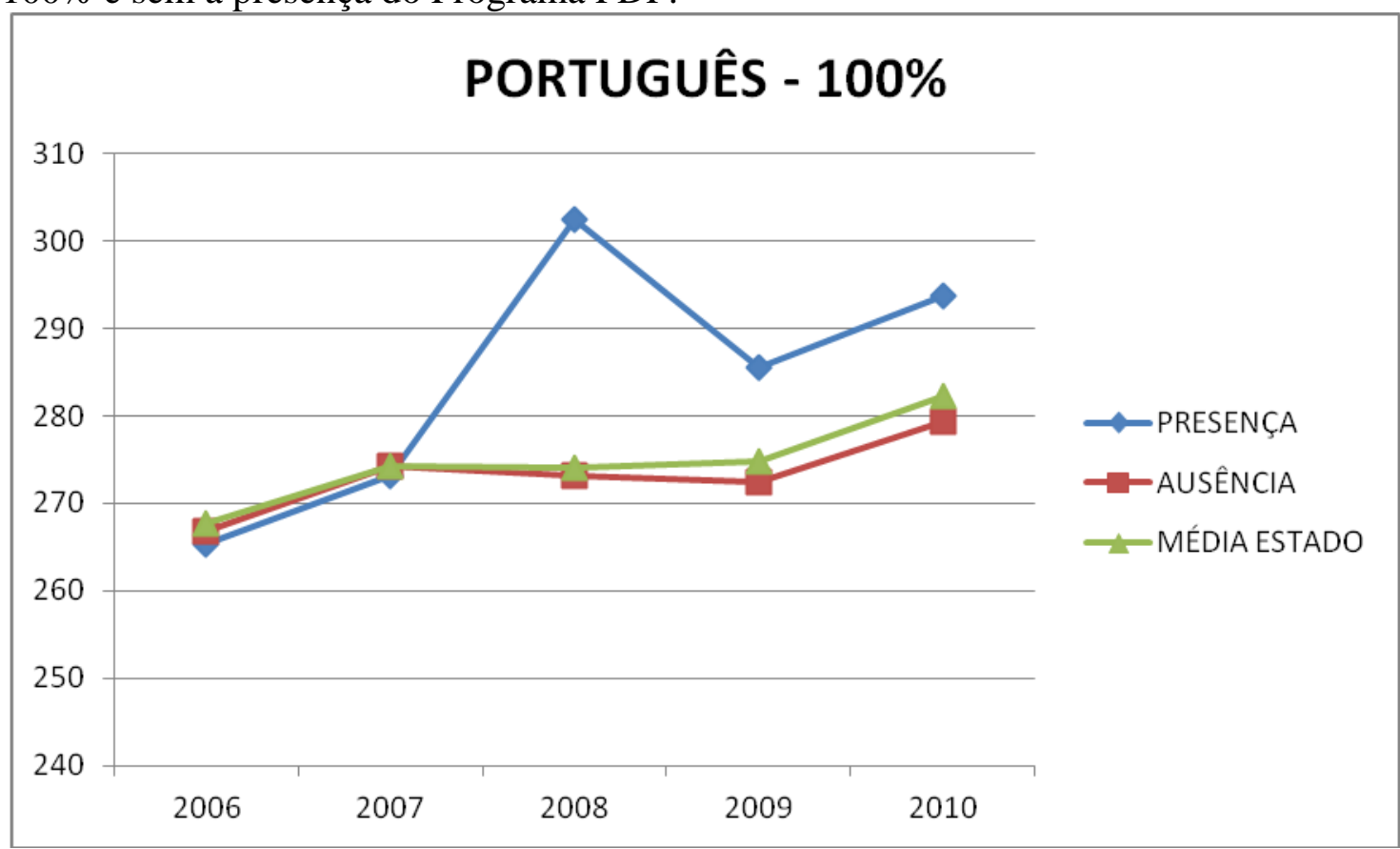

Fonte: Elaborado pelo autor com dados fornecidos pela SEE-MG. 
Os municípios onde o programa PEAS foi implementado em 100\% de suas escolas tinham 2 pontos a mais na média dos estudantes em português e 5 pontos em matemática. Nas cidades com apenas $50 \%$ das escolas contemplas, embora mais tímida, continuou existindo diferença a favor dos municípios contemplados pelo programa.

Gráfico 32 - Média de desempenho em português dos estudantes nos Municípios com $50 \%$ e sem a presença do Programa PDP.

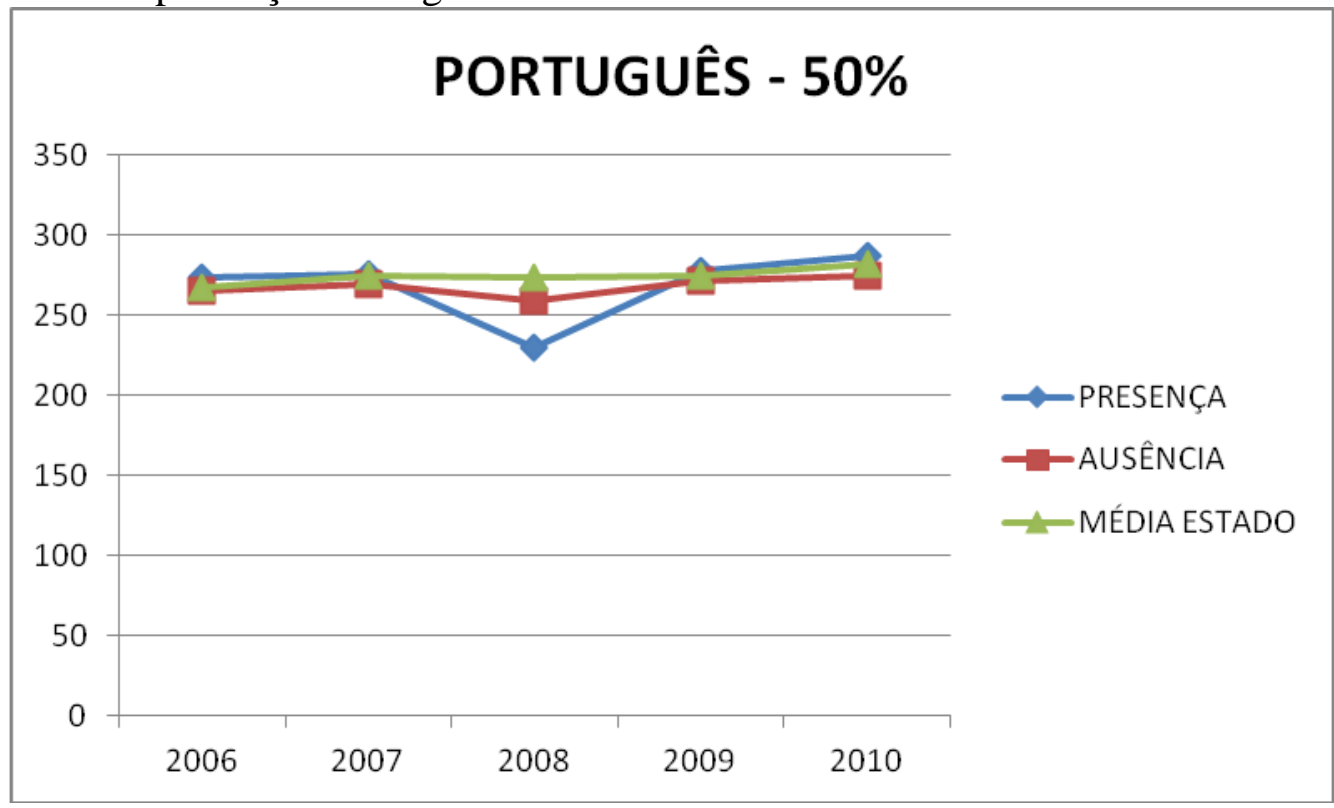

Fonte: Elaborado pelo autor com dados fornecidos pela SEE-MG.

Gráfico 33 - Média de desempenho em matemática dos estudantes nos Municípios com $100 \%$ e sem a presença do Programa PDP.

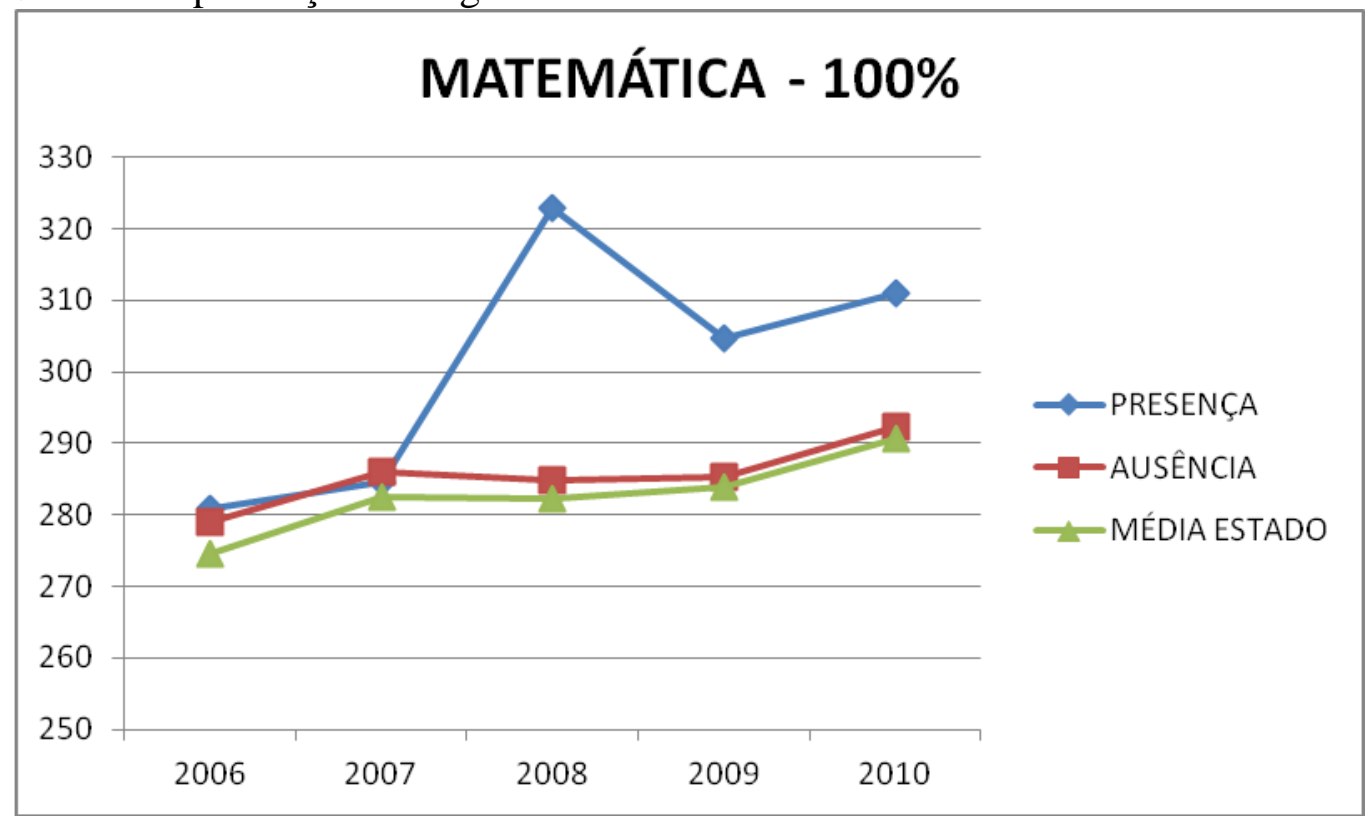

Fonte: Elaborado pelo autor com dados fornecidos pela SEE-MG. 
Gráfico 34 - Média de desempenho em matemática dos estudantes nos Municípios com $50 \%$ e sem a presença do Programa PDP.

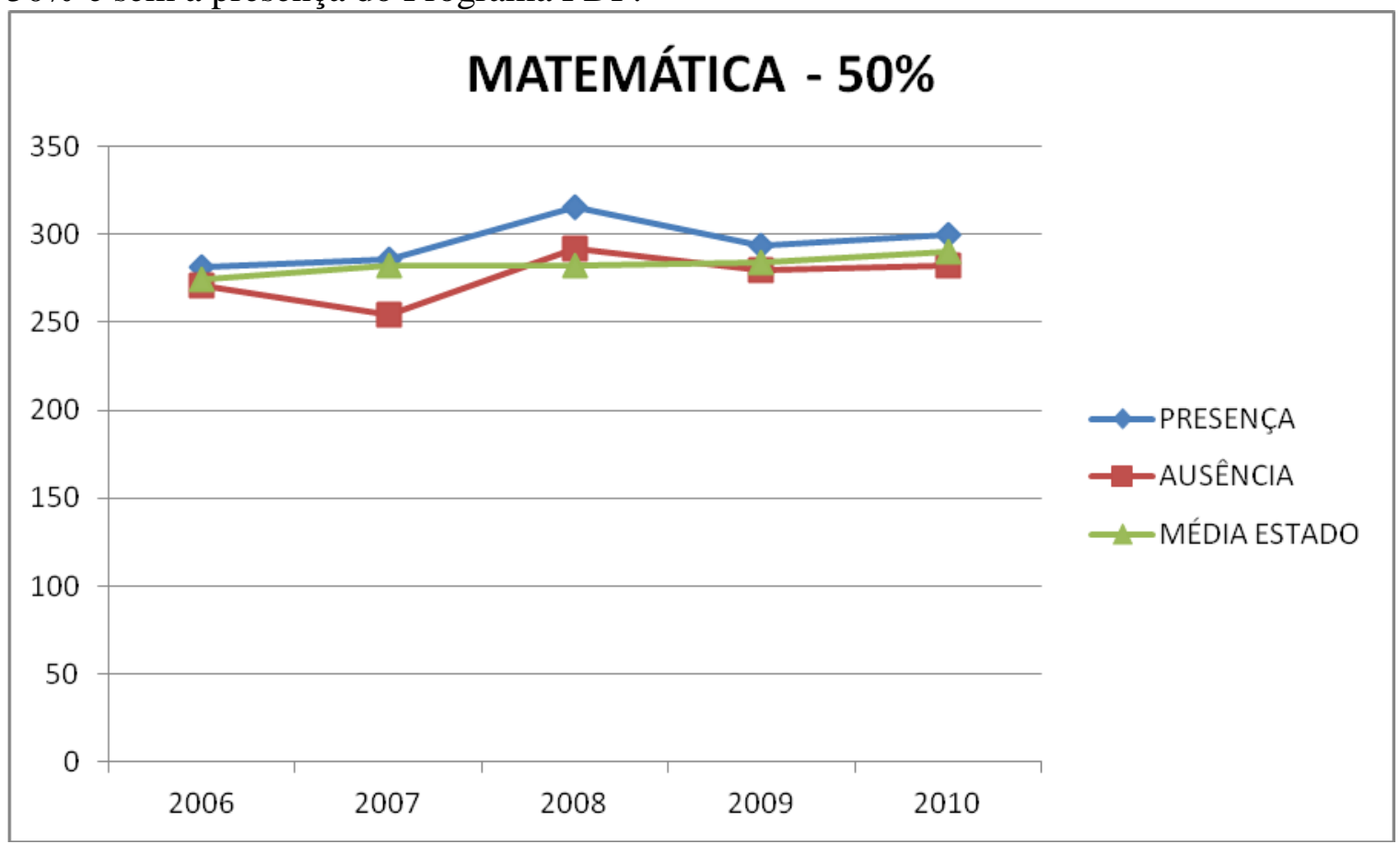

Fonte: Elaborado pelo autor com dados fornecidos pela SEE-MG.

Gráfico 35 - Média de desempenho em português dos estudantes nos Municípios com $100 \%$ e sem a presença do Programa PEAS.

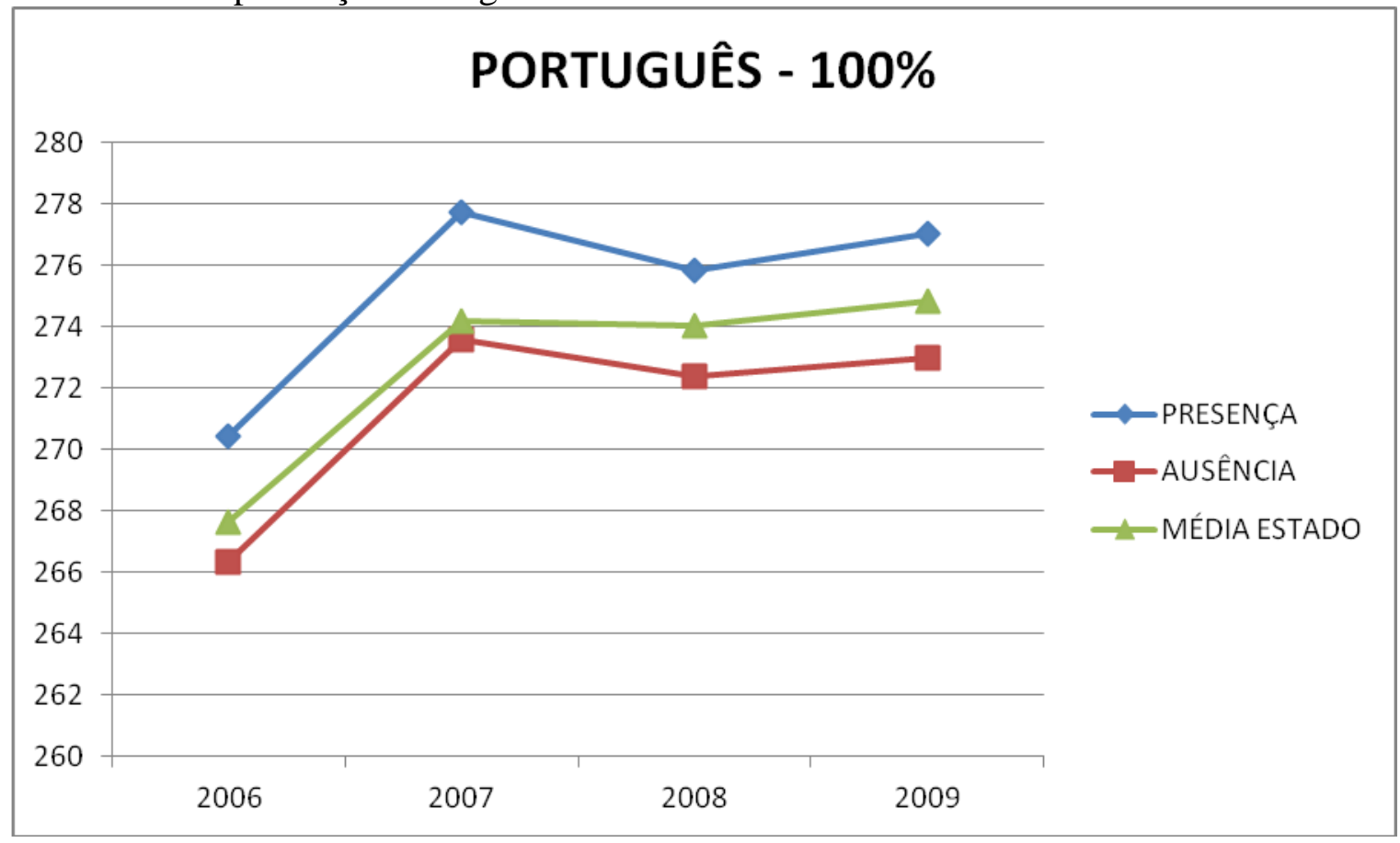

Fonte: Elaborado pelo autor com dados fornecidos pela SEE-MG. 
Gráfico 36 - Média de desempenho em português dos estudantes nos Municípios com $50 \%$ e sem a presença do Programa PEAS.

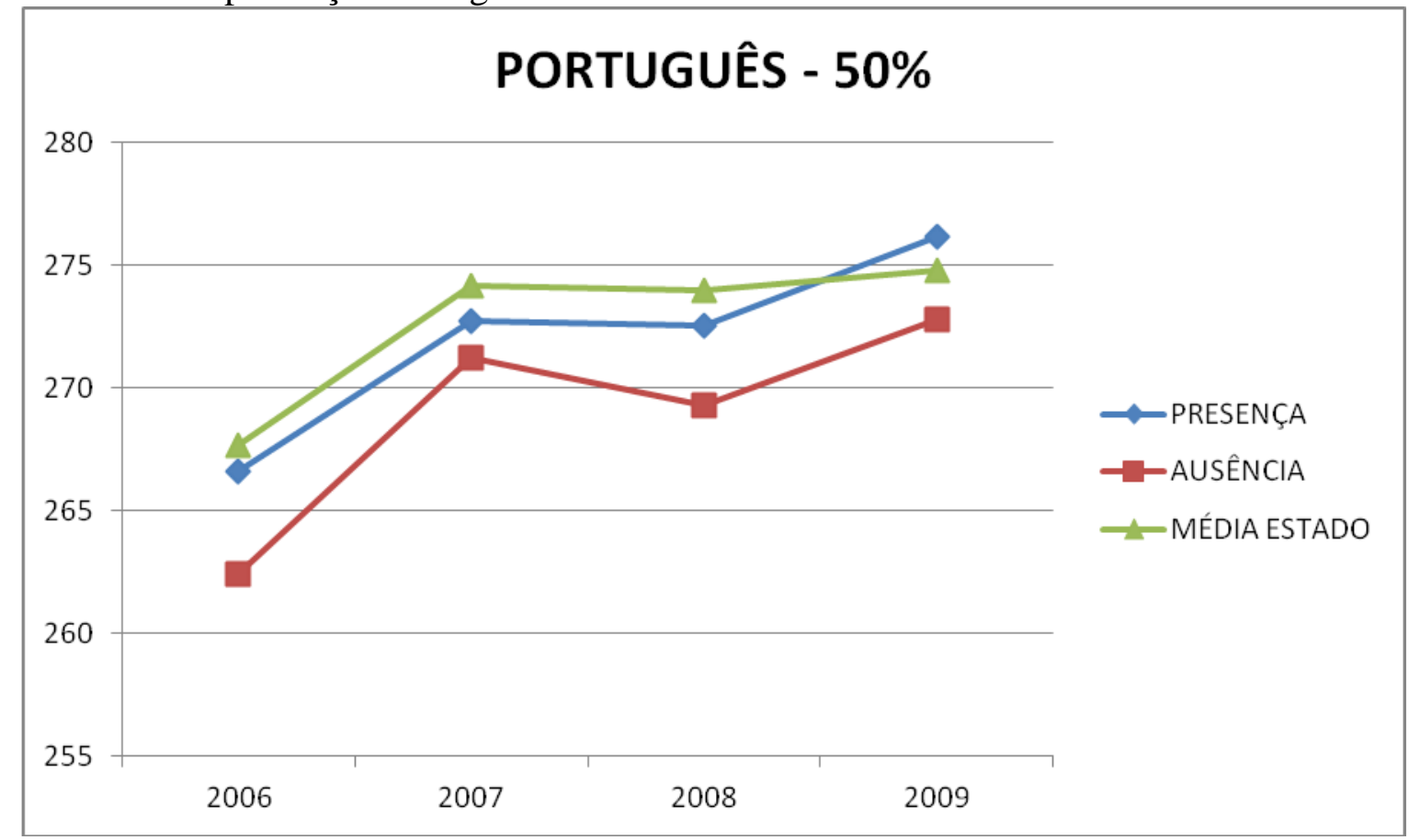

Fonte: Elaborado pelo autor com dados fornecidos pela SEE-MG.

Gráfico 37 - Média de desempenho em matemática dos estudantes nos Municípios com $100 \%$ e sem a presença do Programa PEAS.

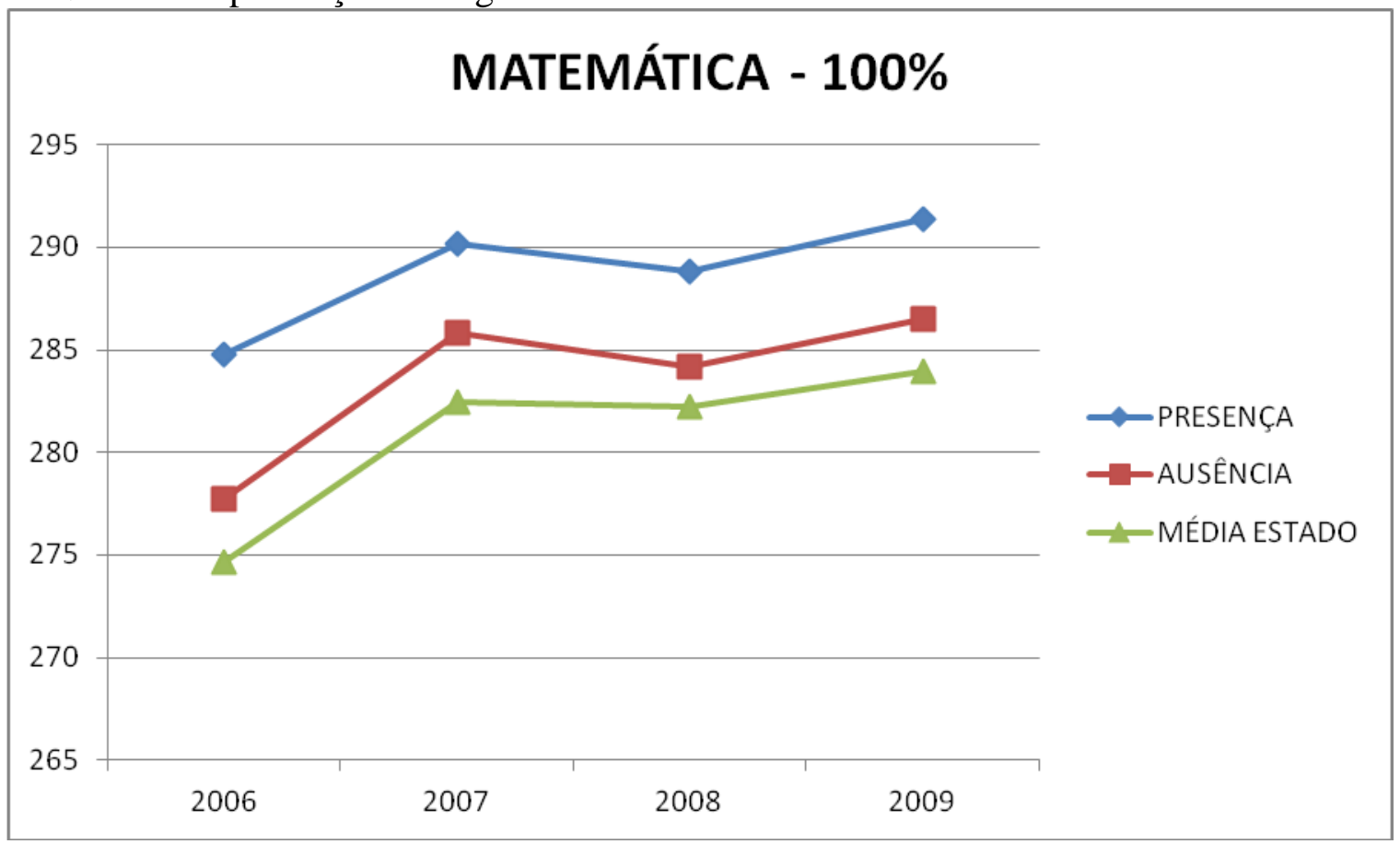

Fonte: Elaborado pelo autor com dados fornecidos pela SEE-MG. 
Gráfico 38 - Média de desempenho em matemática dos estudantes nos Municípios com $100 \%$ e sem a presença do Programa PEAS.

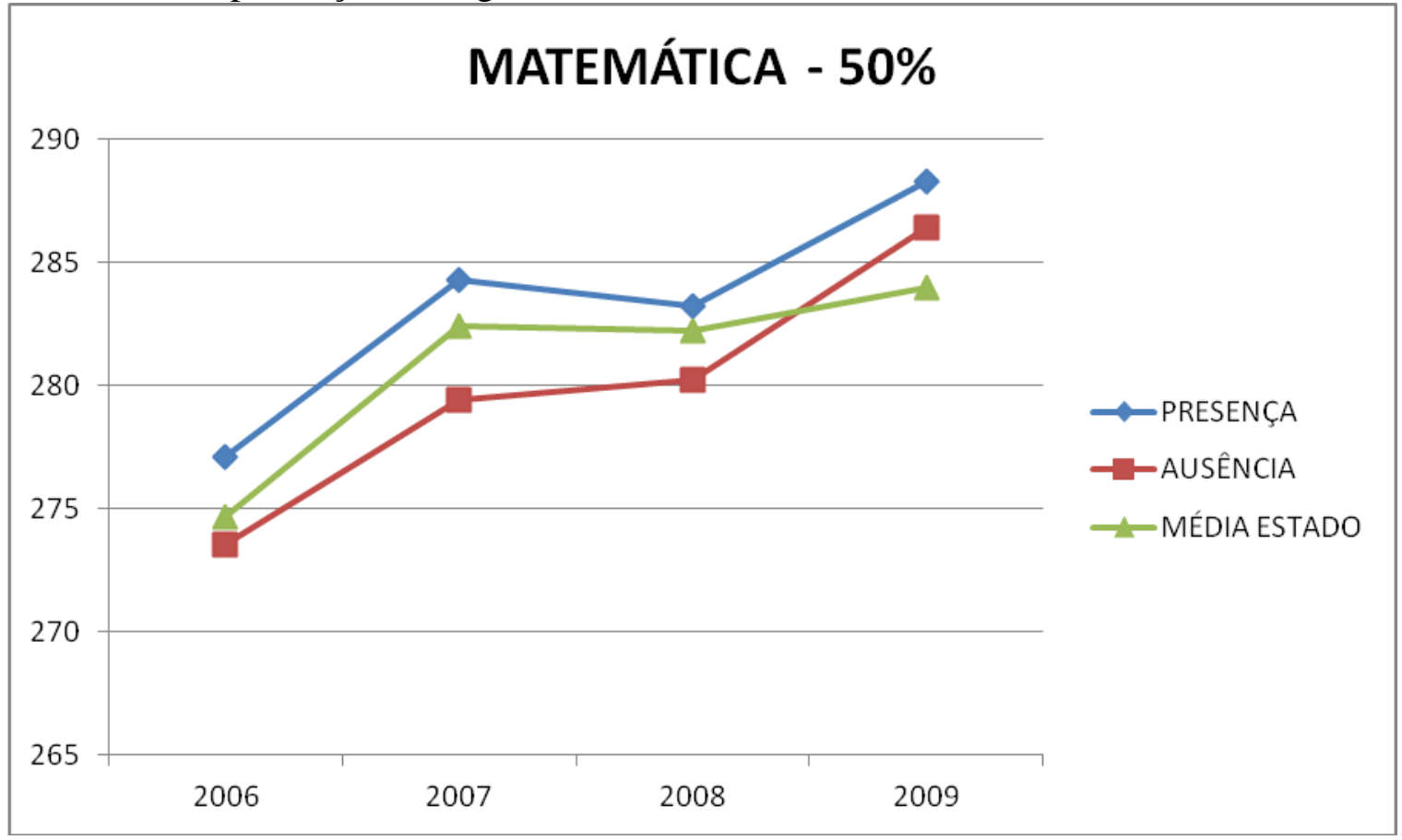

Fonte: Elaborado pelo autor com dados fornecidos pela SEE-MG.

Gráfico 39 - Média de desempenho em português dos estudantes nos Municípios com $100 \%$ e sem a presença do Programa FIT.

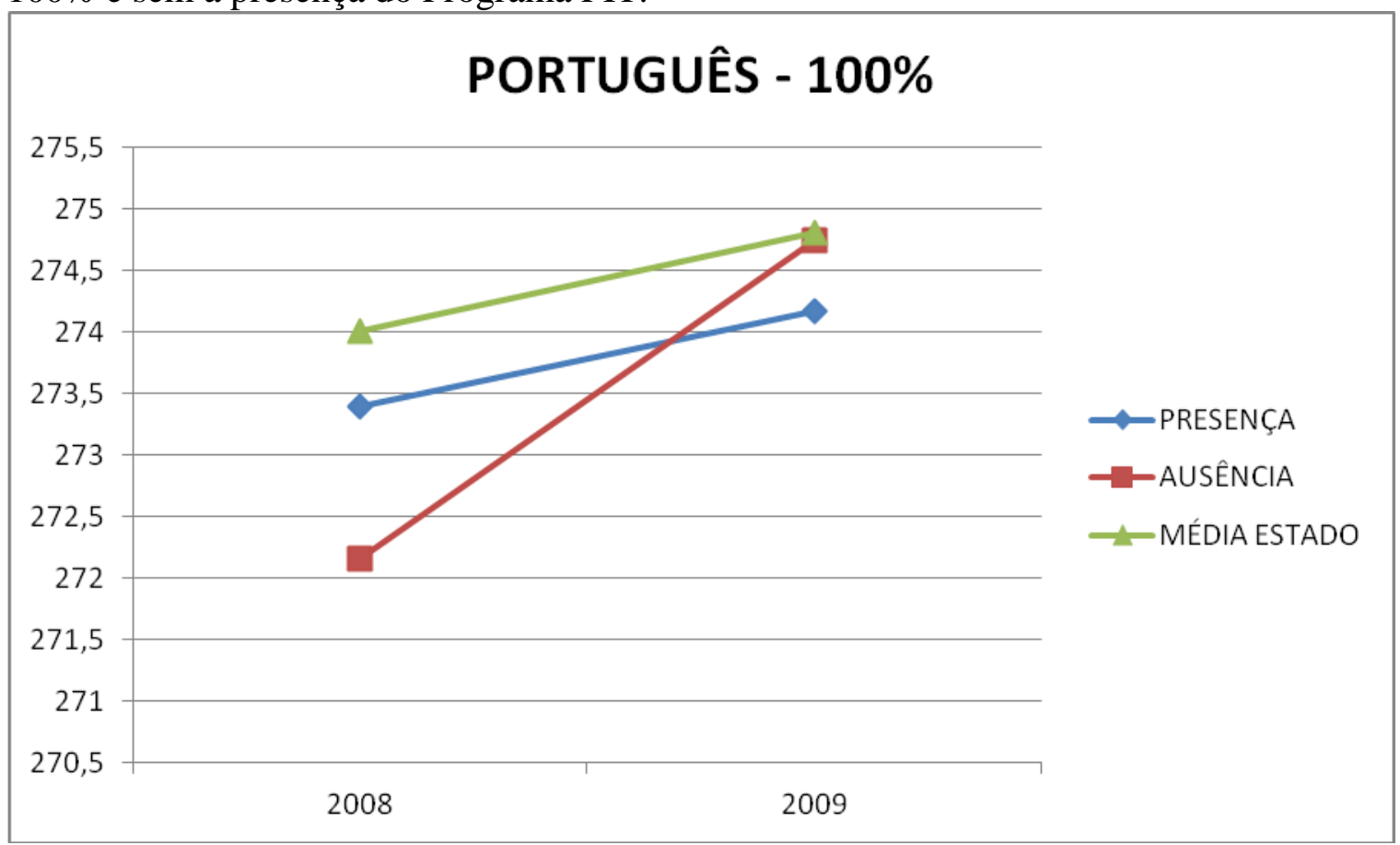

Fonte: Elaborado pelo autor com dados fornecidos pela SEE-MG. 
Gráfico 40 - Média de desempenho em português dos estudantes nos Municípios com $50 \%$ e sem a presença do Programa FIT.

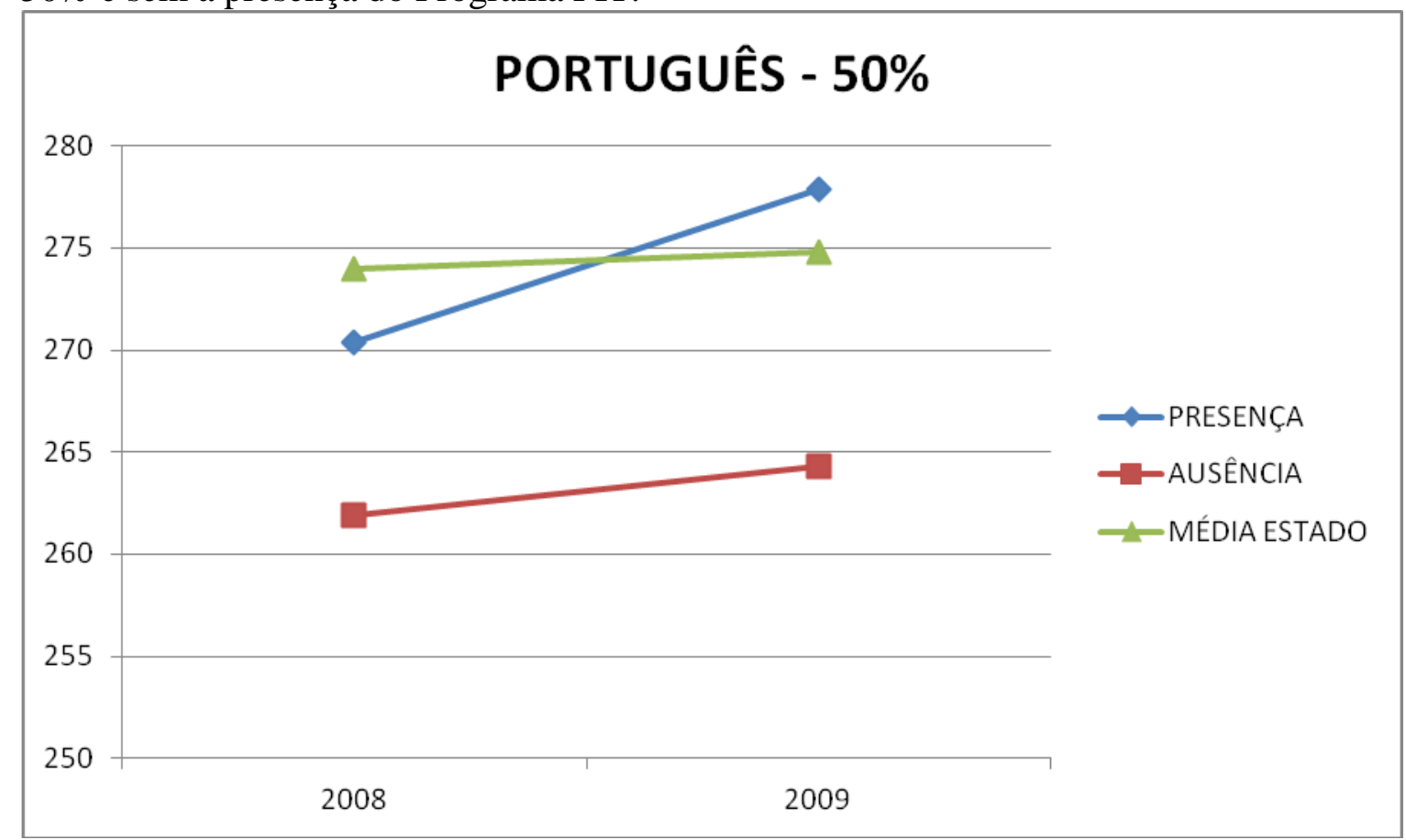

Fonte: Elaborado pelo autor com dados fornecidos pela SEE-MG.

Gráfico 41 - Média de desempenho em matemática dos estudantes nos Municípios com $100 \%$ e sem a presença do Programa FIT.

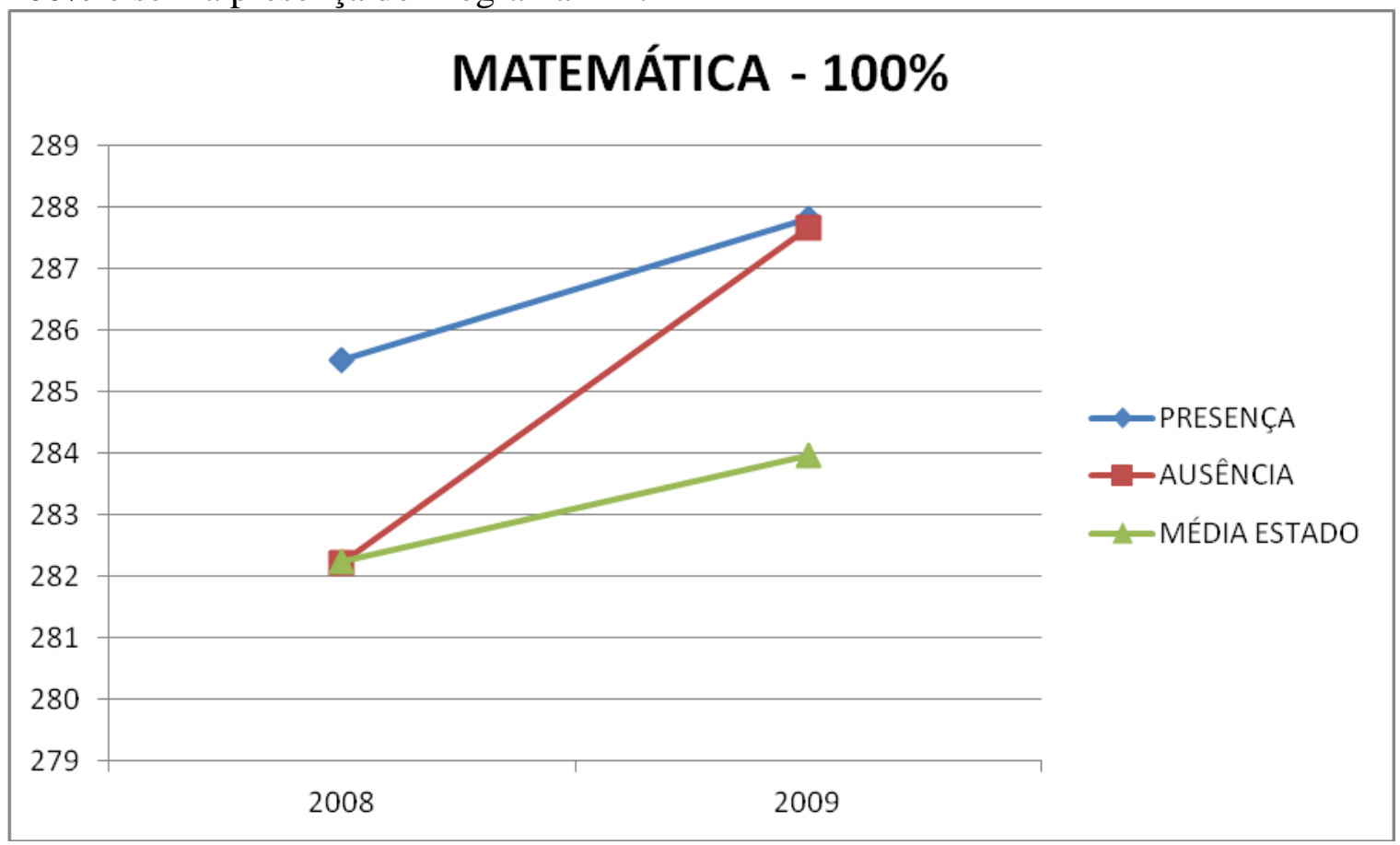

Fonte: Elaborado pelo autor com dados fornecidos pela SEE-MG. 
O programa FIT apresentou uma relação diferente entre os municípios contemplados e não contemplados. Os municípios contemplados pelo programa em $100 \%$ de suas escolas apresentaram desempenho médio inferior aos municípios não contemplados no ano de 2009 em português e em matemática houve empate. Com relação aos municípios contemplados em apenas 50\% de suas escolas, o desempenho foi superior em português e inferior em matemática.

Gráfico 42 - Média de desempenho em matemática dos estudantes nos Municípios com $50 \%$ e sem a presença do Programa FIT.

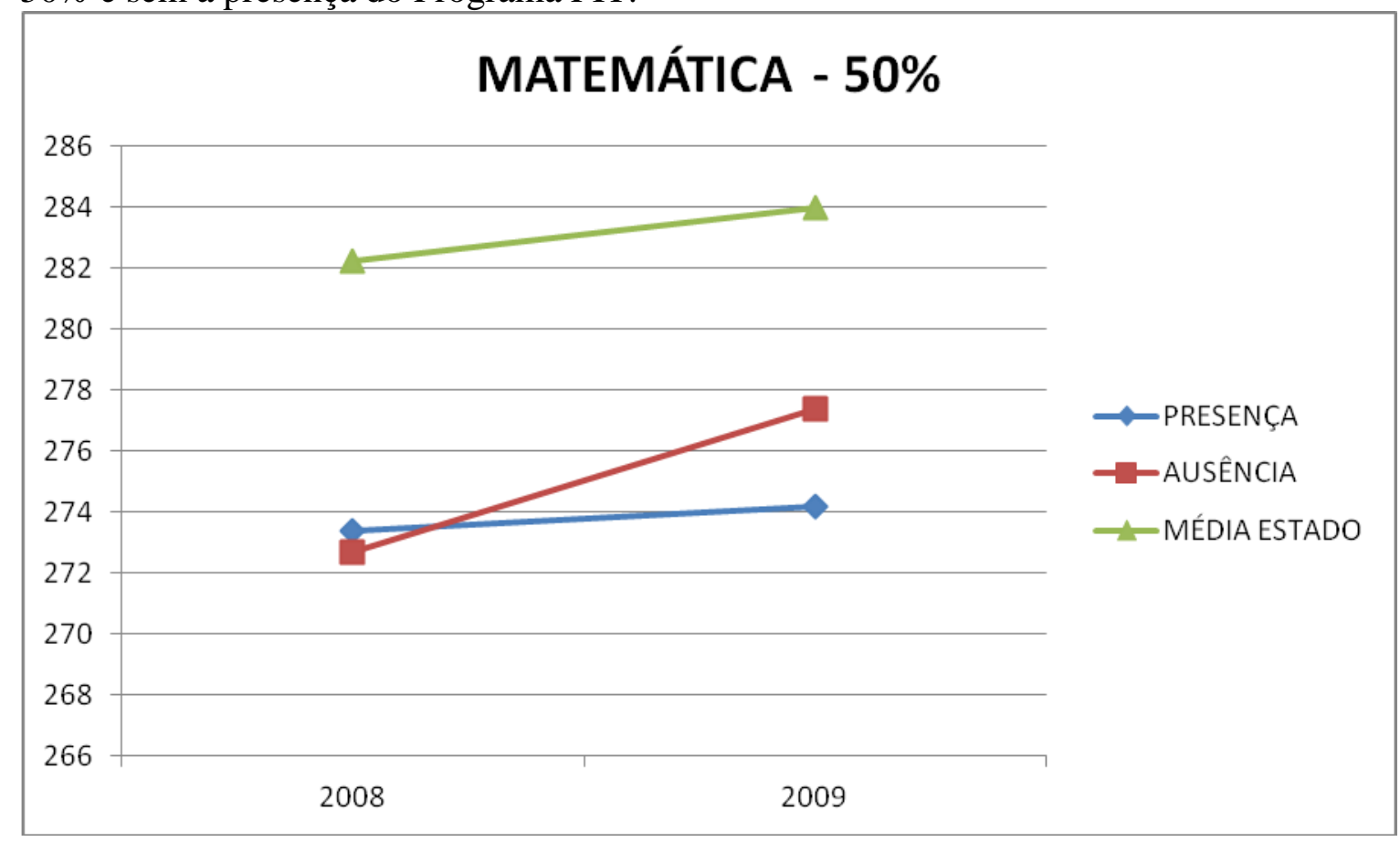

Fonte: Elaborado pelo autor com dados fornecidos pela SEE-MG.

Os programas PEP e PJ, por apresentarem menor abrangência, não possibilitaram a análise comparativa da implementação em $100 \%$ e $50 \%$ das escolas por município. Como verificamos nos gráficos 44 e 45, as escolas contempladas com o PEP apresentaram desempenho médio em português acima dos municípios não contemplados. Já em matemática, o desempenho das escolas não contempladas foi de aproximadamente 2 pontos acima na escala de proficiência em relação as escolas contempladas. 
Gráfico 43 - Média de desempenho em português dos estudantes nos Municípios com $100 \%$ e sem a presença do Programa PEP.

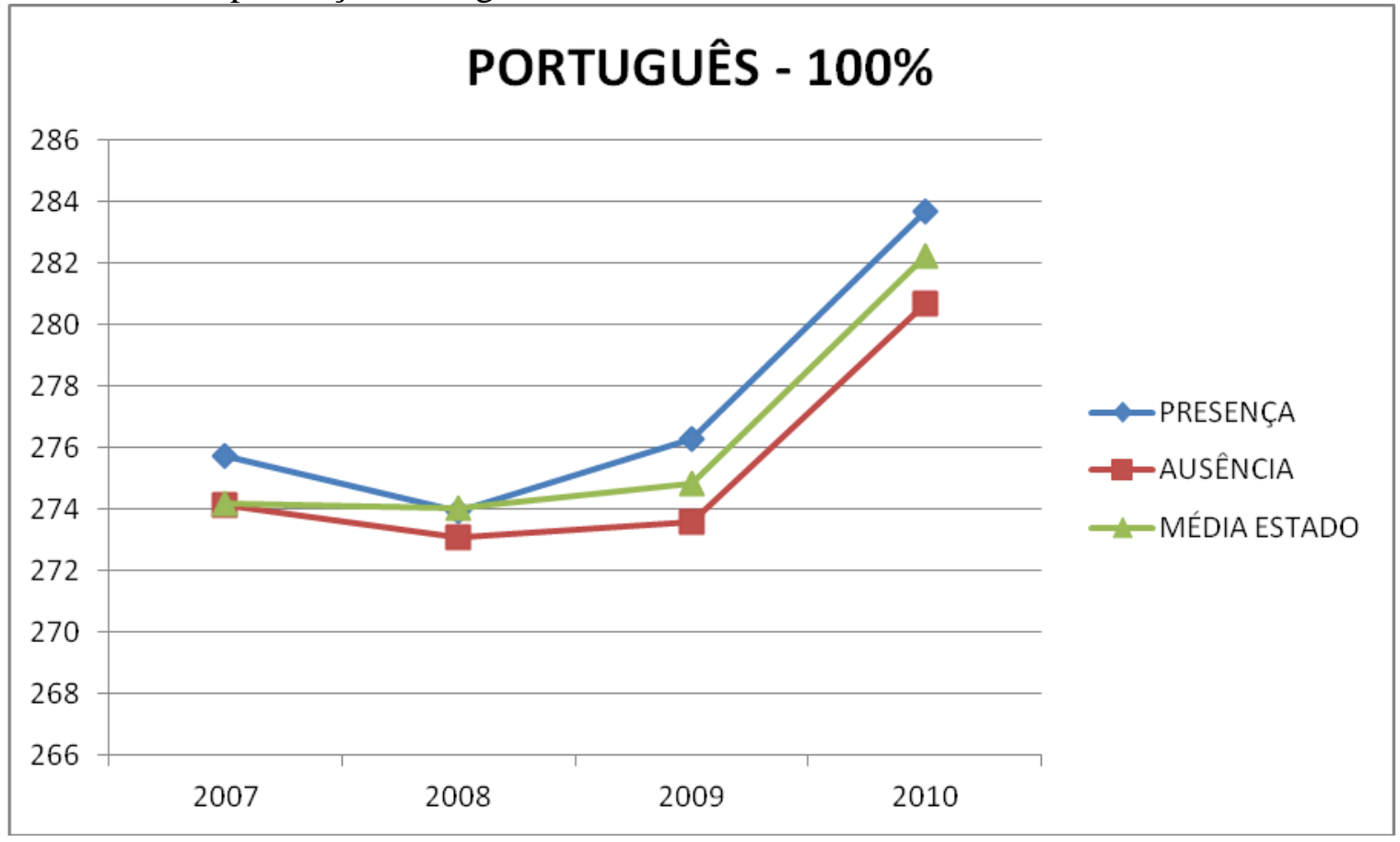

Fonte: Elaborado pelo autor com dados fornecidos pela SEE-MG.

Gráfico 44 - Média de desempenho em matemática dos estudantes nos Municípios com $100 \%$ e sem a presença do Programa PEP.

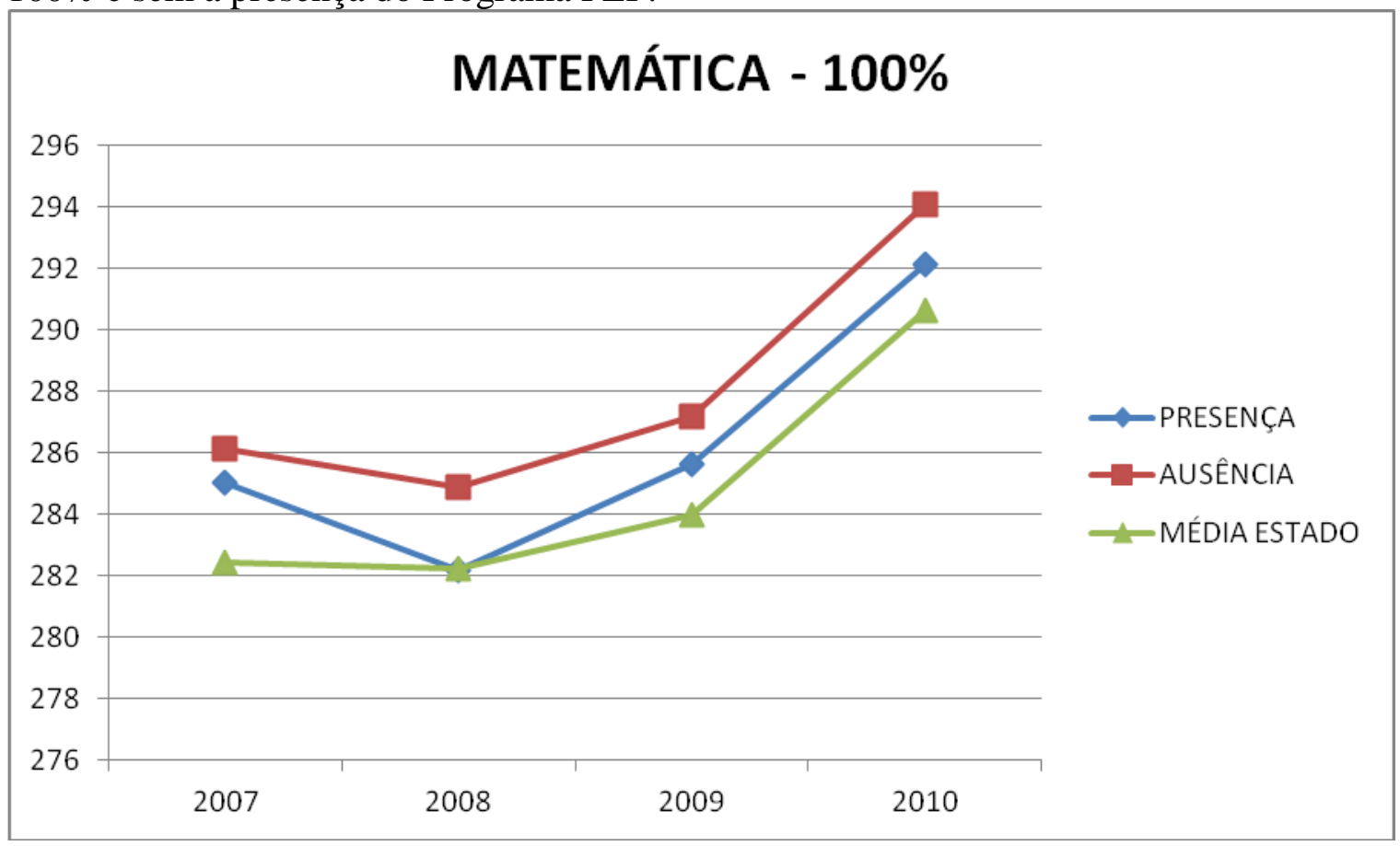

Fonte: Elaborado pelo autor com dados fornecidos pela SEE-MG. 
Gráfico 45 - Média de desempenho em português dos estudantes nos Municípios com $100 \%$ e sem a presença do Programa PJ.

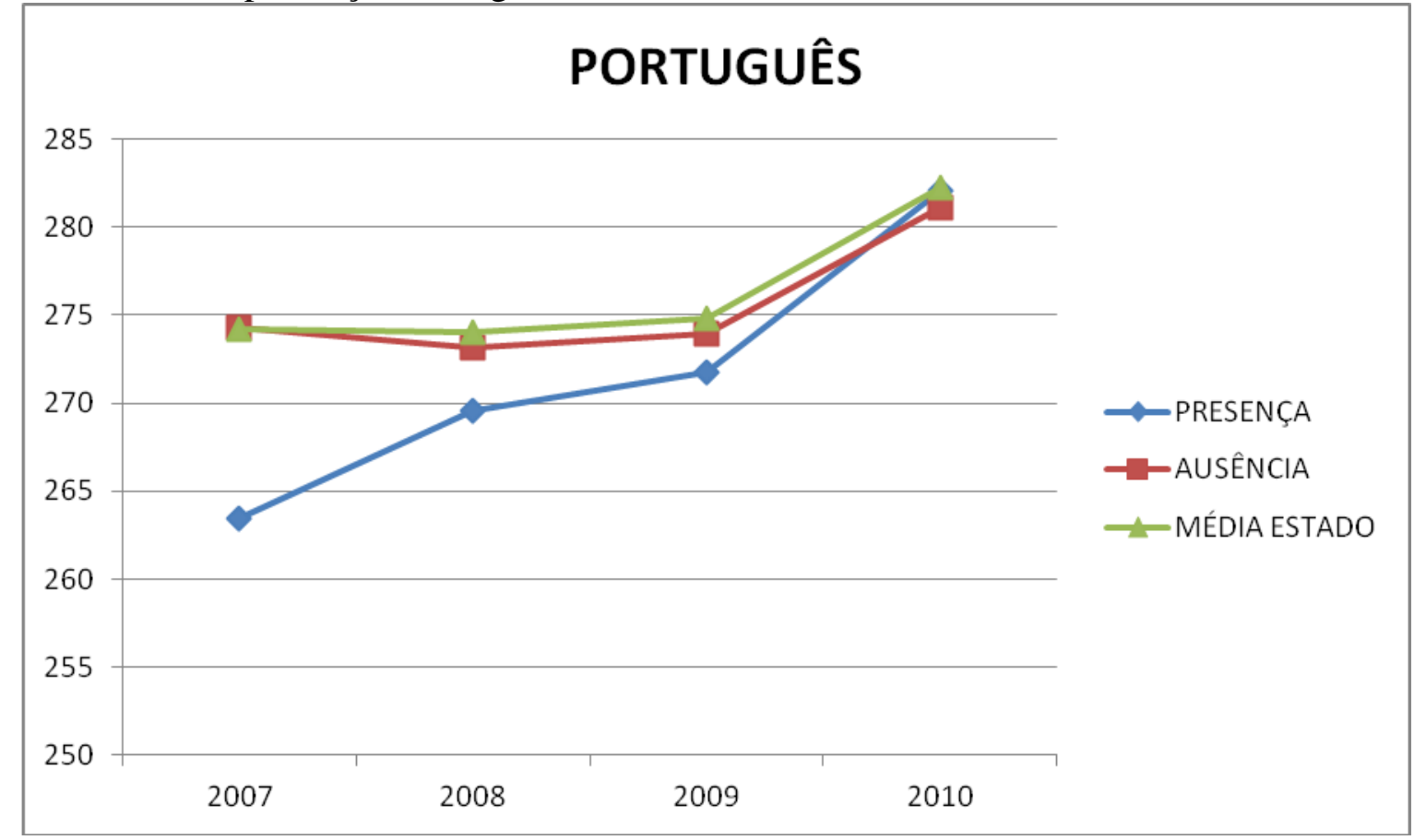

Fonte: Elaborado pelo autor com dados fornecidos pela SEE-MG.

Gráfico 46 - Média de desempenho em matemática dos estudantes nos Municípios com $100 \%$ e sem a presença do Programa PJ.

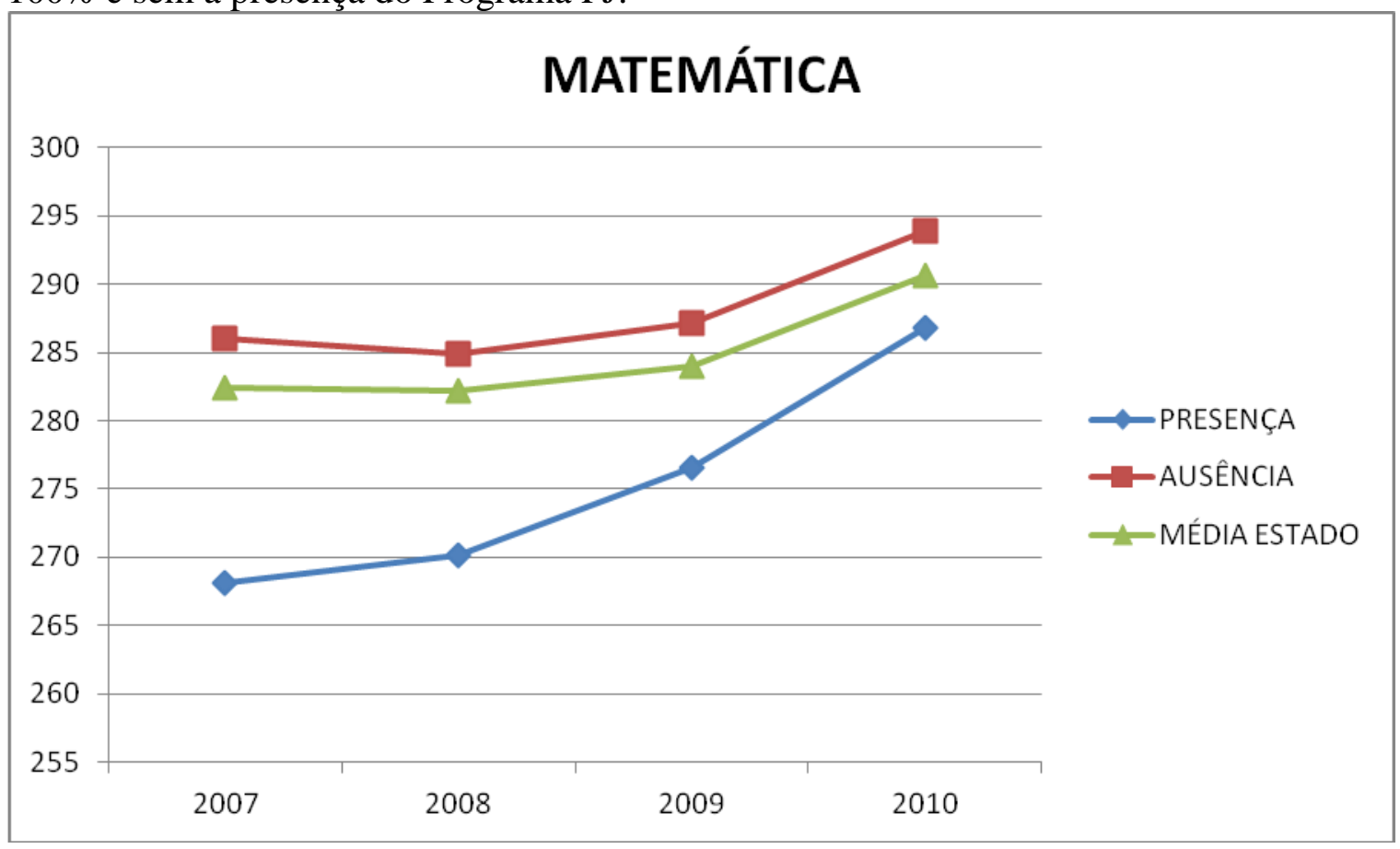

Fonte: Elaborado pelo autor com dados fornecidos pela SEE-MG.

No programa PJ os municípios não contemplados apresentaram desempenho superior em português aos municípios contemplados em todos os anos, exceto em 2010 
quando houve empate entre os dois grupos. Em matemática os municípios não contemplados pelo programa apresentaram desempenho superior ao longo de todo o período. Estes dados confirmam os resultados apresentados na avaliação do CEDEPLAR sobre o programa.

\subsection{3.}

\section{Comparação entre as piores e melhores médias de desempenho}

Nos gráficos abaixo, podemos verificar que, embora ao longo dos anos aqui analisados tenha sido verificada uma melhora geral das médias dos estudantes por município, esta melhora não contribuiu na redução das desigualdades regionais, ou seja, a distância entre os municípios com melhores médias e os municípios com piores médias permaneceu a mesma.

Gráfico 47 - Comparação da Evolução do desempenho médio em matemática entre os $1^{\circ}$ e $9^{\circ}$ quartis.

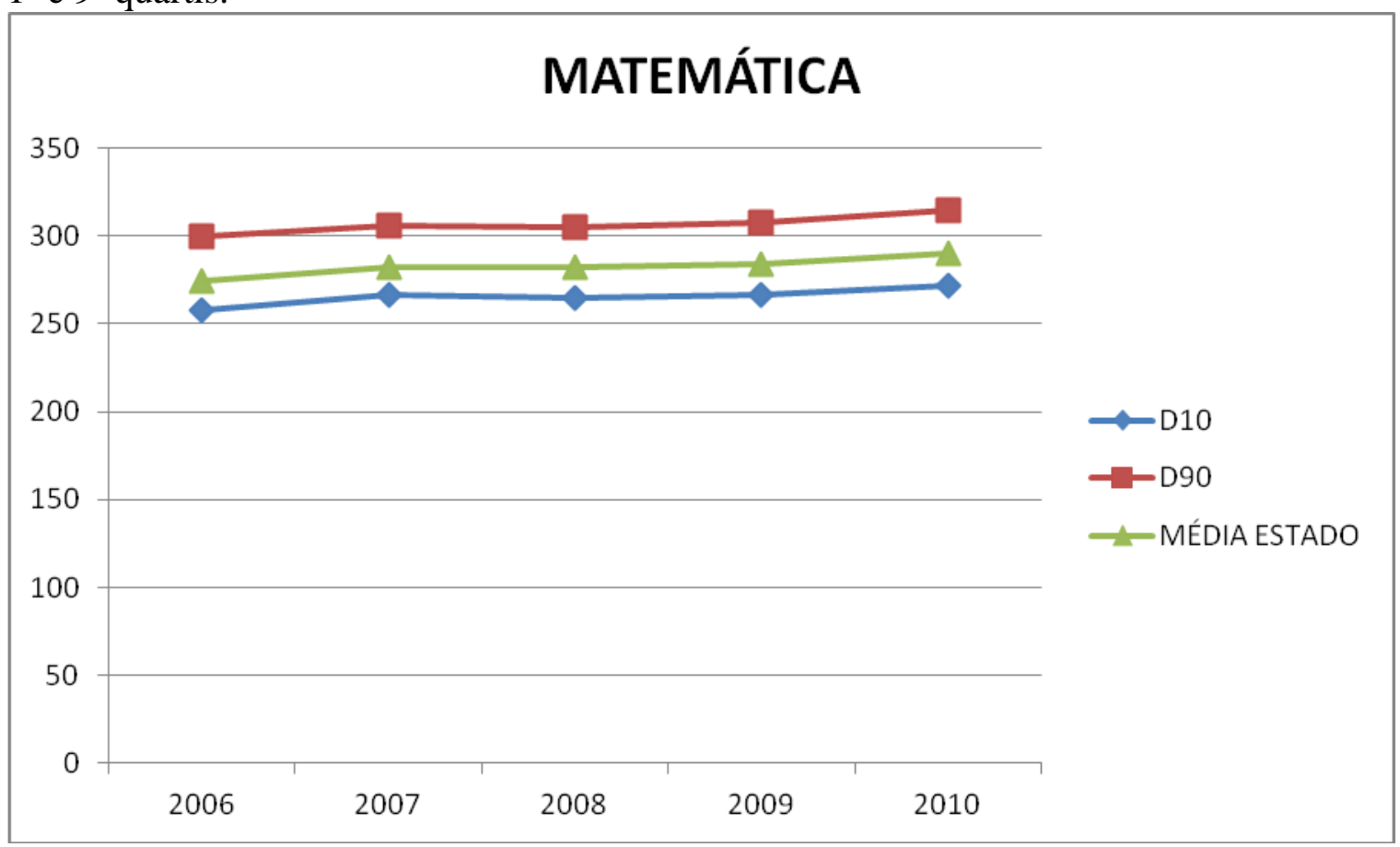

Fonte: Elaborado pelo autor com dados fornecidos pela SEE-MG. 
Gráfico 48 - Comparação da Evolução do desempenho médio em português entre os $1^{\circ}$ e $9^{\circ}$ quartis.

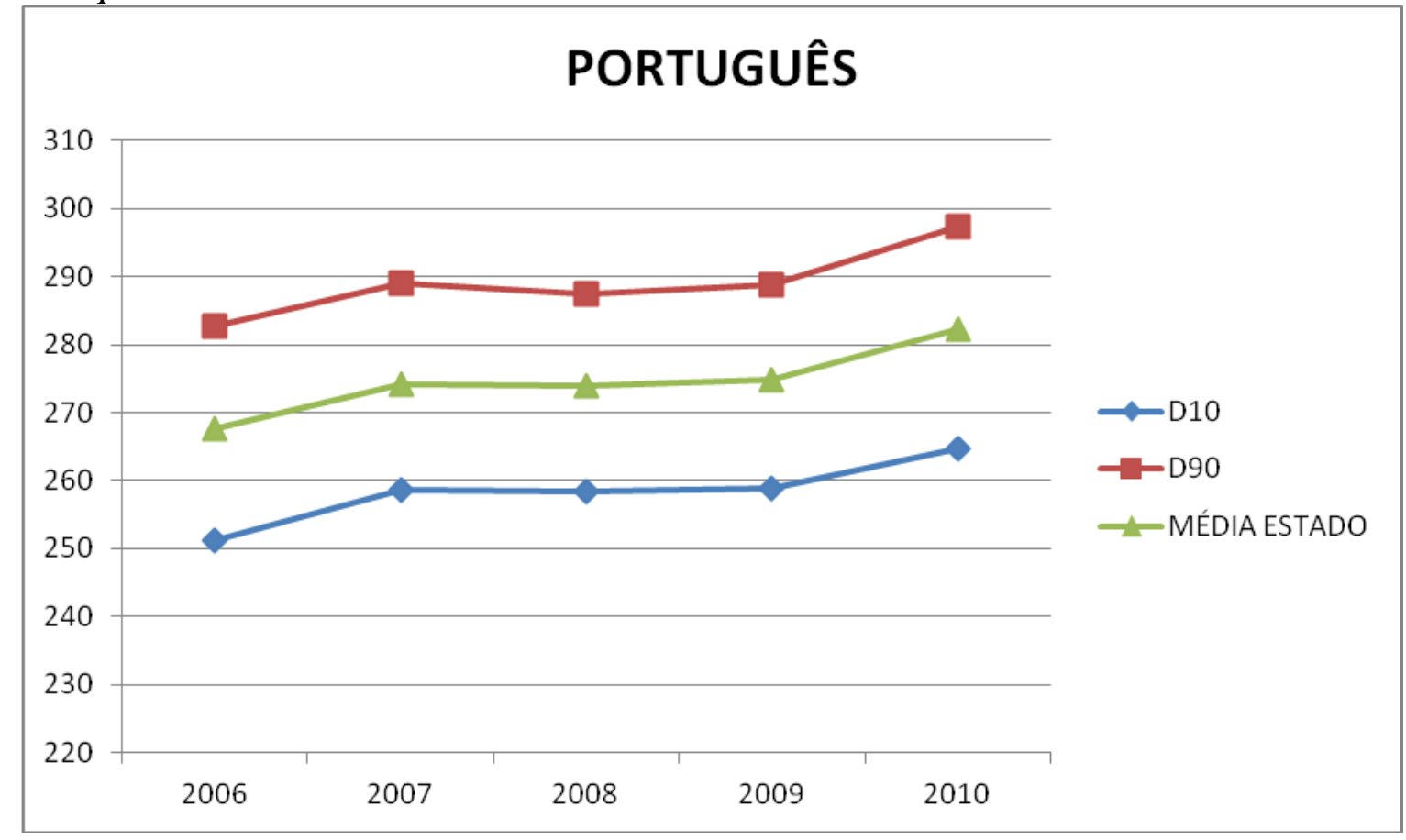

Fonte: Elaborado pelo autor com dados fornecidos pela SEE-MG.

\section{5. \\ Abrangência das políticas considerando as características das Superintendências Regionais de Ensino}

\subsection{1.}

O papel das Superintendências Regionais de Ensino

A Secretaria da Educação de Minas Gerais tem uma estrutura que conta com 46 Superintendências Regionais de Ensino (SRE) sob coordenação direta do governo do Estado. Cada Superintendência é responsável pelas políticas relacionadas às suas regiões, tendo como atribuições coordenar, orientar e supervisionar escolas oferecendo suporte administrativo e pedagógico para a viabilização das políticas da secretaria. A SRE representa a secretaria na área de sua jurisdição, tendo como atribuições também o controle de pessoal para atuar nas escolas e a gestão de seus recursos financeiros e de infraestrutura. De acordo com a estrutura orgânica da SEE-MG, compete às SRE:

I - promover a coordenação e implantação da política educacional do Estado no âmbito de sua jurisdição;

II - orientar as comunidades escolares e prefeituras municipais na elaboração, acompanhamento e avaliação dos planos, programas e projetos educacionais; 
III - promover o desenvolvimento de recursos humanos em consonância com as diretrizes e políticas educacionais do Estado;

IV - coordenar os processos de organização do atendimento escolar e de apoio ao aluno; V - propor a celebração e acompanhar a execução de convênios e contratos e termos de compromisso;

VI - aplicar as normas de administração de pessoal, garantindo o seu cumprimento na respectiva jurisdição;

VII - planejar e coordenar as ações administrativas e financeiras necessárias ao desempenho das suas atividades;

VIII - coordenar o funcionamento da Inspeção Escolar no âmbito da sua jurisdição;

IX - coordenar e promover a produção de dados e informações educacionais na sua jurisdição;

$\mathrm{X}$ - exercer outras atividades correlatas.

Considerando as dimensões do Estado de Minas Gerais, fica evidente a importância do papel exercido pelas SRE's como instância intermediária entre as unidades escolares e SEE-MG na capital do Estado. Dessa forma, com o intuito de captar características específicas de cada uma das SRE's e ao mesmo tempo utilizá-las para compreender a influência das mesmas na maior ou menor abrangência das políticas educacionais, apresento a seguir a metodologia para elaboração de um indicador de complexidade que permite a comparação das SRE's.

\subsection{2. O desempenho dos Estudantes de EM por SER}

Para realizar a comparação entre o desempenho dos estudantes entre as diferentes superintendências de ensino, ordenei em ordem alfabética as 46 SRE, conforme quadro abaixo. Essa numeração criada é utilizada em seguida para a confecção de tabelas e gráficos para a comparação do desempenho dos estudantes entre as diferentes SRE. 
4.5.2.1.

Desempenho em Matemática

Tabela 6 - Desempenho em matemática por Superintendência de Ensino - 2007 à 2010.

\begin{tabular}{|c|c|c|c|c|c|}
\hline № & Matemática_SRE & 2007 & 2008 & 2009 & 2010 \\
\hline 1 & ALMENARA & 273,85 & 264,13 & 270,19 & 279,39 \\
\hline 2 & ARAÇUAÍ & 278,6 & 273,53 & 282,83 & 287,45 \\
\hline 3 & BARBACENA & 293,11 & 296,85 & 300,52 & 301,39 \\
\hline 4 & CAMPO BELO & 287,07 & 296,55 & 300,88 & 313,51 \\
\hline 5 & CARANGOLA & 272,92 & 283,8 & 281,78 & 291,71 \\
\hline 6 & CARATINGA & 290,9 & 293,94 & 298,63 & 306,14 \\
\hline 7 & CAXAMBU & 293,47 & 291,54 & 288,53 & 297,98 \\
\hline 8 & CONSELHEIRO LAFAIETE & 294,85 & 289,02 & 291,64 & 299,91 \\
\hline 9 & CORONEL FABRICIANO & 288,48 & 285,08 & 290,65 & 298,69 \\
\hline 10 & CURVELO & 280,74 & 279,59 & 284,97 & 287,52 \\
\hline 11 & DIAMANTINA & 286,68 & 285,13 & 286,94 & 291,84 \\
\hline 12 & DIVINÓPOLIS & 295,22 & 296,75 & 295,6 & 304,46 \\
\hline 13 & GOVERNADOR VALADARES & 283,94 & 281,11 & 279,98 & 290,06 \\
\hline 14 & GUANHÃES & 276,14 & 280,16 & 286,98 & 291,09 \\
\hline 15 & ITAJUBÁ & 298,08 & 297,91 & 298,57 & 303,77 \\
\hline 16 & ITUIUTABA & 290,62 & 284,04 & 286,87 & 295,1 \\
\hline 17 & JANAÚBA & 264,6 & 262,44 & 264,75 & 265,86 \\
\hline 18 & JANUÁRIA & 259,81 & 254,15 & 256,92 & 256,98 \\
\hline 19 & JUIZ DE FORA & 288,29 & 289,63 & 290,83 & 292,03 \\
\hline 20 & LEOPOLDINA & 278,17 & 279,76 & 283,08 & 291,97 \\
\hline 21 & MANHUAÇU & 285,8 & 282,14 & 292,28 & 301,16 \\
\hline 22 & METROPOLITANA A & 274,52 & 279,81 & 278,72 & 290,95 \\
\hline 23 & METROPOLITANA B & 272,1 & 271,09 & 274,64 & 280,31 \\
\hline 24 & METROPOLITANA C & 273,96 & 272,61 & 276,08 & 279,25 \\
\hline 25 & MONTE CARMELO & 305,2 & 300,84 & 306,05 & 307,23 \\
\hline 26 & MONTES CLAROS & 273,55 & 268,74 & 271,31 & 280,89 \\
\hline 27 & MURIAÉ & 284,77 & 289,45 & 287,77 & 299,52 \\
\hline 28 & NOVA ERA & 292,93 & 289,96 & 290,47 & 294,45 \\
\hline 29 & OURO PRETO & 277,87 & 277,59 & 285,45 & 290,04 \\
\hline 30 & PARÁ DE MINAS & 292,79 & 297,52 & 289,57 & 306,14 \\
\hline 31 & PARACATU & 272,11 & 268,8 & 271,1 & 275,7 \\
\hline 32 & PASSOS & 294,68 & 296,92 & 288,38 & 306,29 \\
\hline 33 & PATOS DE MINAS & 300,09 & 297,45 & 300,06 & 305,69 \\
\hline 34 & PATROCÍNIO & 290,5 & 286,25 & 292,41 & 298,57 \\
\hline 35 & PIRAPORA & 269,53 & 269,02 & 270,23 & 273,38 \\
\hline
\end{tabular}




\begin{tabular}{l|c|c|c|c|c}
36 & POÇOS DE CALDAS & 293,51 & 287,86 & 287,76 & 297,11 \\
\hline 37 & PONTE NOVA & 287,03 & 287,69 & 290 & 298,13 \\
\hline 38 & POUSO ALEGRE & 292,28 & 293,89 & 291,11 & 299,23 \\
\hline 39 & SÃO JOÃO DEL REI & 300,79 & 307,22 & 308,27 & 311,83 \\
\hline 40 & SÃO SEBASTIÃO DO PARAÍSO & 296,19 & 299,1 & 299,94 & 306 \\
\hline 41 & SETE LAGOAS & 283,2 & 287,71 & 287,92 & 293,99 \\
\hline 42 & TEOFILO OTONI & 265,9 & 266,81 & 267,19 & 273,09 \\
\hline 43 & UBÁ & 295,09 & 298,47 & 298,24 & 304,98 \\
\hline 44 & UBERABA & 289,38 & 289,51 & 287,79 & 293,75 \\
\hline 45 & UBERLANDIA & 285,59 & 283,9 & 287,34 & 294,36 \\
\hline 46 & VARGINHA & 290,43 & 290,17 & 289,14 & 296,13 \\
\hline
\end{tabular}

Fonte: Elaborado pelo autor.

Gráfico 49 - Desempenho por SRE em Matemática - 2007.

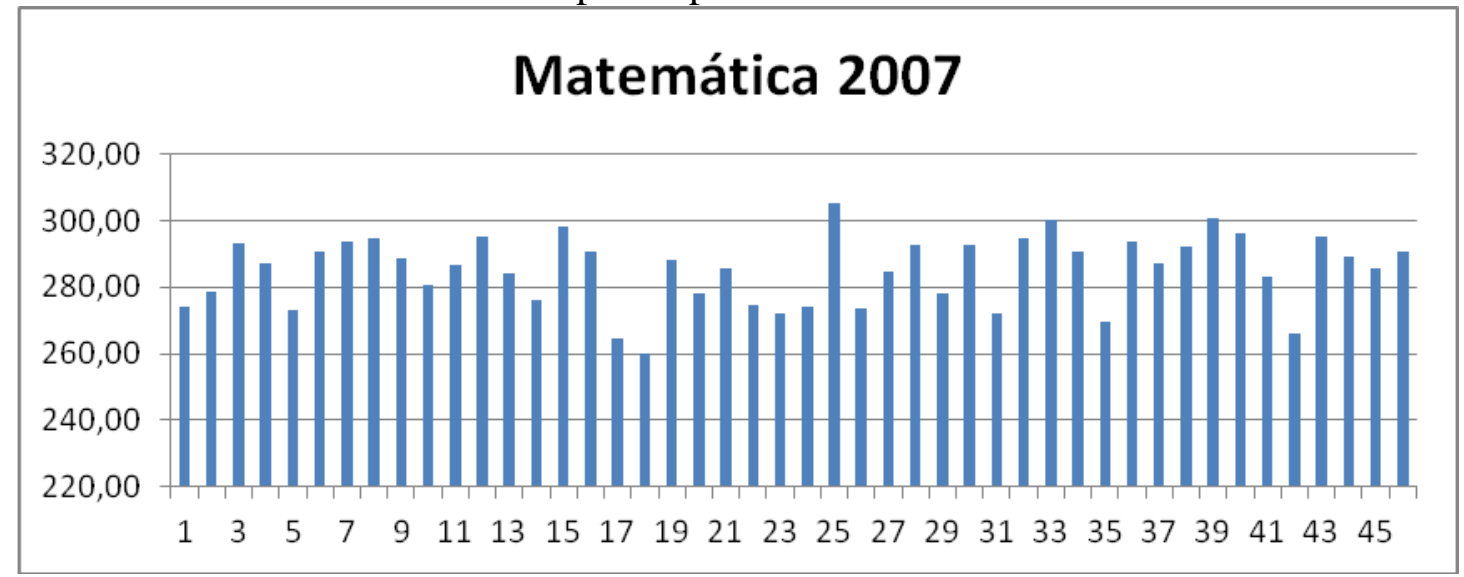

Fonte: Elaborado pelo autor.

Podemos ver pelo gráfico de barras que a SRE de Monte Carmelo (25) se destaca em seu desempenho nesse ano, seguida por São João Del Rei (39) e Patos de Minas (33).

Gráfico 50 - Desempenho por SRE em Matemática - 2008.

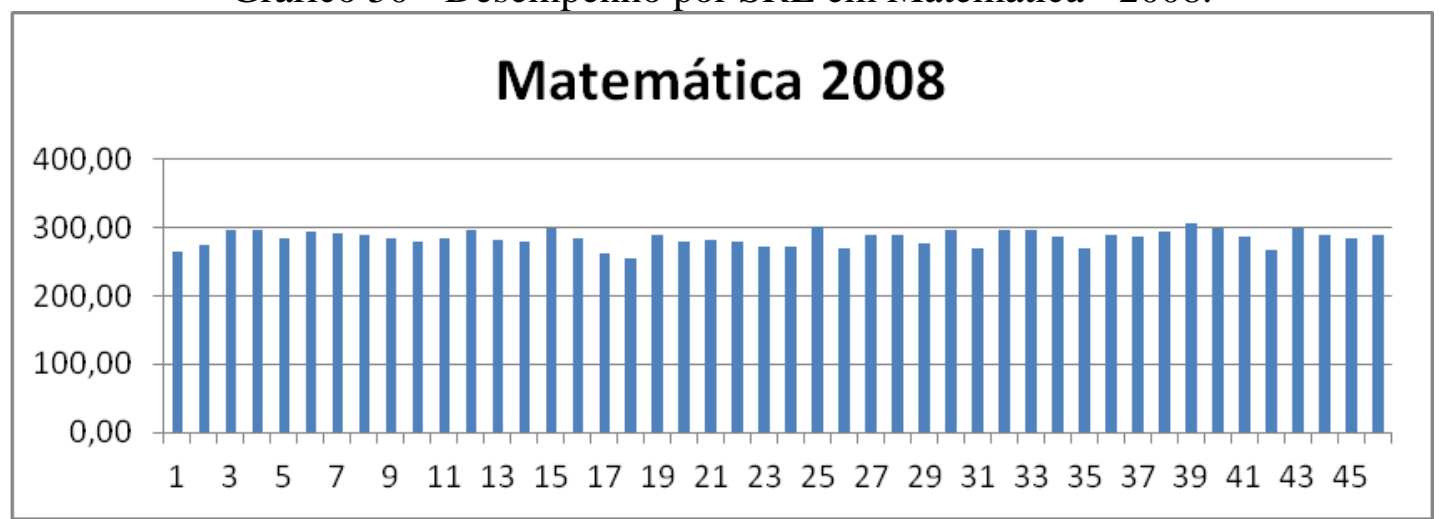

Fonte: Elaborado pelo autor. 
A SRE de São João Del rei (39) se destaca em seu desempenho nesse ano, seguida por Monte Carmelo (25) e São Sebastião do Paraíso (40).

Gráfico 51 - Desempenho por SRE em Matemática - 2009.

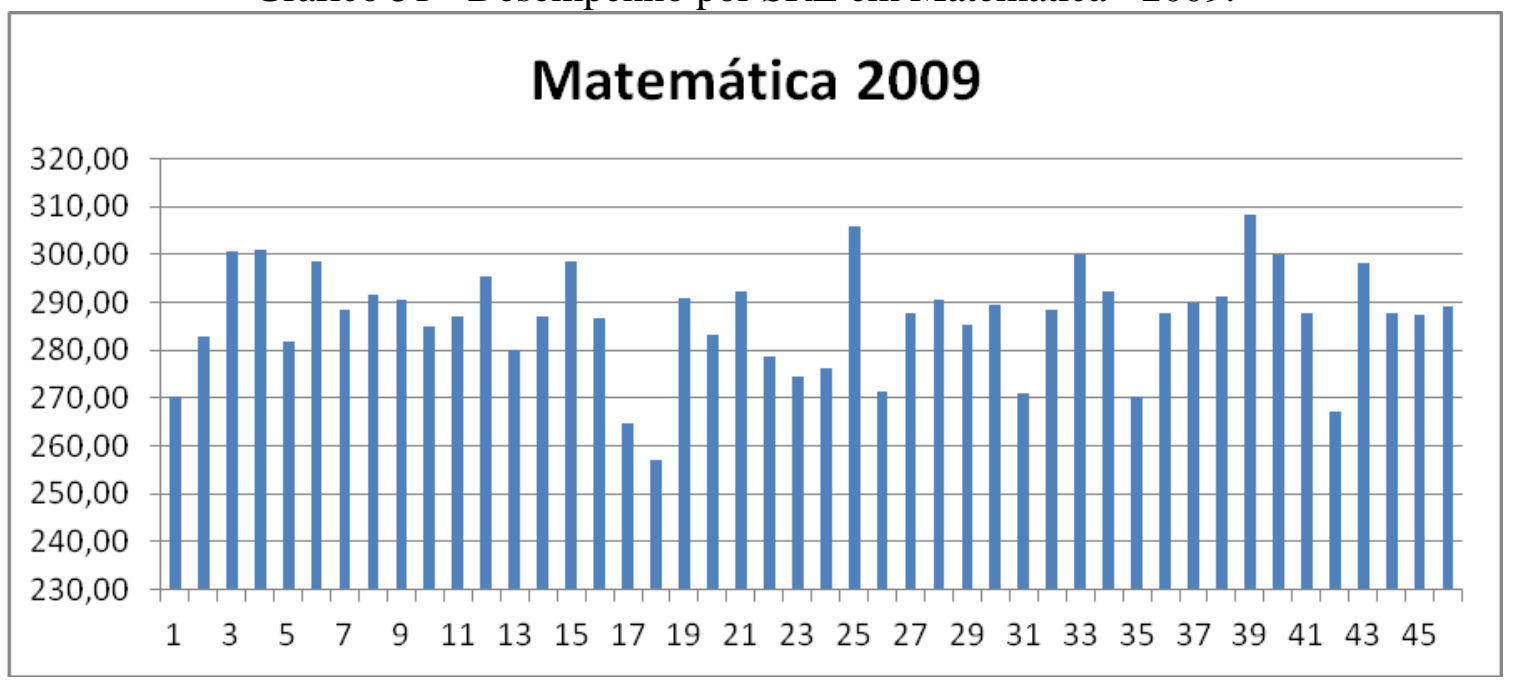

Fonte: Elaborado pelo autor.

Gráfico 52 - Desempenho por SRE em Matemática - 2010.

\section{Matemática 2010}

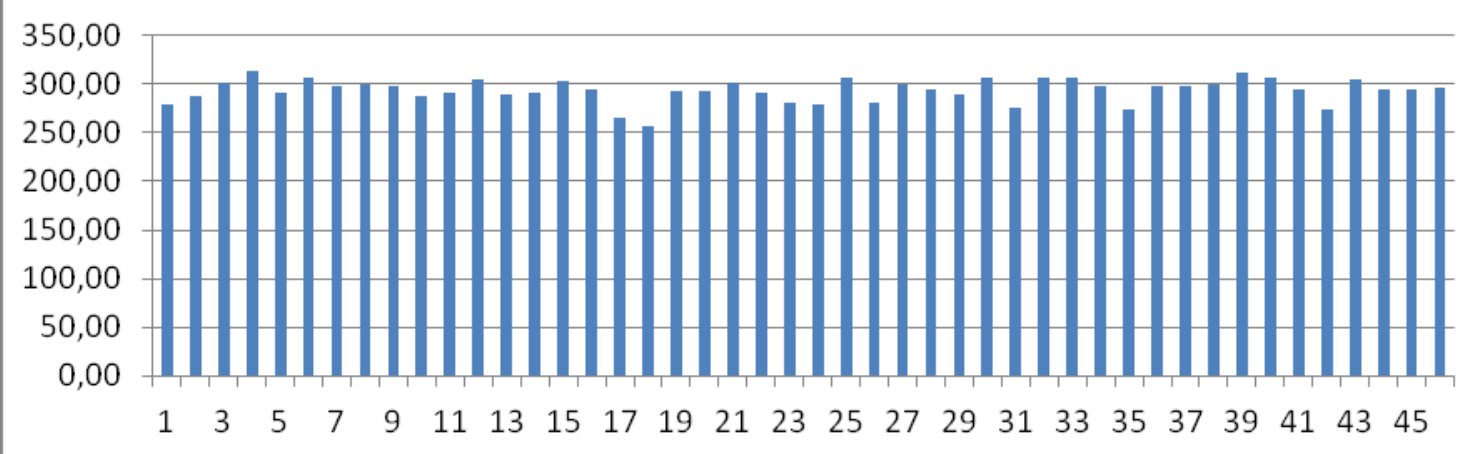

Fonte: Elaborado pelo autor.

A SRE de São João Del Rei (39) se destaca em seu desempenho nesse ano, seguida por Monte Carmelo (25) e Campo Belo (4). A SRE de Campo Belo (4) se destaca em seu desempenho nesse ano, seguida por São João Del Rei (39) e Monte Carmelo (25). 


\subsubsection{2.}

\section{Desempenho em Português}

Tabela 7 - Desempenho em português por Superintendência de Ensino - 2007 à 2010.

\begin{tabular}{|c|c|c|c|c|c|}
\hline $\mathrm{N}^{\mathrm{o}}$ & Português_SRE & 2007 & 2008 & 2009 & 2010 \\
\hline 1 & ALMENARA & 263,52 & 258,19 & 261,52 & 269,91 \\
\hline 2 & ARAÇUAÍ & 266,29 & 264,47 & 266,34 & 270,93 \\
\hline 3 & BARBACENA & 281,54 & 281,79 & 283,89 & 287,77 \\
\hline 4 & CAMPO BELO & 272,46 & 278,81 & 282,16 & 292,89 \\
\hline 5 & CARANGOLA & 267,32 & 277,31 & 276,04 & 281,96 \\
\hline 6 & CARATINGA & 279,19 & 279,48 & 281,49 & 288,84 \\
\hline 7 & CAXAMBU & 281,71 & 278,65 & 278,22 & 285,16 \\
\hline 8 & $\begin{array}{c}\text { CONSELHEIRO } \\
\text { LAFAIETE }\end{array}$ & 283,27 & 279,4 & 280,03 & 290,94 \\
\hline 9 & CORONEL FABRICIANO & 279,35 & 278,07 & 280,53 & 288,42 \\
\hline 10 & CURVELO & 273,99 & 276,25 & 280,19 & 285,25 \\
\hline 11 & DIAMANTINA & 277,05 & 277,17 & 278,83 & 285,54 \\
\hline 12 & DIVINÓPOLIS & 284,78 & 281,83 & 283,63 & 292,44 \\
\hline 13 & $\begin{array}{c}\text { GOVERNADOR } \\
\text { VALADARES }\end{array}$ & 276,21 & 274,16 & 272,55 & 282,28 \\
\hline 14 & GUANHÃES & 269,8 & 270,94 & 273,19 & 280,61 \\
\hline 15 & ITAJUBÁ & 279,85 & 280,32 & 281,77 & 286,49 \\
\hline 16 & ITUIUTABA & 278,1 & 276,4 & 279,09 & 285,27 \\
\hline 17 & JANAÚBA & 253,11 & 254,87 & 254,14 & 256,12 \\
\hline 18 & JANUÁRIA & 252,53 & 253 & 253,29 & 255,04 \\
\hline 19 & JUIZ DE FORA & 278,88 & 281,76 & 281,22 & 283,3 \\
\hline 20 & LEOPOLDINA & 270,82 & 272,77 & 271,88 & 280,32 \\
\hline 21 & MANHUAÇU & 274,79 & 273,47 & 276,21 & 285,87 \\
\hline 22 & METROPOLITANA A & 273,85 & 274,98 & 274,03 & 287,55 \\
\hline 23 & METROPOLITANA B & 269,45 & 270,72 & 271,87 & 280,42 \\
\hline 24 & METROPOLITANA C & 271,46 & 271,53 & 273,15 & 279,97 \\
\hline 25 & MONTE CARMELO & 290,39 & 288,74 & 290,36 & 295,07 \\
\hline 26 & MONTES CLAROS & 268,77 & 266,89 & 265,02 & 273,96 \\
\hline 27 & MURIAÉ & 277,02 & 275,2 & 276,45 & 285,24 \\
\hline 28 & NOVA ERA & 280,51 & 278,26 & 278,93 & 285,86 \\
\hline 29 & OURO PRETO & 272,45 & 271,59 & 271,96 & 284,11 \\
\hline 30 & PARÁ DE MINAS & 285,18 & 280,91 & 286,73 & 294,61 \\
\hline 31 & PARACATU & 261,34 & 259,37 & 264,26 & 267,79 \\
\hline 32 & PASSOS & 280,26 & 282,27 & 281,27 & 291,36 \\
\hline 33 & PATOS DE MINAS & 284,58 & 284,35 & 287,14 & 292,9 \\
\hline 34 & PATROCÍNIO & 278,62 & 272,99 & 278,31 & 284,73 \\
\hline 35 & PIRAPORA & 265,02 & 264,96 & 265,9 & 270,55 \\
\hline
\end{tabular}




\begin{tabular}{r|c|c|c|c|c}
36 & POÇOS DE CALDAS & 282,32 & 278,97 & 279,81 & 285,87 \\
\hline 37 & PONTE NOVA & 277 & 275,08 & 276,24 & 284,14 \\
\hline 38 & POUSO ALEGRE & 277,58 & 278,1 & 276,01 & 285,3 \\
\hline 39 & SÃO JOÃO DEL REI & 287,71 & 285,84 & 288,05 & 295,43 \\
\hline 40 & SÃO SEBASTIÃO DO & 286,18 & 286,78 & 287,13 & 291,81 \\
\hline 41 & PARAIISO & & & 276,7 & 282,88 \\
\hline 42 & SETE LAGOAS & 274,36 & 277,89 & 276,73 & 267,49 \\
\hline 43 & UBOA OTONI & 261,77 & 263,85 & 261,23 & 267,49 \\
\hline 44 & UBERABA & 280,03 & 282,6 & 281 & 291,79 \\
\hline 45 & UBERLANDIA & 278,59 & 277,91 & 275,77 & 282,24 \\
\hline 46 & VARGINHA & 276,26 & 275,71 & 276,87 & 283,79 \\
\hline
\end{tabular}

Fonte: Elaborado pelo autor.

Gráfico 53 - Desempenho por SRE em português - 2007.

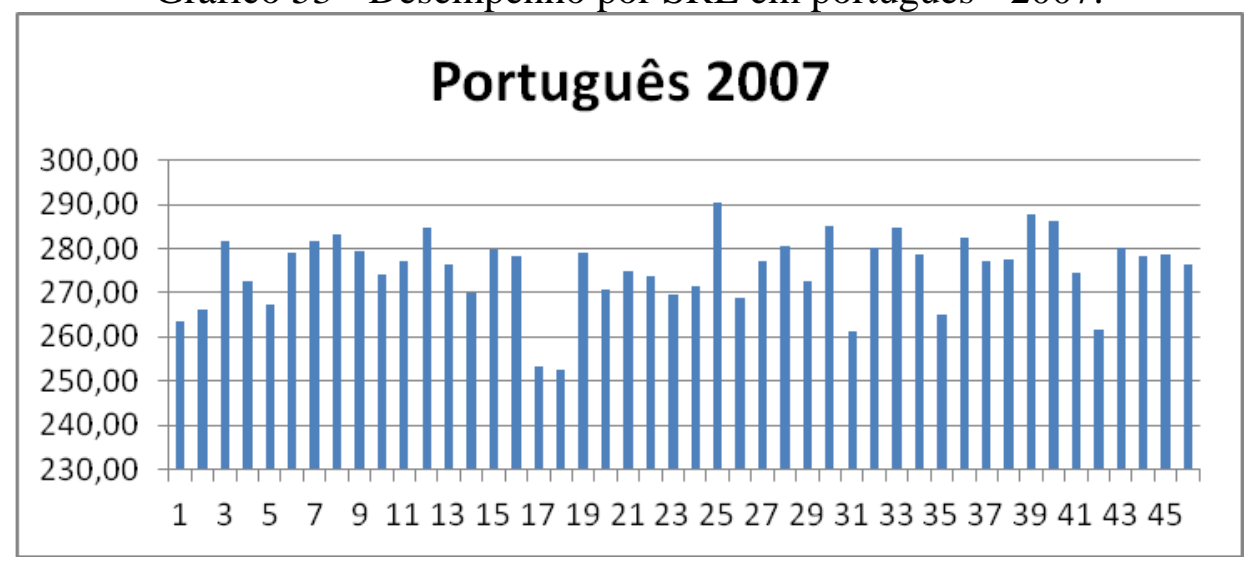

Fonte: Elaborado pelo autor.

A SRE de Monte Carmelo (25) se destaca em seu desempenho nesse ano, seguida por São João Del Rei (39) e São Sebastião do Paraíso (40).

Gráfico 54 - Desempenho por SRE em português - 2008.

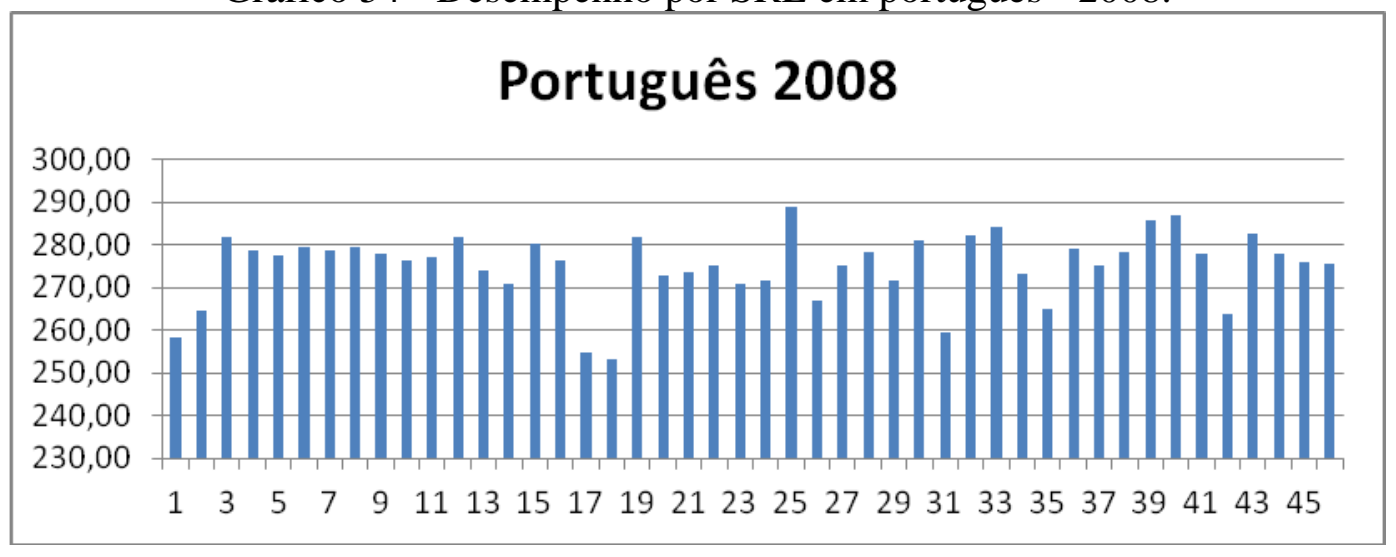

Fonte: Elaborado pelo autor. 
A SRE de Monte Carmelo (25) se destaca em seu desempenho nesse ano, seguida por São Sebastião do Paraíso (40) e São João Del Rei (39).

Gráfico 55 - Desempenho por SRE em português - 2009.

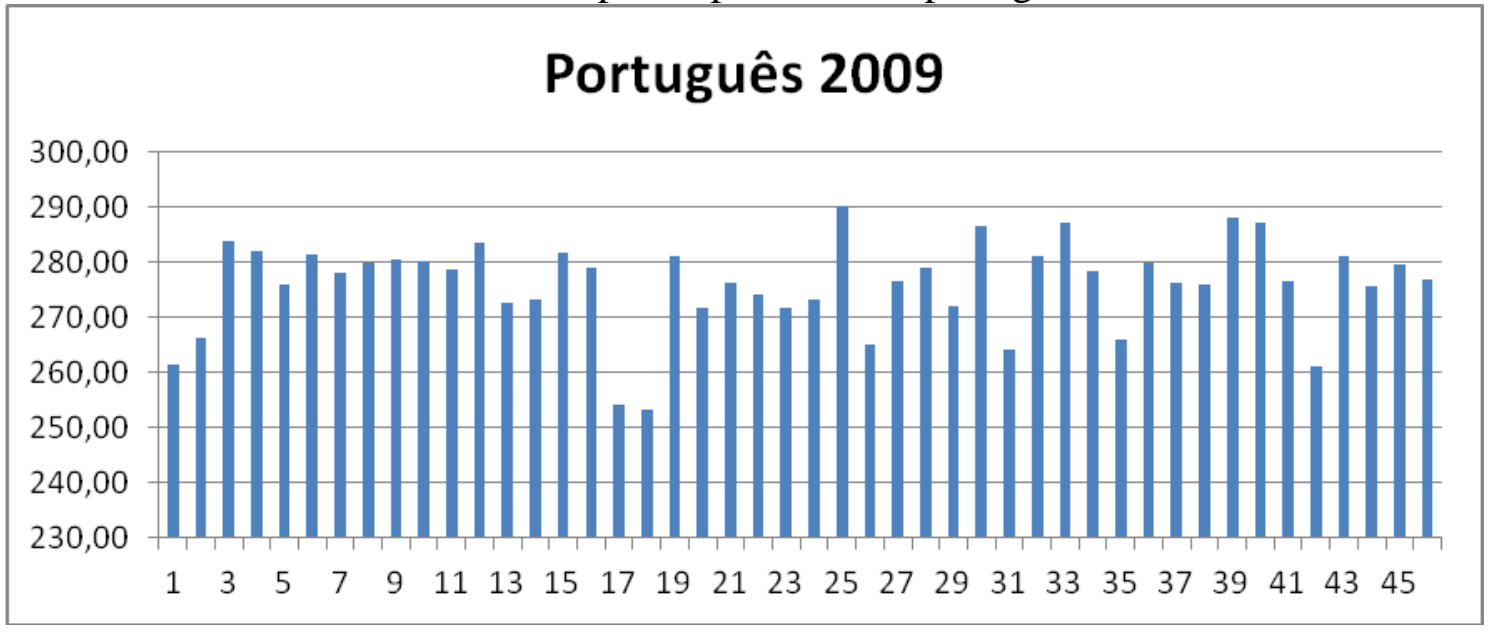

Fonte: Elaborado pelo autor.

A SRE de Monte Carmelo (25) se destaca em seu desempenho nesse ano, seguida por São João Del Rei (39) e Patos de Minas (33).

Gráfico 56 - Desempenho por SRE em português - 2010.

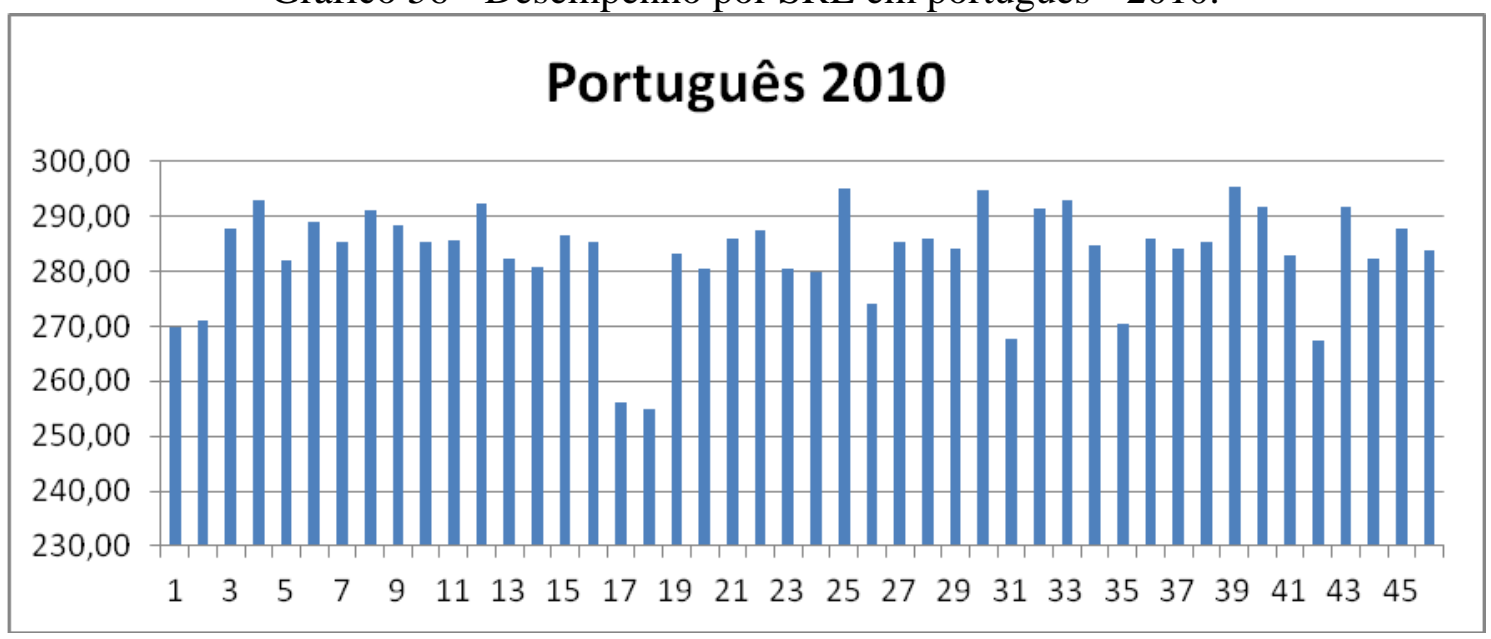

Fonte: Elaborado pelo autor.

A SRE de São João Del Rei (39) se destaca em seu desempenho nesse ano, seguida por Monte Carmelo (25) e Pará de Minas (30).

As SRE de Monte Carmelo e São João Del Rei, se destacam em todos os anos nas duas disciplinas: matemática e português aparecendo entre as 3 melhores SRE's. Analisando o desempenho das 46 SRE's em termos de crescimento contínuo da nota média ao longo dos anos de 2007-2010 verifica-se que a desigualdade entre as mesmas 
é se mantem. Na disciplina de matemática temos as seguintes 11 SRE's: Barbacena, Campo Belo, Caratinga, Ganhães, Juiz de Fora Leopoldina, Ponte Nova, São João Del Rei, São Sebastião do Paraíso, Sete Lagoas e Teofilo Otoni. Em português temos as seguintes 11 SRE's: Barbacena, Campo Belo, Caratinga, Curvelo, Diamantina, Guanhães, Itajubá, Januária, Metropolitana B, Metropolitana C e São Sebastião do Paraíso. Abaixo temos os gráficos de linhas para as 46 SRE por disciplina.

Gráfico 57 - Evolução do desempenho em matemática - SRE-MG - 2007 à 2010.

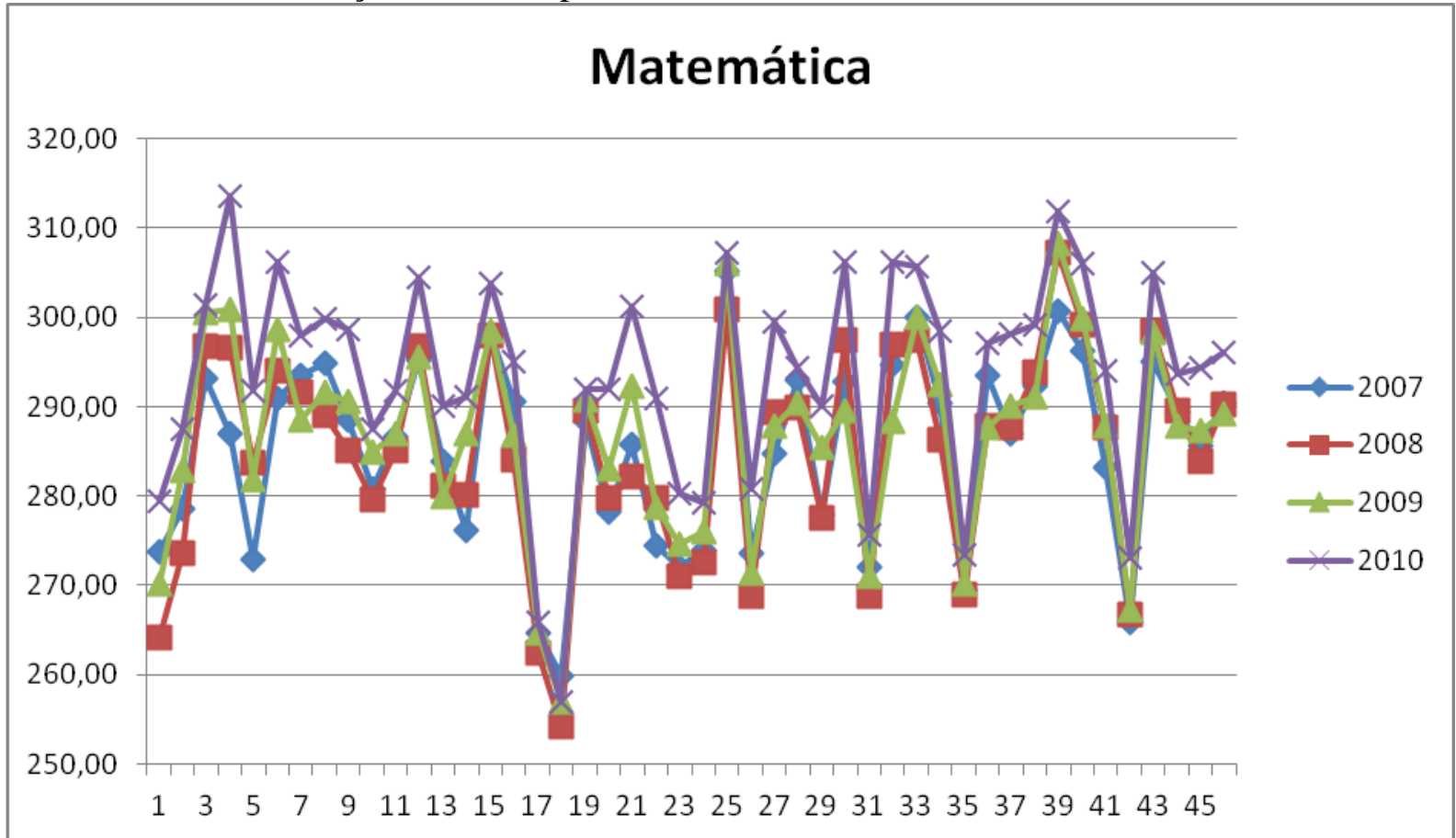

Fonte: Elaborado pelo autor.

Gráfico 58 - Evolução do desempenho em português - SRE-MG - 2007 à 2010.

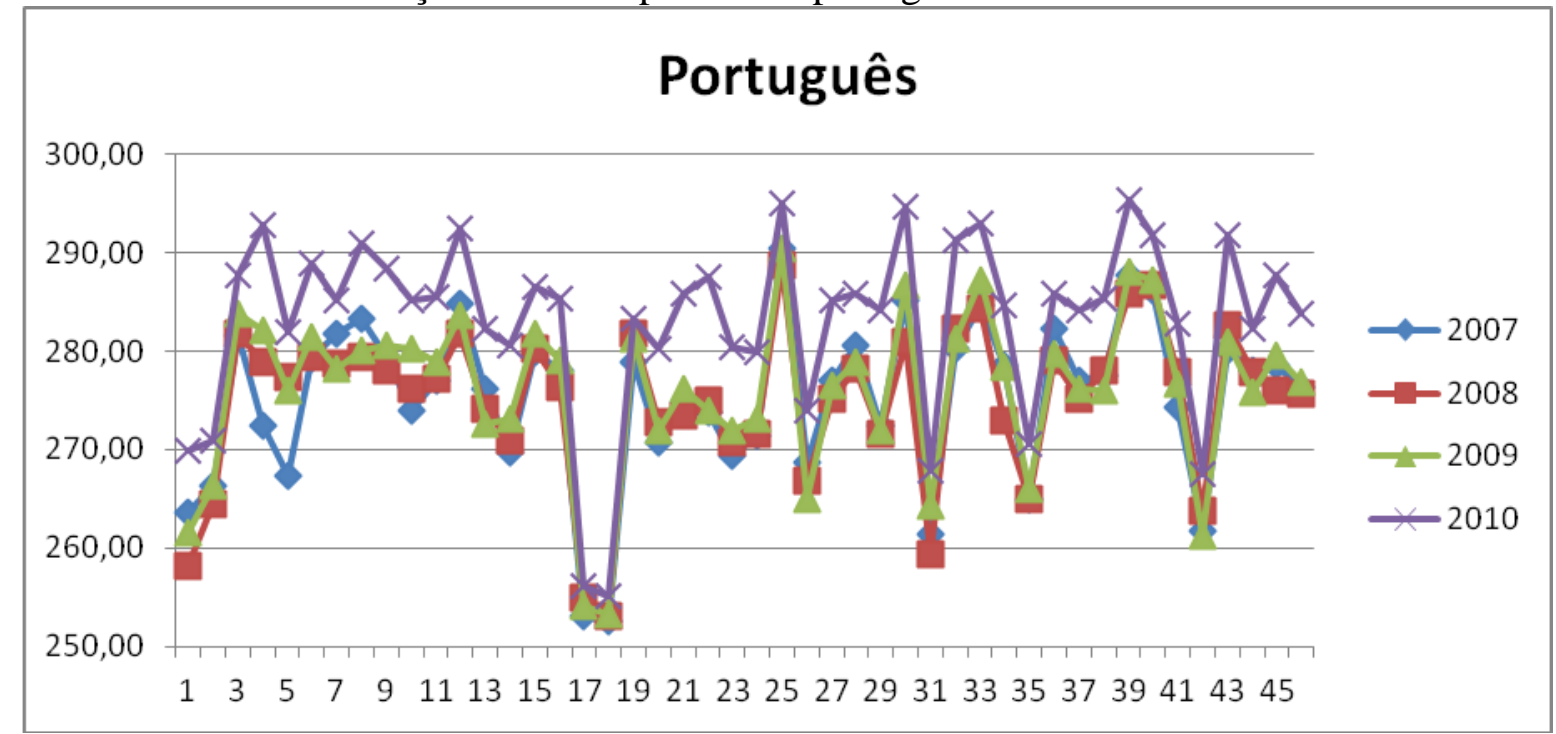

Fonte: Elaborado pelo autor. 


\subsection{3.}

Índice de complexidade das Superintendências Regionais de Ensino (ICS)

O Índice de Complexidade das Superintendências Regionais de Ensino (ICS) incorpora certas especificidades decorrentes das condições particulares de cada uma dessas superintendências, no sentido de fornecer uma medida que permita comparar o desempenho dessas unidades administrativas em relação à abrangência das políticas educacionais implementadas pela SEE-MG.

Metodologia

Foram utilizados indicadores, construídos a partir de variáveis do Censo Escolar do INEP, para a composição do Índice de Complexidade das SRE's conforme segue:

$>$ Número de municípios atendidos pela SRE;

$>$ Número de estudantes atendidos pela SRE;

$>\%$ Estudantes atendidos pela SRE no EF;

$>\%$ de matrículas em escolas rurais.

As quatro variáveis escolhidas apresentam dados específicos de cada SRE, caracterizando situações relativas ao nível de complexidade operacional. Para isso, além de considerar o número de estudantes e municípios atendidos, o índice também considera o percentual de atendimento do EF e número de escolas rurais em cada SRE.

Para a elaboração do Índice de Complexidade das Superintendências Regionais de Ensino - ICS, a exemplo de outros índices sintéticos, realizei, em primeiro lugar, a "normalização" dos valores de cada um dos 4 indicadores. Isso é feito para que todos sejam compatibilizados e tenham o mesmo intervalo de variação numa escala de 0 a 1 $(0=$ menor valor; $1=$ maior valor $)$. Para tanto, aplica-se a fórmula abaixo para cada um dos indicadores:

$\mathrm{VNij}=1-(\mathrm{MVi}-\mathrm{Vij}) /(\mathrm{MVi}-\mathrm{mVi})$, onde:

$\mathrm{VNij}=$ valor normalizado na escala de 0 a 1 do indicador $\mathrm{i}$ no lugar $\mathrm{j}$

$\mathrm{MVi}=$ maior valor obtido pelo indicador i entre todos os recortes geográficos pesquisados;

$\mathrm{mVi}=$ menor valor obtido pelo indicador $\mathrm{i}$ entre todos os recortes geográficos pesquisados;

$\mathrm{Vij}=$ valor obtido pelo indicador $\mathrm{i}$ no lugar $\mathrm{j}$

Em seguida, somei os valores obtidos para cada lugar nos quatro índices utilizados e calculei sua média aritmética, dividindo a soma obtida por quatro. Essa média 
corresponde ao valor do ICS. Note-se que como a média é calculada a partir de quatro diferentes indicadores normalizados, o ICS poderá assumir qualquer valor entre 0 e 1 , sem que necessariamente tenha que assumir os valores 0 e 1. Entretanto, o ICS manterá a hierarquização ordinal necessária para que possamos diferenciar o nível de complexidade de cada SRE.

No presente estudo, o ICS foi calculado para um grupo de referência constituído pelas Superintendências Regionais de Ensino da Secretaria de Educação do Estado de Minas Gerais. Dessa forma, é possível comparar entre si as 46 SRE's por meio do ICS obtido.

A metodologia da construção do índice foi replicada para as 853 cidades do Estado, sendo atribuído para cada município o ICS de sua respectiva SRE.

Abaixo classifiquei em ordem decrescente o resultado do índice de complexidade para cada SRE por ano. O índice varia de 0 a 1 , sendo consideradas de baixa complexidade as SRE's que atingiram menos de 0,289 pontos, de média complexidade as que possuem pontos de 0,290 até 0,399 e de alta complexidade as SRE's que atingiram pontuação superior a 0,400 .

Tabela 8 - ICS por SRE - 2007 à 2010.

\begin{tabular}{l|l|l|l|l|r}
\hline \multicolumn{1}{c}{ ICS por SRE - 2007 - 2009 } \\
\hline SRE & $\mathbf{2 0 0 7}$ & $\mathbf{2 0 0 8}$ & $\mathbf{2 0 0 9}$ & $\mathbf{2 0 1 0}$ & Média \\
\hline SRE TEOFILO OTONI & 0,59 & 0,63 & 0,63 & 0,63 & 0,62 \\
\hline SRE JANUARIA & 0,57 & 0,58 & 0,60 & 0,59 & 0,59 \\
\hline SRE DIAMANTINA & 0,60 & 0,56 & 0,53 & 0,52 & 0,55 \\
\hline SRE ARACUAI & 0,57 & 0,52 & 0,52 & 0,51 & 0,53 \\
\hline SRE GOVERNADOR VALADARES & 0,46 & 0,52 & 0,52 & 0,51 & 0,50 \\
\hline SRE GUANHAES & 0,52 & 0,48 & 0,48 & 0,49 & 0,49 \\
\hline SRE JANAUBA & 0,50 & 0,48 & 0,47 & 0,46 & 0,48 \\
\hline SRE MONTES CLAROS & 0,49 & 0,44 & 0,46 & 0,45 & 0,46 \\
\hline SRE CARATINGA & 0,45 & 0,44 & 0,45 & 0,44 & 0,45 \\
\hline \hline SRE ALMENARA & 0,41 & 0,46 & 0,43 & 0,44 & 0,44 \\
\hline SRE PONTE NOVA & 0,39 & 0,42 & 0,44 & 0,43 & 0,42 \\
\hline SRE MANHUACU & 0,42 & 0,39 & 0,40 & 0,40 & 0,40 \\
\hline SRE METROPOLITANA A & 0,40 & 0,41 & 0,42 & 0,37 & 0,40 \\
\hline SRE VARGINHA & 0,39 & 0,39 & 0,38 & 0,36 & 0,38 \\
\hline SRE DIVINOPOLIS & 0,40 & 0,36 & 0,37 & 0,36 & 0,37 \\
\hline SRE POUSO ALEGRE & 0,34 & 0,37 & 0,36 & 0,37 & 0,36 \\
\hline SRE CARANGOLA & 0,34 & 0,35 & 0,36 & 0,36 & 0,35 \\
\hline SRE UBA & 0,36 & 0,33 & 0,33 & 0,32 & 0,33 \\
\hline SRE BARBACENA & 0,31 & 0,36 & 0,32 & 0,33 & 0,33 \\
\hline & & & & &
\end{tabular}




\begin{tabular}{|c|c|c|c|c|c|}
\hline SRE METROPOLITANA C & 0,27 & 0,32 & 0,32 & 0,32 & 0,31 \\
\hline SRE PARACATU & 0,32 & 0,30 & 0,30 & 0,30 & 0,30 \\
\hline SRE CAXAMBU & 0,26 & 0,33 & 0,32 & 0,30 & 0,30 \\
\hline SRE SAO JOAO DEL REI & 0,28 & 0,29 & 0,30 & 0,30 & 0,29 \\
\hline SRE PARA DE MINAS & 0,31 & 0,29 & 0,30 & 0,27 & 0,29 \\
\hline SRE METROPOLITANA B & 0,19 & 0,31 & 0,33 & 0,31 & 0,28 \\
\hline SRE JUIZ DE FORA & 0,26 & 0,29 & 0,30 & 0,29 & $0,2 \varepsilon$ \\
\hline SRE ITAJUBA & 0,30 & 0,26 & 0,27 & 0,23 & 0,2 \\
\hline SRE MURIAE & 0,23 & 0,26 & 0,23 & 0,25 & 0,2 \\
\hline SRE UBERABA & 0,30 & 0,22 & 0,22 & 0,22 & 0,2 \\
\hline SRE SETE LAGOAS & 0,28 & 0,23 & 0,24 & 0,20 & 0,2 \\
\hline SRE POCOS DE CALDAS & 0,18 & 0,23 & 0,26 & 0,25 & 0,23 \\
\hline SRE PASSOS & 0,28 & 0,22 & 0,22 & 0,20 & 0,23 \\
\hline SRE SAO SEBASTIAO DO PARAISO & 0,23 & 0,24 & 0,22 & 0,22 & 0,2 \\
\hline SRE PATOS DE MINAS & 0,31 & 0,20 & 0,19 & 0,20 & 0,2 \\
\hline SRE CONSELHEIRO LAFAIETE & 0,25 & 0,17 & 0,23 & 0,18 & 0,2 \\
\hline SRE NOVA ERA & 0,27 & 0,18 & 0,20 & 0,17 & 0,20 \\
\hline SRE CURVELO & 0,20 & 0,21 & 0,20 & 0,18 & 0,20 \\
\hline SRE PIRAPORA & 0,22 & 0,20 & 0,19 & 0,15 & 0,19 \\
\hline SRE CAMPO BELO & 0,16 & 0,21 & 0,20 & 0,19 & 0,19 \\
\hline SRE MONTE CARMELO & 0,28 & 0,16 & 0,16 & 0,14 & 0,18 \\
\hline SRE UBERLANDIA & 0,20 & 0,18 & 0,18 & 0,15 & 0,18 \\
\hline SRE PATROCINIO & 0,18 & 0,17 & 0,19 & 0,16 & 0,17 \\
\hline SRE CORONEL FABRICIANO & 0,17 & 0,13 & 0,15 & 0,10 & 0,14 \\
\hline SRE LEOPOLDINA & 0,11 & 0,14 & 0,14 & 0,11 & 0,12 \\
\hline SRE OURO PRETO & 0,06 & 0,12 & 0,12 & 0,11 & 0,10 \\
\hline SRE ITUIUTABA & 0,16 & 0,07 & 0,06 & 0,05 & 0,09 \\
\hline
\end{tabular}

Fonte: Elaborado pelo autor.

Podemos perceber que as SRE de Teófilo Otoni, Januária e Diamantina se mantêm no topo ao longo dos anos, ou seja, como SRE mais complexas do Estado de Minas Gerais. Este resultado é bastante coerente, já que estas superintendências estão localizadas em regiões com elevado número de municípios pobres e, por consequência, assumem uma elevada parcela do atendimento do Ensino Fundamental. O ICS é uma importante medida para a modelagem que será apresentada em seguida. 


\subsection{4. \\ Regressão logística}

Optei pela regressão logística, por ser uma técnica estatística que tem como objetivo produzir, a partir de um conjunto de observações, um modelo que permite a predição de valores tomados por uma variável categórica, frequentemente binária, a partir de uma série de variáveis explicativas contínuas e/ou binárias. Assim, foi possível modelar para o caso de presença ou não dos programas selecionados nos municípios mineiros $^{11}$. O modelo não necessariamente pode afirmar que a política aumentou a proficiência, uma vez que a nossa variável resposta/alvo são os programas implementados. Entretanto, embora não seja o objetivo principal desta tese, fiz uma análise descritiva, observando as notas médias pelos programas por meio de gráficos e tabelas para verificar se essas notas são altas ou não em função de ter o programa ou não. Os resultados da análise descritiva da base de dados, mostraram que, no caso de presença do programa, o desempenho tem se mostrado estável na medida da nota, ou seja, o espaçamento entre as notas é bem próximo, e a nota mínima é maior que a nota mínima da ausência do programa na maioria dos casos. Estas análises estão detalhadas nos anexos deste trabalho.

A regressão logística tem a seguinte lógica: temos uma variável de interesse (Y), que no caso é a presença da política pública no município $(\mathrm{Y}=1)$ e a ausência da política no município $(\mathrm{Y}=0)$. A probabilidade das duas pode ser expressa por P1 e P0. Verificaremos se a variável de interesse é influenciada por variáveis independentes (chamaremos cada uma de x1, x2, x3... e o conjunto de todas elas de x), no caso o ICS, PIB, etc. Assim, a fórmula da regressão é expressa por:

$\log (\mathrm{P} 1 /(1-\mathrm{P} 1))=$ constante $+\mathrm{B}^{*} \mathrm{x}$

Exemplo se tivéssemos 3 variáveis no modelo:

$\log (\mathbf{P} 1 / \mathrm{P} 0)=$ constante $+\mathrm{B} 1 * \mathbf{x} 1+\mathrm{B} 2 * \times 2+B 3 * \times 3$

$\log (\mathbf{P 1} / \mathbf{P 0}):$ chance da política estar presente em relação à chance dela não estar presente no município.

B: estimativa de por quanto deveríamos multiplicar o valor que temos em cada variável independente (x). Se esse B for próximo demais de zero, por exemplo, significa que $\mathrm{x}$ não tem muita influência em $\mathrm{Y}$, afinal, na multiplicação a variável será

\footnotetext{
${ }^{11}$ Por exemplo, se o ICS foi significativo, sendo uma variável continua/numérica dentro do modelo, significa que quanto maior o ICS, maior a multiplicação pelo peso e maior o score para aquele município, ou seja, maior chance de ter o programa.
} 
praticamente anulada do modelo. Se for positiva, significa que enquanto a variável independente aumenta, a chance da política estar presente na cidade aumenta. Se a estimativa é negativa, significa que enquanto a variável independente aumenta, a chance da política estar ausente na cidade aumenta - ou seja, a chance da política estar presente diminui.

Constante: para variáveis independentes que são numéricas (notas, por exemplo), a constante representa sua média. Ela não sai do modelo para sustentar as contas, neste caso. Porém, é desconsiderada de acordo com sua razão de chance (se for nula) ou pvalor (se for maior do que $10 \%$ ).

d.f.: graus de liberdade, ou seja, quantas variáveis são necessárias para estimarmos a variável x em questão. No caso das tabelas, temos apenas 1 grau de liberdade porque apenas elas mesmas e a constante são necessárias para estimarmos B.

S. E.: erro padrão da estimativa B. Ou seja, precisão de B, o quanto ela varia para mais ou para menos.

Wald: estatística que é a divisão de B pelo erro padrão dela. É usada para verificar se a variável independente $(\mathrm{x})$ tem influência na variável de interesse $(\mathrm{Y})$. $\mathrm{O}$ resultado dessa divisão é comparado com a tabela da normal padrão para obtermos o pvalor. Não usamos Wald sozinho para obter qualquer conclusão.

P-valor: probabilidade da variável ser significante no modelo, ou seja, chance da variável x ser influente em Y. Isso se mede estabelecendo um nível de significância, geralmente $5 \%$, mas usaremos $10 \%$, onde se o p-valor é menor ou igual a 0,10 , a variável é significante.

Razão de chances (RC): é o exponencial elevado ao valor de B. No caso, a variável independente teria $\mathrm{RC}$ vezes mais/menos chance de ocorrer enquanto a incidência da política pública analisada aumenta.

Observacão sobre $\mathbf{B}=\mathbf{0}$ e RC's muito altos ou zerados: esses são claros indícios de que o modelo não é bem ajustado, ou seja, as variáveis disponíveis não explicam bem a variação/distribuição das políticas nos municípios. No caso das políticas, o que temos de resultado nas tabelas a seguir é o melhor que estatisticamente podemos estimar sobre como elas se comportam em relação às variáveis disponíveis.

Descrição das Variáveis 
O quadro 3 mostra a estatística descritiva das variáveis usadas nos modelos estimados $^{12}$.

Quadro 5 - Descrição escrita das variáveis.

\begin{tabular}{|c|c|c|c|}
\hline \multicolumn{2}{|r|}{ Variável } & Tipo & Descrição \\
\hline \multirow{5}{*}{ 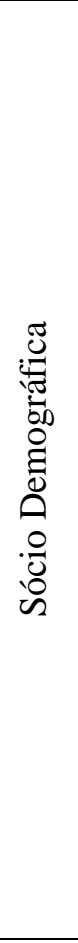 } & GINI 2010 & \multirow{4}{*}{ Contínua } & $\begin{array}{l}\text { Índice por município que varia entre } 0 \text { que corresponde a } \\
\text { uma situação de igualdade perfeita da distribuição de } \\
\text { rendimentos, ou seja, quando todos os habitantes da } \\
\text { população estudada possuem a mesma renda e } 1 \text {, que } \\
\text { indica a desigualdade máxima, ou concentração máxima } \\
\text { de renda, em que apenas um indivíduo ou grupo se } \\
\text { apropria de toda a renda da população estudada. }\end{array}$ \\
\hline & IFDM 2010 & & $\begin{array}{l}\text { Índice que varia entre } 0 \text { e } 1 \text {, sendo que quanto mais } \\
\text { próximo de } 1 \text {, maior o desenvolvimento da localidade. }\end{array}$ \\
\hline & PIB Percapita & & $\begin{array}{l}\text { Produto Interno Bruto (PIB) Percapita anual por } \\
\text { município. }\end{array}$ \\
\hline & IDHM 2010 & & $\begin{array}{l}\text { Índice municipal composto a partir de três dimensões: } \\
\text { IDHM-E, para a educação, IDHM-L, para a saúde } \\
\text { (longevidade), e IDHM-R, para a renda. }\end{array}$ \\
\hline & $\begin{array}{l}\text { Porte do } \\
\text { Município }\end{array}$ & Dummy & $\begin{array}{l}\text { Classifica os municípios em três variáveis dummies } \\
\text { conforme o número de habitantes: Municípios de } \\
\text { Pequeno Porte - população até } 50.000 \text { habitantes (1) sim } \\
\text { e (0) não; Municípios de Médio Porte - população de } \\
50.001 \text { a } 100.000 \text { habitantes (1) sim e (0) não e } \\
\text { Municípios de Grande Porte - população acima de } \\
100.001 \text { mil habitantes (1) sim e (0) não. }\end{array}$ \\
\hline \multirow{2}{*}{ 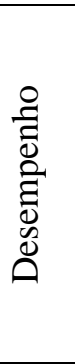 } & $\begin{array}{l}\text { Desempenho } \\
\text { em matemática }\end{array}$ & \multirow{2}{*}{ Contínua } & $\begin{array}{l}\text { Média de desempenho em matemática por município } \\
\text { dos estudantes do } 3^{\circ} \text { ano do EM das escolas da rede } \\
\text { estadual avaliadas pelo SIMAVE nos anos de } 2007 \text {, } \\
2008,2009 \text { e } 2010 \text {. }\end{array}$ \\
\hline & $\begin{array}{l}\text { Desempenho } \\
\text { em Português }\end{array}$ & & $\begin{array}{l}\text { Média de desempenho em português por município dos } \\
\text { estudantes do } 3^{\circ} \text { ano do EM das escolas da rede estadual } \\
\text { avaliadas pelo SIMAVE nos anos de } 2007,2008,2009 \text { e } \\
2010 \text {. }\end{array}$ \\
\hline$\stackrel{\mathscr{\mathscr { V }}}{\stackrel{0}{0}}$ & $\begin{array}{l}\text { Presença de } \\
\text { programas no } \\
\text { município }\end{array}$ & Dummy & $\begin{array}{l}\text { Uma dummy para cada programa: ER, PDP, FIT, PJ, } \\
\text { PEAS, PEP: } 1 \text { = possui o programa e } 0=\text { não possui o } \\
\text { programa. Para cada Programa analisado foram incluídas } \\
\text { todas as variáveis, exceto a do próprio programa. }\end{array}$ \\
\hline 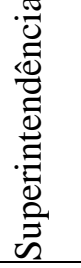 & ICS & Contínua & $\begin{array}{l}\text { Índice criado a partir das seguintes variáveis do Censo } \\
\text { Escolar do INEP: Número de municípios atendidos pela } \\
\text { SRE; Número de estudantes atendidos pela SRE; \% } \\
\text { Estudantes atendidos pela SRE no EF e \% de matrículas } \\
\text { em escolas rurais. }\end{array}$ \\
\hline
\end{tabular}

Fonte: Elaborado pelo autor.

\footnotetext{
${ }^{12}$ Outras variáveis foram consideradas nas análises, entretanto, face aos resultados obtidos, elas não estão incluídas aqui.
} 
Tabela 9 - ESTATÍSTICA DESCRITIVA DAS VARIÁVEIS.

\begin{tabular}{l|r|r|r|r}
\hline Variável & \multicolumn{1}{l|}{ Mínimo } & \multicolumn{1}{l|}{ láximo } & \multicolumn{1}{l}{ Média } & Desvio Padrão \\
\hline GINI 2010 & 0,33 & 0,78 & 0,48 & 0,05 \\
\hline IFDM 2010 & 0,42 & 0,86 & 0,64 & 0,07 \\
\hline PIB Per capita 2007 & 2429,48 & 196487,78 & 8496,98 & 10796,99 \\
\hline PIB Per capita 2008 & 2909,11 & 177303,13 & 9898,61 & 11242,56 \\
\hline PIB Per capita 2009 & 3186,34 & 187389,42 & 9945,43 & 10347,54 \\
\hline PIB Per capita 2010 & 3593,19 & 239773,56 & 12291,08 & 14299,30 \\
\hline IDHM 2010 & 0,53 & 0,81 & 0,67 & 0,05 \\
\hline $\begin{array}{l}\text { Desempenho em matemática } \\
\text { 2007 }\end{array}$ & 227,70 & 353,79 & 285,83 & 18,63 \\
\hline $\begin{array}{l}\text { Desempenho em matemática } \\
\text { 2008 }\end{array}$ & 229,38 & 369,92 & 284,85 & 20,33 \\
\hline $\begin{array}{l}\text { Desempenho em matemática } \\
2009\end{array}$ & 228,66 & 368,55 & 287,12 & 20,42 \\
\hline $\begin{array}{l}\text { Desempenho em matemática } \\
2010\end{array}$ & 234,06 & 367,24 & 294,05 & 20,95 \\
\hline $\begin{array}{l}\text { Desempenho em Português } \\
2007\end{array}$ & 222,65 & 343,46 & 274,29 & 15,47 \\
\hline $\begin{array}{l}\text { Desempenho em Português } \\
2008\end{array}$ & 233,66 & 321,79 & 273,17 & 14,43 \\
\hline $\begin{array}{l}\text { Desempenho em Português } \\
2009\end{array}$ & 191,90 & 324,10 & 273,85 & 14,95 \\
\hline $\begin{array}{l}\text { Desempenho em Português } \\
2010\end{array}$ & 231,91 & 349,51 & 281,13 & 16,14 \\
\hline ICS 2007 & 0,05 & 0,60 & 0,36 & 0,13 \\
\hline ICS 2008 & 0,07 & 0,63 & 0,35 & 0,13 \\
\hline ICS 2009 & 0,06 & 0,63 & 0,35 & 0,13 \\
\hline ICS 2010 & 0,63 & 0,34 & 0,13 \\
\hline
\end{tabular}

Fonte: Elaborado pelo autor.

\subsection{5.}

\section{Análise dos resultados da regressão logística}

Para a seleção dos modelos, considerando a existência de poucas variáveis, optei pela técnica stepwise backward que consiste na inclusão de todas as variáveis no modelo e em seguida da eliminação daquelas que não apresentaram resultados significativos. Abaixo, na tabela 12, podemos ver as variáveis que tiveram mais peso no modelo em cada programa e ano. 
4.5.5.1.

Regressão logística - Escolas Referência - 2007-2010

Tabela 10 - Resultados da regressão logística - ER - 2007 à 2010.

\begin{tabular}{|c|c|c|c|c|c|c|}
\hline \multicolumn{7}{|c|}{2007} \\
\hline Variável & B & S.E. & Wald & df & P. valor & $\begin{array}{l}\text { Razão de } \\
\text { Chances }\end{array}$ \\
\hline População Urbana & 0,036 & 0,008 & 19,450 & 1 & 0,000 & 1,037 \\
\hline PEAS & $-1,083$ & 0,257 & 17,773 & 1 & 0,000 & 0,339 \\
\hline PEP & $-2,379$ & 0,346 & 47,230 & 1 & 0,000 & 0,093 \\
\hline Município Médio Porte & $-4,337$ & 1,046 & 17,198 & 1 & 0,000 & 0,013 \\
\hline Constante & 2,338 & 1,330 & 3,092 & 1 & 0,079 & 10,364 \\
\hline \multicolumn{7}{|c|}{2008} \\
\hline Variável & B & S.E. & Wald & df & P. valor & \begin{tabular}{|l} 
Razão de \\
Chances
\end{tabular} \\
\hline Desempenho Português & 0,078 & 0,009 & 72,209 & 1 & 0,000 & 1,081 \\
\hline Proficiência Matemática & 0,016 & 0,006 & 7,971 & 1 & 0,005 & 1,016 \\
\hline População Urbana & 0,010 & 0,005 & 3,479 & 1 & 0,062 & 1,010 \\
\hline PEAS & $-1,710$ & 0,199 & 73,795 & 1 & 0,000 & 0,181 \\
\hline PEP & $-2,218$ & 0,563 & 15,545 & 1 & 0,000 & 0,109 \\
\hline Município Médio Porte & $-2,464$ & 0,657 & 14,051 & 1 & 0,000 & 0,085 \\
\hline Constante & $-22,074$ & 2,500 & 77,979 & 1 & 0,000 & 0,000 \\
\hline \multicolumn{7}{|c|}{2009} \\
\hline Variável & B & S.E. & Wald & df & P. valor & \begin{tabular}{|l|} 
Razão de \\
Chances
\end{tabular} \\
\hline Desempenho Português & 0,083 & 0,013 & 42,274 & 1 & 0,000 & 1,086 \\
\hline Desempenho Matemática & 0,022 & 0,008 & 7,623 & 1 & 0,006 & 1,022 \\
\hline Município Pequeno Porte & $-0,665$ & 0,361 & 3,389 & 1 & 0,066 & 0,514 \\
\hline PEAS & $-1,709$ & 0,257 & 44,298 & 1 & 0,000 & 0,181 \\
\hline Município Médio Porte & $-1,775$ & 0,780 & 5,173 & 1 & 0,023 & 0,169 \\
\hline PEP & $-2,062$ & 0,444 & 21,577 & 1 & 0,000 & 0,127 \\
\hline PDP & $-6,358$ & 1,023 & 38,616 & 1 & 0,000 & 0,002 \\
\hline Constante & $-19,288$ & 3,526 & 29,920 & 1 & 0,000 & 0,000 \\
\hline \multicolumn{7}{|c|}{2010} \\
\hline Variável & B & S.E. & Wald & df & P. valor & \begin{tabular}{|l|} 
Razão de \\
Chances
\end{tabular} \\
\hline Desempenho Português & 0,068 & 0,008 & 76,228 & 1 & 0,000 & 1,070 \\
\hline Desempenho Matemática & 0,021 & 0,005 & 15,948 & 1 & 0,000 & 1,021 \\
\hline Município Médio Porte & 1,463 & 0,678 & 4,661 & 1 & 0,031 & 0,232 \\
\hline PEP & 2,388 & 0,293 & 66,435 & 1 & 0,000 & 0,092 \\
\hline $\mathrm{PJ}$ & 3,623 & 1,236 & 8,587 & 1 & 0,003 & 0,027 \\
\hline Constante & 19,291 & 2,503 & 59,380 & 1 & 0,000 & 0,000 \\
\hline
\end{tabular}

Fonte: Elaborado pelo autor. 
Gráfico 59 - Razão de chances - ER - 2007 à 2010.

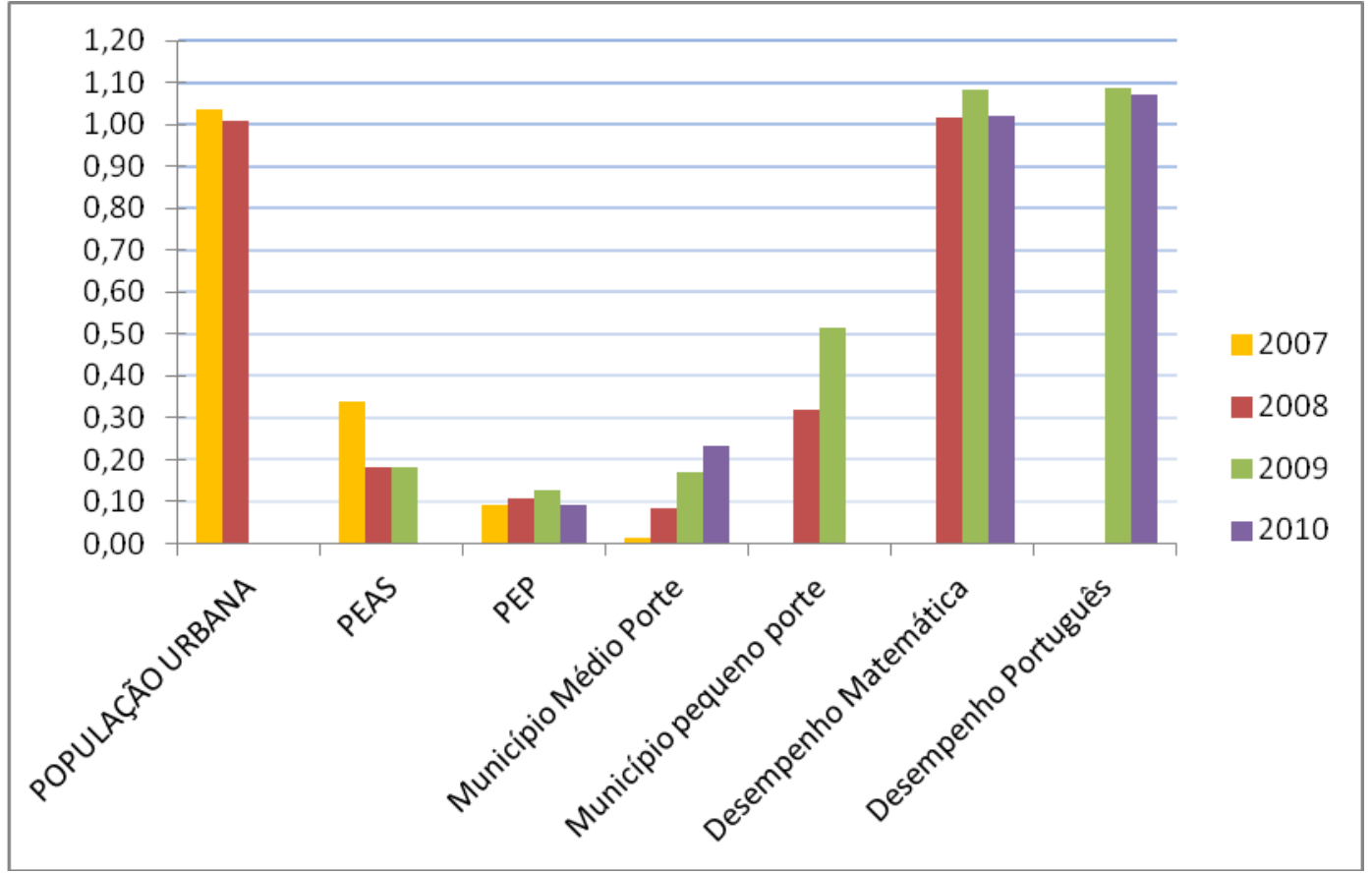

Fonte: Elaborado pelo auto

Ano: 2007

Para este modelo, a População Urbana, a presença do PEAS, PEP e os Municípios de Médio Porte são variáveis que influenciam na política pública ER, pois seus pvalores de acordo com a estatística de Wald são inferiores a 10\%. A constante não foi significativa porque sua estimativa é muito alta e o p-valor também. Ou seja, a média de todas as variáveis significativas não influenciam na incidência da política ER nos municípios.

A razão de chances de cada variável significa:

- População Urbana: a cada pessoa a mais na população, aumenta a chance em 3,7\% de termos a política pública nos municípios.

- PEAS: para cada município que possui o PEAS e ER simultaneamente, existem aproximadamente 3 municípios que possuem o ER e não possuem PEAS.

- PEP: para cada município que possui o PEP e ER simultaneamente, existem aproximadamente 11 municípios que possuem o ER e não possuem PEP.

- Municípios de Médio Porte: para cada município de Médio Porte que possui ER, existem aproximadamente 76 municípios de Médio Porte que não possuem esse programa.

Ano: 2008 
Para este modelo, o Desempenho em matemática e português, a População Urbana, os programas PEAS e PEP e os Municípios de Médio Porte são variáveis que influenciam na política pública ER, pois seus p-valores de acordo com a estatística de Wald são inferiores a $10 \%$.

A razão de chances de cada variável significa:

- Desempenho em português: a cada ponto a mais no Desempenho, aumenta a chance em $8,1 \%$ de termos o programa ER nos municípios.

- Desempenho em matemática: a cada ponto a mais na Desempenho, temos 1,6\% a mais de chance de termos a política pública ER nos municípios.

- População Urbana: a cada pessoa a mais na população, aumenta a chance em $1 \%$ de termos o programa ER nos municípios.

- PEAS: para cada município que possui o PEAS e ER simultaneamente, existem aproximadamente 6 municípios que possuem o ER e não possuem PEAS.

- PEP: para cada município que possui o PEP e ER simultaneamente, existem aproximadamente 9 municípios que possuem o ER e não possuem PEP.

- Municípios de Médio Porte: para cada município de Médio Porte que possui ER, existem aproximadamente 12 municípios de Médio Porte que não possuem esse programa.

Ano: 2009

Em 2009, o Desempenho em matemática e português, Município Pequeno Porte e Médio Porte, e os programas PEAS, PEP e PDP são variáveis que influenciam na política pública ER, pois seus p-valores de acordo com a estatística de Wald são inferiores a $10 \%$.

A razão de chances de cada variável significa:

- Desempenho em português: a cada ponto a mais no Desempenho, aumenta a chance em 8,6\% de termos o programa ER nos municípios.

- Desempenho em matemática: a cada ponto a mais no Desempenho, temos 2,2\% a mais de chance de termos a política pública ER nos municípios.

- PEAS: para cada município que possui o PEAS e ER simultaneamente, existem aproximadamente 6 municípios que possuem o ER e não possuem PEAS.

- PEP: para cada município que possui o PEP e ER simultaneamente, existem aproximadamente 8 municípios que possuem o ER e não possuem PEP. 
- Municípios de Pequeno Porte: para cada município de Pequeno Porte que possui ER, existem aproximadamente 2 municípios de Pequeno Porte que não possuem esse programa.

- Municípios de Médio Porte: para cada município de Médio Porte que possui ER, existem aproximadamente 6 municípios de Médio Porte que não possuem esse programa.

Ano: 2010

Em 2010, o Desempenho em matemática e português, Município Médio Porte, PEP e PJ foram variáveis que influenciaram na política pública ER nesse ano, pois seus p-valores de acordo com a estatística de Wald são inferiores a $10 \%$.

A razão de chances de cada variável significa:

- Desempenho em português: a cada ponto a mais no Desempenho, aumenta a chance em 7,0\% de termos o programa ER nos municípios.

- Desempenho em matemática: a cada ponto a mais no Desempenho, temos 2,1\% a mais de chance de termos a política pública ER nos municípios.

- PEP: para cada município que possui o PEP e ER simultaneamente, existem aproximadamente 11 municípios que possuem o ER e não possuem PEP.

- PJ: para cada município que possui o PJ e ER simultaneamente, existem aproximadamente 37 municípios que possuem o ER e não possuem PJ.

- Municípios de Médio Porte: para cada município de Médio Porte que possui ER, existem aproximadamente 4 municípios de Médio Porte que não possuem esse programa.

Os resultados obtidos nesse modelo foram bastante pertinentes com a concepção do programa, já que sua proposta, como vimos, era selecionar escolas que já apresentavam bons resultados e identificar e desenvolver características intrínsecas dessas escolas para transformá-las posteriormente em centros de referência para as demais escolas da rede. Nesse sentido, as variáveis presentes na maioria dos modelos que mais influenciaram ao longo dos anos na presença do programa positivamente são Desempenho em matemática e português.

A presença de outros programas também está relacionada aos objetivos do ER, considerando que as escolas selecionadas como modelo de referência para a rede estadual mineira também foram contempladas com um conjunto de outros programas. 
Em alguns casos muitos programas foram implementados em caráter experimental primeiramente nas escolas referência.

Dentre as variáveis demográficas que compõem o modelo, a variável "população urbana" apareceu como a de maior peso na abrangência deste programa nos anos de 2007 e 2008. Isso possivelmente deve-se ao fato dos municípios mais urbanizados reunirem melhor infraestrutura para abrigar esse projeto. A esse respeito, Azevedo (2002) e Pissaia (2011) lembram que no processo de descentralização da educação básica brasileira os municípios menos desenvolvidos, principalmente os de pequeno porte, demonstraram maiores dificuldades para gerir seus sistemas educacionais. Assim, os dados demonstram que os municípios mais desenvolvidos têm maiores chances de serem contemplados pelo programa escolas referência.

Este é um aspecto relevante, já que o programa "Escolas Referência" deveria buscar reduzir as desigualdades existentes entre os municípios e não reforçá-las como apontam os resultados.

Esta situação seria menos preocupante, caso houvesse continuidade do projeto e uma política complementar que permitisse a transferência de conhecimento das escolas referências para o restante da rede. Embora esse fosse um dos objetivos do programa, infelizmente não chegou a ser colocado em prática, já que, como vimos, o programa foi descontinuado, atingindo menos que 30\% do total de escolas de EM do Estado.

Ainda, com relação ao programa ER, como já discuti no capítulo 2, Arretche (2004), argumenta que os estados federativos são mais propensos a produzir níveis comparativamente mais baixos de gasto social, bem como menor abrangência e cobertura dos programas sociais. Como vimos, este programa se encaixou perfeitamente a esta perspectiva de redução de gastos tomada pelo governo estadual nesse período. 
4.5.5.2.

Regressão logística - PDP

Tabela 11 - Resultados da regressão logística - PDP - 2007 à 2010.

\begin{tabular}{|c|c|c|c|c|c|c|}
\hline \multicolumn{7}{|c|}{2007} \\
\hline Variável & B & S.E. & Wald & df & $\begin{array}{l}\text { P. } \\
\text { valor }\end{array}$ & $\begin{array}{l}\text { Razão de } \\
\text { Chances }\end{array}$ \\
\hline PEP & $-1,33$ & 0,55 & 5,92 & 1,00 & 0,01 & 0,26 \\
\hline PEAS & $-2,48$ & 1,07 & 5,34 & 1,00 & 0,02 & 0,08 \\
\hline Município Médio Porte & $-2,51$ & 1,22 & 4,20 & 1,00 & 0,04 & 0,08 \\
\hline Município Pequeno Porte & $-2,78$ & 1,13 & 6,09 & 1,00 & 0,01 & 0,06 \\
\hline Município Grande Porte & $-3,93$ & 1,15 & 11,68 & 1,00 & 0,00 & 0,02 \\
\hline Constante & 5,23 & 2,23 & 5,49 & 1,00 & 0,02 & 186,85 \\
\hline \multicolumn{7}{|c|}{2008} \\
\hline Variável & B & S.E. & Wald & $d f$ & $\begin{array}{l}\mathrm{P} . \\
\text { valor }\end{array}$ & $\begin{array}{l}\text { Razão de } \\
\text { Chances } \\
\end{array}$ \\
\hline PEAS & $-1,51$ & 0,72 & 4,40 & 1,00 & 0,04 & 0,22 \\
\hline Município Médio Porte & $-1,90$ & 0,70 & 7,40 & 1,00 & 0,01 & 0,15 \\
\hline Município Grande Porte & $-2,39$ & 0,67 & 12,59 & 1,00 & 0,00 & 0,09 \\
\hline Constante & 0,43 & 0,85 & 0,25 & 1,00 & 0,61 & 1,53 \\
\hline \multicolumn{7}{|c|}{2009} \\
\hline Variável & B & S.E. & Wald & df & $\begin{array}{l}\text { P. } \\
\text { valor }\end{array}$ & $\begin{array}{l}\text { Razão de } \\
\text { Chances }\end{array}$ \\
\hline Município Médio Porte & $-0,83$ & 0,43 & 3,74 & 1,00 & 0,05 & 0,43 \\
\hline Município Grande Porte & $-1,82$ & 0,53 & 11,67 & 1,00 & 0,00 & 0,16 \\
\hline FIT & $-1,99$ & 1,12 & 3,17 & 1,00 & 0,08 & 0,14 \\
\hline ER & $-6,80$ & 1,02 & 44,27 & 1,00 & 0,00 & 0,00 \\
\hline IDHM & $-10,94$ & 3,41 & 10,29 & 1,00 & 0,00 & 0,00 \\
\hline
\end{tabular}

\begin{tabular}{l|r|r|r|r|r|r}
\hline \multicolumn{1}{c}{ Variável } & \multicolumn{1}{c}{ B } & \multicolumn{1}{c|}{ S.E. } & Wald & df & $\begin{array}{l}\text { P. } \\
\text { valor }\end{array}$ & $\begin{array}{l}\text { Razão de } \\
\text { Chances }\end{array}$ \\
\hline Desempenho Português & 0,05 & 0,01 & 29,94 & 1,00 & 0,00 & 1,05 \\
\hline Desempenho Matemática & 0,01 & 0,01 & 5,40 & 1,00 & 0,02 & 1,01 \\
\hline PIB Per capita & 0,00 & 0,00 & 3,24 & 1,00 & 0,07 & 1,00 \\
\hline PEP & $-0,85$ & 0,36 & 5,55 & 1,00 & 0,02 & 0,43 \\
\hline Município Pequeno porte & $-1,28$ & 0,29 & 19,71 & 1,00 & 0,00 & 0,28 \\
\hline Município Médio Porte & $-2,68$ & 0,54 & 24,20 & 1,00 & 0,00 & 0,07 \\
\hline Município Grande Porte & $-4,47$ & 0,81 & 30,52 & 1,00 & 0,00 & 0,01 \\
\hline Constante & $-9,66$ & 2,31 & 17,53 & 1,00 & 0,00 & 0,00 \\
\hline Constante & 10,23 & 2,84 & 12,94 & 1,00 & 0,00 & 27614,59 \\
\hline
\end{tabular}

Fonte: Elaborado pelo autor. 
Gráfico 60 - Razão de chances - PDP - 2007 à 2010.

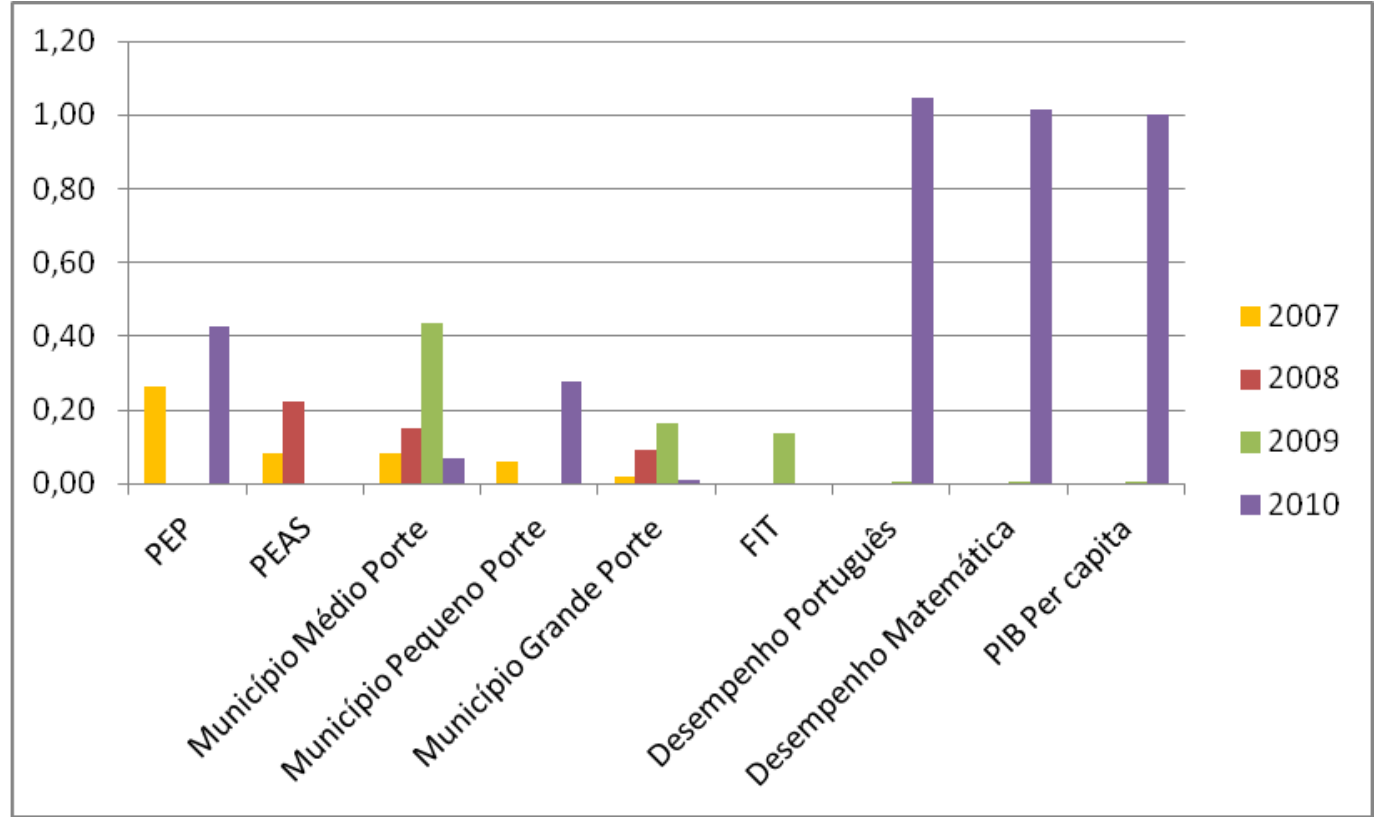

Fonte: Elaborado pelo autor.

Ano: 2007

Para este modelo, os programas PEP, PEAS e os Municípios de Pequeno, Grande e Médio Porte são variáveis que influenciam a política pública PDP, pois seus p-valores de acordo com a estatística de Wald são inferiores a $10 \%$.

A razão de chances de cada variável significa:

- Municípios de Médio Porte: para cada município de Médio Porte que possui PDP, existem aproximadamente 13 municípios de Médio Porte que não possuem esse programa.

- Municípios de Grande Porte: para cada município de Grande Porte que possui PDP, existem aproximadamente 50 municípios de Grande Porte que não possuem esse programa.

- PEP: para cada município que possui o PEP e PDP simultaneamente, existem aproximadamente 4 municípios que possuem o PDP e não possuem PEP.

Ano: 2008

Para este modelo, o programa PEAS e os Municípios de Médio e Grande Porte são variáveis que influenciam na política pública PDP.

A razão de chances de cada variável significa:

- PEAS: para cada município que possui o PEAS e PDP simultaneamente, existem aproximadamente 5 municípios que possuem o PDP e não possuem PEAS. 
- Municípios de Médio Porte: para cada município de Médio Porte que possui PDP, existem aproximadamente 7 municípios de Médio Porte que não possuem esse programa.

- Municípios de Grande Porte: para cada município de Grande Porte que possui PDP, existem aproximadamente 11 municípios de Grande Porte que não possuem esse programa.

Ano: 2009

Em 2009, os Município Médio e Grande Porte, o programa FIT são variáveis que influenciam na política pública PDP, pois seus p-valores de acordo com a estatística de Wald são inferiores a 10\%. Embora o programa ER e o IDHM sejam significativos também a nível 10\%, os mesmos apresentam razão de chances igual a zero.

A razão de chances de cada variável significa:

- Municípios de Médio Porte: para cada município de Médio Porte que possui PDP, existem aproximadamente 2 municípios de Médio Porte que não possuem esse programa.

- Municípios de Grande Porte: para cada município de Grande Porte que possui PDP, existem aproximadamente 6 municípios de Grande Porte que não possuem esse programa.

- FIT: para cada município que possui o FIT e PDP simultaneamente, existem aproximadamente 13 municípios que possuem o PDP e não possuem FIT.

Ano: 2010

Em 2010, o desempenho em matemática e português, o PIB per capita, o programa PEP e os Municípios de Pequeno, Médio e grande Porte foram variáveis que influenciaram na política pública PDP nesse ano, pois seus p-valores de acordo com a estatística de Wald são inferiores a $10 \%$.

A razão de chances de cada variável significa:

- Desempenho em português: a cada ponto a mais no Desempenho, aumenta a chance em 5,0\% de termos o programa PDP nos municípios.

- Desempenho em matemática: a cada ponto a mais no Desempenho, temos $1 \%$ a mais de chance de termos a política pública PDP nos municípios.

- PIB per capita: não aumenta e nem diminui as chances do município possuir o PDP. 
- PEP: para cada município que possui o PEP e PDP simultaneamente, existem aproximadamente 2 municípios que possuem o PDP e não possuem PEP.

- Municípios de Pequeno Porte: para cada município de Pequeno Porte que possui PDP, existem aproximadamente 4 municípios de Pequeno Porte que não possuem esse programa.

- Municípios de Médio Porte: para cada município de Médio Porte que possui ER, existem aproximadamente 14 municípios de Médio Porte que não possuem esse programa.

- Municípios de Grande Porte: para cada município de Grande Porte que possui PDP, existem aproximadamente 100 municípios de Grande Porte que não possuem esse programa.

O Programa de Desenvolvimento Profissional - PDP, como vimos, consistia da criação de grupos de desenvolvimento profissional. Esses grupos deveriam articular-se em torno da concepção e execução de projetos determinados pela SEE-MG. Entre os anos de 2007 e 2009, nenhuma das variáveis demográficas apresentaram relevância no modelo proposto. Apenas no ano de 2010, o PIB per capita teve destaque.

A presença de outros programas não mostrou resultados positivos, sendo que em entre 2007 e 2008 PEP, PEAS e em 2009 o FIT apresentaram resultados negativos em relação a abrangência do PDP.

Em 2010, os Desempenhos em português e matemática influenciarem positivamente a incidência do programa. Como vimos, o crescimento desde programa entre os anos de 2007 e 2010 foi bastante tímido e desta forma o resultado positivo para o Desempenho pode estar associado ao efeito do programa nas escolas comtempladas desde 2007.

\subsubsection{3.}

Regressão logística - PEAS

Tabela 12 - Resultados da regressão logística - PEAS - 2007 à 2009.

\begin{tabular}{l|r|r|r|r|r|r}
\hline \multicolumn{1}{c|}{ Variável } & B & S.E. & Wald & df & $\begin{array}{l}\text { P. } \\
\text { valor }\end{array}$ & $\begin{array}{l}\text { Razão de } \\
\text { Chances }\end{array}$ \\
\hline População Urbana & 0,01 & 0,00 & 6,40 & 1 & 0,01 & 1,01 \\
\hline Município Pequeno Porte & $-0,67$ & 0,23 & 8,52 & 1 & 0,00 & 0,51 \\
\hline Município Médio Porte & $-2,43$ & 0,47 & 26,25 & 1 & 0,00 & 0,09 \\
\hline
\end{tabular}




\begin{tabular}{l|r|r|r|r|r|r} 
Município Grande Porte & $-2,61$ & 0,65 & 16,19 & 1 & 0,00 & 0,07 \\
\hline PDP & $-2,64$ & 1,07 & 6,09 & 1 & 0,01 & 0,07 \\
\hline
\end{tabular}

\begin{tabular}{|c|c|c|c|c|c|c|}
\hline \multicolumn{7}{|c|}{2008} \\
\hline Variável & $B$ & S.E. & Wald & $d f$ & \begin{tabular}{|l} 
P. \\
valor \\
\end{tabular} & \begin{tabular}{|l|} 
Razão de \\
Chances \\
\end{tabular} \\
\hline População Urbana & 0,01 & 0,00 & 8,76 & 1 & 0,00 & 1,01 \\
\hline Desempenho Português & $-0,02$ & 0,01 & 6,46 & 1 & 0,01 & 0,98 \\
\hline FIT & $-0,76$ & 0,46 & 2,72 & 1 & 0,10 & 0,47 \\
\hline ER & $-1,54$ & 0,20 & 59,91 & 1 & 0,00 & 0,21 \\
\hline Município Médio Porte & $-1,54$ & 0,48 & 10,23 & 1 & 0,00 & 0,21 \\
\hline Município de Grande Porte & $-1,73$ & 0,64 & 7,26 & 1 & 0,01 & 0,18 \\
\hline Constante & 6,96 & 1,98 & 12,39 & 1 & 0,00 & 1058,32 \\
\hline \multicolumn{7}{|c|}{2009} \\
\hline Variável & B & S.E. & Wald & df & \begin{tabular}{|l|} 
P. \\
valor \\
\end{tabular} & \begin{tabular}{|l|} 
Razão de \\
Chances
\end{tabular} \\
\hline População Urbana & 0,01 & 0,01 & 7,13 & 1 & 0,01 & 1,01 \\
\hline Desempenho Português & $-0,01$ & 0,01 & 3,93 & 1 & 0,05 & 0,99 \\
\hline PEP & $-0,51$ & 0,30 & 2,83 & 1 & 0,09 & 0,60 \\
\hline FIT & $-0,82$ & 0,46 & 3,27 & 1 & 0,07 & 0,44 \\
\hline Município Médio Porte & $-1,28$ & 0,51 & 6,39 & 1 & 0,01 & 0,28 \\
\hline ER & $-1,42$ & 0,20 & 49,50 & 1 & 0,00 & 0,24 \\
\hline Município Grande Porte & $-1,57$ & 0,65 & 5,86 & 1 & 0,02 & 0,21 \\
\hline Constante & 5,95 & 1,94 & 9,37 & 1 & 0,00 & 384,46 \\
\hline Constante & 6,32 & 1,44 & 19,21 & 1 & 0,00 & 554,98 \\
\hline
\end{tabular}

Fonte: Elaborado pelo autor.

Gráfico 61 - Razão de chances - PEAS - 2007 à 2009.

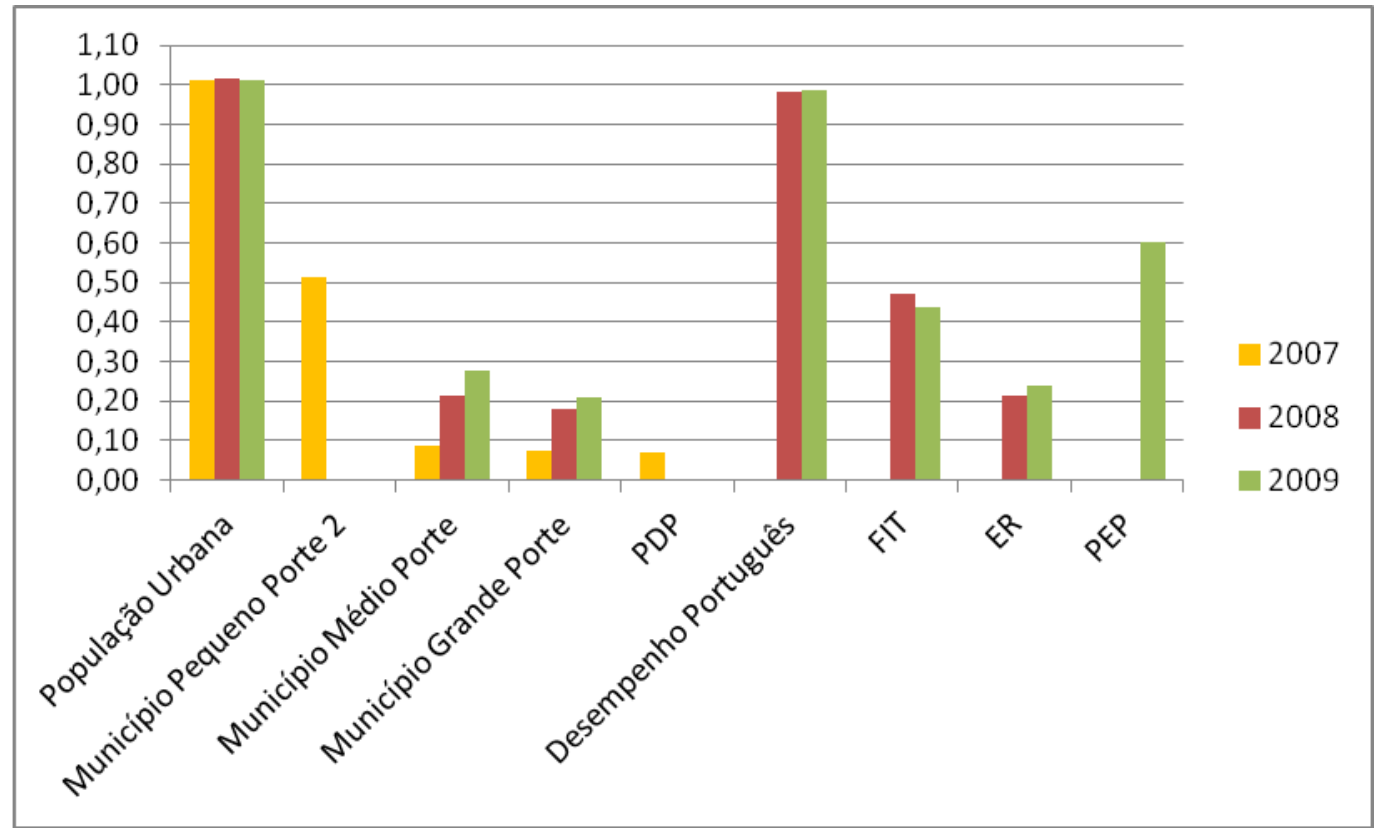

Fonte: Elaborado pelo autor. 
Ano: 2007

Para este modelo, a População Urbana, os Municípios de Pequeno, Médio e Grande Porte e o Programa PDP são variáveis que influenciam a política pública PEAS, pois seus p-valores de acordo com a estatística de Wald são inferiores a $10 \%$.

A razão de chances de cada variável significa:

- População Urbana: a cada pessoa a mais na população, aumenta a chance em $1 \%$ de termos o programa PEAS nos municípios.

- Municípios de Pequeno Porte: para cada município de Pequeno Porte que possui PEAS, existem aproximadamente 2 municípios de Pequeno Porte que não possuem esse programa.

- Municípios de Médio Porte: para cada município de Médio Porte que possui PEAS, existem aproximadamente 11 municípios de Médio Porte que não possuem esse programa.

- Municípios de Grande Porte: para cada município de Grande Porte que possui PEAS, existem aproximadamente 14 municípios de Grande Porte que não possuem esse programa.

- PDP: para cada município que possui o PDP e PEAS simultaneamente, existem aproximadamente 14 municípios que possuem o PEAS e não possuem PDP.

Ano: 2008

Para este modelo, a População Urbana, o desempenho em Português, os programas FIT e ER e os Municípios de Médio e Grande Porte são variáveis que influenciam na política pública PEAS.

A razão de chances de cada variável significa:

- População Urbana: a cada pessoa a mais na população, aumenta a chance em $1 \%$ de termos o programa PEAS nos municípios.

- Desempenho em português: a cada ponto a mais no Desempenho, diminui a chance em $2 \%$ de termos o programa PEAS nos municípios.

- FIT: para cada município que possui o FIT e PEAS simultaneamente, existem aproximadamente 2 municípios que possuem o PEAS e não possuem FIT.

- ER: para cada município que possui o ER e PEAS simultaneamente, existem aproximadamente 5 municípios que possuem o PEAS e não possuem ER. 
- Municípios de Médio Porte: para cada município de Médio Porte que possui PEAS, existem aproximadamente 5 municípios de Médio Porte que não possuem esse programa.

- Municípios de Grande Porte: para cada município de Grande Porte que possui PEAS, existem aproximadamente 6 municípios de Grande Porte que não possuem esse programa.

Ano: 2009

Em 2009, a População Urbana, o Desempenho em Português, os programas PEP, FIT e ER e os Municípios de Médio e Grande Porte são variáveis que influenciam na política pública PEAS, pois seus p-valores de acordo com a estatística de Wald são inferiores a $10 \%$.

A razão de chances de cada variável significa:

- População Urbana: a cada pessoa a mais na população, aumenta a chance em $0,1 \%$ de termos o programa PEAS nos municípios.

- Desempenho em português: a cada ponto a mais no Desempenho, diminui a chance em $1 \%$ de termos o programa PEAS nos municípios.

- PEP: para cada município que possui o PEP e PEAS simultaneamente, existem aproximadamente 2 municípios que possuem o PEAS e não possuem PEP.

- FIT: para cada município que possui o FIT e PEAS simultaneamente, existem aproximadamente 2 municípios que possuem o PEAS e não possuem FIT.

- ER: para cada município que possui o ER e PEAS simultaneamente, existem aproximadamente 4 municípios que possuem o PEAS e não possuem ER.

- Municípios de Médio Porte: para cada município de Médio Porte que possui PEAS, existem aproximadamente 4 municípios de Médio Porte que não possuem esse programa.

- Municípios de Grande Porte: para cada município de Grande Porte que possui PEAS, existem aproximadamente 5 municípios de Grande Porte que não possuem esse programa.

Este modelo revela que o Programa Educacional de Atenção ao Jovem - PEAS Juventude foi influenciado positivamente pelo desempenho médio dos estudantes em português nos anos de 2008 e 2009. Esse fato pode estar associado ao fato da sua associação com a população urbana, onde em média os níveis de proficiência são mais elevados. 
A associação positiva desse programa com a variável população urbana pode ser facilmente explicada considerando dois aspectos que estão correlacionados entre si: primeiramente é necessário compreender que este programa tinha em sua concepção o objetivo de minimizar a vulnerabilidade dos jovens e adolescentes frente a questões como gravidez não planejada, uso indevido de drogas e doenças sexualmente transmissíveis, em especial o HIV/Aids. O segundo ponto a se considerar é que devido às características do programa, além de uma abrangência limitada (deixou a maioria absoluta dos municípios mineiros sem atendimento. $\mathrm{O}$ programa teve sua maior abrangência em 2009 quando contemplou apenas 245 municípios, sendo que desses, apenas 115 tinham 100\% das suas escolas contempladas), concentrou-se nas escolas dos municípios da região metropolitana de Belo Horizonte e nos municípios de grande e médio porte.

Também o desempenho em português pode estar associado ao IDHM desses municípios. A região metropolitana de Belo Horizonte possui o IDHM mais elevado do Estado de Minas Gerais (conforme apresento no capítulo 3), o que revela a coerência deste resultado.

\subsubsection{4.}

\section{Regressão logística - PEP}

Tabela 13 - Resultados da regressão logística - PEP - 2007 à 2010.

\begin{tabular}{|c|c|c|c|c|c|c|}
\hline \multicolumn{7}{|c|}{2007} \\
\hline Variável & $B$ & S.E. & Wald & $d f$ & $\begin{array}{l}\mathrm{P} . \\
\text { valor }\end{array}$ & \begin{tabular}{|l|} 
Razão de \\
Chances
\end{tabular} \\
\hline PDP & $-1,19$ & 0,54 & 4,89 & 1 & 0,03 & 0,30 \\
\hline ER & $-1,43$ & 0,43 & 11,09 & 1 & 0,00 & 0,24 \\
\hline ICS & $-2,16$ & 1,24 & 3,03 & 1 & 0,08 & 0,12 \\
\hline Município Grande Porte & $-2,34$ & 0,63 & 13,66 & 1 & 0,00 & 0,10 \\
\hline Município Pequeno Porte & $-2,49$ & 0,43 & 33,44 & 1 & 0,00 & 0,08 \\
\hline Município Médio Porte & $-2,85$ & 0,59 & 23,03 & 1 & 0,00 & 0,06 \\
\hline Constante & 6,74 & 1,13 & 35,70 & 1 & 0,00 & 846,37 \\
\hline \multicolumn{7}{|c|}{2008} \\
\hline Variável & $B$ & S.E. & Wald & df & $\begin{array}{l}\text { P. } \\
\text { valor }\end{array}$ & \begin{tabular}{|l} 
Razão de \\
Chances
\end{tabular} \\
\hline População Urbana & 0,04 & 0,02 & 3,08 & 1 & 0,08 & 1,04 \\
\hline ER & $-1,02$ & 0,56 & 3,27 & 1 & 0,07 & 0,36 \\
\hline Município Médio Porte & $-2,79$ & 0,95 & 8,61 & 1 & 0,00 & 0,06 \\
\hline Município Pequeno Porte & $-3,22$ & 0,80 & 16,09 & 1 & 0,00 & 0,04 \\
\hline Município Grande Porte & $-3,37$ & 0,98 & 11,76 & 1 & 0,00 & 0,03 \\
\hline
\end{tabular}




\begin{tabular}{|c|c|c|c|c|c|c|}
\hline Const & 1,67 & 3,04 & 0,30 & 1 & 0,58 & 5,31 \\
\hline \multicolumn{7}{|c|}{2009} \\
\hline Variável & B & S.E. & Wald & df & \begin{tabular}{|l|} 
P. \\
valor
\end{tabular} & $\begin{array}{l}\text { Razão de } \\
\text { Chances }\end{array}$ \\
\hline População Urba & 0,02 & 0,01 & 3,71 & 1 & 0,05 & 1,03 \\
\hline PIB Per Capita & 0,00 & 0,00 & 7,07 & 1 & 0,01 & 1,00 \\
\hline Desempenho $\mathrm{P}$ & $-0,03$ & 0,01 & 3,95 & 1 & 0,05 & 0,97 \\
\hline ER & $-1,83$ & 0,39 & 22,18 & 1 & 0,00 & 0,16 \\
\hline Município Grande Porte & $-2,74$ & 0,62 & 19,26 & 1 & 0,00 & 0,06 \\
\hline Município Pequeno Porte & $-2,76$ & 0,40 & 46,59 & 1 & 0,00 & 0,06 \\
\hline Municipio Mé & $-3,85$ & 0,57 & 45,35 & 1 & 0,00 & 0,02 \\
\hline Const & 12,16 & 3,80 & 10,26 & 1 & 0,00 & 191267,25 \\
\hline \multicolumn{7}{|c|}{2010} \\
\hline Variável & $B$ & S.E. & Wald & $d f$ & \begin{tabular}{|l} 
P. \\
valor \\
\end{tabular} & \begin{tabular}{|l|} 
Razão de \\
Chances
\end{tabular} \\
\hline População Urbana & 0,05 & 0,01 & 22,27 & 1 & 0,00 & 1,05 \\
\hline PIB Per Capita & 0,00 & 0,00 & 4,42 & 1 & 0,04 & 1,00 \\
\hline Desempenho Matemática & $-0,03$ & 0,01 & 9,77 & 1 & 0,00 & 0,97 \\
\hline ER & $-1,75$ & 0,32 & 29,66 & 1 & 0,00 & 0,17 \\
\hline Município Grande Porte & $-2,09$ & 0,61 & 11,75 & 1 & 0,00 & 0,12 \\
\hline Município Médio Porte & $-3,81$ & 0,77 & 24,79 & 1 & 0,00 & 0,02 \\
\hline Constante & 8,25 & 2,82 & 8,56 & 1 & 0,00 & 3835,38 \\
\hline
\end{tabular}

Fonte: Elaborado pelo autor.

Gráfico 62 - Razão de chances - PEP - 2007 à 2010.

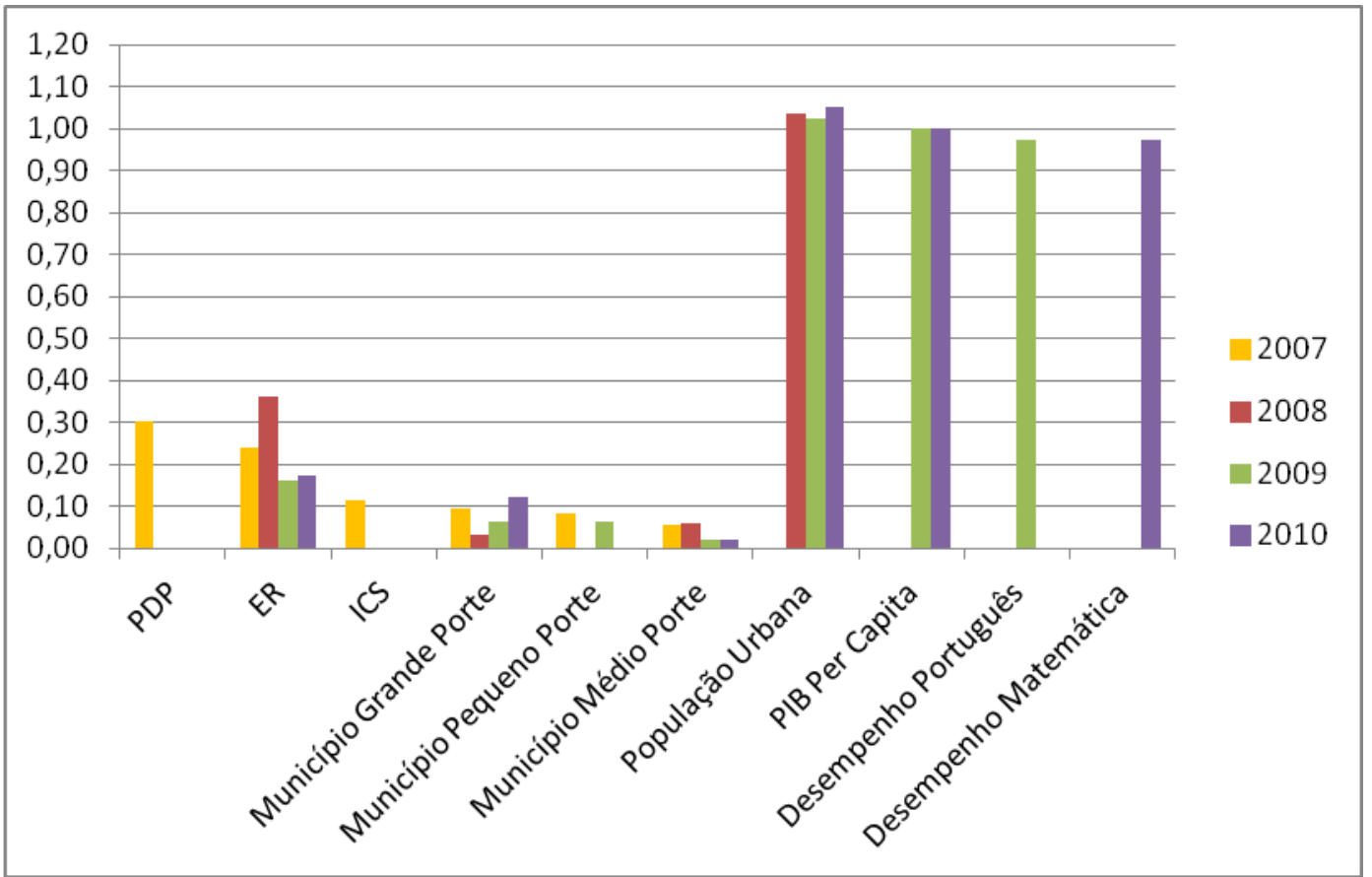

Fonte: Elaborado pelo autor. 
Para este modelo, os programas PDP e ER, o ICS e os Municípios de Pequeno, Grande e Médio Porte são variáveis que influenciam a política pública PEP, pois seus pvalores de acordo com a estatística de Wald são inferiores a $10 \%$.

A razão de chances de cada variável significa:

- PDP: para cada município que possui o PDP e PEP simultaneamente, existem aproximadamente 4 municípios que possuem o PEP e não possuem PDP.

- ER: para cada município que possui o ER e PEP simultaneamente, existem aproximadamente 4 municípios que possuem o PEP e não possuem ER.

- ICS: a cada 0,01 pontos de aumento do ICS, diminui a chance em $1 \%$ de termos o programa PEAS nos municípios.

- Municípios de Pequeno Porte: para cada município de Pequeno Porte que possui PEP, existem aproximadamente 13 municípios de Pequeno Porte que não possuem esse programa.

- Municípios de Médio Porte: para cada município de Médio Porte que possui PEP, existem aproximadamente 17 municípios de Médio Porte que não possuem esse programa.

- Municípios de Grande Porte: para cada município de Grande Porte que possui PEP, existem aproximadamente 10 municípios de Grande Porte que não possuem esse programa.

Ano: 2008

Para este modelo, a População Urbana, o programa ER e os Municípios de Pequeno, Médio e Grande Porte são variáveis que influenciam na política pública PEP. A razão de chances de cada variável significa:

- População Urbana: a cada pessoa a mais na população, aumenta a chance em 0,3\% de termos o programa PEAS nos municípios.

- ER: para cada município que possui o ER e PEP simultaneamente, existem aproximadamente 3 municípios que possuem o PEP e não possuem ER.

- Municípios de Pequeno Porte: para cada município de Pequeno Porte que possui PEP, existem aproximadamente 25 municípios de Pequeno Porte que não possuem esse programa.

- Municípios de Médio Porte: para cada município de Médio Porte que possui PEP, existem aproximadamente 17 municípios de Médio Porte que não possuem esse programa. 
- Municípios de Grande Porte: para cada município de Grande Porte que possui PEP, existem aproximadamente 33 municípios de Grande Porte que não possuem esse programa.

Ano: 2009

Em 2009, a População Urbana, o PIB per capita, o Desempenho em Português, o programa ER e os Município de Pequeno, Médio e Grande Porte são variáveis que influenciam na política pública PEP, pois seus p-valores de acordo com a estatística de Wald são inferiores a $10 \%$.

A razão de chances de cada variável significa:

- População Urbana: a cada pessoa a mais na população, aumenta a chance em $0,3 \%$ de termos o programa PEAS nos municípios.

- PIB per capita: não aumenta e nem diminui as chances do município possuir o PDP.

- Desempenho em português: a cada ponto a mais no Desempenho, diminui a chance em 3\% de termos o programa PEAS nos municípios.

- ER: para cada município que possui o ER e PEP simultaneamente, existem aproximadamente 6 municípios que possuem o PEP e não possuem ER.

- Municípios de Pequeno Porte: para cada município de Pequeno Porte que possui PEP, existem aproximadamente 17 municípios de Pequeno Porte que não possuem esse programa.

- Municípios de Médio Porte: para cada município de Médio Porte que possui PEP, existem aproximadamente 50 municípios de Médio Porte que não possuem esse programa.

- Municípios de Grande Porte: para cada município de Grande Porte que possui PEP, existem aproximadamente 17 municípios de Grande Porte que não possuem esse programa.

Ano: 2010

Em 2010, a População Urbana, o PIB per capita, o desempenho em matemática, o programa ER e os Municípios de Médio e Grande Porte foram variáveis que influenciaram na política pública PEP nesse ano, pois seus p-valores de acordo com a estatística de Wald são inferiores a $10 \%$.

A razão de chances de cada variável significa: 
- População Urbana: a cada pessoa a mais na população, aumenta a chance em $0,5 \%$ de termos o programa PEAS nos municípios.

- PIB per capita: não aumenta e nem diminui as chances do município possuir o PDP.

- Desempenho em matemática: a cada ponto a mais no Desempenho, diminui a chance em 3\% de termos o programa PEAS nos municípios.

- ER: para cada município que possui o ER e PEP simultaneamente, existem aproximadamente 6 municípios que possuem o PEP e não possuem ER.

- Municípios de Médio Porte: para cada município de Médio Porte que possui ER, existem aproximadamente 50 municípios de Médio Porte que não possuem esse programa.

- Municípios de Grande Porte: para cada município de Grande Porte que possui PEP, existem aproximadamente 8 municípios de Grande Porte que não possuem esse programa.

O Programa de Educação Profissional - PEP atendia escolas indicadas pelas SRE's, levando-se em conta as condições de infraestrutura das escolas participantes do Projeto Escolas-Referência existentes no município. Nas escolas escolhidas foram montados laboratórios de informática para a oferta do curso. Um aspecto interessante é o de "voluntariado", ou seja, o caráter não obrigatório do curso que era ofertado apenas aos estudantes do EM interessados em capacitação técnica, ou seja, aqueles que manifestavam interesse em aprender a montar, fazer manutenção e configurar microcomputadores. Esta característica influenciou diretamente a abrangência do programa, já que, entre outros fatores, o PEP também dependia da demanda de estudantes interessados em realizar o curso.

A análise de regressão logística revelou que o percentual de população urbana foi a variável demográfica com maior peso entre os anos de 2008 e 2010, seguida da variável PIB per capita com influência positiva no programa nos anos de 2009 e 2010.

A presença de outros programas não influenciou positivamente a incidência do programa.

Como vimos anteriormente, o PEP teve início em 2007 com o atendimento de 72 municípios. Nos anos seguintes o número de municípios oscilou chegando ao máximo de 117 municípios contemplados em 2010, deixando de fora 736 municípios. Ou seja, este programa, como outros programas implementados na gestão Aécio Neves, 
apresentaram abrangência bastante tímida, conforme já apresentei nas análises descritivas dos dados.

Considerando que esse programa teve associação positiva com o percentual de população urbana, sua abrangência pode ter sido estimulada pela maior procura dos estudantes de baixa renda que buscam qualificação para atender a demanda por mão de obra qualificada nos municípios mais urbanizados, o que contribuiu para a maior abrangência do programa. $O$ programa apresentou ainda associação positiva com o desempenho de português e matemática nos anos de 2009 e 2010 respectivamente. Como já vimos, este resultado pode estar associado as melhores médias obtidas por estudantes das áreas urbanas.

\subsubsection{5.}

Regressão logística - FIT

Tabela 14 - Resultados da regressão logística - FIT - 2008 à 2009.

\begin{tabular}{|c|c|c|c|c|c|c|}
\hline \multicolumn{7}{|c|}{2008} \\
\hline Variável & $B$ & S.E. & Wald & $d f$ & $\begin{array}{l}P . \\
\text { valor }\end{array}$ & $\begin{array}{l}\text { Razão de } \\
\text { Chances }\end{array}$ \\
\hline Desempenho Português & 0,028 & 0,011 & 6,740 & 1 & 0,009 & 1,028 \\
\hline PEAS & 1,073 & 0,447 & 5,768 & 1 & 0,016 & 0,342 \\
\hline Constante & 3,765 & 2,911 & 1,673 & 1 & 0,196 & 0,023 \\
\hline \multicolumn{7}{|c|}{2009} \\
\hline Variável & $B$ & S.E. & Wald & $d f$ & $\begin{array}{l}\mathrm{P} . \\
\text { valor }\end{array}$ & $\begin{array}{l}\text { Razão de } \\
\text { Chances }\end{array}$ \\
\hline Desempenho Português & 0,020 & 0,009 & 4,705 & 1 & 0,030 & 1,021 \\
\hline PDP & 1,983 & 1,027 & 3,726 & 1 & 0,054 & 0,138 \\
\hline PEAS & 0,957 & 0,448 & 4,565 & 1 & 0,033 & 0,384 \\
\hline Constante & 0,160 & 2,859 & 0,003 & 1 & 0,955 & 0,852 \\
\hline
\end{tabular}

Fonte: Elaborado pelo autor. 
Gráfico 63 - Razão de chances - FIT - 2008 à 2009.

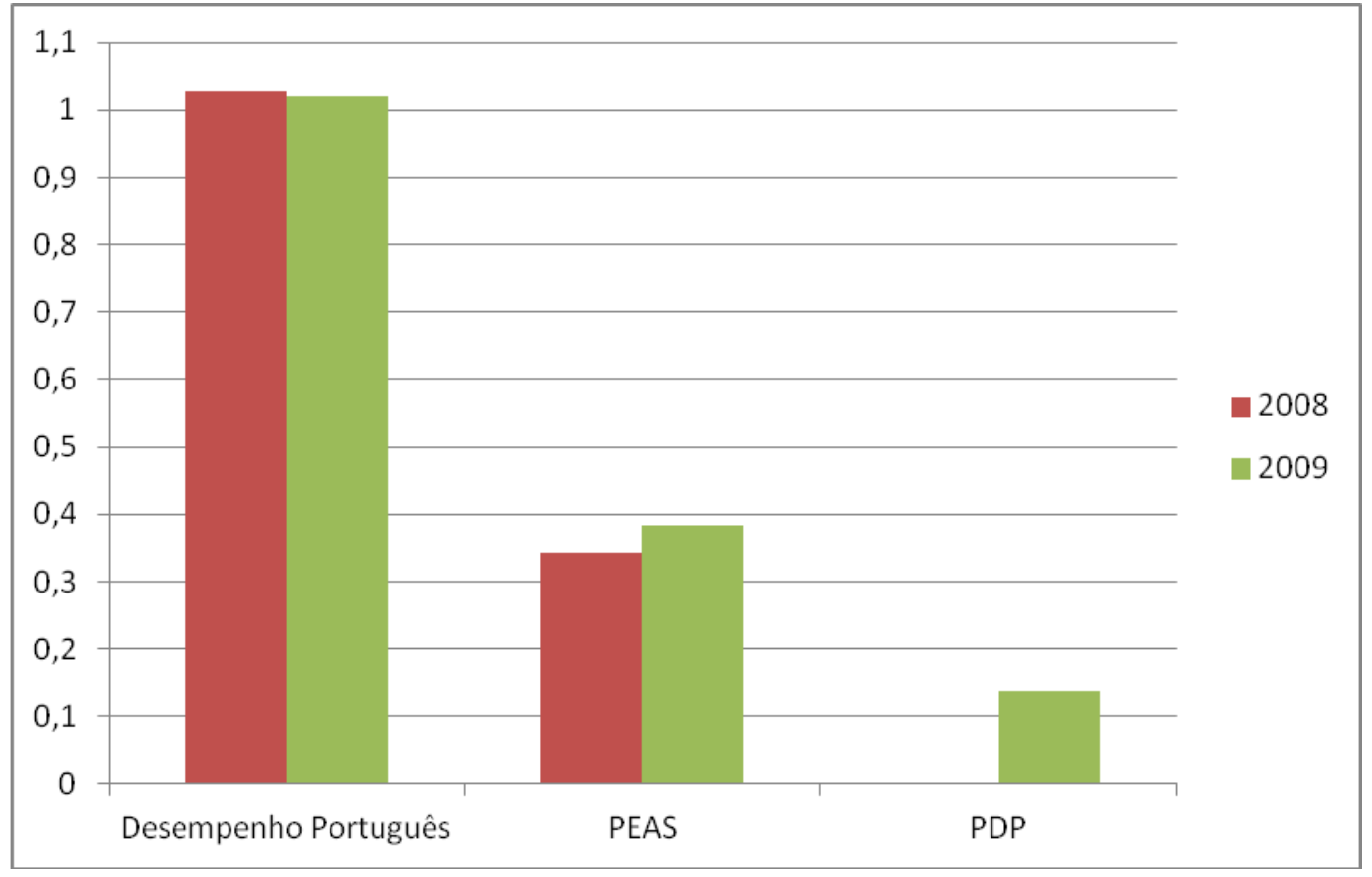

Fonte: Elaborado pelo autor.

Ano: 2008

Para este modelo, o Desempenho em Português e o programa PEAS são variáveis que influenciam na política pública FIT.

A razão de chances de cada variável significa:

- Desempenho em português: a cada ponto a mais no Desempenho, aumenta a chance em 2,1\% de termos o programa FIT nos municípios.

- PEAS: para cada município que possui o PEAS e FIT simultaneamente, existem aproximadamente 3 municípios que possuem o FIT e não possuem PEAS.

Ano: 2009

Em 2009, o Desempenho em Português e os programas PDP e PEAS são variáveis que influenciam na política pública FIT, pois seus p-valores de acordo com a estatística de Wald são inferiores a 10\%. Embora o programa.

A razão de chances de cada variável significa:

- Desempenho em português: a cada ponto a mais no Desempenho, aumenta a chance em 2,8\% de termos o programa FIT nos municípios.

- PDP: para cada município que possui o PDP e FIT simultaneamente, existem aproximadamente 7 municípios que possuem o FIT e não possuem PDP. 
- PEAS: para cada município que possui o PEAS e FIT simultaneamente, existem aproximadamente 3 municípios que possuem o FIT e não possuem PEAS.

O FIT consistia em oferecer formação tecnológica adicional para os estudantes de ensino médio, por meio da formação dos professores que, depois de capacitados, deveriam repassar o mesmo treinamento, na escola, aos alunos interessados. Dessa forma, a SEE-MG conseguiu implementar esse programa utilizando apenas os profissionais da rede e com baixíssimos custos. O programa funcionou apenas entre os anos de 2008 e 2009, porém devido ao baixo custo e dinamismo da proposta, acabou sendo o programa, entre os aqui analisados, com maior abrangência em relação ao número de municípios atendidos. Nos dois anos de funcionamento do programa, foram contemplados 770 municípios, sendo que a maior parte deles teve o programa implementado em $100 \%$ de suas escolas.

$\mathrm{Na}$ análise de regressão, o modelo indicou que o desempenho médio dos estudantes em português foi a variável mais relevante, ou seja, aquela que indicava maiores chances de termos a política FIT no município. A análise não apresentou variáveis demográficas relevantes. Contudo, considerando a elevada abrangência deste programa, esse resultado é pouco consistente para os objetivos desta pesquisa. 
4.5.5.6.

Regressão logística - Poupança Jovem

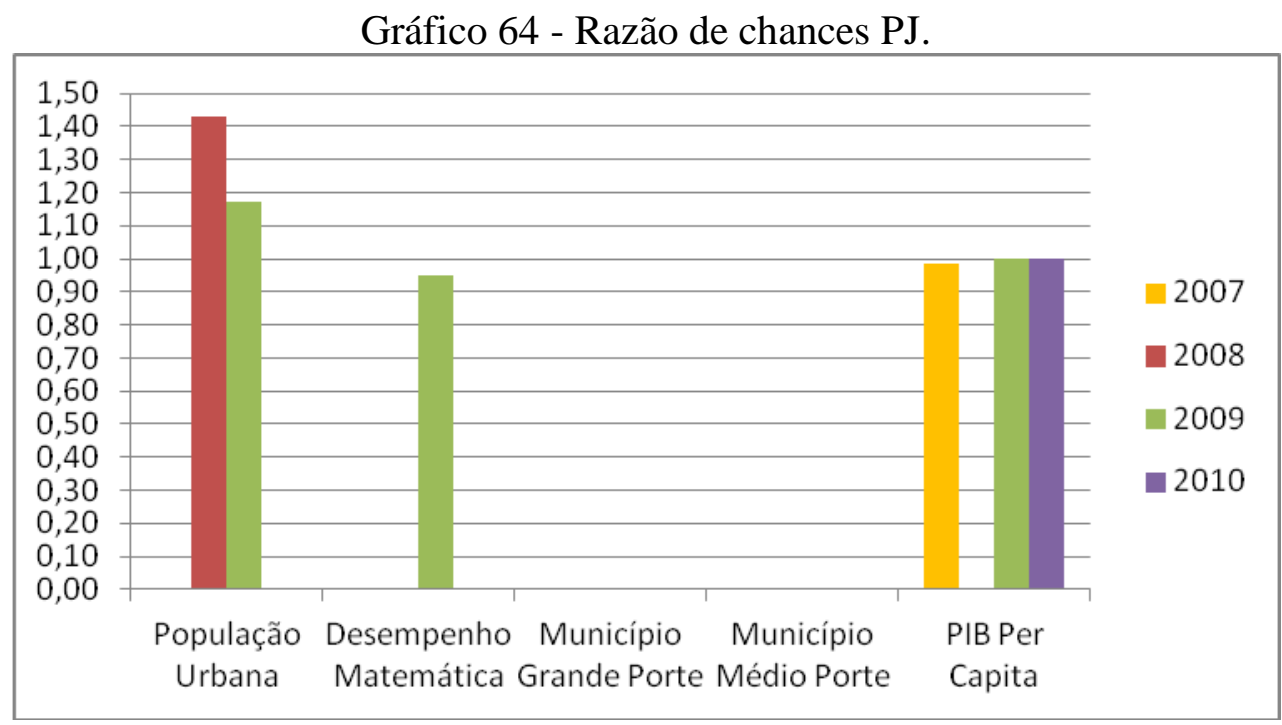

Fonte: Elaborado pelo autor.

Tabela 15 - Resultados da regressão logística - PJ - 2007 à 2010.

\begin{tabular}{l|r|r|r|r|r|r}
\hline \multicolumn{1}{c|}{ Variável } & \multicolumn{1}{|l}{ B } & \multicolumn{1}{l}{ S.E. } & Wald & df & P. valor & $\begin{array}{l}\text { Razão de } \\
\text { Chances }\end{array}$ \\
\hline PIB Per Capita & $-0,01$ & 0,25 & 0,00 & 1 & 0,96 & 0,99 \\
\hline Município Médio Porte & $-9,30$ & 3404,59 & 0,00 & 1 & 1,00 & 0,00 \\
\hline Município Grande Porte & $-42,17$ & 1074,21 & 0,00 & 1 & 0,97 & 0,00 \\
\hline
\end{tabular}

\begin{tabular}{|c|c|c|c|c|c|c|}
\hline \multicolumn{7}{|c|}{2008} \\
\hline Variável & B & S.E. & Wald & df & $\begin{array}{l}\mathrm{P} . \\
\text { valor }\end{array}$ & $\begin{array}{l}\text { Razão de } \\
\text { Chances } \\
\end{array}$ \\
\hline População Urbana & 0,3569 & 0,15949 & 5,01 & 1 & 0,0253 & 1,43 \\
\hline Constante & $-37,66$ & 15,4749 & 5,92 & 1 & 0,0149 & 4,40 \\
\hline \multicolumn{7}{|c|}{2009} \\
\hline Variável & B & S.E. & Wald & df & $\begin{array}{l}\mathrm{P} . \\
\text { valor }\end{array}$ & $\begin{array}{l}\text { Razão de } \\
\text { Chances }\end{array}$ \\
\hline População Urbana & 0,157 & 0,07 & 5,01 & 1 & 0,025 & 1,17 \\
\hline PIB Percapita & 0 & 0 & 3,41 & 1 & 0,065 & 1 \\
\hline Desempenho Matemática & $-0,053$ & 0,035 & 2,26 & 1 & 0,133 & 0,95 \\
\hline Constante & 62,593 & 36,41 & 2,96 & 1 & 0,086 & 1,53 \\
\hline \multicolumn{7}{|c|}{2010} \\
\hline Variável & B & S.E. & Wald & df & $\begin{array}{l}\mathrm{P} . \\
\text { valor }\end{array}$ & \begin{tabular}{|l|} 
Razão de \\
Chances
\end{tabular} \\
\hline PIB Per Capita & 0,00 & 0,00 & 3,52 & 1 & 0,06 & 1,00 \\
\hline Município Grande Porte & $-6,83$ & 1,20 & 32,23 & 1 & 0,00 & 0,00 \\
\hline Constante & 1,45 & 1,19 & 1,49 & 1 & 0,22 & 4,26 \\
\hline tante & 67.55 & 36 & 0 & & & 99 \\
\hline
\end{tabular}

Fonte: Elaborado pelo autor 
Ano: 2007

Para este modelo, nenhuma variável foi relevante para analise da abrangência da política pública PJ. Embora o PIB per capita e os Municípios de Grande e Médio Porte tenham seus p-valores de acordo com a estatística de Wald são inferiores a 10\%, o PIB per capita apresentou razão de chances 1 e o Municípios e Grande e Médio Porte razão de chance 0 .

Ano: 2008

Para este modelo, apenas a População Urbana influenciou a política pública PJ.

A razão de chances dessa variável significa:

- População Urbana: a cada pessoa a mais na população, aumenta a chance em $0,43 \%$ de termos o programa PEAS nos municípios.

Ano: 2009

Em 2009, a População Urbana, o PIB per capita, o Desempenho em matemática são variáveis que influenciam na política pública $\mathrm{PJ}$, pois seus p-valores de acordo com a estatística de Wald são inferiores a $10 \%$.

A razão de chances de cada variável significa:

- População Urbana: a cada pessoa a mais na população, aumenta a chance em 0,17\% de termos o programa PEAS nos municípios.

- PIB per capita: não aumenta e nem diminui as chances do município possuir o PDP.

- Desempenho em português: a cada ponto a mais no Desempenho, diminui a chance em $0,5 \%$ de termos o programa PEAS nos municípios.

Ano: 2010

Para este modelo, nenhuma variável foi relevante para análise da abrangência da política pública PJ. Embora o PIB per capita e os Municípios de Grande Porte tenham seus p-valores de acordo com a estatística de Wald são inferiores a 10\%, o PIB per capita apresentou razão de chances 1 (que não influencia na abrangência) e os Municípios de Grande Porte razão de chance 0.

O Programa Poupança Jovem consistia do oferecimento de uma caderneta de poupança aos estudantes do EM. Ao concluir o EM e cumprir atividades extracurriculares do programa, os jovens tinham direito de sacar uma poupança no valor de R\$ 3 mil após a conclusão do EM. O PJ era voltado exclusivamente para jovens matriculados nas escolas públicas do Estado de Minas Gerais e tinha como justificativa 
atender estudantes residentes em municípios ou regiões com elevadas taxas de evasão escolar, combinadas com violência e baixo Índice de Desenvolvimento Humano (IDH).

Em 2007, devido a reduzida abrangência deste programa, a análise de regressão apresentou sua associação apenas com a variável demográficas PIB per capita, o que pode ser justificado pelo fato deste programa ter sido implantado nesse ano apenas da Região Metropolitana de Belo Horizonte. Entre 2008 e 2010 o programa continuou apresentando associação com os indicadores demográficos, principalmente população urbana, sendo totalmente coerente já que esse programa se concentrou principalmente em municípios da região metropolitana do Estado. É importante lembrar que o programa poupança jovem - PJ foi o que apresentou menor percentual de municípios atendidos. Tendo iniciado como um projeto piloto em 2007 com apenas um município, o programa atingiu oito municípios em 2009 e apenas sete municípios em 2010.

\subsubsection{7. Variáveis com maior impacto na abrangência}

Abaixo, na tabela 16, apresento uma síntese das variáveis que apresentaram maior impacto na abrangência geral do programas analisados. Entre as variáveis demográficas que mais impactaram de forma geral na maior ou menor abrangências dos programas implementados pela SEE-MG podemos destacar a população urbana. Em geral, as variáveis demográficas que apresentaram maior influência na abrangência dos programas analisados, temos a população urbana e o PIB per capita, seguidas do porte do município. O desempenho médio dos estudantes em português e matemática, teve influência em quase todos os programas, com destaque no ER e PEAS. A influência de outros programas, apareceu timidamente em alguns programas, sendo que na maioria das vezes influenciando negativamente a abrangência dos mesmos.

Outra variável que merece destaque é o ICS. Embora este indicador tenha apresentado baixa relevância no modelo de análise aqui proposto, sua baixa aderência sugere que o nível de complexidade das superintendências não foi relevante para escolha do local de implementação dos demais programas analisados. Considerando que o ICS é um índice composto por indicadores que buscam medir características específicas das Superintendências de Ensino, como número de municípios, número total de estudantes e percentual de estudantes atendidos, esperava que houvesse maior número de municípios atendidos nas SRE's mais complexas, ou seja, aquelas SRE's que 
de acordo com seu respectivo ICS apresentam maiores desafios de gestão. No entanto, o modelo aqui apresentado revela o contrário.

Outro aspecto importantíssimo que deve ser considerado sobre o ICS é que esse índice trás o percentual de atendimento ao ensino municipal em cada SRE. As SRE's com maior percentual de estudantes atendidos no EF tendem a ter maior ICS e isso pode estar relacionado diretamente ao desempenho dos estudantes de ensino médio da rede mineira, já que esses são oriundos, em sua maioria, das escolas municipais e estaduais de seus respectivos município. Conforme destaca Arretche (2004 p.23):

A oferta de ensino fundamental é responsabilidade de Estados e municípios, sendo que estas duas redes operam de modo inteiramente independente. Devido à forma como historicamente evoluiu a expansão das matrículas, é muito variável a participação das duas redes na oferta de matrículas em cada Estado.

Em Minas Gerais, esta divisão entre rede estadual e municipal citada pela autora está diretamente relacionada ao porte dos municípios, bem como a capacidade dos mesmos em gerirem suas próprias redes. Assim, nos municípios menores e mais pobres, a SEE-MG assume os estudantes antes do EM. Aceitando o fato de que o desempenho de um estudante é influenciado por diversos fatores, entre eles, a influência das escolas que frequentou no EF e EM; quando a SEE-MG assume estes estudantes ainda no EF, acaba tendo uma participação maior em seu desenvolvimento comparado aos casos em que o estudante é transferido para a rede estadual apenas no EM. Nesse sentido, em futuros estudos, o ICS pode ser um importante instrumento para estudar as relações entre essas redes. 
Tabela 16 - Variáveis que mais impactaram a abrangência.

\begin{tabular}{|c|c|c|}
\hline PROGRAMA & VARIÁVEL & ANO \\
\hline \multirow{4}{*}{ ER } & $\begin{array}{l}\text { População Urbana, PEAS, PEP, Município Médio } \\
\text { Porte. }\end{array}$ & 2007 \\
\hline & $\begin{array}{l}\text { Desempenho em Português e Matemática, População } \\
\text { Urbana. }\end{array}$ & 2008 \\
\hline & $\begin{array}{l}\text { Desempenho em Português e Matemática e Município } \\
\text { Médio Porte. }\end{array}$ & 2009 \\
\hline & $\begin{array}{l}\text { Desempenho em Português e Matemática e Município } \\
\text { Médio Porte. }\end{array}$ & 2010 \\
\hline \multirow{4}{*}{ PDP } & PEP, PEAS e Município Médio Porte. & 2007 \\
\hline & $\begin{array}{l}\text { PEAS, Município Médio Porte e Município Grande } \\
\text { Porte. }\end{array}$ & 2008 \\
\hline & $\begin{array}{l}\text { Município Médio Porte, Município Grande Porte e } \\
\text { FIT. }\end{array}$ & 2009 \\
\hline & $\begin{array}{l}\text { Desempenho em Matemática e Português e PIB per } \\
\text { capita. }\end{array}$ & 2010 \\
\hline \multirow{3}{*}{ PEAS } & População Urbana & 2007 \\
\hline & População Urbana e Desempenho em Português. & 2008 \\
\hline & População Urbana e Desempenho em Português. & 2009 \\
\hline \multirow{4}{*}{ PEP } & PDP, ER e ICS. & 2007 \\
\hline & População Urbana e ER. & 2008 \\
\hline & População Urbana e PIB per capita & 2009 \\
\hline & População Urbana e PIB per capita & 2010 \\
\hline \multirow{2}{*}{ FIT } & Desempenho em Português & 2008 \\
\hline & Desempenho em Português & 2009 \\
\hline \multirow{4}{*}{ PJ } & PIB per capita & 2007 \\
\hline & População Urbana & 2008 \\
\hline & População Urbana & 2009 \\
\hline & PIB per capita & 2010 \\
\hline
\end{tabular}

Fonte: Elaborado pelo autor. 


\section{5. CONCLUSÕES}

Conforme exposto no primeiro capítulo, neste estudo busquei entender a abrangência das políticas educacionais voltadas para o EM implementadas na gestão do Governo Aécio Neves entre os anos de 2007 e 2010, bem como suas correlações com os indicadores sociais e demográficos e também com as médias municipais de proficiência em matemática e português. Para o desenvolvimento deste trabalho, parti de alguns pressupostos a partir da literatura específica comentada no capítulo dois. Assim, retomo algumas dessas ideias nesta discussão final, na tentativa de destacar o que foi observado.

Inicialmente retomo as duas principais questões apresentadas na introdução: Qual a abrangência das políticas implementadas? Quais indicadores educacionais, sociais e demográficos estão relacionados com a abrangência destas políticas? Os resultados obtidos mostram que, no período estudado, as políticas educacionais implementadas pelo governo de Minas Gerais, tiveram uma abrangência bastante limitada em relação ao número de municípios contemplados. Como apresentei no capítulo quatro, entre os anos de 2007 e 2010, a SEE-MG implementou diferentes políticas educacionais voltadas para o EM. Estas políticas tinham diferentes finalidades como a criação de escolas referência para o compartilhamento de boas práticas escolares, programas de desenvolvimento profissional para professores, ações para minimizar a vulnerabilidade dos jovens em situação de risco social, oferecimento de formação tecnológica adicional e/ou formação técnica profissional para os estudantes de EM, redução das taxas de evasão escolar, entre outros.

Conforme apresento no anexo I deste trabalho, a análise descritiva dos dados mostrou que o desempenho médio dos estudantes foi, de acordo com os parâmetros do SIMAVE, predominantemente baixo nas avaliações de matemática e português aplicadas entre os anos de 2006-2010. É interessante notar que o desempenho dos alunos em matemática tem se mostrado levemente superior em relação ao desempenho em português. A base de dados também mostrou a representatividade dos estudantes matriculados nos turnos da manhã, tarde e da noite, mostrando que os estudantes dos períodos diurnos tendem a apresentar melhor desempenho que os estudantes do período noturno. Progressivamente, o desempenho médio em matemática subiu de 274,66 
pontos em 2006 para 290,63 pontos em 2010 e de 267,64 pontos em 2006 para 282,22 pontos em português.

Também por meio da análise descritiva dos dados, foi possível comparar o desempenho dos estudantes entre os municípios contemplados ou não com as políticas educacionais aqui estudadas. Conforme apresento no capítulo quatro, os municípios contemplados com os programas "escolas referências - ER", "programa de atenção ao jovem - PEAS" e programa “desenvolvimento profissional - PDP” em 100\% das suas escolas obtiveram notas médias mais elevadas se comparados aos municípios contemplados em apenas $50 \%$ de suas escolas e aos não contemplados. No programa de “formação inicial para o trabalho - FIT" com exceção do ano de 2008 em que o desempenho recomendável em matemática e em português foram inferiores ao desempenho dos municípios que não têm o programa. Os municípios contemplados com “programa de educação profissional- PEP” obtiveram desempenho médio superior apenas na avaliação de português, ficando abaixo dos municípios não contemplados na avaliação de matemática.

Os municípios contemplados pelo "programa poupança jovem - PJ" apresentaram resultado inferior ao dos municípios não contemplados pelo programa, não apresentando relação positiva com o desempenho dos estudantes em ambas avaliações.

Como já mencionei, a análise descritiva acima apresentada não é suficiente para confirmar a relação de causalidade entre as políticas implementadas e o desempenho dos estudantes, sendo necessária uma análise mais aprofundada das políticas conforme argumenta Arretche (1998). Entretanto, como vimos, os resultados encontrados mostram que, em alguns destes programas, os municípios com maior número de escolas contempladas obtiveram médias de desempenho superiores em relação aos que não foram contemplados por estas mesmas políticas. Outro aspecto relevante na análise desses dados refere-se à capacidade das políticas contribuírem para a redução da desigualdade existente entre os municípios mineiros. Embora, como já dito, tenham sido registrados avanços nas médias globais entre 2007 e 2010, quando comparamos as médias entre os melhores municípios e os piores, verificamos que a distância entre os mesmos permanece estável. Nesse sentido, a focalização destas políticas parece não constituir, junto com as demais políticas sociais, um desenho que possibilite reduzir as desigualdades existentes dentro do sistema mineiro de educação, conforme discute Kerstenetzky (2006) a respeito das políticas focalizadas e políticas universais. Conforme constatado entre os anos de 2006 e 2010, a diferença entre o desempenho 
médio dos estudantes do $3^{\circ}$ ano entre os melhores e piores municípios permaneceu muito desigual, como apresento no anexo I. Na análise do desempenho médio dos estudantes por Superintendências Regionais de Ensino - SRE, mostrada no capítulo quatro, também foi encontrada grande variação dos indicadores do EM. Os melhores desempenhos estão presentes nas SRE's localizadas nas regiões centro e sul do Estado que, como apresentei, se destacam em todos os anos nas duas disciplinas avaliadas. Entre as SRE's com pior desempenho escolar dos estudantes de EM estão as localizadas nas regiões norte e nordeste do Estado. Estes resultados também demostram a correlação entre o desempenho e as variáveis sociais e demográficas apresentadas no capítulo três.

O mapeamento das políticas educacionais implementadas pela rede mineira de ensino demonstra que, embora tenham sido registrados melhores médias de desempenho global, a desigualdade regional continuou inalterada durante este período, como demonstro nos gráficos apresentados no item 4.3.3. Nesta análise constato que a melhora não contribuiu na redução das desigualdades regionais, ou seja, a distância entre os municípios com melhores médias e os municípios com piores médias permaneceu a mesma durante o período.

De maneira geral, as políticas educacionais implementadas ao longo do período estudado foram marcadas pelo "choque de gestão", o que significou o baixíssimo investimento por parte do governo estadual e a busca de soluções alternativas e de baixo custo, conforme pudemos constatar na descrição detalhada das políticas apresentadas no capítulo quatro. A maior parte das políticas partiu da ideia de se aproveitar soluções já utilizadas em escolas da rede, em uma espécie de benchmarking educacional, sendo um dos exemplos mais contundentes dessa ideia o projeto Escolas Referência-ER. Outro projeto que apresentou uma eficiente forma de contenção de custos foi o programa de Formação Inicial para o Trabalho - FIT. Como vimos, neste programa os custos foram extremamente reduzidos, utilizando-se como mão de obra, os próprios professores das escolas estaduais que eram treinados e repassavam esse treinamento numa espécie de "corrente" instrucional.

A análise dos dados também demonstra que, mesmo com os avanços nas médias de proficiência dos estudantes por município, ainda são grandes os desafios que se colocam para uma educação de qualidade em Minas Gerais. Considerando a escala de desempenho do SIMAVE, como apresento no capítulo três, o desempenho médio dos estudantes entre os anos de 2006 e 2010 ficou dentro da faixa considerada como 
intermediária em português, sendo registrada uma melhora de 14,6 pontos na escala de proficiência dentro desse período. Mesmo com essa evolução, em média, os estudantes ainda estão abaixo da faixa considerada como recomendada para o $3^{\circ}$ ano do EM, o que é preocupante, considerando que a rede estadual concentra a maior parte dos estudantes de EM. Em Matemática, a situação é ainda pior, pois, embora também apresente uma progressiva melhora no desempenho entre os anos aqui apresentados, em média, a proficiência em matemática dos alunos do $3^{\circ}$ ano está abaixo do nível intermediário, sendo necessária uma melhoria de 85 pontos na escala SIMAVE para se chegar ao nível considerado como recomendável. Conforme já afirmei, estes dados evidenciam que a questão da qualidade da educação ainda é um grande desafio para o Estado de Minas Gerais; contudo, não é meu objetivo aqui propor soluções para estas questões.

Como argumento ao longo do trabalho, minha intenção é estudar a abrangência das políticas educacionais implementadas durante o período aqui analisado, o que faço por meio da análise de regressão logística. Conforme detalhado no capítulo quatro, neste modelo de análise, utilizo entre outras variáveis, o índice de complexidade das superintendências regionais de ensino - ICS, que busca captar características específicas das SRE's e do importante papel que estas unidades desempenham na determinação da abrangência das políticas educacionais.

Entretanto, no modelo de análise apresentado, não foi possível constatar a influência do ICS no aumento da abrangência dos programas implementados, revelando que a influência desse indicador foi pequena, o que sugere que não houve, por parte da SEE-MG, uma preocupação em priorizar o atendimento das superintendências mais complexas com os programas aqui analisados. A maior parte dos programas analisados, recebeu, de forma geral, maior influência da variável população urbana e PIB per capita, o que indica que, de modo geral, os municípios de pequeno porte que, como vimos, concentram cerca de $40 \%$ da população mineira, não foram contemplados pela maior parte das políticas propostas.

O programa Escolas Referência, como vimos, também recebeu a influência do desempenho médio em matemática e português. Esta correlação é perfeitamente explicável pelo fato destas escolas terem sido selecionadas por apresentarem bons resultados e, por isso, tornaram-se referência para as demais unidades escolares da rede. Já os resultados obtidos com os programas PEP e PEAS podem estar relacionados ao fato de possuírem pequena abrangência, com 117 e 245 municípios atendidos respectivamente. 
No decorrer da análise, mesmo considerando as características específicas de cada um dos seis programas selecionados, os resultados demonstraram o alinhamento das políticas educacionais mineiras com a redução do gasto social, bem como menor abrangência e cobertura dos programas sociais (Arretche, 2004).

Embora, como já dito, não seja possível afirmar que as políticas implementadas tenham causalidade no desempenho dos estudantes, pude constatar que, em alguns destes programas, os municípios com maior números de escolas contempladas obtiveram médias de desempenho superiores em relação aos que não foram contemplados por estas mesmas políticas. Outro aspecto relevante refere-se à capacidade das políticas promoverem equidade. Embora, como já dito, tenham sido registrados avanços nas médias globais durante o período aqui estudado, quando comparamos as médias entre os melhores municípios e os piores, verificamos que a distância entre os mesmos permanece estável. Nesse sentido, pode-se afirmar que, durante este período, não houveram avanços no sentido de minimizar a desigualdade entre os municípios mineiros.

Embora, a SEE-MG tenha implementado um conjunto bastante variado de projetos e programas, os resultados da análise de regressão logística foram bastante esclarecedores em relação à abrangência dos programas educacionais analisados, revelando a inexistência de um projeto mais amplo e integrado para a implementação das mesmas.

Assim, constato que os programas e projetos propostos pela SEE-MG ao longo do período avaliado foram elaborados de forma centralizada, não considerando as características específicas dos órgãos intermediários e por, consequência, as reais demandas educacionais das escolas, bem como suas características sociais e demográficas. A abrangência das políticas implementadas durante o período aqui analisado pode ser caracterizada como iniciativas pulverizadas e com pouca unidade entre si, não chegando a constituir uma política educacional global de Estado, mas sim políticas de governo.

Nesse sentido, mesmo que os dados aqui apresentados não sejam suficientes para afirmar a existência de correlação entre as políticas implementadas e os ganhos em proficiência dos estudantes de EM, acredito que estas e outras políticas, se implementadas por meio de critérios que levem em consideração a diversidade sócio demográfica dos municípios mineiros, podem contribuir para a melhoria da qualidade e a redução da desigualdade educacional existente no Estado. 


\section{6. REFERÊNCIAS BIBLIOGRÁFICAS}

ABRUCIO. F. L. A coordenação federativa no Brasil: a experiência do período FHC e os desafios do Governo Lula. Rev. Sociol. Polít., Curitiba, 24, p. 41-67, jun. 2005.

ALAVARSE, O. M; BRAVO, M. H.; MACHADO, C. Avaliações externas e qualidade na educação básica: Articulações e tendências. Est. Aval. Educ., São Paulo, v. 24, n. 54, p. 12-31, jan./abr. 2013

ALVES, F. Qualidade na educação fundamental pública nas capitais brasileiras: tendências, contextos e desafios. 2007. 244 f. Tese (Doutorado em Educação). Faculdade de Educação da PUC-Rio. Pontifícia Universidade Católica do Rio de Janeiro, Rio de Janeiro.

ALVES, F; FRANCO, C.; RIBEIRO, L. C. de Q. Segregação residencial e desigualdade escolar no Rio de Janeiro. In: KAZTMAN, R.; RIBEIRO, L. C. de Q. A Cidade contra a Escola? Segregação urbana e desigualdades educacionais em grandes cidades da América. Rio de Janeiro: LETRA CAPITAL, 2008.

AMARAL, P. V. M. Desenvolvimento desigual em Minas Gerais. Cadernos BDMG, v. 14, p. 43-94, 2007.

ARRETCHE, M. Tendências no estudo sobre avaliação. In: RICO, E. Avaliação de Políticas: uma Questão em Debate. São Paulo: Cortez Editora, IEE/PUC/SP, 1998.

Uma contribuição para fazermos avaliações menos ingênuas. In:

BARREIRA, M. C. R. N.; CARVALHO, M. do C. B. (Orgs.). Tendências e perspectivas na avaliação de políticas e programas sociais. São Paulo: IEE/PUC-SP, 2001. n. 80 , p. $25-48,2002$.

Relações federativas nas políticas sociais. Educ. Soc, Campinas, v.23, Federalismo e políticas sociais no Brasil: problemas de coordenação e autonomia. São Paulo em Perspectiva, v.2, n.18, p. 17-26, 2004.

AZEVEDO, J. M. de L. de. Implicações da nova lógica de ação do Estado para a Educação municipal. Educ. Soc., Campinas, v. 23, n. 80, setembro/2002

BELL, L.; STEVENSON, H. Education Policy: Process, Themes and Impact. London: Routledge, 2006.

BONAMINO, A.; FRANCO, C. Avaliação e política educacional: o processo de institucionalização. Cadernos de Pesquisa, São Paulo, n. 108, p. 101-132, nov. 1999.

CARDOSO, J. C.; JACCOUD, L. Políticas Sociais no Brasil: organização, abrangência e tensões da ação estatal. In: JACCOUD, L. (Org.). Questão Social e Políticas Sociais no Brasil Contemporâneo. Brasília: IPEA, 2005.

CIRINO, J. F.; CASSUCE, F. C. da C. A relação entre geração e a qualidade da educação no estado de Minas Gerais. XV Seminário sobre a Economia Mineira, Diamantina, 2012.

COSTA, C. C. de M.; FERREIRA, M. A. M.; BRAGA, M. J.; ABRANTES, L. A. Disparidades Inter-Regionais e Características dos Municípios do Estado de Minas Gerais. Jundiaí: Editora Unijuí, 2012.

COSTA, N. do R. Política social e ajuste macroeconômico. Cad. Saúde Pública, Rio de Janeiro, n.18, p.13-21, 2002. 
CUNHA. L. A. Educação, Estado e democracia no Brasil. São Paulo: Cortez; Rio de Janeiro, 1991.

Zig-Zag no primeiro grau: o Rio de Janeiro nos anos 80. Revista do Rio de Janeiro, Rio de Janeiro, n.3, p. 21-26, 1994.

DOURADO, L. F. Os desafios da universalização da Educação Básica. In: BRASIL, Salto para o Futuro, Debate: Os desafios da universalização da educação básica, Ano XXI, Boletim 16, Novembro de 2011.

DUBET, F. A escola e a exclusão. Cad. Pesqui., São Paulo, v. 40, n. 119, 2003.

2004. O que é uma escola justa?. Cad. Pesqui., São Paulo, v. 34, n. 123,

FRANCO, C. et al. Qualidade e eqüidade em educação: reconsiderando o significado de "fatores intra-escolares". Ensaio: aval.pol.públ.Educ., Rio de Janeiro, v. 15, n. 55, 2007.

GALSTER, G.; KILLEN, S. The Geography of Metropolitan Opportunity: A Reconnaissance and Conceptual Framework. Alexandria: Housing Policy Debate, 1995. GATTI, B. A.; BARRETTO, E. S. de S; ANDRÉ, M. E. D. de A. Políticas docentes no Brasil: um estado da arte. Brasília: UNESCO, 2011.

GOMES, A. M. Ensino Médio no Brasil: indicadores e desafios. In: BRASIL, Salto para o Futuro, Debate: Os desafios da universalização da educação básica, Ano XXI, Boletim 16, Novembro de 2011.

GOMES, G. e MAC DOWELL, M. C. Descentralização política, Federalismo Fiscal e Criação de Municípios: O que é mau para o Econômico, nem sempre é bom para o Social. Brasília: IPEA, 2000.

HOFLING, E. de M. Estado e políticas (públicas) sociais. Cadernos CEDES, v.21, n.55, p. 30-41, 2001.

JANNUZZI, P. M. Indicadores para diagnóstico, monitoramento e avaliação de programas sociais no Brasil. Revista do Serviço Público Brasília, v. 2, n.56, p. 137$160 \mathrm{Abr} / \mathrm{Jun} 2005$.

Indicadores Sociais no Brasil: conceitos, medidas e aplicações. Campinas: Allínea, 2009.

KERSTENETZKY, C L. Políticas sociais: focalização ou universalização? Revista de Economia Política, v. 26, n. 4, p. 104-124, 2006.

LIMA, C. R. et al. Políticas públicas educacionais brasileiras: O Ensino Médio no contexto da LDB, PNE e PDE. IX Congresso Nacional de Educação, PUCPR, 2009.

LIMA, L. C. A. Da universalização do ensino fundamental ao desafio de democratizar o ensino médio em 2016: o que evidenciam as estatísticas? Revista Brasileira de Estudos Pedagógicos, Brasília, v. 92, n. 231, p. 268-284, maio/ago. 2011.

LOWI. T. Decision making vs. policy makink: toward na antidote for technocracy. (BOOK). Public Administration Review [serial online]. May 1970.

NUDZOR, H. What is "policy", a problem-solving definition or a process conceptualisation? E-journal of the British Education Studies Association, v. 2, n.1, p. ,September, 2009.

OLIVEIRA, D. A. A reestruturação do trabalho docente: precarização e flexibilização. Educação \& Sociedade, Campinas, v. 25, n. 89, Dec. 2004 .

. Das políticas de governo à política de estado: reflexões sobre a atual agenda educacional Brasileira. Educação \& Sociedade, Campinas, v.32, n.115, p. 323337, 2011.

PISSAIA, V. H. A Municipalização do ensino em municípios de pequeno porte: a Região de Taquaritinga - (1998-2009). 2011. Dissertação de Mestrado - Universidade Estadual de Campinas, Campinas. 
RIBEIRO, L. C. de Q.; KOSLINSKI, M. C; ALVES, F.; LASMAR, C. Desigualdades Urbanas, Desigualdades Escolares. Rio de Janeiro: LETRA CAPITAL, 2010.

ROCHA, C. V. Anatomia de uma Reforma: Descentralização da Educação Pública de Minas Gerais e Mudança Institucional. DADOS - Revista de Ciências Sociais, Rio de Janeiro, v. 46, n. 3, p. 557-592, 2003.

RODRIGUES, J. R. da S. Jovens, Gestores e Escolas fora de Lugar? Geografias de oportunidades educacionais do Ensino Médio na Cidade do Rio de Janeiro. 2011. 188 f. Tese (Doutorado em Educação). Faculdade de Educação da PUC-RIO. Pontifícia Universidade Católica do Rio de Janeiro, Rio de Janeiro.

RUS PEREZ, J. R. Por que pesquisar implementação de políticas educacionais atualmente? Educação \& Sociedade, Campinas, v. 31, n. 113, p. 1179-1193, 2010.

SANTOS, G. R.; PALES, Raíssa Cota. Desenvolvimento Regional e Desigualdades Sociais entre as Macrorregiões de Planejamento de Minas Gerais. 36 ${ }^{\circ}$ Encontro Anual da ANPOCS, 2012a, Águas de Lindóia-SP. Anais do Encontro, 2012.

.; PALES, R. C. Desenvolvimento Regional e Desigualdades Sociais entre as Macrorregiões de Planejamento de Minas Gerais. $36^{\circ}$ Encontro Anual da ANPOCS, Montes Claros - MG, 2012b.

SECCHI, L. Modelos organizacionais e reformas da administração pública. Rap, Rio de Janeiro, v. 3, n.43, p.347-369, 2009.

SILVA, M. S. P. da. Marcas de um caminho: Uma análise da construção da gestão democrática da escola em Minas Gerais (1991-2006). XXIII Simpósio Brasileiro V Congresso Luso-Brasileiro I Colóquio Ibero-Americano de Política e Administração da Educação., 2007, Porto Alegre. Cadernos ANPAE n. 4. 2007.

SILVA, S. Educação, projeto político-pedagógico, diversidade: em foco a educação especial. XXV Simpósio Brasileiro II Congresso Ibero-Americano de Política e Administração da Educação., 2011, São Paulo. Cadernos ANPAE n. 11., 2011.

SILVA, E.; FONTES, R.; ALVES, L. F. Análise das disparidades regionais em Minas Gerais. In: XI SEMINÁRIO SOBRE A ECONOMIA MINEIRA, 11., 2004, Diamantina. Anais... Diamantina, 2004.

SILVA, A.A.P. Eficiência na alocação de recursos públicos e qualidade de vida nos municípios de Minas Gerais. 2009. 98p. Dissertação (Mestrado em Administração) Universidade Federal de Viçosa.

SOARES, C. R. Sistemas de Avaliações em Larga Escala na Perspectiva HistóricoCultural: o caso do Sistema Mineiro de Avaliação da Educação Pública - SIMAVE. 2011. 204 f. Dissertação (Mestrado em Educação). Faculdade de Educação da UFJF. Universidade Federal de Juiz de Fora-MG.

SOARES, J. F.; ANDRADE, R. J. de. Nível socioeconômico, qualidade e eqüidade das escolas de Belo Horizonte. Ensaio: aval.pol.públ.Educ., Rio de Janeiro, v. 14, n. 50, Mar. 2006.

SOARES, T. M. Correção do atraso escolar é fundamental. Relatório De Olho nas Metas de 2012. Disponível em: http://www.todospelaeducacao.org.br/biblioteca/1440/de-olho-nas-metas-2011--4relatorio-de-monitoramento/. Acesso em 18/06/2012.

SOUZA, C. Políticas Públicas: uma revisão da literatura. Sociologias, Porto Alegre, ano 8, n. 16, p.20-45, 2006.

SOUZA, L. M. de. Comentando as classificações de políticas públicas. Cronos, Natal, v.11,n.3,p.189-207, 2010.

TORRES, H. da G.; FERREIRA, M. P.; DINI, N. P. Indicadores sociais: Porque construir novos indicadores como o IPRS. São Paulo em Perspectiva, v.4, n.17, p. 8090, 2003. 
CEDEPLAR. UNIVERSIDADE FEDERAL DE MINAS GERAIS. Centro de Desenvolvimento e Planejamento Regional. Avaliação de impacto do programa poupança jovens - Relatório Final. Belo Horizonte, 2011.

VAITSMAM, J.; RODRIGUES, R. W. S; PAES-SOUSA, R. O Sistema de Avaliação e Monitoramento das Políticas e Programas Sociais: a experiência do Ministério do Desenvolvimento Social e Combate à Fome do Brasil. UNESCO: Brasília, 2006. 
7.

\section{ANEXOS}

7.1.

Análise descritiva da base de dados

As notas individuais de português e matemática dos alunos foram classificadas de acordo com os seguintes intervalos avaliação de desempenho estabelecidos pelo SIMAVE:

\begin{tabular}{|l|l|}
\hline Português & Desempenho \\
\hline Até 300 & Baixo \\
\hline [301 - 325] & Intermediário \\
\hline $\begin{array}{l}\text { Acima de } \\
326\end{array}$ & Recomendado \\
\hline
\end{tabular}

\begin{tabular}{|l|l|}
\hline Matemática & Desempenho \\
\hline Até 300 & Baixo \\
\hline$[301-375]$ & Intermediário \\
\hline $\begin{array}{l}\text { Acima de } \\
375\end{array}$ & Recomendado \\
\hline
\end{tabular}

Análise por Ano

Foram calculadas as estatísticas por tipo de avaliação e por ano resultando conforme podemos verificar abaixo.

Estatística descritiva da base de proficiência 2006-2010.

\begin{tabular}{|c|c|c|c|c|c|c|c|c|c|c|c|c|c|c|}
\hline PROVA_ANO & Média & $\begin{array}{l}\text { Erro } \\
\text { padrão }\end{array}$ & $\begin{array}{l}\text { Desvio } \\
\text { padrão }\end{array}$ & Variância & $\begin{array}{l}\text { Coeficiente de } \\
\text { Variação (CV) }\end{array}$ & Máximo & $75 \mathrm{Per}$ & $\begin{array}{c}\text { Mediana } \\
\text { (50 percentil) }\end{array}$ & 25 & Mínimo & 5 Percentil & 95 Percent & 9 Percenti & Freque \\
\hline TTEMATICA_2006 & 274,66 & 0,1450 & 52,99 & 2807,48 & 0,1929 & 440,30 & 312,01 & 275,33 & 236,72 & 136,13 & 186,04 & 361,70 & 393,30 & 133593 \\
\hline IATEMATICA_2007 & 282,43 & \begin{tabular}{|l|}
0,1409 \\
\end{tabular} & 51,27 & 2628,59 & 0,1815 & 442,83 & 318,14 & 283,62 & 248,28 & 132,71 & 193,23 & 365,32 & 395,55 & 132469 \\
\hline MATEMATICA_2008 & 282,23 & 0,1420 & 53,26 & 2836,91 & 0,1887 & 455,43 & 319,83 & 283,52 & 244,55 & 129,73 & 192,38 & 368,80 & 399,32 & 140693 \\
\hline IATEMATICA_2009 & 283,96 & 0,1343 & 52,38 & 2744,16 & 0,1845 & 452,15 & 320,47 & 285,06 & 249,34 & 109,59 & 193,40 & 368,03 & 400,39 & 152126 \\
\hline ИATEMATICA_2010 & 290,63 & 0,1335 & 51,60 & 2662,79 & 776 & 445,35 & 326,97 & 293,71 & 256,76 & 93,35 & 199,72 & 371,10 & 399,19 & 149307 \\
\hline PORTUGUES_2006 & 267,64 & 0,1311 & 49,62 & 2461,69 & 0,1854 & 417,92 & 303,37 & 270,01 & 234,91 & 93,14 & 180,28 & 345,08 & 369,06 & 143317 \\
\hline PORTUGUES_2007 & 274,18 & 0,1267 & 47,64 & 2269,63 & 0,1738 & 419,45 & 308,97 & 276,59 & 241,66 & 125,74 & 190,48 & 348,42 & 370,92 & 141340 \\
\hline PORTUGUES_2008 & 274,01 & 0,1182 & 45,72 & 2090,61 & 1669 & 425,38 & 307,11 & 276,08 & 242,90 & 132,54 & 193,88 & 345,97 & 369,91 & 149523 \\
\hline PORTUGUES_2009 & 274,81 & \begin{tabular}{|l|l|}
0,1146 \\
\end{tabular} & 45,29 & 2050,73 & 0,1648 & 415,95 & 306,91 & 277,69 & 245,63 & 108,33 & 194,10 & 344,65 & 367,95 & 156056 \\
\hline PORTUGUES_2010 & 282,22 & 0,1198 & 46,74 & 2184,88 & 0,1656 & 423,19 & 315,69 & 285,28 & 252,10 & 114,36 & 199,06 & 353,94 & 376,42 & 152185 \\
\hline
\end{tabular}

Fonte: Elaborado pelo autor.

Porcentagem de alunos avaliados em matemática - 2006-2010.

\begin{tabular}{l|l|l}
\hline PROVA_ANO & Frequência & Porcentagem \\
\hline MATEMATICA_2006 & 133593 & $18,86 \%$ \\
\hline MATEMATICA_2007 & 132469 & $18,71 \%$ \\
\hline MATEMATICA_2008 & 140693 & $19,87 \%$ \\
\hline MATEMATICA_2009 & 152126 & $21,48 \%$ \\
\hline MATEMATICA_2010 & 149307 & $21,08 \%$ \\
\hline Total & 708188 & $100,00 \%$ \\
\hline
\end{tabular}

Fonte: Elaborado pelo autor. 
Porcentagem de alunos avaliados em português - 2006-2010.

\begin{tabular}{l|l|l}
\hline PROVA_ANO & Frequência & Porcentagem \\
\hline PORTUGUES_2006 & 143317 & $19,30 \%$ \\
\hline PORTUGUES_2007 & 141340 & $19,04 \%$ \\
\hline PORTUGUES_2008 & 149523 & $20,14 \%$ \\
\hline PORTUGUES_2009 & 156056 & $21,02 \%$ \\
\hline PORTUGUES_2010 & 152185 & $20,50 \%$ \\
\hline Total & 742421 & $100 \%$ \\
\hline
\end{tabular}

Fonte: Elaborado pelo autor.

Analisando as tabelas, é possível constatar que a diferença porcentual entre o número total de alunos avaliados de um ano a outro não sofrerem grandes variações, sendo dessa forma muito próximas. No caso da prova de matemática, observamos um leve aumento gradativo ao longo dos anos e no caso da prova de português há aumentos e declínios ao longo dos anos, de forma aleatória.

Pontuação máxima e mínima em matemática e português - 2006-2010.

\begin{tabular}{l|l|l}
\hline PROVA_ANO & Máximo & Mínimo \\
\hline MATEMATICA_2006 & 440,30 & 136,13 \\
\hline MATEMATICA_2007 & 442,83 & 132,71 \\
\hline MATEMATICA_2008 & $\mathbf{4 5 5 , 4 3}$ & 129,73 \\
\hline MATEMATICA_2009 & 452,15 & 109,59 \\
\hline MATEMATICA_2010 & 445,35 & $\mathbf{9 3 , 3 5}$ \\
\hline PORTUGUES_2006 & 417,92 & $\mathbf{9 3 , 1 4}$ \\
\hline PORTUGUES_2007 & 419,45 & 125,74 \\
\hline PORTUGUES_2008 & $\mathbf{4 2 5 , 3 8}$ & 132,54 \\
\hline PORTUGUES_2009 & 415,95 & 108,33 \\
\hline PORTUGUES_2010 & 423,19 & 114,36 \\
\hline
\end{tabular}

Fonte: Elaborado pelo autor.

A maior nota encontrada em matemática foi do ano de 2008 com 455,43 e a menor nota foi em 2010 com 93,35. Já na prova de português a maior nota foi encontrada em 2008 com 425,38 e a menor nota em 2006 com 93,14.

Média

As maiores médias são do ano de 2010 para ambas as avaliações, sendo a de português com 282,22 e a de matemática com 290,63.

Erro padrão da média

No caso da avaliação de português, entre os anos de 2006 - 2010, o ano de 2009 se mostrou com o menor erro padrão com 0,1146 , com média de 274,81. 
Já no caso da avaliação de matemática, entre os anos de 2006 - 2010, o ano de 2010 se mostrou com o menor erro padrão com 0,1335, com média de 290,63.

Desvio padrão

O menor desvio padrão em português foi do ano de 2009 com 45,29 e média 274,81 e em matemática foi do ano de 2007 com desvio de 51,27 e média de 282,43.

Variância

A menor variância em português foi do ano de 2009 com 2050,73 e média 274,81 e em matemática foi do ano de 2007 com 2628,59 e média de 282,43.

Coeficiente de variação

Nas avaliações temos que o ano de 2009 apresentou o menor coeficiente de variação para português com 0,1648 e em 2010 para matemática com 0,1776.

Percentis

Os percentis são calculados ordenando a amostra, logo são medidas de classificação, conforme verificamos na tabela abaixo.

Percentis pontuação em Matemática E Português - 2006-2010.

\begin{tabular}{l|l|l|l|l|l|l}
\hline PROVA_ANO & $\begin{array}{l}5 \\
\text { Percentil }\end{array}$ & $\begin{array}{l}25 \\
\text { Percentil }\end{array}$ & $\begin{array}{l}\text { Mediana } \\
(50 \text { percentil })\end{array}$ & $\begin{array}{l}75 \\
\text { Percentil }\end{array}$ & $\begin{array}{l}95 \\
\text { Percentil }\end{array}$ & $\begin{array}{l}99 \\
\text { Percentil }\end{array}$ \\
\hline MATEMATICA_2006 & 186,04 & 236,72 & 275,33 & 312,01 & 361,70 & 393,30 \\
\hline MATEMATICA_2007 & 193,23 & 248,28 & 283,62 & 318,14 & 365,32 & 395,55 \\
\hline MATEMATICA_2008 & 192,38 & 244,55 & 283,52 & 319,83 & 368,80 & 399,32 \\
\hline MATEMATICA_2009 & 193,40 & 249,34 & 285,06 & 320,47 & 368,03 & 400,39 \\
\hline MATEMATICA_2010 & 199,72 & 256,76 & 293,71 & 326,97 & 371,10 & 399,19 \\
\hline PORTUGUES_2006 & 180,28 & 234,91 & 270,01 & 303,37 & 345,08 & 369,06 \\
\hline PORTUGUES_2007 & 190,48 & 241,66 & 276,59 & 308,97 & 348,42 & 370,92 \\
\hline PORTUGUES_2008 & 193,88 & 242,90 & 276,08 & 307,11 & 345,97 & 369,91 \\
\hline PORTUGUES_2009 & 194,10 & 245,63 & 277,69 & 306,91 & 344,65 & 367,95 \\
\hline PORTUGUES_2010 & 199,06 & 252,10 & 285,28 & 315,69 & 353,94 & 376,42 \\
\hline
\end{tabular}

Fonte: Elaborado pelo autor.

Começando pela avaliação de matemática, percebemos que o ano de 2006 foi o pior de todos em todos os percentis avaliados (marcados em azul escuro), e no ano de 2010 todos foram melhores (marcados em azul claro) com exceção do 99 percentil, em que o ano de 2009 se mostrou superior.

Em relação a prova de português, 2006 também apresenta resultados piores, com exceção do 95 e 99 percentil que ficou para o ano de 2009. Já em 2010 todos os percentis foram superiores com relação aos outros anos. 
A mediana é uma medida resumo muito melhor que a média quando temos dados discrepantes dentro de nossa amostra que poderiam mascarar o resultado se avaliássemos apenas com a informação da média. O resultado é bastante semelhante ao da média, com queda imperceptível de 2007 para 2008 em ambas as disciplinas, e crescimento contínuo na comparação ano a ano nos demais casos.

Para comparar efetivamente a mediana do desempenho entre os anos, utilizamos o gráfico "BOX PLOT". Conhecido como o diagrama de caixas, este gráfico é útil para representar o comportamento da amostra, e seus valores atípicos como os outliers. Com a mediana exatamente no meio da amostra, temos um comportamento equilibrado dentro da amostra, ou seja, as observações estão com um espaçamento próximo entre elas.

Exemplo de gráfico Box Spot.

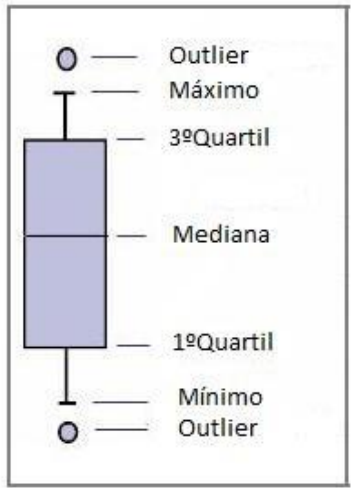

Box Spot desempenho dos estudantes em Matemática - 2006-2010.

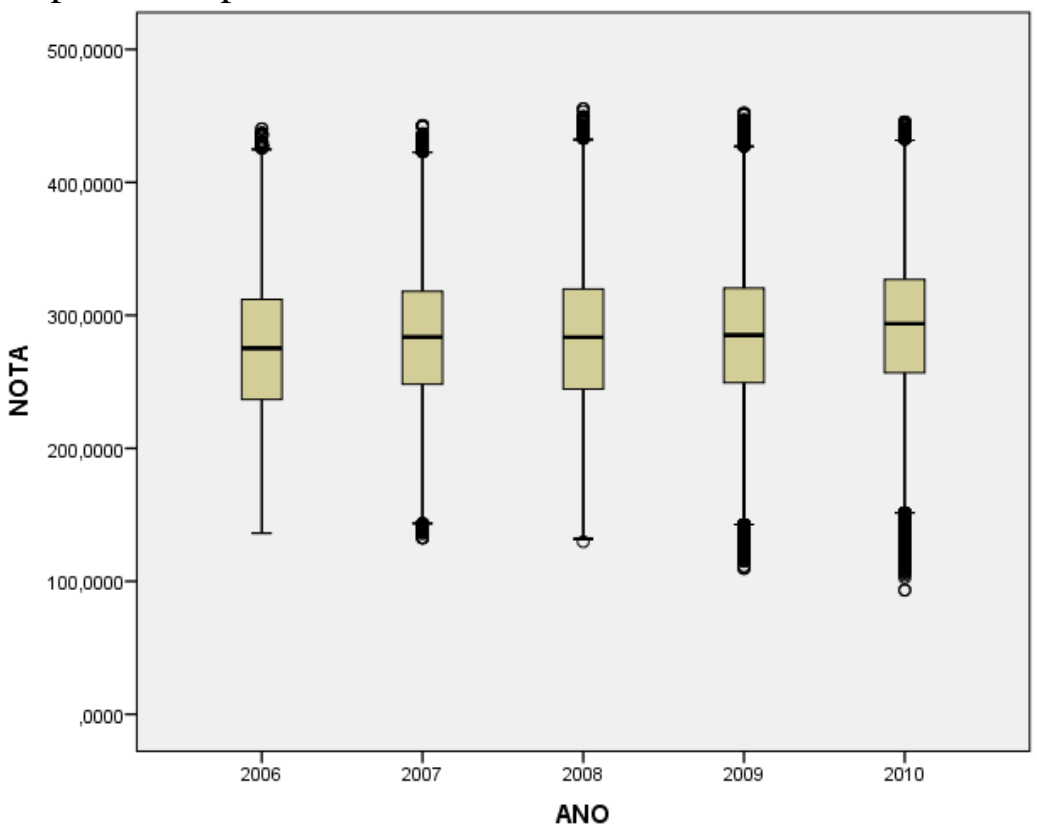


A comparação do desempenho é feita pela linha central conhecida como mediana ou $2^{\circ}$ quartil, a comparação entre os anos mostra que em 2010 o desempenho foi superior aos demais anos.

Box Spot desempenho dos estudantes em Português - 2006-2010.

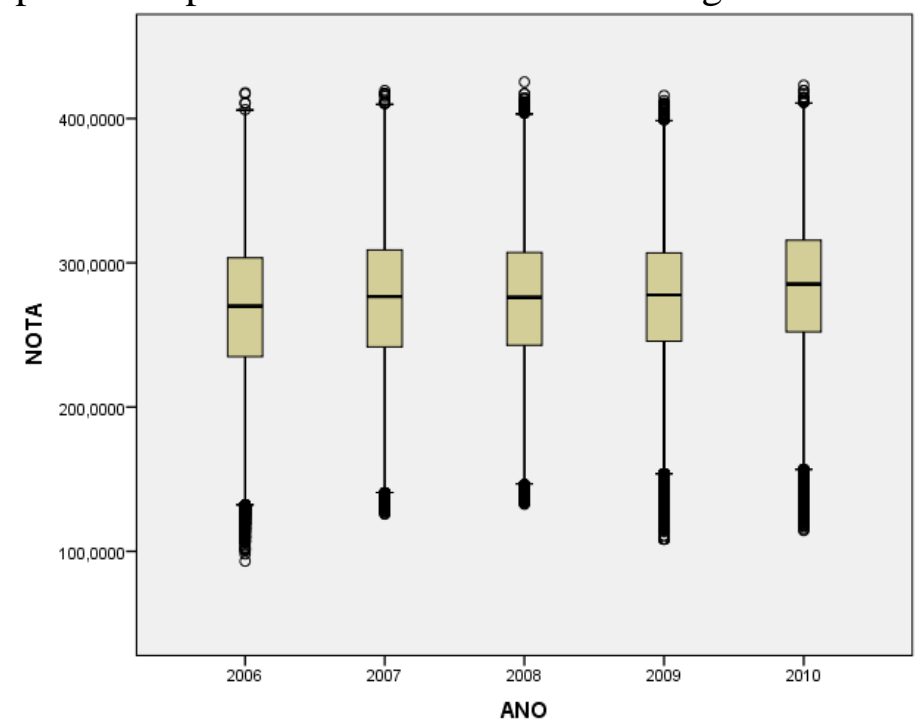

Fonte: Elaborado pelo autor.

A comparação do desempenho é feita pela linha central conhecida como mediana ou $2^{\circ}$ quartil, a comparação entre os anos mostra que em 2010 o desempenho em português também foi superior aos demais anos.

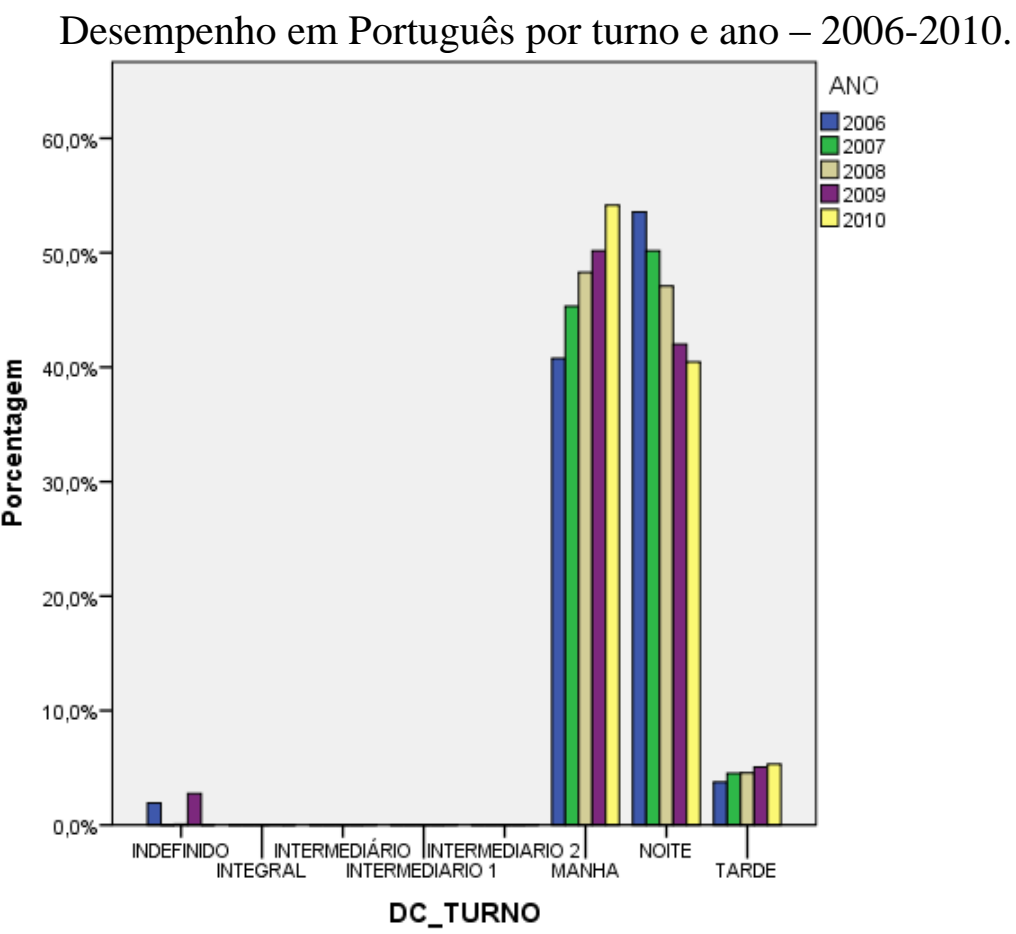

Fonte: Elaborado pelo autor. 
Ao longo dos anos podemos perceber que o número de alunos por turno ano é de $53,6 \%$ para o turno da noite em $2006,50,2 \%$ no turno da noite em $2007,48,3 \%$ no turno da manhã em 2008, 50,2\% no turno da manhã em 2009 e 54,2\% no turno da manhã para 2010. Esses resultados refletem o nosso banco de dados, em que temos mais notas de alunos do turno noturno nos primeiros anos (2006 - 2007) e nos demais há uma representação maior para o turno da manhã (2008- 2010), o turno da tarde teve uma representação menor, atingindo o máximo de 5,3\% em 2010, e o intermediário o resultado chega a aproximadamente em $0 \%$, aparecendo na base somente no ano de 2010.

Desempenho em Português por turno e por ano - 2006-2010.

\begin{tabular}{|c|c|c|c|}
\hline \multirow{2}{*}{\multicolumn{2}{|c|}{ ANO/TURNO }} & \multicolumn{2}{|l|}{ NOTA } \\
\hline & & \multirow{2}{*}{\begin{tabular}{|l|} 
Soma \\
2754 \\
\end{tabular}} & \multirow{2}{*}{\begin{tabular}{|l|}
$\%$ \\
$1,9 \%$ \\
\end{tabular}} \\
\hline \multirow{5}{*}{2006} & INDEFINIDO & & \\
\hline & MANHA & 58427 & $40,8 \%$ \\
\hline & NOITE & 76750 & $53,6 \%$ \\
\hline & TARDE & 5386 & $3,8 \%$ \\
\hline & Total & 143317 & $100,0 \%$ \\
\hline \multirow{4}{*}{2007} & MANHA & 64068 & $45,3 \%$ \\
\hline & NOITE & 70903 & $50,2 \%$ \\
\hline & TARDE & 6369 & $4,5 \%$ \\
\hline & Total & 141340 & $100,0 \%$ \\
\hline \multirow{5}{*}{2008} & INDEFINIDO & 95 & $0,1 \%$ \\
\hline & MANHA & 72187 & $48,3 \%$ \\
\hline & NOITE & 70417 & $47,1 \%$ \\
\hline & TARDE & 6824 & $4,6 \%$ \\
\hline & Total & 149523 & $100,0 \%$ \\
\hline \multirow{6}{*}{2009} & INDEFINIDO & 4294 & $2,8 \%$ \\
\hline & INTEGRAL & 27 & $0,0 \%$ \\
\hline & MANHA & 78289 & $50,2 \%$ \\
\hline & NOITE & 65555 & $42,0 \%$ \\
\hline & TARDE & 7891 & $5,1 \%$ \\
\hline & Total & 156056 & $100,0 \%$ \\
\hline \multirow{7}{*}{2010} & INTERMEDIÁRIO & 24 & $0,0 \%$ \\
\hline & INTERMEDIARIO 1 & 32 & $0,0 \%$ \\
\hline & INTERMEDIARIO 2 & 38 & $0,0 \%$ \\
\hline & MANHA & 82422 & $54,2 \%$ \\
\hline & NOITE & 61570 & $40,5 \%$ \\
\hline & TARDE & 8099 & $5,3 \%$ \\
\hline & Total & 152185 & $100,0 \%$ \\
\hline
\end{tabular}


Desempenho em Português por classificação do PROEB - 2006-2010.

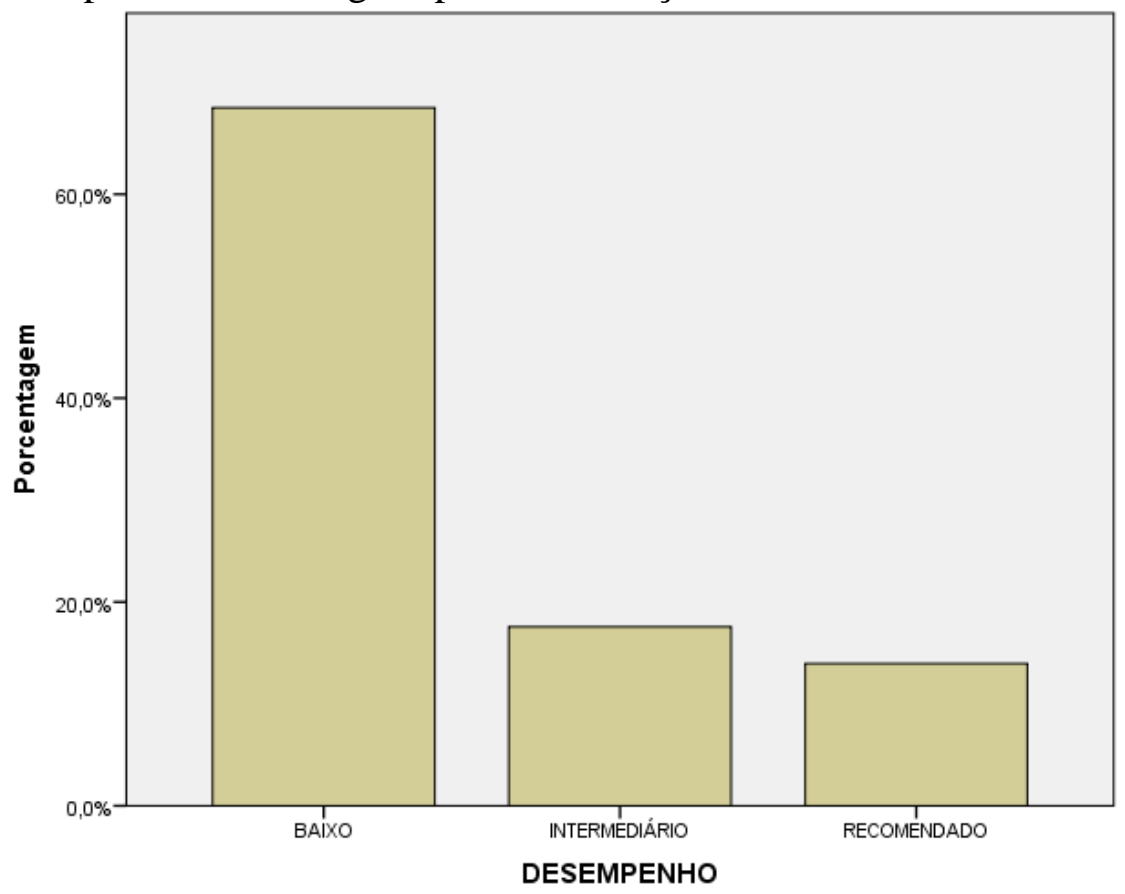

Fonte: Elaborado pelo autor.

Como vimos, embora tenha sido percebida uma sensível melhora no desempenho dos estudantes entre os anos de 2006-2010, a maioria dos estudantes avaliados na $3^{\text {a }}$ série do EM de Minas Gerais tinham índice de desempenho baixo (68,5\%), seguido por intermediário $(17,6 \%)$ e por último o recomendado $(13,9 \%)$.

Desempenho em Português por classificação PROEB - 2006-2010.

\begin{tabular}{l|l|l}
\hline \multirow{2}{*}{ DESEMPENHO } & \multicolumn{2}{|l}{ NOTA } \\
\cline { 2 - 3 } & SOMA & $\%$ \\
\hline BAIXO & 508506 & $68,5 \%$ \\
\hline INTERMEDIÁRIO & 130371 & $17,6 \%$ \\
\hline RECOMENDADO & 103544 & $13,9 \%$ \\
\hline Total & 742421 & $100,0 \%$ \\
\hline
\end{tabular}




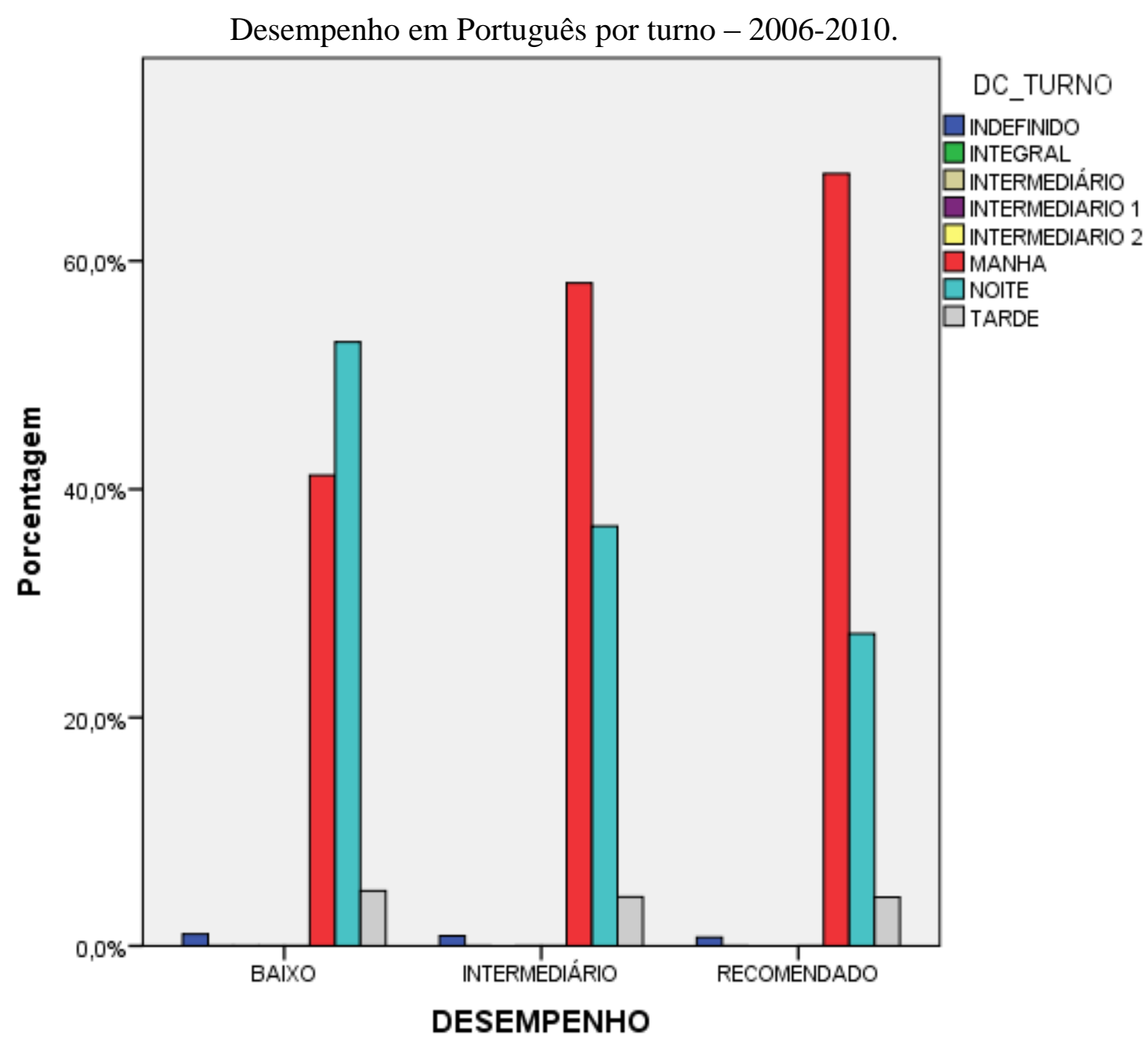

Fonte: Elaborado pelo autor.

No geral considerando a análise dos dados de 2006 -2010 de português, o desempenho baixo é atribuído ao turno noturno $(52,9 \%)$ e o desempenho intermediário $(58,1 \%)$ e recomendado $(67,6 \%)$ ao turno da manhã. 
Desempenho em Português por turno - 2006-2010.

\begin{tabular}{|c|c|c|c|}
\hline \multirow{2}{*}{\multicolumn{2}{|c|}{ DESEMPENHO/TURNO }} & \multicolumn{2}{|l|}{ NOTA } \\
\hline & & \multirow{2}{*}{\begin{tabular}{l|} 
SOMA \\
5241 \\
\end{tabular}} & \multirow{2}{*}{$\begin{array}{l}\% \\
1,0 \%\end{array}$} \\
\hline \multirow{9}{*}{ BAIXO } & INDEFINIDO & & \\
\hline & INTEGRAL & 20 & $0,0 \%$ \\
\hline & INTERMEDIÁRIO & 24 & $0,0 \%$ \\
\hline & INTERMEDIARIO 1 & 24 & $0,0 \%$ \\
\hline & INTERMEDIARIO 2 & 27 & $0,0 \%$ \\
\hline & MANHA & 209655 & $41,2 \%$ \\
\hline & NOITE & 268961 & $52,9 \%$ \\
\hline & TARDE & 24554 & $4,8 \%$ \\
\hline & Total & 508506 & $100,0 \%$ \\
\hline \multirow{8}{*}{ INTERMEDIÁRIO } & INDEFINIDO & 1137 & $0,9 \%$ \\
\hline & INTEGRAL & 6 & $0,0 \%$ \\
\hline & INTERMEDIARIO 1 & 8 & $0,0 \%$ \\
\hline & INTERMEDIARIO 2 & 6 & $0,0 \%$ \\
\hline & MANHA & 75698 & $58,1 \%$ \\
\hline & NOITE & 47921 & $36,8 \%$ \\
\hline & TARDE & 5595 & $4,3 \%$ \\
\hline & Total & 130371 & $100,0 \%$ \\
\hline \multirow{7}{*}{ RECOMENDADO } & INDEFINIDO & 765 & $0,7 \%$ \\
\hline & INTEGRAL & 1 & $0,0 \%$ \\
\hline & \begin{tabular}{|l} 
INTERMEDIARIO 2 \\
\end{tabular} & 5 & $0,0 \%$ \\
\hline & MANHA & 70040 & $67,6 \%$ \\
\hline & NOITE & 28313 & $27,3 \%$ \\
\hline & TARDE & 4420 & $4,3 \%$ \\
\hline & Total & 103544 & $100,0 \%$ \\
\hline \multirow{9}{*}{ Total } & INDEFINIDO & 7143 & $1,0 \%$ \\
\hline & INTEGRAL & 27 & $0,0 \%$ \\
\hline & INTERMEDIÁRIO & 24 & $0,0 \%$ \\
\hline & INTERMEDIARIO 1 & 32 & $0,0 \%$ \\
\hline & INTERMEDIARIO 2 & 38 & $0,0 \%$ \\
\hline & MANHA & 355393 & $47,9 \%$ \\
\hline & NOITE & 345195 & $46,5 \%$ \\
\hline & TARDE & 34569 & $4,7 \%$ \\
\hline & Total & 742421 & $100,0 \%$ \\
\hline
\end{tabular}

Fonte: Elaborado pelo autor. 
Desempenho em Português por ano e turno - 2006-2010.

\begin{tabular}{|c|c|c|c|c|}
\hline \multirow{2}{*}{ ANO } & \multirow{2}{*}{ DESEMPENHO } & \multirow{2}{*}{ TURNO } & \multicolumn{2}{|l|}{ NOTA } \\
\hline & & & SOMA & $\%$ \\
\hline \multirow{15}{*}{2006} & \multirow[t]{5}{*}{ BAIXO } & INDEFINIDO & 2164 & $2,1 \%$ \\
\hline & & MANHA & 36640 & $35,2 \%$ \\
\hline & & NOITE & 61457 & $59,0 \%$ \\
\hline & & TARDE & 3956 & $3,8 \%$ \\
\hline & & Total & 104217 & $100,0 \%$ \\
\hline & \multirow[t]{5}{*}{ INTERMEDIÁRIO } & INDEFINIDO & 352 & $1,6 \%$ \\
\hline & & MANHA & 11287 & $51,2 \%$ \\
\hline & & NOITE & 9610 & $43,6 \%$ \\
\hline & & TARDE & 781 & $3,5 \%$ \\
\hline & & Total & 22030 & $100,0 \%$ \\
\hline & \multirow[t]{5}{*}{ RECOMENDADO } & INDEFINIDO & 238 & $1,4 \%$ \\
\hline & & MANHA & 10500 & $61,5 \%$ \\
\hline & & NOITE & 5683 & $33,3 \%$ \\
\hline & & TARDE & 649 & $3,8 \%$ \\
\hline & & Total & 17070 & $100,0 \%$ \\
\hline \multirow{12}{*}{2007} & \multirow[t]{4}{*}{ BAIXO } & MANHA & 37272 & $38,5 \%$ \\
\hline & & NOITE & 54918 & $56,8 \%$ \\
\hline & & TARDE & 4503 & $4,7 \%$ \\
\hline & & Total & 96693 & $100,0 \%$ \\
\hline & \multirow[t]{4}{*}{ INTERMEDIÁRIO } & MANHA & 13573 & $55,5 \%$ \\
\hline & & NOITE & 9846 & $40,3 \%$ \\
\hline & & TARDE & 1020 & $4,2 \%$ \\
\hline & & Total & 24439 & $100,0 \%$ \\
\hline & \multirow[t]{4}{*}{ RECOMENDADO } & MANHA & 13223 & $65,4 \%$ \\
\hline & & NOITE & 6139 & $30,4 \%$ \\
\hline & & TARDE & 846 & $4,2 \%$ \\
\hline & & Total & 20208 & $100,0 \%$ \\
\hline \multirow{13}{*}{2008} & \multirow[t]{5}{*}{ BAIXO } & INDEFINIDO & 74 &, $1 \%$ \\
\hline & & MANHA & 43427 & $41,7 \%$ \\
\hline & & NOITE & 55619 & $53,4 \%$ \\
\hline & & TARDE & 4983 & $4,8 \%$ \\
\hline & & Total & 104103 & $100,0 \%$ \\
\hline & \multirow[t]{5}{*}{ INTERMEDIÁRIO } & INDEFINIDO & 15 &, $1 \%$ \\
\hline & & MANHA & 15326 & $59,1 \%$ \\
\hline & & NOITE & 9534 & $36,8 \%$ \\
\hline & & TARDE & 1055 & $4,1 \%$ \\
\hline & & Total & 25930 & $100,0 \%$ \\
\hline & \multirow[t]{3}{*}{ RECOMENDADO } & INDEFINIDO & 6 &, $0 \%$ \\
\hline & & MANHA & 13434 & $68,9 \%$ \\
\hline & & NOITE & 5264 & $27,0 \%$ \\
\hline
\end{tabular}




\begin{tabular}{|c|c|c|c|c|}
\hline & & TARDE & 786 & $4,0 \%$ \\
\hline & & Total & 19490 & $100,0 \%$ \\
\hline \multirow{18}{*}{2009} & \multirow[t]{6}{*}{ BAIXO } & INDEFINIDO & 3003 & $2,8 \%$ \\
\hline & & INTEGRAL & 20 &, $0 \%$ \\
\hline & & MANHA & 47954 & $44,2 \%$ \\
\hline & & NOITE & 51653 & $47,7 \%$ \\
\hline & & TARDE & 5748 & $5,3 \%$ \\
\hline & & Total & 108378 & $100,0 \%$ \\
\hline & \multirow[t]{6}{*}{ INTERMEDIÁRIO } & INDEFINIDO & 770 & $2,7 \%$ \\
\hline & & \begin{tabular}{|l} 
INTEGRAL \\
\end{tabular} & 6 &, $0 \%$ \\
\hline & & MANHA & 16886 & $60,0 \%$ \\
\hline & & \begin{tabular}{|l|} 
NOITE \\
\end{tabular} & 9183 & $32,7 \%$ \\
\hline & & TARDE & 1278 & $4,5 \%$ \\
\hline & & Total & 28123 & $100,0 \%$ \\
\hline & \multirow[t]{6}{*}{ RECOMENDADO } & INDEFINIDO & 521 & $2,7 \%$ \\
\hline & & INTEGRAL & 1 &, $0 \%$ \\
\hline & & MANHA & 13449 & $68,8 \%$ \\
\hline & & NOITE & 4719 & $24,1 \%$ \\
\hline & & TARDE & 865 & $4,4 \%$ \\
\hline & & Total & 19555 & $100,0 \%$ \\
\hline \multirow{7}{*}{2010} & \multirow[t]{7}{*}{ BAIXO } & INTERMEDIÁRIO & 24 &, $0 \%$ \\
\hline & & INTERMEDIARIO 1 & 24 &, $0 \%$ \\
\hline & & INTERMEDIARIO 2 & 27 &, $0 \%$ \\
\hline & & MANHA & 44362 & $46,6 \%$ \\
\hline & & NOITE & 45314 & $47,6 \%$ \\
\hline & & TARDE & 5364 & $5,6 \%$ \\
\hline & & Total & 95115 & $100,0 \%$ \\
\hline
\end{tabular}

Fonte: Elaborado pelo autor.

Como podemos verificar na tabela acima, apresentada acima, todos os desempenhos classificados como baixo em todos os anos, são predominantemente do turno noturno e os demais desempenhos, intermediário e recomendado são predominantemente do turno da manhã, como podemos confirmar pela análise do gráfico 21 . 
Desempenho em Português por ano, turno e classificação PROEB - 2006-2010.

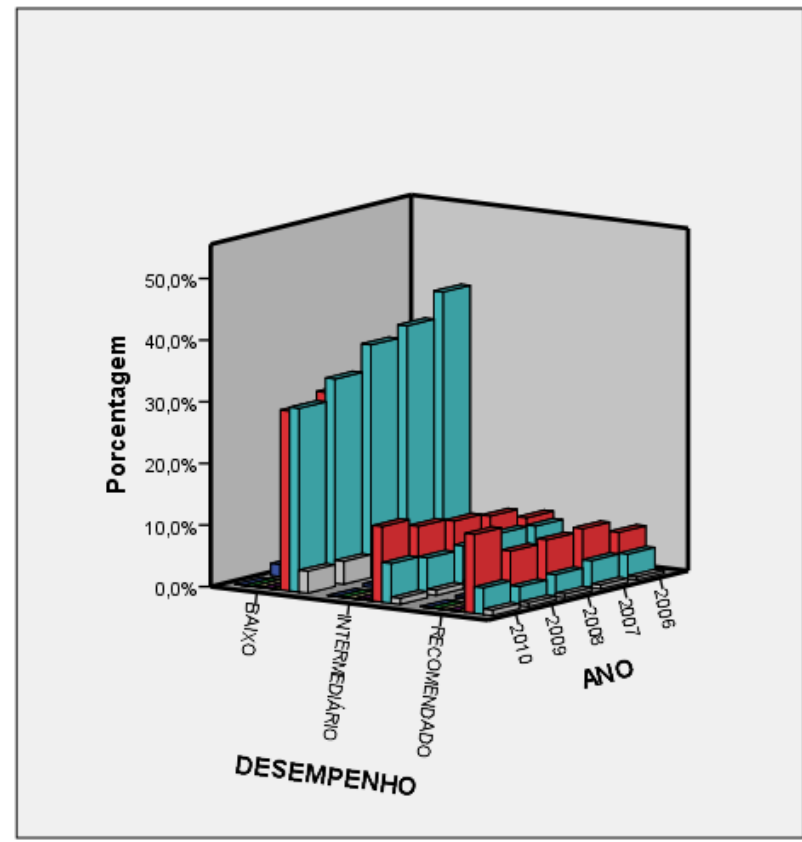

DC TURNO

GINDEFINIDO

INTEGRAL,

INTERMEDIÁRIO

INTERMEDIARIO

MANHA

NOITE

TTARDE

Fonte: Elaborado pelo autor.

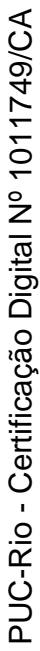

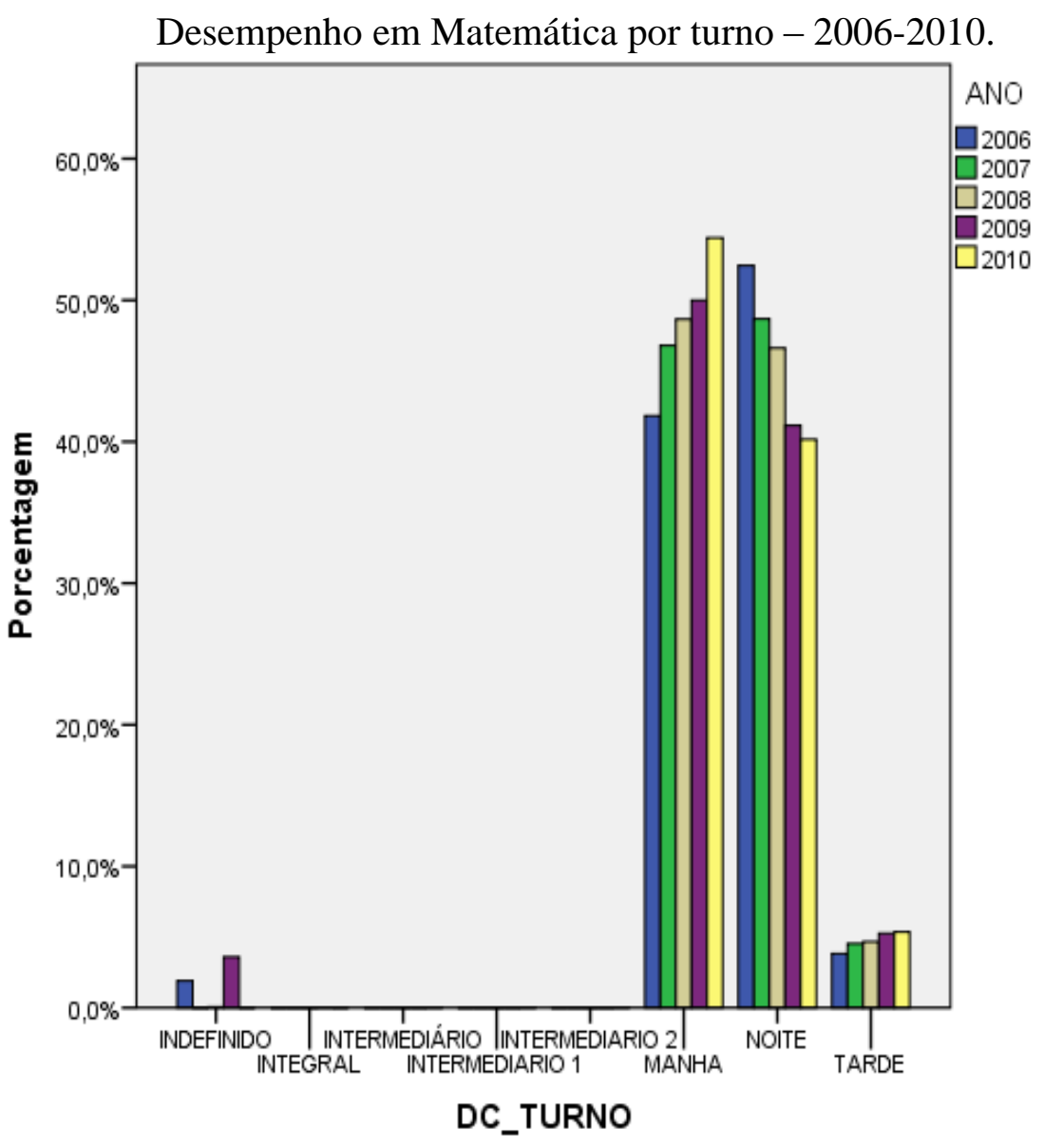

Fonte: Elaborado pelo autor. 
Ao longo dos anos podemos perceber que o número de alunos dentro do ano de 2006 é de 52,4 \% para o turno da noite, 48,7\% no turno da noite em $2007,48,7 \%$ no turno da manhã em 2008, 50\% no turno da manhã em 2009 e 54,4\% no turno da manhã para 2010. Esses resultados refletem o nosso banco de dados, em que temos mais notas de alunos do turno noturno nos primeiros anos (2006 - 2007) e nos demais há uma representação maior para o turno da manhã (2008-2010), o turno da tarde teve pequena representação, atingindo o máximo de 5,4\% em 2010, e o intermediário o resultado chega a aproximadamente em 0\%, e esse turno aparece somente em 2010.

Desempenho em Matemática por ano e turno - 2006-2010.

\begin{tabular}{|c|c|c|c|}
\hline \multirow{2}{*}{ ANO } & \multirow{2}{*}{ TURNO } & \multicolumn{2}{|l|}{ NOTA } \\
\hline & & SOMA & $\%$ \\
\hline \multirow{5}{*}{2006} & INDEFINIDO & 2549 & $1,9 \%$ \\
\hline & MANHA & 55879 & $41,8 \%$ \\
\hline & NOITE & 70055 & $52,4 \%$ \\
\hline & TARDE & 5110 & $3,8 \%$ \\
\hline & Total & 133593 & $100,0 \%$ \\
\hline \multirow{4}{*}{2007} & MANHA & 61984 & $46,8 \%$ \\
\hline & NOITE & 64483 & $48,7 \%$ \\
\hline & TARDE & 6002 & $4,5 \%$ \\
\hline & Total & 132469 & $100,0 \%$ \\
\hline \multirow{5}{*}{2008} & INDEFINIDO & 78 & $0,1 \%$ \\
\hline & MANHA & 68466 & $48,7 \%$ \\
\hline & NOITE & 65575 & $46,6 \%$ \\
\hline & TARDE & 6574 & $4,7 \%$ \\
\hline & Total & 140693 & $100,0 \%$ \\
\hline \multirow{6}{*}{2009} & INDEFINIDO & 5471 & $3,6 \%$ \\
\hline & INTEGRAL & 29 & $0,0 \%$ \\
\hline & MANHA & 76036 & $50,0 \%$ \\
\hline & NOITE & 62597 & $41,1 \%$ \\
\hline & TARDE & 7993 & $5,3 \%$ \\
\hline & Total & 152126 & $100,0 \%$ \\
\hline \multirow{7}{*}{2010} & INTERMEDIÁRIO & 20 & $0,0 \%$ \\
\hline & INTERMEDIARIO 1 & 34 & $0,0 \%$ \\
\hline & INTERMEDIARIO 2 & 34 & $0,0 \%$ \\
\hline & MANHA & 81243 & $54,4 \%$ \\
\hline & NOITE & 59978 & $40,2 \%$ \\
\hline & TARDE & 7998 & $5,4 \%$ \\
\hline & Total & 149307 & $100,0 \%$ \\
\hline
\end{tabular}

Fonte: Elaborado pelo autor. 


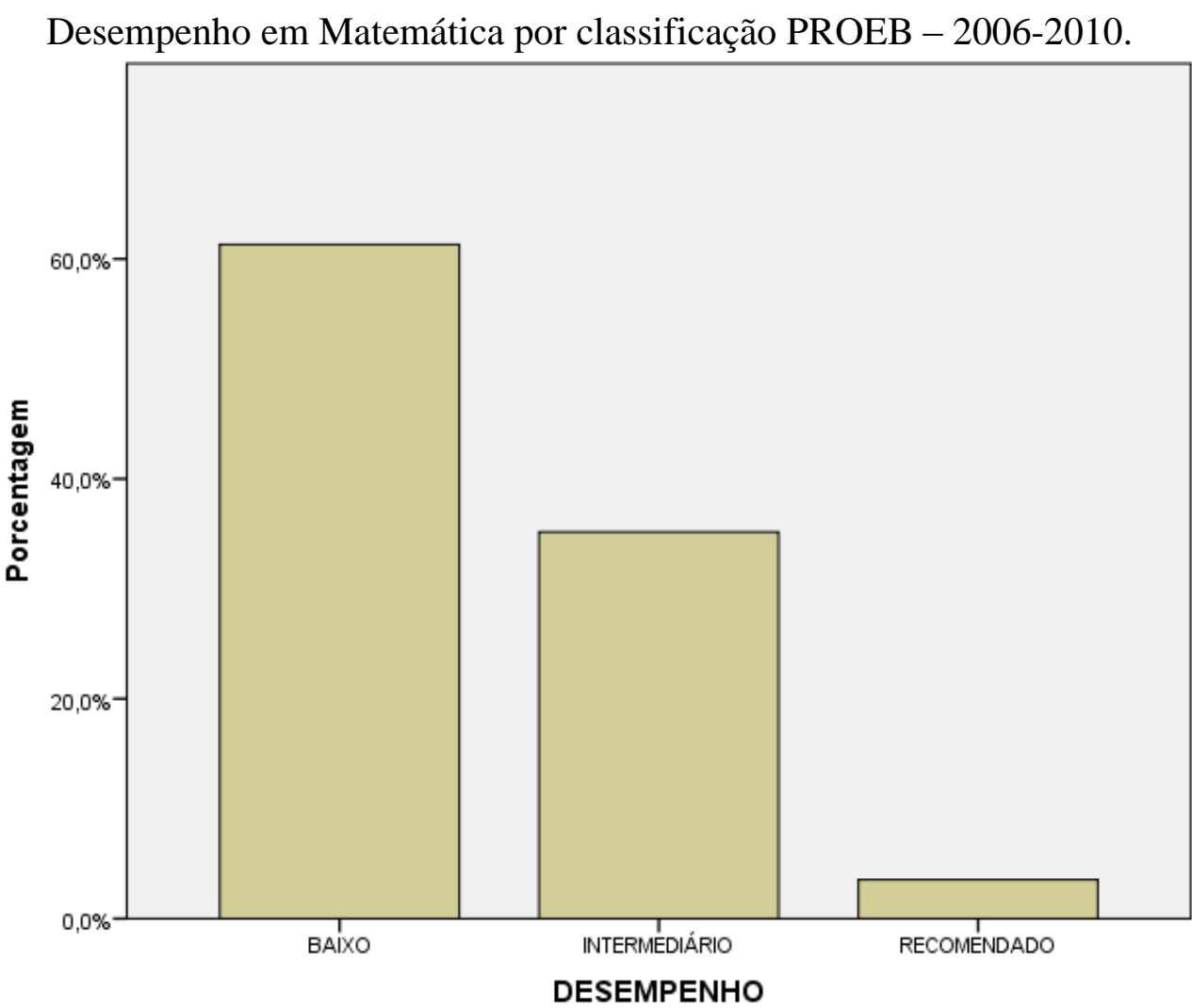

Fonte: Elaborado pelo autor.

Desempenho em Matemática por classificação PROEB - 2006-2010.

\begin{tabular}{l|l|l}
\hline \multirow{2}{*}{ DESEMPENHO } & \multicolumn{2}{|l}{ NOTA } \\
\cline { 2 - 3 } & SOMA & $\%$ \\
\hline BAIXO & 434244 & $61,3 \%$ \\
\hline INTERMEDIÁRIO & 248982 & $35,2 \%$ \\
\hline RECOMENDADO & 24962 & $3,5 \%$ \\
\hline Total & 708188 & $100,0 \%$ \\
\hline
\end{tabular}

Fonte: Elaborado pelo autor.

A maioria das notas dos alunos avaliados entre os anos de 2006-2010 obtiveram desempenho baixo $(61,3 \%)$ no PROEB, seguido por intermediário $(35,2 \%)$ e apenas 3,5\% dos estudantes obtiveram o desempenho recomendado para o terceiro ano do EM. 


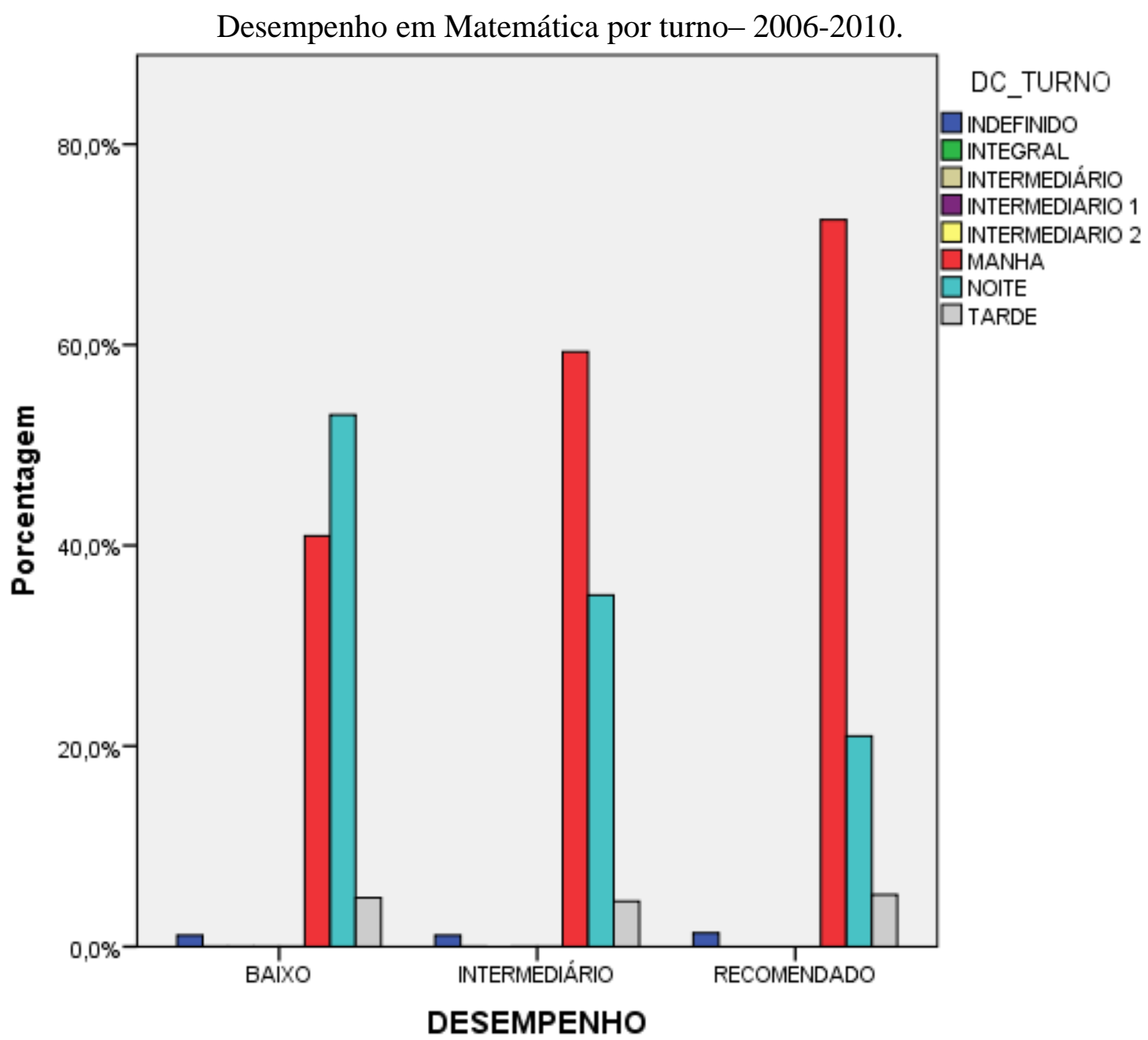

Fonte: Elaborado pelo autor.

No geral considerando os dados de 2006 -2010 de matemática, o desempenho baixo é predominantemente encontrado no turno da noite (53\%) e o desempenho intermediário $(59,3 \%)$ e recomendado $(72,5 \%)$ ao turno da manhã. 
Desempenho em Matemática por turno e classificação PROEB - 2006-2010.

\begin{tabular}{|c|c|c|c|}
\hline \multirow{2}{*}{ DESEMPENHO } & \multirow{2}{*}{ TURNO } & \multicolumn{2}{|l|}{ NOTA } \\
\hline & & SOMA & $\%$ \\
\hline \multirow{9}{*}{ BAIXO } & INDEFINIDO & 4945 & $1,1 \%$ \\
\hline & INTEGRAL & 23 & $0,0 \%$ \\
\hline & INTERMEDIÁRIO & 20 & $0,0 \%$ \\
\hline & INTERMEDIARIO 1 & 27 & $0,0 \%$ \\
\hline & INTERMEDIARIO 2 & 22 & $0,0 \%$ \\
\hline & MANHA & 177864 & $41,0 \%$ \\
\hline & NOITE & 230187 & $53,0 \%$ \\
\hline & TARDE & 21156 & $4,9 \%$ \\
\hline & Total & 434244 & $100,0 \%$ \\
\hline \multirow{8}{*}{ INTERMEDIÁRIO } & INDEFINIDO & 2813 & $1,1 \%$ \\
\hline & INTEGRAL & 6 & $0,0 \%$ \\
\hline & INTERMEDIARIO 1 & 7 & $0,0 \%$ \\
\hline & INTERMEDIARIO 2 & 12 & $0,0 \%$ \\
\hline & MANHA & 147654 & $59,3 \%$ \\
\hline & NOITE & 87260 & $35,0 \%$ \\
\hline & TARDE & 11230 & $4,5 \%$ \\
\hline & Total & 248982 & $100,0 \%$ \\
\hline \multirow{5}{*}{ RECOMENDADO } & INDEFINIDO & 340 & $1,4 \%$ \\
\hline & MANHA & 18090 & $72,5 \%$ \\
\hline & NOITE & 5241 & $21,0 \%$ \\
\hline & TARDE & 1291 & $5,2 \%$ \\
\hline & Total & 24962 & $100,0 \%$ \\
\hline \multirow{9}{*}{ Total } & INDEFINIDO & 8098 & $1,1 \%$ \\
\hline & INTEGRAL & 29 & $0,0 \%$ \\
\hline & INTERMEDIÁRIO & 20 & $0,0 \%$ \\
\hline & INTERMEDIARIO 1 & 34 & $0,0 \%$ \\
\hline & INTERMEDIARIO 2 & 34 & $0,0 \%$ \\
\hline & MANHA & 343608 & $48,5 \%$ \\
\hline & NOITE & 322688 & $45,6 \%$ \\
\hline & TARDE & 33677 & $4,8 \%$ \\
\hline & Total & 708188 & $100,0 \%$ \\
\hline
\end{tabular}

Fonte: Elaborado pelo autor. 
Desempenho em Matemática por ano, turno e classificação PROEB - 2006-2010.

\begin{tabular}{|c|c|c|c|c|}
\hline \multirow{2}{*}{ ANO } & \multirow{2}{*}{ DESEMPENHO } & \multirow{2}{*}{ TURNO } & \multicolumn{2}{|l|}{ NOTA } \\
\hline & & & SOMA & $\%$ \\
\hline \multirow{15}{*}{2006} & \multirow[t]{5}{*}{ BAIXO } & INDEFINIDO & 1844 & $2,1 \%$ \\
\hline & & MANHA & 31666 & $35,3 \%$ \\
\hline & & NOITE & 52735 & $58,8 \%$ \\
\hline & & TARDE & 3461 & $3,9 \%$ \\
\hline & & Total & 89706 & $100,0 \%$ \\
\hline & \multirow[t]{5}{*}{ INTERMEDIÁRIO } & INDEFINIDO & 650 & $1,6 \%$ \\
\hline & & MANHA & 21683 & $54,0 \%$ \\
\hline & & NOITE & 16354 & $40,7 \%$ \\
\hline & & TARDE & 1493 & $3,7 \%$ \\
\hline & & Total & 40180 & $100,0 \%$ \\
\hline & \multirow[t]{5}{*}{ RECOMENDADO } & INDEFINIDO & 55 & $1,5 \%$ \\
\hline & & MANHA & 2530 & $68,2 \%$ \\
\hline & & NOITE & 966 & $26,1 \%$ \\
\hline & & TARDE & 156 & $4,2 \%$ \\
\hline & & Total & 3707 & $100,0 \%$ \\
\hline \multirow{12}{*}{2007} & \multirow[t]{4}{*}{ BAIXO } & MANHA & 32804 & $39,6 \%$ \\
\hline & & NOITE & 46040 & $55,6 \%$ \\
\hline & & TARDE & 3931 & $4,7 \%$ \\
\hline & & Total & 82775 & $100,0 \%$ \\
\hline & \multirow[t]{4}{*}{ INTERMEDIÁRIO } & MANHA & 26155 & $57,6 \%$ \\
\hline & & NOITE & 17378 & $38,3 \%$ \\
\hline & & TARDE & 1896 & $4,2 \%$ \\
\hline & & Total & 45429 & $100,0 \%$ \\
\hline & \multirow[t]{4}{*}{ RECOMENDADO } & MANHA & 3025 & $70,9 \%$ \\
\hline & & NOITE & 1065 & $25,0 \%$ \\
\hline & & TARDE & 175 & $4,1 \%$ \\
\hline & & Total & 4265 & $100,0 \%$ \\
\hline
\end{tabular}




\begin{tabular}{|c|c|c|c|c|}
\hline \multirow{14}{*}{2008} & \multirow[t]{5}{*}{ BAIXO } & INDEFINIDO & 49 &, $1 \%$ \\
\hline & & MANHA & 35848 & $41,2 \%$ \\
\hline & & NOITE & 46823 & $53,8 \%$ \\
\hline & & TARDE & 4266 & $4,9 \%$ \\
\hline & & Total & 86986 & $100,0 \%$ \\
\hline & \multirow[t]{5}{*}{ INTERMEDIÁRIO } & INDEFINIDO & 29 &, $1 \%$ \\
\hline & & MANHA & 28675 & $59,3 \%$ \\
\hline & & NOITE & 17607 & $36,4 \%$ \\
\hline & & TARDE & 2081 & $4,3 \%$ \\
\hline & & Total & 48392 & $100,0 \%$ \\
\hline & \multirow{4}{*}{ RECOMENDADO } & MANHA & 3943 & $74,2 \%$ \\
\hline & & NOITE & 1145 & $21,5 \%$ \\
\hline & & TARDE & 227 & $4,3 \%$ \\
\hline & & Total & 5315 & $100,0 \%$ \\
\hline \multirow{17}{*}{2009} & \multirow[t]{6}{*}{ BAIXO } & INDEFINIDO & 3052 & $3,3 \%$ \\
\hline & & INTEGRAL & 23 &, $0 \%$ \\
\hline & & MANHA & 40266 & $43,3 \%$ \\
\hline & & NOITE & 44559 & $48,0 \%$ \\
\hline & & TARDE & 4995 & $5,4 \%$ \\
\hline & & Total & 92895 & $100,0 \%$ \\
\hline & \multirow[t]{6}{*}{ INTERMEDIÁRIO } & INDEFINIDO & 2134 & $4,0 \%$ \\
\hline & & INTEGRAL & 6 &, $0 \%$ \\
\hline & & MANHA & 31860 & $59,4 \%$ \\
\hline & & NOITE & 16996 & $31,7 \%$ \\
\hline & & TARDE & 2669 & $5,0 \%$ \\
\hline & & Total & 53665 & $100,0 \%$ \\
\hline & \multirow[t]{5}{*}{ RECOMENDADO } & INDEFINIDO & 285 & $5,1 \%$ \\
\hline & & MANHA & 3910 & $70,2 \%$ \\
\hline & & NOITE & 1042 & $18,7 \%$ \\
\hline & & TARDE & 329 & $5,9 \%$ \\
\hline & & Total & 5566 & $100,0 \%$ \\
\hline
\end{tabular}




\begin{tabular}{|c|c|c|c|c|}
\hline & BAIXO & INTERMEDIÁRIO & 20 &, $0 \%$ \\
\hline & & INTERMEDIARIO 1 & 27 &, $0 \%$ \\
\hline & & INTERMEDIARIO 2 & 22 &, $0 \%$ \\
\hline & & MANHA & 37280 & $45,5 \%$ \\
\hline & & NOITE & 40030 & $48,9 \%$ \\
\hline & & TARDE & 4503 & $5,5 \%$ \\
\hline & & Total & 81882 & $100,0 \%$ \\
\hline & INTERMEDIÁRIO & INTERMEDIARIO 1 & 7 &, $0 \%$ \\
\hline 2010 & & INTERMEDIARIO 2 & 12 &, $0 \%$ \\
\hline & & MANHA & 39281 & $64,1 \%$ \\
\hline & & NOITE & 18925 & $30,9 \%$ \\
\hline & & TARDE & 3091 & $5,0 \%$ \\
\hline & & Total & 61316 & $100,0 \%$ \\
\hline & RECOMENDADO & MANHA & 4682 & $76,6 \%$ \\
\hline & & NOITE & 1023 & $16,7 \%$ \\
\hline & & TARDE & 404 & $6,6 \%$ \\
\hline & & Total & 6109 & $100,0 \%$ \\
\hline
\end{tabular}

Fonte: Elaborado pelo autor.

Como podemos verificar na tabela acima, todos os desempenhos classificados como baixo em todos os anos, são predominantes no turno da noite e os demais desempenhos, intermediário e recomendado são predominantes no turno da manhã, como podemos visualizar abaixo no gráfico 23 .

Desempenho em Matemática por ano, turno e classificação PROEB - 2006-2010.

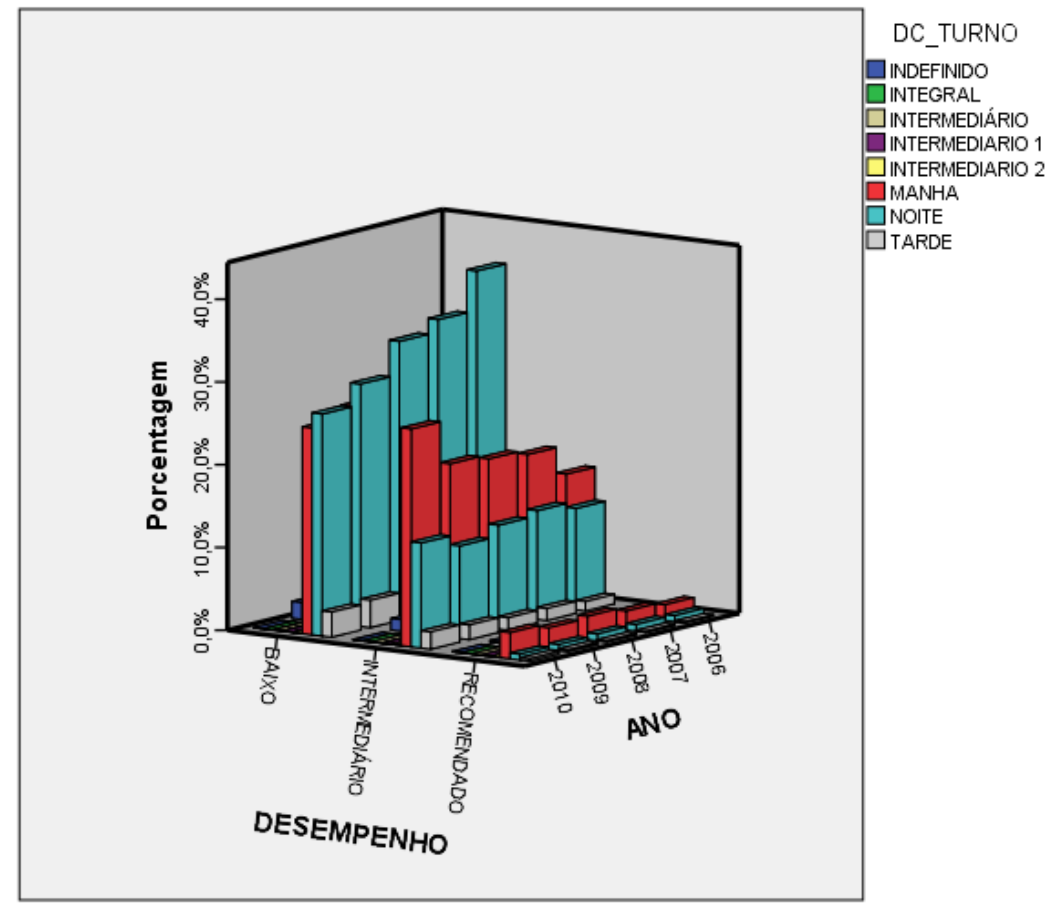

Fonte: Elaborado pelo autor. 
Desempenho em Matemática por ano e classificação PROEB - 2006-2010.

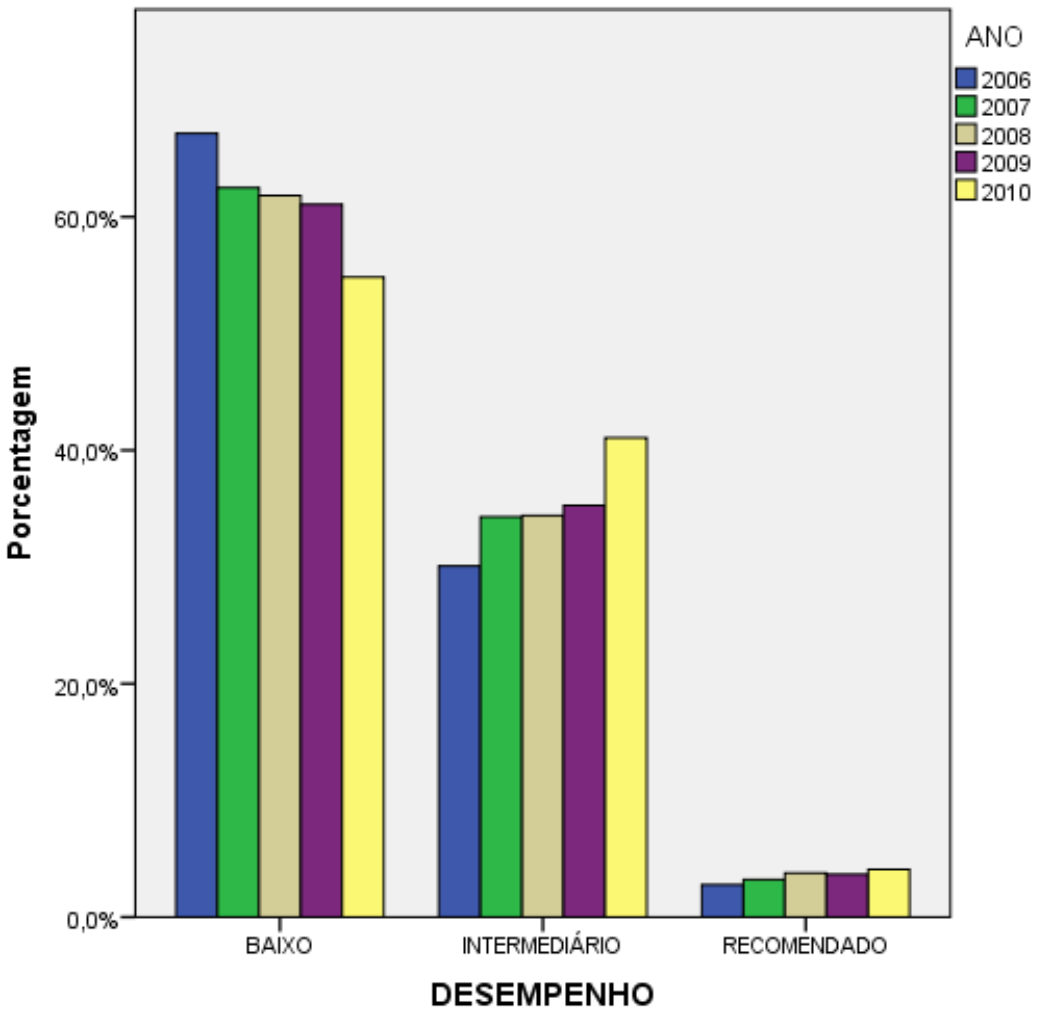

Fonte: Elaborado pelo autor.

Desempenho em Português por ano e classificação PROEB - 2006-2010.

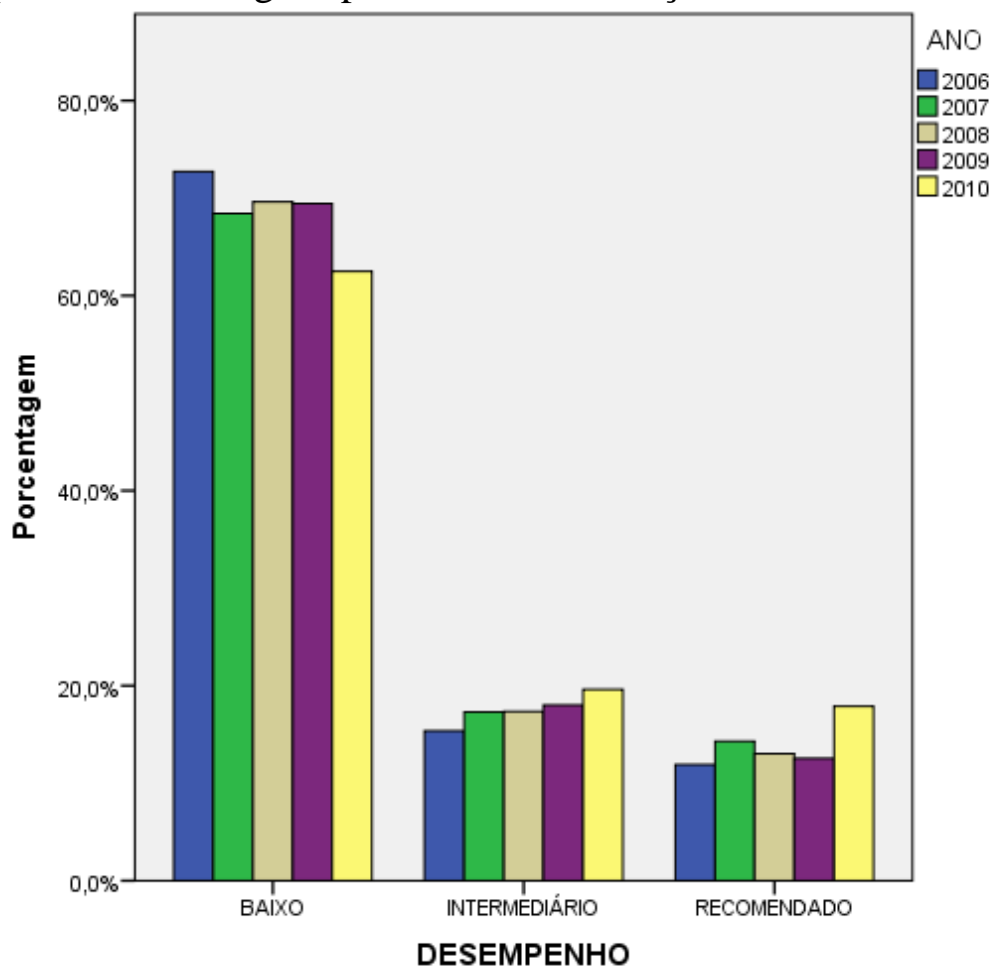

Fonte: Elaborado pelo autor. 
Analisando os gráficos 24 e 25 constatamos que em ambas as disciplinas avaliadas pelo PROEB entre os anos de 2006 e 2010, houve queda leve e gradativa do número de estudantes com baixo desempenho e por consequência aumento dos estudantes com desempenho intermediário e recomendado. Contudo, em todos os anos sobresai o número de estudantes com desempenho considerado baixo de acordo com os parâmetros do SIMAVE.

Com relação a análise espacial da proficiência média dos estudantes, verificamos que a sitação dos municípios mineiros durante o período analisado não sofreu grades variações. Como verificamos no mapa 4, o desempenho médio em matemática dos estudantes do $3^{\circ}$ ano do ensino médio em 2006 por município foi baixo, sendo que a maior parte dos municípios do noroeste, norte e Jequitinhonha apresentaram desempenho médio correspondente ao esperado para estudantes do $9^{\circ}$ ano do ensino fundamento. Nesse ano, 30 municípios não foram avaliados. Dos 853 municípios do Estado, apenas os estudantes de $112(13,1 \%)$ alcançaram o desempenho médio considerado intermediário pelo SIMAVE e em nenhum município mineiro o desempenho médio dos estudantes ficou dentro do parâmetro recomendado para matemática. 


\section{2.}

\section{Mapas temáticos - Desempenho médio}

MINAS GERAIS - DESEMPENHO DOS ESTUDANTES DO $3^{\circ}$ ANO DO EM DA REDE ESTADUAL EM MATEMÁTICA-PROEB - 2006.

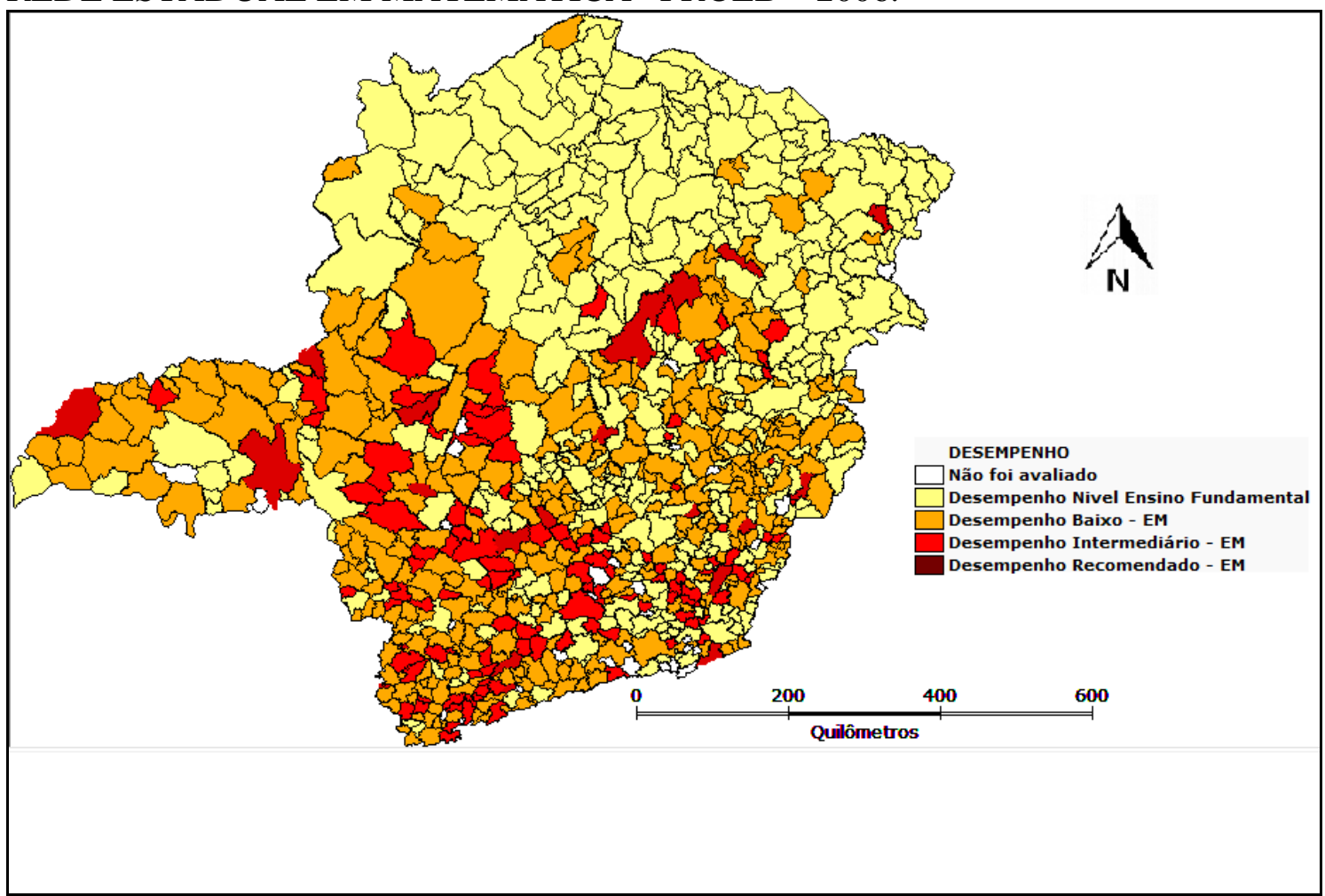

Fonte: Elaborado pelo autor.

MINAS GERAIS - DESEMPENHO DOS ESTUDANTES DO $3^{\circ}$ ANO DO EM DA REDE ESTADUAL EM MATEMÁTICA- PROEB - 2007.

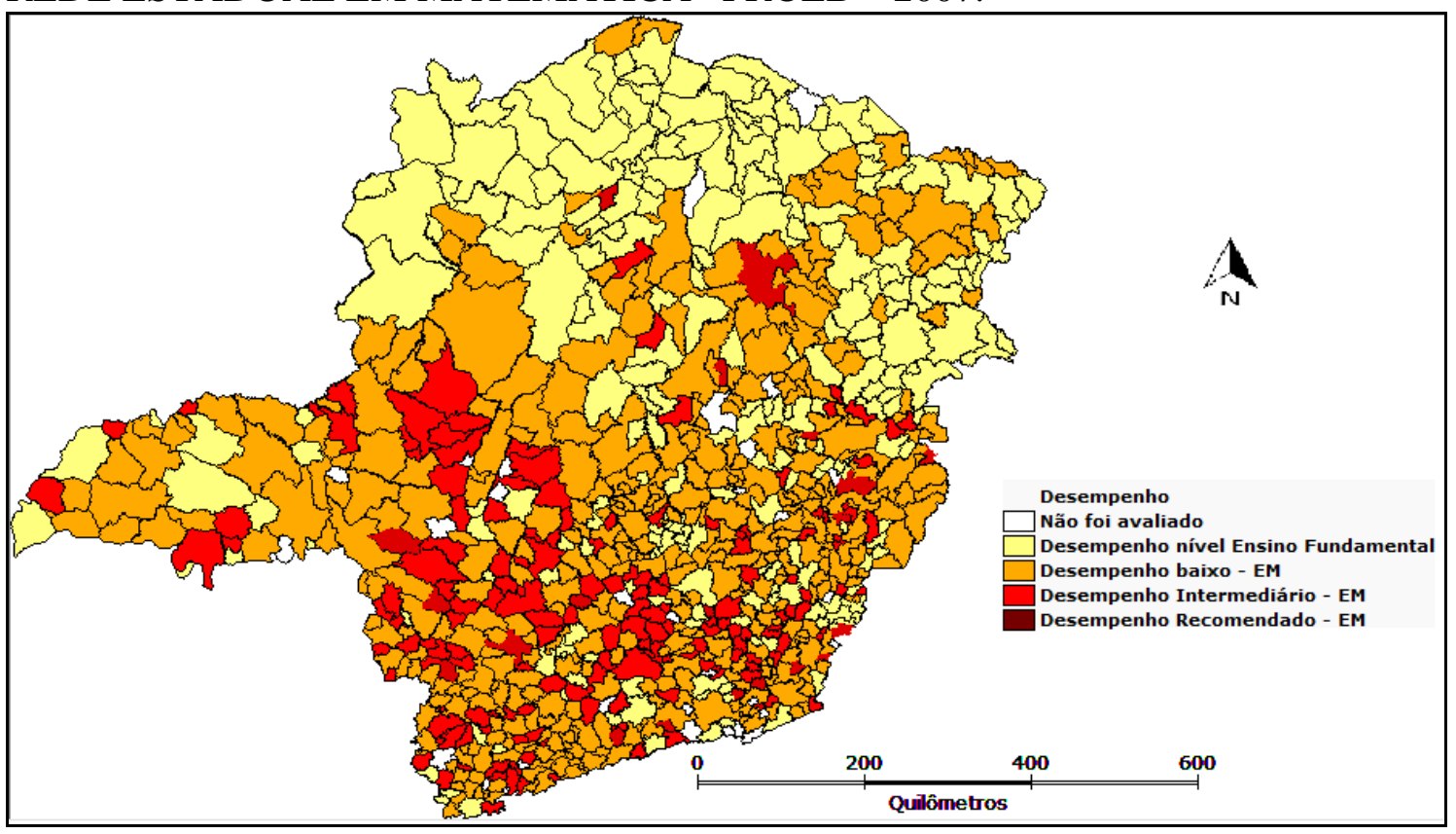

Fonte: Elaborado pelo autor. 
MINAS GERAIS - DESEMPENHO DOS ESTUDANTES DO $3^{\circ}$ ANO DO EM DA REDE ESTADUAL EM MATEMÁTICA- PROEB - 2008.

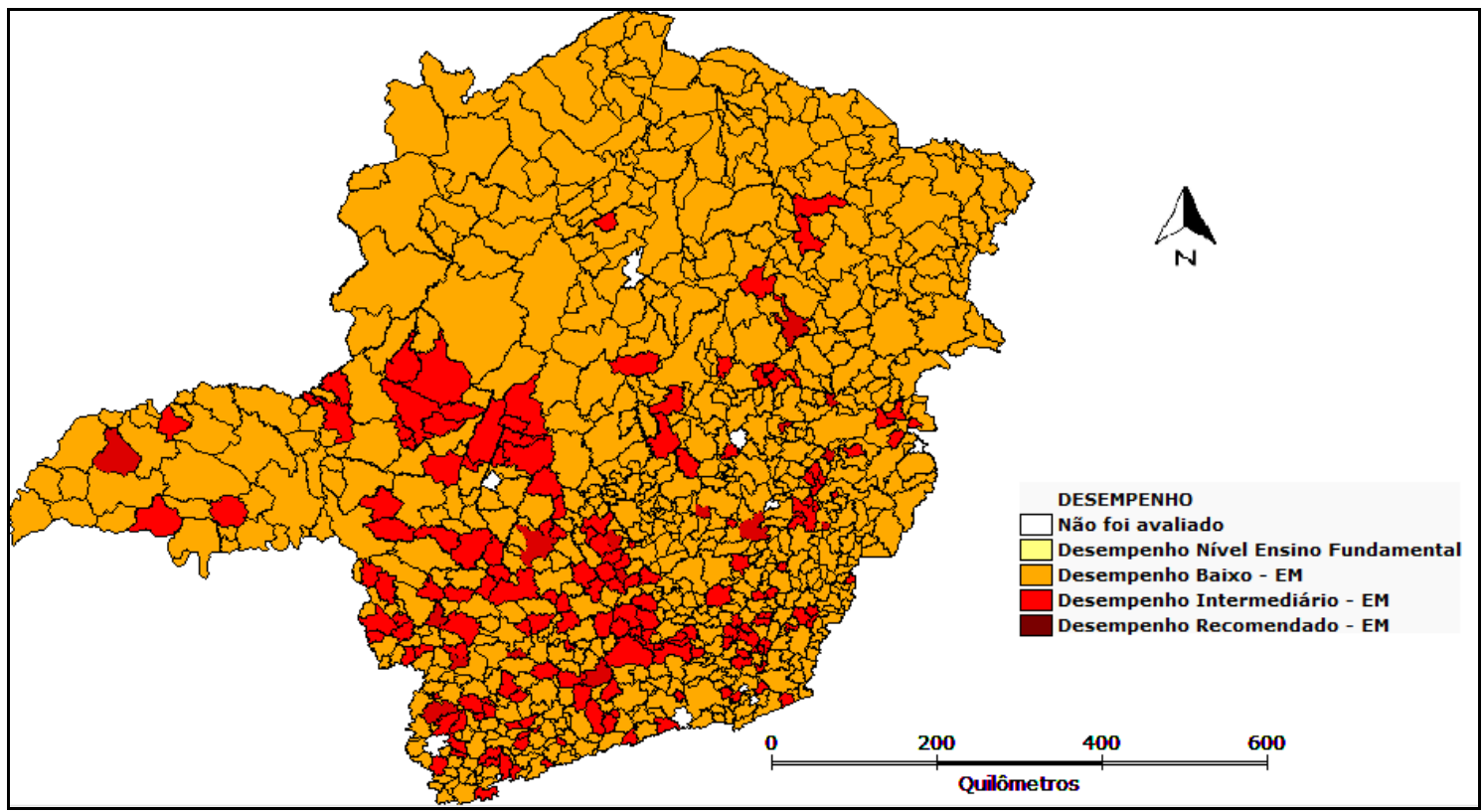

Fonte: Elaborado pelo autor.

MINAS GERAIS - DESEMPENHO DOS ESTUDANTES DO $3^{\circ}$ ANO DO EM DA REDE ESTADUAL EM MATEMÁTICA- PROEB - 2009.

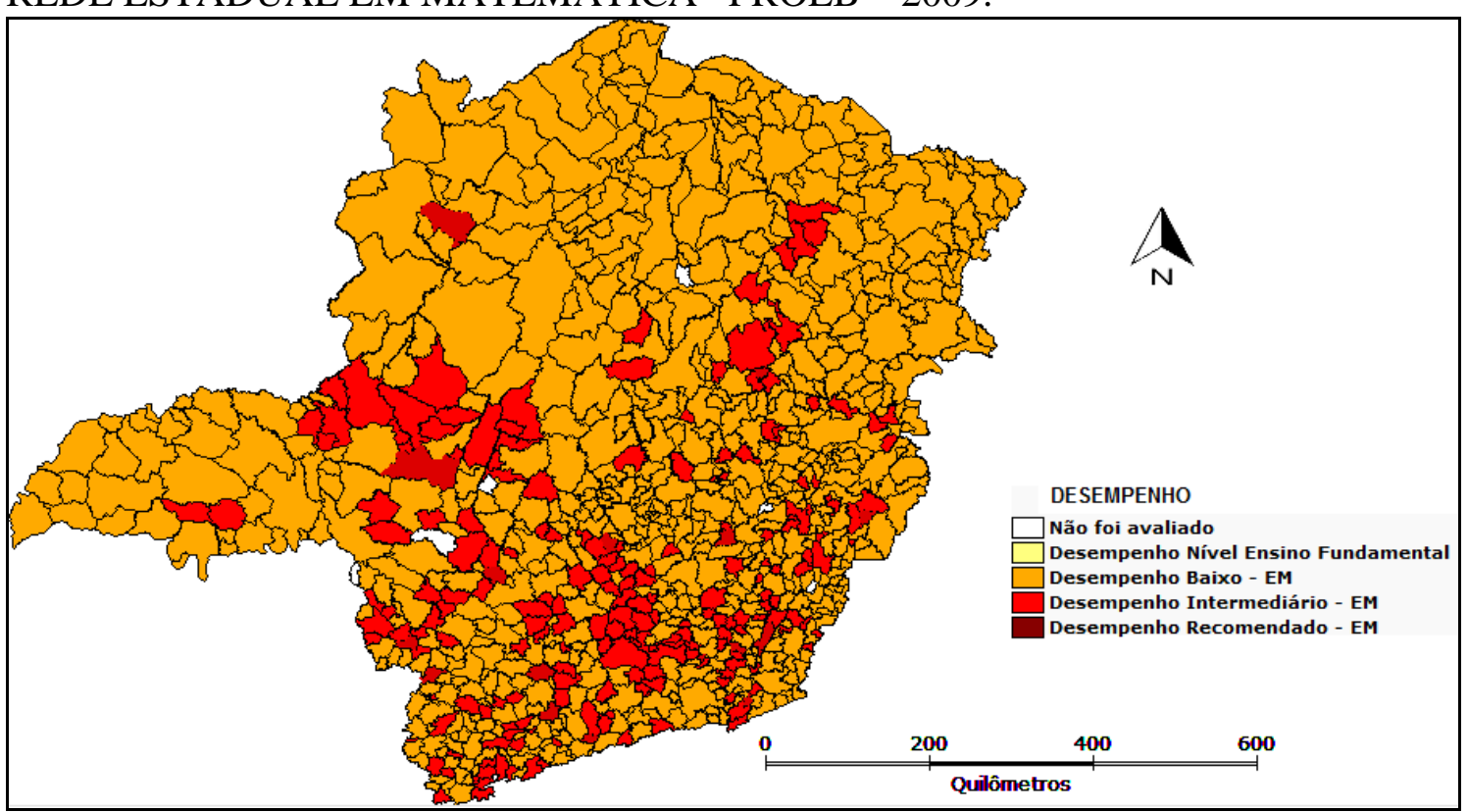

Fonte: Elaborado pelo autor. 
MINAS GERAIS - DESEMPENHO DOS ESTUDANTES DO $3^{\circ}$ ANO DO EM DA REDE ESTADUAL EM MATEMÁTICA- PROEB - 2010.

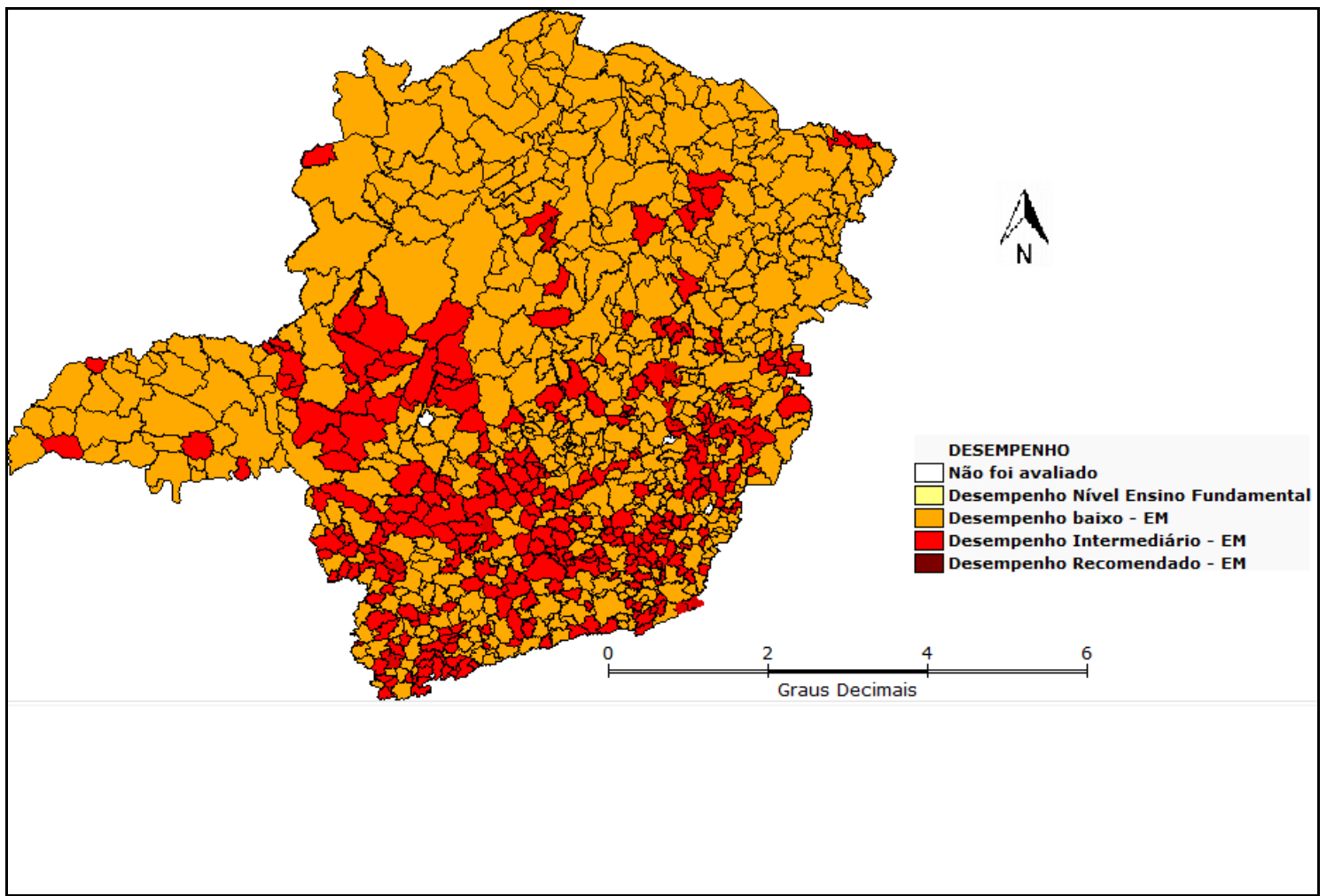

Fonte: Elaborado pelo autor.

MINAS GERAIS - DESEMPENHO DOS ESTUDANTES DO $3^{\circ}$ ANO DO EM DA REDE ESTADUAL EM PORTUGUÊS - PROEB - 2006.

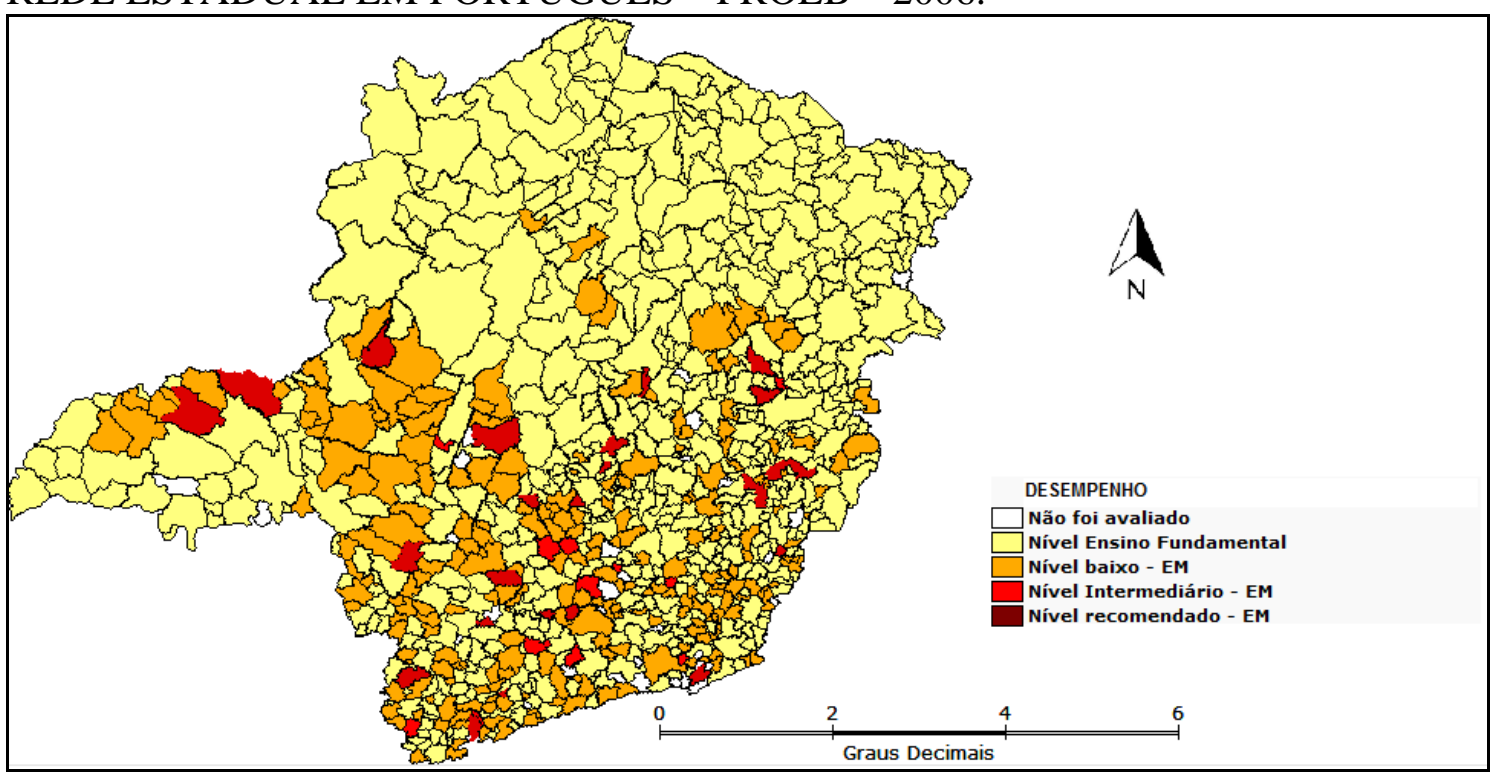

Fonte: Elaborado pelo autor. 
MINAS GERAIS - DESEMPENHO DOS ESTUDANTES DO $3^{\circ}$ ANO DO EM DA REDE ESTADUAL EM PORTUGUÊS - PROEB - 2007.

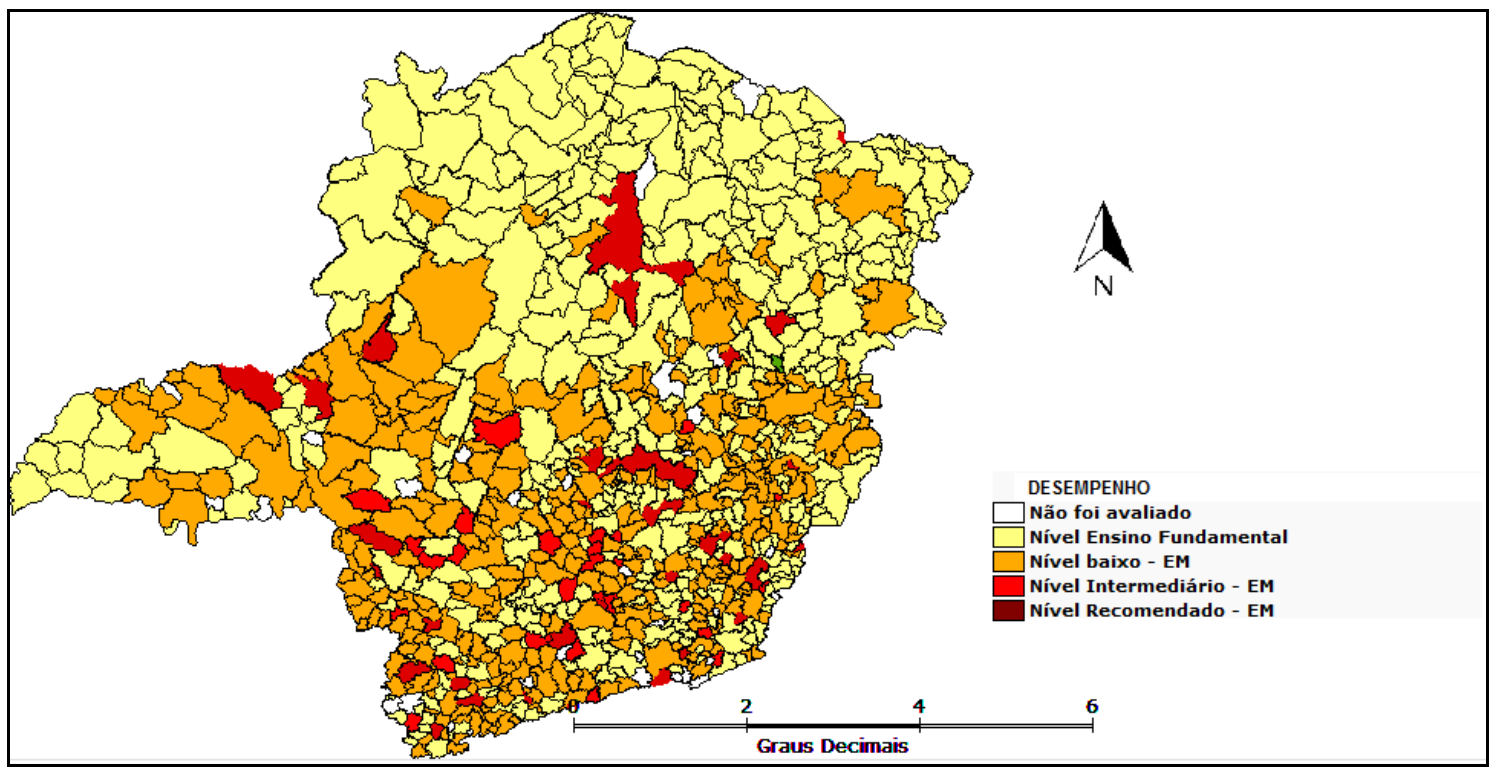

Fonte: Elaborado pelo autor.

MINAS GERAIS - DESEMPENHO DOS ESTUDANTES DO $3^{\circ}$ ANO DO EM DA REDE ESTADUAL EM PORTUGUÊS - PROEB - 2008.

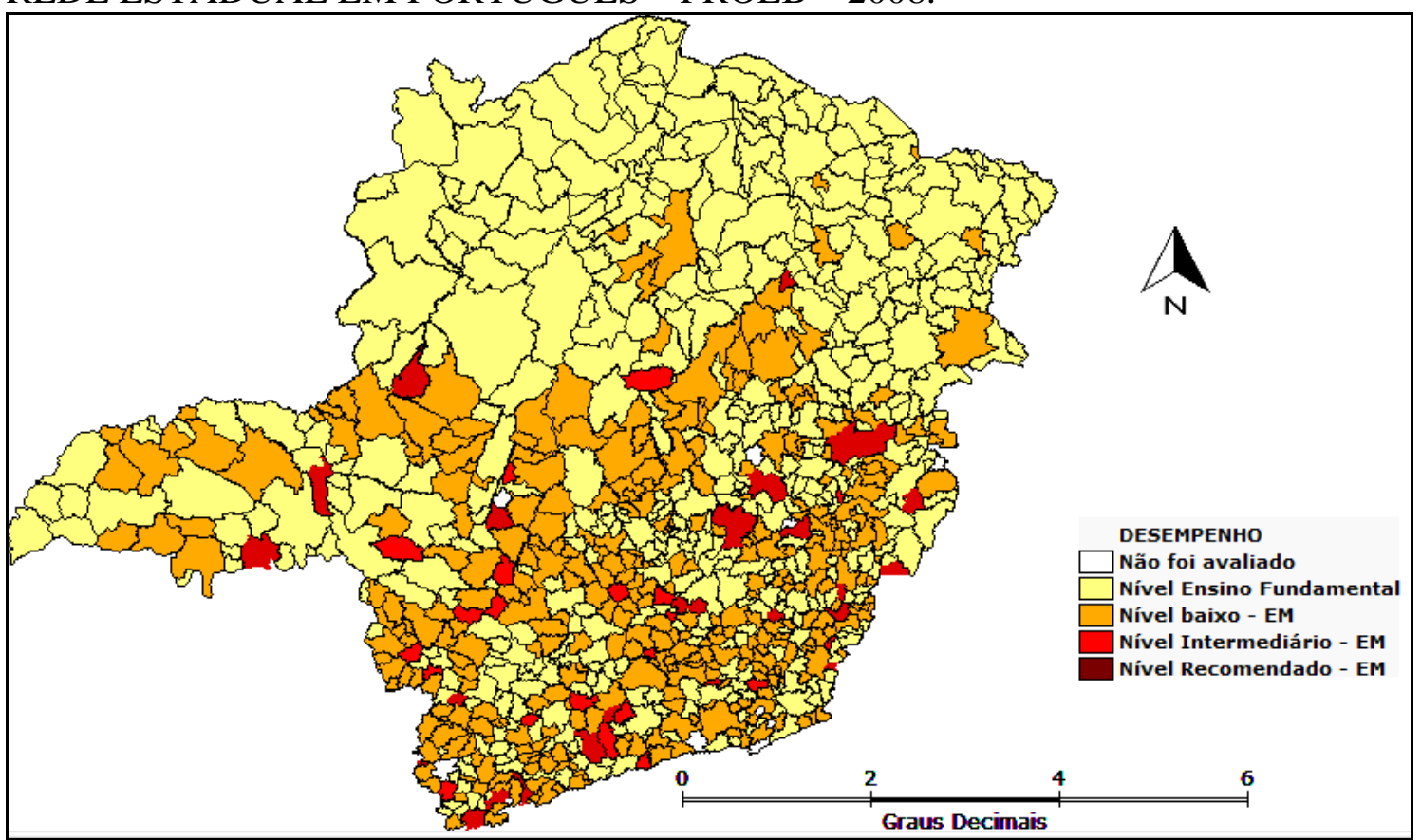

Fonte: Elaborado pelo autor. 
MINAS GERAIS - DESEMPENHO DOS ESTUDANTES DO $3^{\circ}$ ANO DO EM DA REDE ESTADUAL EM PORTUGUÊS - PROEB - 2009.

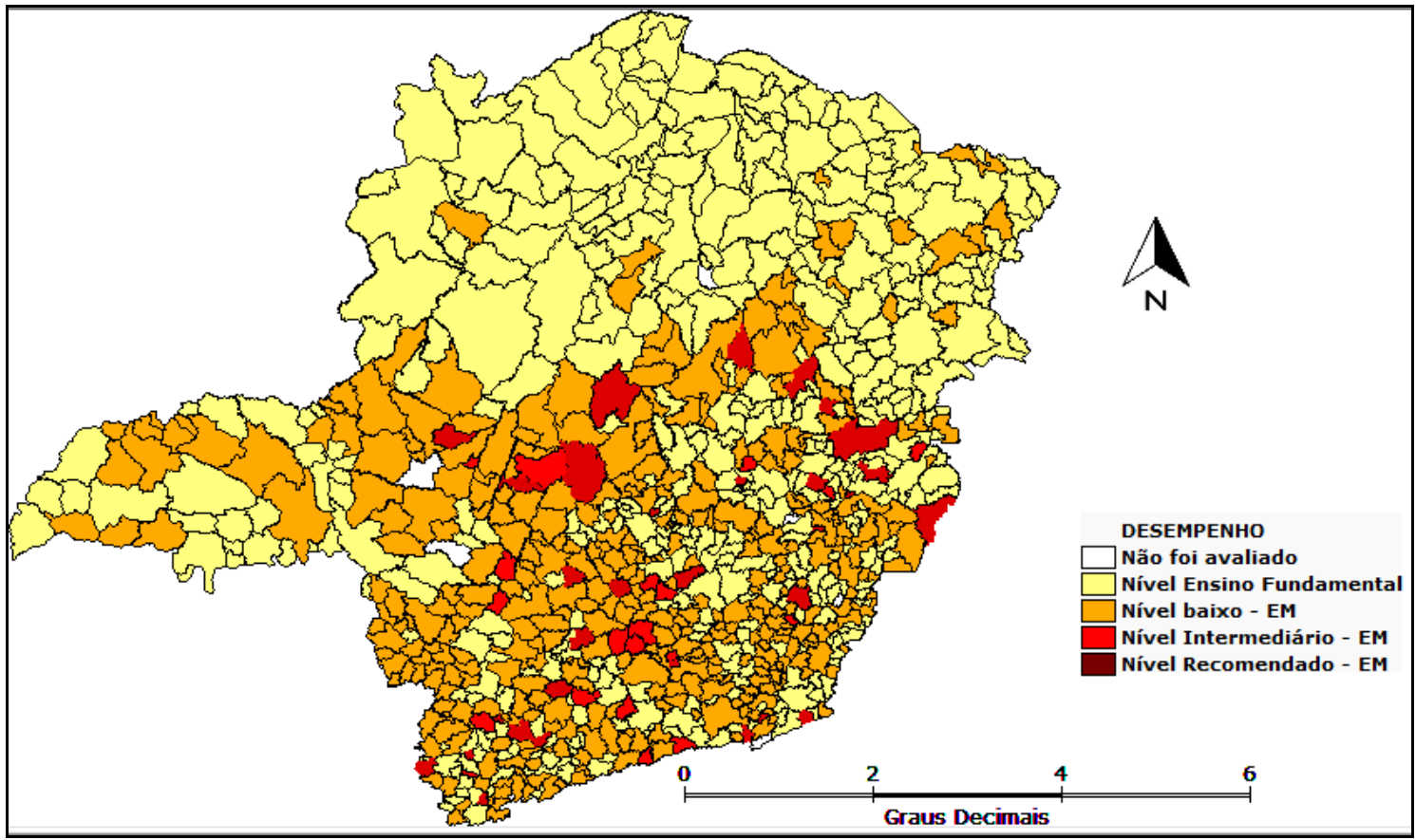

Fonte: Elaborado pelo autor.

MINAS GERAIS - DESEMPENHO DOS ESTUDANTES DO $3^{\circ}$ ANO DO EM DA REDE ESTADUAL EM PORTUGUÊS - PROEB - 2010.

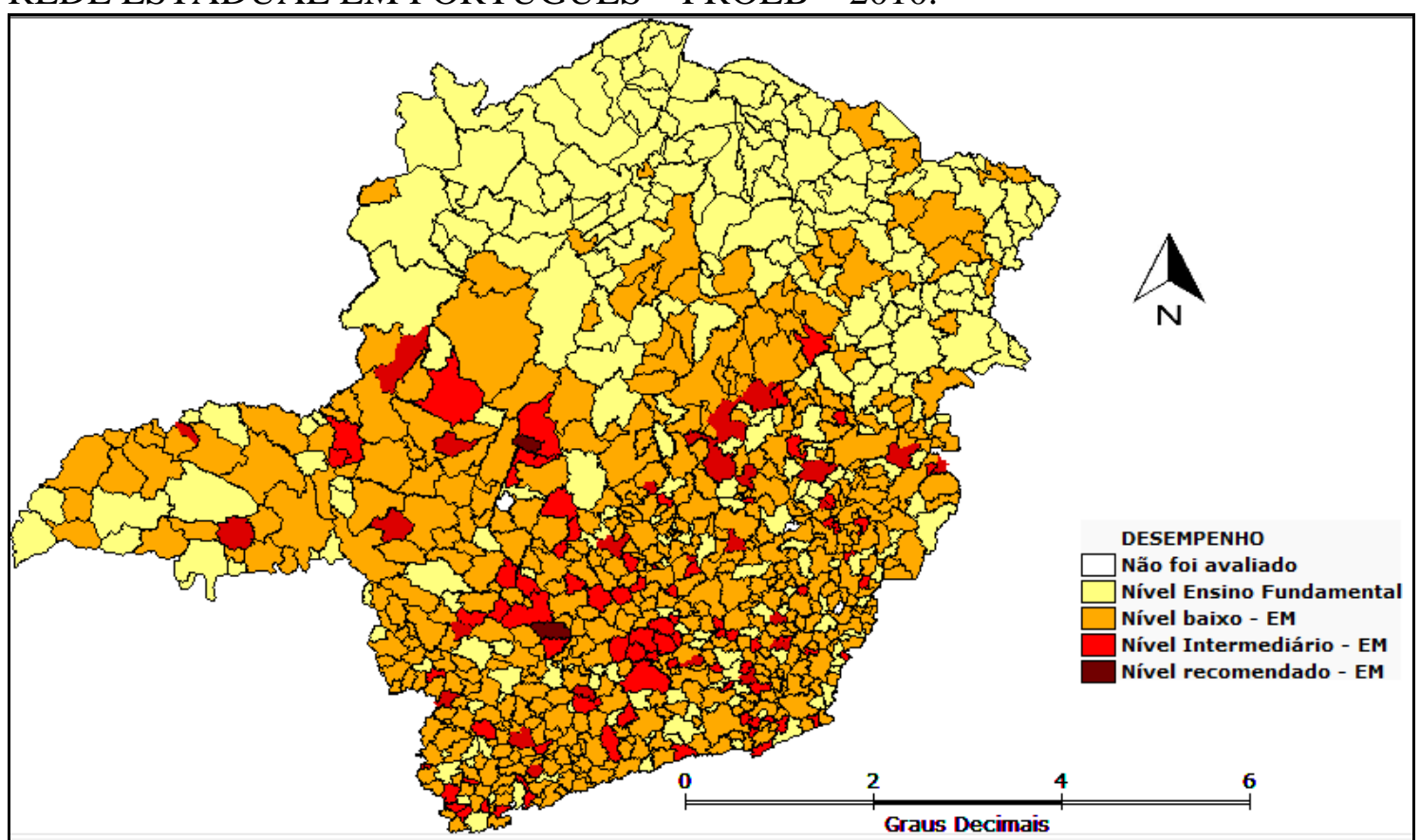

Fonte: Elaborado pelo autor. 


\section{3.}

\section{Análise por nota média dos municípios e indicadores sócio demográficos}

Análise por nota média dos municípios e indicadores sócio demográficos

Proficiência dos estudantes por cidade em matemática - 2006

A análise dos dados das avaliações de matemática e português dos anos de 2006 a 2010, com base nas estatísticas resumo tal como a média, erro padrão da média, desvio padrão, variância, coeficiente de variação, máximo, mínimo, mediana, 5,25,75,95,99 percentil, diferença entre o máximo valor e o mínimo e a frequência bruta, resultou na descrição constante nas tabelas abaixo.

MUNICÍPIOS COM PIOR E MELHOR MÉDIA, ERRO PADRÃO DA MÉDIA, DESVIO PADRÃO, VARIÂNCIA, COEFICIENTE DE VARIAÇÃO, MÁXIMO, MÍNIMO, MEDIANA, 5,25,75,95,99 PERCENTIL, DIFERENÇA ENTRE O MÁXIMO VALOR E O MÍNIMO E A FREQUÊNCIA BRUTA NO DESEMPENHO EM MAT - 2006.

\begin{tabular}{|c|c|c|c|c|}
\hline \multicolumn{5}{|l|}{ MATEMÁTICA 2006} \\
\hline \multirow{2}{*}{$\begin{array}{l}\text { Estatísticas } \\
\text { Média }\end{array}$} & \multicolumn{2}{|l|}{ Melhor } & \multicolumn{2}{|l|}{ Pior } \\
\hline & \begin{tabular}{|ll} 
SENHORA & DE \\
OLIVEIRA
\end{tabular} & 348,83 & ARACITABA & 187,43 \\
\hline Erro padrão da média & BELO HORIZONTE & 0,44 & $\begin{array}{|ll|}\text { PEDRA } & \text { DO } \\
\text { ANTA } & \end{array}$ & 19,28 \\
\hline Desvio padrão & TAPARUBA & 21,87 & $\begin{array}{l}\text { SANTA RITA } \\
\text { DE MINAS }\end{array}$ & 68,50 \\
\hline Variância & TAPARUBA & 478,10 & $\begin{array}{l}\text { SANTA RITA } \\
\text { DE MINAS }\end{array}$ & 4692,16 \\
\hline $\begin{array}{ll}\text { Coeficiente } & \mathrm{de} \\
\text { Variação }(\mathrm{CV}) & \end{array}$ & TAPARUBA & 0,08 & PALMA & 0,27 \\
\hline Máximo & ARAXA & 440,30 & ARACITABA & 225,14 \\
\hline 75 Percentil & $\begin{array}{l}\text { SENHORA } \\
\text { OLIVEIRA }\end{array}$ & 383,07 & ARACITABA & 211,61 \\
\hline Mediana & \begin{tabular}{|l} 
LUMINARIAS \\
\end{tabular} & 355,29 & ARACITABA & 189,81 \\
\hline 25 Percentil & LUMINARIAS & 329,25 & ARACITABA & 159,69 \\
\hline Mínimo & $\begin{array}{l}\text { SAO JOSE DA } \\
\text { SAFIRA }\end{array}$ & 276,61 & ARACITABA & 136,13 \\
\hline 5 Percentil & $\begin{array}{ll}\begin{array}{l}\text { SAO JOSE DA } \\
\text { SAFIRA }\end{array} \\
\end{array}$ & 279,99 & ARACITABA & 136,13 \\
\hline 95 Percentil & $\begin{array}{ll}\begin{array}{l}\text { SOLEDADE } \\
\text { MINAS }\end{array} & \text { DE } \\
\end{array}$ & 418,75 & ARACITABA & 225,14 \\
\hline 99 Percentil & BOTELHOS & 436,93 & ARACITABA & 225,14 \\
\hline $\begin{array}{l}\text { Intervalo (Máximo } \\
\text { Mínimo) }\end{array}$ & $\begin{array}{l}\text { GOVERNADOR } \\
\text { VALADARES }\end{array}$ & 295,65 & TAPARUBA & 58,21 \\
\hline Frequência & BELO HORIZONTE & 15140 & \begin{tabular}{|l|} 
ALTO \\
JEQUITIBA
\end{tabular} & 7 \\
\hline
\end{tabular}

Fonte: Elaborado pelo autor. 
O melhor desempenho médio que temos em 2006 para a avaliação de matemática é da cidade de Senhora de Oliveira com 348,82 de nota média, um desempenho considerado intermediário (301-375) e pior desempenho médio é da cidade de Aracitaba com 187,43 de nota média, um desempenho muito baixo.

A maior frequência de participantes na avaliação é da cidade de Belo Horizonte (15140 alunos) e por conta disso, tem a melhor qualidade da média $(264,93)$, ou seja, o menor erro padrão da média $(0,4426)$, que confirma que se tivermos outros participantes e fosse calculada uma nova média, esta seria muito próxima da média das notas da amostra anterior.

A pior qualidade da média é da cidade de Pedra do Anta, que tem um erro padrão da média de 19,28, apesar da cidade de Alto Jequitiba ter o menor número de alunos que fizeram a prova, sete apenas, seu erro padrão é de 17,12 menor que de Pedra do Anta que teve apenas 10 participantes.

O melhor desvio padrão, ou seja, o menor desvio padrão é da cidade de Taparuba com 21,86 e média de 275,33, logo os alunos tem um desempenho semelhante nesta cidade. E o pior desvio padrão, ou seja, o maior desvio padrão é da cidade de Santa Rita de Minas com 68,49 e média de 260,90, isso significa que os alunos dessa cidade são heterogêneos com relação as suas notas obtidas. A interpretação da Variância é a mesma, uma vez que a medida é o quadrado do desvio padrão.

O melhor coeficiente de variação, ou seja, o menor cv é de Taparuba com 0,079, isso nos diz que em média os desvios relativos à média atingem $7 \%$ do valor desta, o que nos dá entre os municípios aquele que tem a melhor relação desvio padrão e média, e o resultado é coerente uma vez que Taparuba tem o menor desvio padrão. A pior relação desvio padrão e média é da cidade de Palma com 0,26 de cv.

A maior nota obtida entre todos os participantes é da cidade de Araxá com 440,30 e a menor nota obtida é da cidade de Aracitaba com 225,14 que também tem a menor nota se considerarmos o ranking das que obtiveram as menores notas $(136,13)$. E dentro do ranking das notas que foram consideradas mínimas, o maior valor é da cidade de São José da Safira com 276,60 de nota.

A maior diferença entre o valor máximo e o valor mínimo é da cidade de Governador Valadares com amplitude de 295,65, e a menor diferença é da cidade de Taparuba com 58,21.

Analisando os percentis, podemos visualizar que quando temos o ponto de corte que deixa $5 \%$ da amostra para trás e $95 \%$ da amostra para frente, a cidade de São José 
da Safira tem um desempenho melhor com o ponto de corte de 279,98, ou seja, até 5\% da amostra ordenada, entre todas as cidades a melhor classificação é de São José da Safira. Avançando para 25percentil ou $1^{\circ}$ quartil, temos a cidade de Luminarias com 329,24 , e no 50 percentil ou mediana que deixa $50 \%$ da amostra abaixo e $50 \%$ da amostra acima desse ponto de corte temos o melhor desempenho da cidade de Luminarias também, já no 75 percentil é a cidade de Senhora de Oliveira com 383,069, logo mais no 95 percentil, a cidade de Soledade de Minas com 418,75 e finalmente no 99 percentil com a cidade de Botelhos com 436,93. Com relação ao pior desempenho ou a pior classificação dos percentis fica todos com a cidade de Aracitaba, no 5 percentil com 136,13, no 25 percentil com 159,68 , na mediana com 189,81, no 75 percentil com 211,61, no 95 percentil com 225,14 e no 99 percentil com 225,14, o valor do 95 é idêntico ao 99 percentil, uma vez que a amostra é pequena trata-se de 14 alunos participantes. Veja que $95 \%$ de 14 é 13,3 e $99 \%$ de 14 é 13,8.

Proficiência dos estudantes por cidade em matemática - 2007

MUNICÍPIOS COM PIOR E MELHOR MÉDIA, ERRO PADRÃO DA MÉDIA, DESVIO PADRÃO, VARIÂNCIA, COEFICIENTE DE VARIAÇÃO, MÁXIMO, MÍNIMO, MEDIANA, 5,25,75,95,99 PERCENTIL, DIFERENÇA ENTRE O MÁXIMO VALOR E O MÍNIMO E A FREQUÊNCIA BRUTA NO DESEMPENHO EM MAT - 2007.

\begin{tabular}{|c|c|c|c|c|}
\hline \multicolumn{5}{|l|}{ MATEMÁTICA 2007} \\
\hline \multirow{2}{*}{$\begin{array}{l}\text { Estatísticas } \\
\text { Média }\end{array}$} & \multicolumn{2}{|l|}{ Melhor } & \multicolumn{2}{|l|}{ Pior } \\
\hline & BUENO BRANDAO & 353,79 & CAMPANARIO & 227,70 \\
\hline Erro padrão da média & BELO HORIZONTE & 0,46 & CAJURI & 16,29 \\
\hline Desvio padrão & VARGEM BONITA & 20,41 & $\begin{array}{l}\text { SANTANA } \\
\text { JACARE }\end{array}$ & 65,93 \\
\hline Variância & VARGEM BONITA & 416,65 & $\begin{array}{ll}\text { SANTANA } & \text { DO } \\
\text { JACARE } & \\
\end{array}$ & 4346,89 \\
\hline Coeficiente de Variação (CV) & VARGEM BONITA & 0,06 & $\begin{array}{l}\text { PRESIDENTE } \\
\text { BERNARDES }\end{array}$ & 0,24 \\
\hline Máximo & MUTUM & 442,83 & DIVINESIA & 293,43 \\
\hline 75 Percentil & BUENO BRANDAO & 384,24 & CAMPANARIO & 253,60 \\
\hline Mediana & BUENO BRANDAO & 361,48 & CAMPANARIO & 219,18 \\
\hline 25 Percentil & GRUPIARA & 347,84 & CAMPANARIO & 197,24 \\
\hline Mínimo & VARGEM BONITA & 294,22 & BELO HORIZONTE & 132,71 \\
\hline 5 Percentil & PASSA VINTE & 295,66 & $\begin{array}{ll}\text { SANTANA } & \text { DO } \\
\text { JACARE } & \\
\end{array}$ & 144,65 \\
\hline 95 Percentil & $\begin{array}{l}\text { SENADOR } \\
\text { FIRMINO }\end{array}$ & 416,97 & $\begin{array}{lll}\text { OURO } & \text { VERDE } & \text { DE } \\
\text { MINAS } & & \\
\end{array}$ & 290,62 \\
\hline 99 Percentil & PAULA CANDIDO & 442,44 & DIVINESIA & 293,43 \\
\hline Intervalo (Máximo - Mínimo) & BELO HORIZONTE & 310,13 & VARGEM BONITA & 51,65 \\
\hline Frequência & BELO HORIZONTE & 14640 & VARGEM BONITA & 7 \\
\hline
\end{tabular}

Fonte: Elaborado pelo autor. 
O melhor desempenho médio que temos em 2007 para a avaliação de matemática é da cidade de Bueno Brandão com 353,78 de nota média, um desempenho considerado intermediário (301-375) e pior desempenho médio é da cidade de Campanário com 227,70 de nota média, um desempenho baixo.

A maior frequência de participantes na avaliação é da cidade de Belo Horizonte com 14640 alunos e por conta disso, tem a melhor qualidade da média $(273,59)$, ou seja, o menor erro padrão da média $(0,45)$, que confirma que se tivermos outros participantes e fosse calculada uma nova média, esta seria muito próxima da média das notas da amostra anterior.

A pior qualidade da média é da cidade de Cajuri, que tem um erro padrão da média de 16,29, apesar da cidade de Vargem Bonita ter o menor número de alunos que fizeram a prova, sete apenas, seu erro padrão é de 7,71 menor que de Cajuri que teve apenas 14 participantes.

O melhor desvio padrão, ou seja, o menor desvio padrão é da cidade de Vargem Bonita com 20,41 e média de 320,85, logo os alunos tem um desempenho semelhante nesta cidade. E o pior desvio padrão, ou seja, o maior desvio padrão é da cidade de Santana do Jacaré com 65,93 e média de 292,74, isso significa que os alunos dessa cidade são heterogêneos com relação as suas notas obtidas. A interpretação da Variância é a mesma, uma vez que a medida é o quadrado do desvio padrão.

O melhor coeficiente de variação, ou seja, o menor cv é de Vargem Bonita com 0,063, isso nos diz que em média os desvios relativos à média atingem $6 \%$ do valor desta, o que nos dá entre os municípios aquele que tem a melhor relação desvio padrão e média, e o resultado é coerente uma vez que Vargem Bonita tem o menor desvio padrão. A pior relação desvio padrão e média é da cidade de Presidente Bernardes com $0,23 \mathrm{de}$ cv.

A maior nota obtida entre todos os participantes é da cidade de Mutum com 284,94 e a menor nota obtida é da cidade de Belo Horizonte com 132,70. E dentro do ranking das notas que foram consideradas mínimas, o maior valor é da cidade de Vargem Bonita com 294,21 de nota, e o menor valor dentro do ranking das notas consideradas máximas é da cidade de Divinésia com 293,42.

A maior diferença entre o valor máximo e o valor mínimo é da cidade de Belo Horizonte com amplitude de 310,12, e a menor diferença é da cidade de Vargem Bonita com 51,64. 
Analisando os percentis, podemos visualizar que quando temos o ponto de corte que deixa $5 \%$ da amostra para trás e $95 \%$ da amostra para frente, a cidade de Passa Vinte tem um desempenho melhor com o ponto de corte de 295,66, ou seja, até $5 \%$ da amostra ordenada, entre todas as cidades a melhor classificação é de Passa Vinte. Avançando para 25 percentil ou $1^{\circ}$ quartil, temos a cidade de Grupiara com 347,84, e no 50 percentil ou mediana que deixa 50\% da amostra abaixo e 50\% da amostra acima desse ponto de corte temos o melhor desempenho da cidade de Bueno Brandão com 361,48, e também no 75 percentil é a cidade de Bueno Brandão com 384,24, logo mais no 95 percentil, a cidade de Senador Firmino com 416,97 e finalmente no 99 percentil com a cidade de Paula Candido com 442,44. Com relação ao pior desempenho ou a pior classificação dos percentis temos a cidade de Santana do Jacaré, no 5 percentil com 144,65, no 25 percentil temos a cidade de Campanário com 197,24, na mediana também Campanário com 219,17, no 75 percentil com 253,60 na cidade de Campanário, no 95 percentil com 290,62 em Ouro Verde de Minas e em Divinésia no 99 percentil com 293,42 .

Proficiência dos estudantes por cidade em matemática - 2008 
MUNICÍPIOS COM PIOR E MELHOR MÉDIA, ERRO PADRÃO DA MÉDIA, DESVIO PADRÃO, VARIÂNCIA, COEFICIENTE DE VARIAÇÃO, MÁXIMO, MÍNIMO, MEDIANA, 5,25,75,95,99 PERCENTIL, DIFERENÇA ENTRE O MÁXIMO VALOR E O MÍNIMO E A FREQUÊNCIA BRUTA NO DESEMPENHO EM MAT - 2008.

\begin{tabular}{|c|c|c|c|c|}
\hline \multicolumn{5}{|l|}{ MATEMÁTICA 2008} \\
\hline Estatísticas & \multicolumn{2}{|l|}{ Melhor } & \multicolumn{2}{|l|}{ Pior } \\
\hline Desvio padrão & SIMAO PEREIRA & 17,81 & $\begin{array}{l}\text { CONCEICAO } \\
\text { DAS PEDRAS }\end{array}$ & 73,73 \\
\hline Variância & SIMAO PEREIRA & 317,09 & $\begin{array}{l}\text { CONCEICAO } \\
\text { DAS PEDRAS }\end{array}$ & 5436,26 \\
\hline Coeficiente de Variação (CV) & SIMAO PEREIRA & 0,06 & $\begin{array}{l}\text { CONCEICAO } \\
\text { DAS PEDRAS }\end{array}$ & 0,24 \\
\hline Máximo & $\begin{array}{l}\text { SANTO ANTONIO } \\
\text { DO MONTE }\end{array}$ & 455,43 & $\begin{array}{l}\text { SAO JOSE DO } \\
\text { DIVINO }\end{array}$ & 301,37 \\
\hline 75 Percentil & JACUI & 393,92 & $\begin{array}{ll}\text { BONITO } & \text { DE } \\
\text { MINAS } & \\
\end{array}$ & 246,25 \\
\hline Mediana & $\begin{array}{l}\text { CORONEL } \\
\text { XAVIER CHAVES }\end{array}$ & 382,56 & $\begin{array}{l}\text { BONITO DE } \\
\text { MINAS }\end{array}$ & 220,78 \\
\hline 25 Percentil & VIEIRAS & 354,98 & BERIZAL & 196,83 \\
\hline Mínimo & VIEIRAS & 302,10 & JAIBA & 129,73 \\
\hline 5 Percentil & VIEIRAS & 304,82 & DORESOPOLIS & 139,11 \\
\hline 95 Percentil & GUARANI & 436,34 & MIRAVANIA & 288,77 \\
\hline 99 Percentil & JACUI & 447,12 & $\begin{array}{l}\text { SAO JOSE DO } \\
\text { DIVINO }\end{array}$ & 301,37 \\
\hline Intervalo (Máximo - Mínimo) & $\begin{array}{l}\text { BELO } \\
\text { HORIZONTE }\end{array}$ & 316,45 & $\begin{array}{l}\text { SIMAO } \\
\text { PEREIRA }\end{array}$ & 65,09 \\
\hline Frequência & \begin{tabular}{|l} 
BELO \\
HORIZONTE
\end{tabular} & 14079 & QUELUZITA & 8 \\
\hline Média & VIEIRAS & 369,92 & $\begin{array}{l}\text { BONITO DE } \\
\text { MINAS }\end{array}$ & 229,38 \\
\hline Erro padrão da média & BELO HORIZONTE & 0,48 & QUELUZITA & 20,21 \\
\hline 5 Percentil & BUGRE & 314,52 & $\begin{array}{l}\text { CONCEICAO } \\
\text { DO PARA } \\
\end{array}$ & 140,86 \\
\hline 95 Percentil & $\begin{array}{l}\text { CORONEL } \\
\text { XAVIER CHAVES }\end{array}$ & 439,00 & PIRAJUBA & 294,74 \\
\hline 99 Percentil & $\begin{array}{l}\text { ROSARIO } \quad \text { DA } \\
\text { LIMEIRA }\end{array}$ & 452,15 & PIRAJUBA & 301,12 \\
\hline Intervalo (Máximo - Mínimo) & $\begin{array}{l}\text { BELO } \\
\text { HORIZONTE }\end{array}$ & 333,71 & QUELUZITA & 77,76 \\
\hline Frequência & $\begin{array}{l}\text { BELO } \\
\text { HORIZONTE }\end{array}$ & 14607 & $\begin{array}{l}\text { SANTANA } \\
\text { DO DESERTO }\end{array}$ & 7 \\
\hline
\end{tabular}

Fonte: Elaborado pelo autor. 
O melhor desempenho médio que temos para 2008 para a avaliação de matemática é da cidade de Vieiras com 369,92 de nota média, um desempenho considerado intermediário (301-375) e pior desempenho médio é da cidade de Bonito de Minas com 229,38 de nota média, um desempenho baixo.

A maior frequência de participantes na avaliação é da cidade de Belo Horizonte com 14079 alunos e por conta disso, tem a melhor qualidade da média $(275,41)$, ou seja, o menor erro padrão da média $(0,48)$, que confirma que se tivermos outros participantes e fosse calculada uma nova média, esta seria muito próxima da média das notas da amostra anterior.

A pior qualidade da média é da cidade de Queluzita, que tem um erro padrão da média de 20,21, isso se deve a baixa frequência, temos apenas 8 alunos participantes, além disso é a menor frequência de todas as cidades desse ano.

O melhor desvio padrão, ou seja, o menor desvio padrão é da cidade de Simão Pereira com 17,81 e média de 277,91, logo os alunos tem um desempenho semelhante nesta cidade. E o pior desvio padrão, ou seja, o maior desvio padrão é da cidade de Conceição das Pedras com 73,73 e média de 302,99, isso significa que os alunos dessa cidade são heterogêneos com relação as suas notas obtidas. A interpretação da Variância é a mesma, uma vez que a medida é o quadrado do desvio padrão.

O melhor coeficiente de variação, ou seja, o menor cv é de Simão Pereira com 0,06 , isso nos diz que em média os desvios relativos à média atingem $6 \%$ do valor desta, o que nos dá entre os municípios aquele que tem a melhor relação desvio padrão e média, e o resultado é coerente uma vez que Simão Pereira tem o menor desvio padrão.

A pior relação desvio padrão e média é da cidade de Conceição das Pedras com 0,24 de cv.

A maior nota obtida entre todos os participantes é da cidade de Santo Antonio do Monte com 455,43 e a menor nota obtida é da cidade de Jaiba com 129,73.

E dentro do ranking das notas que foram consideradas mínimas, o maior valor é da cidade de Vieiras com 302,10 de nota, e o menor valor dentro do ranking das notas consideradas máximas é da cidade de São José do Divino com 301,37.

A maior diferença entre o valor máximo e o valor mínimo é da cidade de Belo Horizonte com amplitude de 316,45, e a menor diferença é da cidade de Simão Pereira com 65,09.

Analisando os percentis, podemos visualizar que quando temos o ponto de corte que deixa $5 \%$ da amostra para trás e $95 \%$ da amostra para frente, a cidade de Vieiras 
tem um desempenho melhor com o ponto de corte de 304,82, ou seja, até $5 \%$ da amostra ordenada, entre todas as cidades a melhor classificação é de Vieiras. Avançando para 25 percentil ou $1^{\circ}$ quartil, temos a cidade de Vieiras novamente com 354,98 , e no 50 percentil ou mediana que deixa $50 \%$ da amostra abaixo e $50 \%$ da amostra acima desse ponto de corte temos o melhor desempenho da cidade de Coronel Xavier Chaves com 382,56, e no 75 percentil a cidade de Jacui com 393,92, logo mais no 95 percentil, a cidade de Guarani com 436,34 e finalmente no 99 percentil com a cidade de Jacui com 447,12. Com relação ao pior desempenho ou a pior classificação dos percentis temos a cidade de Doresopolis, no 5 percentil com 139,11, no 25 percentil temos a cidade de Berizal com 196,83, na mediana temos Bonito de Minas com 220,78, no 75 percentil também Bonito de Minas com 246,25, no 95 percentil com 288,77 em Miravania e em São José do Divino no 99 percentil com 301,37.

1.2.4. Proficiência dos estudantes por cidade em matemática - 2009

MUNICÍPIOS COM PIOR E MELHOR MÉDIA, ERRO PADRÃO DA MÉDIA, DESVIO PADRÃO, VARIÂNCIA, COEFICIENTE DE VARIAÇÃO, MÁXIMO, MÍNIMO, MEDIANA, 5,25,75,95,99 PERCENTIL, DIFERENÇA ENTRE O MÁXIMO VALOR E O MÍNIMO E A FREQUÊNCIA BRUTA NO DESEMPENHO EM MAT - 2009.

\begin{tabular}{|c|c|c|c|c|}
\hline \multicolumn{5}{|l|}{ MATEMÁTICA 2009} \\
\hline \multirow{2}{*}{$\begin{array}{l}\text { Estatísticas } \\
\text { Média }\end{array}$} & \multicolumn{2}{|l|}{ Melhor } & \multicolumn{2}{|l|}{ Pior } \\
\hline & $\begin{array}{l}\text { CORONEL } \\
\text { XAVIER CHAVES }\end{array}$ & 368,55 & SAO ROMAO & 228,66 \\
\hline Erro padrão da média & \begin{tabular}{|l} 
BELO \\
HORIZONTE
\end{tabular} & 0,46 & DORESOPOLIS & 16,93 \\
\hline Desvio padrão & QUELUZITA & 22,11 & ABAETE & 79,06 \\
\hline Variância & QUELUZITA & 488,73 & ABAETE & 6250,82 \\
\hline Coeficiente de Variação (CV) & BUGRE & 0,06 & $\begin{array}{l}\text { CONCEICAO } \\
\text { DO PARA }\end{array}$ & 0,30 \\
\hline Máximo & \begin{tabular}{|lll} 
SAO & JOAO & DEL \\
REI & & \\
\end{tabular} & 452,15 & PIRAJUBA & 301,12 \\
\hline 75 Percentil & $\begin{array}{l}\text { CORONEL } \\
\text { XAVIER CHAVES }\end{array}$ & 408,97 & SAO ROMAO & 248,64 \\
\hline Mediana & \begin{tabular}{|l} 
BUENO \\
BRANDAO
\end{tabular} & 371,53 & PIRAJUBA & 225,22 \\
\hline 25 Percentil & BUGRE & 354,21 & $\begin{array}{l}\text { CONCEICAO } \\
\text { DO PARA }\end{array}$ & 169,48 \\
\hline Mínimo & BUGRE & 288,69 & CARANDAI & 109,59 \\
\hline
\end{tabular}

Fonte: Elaborado pelo autor.

O melhor desempenho médio que temos para 2009 para a avaliação de matemática é da cidade de Coronel Xavier Chaves com 368,55 de nota média, um 
desempenho considerado intermediário (301-375) e o pior desempenho médio é da cidade de São Romão com 228,66 de nota média, um desempenho baixo.

A maior frequência de participantes na avaliação é da cidade de Belo Horizonte com 14607 alunos e por conta disso, tem a melhor qualidade da média $(279,41)$, ou seja, o menor erro padrão da média $(0,46)$, que confirma que se tivermos outros participantes e fosse calculada uma nova média, esta seria muito próxima da média das notas da amostra anterior.

A pior qualidade da média é da cidade de Doresópolis, que tem um erro padrão da média de 16,93, isso se deve a baixa frequência, temos apenas 11 alunos participantes, apesar de ter mais participantes que a cidade de Santana do Deserto que teve o menor número entre todos as cidades, apenas sete alunos, o desvio padrão desta cidade de 35,86 é menor que o de Doresópolis de 56,14.

O melhor desvio padrão, ou seja, o menor desvio padrão é da cidade de Queluzita com 22,11 e média de 279,72, logo os alunos tem um desempenho semelhante nesta cidade. E o pior desvio padrão, ou seja, o maior desvio padrão é da cidade de Abaete com 79,06 e média de 282,75, isso significa que os alunos dessa cidade são heterogêneos com relação as suas notas obtidas. A interpretação da Variância é a mesma, uma vez que a medida é o quadrado do desvio padrão.

O melhor coeficiente de variação, ou seja, o menor cv é de Bugre com 0,06, isso nos diz que em média os desvios relativos à média atingem $6 \%$ do valor desta, o que nos dá entre os municípios aquele que tem a melhor relação desvio padrão e média, e o resultado é coerente uma vez que Simão Pereira tem o menor desvio padrão e a maior média dentro deste contexto. Apesar de Bugre ter um desvio padrão maior $(23,17)$ que Queluzita (22,10), a média de Bugre $(363,20)$ é maior que Queluzita(279,72).

A pior relação desvio padrão e média é da cidade de Conceição do Para com 0,30 de cv.

A maior nota obtida entre todos os participantes é da cidade de São João Del Rei com 452,15 e a menor nota obtida é da cidade de Carandai com 109,59.

E dentro do ranking das notas que foram consideradas mínimas, o maior valor é da cidade de Bugre com 288,69 de nota, e o menor valor dentro do ranking das notas consideradas máximas é da cidade de Pirajuba com 225,22.

A maior diferença entre o valor máximo e o valor mínimo é da cidade de Belo Horizonte com amplitude de 333,71, e a menor diferença é da cidade de Queluzita com $77,76$. 
Analisando os percentis, podemos visualizar que quando temos o ponto de corte que deixa $5 \%$ da amostra para trás e $95 \%$ da amostra para frente, a cidade de Bugre tem um desempenho melhor com o ponto de corte de 314,52, ou seja, até 5\% da amostra ordenada, entre todas as cidades a melhor classificação é do Bugre. Avançando para 25percentil ou $1^{\circ}$ quartil, temos a cidade de Bugre novamente com 354,21, e no 50 percentil ou mediana que deixa $50 \%$ da amostra abaixo e $50 \%$ da amostra acima desse ponto de corte temos o melhor desempenho da cidade de Bueno Brandão com 371,53, e no 75 percentil a cidade de Coronel Xavier Chaves com 408,97, logo mais no 95 percentil, a cidade de Coronel Xavier Chaves novamente com 439,00 e finalmente no 99 percentil com a cidade de Rosário da Limeira com 452,15. Com relação ao pior desempenho ou a pior classificação dos percentis temos a cidade de Conceição do Para, no 5 percentil com 140,86, no 25 percentil temos a cidade de Conceição do Para novamente com 169,48, na mediana temos Pirajuba com 225,22, no 75 percentil São Romão com 248,64, no 95 percentil com 294,74 em Pirajuba e em Pirajuba novamente no 99 percentil com 301,12.

1.2.5. Proficiência dos estudantes por cidade em matemática - 2010

MUNICÍPIOS COM PIOR E MELHOR MÉDIA, ERRO PADRÃO DA MÉDIA, DESVIO PADRÃO, VARIÂNCIA, COEFICIENTE DE VARIAÇÃO, MÁXIMO, MÍNIMO, MEDIANA, 5,25,75,95,99 PERCENTIL, DIFERENÇA ENTRE O MÁXIMO VALOR E O MÍNIMO E A FREQUÊNCIA BRUTA NO DESEMPENHO EM MAT - 2010.

\begin{tabular}{l|l|l|lr|l}
\hline \multicolumn{7}{l}{ MATEMÁTICA 2010 } & \multicolumn{5}{l}{ Melhor } & 367,24 & $\begin{array}{l}\text { ROCHEDO } \\
\text { MINAS }\end{array}$ & DE & 231,22 \\
\hline Estatísticas & CANDEIAS & 0,45 & $\begin{array}{l}\text { CEDRO } \\
\text { ABAETE }\end{array}$ & DO & 22,10 \\
\hline Erro padrão da média & $\begin{array}{l}\text { BELO } \\
\text { HORIZONTE }\end{array}$ & BUGRE & 21,15 & GOIANA & 72,15 \\
\hline Desvio padrão & BUGRE & 447,49 & GOIANA & $\begin{array}{l}5205,1 \\
0\end{array}$ \\
\hline $\begin{array}{l}\text { Variância } \\
\text { (CV) })\end{array}$ & BUGRE & 0,06 & GOIANA & 0,27 \\
\hline Máximo & POUSO ALEGRE & 445,35 & $\begin{array}{l}\text { ROCHEDO } \\
\text { MINAS }\end{array}$ & DE & 308,25 \\
\hline 75 Percentil & $\begin{array}{l}\text { SENHORA } \\
\text { OLIVEIRA }\end{array}$ & DE & 394,42 & MIRAVANIA & 255,98 \\
\hline Mediana & CANDEIAS & 370,68 & $\begin{array}{l}\text { ROCHEDO } \\
\text { MINAS }\end{array}$ & 228,24 \\
\hline 25 Percentil & CANDEIAS & 355,62 & $\begin{array}{l}\text { PADRE } \\
\text { CARVALHO }\end{array}$ & 194,49 \\
\hline Mínimo & SAO JOSE & DA & 312,03 & PONTE NOVA & 93,35 \\
\hline
\end{tabular}




\begin{tabular}{|c|c|c|c|c|}
\hline & SAFIRA & & & \\
\hline 5 Percentil & CANDEIAS & 339,22 & BIQUINHAS & 115,88 \\
\hline 95 Percentil & NACIP RAYDAN & 433,62 & MIRAVANIA & 302,18 \\
\hline 99 Percentil & ABRE CAMPO & 443,60 & $\begin{array}{ll}\text { ROCHEDO } & \text { DE } \\
\text { MINAS } & \\
\end{array}$ & 308,25 \\
\hline $\begin{array}{lll}\text { Intervalo } & \text { (Máximo - } \\
\text { Mínimo) } & & \\
\end{array}$ & UBERLANDIA & 340,53 & CHIADOR & 77,24 \\
\hline Frequência & \begin{tabular}{|l|} 
BELO \\
HORIZONTE
\end{tabular} & 14658 & \begin{tabular}{|ll} 
CEDRO & DO \\
ABAETE & \\
\end{tabular} & 7 \\
\hline
\end{tabular}

O melhor desempenho médio que temos para 2010 para a avaliação de matemática é da cidade de Candeias com 367,24 de nota média, um desempenho considerado intermediário (301-375) e o pior desempenho médio é da cidade de Rochedo de Minas com 231,22 de nota média, um desempenho baixo.

A maior frequência de participantes na avaliação é da cidade de Belo Horizonte com 14658 alunos e por conta disso, tem a melhor qualidade da média $(287,69)$, ou seja, o menor erro padrão da média $(0,45)$, que confirma que se tivermos outros participantes e fosse calculada uma nova média, esta seria muito próxima da média das notas da amostra anterior.

A pior qualidade da média é da cidade de Cedro do Abaeté, que tem um erro padrão da média de 22,10, isso se deve a baixa frequência, temos apenas sete alunos participantes, e esta é a cidade com menor frequência registrada de alunos participantes.

O melhor desvio padrão, ou seja, o menor desvio padrão é da cidade do Bugre com 21,15 e média de 361,40, logo os alunos tem um desempenho semelhante nesta cidade. E o pior desvio padrão, ou seja, o maior desvio padrão é da cidade de Goiana com 72,15 e média de 264,92, isso significa que os alunos dessa cidade são heterogêneos com relação as suas notas obtidas. A interpretação da Variância é a mesma, uma vez que a medida é o quadrado do desvio padrão.

O melhor coeficiente de variação, ou seja, o menor cv é da cidade de Bugre com 0,06, isso nos diz que em média os desvios relativos à média atingem $6 \%$ do valor desta, o que nos dá entre os municípios aquele que tem a melhor relação desvio padrão e média, e o resultado é coerente uma vez que Bugre tem o menor desvio padrão e a maior média dentro deste contexto.

A pior relação desvio padrão e média é da cidade de Goiana com 0,27 de cv.

A maior nota obtida entre todos os participantes é da cidade de Pouso Alegre com 445,35 e a menor nota obtida é da cidade de Ponte Nova com 93,35. 
E dentro do ranking das notas que foram consideradas mínimas, o maior valor é da cidade de São José da Safira com 312,03 de nota, e o menor valor dentro do ranking das notas consideradas máximas é da cidade de Rochedo de Minas com 308,25.

A maior diferença entre o valor máximo e o valor mínimo é da cidade de Uberlândia com amplitude de 340,53, e a menor diferença é da cidade de Chiador com 77,24 .

Analisando os percentis, podemos visualizar que quando temos o ponto de corte que deixa 5\% da amostra para trás e $95 \%$ da amostra para frente, a cidade de Candeias tem um desempenho melhor com o ponto de corte de 339,22, ou seja, até 5\% da amostra ordenada, entre todas as cidades a melhor classificação é de Candeias. Avançando para 25 percentil ou $1^{\circ}$ quartil, temos a cidade de Candeias novamente com 355,62, e no 50 percentil ou mediana que deixa $50 \%$ da amostra abaixo e $50 \%$ da amostra acima desse ponto de corte temos o melhor desempenho da cidade de Candeias também com 370,68, e no 75 percentil a cidade de Senhora de Oliveira com 394,42, logo mais no 95 percentil, a cidade de Nacip Raydan novamente com 433,62 e finalmente no 99 percentil com a cidade de Abre Campo com 443,60. Com relação ao pior desempenho ou a pior classificação dos percentis temos a cidade de Biquinhas, no 5 percentil com 115,88, no 25 percentil temos a cidade de Padre Carvalho com 194,49, na mediana temos Rochedo de Minas com 308,25, no 75 percentil Miravania com 255,98, no 95 percentil com 302,18 temos Miravania novamente e no 99 percentil com 308,25 temos Rochedo de Minas.

Proficiência dos estudantes por cidade em português - 2006 
MUNICÍPIOS COM PIOR E MELHOR MÉDIA, ERRO PADRÃO DA MÉDIA, DESVIO PADRÃO, VARIÂNCIA, COEFICIENTE DE VARIAÇÃO, MÁXIMO, MÍNIMO, MEDIANA, 5,25,75,95,99 PERCENTIL, DIFERENÇA ENTRE O MÁXIMO VALOR E O MÍNIMO E A FREQUÊNCIA BRUTA NO DESEMPENHO EM PORT - 2006.

\begin{tabular}{l|l|l|l|l}
\hline \multicolumn{2}{l}{ PORTUGUẾS 2006 } & \multicolumn{5}{l}{ Pelhor } & \multicolumn{2}{l}{ Pior } & 215,01 \\
\hline Estatísticas & ITAGUARA & 316,95 & BERIZAL & 18,09 \\
\hline Média & $\begin{array}{l}\text { BELO } \\
\text { EORIZONTE }\end{array}$ & 0,42 & PASSA VINTE & 74,30 \\
\hline Desvio padrão & TAPARUBA & 24,30 & CONCEICAO DAS PEDRAS & padrão da média \\
\hline Variância & TAPARUBA & 590,39 & CONCEICAO DAS PEDRAS & 5520,41 \\
\hline $\begin{array}{l}\text { Coeficiente } \\
\text { Variação (CV) }\end{array}$ & TAPARUBA & 0,09 & PAIVA & 0,28 \\
\hline Máximo & LAVRAS & 417,92 & ARACITABA & 287,18 \\
\hline 75 Percentil & ITAGUARA & 346,57 & INDAIABIRA & 247,99 \\
\hline Mediana & ITAGUARA & 319,68 & BERIZAL & 207,53 \\
\hline 25 Percentil & ITAGUARA & 297,78 & PAIVA & 177,08 \\
\hline Mínimo & TAPARUBA & 246,68 & VESPASIANO & 93,14 \\
\hline 5 Percentil & $\begin{array}{l}\text { BUENO } \\
\text { BRANDAO }\end{array}$ & 263,20 & PASSA VINTE & 107,05 \\
\hline 95 Percentil & CAPARAO & 392,60 & ARACITABA & 287,18 \\
\hline 99 Percentil & LUMINARIAS & 400,44 & ARACITABA & 287,18 \\
\hline $\begin{array}{l}\text { Intervalo (Máximo } \\
\text { Mínimo) }\end{array}$ & $\begin{array}{l}\text { BELO } \\
\text { HORIZONTE }\end{array}$ & 309,82 & TAPARUBA & 87,40 \\
\hline Frequência & $\begin{array}{l}\text { BELO } \\
\text { HORIZONTE }\end{array}$ & 15999 & ANGELANDIA/INGAI & 10 \\
\hline
\end{tabular}
Fonte: Elaborado pelo autor.

O melhor desempenho médio que temos para 2006 para a avaliação de português é da cidade de Itaguara com 316,95 de nota média, um desempenho considerado intermediário (301-375) e o pior desempenho médio é da cidade de Berizal com 215,01 de nota média, um desempenho baixo.

A maior frequência de participantes na avaliação é da cidade de Belo Horizonte com 15999 alunos e por conta disso, tem a melhor qualidade da média $(266,17)$, ou seja, o menor erro padrão da média $(0,42)$, que confirma que se tivermos outros participantes e fosse calculada uma nova média, esta seria muito próxima da média das notas da amostra anterior.

A pior qualidade da média é da cidade de Passa vinte, que tem um erro padrão da média de 18,09, isso se deve a baixa frequência, temos apenas 16 alunos participantes,

Apesar de ter mais participantes que a cidade de Angelândia e Ingaí que teve o menor número entre todos as cidades, apenas 10 alunos em ambas, o desvio padrão de Passa Vinte de 72,36 é maior que o de Angelândia de 41,17 e de Ingaí de 44,69. 
O melhor desvio padrão, ou seja, o menor desvio padrão é da cidade de Taparuba com 24,30 e média de 279,28, logo os alunos tem um desempenho semelhante nesta cidade. E o pior desvio padrão, ou seja, o maior desvio padrão é da cidade Conceição das Pedras com 74,30 e média de 279,06, isso significa que os alunos dessa cidade são heterogêneos com relação as suas notas obtidas. A interpretação da Variância é a mesma, uma vez que a medida é o quadrado do desvio padrão.

O melhor coeficiente de variação, ou seja, o menor cv é da cidade de Taparuba com 0,06 , isso nos diz que em média os desvios relativos à média atingem $6 \%$ do valor desta, o que nos dá entre os municípios aquele que tem a melhor relação desvio padrão e média, e o resultado é coerente uma vez que Taparuba tem o menor desvio padrão e a maior média dentro deste contexto.

A pior relação desvio padrão e média é da cidade de Paiva com 0,28 de cv.

A maior nota obtida entre todos os participantes é da cidade de Lavras com 417,92 e a menor nota obtida é da cidade de Vespasiano com 93,14.

E dentro do ranking das notas que foram consideradas mínimas, o maior valor é da cidade de Taparuba com 246,68 de nota, e o menor valor dentro do ranking das notas consideradas máximas é da cidade de Aracitaba com 287,18.

A maior diferença entre o valor máximo e o valor mínimo é da cidade de Belo Horizonte com amplitude de 309,82, e a menor diferença é da cidade de Taparuba com 87,40 .

Analisando os percentis, podemos visualizar que quando temos o ponto de corte que deixa 5\% da amostra para trás e $95 \%$ da amostra para frente, a cidade de Bueno Brandão tem um desempenho melhor com o ponto de corte de 263,20 , ou seja, até $5 \%$ da amostra ordenada, entre todas as cidades a melhor classificação é de Bueno Brandão. Avançando para 25percentil ou $1^{\circ}$ quartil, temos a cidade de Itaguara com 297,78, e no 50 percentil ou mediana que deixa $50 \%$ da amostra abaixo e $50 \%$ da amostra acima desse ponto de corte temos o melhor desempenho da cidade de Itaguara também com 319,68 , e no 75 percentil a cidade de Itaguara novamente com 346,57, logo mais no 95 percentil, a cidade de Caparão com 392,60 e finalmente no 99 percentil com a cidade de Luminarias com 400,44. Com relação ao pior desempenho ou a pior classificação dos percentis temos a cidade de Passa Vinte, no 5 percentil com 107,05, no 25 percentil temos a cidade de Paiva com 177,08, na mediana temos Berizal com 207,53, no 75 percentil Indaiabira com 247,99, no 95 percentil com 287,18 temos Aracitaba e no 99 percentil novamente temos Aracitaba com 287,18. 
Proficiência dos estudantes por cidade em português - 2007

MUNICÍPIOS COM PIOR E MELHOR MÉDIA, ERRO PADRÃO DA MÉDIA, DESVIO PADRÃO, VARIÂNCIA, COEFICIENTE DE VARIAÇÃO, MÁXIMO, MÍNIMO, MEDIANA, 5,25,75,95,99 PERCENTIL, DIFERENÇA ENTRE O MÁXIMO VALOR E O MÍNIMO E A FREQUÊNCIA BRUTA NO DESEMPENHO EM PORT - 2007.

\begin{tabular}{|c|c|c|c|c|}
\hline \multicolumn{5}{|l|}{ PORTUGUÊS 2007} \\
\hline Estatísticas & \multicolumn{2}{|l|}{ Melhor } & \multicolumn{2}{|l|}{ Pior } \\
\hline Média & \begin{tabular}{|lr} 
SAO JOSE & DA \\
SAFIRA &
\end{tabular} & 343,46 & \begin{tabular}{|l} 
BONITO DE \\
MINAS
\end{tabular} & 222,65 \\
\hline Erro padrão da média & BELO HORIZONTE & 0,41 & $\begin{array}{l}\text { SAO JOAO DA } \\
\text { MATA }\end{array}$ & 15,65 \\
\hline Desvio padrão & DOURADOQUARA & 23,71 & \begin{tabular}{|l|} 
SAO \\
GERALDO
\end{tabular} & 61,63 \\
\hline Variância & DOURADOQUARA & 561,95 & \begin{tabular}{|l} 
SAO \\
GERALDO
\end{tabular} & 3798,47 \\
\hline $\begin{array}{l}\text { Coeficiente de Variação } \\
\text { (CV) }\end{array}$ & DOURADOQUARA & 0,08 & \begin{tabular}{|l|} 
SAO \\
GERALDO
\end{tabular} & 0,25 \\
\hline Máximo & BELO HORIZONTE & 419,45 & CRISOLITA & 296,84 \\
\hline 75 Percentil & $\begin{array}{l}\text { SAO VICENTE DE } \\
\text { MINAS }\end{array}$ & 352,46 & \begin{tabular}{|l} 
BONITO DE \\
MINAS
\end{tabular} & 252,11 \\
\hline Mediana & $\begin{array}{ll}\text { SAO JOSE } & \text { DA } \\
\text { SAFIRA } & \end{array}$ & 345,70 & \begin{tabular}{|l} 
BONITO DE \\
MINAS
\end{tabular} & 222,59 \\
\hline 25 Percentil & \begin{tabular}{|ll} 
SAO JOSE DA \\
SAFIRA
\end{tabular} & 337,62 & \begin{tabular}{|l|} 
SAO \\
GERALDO \\
\end{tabular} & 189,42 \\
\hline Mínimo & VARGEM BONITA & 283,15 & $\begin{array}{l}\text { SAO } \\
\text { SEBASTIAO } \\
\text { DO PARAISO }\end{array}$ & 125,74 \\
\hline 5 Percentil & $\begin{array}{|ll|}\text { SAO JOSE DA } \\
\text { SAFIRA }\end{array}$ & 292,36 & DIVINESIA & 144,42 \\
\hline 95 Percentil & $\begin{array}{l}\text { CORONEL XAVIER } \\
\text { CHAVES }\end{array}$ & 390,26 & \begin{tabular}{|l|} 
BONITO DE \\
MINAS
\end{tabular} & 281,61 \\
\hline 99 Percentil & $\begin{array}{ll}\text { SENHORA } & \text { DOS } \\
\text { REMEDIOS } & \\
\end{array}$ & 417,47 & CRISOLITA & 296,84 \\
\hline $\begin{array}{l}\text { Intervalo } \quad \text { (Máximo } \\
\text { Mínimo) }\end{array}$ & BELO HORIZONTE & 289,79 & $\begin{array}{l}\text { VARGEM } \\
\text { BONITA } \\
\end{array}$ & 74,50 \\
\hline Frequência & BELO HORIZONTE & 15804 & $\begin{array}{l}\text { VARGEM } \\
\text { BONITA }\end{array}$ & 8 \\
\hline
\end{tabular}

O melhor desempenho médio que temos para 2007 para a avaliação de português é da cidade de São José da Safira com 343,46 de nota média, um desempenho considerado intermediário (301-375) e o pior desempenho médio é da cidade de Bonito de Minas com 222,65 de nota média, um desempenho baixo.

A maior frequência de participantes na avaliação é da cidade de Belo Horizonte com 15804 alunos e por conta disso, tem a melhor qualidade da média $(272,66)$, ou seja, o menor erro padrão da média $(0,41)$, que confirma que se tivermos outros participantes 
e fosse calculada uma nova média, esta seria muito próxima da média das notas da amostra anterior.

A pior qualidade da média é da cidade de São João da Mata, que tem um erro padrão da média de 15,65, isso se deve a baixa frequência, temos apenas 11 alunos participantes,

Apesar de ter mais participantes que a cidade de Vargem Bonita que teve o menor número entre todos as cidades, apenas 8 alunos, o desvio padrão de São João da Mata de 51,88 é maior que o de Vargem Bonita de 28,87.

O melhor desvio padrão, ou seja, o menor desvio padrão é da cidade de Douradoquara com 23,71 e média de $287,35, \log$ os alunos tem um desempenho semelhante nesta cidade. E o pior desvio padrão, ou seja, o maior desvio padrão é da cidade São Geraldo com 61,63 e média de 249,82, isso significa que os alunos dessa cidade são heterogêneos com relação as suas notas obtidas. A interpretação da Variância é a mesma, uma vez que a medida é o quadrado do desvio padrão.

O melhor coeficiente de variação, ou seja, o menor cv é da cidade de Douradoquara com 0,08 , isso nos diz que em média os desvios relativos à média atingem $8 \%$ do valor desta, o que nos dá entre os municípios aquele que tem a melhor relação desvio padrão e média, e o resultado é coerente uma vez que Douradoquara tem o menor desvio padrão.

A pior relação desvio padrão e média é da cidade de São Geraldo com 0,25 de cv.

A maior nota obtida entre todos os participantes é da cidade de Belo Horizonte com 419,45 e a menor nota obtida é da cidade de São Sebastião do Paraíso com 125,74.

E dentro do ranking das notas que foram consideradas mínimas, o maior valor é da cidade de Vargem Bonita com 283,15 de nota, e o menor valor dentro do ranking das notas consideradas máximas é da cidade de Crisolita com 296,84.

A maior diferença entre o valor máximo e o valor mínimo é da cidade de Belo Horizonte com amplitude de 289,79, e a menor diferença é da cidade de Vargem Bonita com 74,50 .

Analisando os percentis, podemos visualizar que quando temos o ponto de corte que deixa $5 \%$ da amostra para trás e $95 \%$ da amostra para frente, a cidade de São José da Safira tem um desempenho melhor com o ponto de corte de 292,36, ou seja, até 5\% da amostra ordenada, entre todas as cidades a melhor classificação é de São José da Safira. Avançando para 25percentil ou $1^{\circ}$ quartil, temos a cidade de São José da Safira novamente com 337,62 , e no 50 percentil ou mediana que deixa $50 \%$ da amostra abaixo 
e 50\% da amostra acima desse ponto de corte temos o melhor desempenho da cidade de São José da Safira também com 345,70, e no 75 percentil a cidade de São Vicente de Minas com 352,46, logo mais no 95 percentil, a cidade de Coronel Xavier Chaves com 390,26 e finalmente no 99 percentil com a cidade de Senhora dos Remédios com 417,47. Com relação ao pior desempenho ou a pior classificação dos percentis temos a cidade de Divinesia, no 5 percentil com 144,42, no 25 percentil temos a cidade de São Geraldo com 189,42, na mediana temos Bonito de Minas com 222,59, no 75 percentil Bonitos de Minas novamente com 252,11, no 95 percentil com 281,61 temos Bonito de Minas também e no 99 percentil temos Crisolita com 296,84.

Proficiência dos estudantes por cidade em português - 2008

MUNICÍPIOS COM PIOR E MELHOR MÉDIA, ERRO PADRÃO DA MÉDIA, DESVIO PADRÃO, VARIÂNCIA, COEFICIENTE DE VARIAÇÃO, MÁXIMO, MÍNIMO, MEDIANA, 5,25,75,95,99 PERCENTIL, DIFERENÇA ENTRE O MÁXIMO VALOR E O MÍNIMO E A FREQUÊNCIA BRUTA NO DESEMPENHO EM PORT - 2008.

PORTUGUÊS 2008

\begin{tabular}{l|l|l|l|l}
\hline Estatísticas & Melhor & Pior & \multicolumn{2}{l}{} \\
\hline Média & VIEIRAS & 321,79 & SANTO ANTONIO DO RETIRO & 233,66 \\
\hline Erro padrão da média & BELO HORIZONTE & 0,39 & QUELUZITA & 19,26 \\
\hline Desvio padrão & SERRANOS & 25,47 & ARACITABA & 69,47 \\
\hline Variância & SERRANOS & 648,63 & ARACITABA & 4826,50 \\
\hline Coeficiente de Variação (CV) & BELO VALE & 0,08 & ARACITABA & 0,25 \\
\hline Máximo & PERDIGAO & 425,38 & DORESOPOLIS & 291,11 \\
\hline
\end{tabular}


75 Percentil

Mediana

25 Percentil

Mínimo

5 Percentil

95 Percentil

99 Percentil

Intervalo (Máximo - Mínimo)

Frequência

CEDRO DO ABAETE 345,39 SANTO ANTONIO DO RETIRO

\begin{tabular}{|l|l|l}
\hline VIEIRAS & 33 \\
\hline VIEIRAS & 30 \\
\hline
\end{tabular}

PEDRO TEIXEIRA

303,65 SENADOR JOSE BENTO

250,15 BELO HORIZONTE

BELO VALE

LUMINARIAS

PERDIGAO

276,43 SENADOR JOSE BENTO

390,42 PIAU

425,38 DORESOPOLIS

BELO HORIZONTE
BELO HORIZONTE

15160

Fonte: Elaborado pelo autor.

O melhor desempenho médio que temos para 2008 para a avaliação de português é da cidade de Vieiras com 321,79 de nota média, um desempenho considerado intermediário (301-375) e o pior desempenho médio é da cidade de Santo Antonio do Retiro com 233,66 de nota média, um desempenho baixo.

A maior frequência de participantes na avaliação é da cidade de Belo Horizonte com 15160 alunos e por conta disso, tem a melhor qualidade da média $(274,27)$, ou seja, o menor erro padrão da média $(0,39)$, que confirma que se tivermos outros participantes e fosse calculada uma nova média, esta seria muito próxima da média das notas da amostra anterior.

A pior qualidade da média é da cidade de Queluzita, que tem um erro padrão da média de 19,26, isso se deve a baixa frequência, temos apenas 8 alunos participantes, este número também representa a menor frequência bruta dentre todas as cidades avaliadas deste ano.

O melhor desvio padrão, ou seja, o menor desvio padrão é da cidade de Serranos com 25,47 e média de 264,82, logo os alunos tem um desempenho semelhante nesta cidade. E o pior desvio padrão, ou seja, o maior desvio padrão é da cidade Aracitaba com 69,47 e média de 279,80, isso significa que os alunos dessa cidade são heterogêneos com relação as suas notas obtidas. A interpretação da Variância é a mesma, uma vez que a medida é o quadrado do desvio padrão.

O melhor coeficiente de variação, ou seja, o menor cv é da cidade de Belo Vale com 0,08 , isso nos diz que em média os desvios relativos à média atingem $8 \%$ do valor desta, o que nos dá entre os municípios aquele que tem a melhor relação desvio padrão e média, apesar do desvio padrão de Serranos $(25,46)$ ser menor que o de Belo Vale $(26,27)$ a média de Belo Vale $(310,41)$ é maior que a de Serrano $(264,82)$, confirmando a relação de desvio padrão e média, uma vez que se trata de uma razão.

A pior relação desvio padrão e média é da cidade de Aracitaba com 0,25 de cv. 
A maior nota obtida entre todos os participantes é da cidade de Perdigão com 425,38 e a menor nota obtida é da cidade de Belo Horizonte com 132,54.

E dentro do ranking das notas que foram consideradas mínimas, o maior valor é da cidade de Pedro Teixeira com 250,15 de nota, e o menor valor dentro do ranking das notas consideradas máximas é da cidade de Doresopolis com 291,11.

A maior diferença entre o valor máximo e o valor mínimo é da cidade de Belo Horizonte com amplitude de 284,70, e a menor diferença é da cidade de Santo Antonio do Grama com 95,95.

Analisando os percentis, podemos visualizar que quando temos o ponto de corte que deixa 5\% da amostra para trás e 95\% da amostra para frente, a cidade de Belo Vale tem um desempenho melhor com o ponto de corte de 276,43, ou seja, até $5 \%$ da amostra ordenada, entre todas as cidades a melhor classificação é de Belo Vale. Avançando para 25 percentil ou $1^{\circ}$ quartil, temos a cidade de Vieiras com 303,65, e no 50 percentil ou mediana que deixa $50 \%$ da amostra abaixo e 50\% da amostra acima desse ponto de corte temos o melhor desempenho da cidade de Vieiras novamente com 331,53, e no 75 percentil a cidade de Cedro do Abaete com 345,39, logo mais no 95 percentil, a cidade de Luminarias com 390,42 e finalmente no 99 percentil com a cidade de Perdigão com 425,38. Com relação ao pior desempenho ou a pior classificação dos percentis temos a cidade de Senador José Bento, no 5 percentil com 151,87, no 25 percentil temos a cidade de Senador José Bento novamente com 197,76, na mediana temos Gameleiras com 229,44, no 75 percentil temos Santo Antonio do Retiro com 257,68, no 95 percentil com 284,63 temos Piau e no 99 percentil temos Doresopolis com 291,11.

Proficiência dos estudantes por cidade em português - 2009

MUNICÍPIOS COM PIOR E MELHOR MÉDIA, ERRO PADRÃO DA MÉDIA, DESVIO PADRÃO, VARIÂNCIA, COEFICIENTE DE VARIAÇÃO, MÁXIMO, MÍNIMO, MEDIANA, 5,25,75,95,99 PERCENTIL, DIFERENÇA ENTRE O MÁXIMO VALOR E O MÍNIMO E A FREQUÊNCIA BRUTA NO DESEMPENHO EM PORT - 2009.

PORTUGUÊS 2009

\begin{tabular}{l|l|l|l|l}
\hline Estatísticas & Melhor & Pior & \multicolumn{2}{l}{} \\
\hline Média & BELO VALE JOAO DO & 324,10 & $\begin{array}{l}\text { SAO JOA,90 } \\
\text { PARAISO }\end{array}$ \\
\hline Erro padrão da média & $\begin{array}{l}\text { BELO } \\
\text { HORIZONTE }\end{array}$ & 0,39 & $\begin{array}{l}\text { AGUA } \\
\text { COMPRIDA }\end{array}$ & 14,93 \\
\hline Desvio padrão & QUELUZITA & 22,85 & $\begin{array}{l}\text { SAO JOAO DO } \\
\text { PARAISO }\end{array}$ & 73,03 \\
\hline Variância & QUELUZITA & 522,06 & $\begin{array}{l}\text { SAO JOAO DO } \\
\text { PARAISO }\end{array}$ & 5332,94 \\
\hline
\end{tabular}




\begin{tabular}{l|l|l|ll|l} 
Coeficiente de Variação (CV) & QUELUZITA & 0,08 & $\begin{array}{l}\text { SAO JOAO DO } \\
\text { PARAISO }\end{array}$ & 0,38 \\
\hline Máximo & PASSOS & 415,95 & PEQUERI & 292,91 \\
\hline 75 Percentil & BELO VALE & 345,33 & $\begin{array}{l}\text { SAO JOAO DO } \\
\text { PARAISO }\end{array}$ & 253,04 \\
\hline Mediana & BELO VALE & 323,80 & $\begin{array}{l}\text { SAO JOAO DO } \\
\text { PARAISO }\end{array}$ & 169,10 \\
\hline 25 Percentil & BELO VALE & 309,43 & $\begin{array}{l}\text { SAO JOAO DO } \\
\text { PARAISO }\end{array}$ & 125,99 \\
\hline Mínimo & IGUATAMA & 256,09 & $\begin{array}{l}\text { SAO JOAO DO } \\
\text { PARAISO }\end{array}$ & 108,33 \\
\hline 5 Percentil & BELO VALE & 287,07 & $\begin{array}{l}\text { SAO JOAO DO } \\
\text { PARAISO }\end{array}$ & 115,45 \\
\hline 95 Percentil & PASSA VINTE & 397,05 & $\begin{array}{l}\text { SANTO } \\
\text { ANTONIO DO DO DO } \\
\text { RETIRO }\end{array}$ & 288,30 \\
\hline 99 Percentil & $\begin{array}{l}\text { BOM JESUS DA } \\
\text { PENHA }\end{array}$ & 410,59 & PEQUERI & 292,91 \\
\hline Intervalo (Máximo - Mínimo) & $\begin{array}{l}\text { BELO } \\
\text { HORIZONTE }\end{array}$ & $\begin{array}{l}\text { BELO } \\
\text { HORIZONTE }\end{array}$ & 14973 & $\begin{array}{l}\text { SANTANA DO DO } \\
\text { DESERTO }\end{array}$ & 6 \\
\hline Frequência & QUELUZITA & 77,51 \\
\hline
\end{tabular}

Fonte: Elaborado pelo autor.

O melhor desempenho médio que temos para 2009 para a avaliação de português é da cidade de Belo Vale com 324,10 de nota média, um desempenho considerado intermediário (301-375) e o pior desempenho médio é da cidade de São João do Paraíso com 191,90 de nota média, um desempenho baixo.

A maior frequência de participantes na avaliação é da cidade de Belo Horizonte com 14973 alunos e por conta disso, tem a melhor qualidade da média $(276,18)$, ou seja, o menor erro padrão da média $(0,39)$, que confirma que se tivermos outros participantes e fosse calculada uma nova média, esta seria muito próxima da média das notas da amostra anterior.

A pior qualidade da média é da cidade de Água comprida, que tem um erro padrão da média de 14,93, isso se deve a baixa frequência, temos apenas 16 alunos participantes, entretanto não é a menor frequência registrada neste ano, que é de Santana do Deserto com apenas 6 participantes e desvio padrão de 30,76, menor que de Água comprida com 59,70 de desvio padrão.

O melhor desvio padrão, ou seja, o menor desvio padrão é da cidade de Queluzita com 22,85 e média de 291,75, logo os alunos tem um desempenho semelhante nesta cidade. E o pior desvio padrão, ou seja, o maior desvio padrão é da cidade São João do 
Paraíso com 73,03 e média de 191,90, isso significa que os alunos dessa cidade são heterogêneos com relação as suas notas obtidas. A interpretação da Variância é a mesma, uma vez que a medida é o quadrado do desvio padrão.

O melhor coeficiente de variação, ou seja, o menor cv é da cidade de Queluzita com 0,08 , isso nos diz que em média os desvios relativos à média atingem $8 \%$ do valor desta, o que nos dá entre os municípios aquele que tem a melhor relação desvio padrão e média, visto também que Queluzita tem o menor desvio padrão também de 22,85.

A pior relação desvio padrão e média é da cidade de São João do Paraíso com 0,38 de cv.

A maior nota obtida entre todos os participantes é da cidade de Passos com 415,95 e a menor nota obtida é da cidade de São João do Paraíso com 115,45.

E dentro do ranking das notas que foram consideradas mínimas, o maior valor é da cidade de Iguatama com 256,09 de nota, e o menor valor dentro do ranking das notas consideradas máximas é da cidade de Pequeri com 292,91.

A maior diferença entre o valor máximo e o valor mínimo é da cidade de Belo Horizonte com amplitude de 300,55, e a menor diferença é da cidade de Queluzita com 77,51 .

Analisando os percentis, podemos visualizar que quando temos o ponto de corte que deixa $5 \%$ da amostra para trás e $95 \%$ da amostra para frente, a cidade de Belo Vale tem um desempenho melhor com o ponto de corte de 287,07, ou seja, até $5 \%$ da amostra ordenada, entre todas as cidades a melhor classificação é de Belo Vale. Avançando para 25 percentil ou $1^{\text {o }}$ quartil, temos a cidade de Belo Vale novamente com 309,43, e no 50 percentil ou mediana que deixa $50 \%$ da amostra abaixo e $50 \%$ da amostra acima desse ponto de corte temos o melhor desempenho da cidade de Belo Vale também com 323,80, e no 75 percentil a cidade de Belo Vale com 345,33, logo mais no 95 percentil, a cidade de Passa Vinte com 397,05 e finalmente no 99 percentil com a cidade de Bom Jesus da Penha com 410,59. Com relação ao pior desempenho ou a pior classificação dos percentis temos a cidade de São João do Paraíso, no 5 percentil com 115,45, no 25 percentil com 125,99, na mediana com 169,10, no 75 percentil com 253,04, no 95 percentil temos Santo Antonio do Retiro com 288,30 e no 99 percentil temos Pequeri com 292,91 .

Proficiência dos estudantes por cidade em português - 2010 
MUNICÍPIOS COM PIOR E MELHOR MÉDIA, ERRO PADRÃO DA MÉDIA, DESVIO PADRÃO, VARIÂNCIA, COEFICIENTE DE VARIAÇÃO, MÁXIMO, MÍNIMO, MEDIANA, 5,25,75,95,99 PERCENTIL, DIFERENÇA ENTRE O MÁXIMO VALOR E O MÍNIMO E A FREQUÊNCIA BRUTA NO DESEMPENHO EM PORT - 2010.

\begin{tabular}{|c|c|c|c|c|}
\hline \multicolumn{5}{|l|}{ PORTUGUÊS 2010} \\
\hline \multirow{2}{*}{$\begin{array}{l}\text { Estatísticas } \\
\text { Média }\end{array}$} & \multicolumn{2}{|l|}{ Melhor } & \multicolumn{2}{|l|}{ Pior } \\
\hline & CANDEIAS & 349,51 & $\begin{array}{l}\text { PADRE } \\
\text { CARVALHO }\end{array}$ & 231,91 \\
\hline Erro padrão da média & BELO HORIZONTE & 0,40 & $\begin{array}{|ll|}\text { ANTONIO } & \\
\text { PRADO } & \text { DE } \\
\text { MINAS } & \\
\end{array}$ & 16,78 \\
\hline Desvio padrão & BIQUINHAS & 24,27 & PALMA & 63,15 \\
\hline Variância & BIQUINHAS & 588,99 & PALMA & 3988,17 \\
\hline Coeficiente de Variação (CV) & BIQUINHAS & 0,07 & PALMA & 0,25 \\
\hline Máximo & BELO HORIZONTE & 423,19 & UMBURATIBA & 293,87 \\
\hline 75 Percentil & CANDEIAS & 365,49 & MIRAVANIA & 256,66 \\
\hline Mediana & CANDEIAS & 351,79 & GAMELEIRAS & 230,70 \\
\hline 25 Percentil & CANDEIAS & 339,75 & MESQUITA & 183,43 \\
\hline Mínimo & BIQUINHAS & 277,39 & $\begin{array}{l}\text { BELO } \\
\text { HORIZONTE }\end{array}$ & 114,36 \\
\hline 5 Percentil & CANDEIAS & 306,50 & \begin{tabular}{|l} 
MATHIAS \\
LOBATO
\end{tabular} & 128,06 \\
\hline 95 Percentil & $\begin{array}{ll}\text { ANTONIO } & \text { PRADO } \\
\text { DE MINAS } & \\
\end{array}$ & 402,41 & MIRAVANIA & 285,44 \\
\hline 99 Percentil & CASA GRANDE & 419,38 & UMBURATIBA & 293,87 \\
\hline Intervalo (Máximo - Mínimo) & BELO HORIZONTE & 308,83 & CHACARA & 82,23 \\
\hline Frequência & BELO HORIZONTE & 15003 & \begin{tabular}{|ll} 
CEDRO & DO \\
ABAETE & \\
\end{tabular} & 7 \\
\hline
\end{tabular}


Fonte: Elaborado pelo autor.

O melhor desempenho médio que temos para 2010 para a avaliação de português é da cidade de Candeias com 349,51 de nota média, um desempenho considerado intermediário (301-375) e o pior desempenho médio é da cidade de Padre Carvalho com 231,91 de nota média, um desempenho baixo.

A maior frequência de participantes na avaliação é da cidade de Belo Horizonte com 15003 alunos e por conta disso, tem a melhor qualidade da média $(287,10)$, ou seja, o menor erro padrão da média $(0,40)$, que confirma que se tivermos outros participantes e fosse calculada uma nova média, esta seria muito próxima da média das notas da amostra anterior.

A pior qualidade da média é da cidade de Antônio Prado de Minas, que tem um erro padrão da média de 16,78, isso se deve a baixa frequência, temos apenas 12 alunos participantes, entretanto não é a menor frequência registrada neste ano, que é de Cedro do Abaete com apenas 7 participantes e desvio padrão de 44,18, menor que de Antônio Prado de Minas com 58,12 de desvio padrão.

O melhor desvio padrão, ou seja, o menor desvio padrão é da cidade de Biquinhas com 24,27 e média de 338,56, logo os alunos tem um desempenho semelhante nesta cidade. E o pior desvio padrão, ou seja, o maior desvio padrão é da cidade Palma com 63,15 e média de 251,36, isso significa que os alunos dessa cidade são heterogêneos com relação as suas notas obtidas. A interpretação da Variância é a mesma, uma vez que a medida é o quadrado do desvio padrão.

O melhor coeficiente de variação, ou seja, o menor cv é da cidade de Biquinhas com 0,07 , isso nos diz que em média os desvios relativos à média atingem $7 \%$ do valor desta, o que nos dá entre os municípios aquele que tem a melhor relação desvio padrão e média, visto também que Biquinhas tem o menor desvio padrão também de 24,27 entre todas as cidades.

A pior relação desvio padrão e média é da cidade de Palma com 0,25 de cv.

A maior nota obtida entre todos os participantes é da cidade de Belo Horizonte com 423,19 e a menor nota obtida é da cidade de Belo Horizonte também com 114,36.

E dentro do ranking das notas que foram consideradas mínimas, o maior valor é da cidade de Biquinhas com 277,39 de nota, e o menor valor dentro do ranking das notas consideradas máximas é da cidade de Umburatiba com 293,87. 
A maior diferença entre o valor máximo e o valor mínimo é da cidade de Belo Horizonte com amplitude de 308,83, e a menor diferença é da cidade de Chácara com 82,23 .

Analisando os percentis, podemos visualizar que quando temos o ponto de corte que deixa $5 \%$ da amostra para trás e $95 \%$ da amostra para frente, a cidade de Candeias tem um desempenho melhor com o ponto de corte de 306,50, ou seja, até $5 \%$ da amostra ordenada, entre todas as cidades a melhor classificação é de Candeias. Avançando para 25 percentil ou $1^{\circ}$ quartil, temos a cidade de Candeias novamente com 339,75, e no 50 percentil ou mediana que deixa $50 \%$ da amostra abaixo e $50 \%$ da amostra acima desse ponto de corte temos o melhor desempenho da cidade de Candeias também com 351,79, e no 75 percentil a cidade de Candeias com 365,49, logo mais no 95 percentil, a cidade de Antônio Prado de Minas com 402,41 e finalmente no 99 percentil com a cidade de Casa Grande com 419,38. Com relação ao pior desempenho ou a pior classificação dos percentis temos a cidade de Mathias Lobato, no 5 percentil com 128,06, no 25 percentil a cidade de Mesquita com 183,43, na mediana na cidade de Gameleiras com 230,70, no 75 percentil na cidade de Miravania com 256,66, no 95 percentil temos Miravania novamente com 285,44 e no 99 percentil temos Umburatiba com 293,87.

Média das notas dos alunos participantes por município e por ano das provas de português e matemática.

Com relação a média das notas dos alunos participantes por município e por ano das provas de português e matemática temos a seguinte distribuição de frequências brutas e relativas (porcentagem) com relação ao desempenho:

NÚMERO DE MUNICÍPIOS COM MÉDIA DE DESEMPENHO BAIXO, INTERMEDIÁRIO E RECOMENDADO NA AVALIAÇÃO SIMAVE DOS ALUNOS DO $3^{\circ}$ ANO EM EM PORTUGUÊS POR ANO (2006-2010).

DESEMPENHO DE PORTUGUÊS

\begin{tabular}{l|l|l|l|l}
\hline ANO & BAIXO & INTERMEDIÁRIO & RECOMENDADO & Contagem \\
\hline 2006 & 807 & 15 & 0 & 822 \\
\hline 2007 & 790 & 32 & $1^{*}$ & 823 \\
\hline 2008 & 822 & 22 & 0 & 844 \\
\hline 2009 & 821 & 26 & 0 & 847 \\
\hline 2010 & 756 & 92 & $2^{* *}$ & 850 \\
\hline Total Geral & 3996 & 187 & 3 & 4186 \\
\hline
\end{tabular}

Fonte: Elaborado pelo autor.

*São José da Safira

**Biquinhas e Candeias 
PERCENTUAL DE MUNICÍPIOS COM MÉDIA DE DESEMPENHO BAIXO, INTERMEDIÁRIO E RECOMENDADO NA AVALIAÇÃO SIMAVE DOS ALUNOS DO $3^{\circ}$ ANO EM EM PORTUGUÊS ENTRE OS ANOS DE 2006-2010.

\begin{tabular}{l|l|l|l|l}
\hline \multicolumn{2}{l}{ DESEMPENHO DE PORTUGUES } \\
\hline ANO & BAIXO & INTERMEDIÁRIO & RECOMENDADO & Porcentagem \\
\hline 2006 & $20 \%$ & $8 \%$ & $0 \%$ & $20 \%$ \\
\hline 2007 & $20 \%$ & $17 \%$ & $33 \%$ & $20 \%$ \\
\hline 2008 & $21 \%$ & $12 \%$ & $0 \%$ & $20 \%$ \\
\hline 2009 & $21 \%$ & $14 \%$ & $0 \%$ & $20 \%$ \\
\hline 2010 & $19 \%$ & $49 \%$ & $67 \%$ & $20 \%$ \\
\hline Total Geral & $100 \%$ & $100 \%$ & $100 \%$ & $100 \%$ \\
\hline
\end{tabular}

Fonte: Elaborado pelo autor.

NÚMERO DE MUNICÍPIOS COM MÉDIA DE DESEMPENHO BAIXO, INTERMEDIÁRIO E RECOMENDADO NA AVALIAÇÃO SIMAVE DOS ALUNOS DO $3^{\circ}$ ANO EM EM MATEMÁTICA POR ANO (2006-2010).

\begin{tabular}{l|l|l|l}
\hline DESEMPENHO DE MATEMÁTICA \\
\hline ANO & BAIXO & INTERMEDIÁRIO & Contagem \\
\hline 2006 & 704 & 119 & 823 \\
\hline 2007 & 650 & 173 & 823 \\
\hline 2008 & 662 & 182 & 844 \\
\hline 2009 & 632 & 215 & 847 \\
\hline 2010 & 539 & 311 & 850 \\
\hline Total Geral & 3187 & 1000 & 4187 \\
\hline
\end{tabular}

Fonte: Elaborado pelo autor

PERCENTUAL DE MUNICÍPIOS COM MÉDIA DE DESEMPENHO BAIXO, INTERMEDIÁRIO E RECOMENDADO NA AVALIAÇÃO SIMAVE DOS ALUNOS DO $3^{\circ}$ ANO EM EM MATEMÁTICA ENTRE OS ANOS DE 2006-2010.

\begin{tabular}{l|l|l|l}
\hline DESEMPENHO DE MATEMÁTICA \\
\hline ANO & BAIXO & INTERMEDIÁRIO & Porcentagem \\
\hline 2006 & $22 \%$ & $12 \%$ & $20 \%$ \\
\hline 2007 & $20 \%$ & $17 \%$ & $20 \%$ \\
\hline 2008 & $21 \%$ & $18 \%$ & $20 \%$ \\
\hline 2009 & $20 \%$ & $22 \%$ & $20 \%$ \\
\hline 2010 & $17 \%$ & $31 \%$ & $20 \%$ \\
\hline Total Geral & $100 \%$ & $100 \%$ & $100 \%$ \\
\hline
\end{tabular}

Fonte: Elaborado pelo autor.

As tabelas acima são dados referentes a contagem e porcentagem das cidades totais em cada categoria de classificação do desempenho (baixo, intermediário, recomendado). Veja que na categoria matemática não tivemos nenhuma cidade com 
nota média considerada recomendada, enquanto que na categoria português, tivemos apenas 3 municípios. Além disso, percebemos o aumento gradual das cidades incluídas ano após ano, das 853 cidades totais de Minas Gerais, no ano de 2010 temos 850 cidades participantes.

Proficiência média por município x indicadores sócio demográficos municipais.

Nos gráficos e tabelas a seguir, apresento os resultados da dispersão e correlação entre as variáveis municipais e a nota média dos municípios na avaliação dos alunos do terceiro ano do Ensino Médio entre os anos de 2006-2010.

DISPERSÃO E CORRELAÇÕES ENTRE NOTA MÉDIA EM MATEMÁTICA E VARIÁVEIS DOS MUNICÍPIOS - PROEB - 2006.
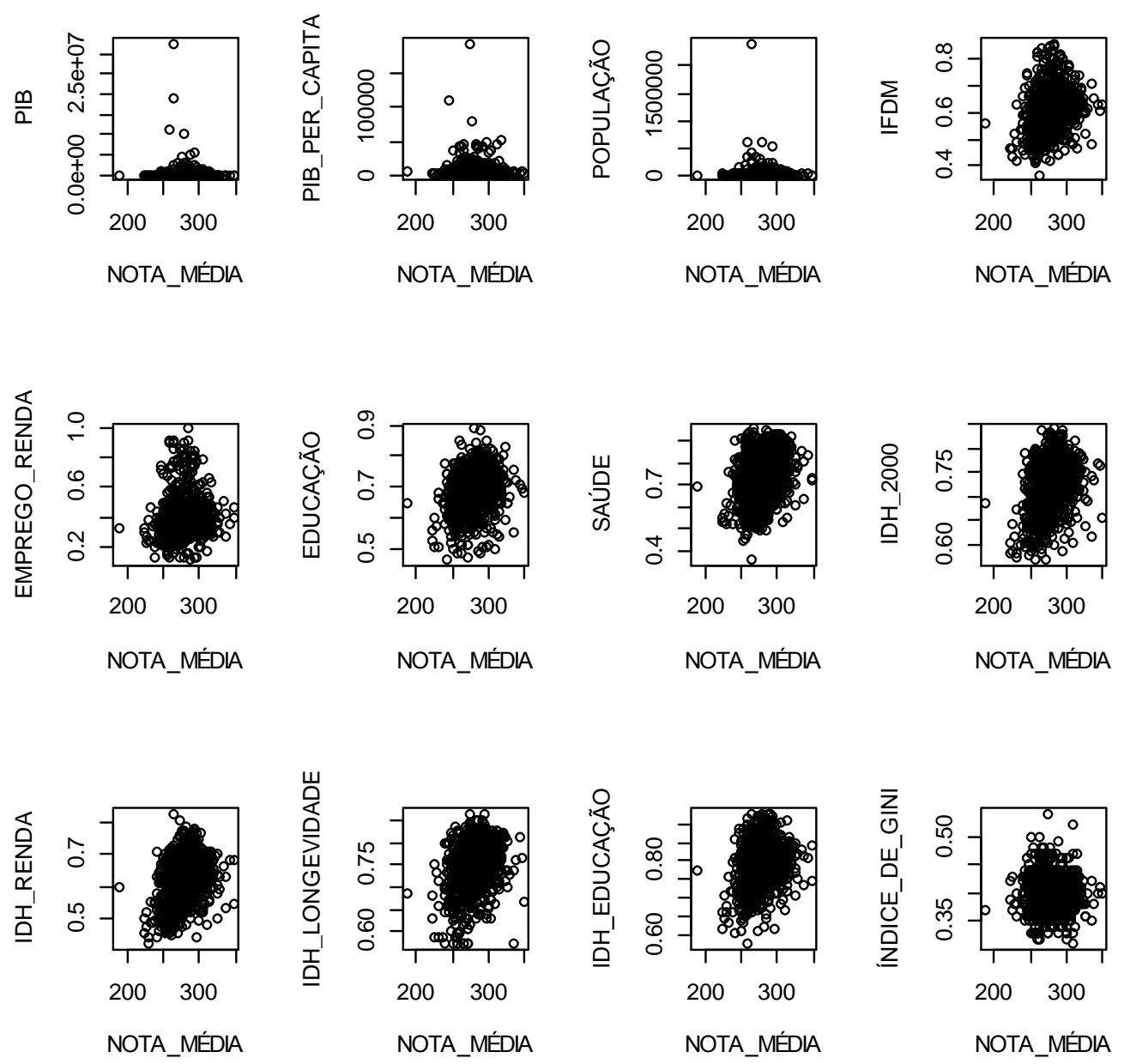

Fonte: Elaborado pelo autor. 
COEFICIENTE DE CORRELAÇÃO ENTRE NOTA MÉDIA EM MATEMÁTICA E VARIÁVEIS DO MUNICÍPIO - PROEB - 2006.

\begin{tabular}{l|l}
\hline NOTA_MÉDIA COM & COEFICIENTE DE CORRELAÇÃO \\
\hline PIB & $-0,028$ \\
\hline PIB_PER_CAPITA & 0,052 \\
\hline POPULAÇÃO & $-0,037$ \\
\hline IFDM & 0,296 \\
\hline EMPREGO_RENDA & 0,113 \\
\hline EDUCAÇÃO & 0,288 \\
\hline SAÚDE & 0,348 \\
\hline IDH_2000 & 0,369 \\
\hline IDH_RENDA & 0,366 \\
\hline IDH_LONGEVIDADE & 0,338 \\
\hline IDH_EDUCAÇÃO & 0,287 \\
\hline ÍNDICE_DE_GINI & $-0,009$ \\
\hline
\end{tabular}

Fonte: Elaborado pelo autor.

DISPERSÃO E CORRELAÇÕES ENTRE NOTA MÉDIA EM MATEMÁTICA E VARIÁVEIS DOS MUNICÍPIOS - PROEB - 2007.
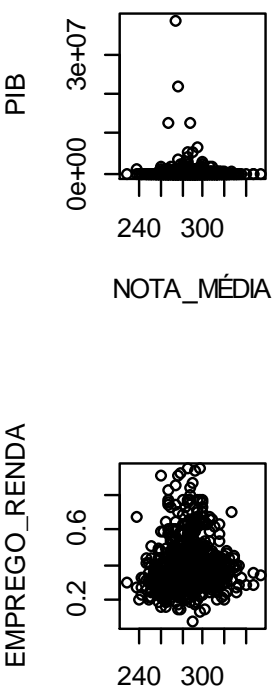

NOTA_MÉDIA
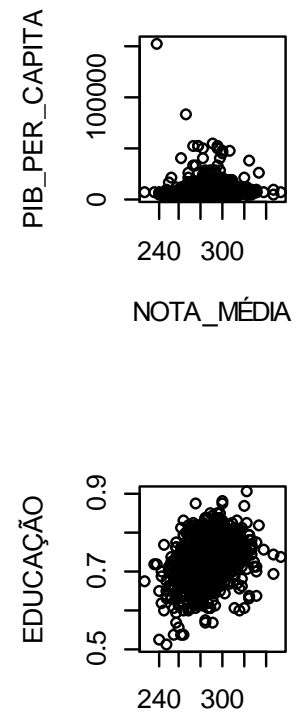

NOTA_MÉDIA
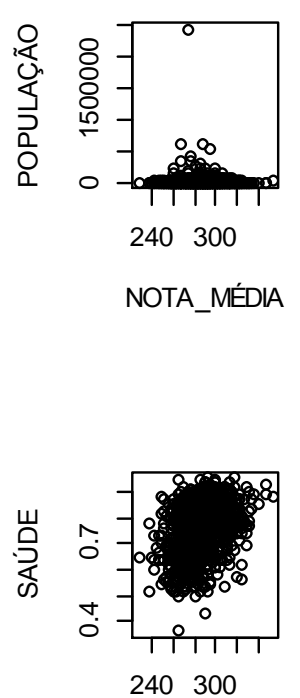

NOTA_MÉDIA
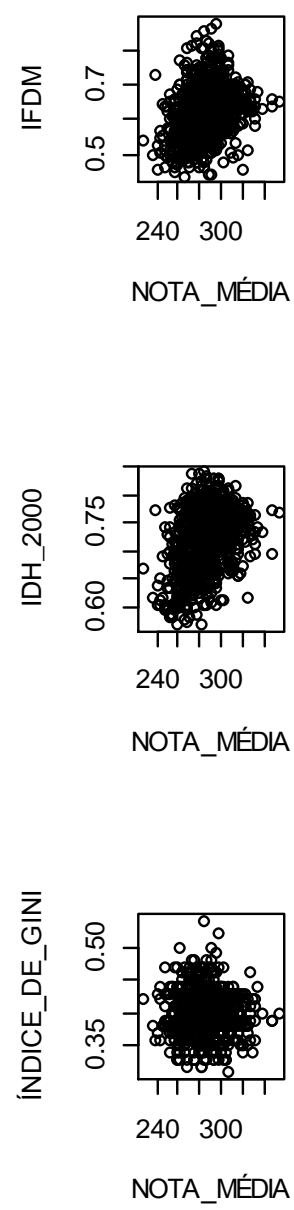

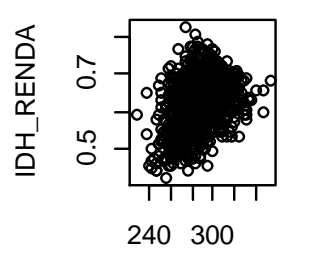

NOTA_MÉDIA
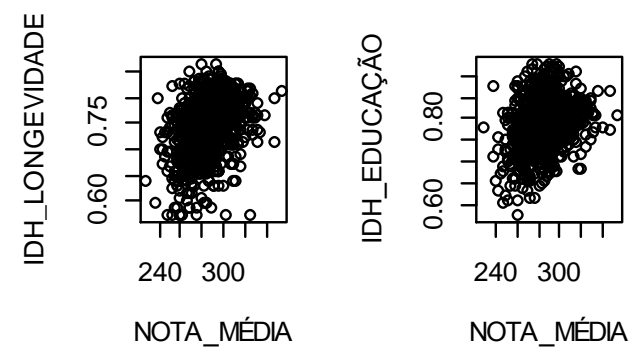

Fonte: Elaborado pelo autor. 
COEFICIENTE DE CORRELAÇÃO ENTRE NOTA MÉDIA EM MATEMÁTICA E VARIÁVEIS DO MUNICÍPIO - PROEB - 2007.

\begin{tabular}{l|l}
\hline NOTA_MÉDIA COM & COEFICIENTE DE CORRELAÇÃO \\
\hline PIB & $-0,030$ \\
\hline PIB_PER_CAPITA & 0,018 \\
\hline POPULAÇÃO & $-0,038$ \\
\hline IFDM & 0,301 \\
\hline EMPREGO_RENDA & 0,070 \\
\hline EDUCAÇÃO & 0,349 \\
\hline SAÚDE & 0,361 \\
\hline IDH_2000 & 0,382 \\
\hline IDH_RENDA & 0,366 \\
\hline IDH_LONGEVIDADE & 0,345 \\
\hline IDH_EDUCAÇÃO & 0,315 \\
\hline ÍNDICE_DE_GINI & $-0,028$ \\
\hline
\end{tabular}

Fonte: Elaborado pelo autor.

COEFICIENTE DE CORRELAÇÃO ENTRE NOTA MÉDIA EM MATEMÁTICA E VARIÁVEIS DO MUNICÍPIO - PROEB - 2007.
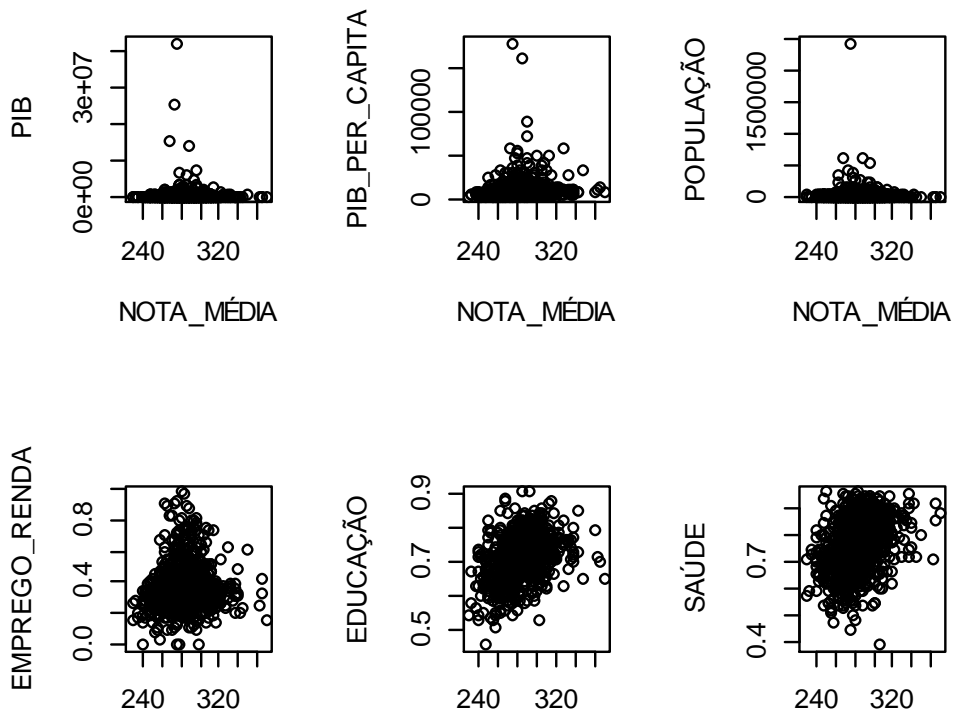

NOTA_MÉDIA
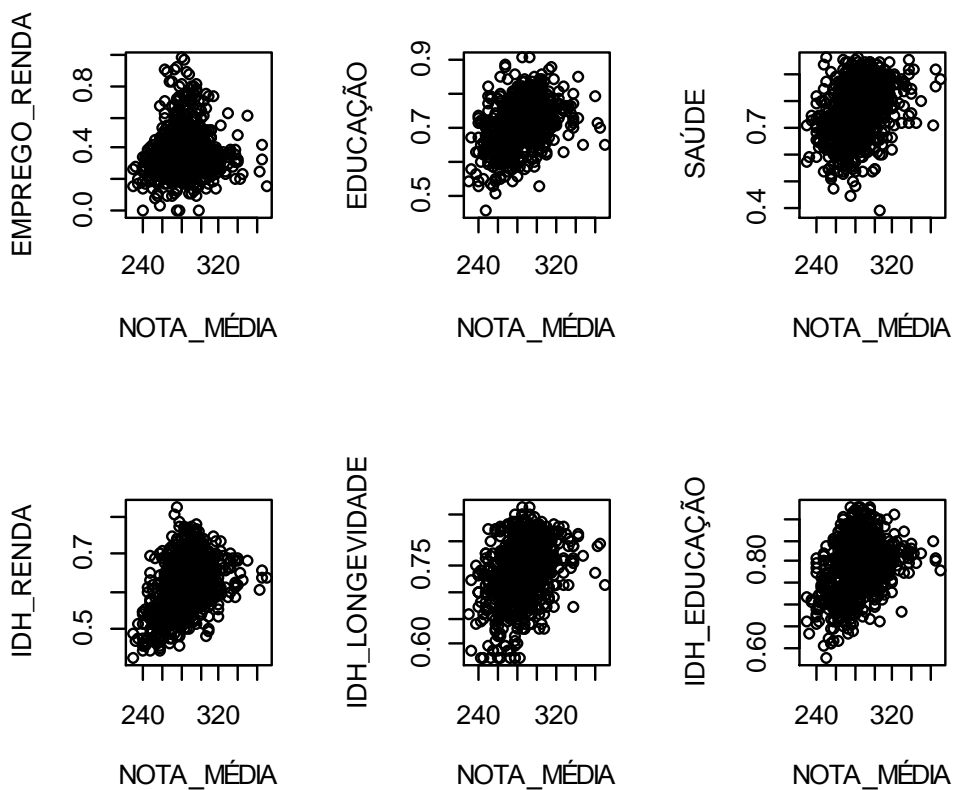

Fonte: Elaborado pelo autor.
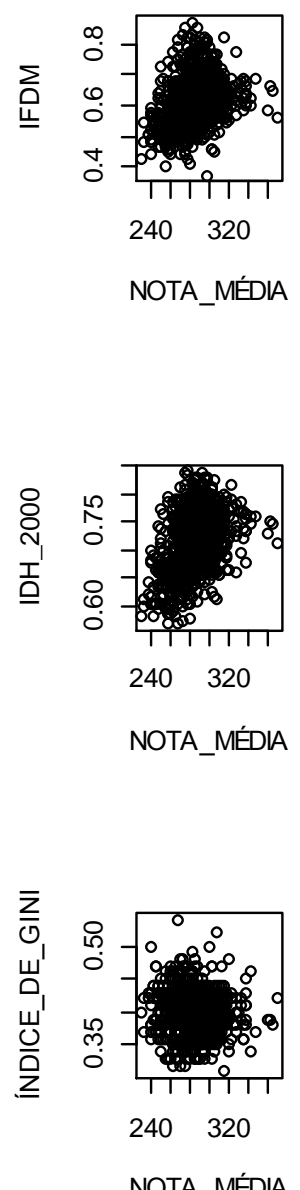

NOTA_MÉDIA

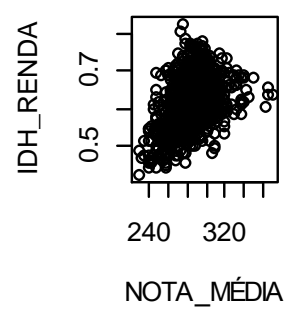


COEFICIENTE DE CORRELAÇÃO ENTRE NOTA MÉDIA EM MATEMÁTICA E VARIÁVEIS DO MUNICÍPIO - PROEB - 2008.

\begin{tabular}{l|l}
\hline NOTA_MÉDIA COM & COEFICIENTE DE CORRELAÇÃO \\
\hline PIB & $-0,018$ \\
\hline PIB_PER_CAPITA & 0,095 \\
\hline POPULAÇÃO & $-0,026$ \\
\hline IFDM & 0,309 \\
\hline EMPREGO_RENDA & 0,096 \\
\hline EDUCAÇÃO & 0,378 \\
\hline SAÚDE & 0,348 \\
\hline IDH_2000 & 0,412 \\
\hline IDH_RENDA & 0,403 \\
\hline IDH_LONGEVIDADE & 0,348 \\
\hline IDH_EDUCAÇÃO & 0,353 \\
\hline ÍNDICE_DE_GINI & $-0,033$
\end{tabular}

Fonte: Elaborado pelo autor.

DISPERSÃO E CORRELAÇÕES ENTRE NOTA MÉDIA EM MATEMÁTICA E VARIÁVEIS DOS MUNICÍPIOS - PROEB - 2009.
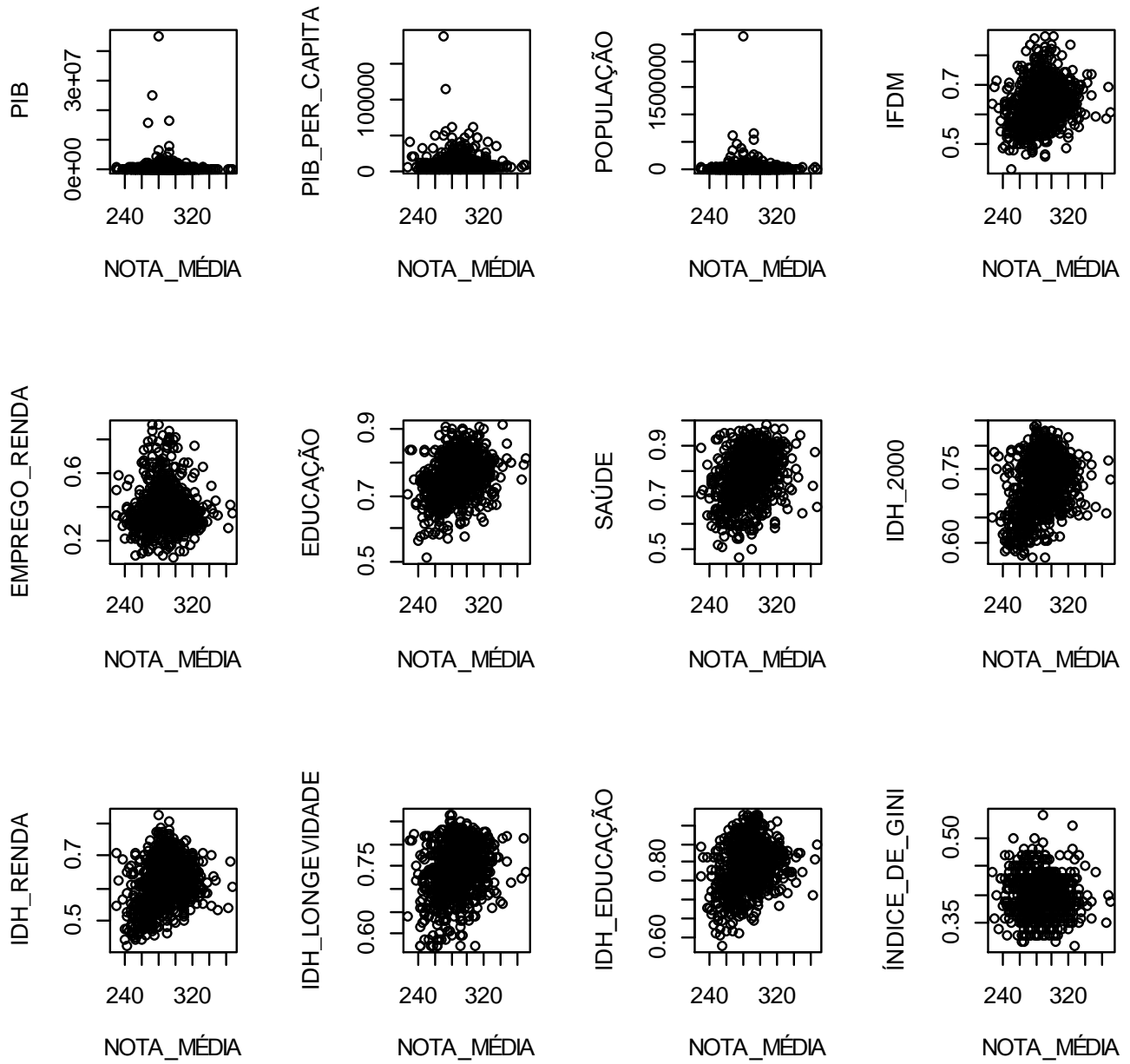

Fonte: Elaborado pelo autor.
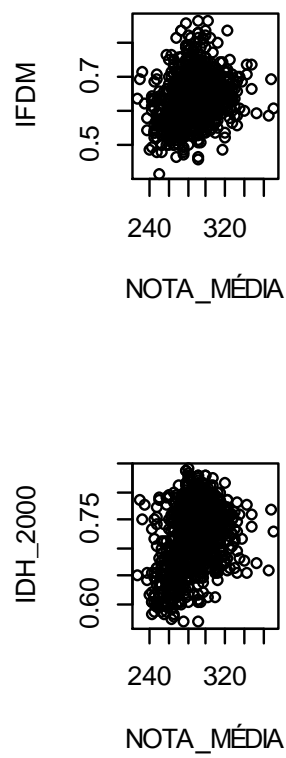

NOTA_MÉDIA 
COEFICIENTE DE CORRELAÇÃO ENTRE NOTA MÉDIA EM MATEMÁTICA E VARIÁVEIS DO MUNICÍPIO - PROEB - 2009.

\begin{tabular}{l|l}
\hline NOTA_MÉDIA COM & COEFICIENTE DE CORRELAÇÃO \\
\hline PIB & $-0,026$ \\
\hline PIB_PER_CAPITA & 0,030 \\
\hline POPULAÇÃO & $-0,034$ \\
\hline IFDM & 0,251 \\
\hline EMPREGO_RENDA & 0,024 \\
\hline EDUCAÇÃO & 0,315 \\
\hline SAÚDE & 0,314 \\
\hline IDH_2000 & 0,318 \\
\hline IDH_RENDA & 0,304 \\
\hline IDH_LONGEVIDADE & 0,256 \\
\hline IDH_EDUCAÇÃO & 0,291 \\
\hline ÍNDICE_DE_GINI & $-0,032$
\end{tabular}

Fonte: Elaborado pelo autor.

DISPERSÃO E CORRELAÇÕES ENTRE NOTA MÉDIA EM MATEMÁTICA E VARIÁVEIS DOS MUNICÍPIOS - PROEB - 2010.
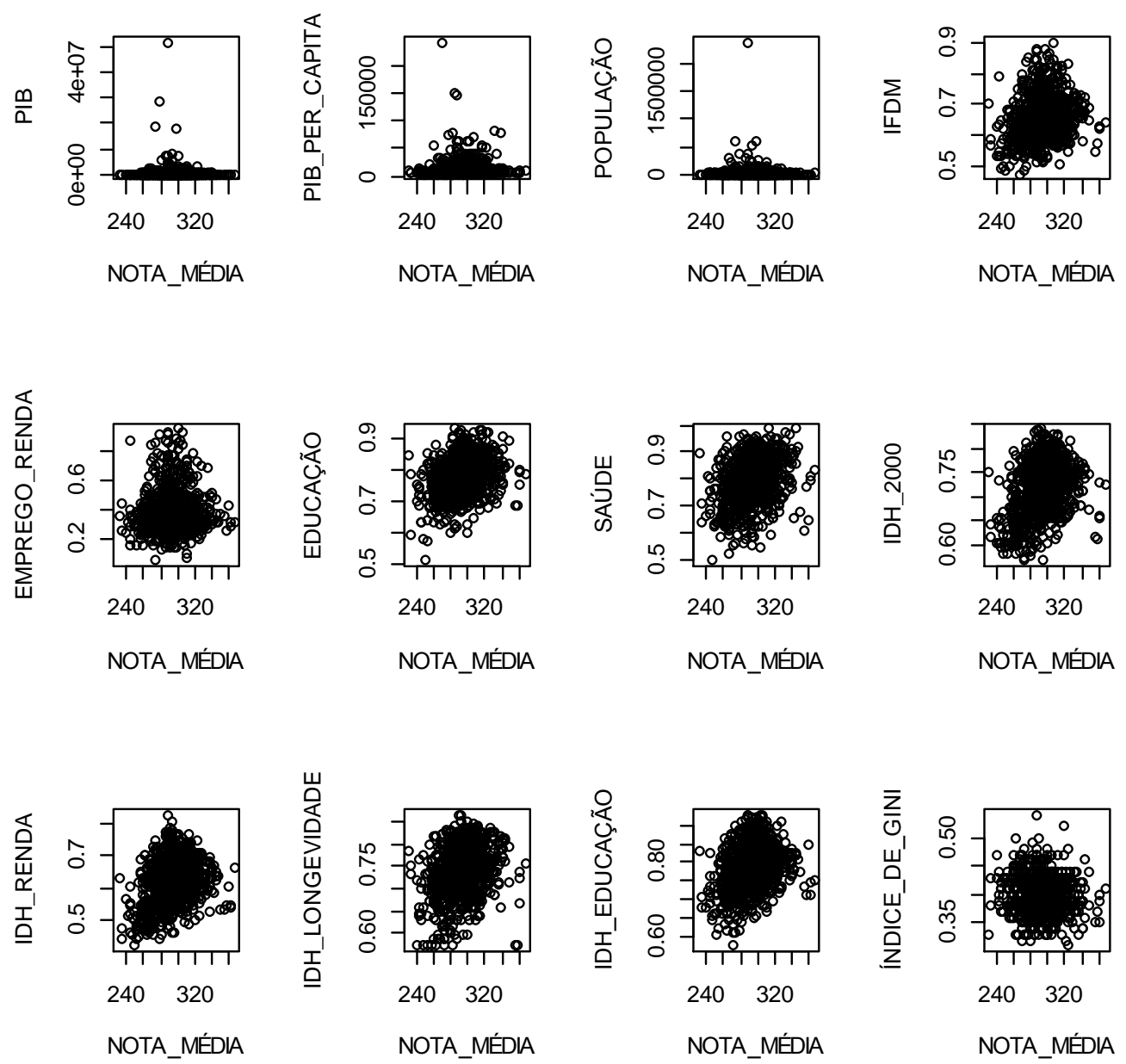

Fonte: Elaborado pelo autor. 
COEFICIENTE DE CORRELAÇÃO ENTRE NOTA MÉDIA EM MATEMÁTICA E VARIÁVEIS DO MUNICÍPIO - PROEB - 2010.

\begin{tabular}{l|l}
\hline NOTA_MÉDIA COM & COEFICIENTE DE CORRELAÇÃO \\
\hline PIB & $-0,026$ \\
\hline PIB_PER_CAPITA & 0,044 \\
\hline POPULAÇÃO & $-0,031$ \\
\hline IFDM & 0,231 \\
\hline EMPREGO_RENDA & 0,035 \\
\hline EDUCAÇÃO & 0,308 \\
\hline SAÚDE & 0,295 \\
\hline IDH_2000 & 0,335 \\
\hline IDH_RENDA & 0,331 \\
\hline IDH_LONGEVIDADE & 0,277 \\
\hline IDH_EDUCAÇÃO & 0,289 \\
\hline ÍNDICE_DE_GINI & $-0,061$
\end{tabular}

Fonte: Elaborado pelo autor.

DISPERSÃO E CORRELAÇÕES ENTRE NOTA MÉDIA EM PORTUGUÊS E VARIÁVEIS DOS MUNICÍPIOS - PROEB - 2006.
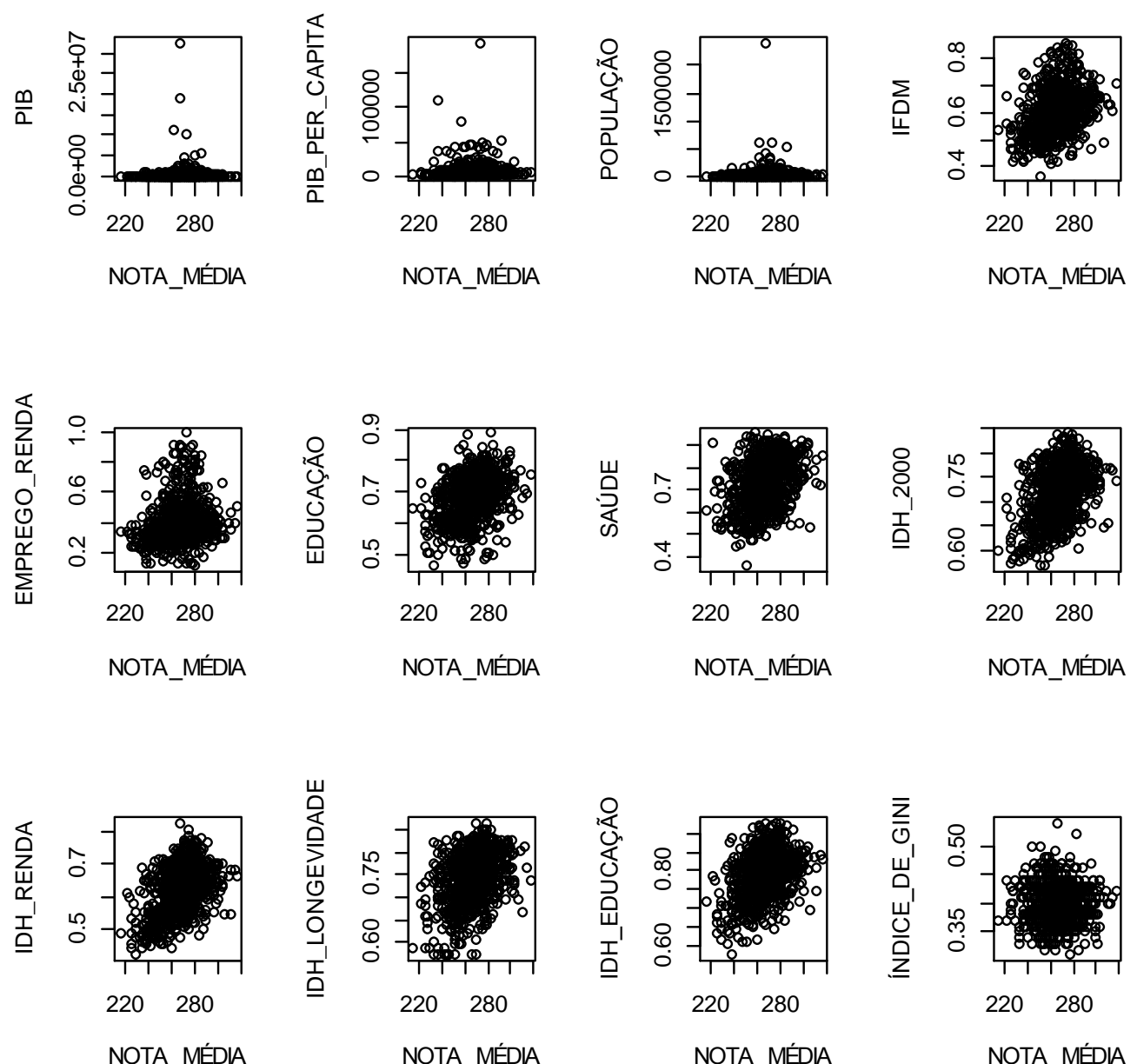

Fonte: Elaborado pelo autor. 
COEFICIENTE DE CORRELAÇÃO ENTRE NOTA MÉDIA EM PORTUGUÊS E VARIÁVEIS DO MUNICÍPIO - PROEB - 2006.

\begin{tabular}{l|l}
\hline NOTA_MÉDIA COM & COEFICIENTE DE CORRELAÇÃO \\
\hline PIB & 0,029 \\
\hline PIB_PER_CAPITA & 0,068 \\
\hline POPULAÇÃO & 0,024 \\
\hline IFDM & 0,371 \\
\hline EMPREGO_RENDA & 0,189 \\
\hline EDUCAÇÃO & 0,365 \\
\hline SAÚDE & 0,374 \\
\hline IDH_2000 & 0,462 \\
\hline IDH_RENDA & 0,464 \\
\hline IDH_LONGEVIDADE & 0,369 \\
\hline IDH_EDUCAÇÃO & 0,401 \\
\hline ÍNDICE_DE_GINI & 0,019 \\
\hline
\end{tabular}

Fonte: Elaborado pelo autor.

DISPERSÃO E CORRELAÇÕES ENTRE NOTA MÉDIA EM PORTUGUÊS E VARIÁVEIS DOS MUNICÍPIOS - PROEB - 2007.
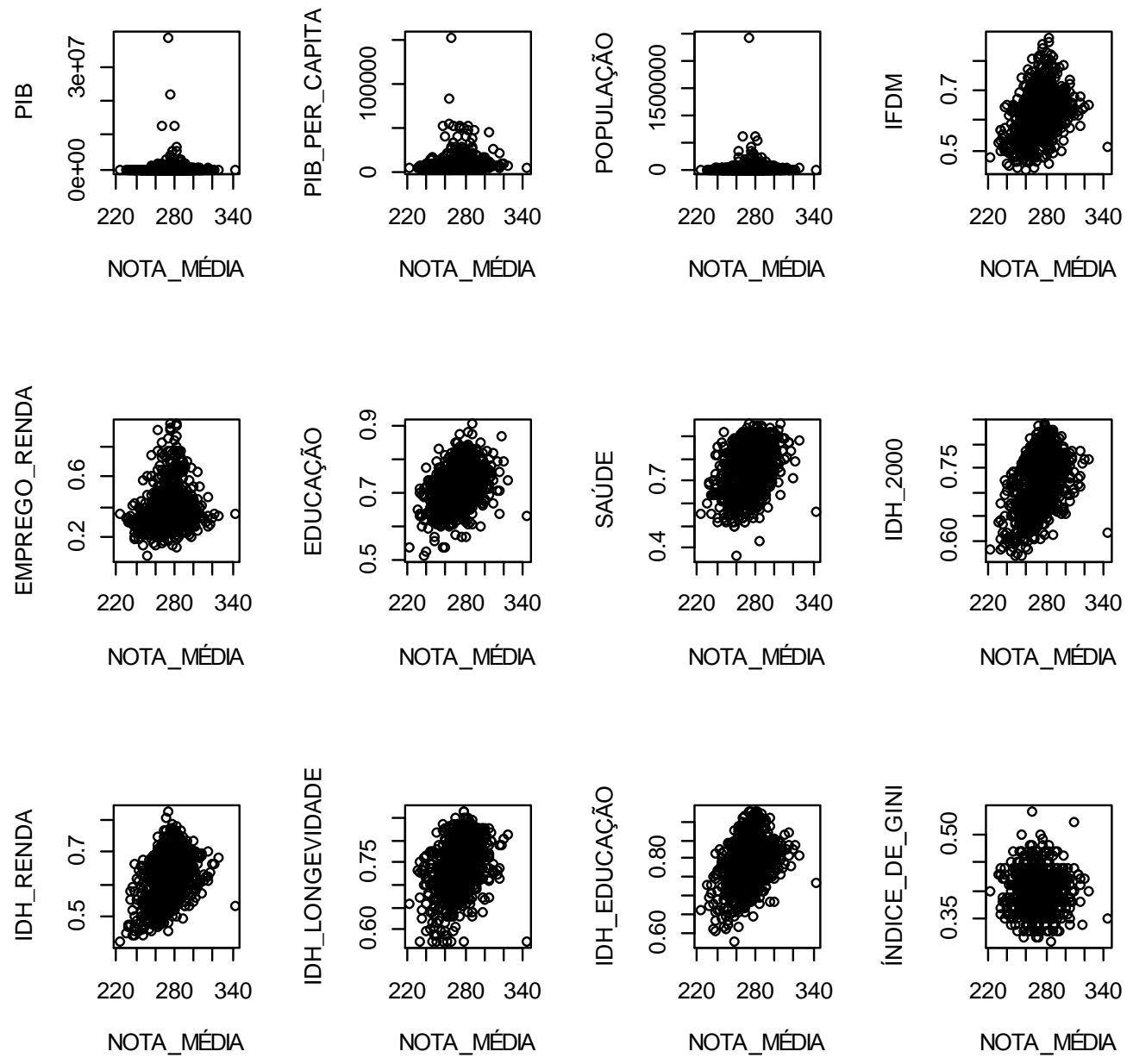

Fonte: Elaborado pelo autor. 
COEFICIENTE DE CORRELAÇÃO ENTRE NOTA MÉDIA EM PORTUGUÊS E VARIÁVEIS DO MUNICÍPIO - PROEB - 2007.

\begin{tabular}{l|l}
\hline NOTA_MÉDIA COM & COEFICIENTE DE CORRELAÇÃO \\
\hline PIB & 0,018 \\
\hline PIB_PER_CAPITA & 0,076 \\
\hline POPULAÇÃO & 0,013 \\
\hline IFDM & 0,355 \\
\hline EMPREGO_RENDA & 0,146 \\
\hline EDUCAÇÃO & 0,373 \\
\hline SAÚDE & 0,367 \\
\hline IDH_2000 & 0,439 \\
\hline IDH_RENDA & 0,427 \\
\hline IDH_LONGEVIDADE & 0,350 \\
\hline IDH_EDUCAÇÃO & 0,398 \\
\hline ÍNDICE_DE_GINI & $-0,003$
\end{tabular}

Fonte: Elaborado pelo autor.

DISPERSÃO E CORRELAÇÕES ENTRE NOTA MÉDIA EM PORTUGUÊS E VARIÁVEIS DOS MUNICÍPIOS - PROEB - 2008.

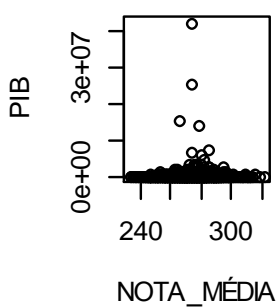

NOTA MÉDIA

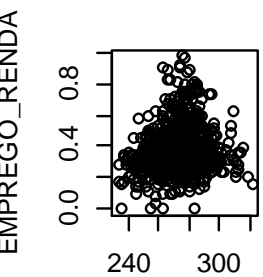

NOTA_MÉDIA

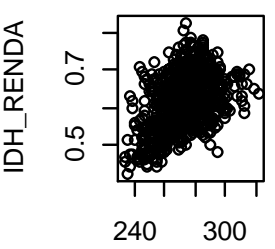

NOTA_MÉDIA
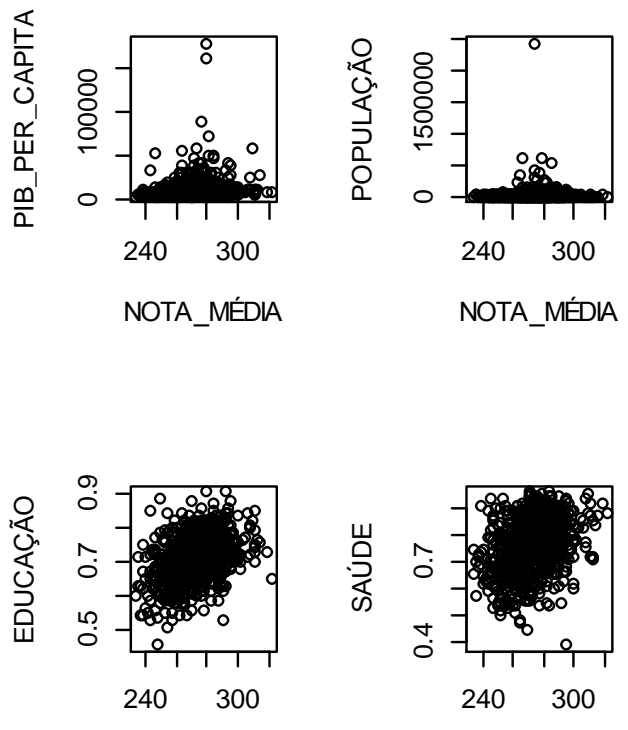

NOTA_MÉDIA

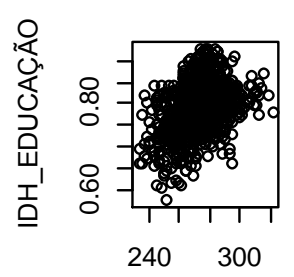

NOTA_MÉDIA

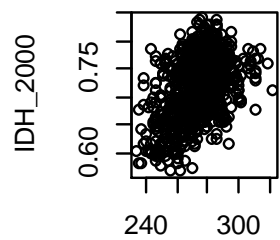

NOTA_MÉDIA
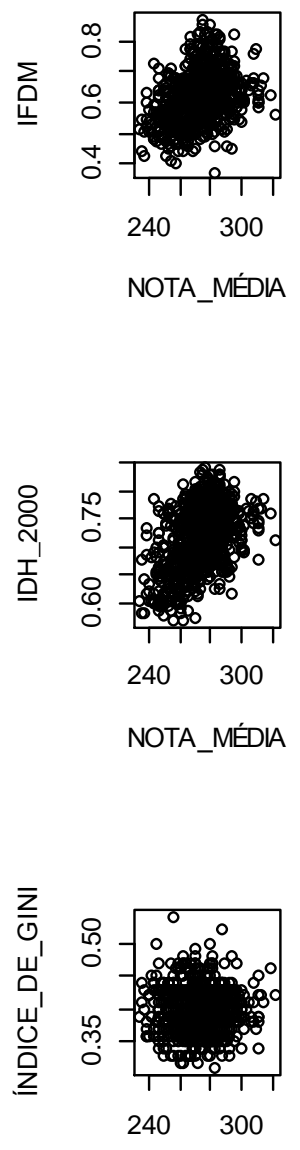

NOTA_MÉDIA

Fonte: Elaborado pelo autor. 
COEFICIENTE DE CORRELAÇÃO ENTRE NOTA MÉDIA EM PORTUGUÊS E VARIÁVEIS DO MUNICÍPIO - PROEB - 2008.

\begin{tabular}{l|l}
\hline NOTA_MÉDIA COM & COEFICIENTE DE CORRELAÇÃO \\
\hline PIB & 0,031 \\
\hline PIB_PER_CAPITA & 0,120 \\
\hline POPULAÇÃO & 0,027 \\
\hline IFDM & 0,345 \\
\hline EMPREGO_RENDA & 0,156 \\
\hline EDUCAÇÃO & 0,404 \\
\hline SAÚDE & 0,327 \\
\hline IDH_2000 & 0,446 \\
\hline IDH_RENDA & 0,437 \\
\hline IDH_LONGEVIDADE & 0,348 \\
\hline IDH_EDUCAÇÃO & 0,410 \\
\hline ÍNDICE_DE_GINI & 0,023
\end{tabular}

Fonte: Elaborado pelo autor.

DISPERSÃO E CORRELAÇÕES ENTRE NOTA MÉDIA EM PORTUGUÊS E VARIÁVEIS DOS MUNICÍPIOS - PROEB - 2009.

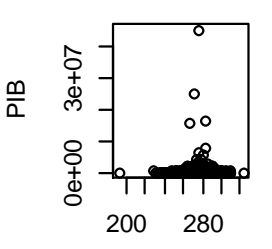

NOTA_MÉDIA

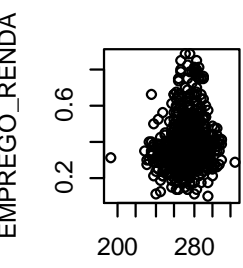

NOTA_MÉDIA

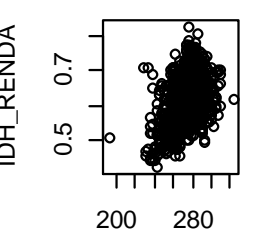

NOTA_MÉDIA
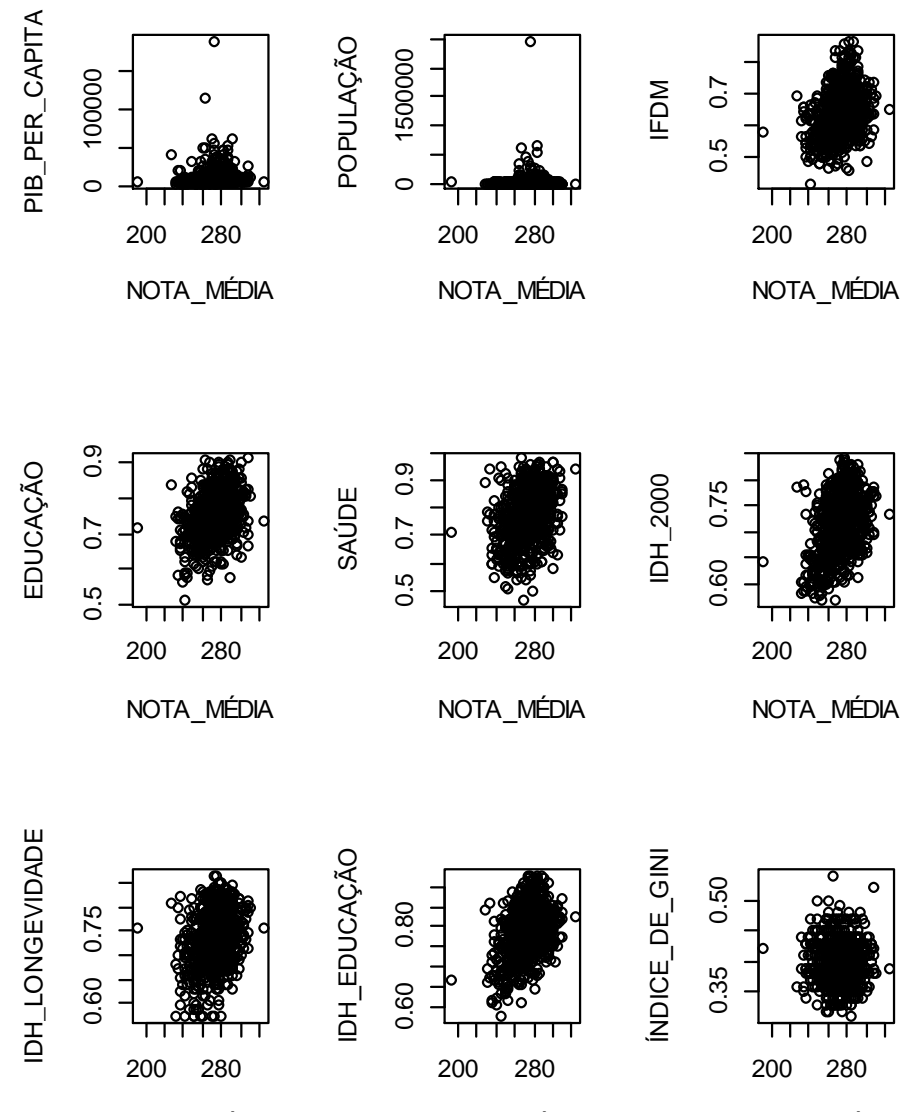

NOTA_MÉDIA
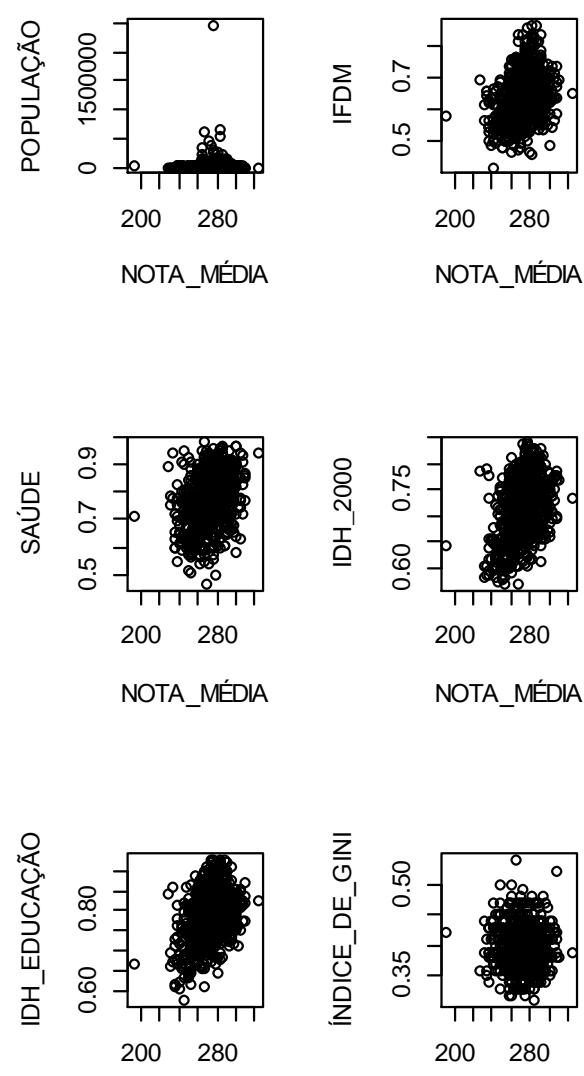

NOTA_MÉDIA

NOTA_MÉDIA
NOTA_MÉDIA

Fonte: Elaborado pelo autor. 
COEFICIENTE DE CORRELAÇÃO ENTRE NOTA MÉDIA EM PORTUGUÊS E VARIÁVEIS DO MUNICÍPIO - PROEB - 2009.

\begin{tabular}{l|l}
\hline NOTA_MÉDIA COM & COEFICIENTE DE CORRELAÇÃO \\
\hline PIB & 0,027 \\
\hline PIB_PER_CAPITA & 0,071 \\
\hline POPULAÇÃO & 0,026 \\
\hline IFDM & 0,332 \\
\hline EMPREGO_RENDA & 0,098 \\
\hline EDUCAÇÃO & 0,391 \\
\hline SAÚDE & 0,343 \\
\hline IDH_2000 & 0,429 \\
\hline IDH_RENDA & 0,419 \\
\hline IDH_LONGEVIDADE & 0,316 \\
\hline IDH_EDUCAÇÃO & 0,410 \\
\hline ÍNDICE_DE_GINI & 0,003
\end{tabular}

Fonte: Elaborado pelo autor.

DISPERSÃO E CORRELAÇÕES ENTRE NOTA MÉDIA EM PORTUGUÊS E VARIÁVEIS DOS MUNICÍPIOS - PROEB - 2010.
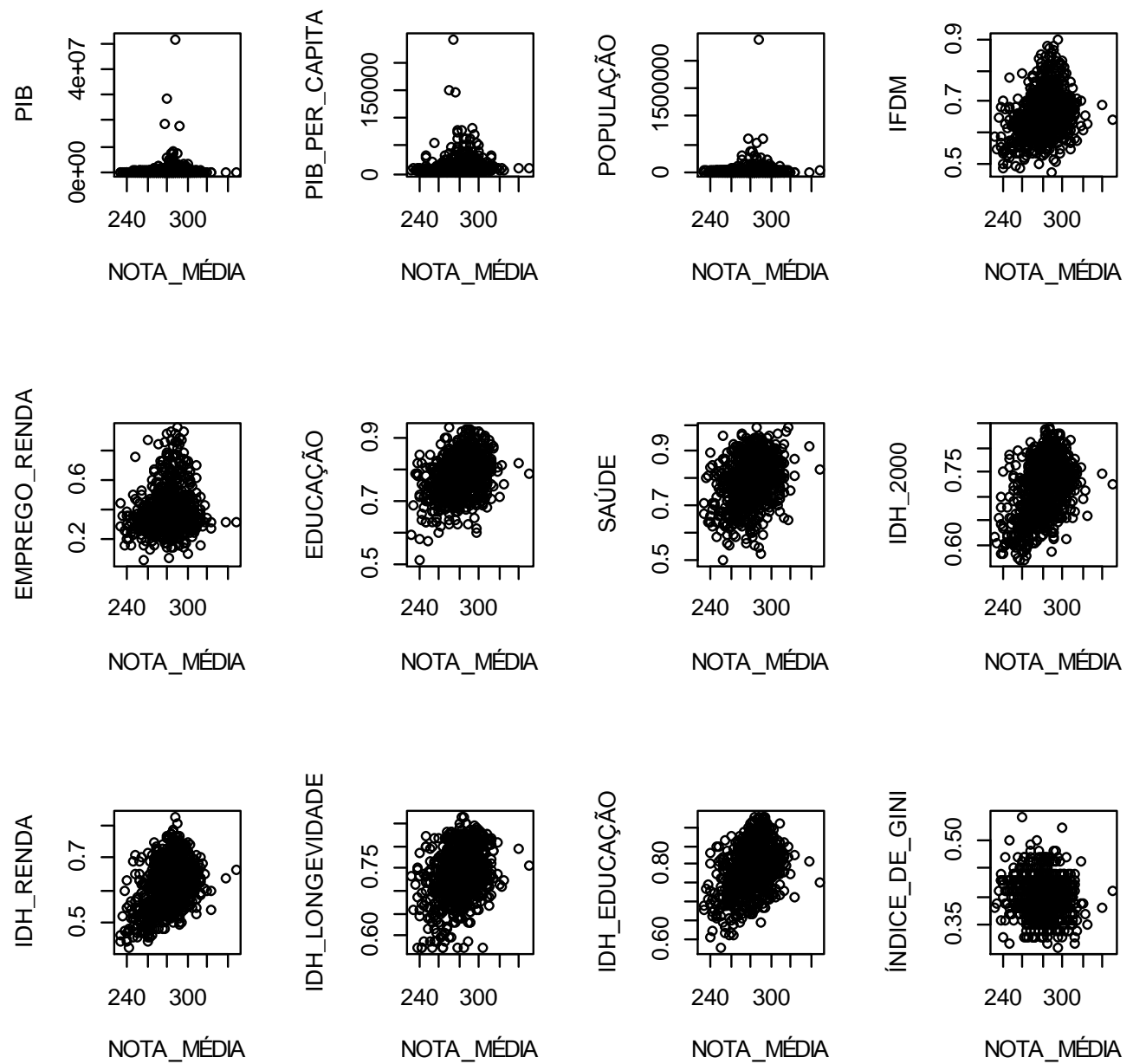

Fonte: Elaborado pelo autor.

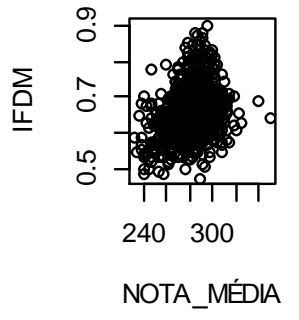

NOTA_MÉDIA 
COEFICIENTE DE CORRELAÇÃO ENTRE NOTA MÉDIA EM PORTUGUÊS E VARIÁVEIS DO MUNICÍPIO - PROEB - 2010.

\begin{tabular}{l|l}
\hline NOTA_MÉDIA COM & COEFICIENTE DE CORRELAÇÃO \\
\hline PIB & 0,036 \\
\hline PIB_PER_CAPITA & 0,070 \\
\hline POPULAÇÃO & 0,033 \\
\hline IFDM & 0,311 \\
\hline EMPREGO_RENDA & 0,121 \\
\hline EDUCAÇÃO & 0,348 \\
\hline SAÚDE & 0,321 \\
\hline IDH_2000 & 0,417 \\
\hline IDH_RENDA & 0,414 \\
\hline IDH_LONGEVIDADE & 0,314 \\
\hline IDH_EDUCAÇÃO & 0,386 \\
\hline ÍNDICE_DE_GINI & $-0,077$
\end{tabular}

\section{4 .}

Fonte: Elaborado pelo autor.

\section{Desempenho $x$ indicadores sócio demográficos - gráficos e suas respectivas tabelas de frequência}

Os gráficos e suas respectivas tabelas de frequência

Matemática 2006

DESEMPENHO DE MATEMÁTICA 2006 X IFDM

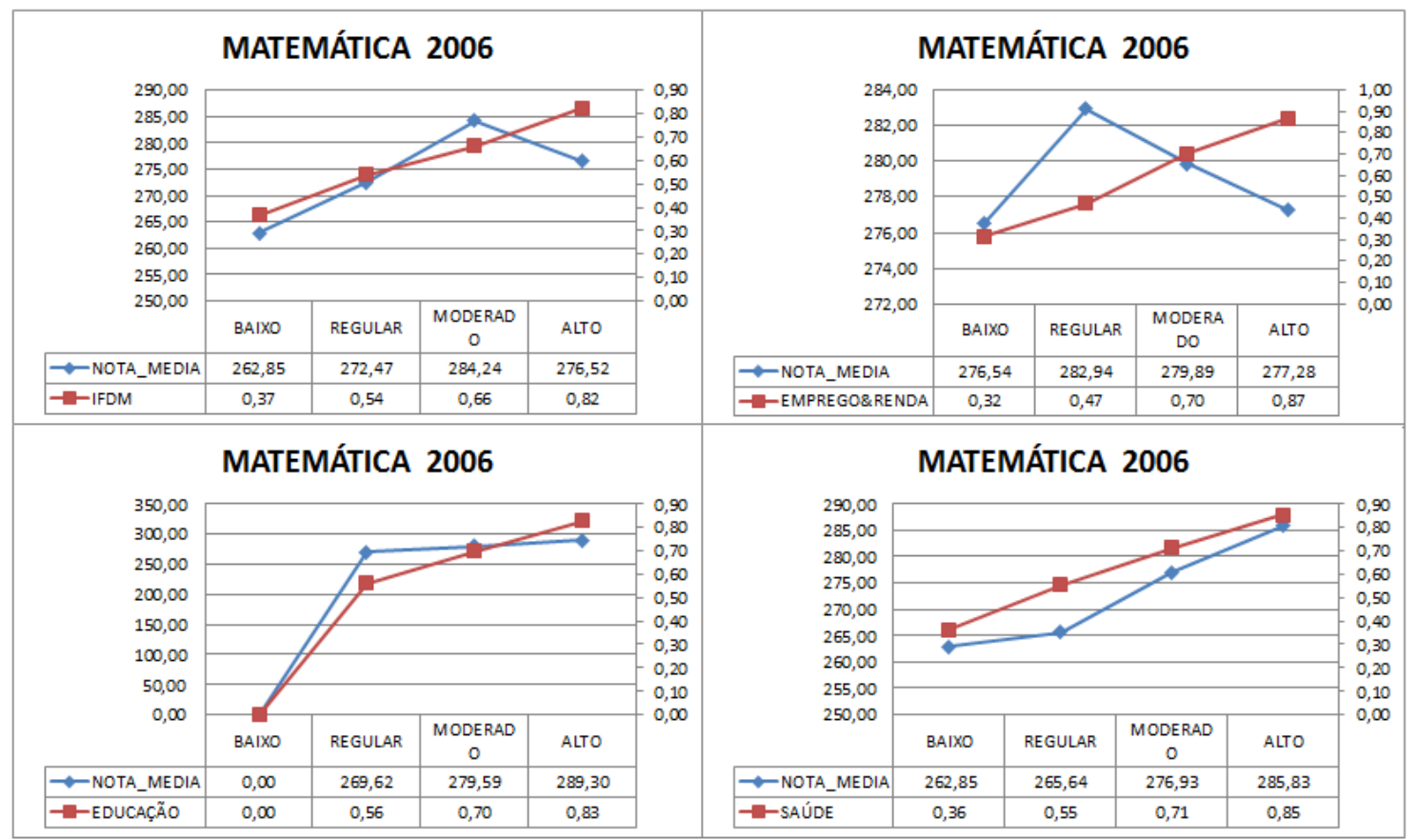

Fonte: Elaborado pelo autor. 
DESEMPENHO DE MATEMÁTICA 2006 X IFDM

\begin{tabular}{l|l|l|l|l}
\hline 2006 & IFDM & EMPREGO\&RENDA & EDUCAÇÃO & SAÚDE \\
\hline BAIXO & 1 & 507 & 0 & 1 \\
\hline REGULAR & 376 & 247 & 95 & 104 \\
\hline MODERADO & 429 & 50 & 706 & 422 \\
\hline ALTO & 16 & 18 & 21 & 295 \\
\hline TOTAL & 822 & 822 & 822 & 822 \\
\hline
\end{tabular}

Fonte: Elaborado pelo autor.

DESEMPENHO DE MATEMÁTICA 2006 X IFDM (\%)

\begin{tabular}{l|l|l|l|l}
\hline 2006 & IFDM & EMPREGO\&RENDA & EDUCAÇÃO & SAÚDE \\
\hline BAIXO & $0,1 \%$ & $61,7 \%$ & $0,0 \%$ & $0,1 \%$ \\
\hline REGULAR & $45,7 \%$ & $30,0 \%$ & $11,6 \%$ & $12,7 \%$ \\
\hline MODERADO & $52,2 \%$ & $6,1 \%$ & $85,9 \%$ & $51,3 \%$ \\
\hline ALTO & $1,9 \%$ & $2,2 \%$ & $2,6 \%$ & $35,9 \%$ \\
\hline TOTAL & $100,0 \%$ & $100,0 \%$ & $100,0 \%$ & $100,0 \%$ \\
\hline
\end{tabular}

Fonte: Elaborado pelo autor.

No índice IFDM, as notas médias de 2006 acompanham bem até o nível moderado, no nível alto as notas médias sofrem uma queda, não refletindo melhores desempenhos para a faixa do alto índice do IFDM, talvez por representar poucas observações, pois só temos 16 cidades que se adequam a essa faixa IFDM que representam $1,9 \%$ do total de 822 cidades.

Para o componente Emprego \& Renda do IFDM, percebemos queda após o nível regular que ocorre novamente no nível alto seguido do moderado, novamente termos poucos representantes nessas faixas 50 cidades no moderado e 18 no nível alto.

Nos componentes educação e saúde, o comportamento foi crescente na medida que avançamos nas faixas do baixo até o alto. Vale ressaltar que não foram encontradas cidades para o nível baixo do componente educação e apenas a cidade de São João Do Pacui foi encontrada para o nível baixo da componente saúde.

DESEMPENHO DE MATEMÁTICA 2006 X IDHM-2000 


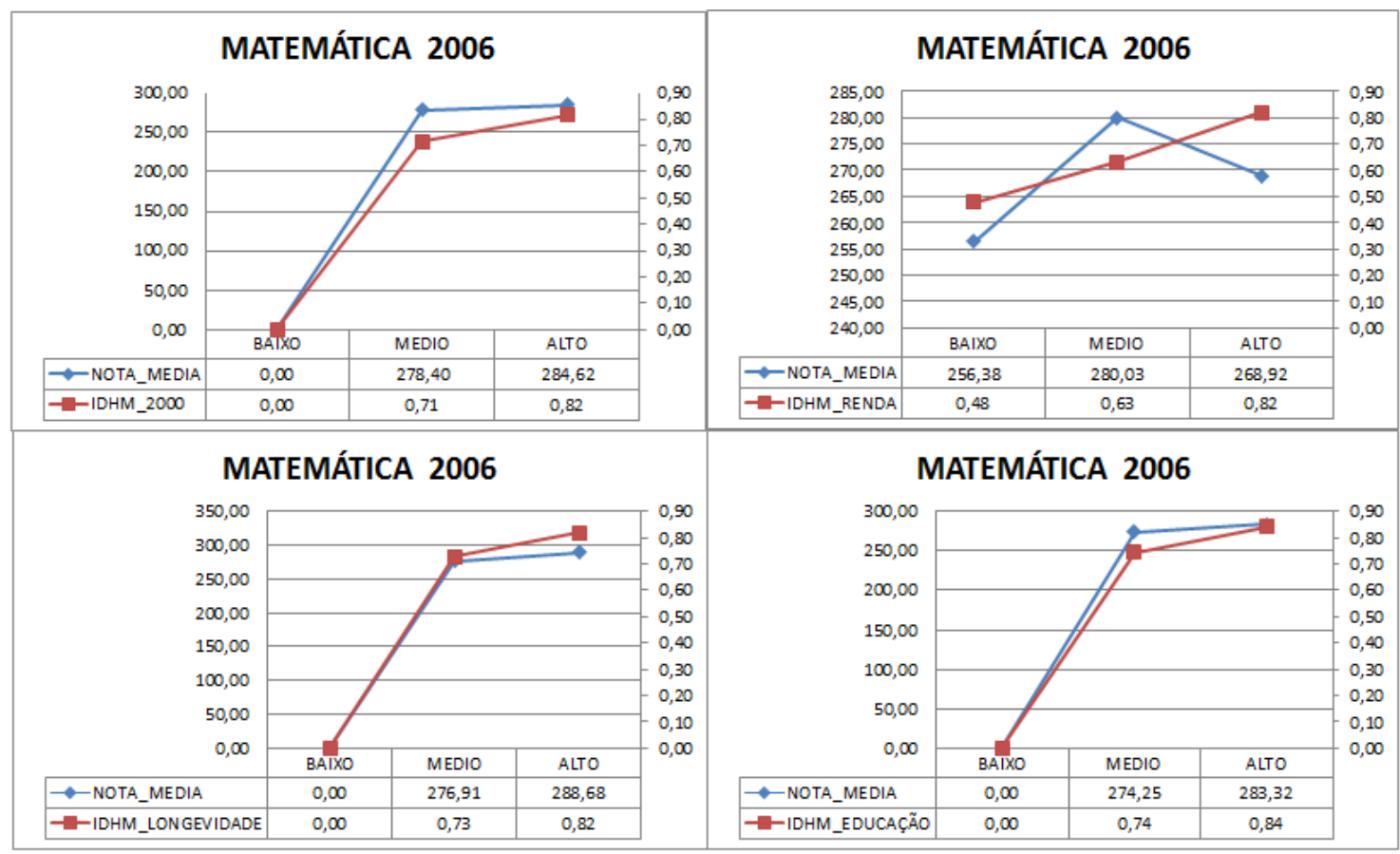

Fonte: Elaborado pelo autor.

DESEMPENHO DE MATEMÁTICA 2006 X Índice de Gini - 2000 e 2010

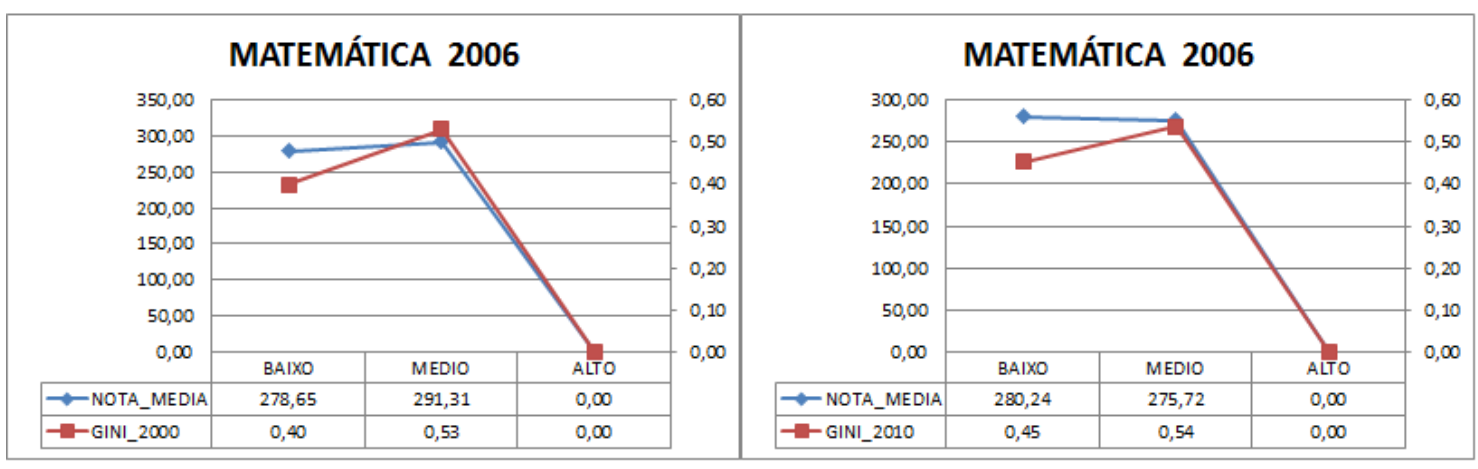

Fonte: Elaborado pelo autor.

DESEMPENHO DE MATEMÁTICA 2006 X IDHM-2000 E ÍNDICE DE GINI

\begin{tabular}{l|c|c|c|c|c|c}
\hline 2006 & IDHM_2000 & IDHM_RENDA & IDHM_LONGEVIDADE & IDHM_EDUCAÇÃO & GINI_2000 & GINI_2010 \\
\hline BAIXO & 0 & 46 & 0 & 0 & 820 & 539 \\
\hline MEDIO & 785 & 774 & 698 & 420 & 2 & 283 \\
\hline ALTO & 37 & 2 & 124 & 402 & 0 & 0 \\
\hline
\end{tabular}




\begin{tabular}{l|l|l|l|l|l|l}
\hline TOTAL & 822 & 822 & 822 & 822 & 822 & 822 \\
\hline \multicolumn{5}{c}{ Fonte: Elaborado pelo autor. }
\end{tabular}

Fonte: Elaborado pelo autor.

DESEMPENHO DE MATEMÁTICA 2006 X IDHM-2000 E ÍNDICE DE GINI (\%)

\begin{tabular}{l|l|l|l|l|l|l}
\hline 2006 & IDHM_2000 & IDHM_RENDA & IDHM_LONGEVIDADE & IDHM_EDUCAÇÃO & GINI_2000 & GINI_2010 \\
\hline BAIXO & $0,0 \%$ & $5,6 \%$ & $0,0 \%$ & $0,0 \%$ & $99,8 \%$ & $65,6 \%$ \\
\hline MEDIO & $95,5 \%$ & $94,2 \%$ & $84,9 \%$ & $51,1 \%$ & $0,2 \%$ & $34,4 \%$ \\
\hline ALTO & $4,5 \%$ & $0,2 \%$ & $15,1 \%$ & $48,9 \%$ & $0,0 \%$ & $0,0 \%$ \\
\hline TOTAL & $100,0 \%$ & $100,0 \%$ & $100,0 \%$ & $100,0 \%$ & $100,0 \%$ & $100,0 \%$ \\
\hline
\end{tabular}

Fonte: Elaborado pelo autor.

No índice do IDHM, e da componente longevidade, e educação, há um acompanhamento perfeito, com exceção da renda, em que o nível alto não possui notas médias altas, mas uma queda, além disso, temos apenas duas cidades nesse nível: Belo Horizonte e São Gotardo. Já no índice de Gini, percebemos um acompanhamento do índice de 2000, mas não no de 2010, em que o nível médio apresenta queda em vez de acompanhamento. Outro fato que percebemos é que temos mais cidades na faixa média do índice Gini 2010 do que a concentração da faixa baixa do índice de Gini 2000, em que somente duas cidades estavam nesse nível: Carmesia e Morro do Pilar. Vale ressaltar que não há nenhuma cidade no nível alto.

\section{DESEMPENHO DE MATEMÁTICA 2006 X IDHM-2000}

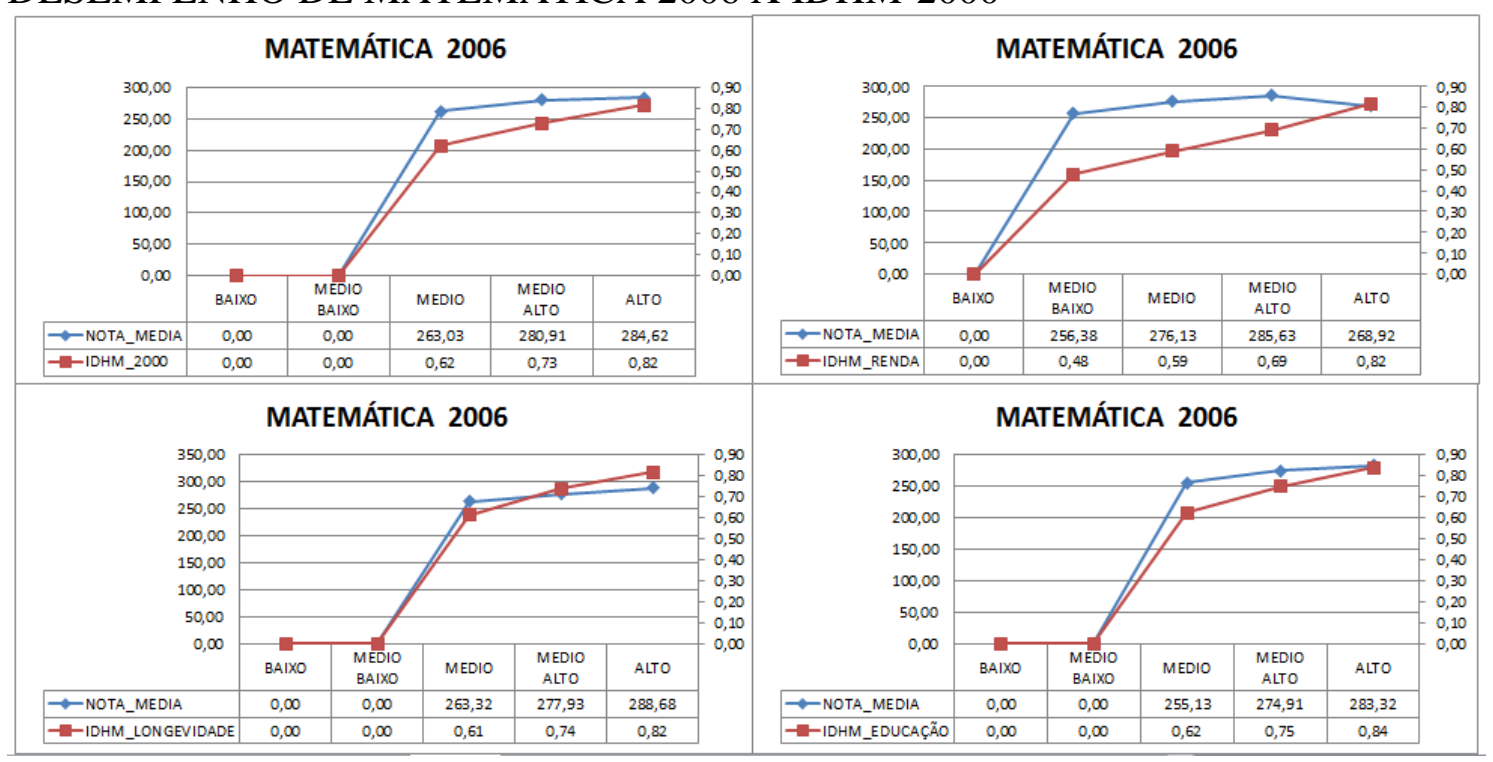

Fonte: Elaborado pelo autor 
DESEMPENHO DE MATEMÁTICA 2006 X IDHM-2000 - 5 FAIXAS

\begin{tabular}{l|l|l|l|l}
\hline 2006 & IDHM_2000 & IDHM_RENDA & IDHM_LONGEVIDADE & IDHM_EDUCAÇÃO \\
\hline BAIXO & 0 & 0 & 0 & 0 \\
\hline BAIXO MEDIO & 0 & 46 & 0 & 0 \\
\hline MEDIO & 110 & 456 & 49 & 14 \\
\hline MEDIO ALTO & 675 & 318 & 649 & 406 \\
\hline ALTO & 37 & 2 & 124 & 402 \\
\hline TOTAL & 822 & 822 & 822 & 822 \\
\hline
\end{tabular}

Fonte: Elaborado pelo autor.

DESEMPENHO DE MATEMÁTICA 2006 X IDHM-2000 - 5 FAIXAS (\%)

\begin{tabular}{l|l|l|l|l}
\hline 2006 & IDHM_2000 & IDHM_RENDA & IDHM_LONGEVIDADE & IDHM_EDUCAÇÃO \\
\hline BAIXO & $0,0 \%$ & $0,0 \%$ & $0,0 \%$ & $0,0 \%$ \\
\hline BAIXO MEDIO & $0,0 \%$ & $5,6 \%$ & $0,0 \%$ & $0,0 \%$ \\
\hline MEDIO & $13,4 \%$ & $55,5 \%$ & $6,0 \%$ & $1,7 \%$ \\
\hline MEDIO ALTO & $82,1 \%$ & $38,7 \%$ & $79,0 \%$ & $49,4 \%$ \\
\hline ALTO & $4,5 \%$ & $0,2 \%$ & $15,1 \%$ & $48,9 \%$ \\
\hline TOTAL & $100,0 \%$ & $100,0 \%$ & $100,0 \%$ & $100,0 \%$ \\
\hline
\end{tabular}

Fonte: Elaborado pelo autor. 
Realizando uma nova divisão no IDHM, segmentando em 5 faixas, observamos o mesmo resultado da divisão em 3 faixas, a componente Renda novamente tem em seu nível alto, uma queda da nota média, e possui apenas duas cidades representando esse nível: Belo Horizonte e São Gotardo.

Matemática 2007

DESEMPENHO DE MATEMÁTICA 2007 X IFDM

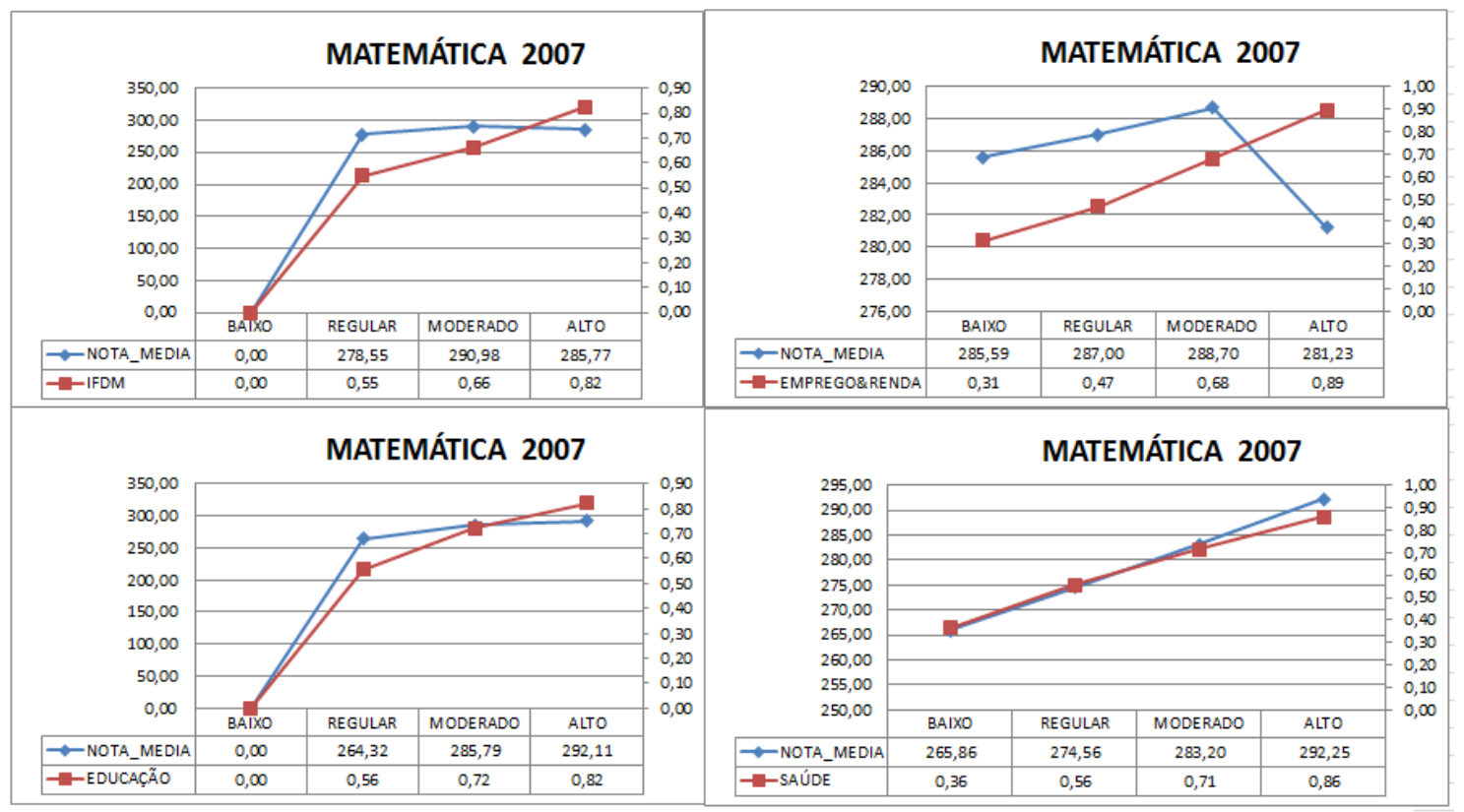

Fonte: Elaborado pelo autor.

DESEMPENHO DE MATEMÁTICA 2007 X IFDM

\begin{tabular}{l|l|l|l|l}
\hline 2007 & IFDM & EMPREGO\&RENDA & EDUCAÇÃO & SAÚDE \\
\hline BAIXO & 0 & 568 & 0 & 1 \\
\hline REGULAR & 319 & 186 & 12 & 66 \\
\hline MODERADO & 489 & 57 & 734 & 430 \\
\hline ALTO & 14 & 11 & 76 & 325 \\
\hline TOTAL & 822 & 822 & 822 & 822 \\
\hline
\end{tabular}

Fonte: Elaborado pelo autor.

DESEMPENHO DE MATEMÁTICA 2007 X IFDM (\%)

\begin{tabular}{l|l|l|l|l}
\hline 2007 & IFDM & EMPREGO\&RENDA & EDUCAÇÃO & SAÚDE \\
\hline BAIXO & $0,0 \%$ & $69,1 \%$ & $0,0 \%$ & $0,1 \%$ \\
\hline REGULAR & $38,8 \%$ & $22,6 \%$ & $1,5 \%$ & $8,0 \%$ \\
\hline MODERADO & $59,5 \%$ & $6,9 \%$ & $89,3 \%$ & $52,3 \%$ \\
\hline ALTO & $1,7 \%$ & $1,3 \%$ & $9,2 \%$ & $39,5 \%$ \\
\hline TOTAL & $100,0 \%$ & $100,0 \%$ & $100,0 \%$ & $100,0 \%$ \\
\hline
\end{tabular}

Fonte: Elaborado pelo autor. 
No índice IFDM, as notas médias de 2007 acompanham bem até o nível moderado, no nível alto as notas médias sofrem uma queda, não refletindo melhores desempenhos para a faixa do alto índice do IFDM, há poucas cidades nesse nível, temos apenas 14 cidades que se adequam a essa faixa IFDM que representam 1,7\% do total de 822 cidades.

Para o componente Emprego \& Renda do IFDM, percebemos queda no nível alto, novamente termos poucos representantes nessas faixas, apenas 11 cidades nesse nível. Nas componentes educação e saúde, o comportamento foi condizente com a faixa e índice. Vale ressaltar que não foram encontradas cidades para o nível baixo da componente educação e IFDM apenas a cidade de Sao Joao Do Pacui foi encontrada para o nível baixo da componente saúde. 
DESEMPENHO DE MATEMÁTICA 2007 X IDHM-2000 - 3 FAIXAS

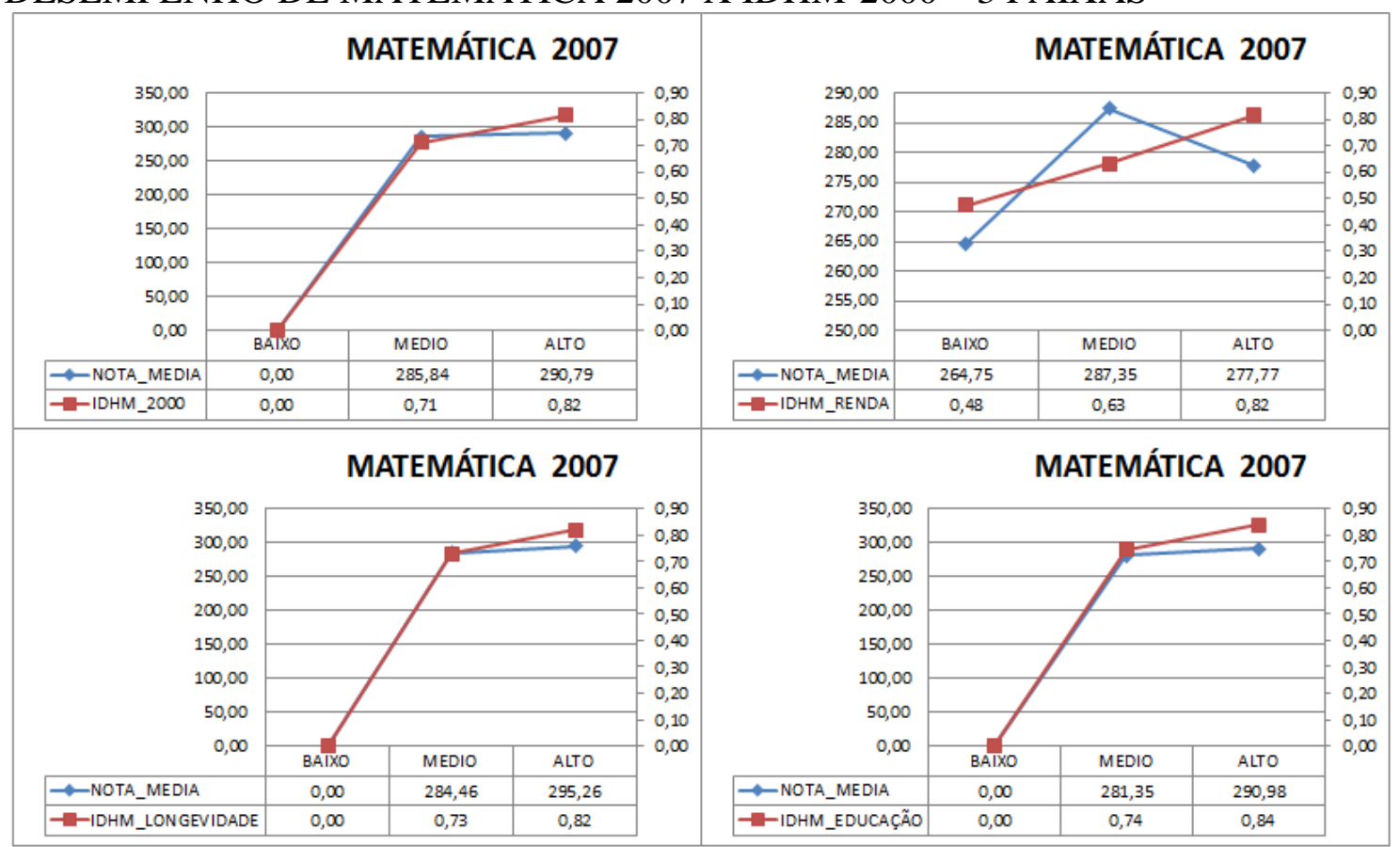

Fonte: Elaborado pelo autor.

\section{DESEMPENHO DE MATEMÁTICA 2007 X GINI 2000 E 2010}

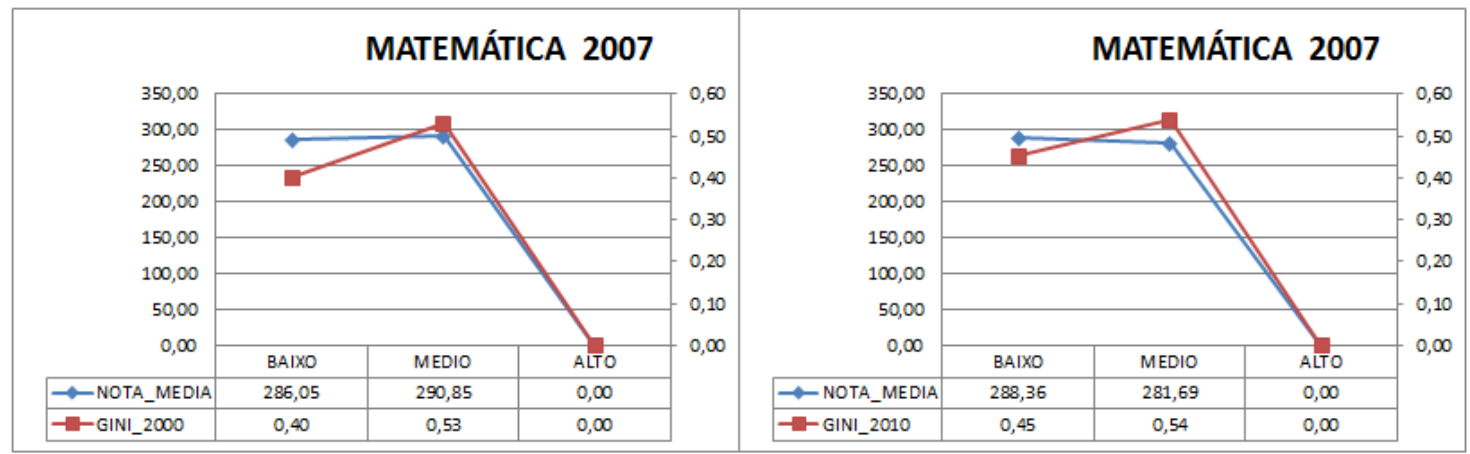

Fonte: Elaborado pelo autor.

DESEMPENHO DE MATEMÁTICA 2007 X IDHM E ÍNDICE DE GINI

\begin{tabular}{l|l|l|l|l|l|l}
\hline 2007 & IDHM_2000 & IDHM_RENDA & IDHM_LONGEVIDADE & IDHM_EDUCAÇÃO & GINI_2000 & GINI_2010 \\
\hline BAIXO & 0 & 46 & 0 & 0 & 820 & 539 \\
\hline MEDIO & 785 & 774 & 700 & 420 & 2 & 283 \\
\hline ALTO & 37 & 2 & 122 & 402 & 0 & 0 \\
\hline TOTAL & 822 & 822 & 822 & 822 & 822 & 822 \\
\hline
\end{tabular}

Fonte: Elaborado pelo autor.

DESEMPENHO DE MATEMÁTICA 2007 X IDHM E ÍNDICE DE GINI (\%)

\begin{tabular}{l|l|l|l|l|l|l}
\hline 2007 & IDHM_2000 & IDHM_RENDA & IDHM_LONGEVIDADE & IDHM_EDUCAÇÃO & GINI_2000 & GINI_2010 \\
\hline BAIXO & $0,0 \%$ & $5,6 \%$ & $0,0 \%$ & $0,0 \%$ & $99,8 \%$ & $65,6 \%$ \\
\hline MEDIO & $95,5 \%$ & $94,2 \%$ & $85,2 \%$ & $51,1 \%$ & $0,2 \%$ & $34,4 \%$ \\
\hline ALTO & $4,5 \%$ & $0,2 \%$ & $14,8 \%$ & $48,9 \%$ & $0,0 \%$ & $0,0 \%$ \\
\hline TOTAL & $100,0 \%$ & $100,0 \%$ & $100,0 \%$ & $100,0 \%$ & $100,0 \%$ & $100,0 \%$ \\
\hline
\end{tabular}

Fonte: Elaborado pelo autor. 
No índice do IDHM, e da componente longevidade, e educação, há um acompanhamento perfeito, com exceção da renda, em que o nível alto não possui notas médias altas, mas uma queda, além disso, temos apenas duas cidades nesse nível: Belo Horizonte e São Gotardo.

Já no índice de Gini, percebemos um acompanhamento do índice de 2000, mas não no de 2010, em que o nível médio apresenta queda em vez de acompanhamento. Outro fato que percebemos é que temos mais cidades na faixa média do índice Gini 2010 do que a concentração da faixa baixa do índice de Gini 2000, em que somente duas cidades estavam nesse nível: Carmesia e Morro do Pilar. Vale ressaltar que não há nenhuma cidade no nível alto.

\section{DESEMPENHO DE MATEMÁTICA 2007 X IDHM-2000 - 5 FAIXAS}

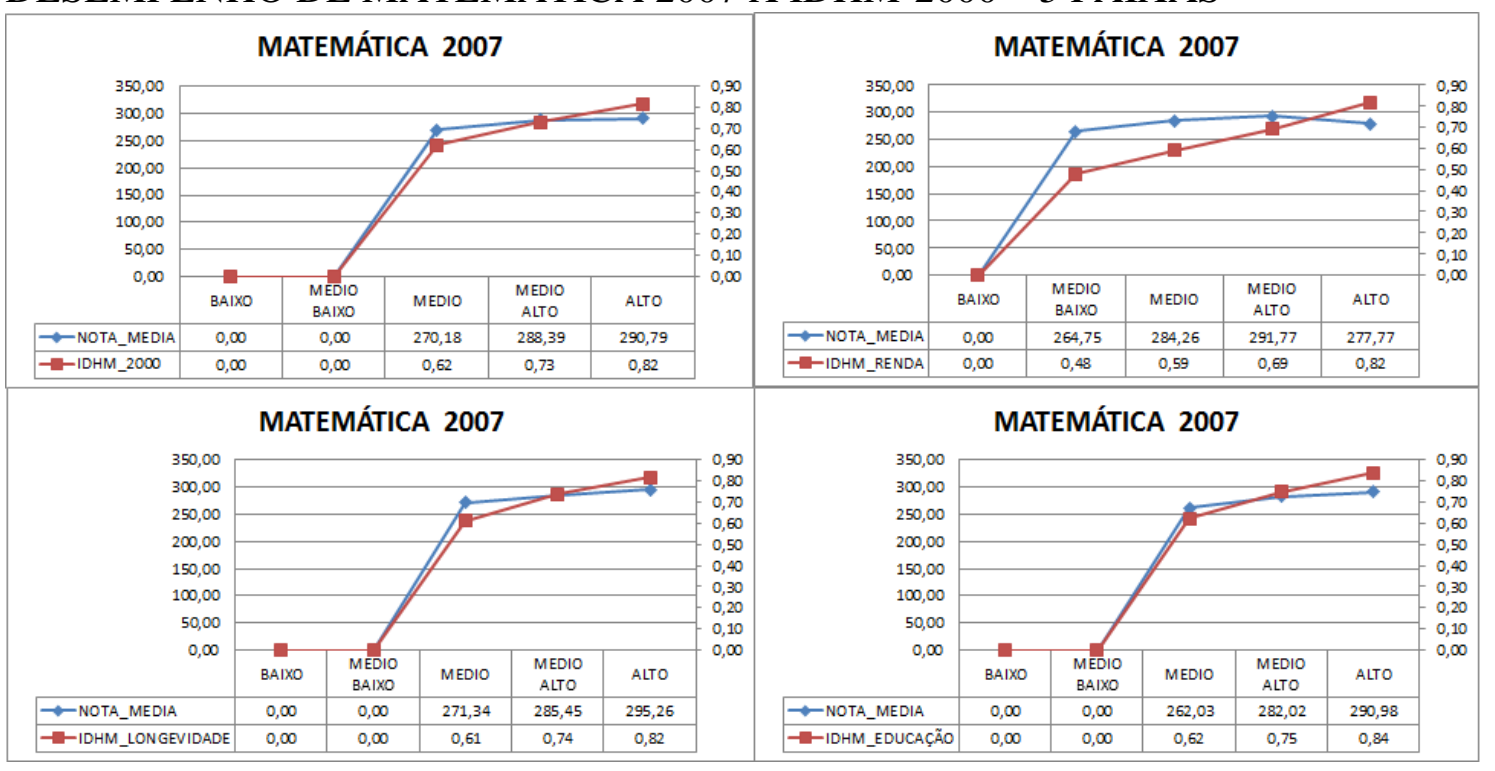

Fonte: Elaborado pelo autor.

DESEMPENHO DE MATEMÁTICA 2007 X IDHM - 5 FAIXAS

\begin{tabular}{l|l|l|l|l}
\hline 2007 & IDHM_2000 & IDHM_RENDA & IDHM_LONGEVIDADE & IDHM_EDUCAÇÃO \\
\hline BAIXO & 0 & 0 & 0 & 0 \\
\hline BAIXO MEDIO & 0 & 46 & 0 & 0 \\
\hline MEDIO & 110 & 455 & 49 & 14 \\
\hline MEDIO ALTO & 675 & 319 & 651 & 406 \\
\hline ALTO & 37 & 2 & 122 & 402 \\
\hline TOTAL & 822 & 822 & 822 & 822 \\
\hline
\end{tabular}

Fonte: Elaborado pelo autor. 
DESEMPENHO DE MATEMÁTICA 2007 X IDHM - 5 FAIXAS (\%)

\begin{tabular}{l|l|l|l|l}
\hline 2007 & IDHM_2000 & IDHM_RENDA & IDHM_LONGEVIDADE & IDHM_EDUCAÇ̃̃O \\
\hline BAIXO & $0,0 \%$ & $0,0 \%$ & $0,0 \%$ & $0,0 \%$ \\
\hline BAIXO MEDIO & $0,0 \%$ & $5,6 \%$ & $0,0 \%$ & $0,0 \%$ \\
\hline MEDIO & $13,4 \%$ & $55,4 \%$ & $6,0 \%$ & $1,7 \%$ \\
\hline MEDIO ALTO & $82,1 \%$ & $38,8 \%$ & $79,2 \%$ & $49,4 \%$ \\
\hline ALTO & $4,5 \%$ & $0,2 \%$ & $14,8 \%$ & $48,9 \%$ \\
\hline TOTAL & $100,0 \%$ & $100,0 \%$ & $100,0 \%$ & $100,0 \%$ \\
\hline
\end{tabular}

Fonte: Elaborado pelo autor.

Realizando uma nova divisão no IDHM, segmentando em 5 faixas, observamos o mesmo resultado da divisão em 3 faixas, a componente Renda novamente tem em seu nível alto, uma queda da nota média, e possui apenas duas cidades representando esse nível: Belo Horizonte e São Gotardo

Matemática 2008

DESEMPENHO DE MATEMÁTICA 2008 X IFDM

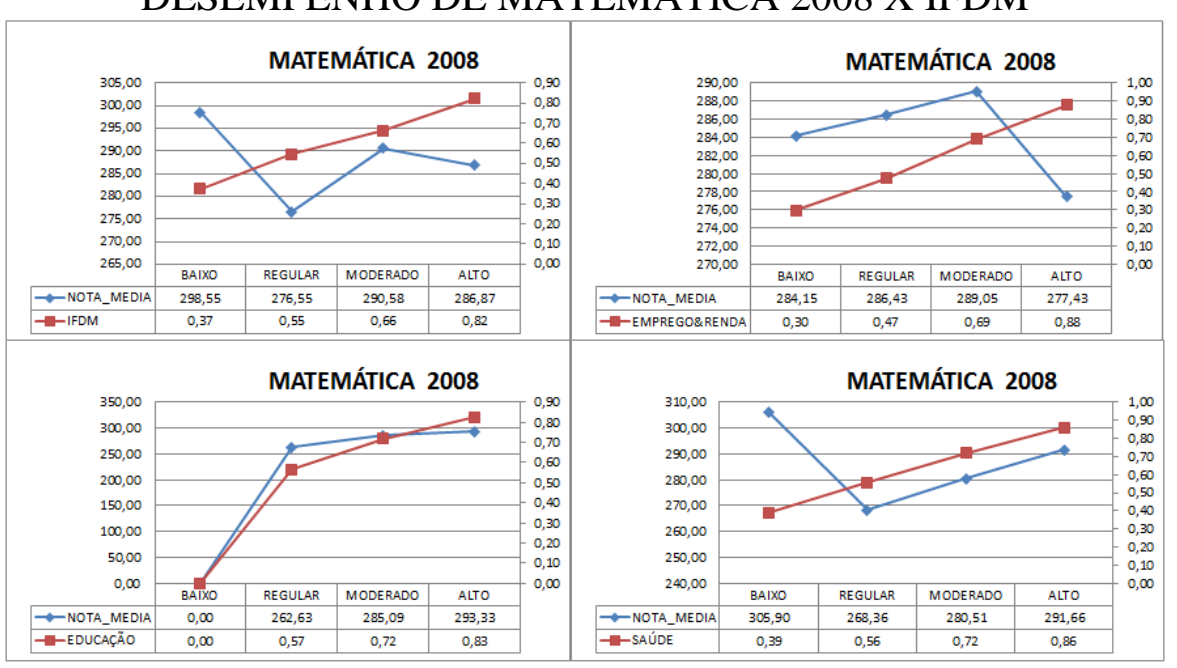

Fonte: Elaborado pelo autor.

DESEMPENHO DE MATEMÁTICA 2008 X IFDM

\begin{tabular}{l|l|l|l|l}
\hline 2008 & IFDM & EMPREGO\&RENDA & EDUCAÇÃO & SAÚDE \\
\hline BAIXO & 1 & 599 & 0 & 1 \\
\hline REGULAR & 342 & 183 & 38 & 46 \\
\hline MODERADO & 483 & 48 & 729 & 422 \\
\hline ALTO & 17 & 13 & 76 & 374 \\
\hline TOTAL & 843 & 843 & 843 & 843 \\
\hline
\end{tabular}

Fonte: Elaborado pelo autor. 
DESEMPENHO DE MATEMÁTICA 2008 X IFDM (\%)

\begin{tabular}{l|l|l|l|l}
\hline 2008 & IFDM & EMPREGO\&RENDA & EDUCAÇÃO & SAÚDE \\
\hline BAIXO & $0,1 \%$ & $71,1 \%$ & $0,0 \%$ & $0,1 \%$ \\
\hline REGULAR & $40,6 \%$ & $21,7 \%$ & $4,5 \%$ & $5,5 \%$ \\
\hline MODERADO & $57,3 \%$ & $5,7 \%$ & $86,5 \%$ & $50,1 \%$ \\
\hline ALTO & $2,0 \%$ & $1,5 \%$ & $9,0 \%$ & $44,4 \%$ \\
\hline TOTAL & $100,0 \%$ & $100,0 \%$ & $100,0 \%$ & $100,0 \%$ \\
\hline
\end{tabular}

Fonte: Elaborado pelo autor.

No caso das notas médias de 2008, apenas a componente do índice IFDM Educação mostra coerência com os níveis, no próprio índice IFDM, as notas médias não acompanham o índice no nível regular e alto, já emprego \& renda acontece no nível alto, e na saúde no nível baixo. Isso pode também ser o reflexo de termos apenas uma cidade no nível baixo do IFDM: Imbe de Minas e apenas uma no nível baixo da saúde: São joão do Pacui, em que a média é a própria observação. Não foram encontradas cidades no nível baixo da Saúde. O número de cidades aumenta e passa a ser 843 .

\section{DESEMPENHO DE MATEMÁTICA 2008 X IDHM - 2000 - 3 FAIXAS}

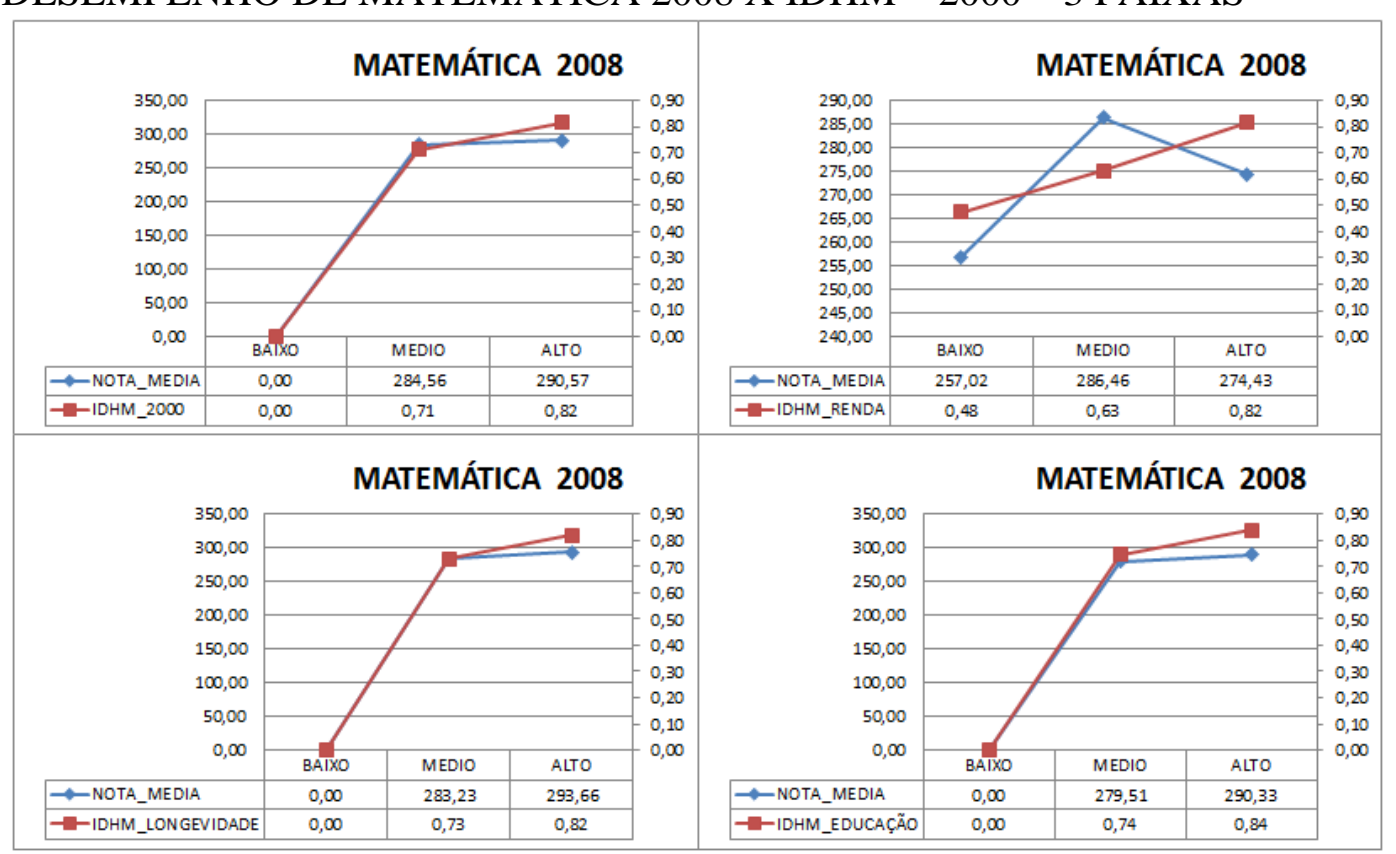

Fonte: Elaborado pelo autor. 
DESEMPENHO DE MATEMÁTICA 2008 X ÍNDICE DE GINI 2000 E 2010

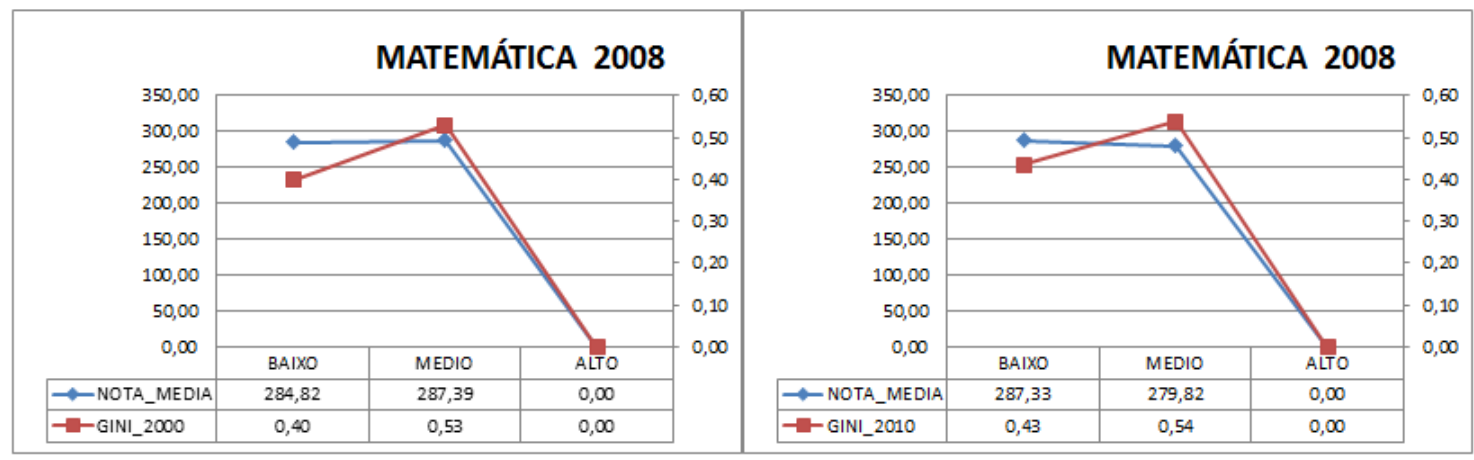

Fonte: Elaborado pelo autor.

DESEMPENHO DE MATEMÁTICA 2008 X IDHM E ÍNDICE DE GINI

\begin{tabular}{l|l|l|l|l|l|l}
\hline 2008 & IDHM_2000 & IDHM_RENDA & IDHM_LONGEVIDADE & IDHM_EDUCAÇÃO & GINI_2000 & GINI_2010 \\
\hline BAIXO & 0 & 46 & 0 & 0 & 841 & 562 \\
\hline MEDIO & 806 & 795 & 714 & 429 & 2 & 281 \\
\hline ALTO & 37 & 2 & 129 & 414 & 0 & 0 \\
\hline TOTAL & 843 & 843 & 843 & 843 & 843 & 843 \\
\hline
\end{tabular}

Fonte: Elaborado pelo autor.

DESEMPENHO DE MATEMÁTICA 2008 X IDHM E ÍNDICE DE GINI (\%)

\begin{tabular}{l|l|l|l|l|l|l}
\hline 2008 & IDHM_2000 & IDHM_RENDA & IDHM_LONGEVIDADE & IDHM_EDUCAÇÃO & GINI_2000 & GINI_2010 \\
\hline BAIXO & $0,0 \%$ & $5,5 \%$ & $0,0 \%$ & $0,0 \%$ & $99,8 \%$ & $66,7 \%$ \\
\hline MEDIO & $95,6 \%$ & $94,3 \%$ & $84,7 \%$ & $50,9 \%$ & $0,2 \%$ & $33,3 \%$ \\
\hline ALTO & $4,4 \%$ & $0,2 \%$ & $15,3 \%$ & $49,1 \%$ & $0,0 \%$ & $0,0 \%$ \\
\hline TOTAL & $100,0 \%$ & $100,0 \%$ & $100,0 \%$ & $100,0 \%$ & $100,0 \%$ & $100,0 \%$ \\
\hline
\end{tabular}

Fonte: Elaborado pelo autor.

No índice do IDHM, e da componente longevidade, e educação, há um acompanhamento perfeito, com exceção da renda, em que o nível alto não possui notas médias altas, mas uma queda, além disso, temos apenas duas cidades nesse nível: Belo Horizonte e São Gotardo. Já no índice de Gini, percebemos um acompanhamento do índice de 2000, mas não no de 2010, em que o nível médio apresenta queda em vez de acompanhamento. Outro fato que percebemos é que temos mais cidades na faixa média do índice Gini 2010 do que a concentração da faixa baixa do índice de Gini 2000, em que somente duas cidades estavam nesse nível: Carmesia e Morro do Pilar. Vale ressaltar que não há nenhuma cidade no nível alto. 
DESEMPENHO DE MATEMÁTICA 2008 X IDHM - 2000 - 5 FAIXAS

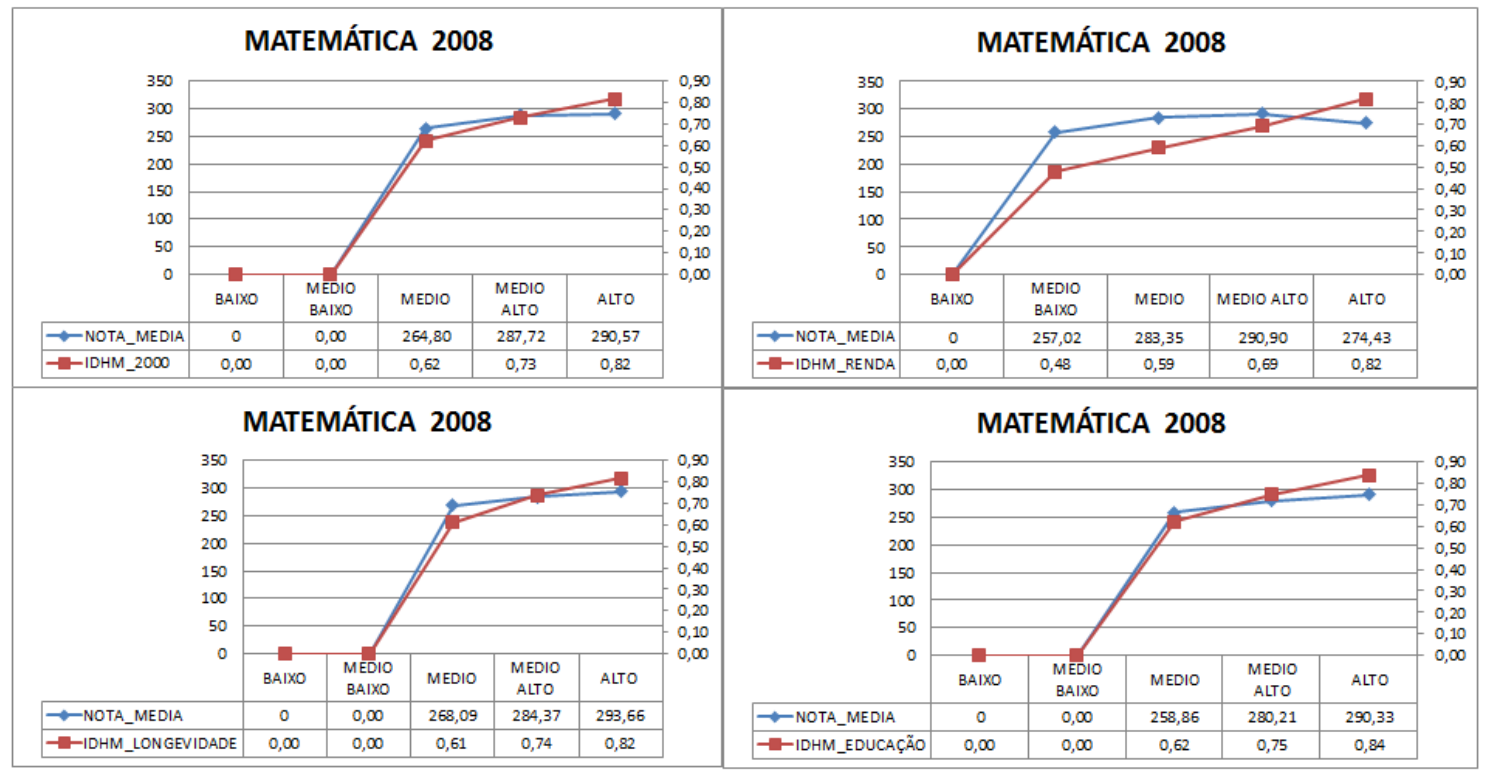

Fonte: Elaborado pelo autor.

DESEMPENHO DE MATEMÁTICA 2008 X IDHM - 5 FAIXAS

\begin{tabular}{l|l|l|l|l}
\hline 2008 & IDHM_2000 & IDHM_RENDA & IDHM_LONGEVIDADE & IDHM_EDUCAÇÃO \\
\hline BAIXO & 0 & 0 & 0 & 0 \\
\hline BAIXO MEDIO & 0 & 46 & 0 & 0 \\
\hline MEDIO & 111 & 468 & 50 & 14 \\
\hline MEDIO ALTO & 695 & 327 & 664 & 415 \\
\hline ALTO & 37 & 2 & 129 & 414 \\
\hline TOTAL & 843 & 843 & 843 & 843 \\
\hline
\end{tabular}

Fonte: Elaborado pelo autor.

DESEMPENHO DE MATEMÁTICA 2008 X IDHM - 5 FAIXAS

\begin{tabular}{l|l|l|l|l}
\hline 2008 & IDHM_2000 & IDHM_RENDA & IDHM_LONGEVIDADE & IDHM_EDUCAÇÃO \\
\hline BAIXO & $0,0 \%$ & $0,0 \%$ & $0,0 \%$ & $0,0 \%$ \\
\hline BAIXO MEDIO & $0,0 \%$ & $5,5 \%$ & $0,0 \%$ & $0,0 \%$ \\
\hline MEDIO & $13,2 \%$ & $55,5 \%$ & $5,9 \%$ & $1,7 \%$ \\
\hline MEDIO ALTO & $82,4 \%$ & $38,8 \%$ & $78,8 \%$ & $49,2 \%$ \\
\hline ALTO & $4,4 \%$ & $0,2 \%$ & $15,3 \%$ & $49,1 \%$ \\
\hline TOTAL & $100,0 \%$ & $100,0 \%$ & $100,0 \%$ & $100,0 \%$ \\
\hline
\end{tabular}

Fonte: Elaborado pelo autor.

Realizando uma nova divisão no IDHM, segmentando em 5 faixas, observamos o mesmo resultado da divisão em 3 faixas, a componente Renda novamente tem em seu nível alto, uma queda da nota média, e possui apenas duas cidades representando esse nível: Belo Horizonte e São Gotardo.

Matemática 2009 
DESEMPENHO DE MATEMÁTICA 2009 X IFDM

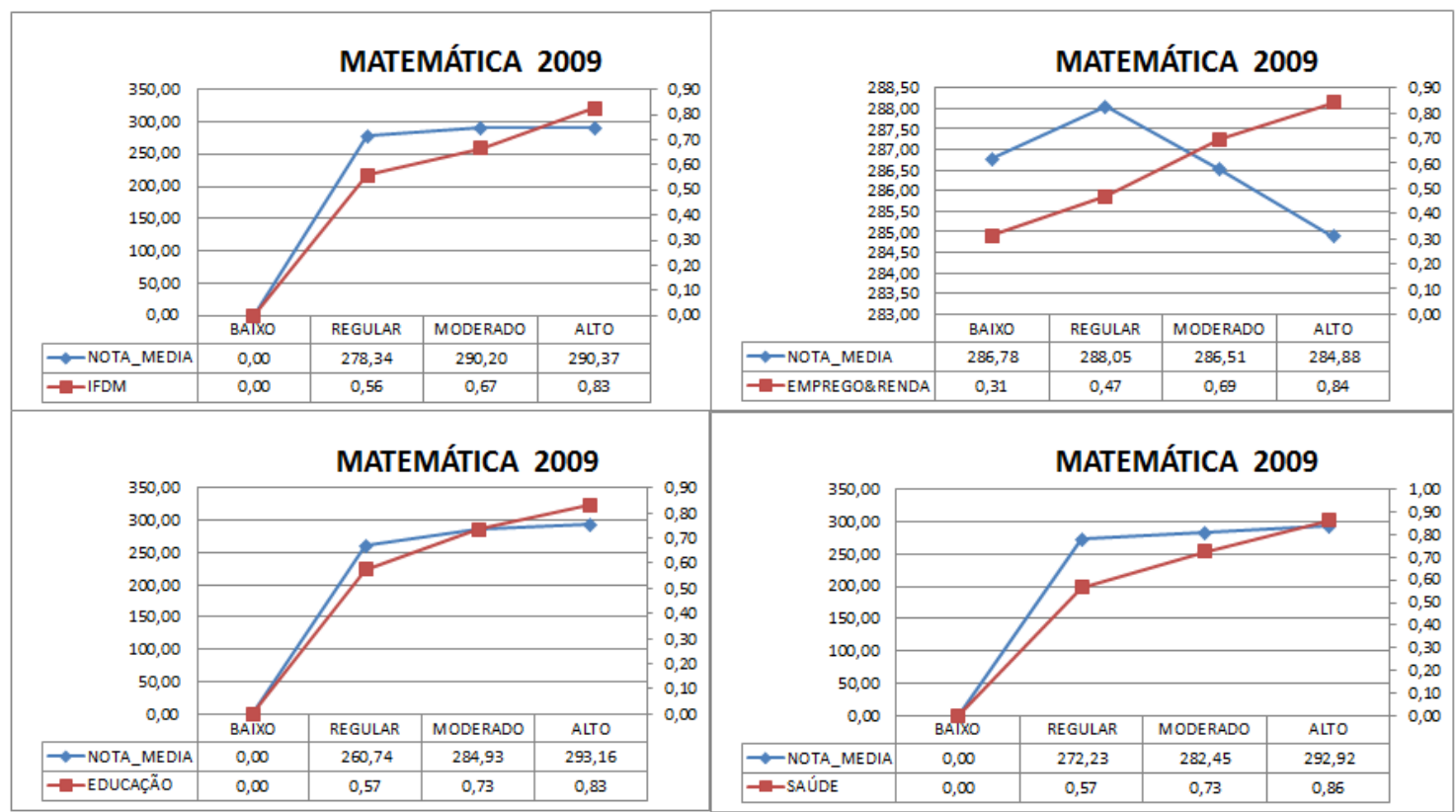

Fonte: Elaborado pelo autor.

DESEMPENHO DE MATEMÁTICA 2009 X IFDM

\begin{tabular}{l|l|l|l|l}
\hline 2009 & IFDM & EMPREGO\&RENDA & EDUCAÇÃO & SAÚDE \\
\hline BAIXO & 0 & 584 & 0 & 0 \\
\hline REGULAR & 224 & 211 & 11 & 34 \\
\hline MODERADO & 605 & 44 & 583 & 406 \\
\hline ALTO & 17 & 7 & 252 & 406 \\
\hline TOTAL & 846 & 846 & 846 & 846 \\
\hline
\end{tabular}

Fonte: Elaborado pelo autor.

DESEMPENHO DE MATEMÁTICA 2009 X IFDM (\%)

\begin{tabular}{l|l|l|l|l}
\hline 2009 & IFDM & EMPREGO\&RENDA & EDUCAÇÃO & SAÚDE \\
\hline BAIXO & $0,0 \%$ & $69,0 \%$ & $0,0 \%$ & $0,0 \%$ \\
\hline REGULAR & $26,5 \%$ & $24,9 \%$ & $1,3 \%$ & $4,0 \%$ \\
\hline MODERADO & $71,5 \%$ & $5,2 \%$ & $68,9 \%$ & $48,0 \%$ \\
\hline ALTO & $2,0 \%$ & $0,8 \%$ & $29,8 \%$ & $48,0 \%$ \\
\hline TOTAL & $100,0 \%$ & $100,0 \%$ & $100,0 \%$ & $100,0 \%$ \\
\hline
\end{tabular}

Fonte: Elaborado pelo autor.

As notas médias de 2009 não acompanham a componente do IFDM Emprego \& Renda no nível moderado e alto, sofrendo quedas. Não há nenhuma observação no nível baixo nas outras componentes e no IFDM. 
DESEMPENHO DE MATEMÁTICA 2009 X IDHM-2000 - 3 FAIXAS

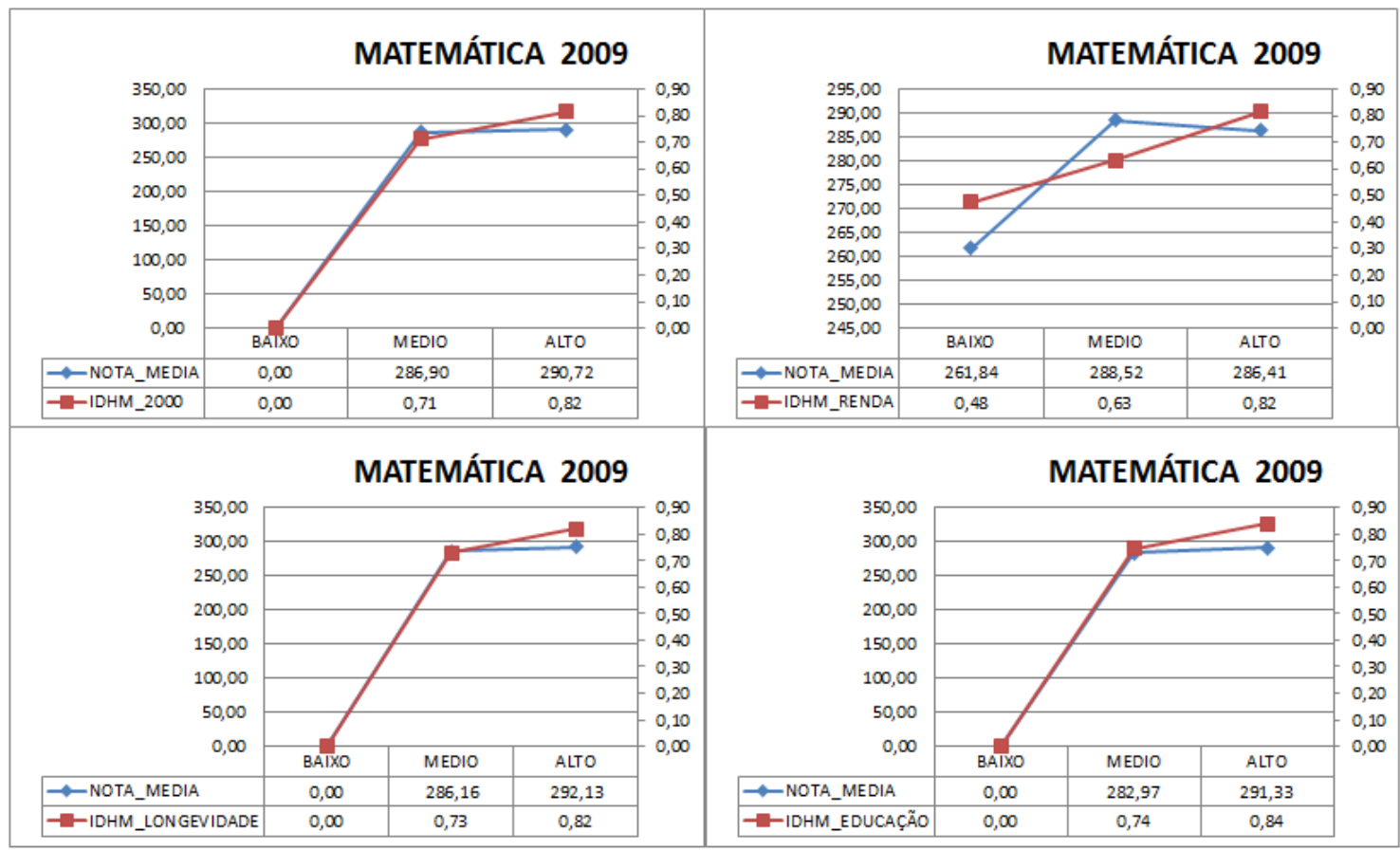

Fonte: Elaborado pelo autor.

DESEMPENHO DE MATEMÁTICA 2009 X ÍNDICE DE GINI 2000 E 2010

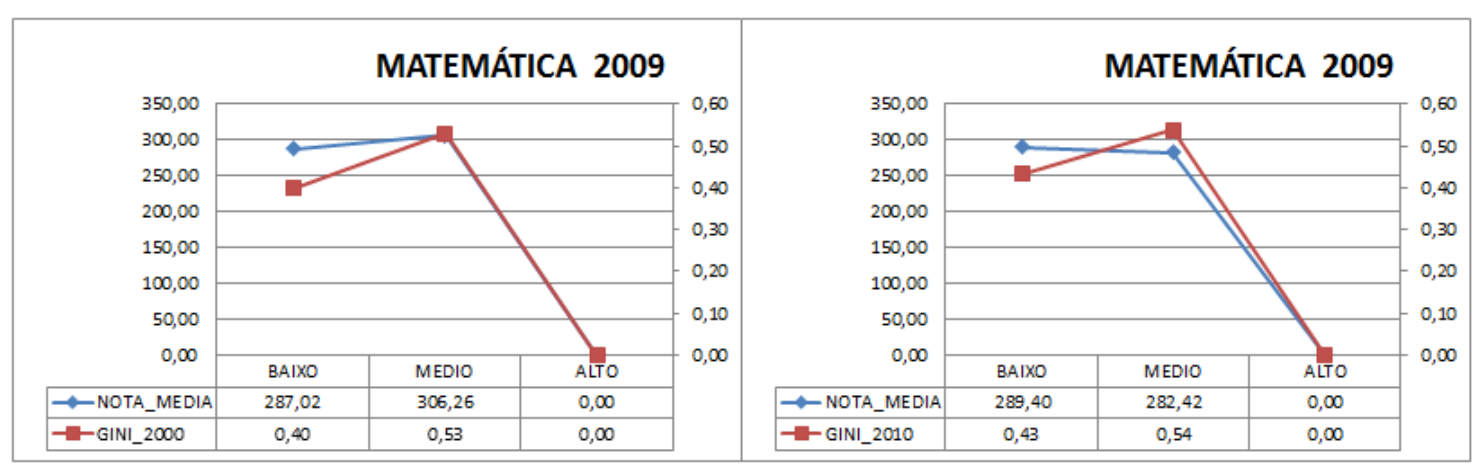

Fonte: Elaborado pelo autor.

DESEMPENHO DE MATEMÁTICA 2009 X IDHM E ÍNDICE DE GINI

\begin{tabular}{l|l|l|l|l|l|l}
\hline 2009 & IDHM_2000 & IDHM_RENDA & IDHM_LONGEVIDADE & IDHM_EDUCAÇÃO & GINI_2000 & GINI_2010 \\
\hline BAIXO & 0 & 46 & 0 & 0 & 844 & 563 \\
\hline MEDIO & 809 & 798 & 718 & 432 & 2 & 283 \\
\hline ALTO & 37 & 2 & 128 & 414 & 0 & 0 \\
\hline TOTAL & 846 & 846 & 846 & 846 & 846 & 846 \\
\hline
\end{tabular}

Fonte: Elaborado pelo autor.

DESEMPENHO DE MATEMÁTICA 2009 X IDHM E ÍNDICE DE GINI (\%)

\begin{tabular}{l|l|l|l|l|l|l}
\hline 2009 & IDHM_2000 & IDHM_RENDA & IDHM_LONGEVIDADE & IDHM_EDUCAÇÃO & GINI_2000 & GINI_2010 \\
\hline BAIXO & $0,0 \%$ & $5,4 \%$ & $0,0 \%$ & $0,0 \%$ & $99,8 \%$ & $66,5 \%$ \\
\hline MEDIO & $95,6 \%$ & $94,3 \%$ & $84,9 \%$ & $51,1 \%$ & $0,2 \%$ & $33,5 \%$ \\
\hline ALTO & $4,4 \%$ & $0,2 \%$ & $15,1 \%$ & $48,9 \%$ & $0,0 \%$ & $0,0 \%$ \\
\hline TOTAL & $100,0 \%$ & $100,0 \%$ & $100,0 \%$ & $100,0 \%$ & $100,0 \%$ & $100,0 \%$ \\
\hline
\end{tabular}

Fonte: Elaborado pelo autor. 
No índice do IDHM, e da componente longevidade, e educação, há um acompanhamento perfeito, com exceção da renda, em que o nível alto não possui notas médias altas, mas uma queda, além disso, temos apenas duas cidades nesse nível: Belo Horizonte e São Gotardo. Já no índice de Gini, percebemos um acompanhamento do índice de 2000, mas não no de 2010, em que o nível médio apresenta queda em vez de acompanhamento. Outro fato que percebemos é que temos mais cidades na faixa média do índice Gini 2010 do que a concentração da faixa baixa do índice de Gini 2000, em que somente duas cidades estavam nesse nível: Carmesia e Morro do Pilar. Vale ressaltar que não há nenhuma cidade no nível alto.

\section{DESEMPENHO DE MATEMÁTICA 2009 X IDHM-2000 - 5 FAIXAS}

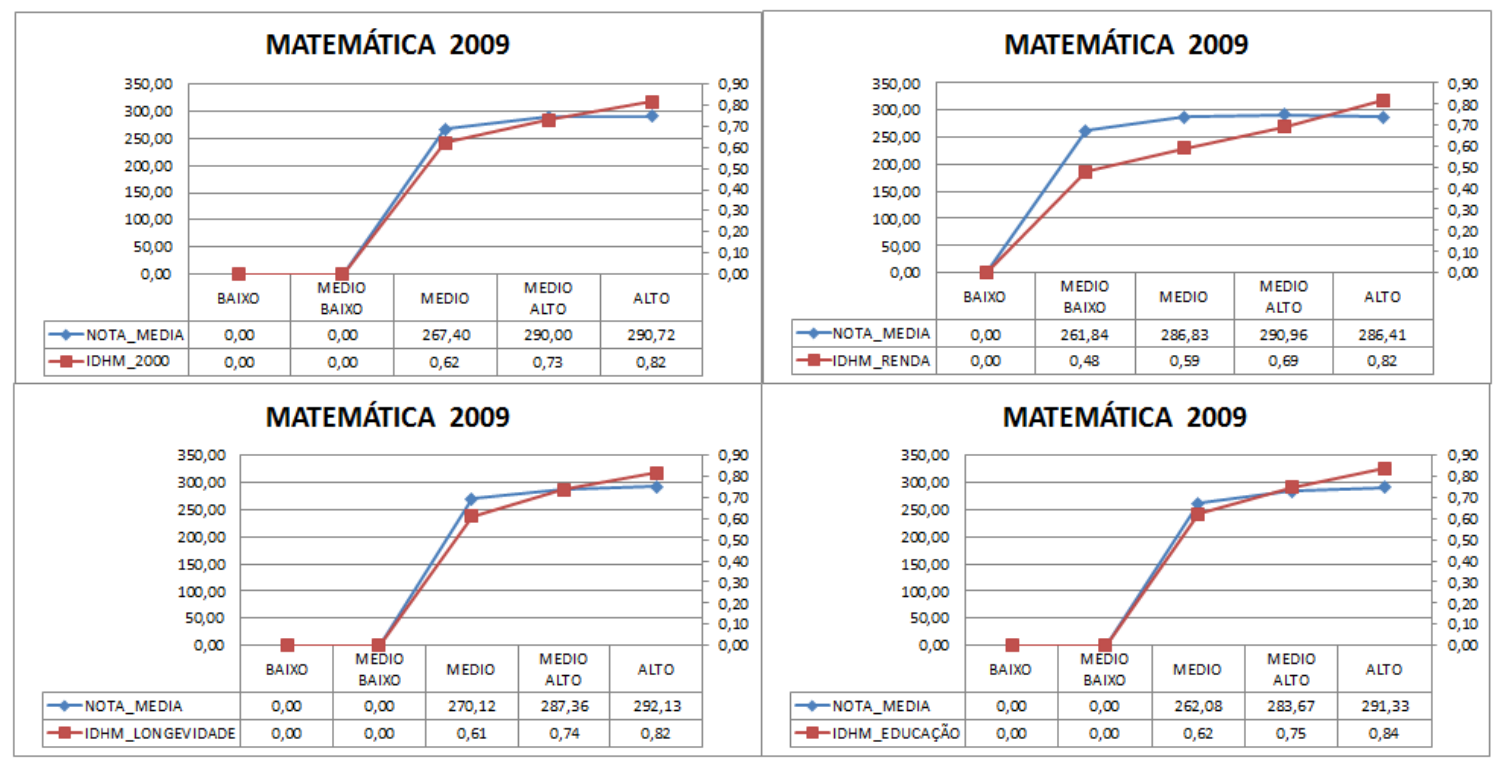

Fonte: Elaborado pelo autor.

DESEMPENHO DE MATEMÁTICA 2009 X IDHM - 5 FAIXAS

\begin{tabular}{l|l|l|l|l}
\hline 2009 & IDHM_2000 & IDHM_RENDA & IDHM_LONGEVIDADE & IDHM_EDUCAÇÃO \\
\hline BAIXO & 0 & 0 & 0 & 0 \\
\hline BAIXO MEDIO & 0 & 46 & 0 & 0 \\
\hline MEDIO & 111 & 472 & 50 & 14 \\
\hline MEDIO ALTO & 698 & 326 & 668 & 418 \\
\hline ALTO & 37 & 2 & 128 & 414 \\
\hline TOTAL & 846 & 846 & 846 & 846 \\
\hline
\end{tabular}

Fonte: Elaborado pelo autor. 
DESEMPENHO DE MATEMÁTICA 2009 X IDHM - 5 FAIXAS (\%)

\begin{tabular}{l|l|l|l|l}
\hline 2009 & IDHM_2000 & IDHM_RENDA & IDHM_LONGEVIDADE & IDHM_EDUCAÇ̃̃O \\
\hline BAIXO & $0,0 \%$ & $0,0 \%$ & $0,0 \%$ & $0,0 \%$ \\
\hline BAIXO MEDIO & $0,0 \%$ & $5,4 \%$ & $0,0 \%$ & $0,0 \%$ \\
\hline MEDIO & $13,1 \%$ & $55,8 \%$ & $5,9 \%$ & $1,7 \%$ \\
\hline MEDIO ALTO & $82,5 \%$ & $38,5 \%$ & $79,0 \%$ & $49,4 \%$ \\
\hline ALTO & $4,4 \%$ & $0,2 \%$ & $15,1 \%$ & $48,9 \%$ \\
\hline TOTAL & $100,0 \%$ & $100,0 \%$ & $100,0 \%$ & $100,0 \%$ \\
\hline
\end{tabular}

Fonte: Elaborado pelo autor.

Realizando uma nova divisão no IDHM, segmentando em 5 faixas, observamos o mesmo resultado da divisão em 3 faixas, a componente Renda novamente tem em seu nível alto, uma queda da nota média, e possui apenas duas cidades representando esse nível: Belo Horizonte e São Gotardo.

Matemática 2010

\section{DESEMPENHO DE MATEMÁTICA 2010 X IFDM}

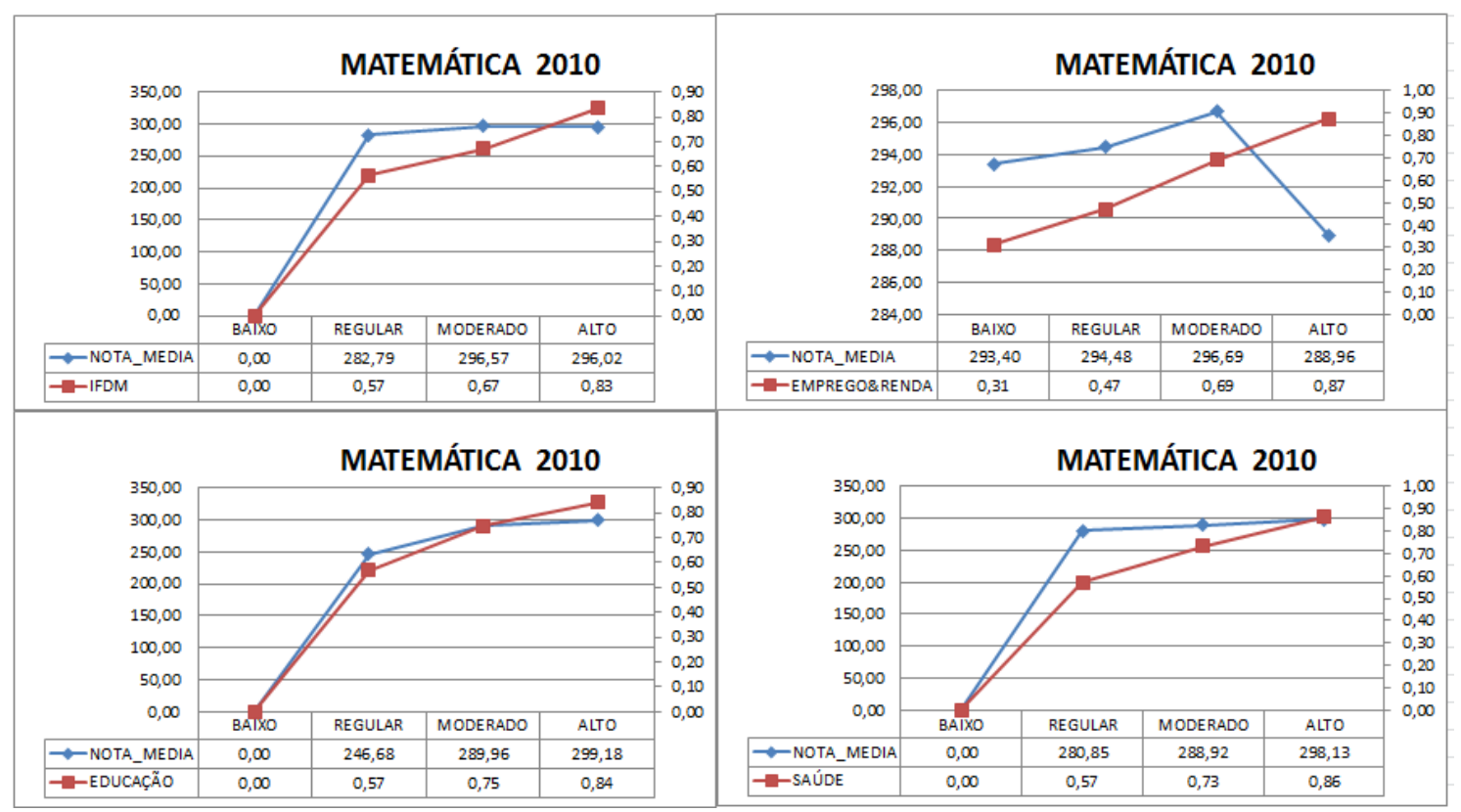

Fonte: Elaborado pelo autor.

\section{DESEMPENHO DE MATEMÁTICA 2010 X IFDM}

\begin{tabular}{l|l|l|l|l}
\hline 2010 & IFDM & EMPREGO\&RENDA & EDUCAÇÃO & SAÚDE \\
\hline BAIXO & 0 & 566 & 0 & 0 \\
\hline REGULAR & 169 & 209 & 4 & 15 \\
\hline MODERADO & 645 & 56 & 472 & 370 \\
\hline ALTO & 33 & 16 & 371 & 462 \\
\hline TOTAL & 847 & 847 & 847 & 847 \\
\hline
\end{tabular}

Fonte: Elaborado pelo autor. 
DESEMPENHO DE MATEMÁTICA 2010 X IFDM (\%)

\begin{tabular}{l|l|l|l|l}
\hline 2010 & IFDM & EMPREGO\&RENDA & EDUCAÇÃO & SAÚDE \\
\hline BAIXO & $0,0 \%$ & $66,8 \%$ & $0,0 \%$ & $0,0 \%$ \\
\hline REGULAR & $20,0 \%$ & $24,7 \%$ & $0,5 \%$ & $1,8 \%$ \\
\hline MODERADO & $76,2 \%$ & $6,6 \%$ & $55,7 \%$ & $43,7 \%$ \\
\hline ALTO & $3,9 \%$ & $1,9 \%$ & $43,8 \%$ & $54,5 \%$ \\
\hline TOTAL & $100,0 \%$ & $100,0 \%$ & $100,0 \%$ & $100,0 \%$ \\
\hline
\end{tabular}

Fonte: Elaborado pelo autor.

No índice IFDM, as notas médias de 2010 acompanham bem até o nível moderado, no nível alto as notas médias sofrem uma queda, não refletindo melhores desempenhos para a faixa do alto índice do IFDM. Para o componente Emprego \& Renda do IFDM, percebemos queda após o nível moderado. Nas componentes educação e saúde, o comportamento foi crescente na medida que avançamos nas faixas do baixo até o alto.

\section{DESEMPENHO DE MATEMÁTICA 2009 X IDHM-2000 - 3 FAIXAS}

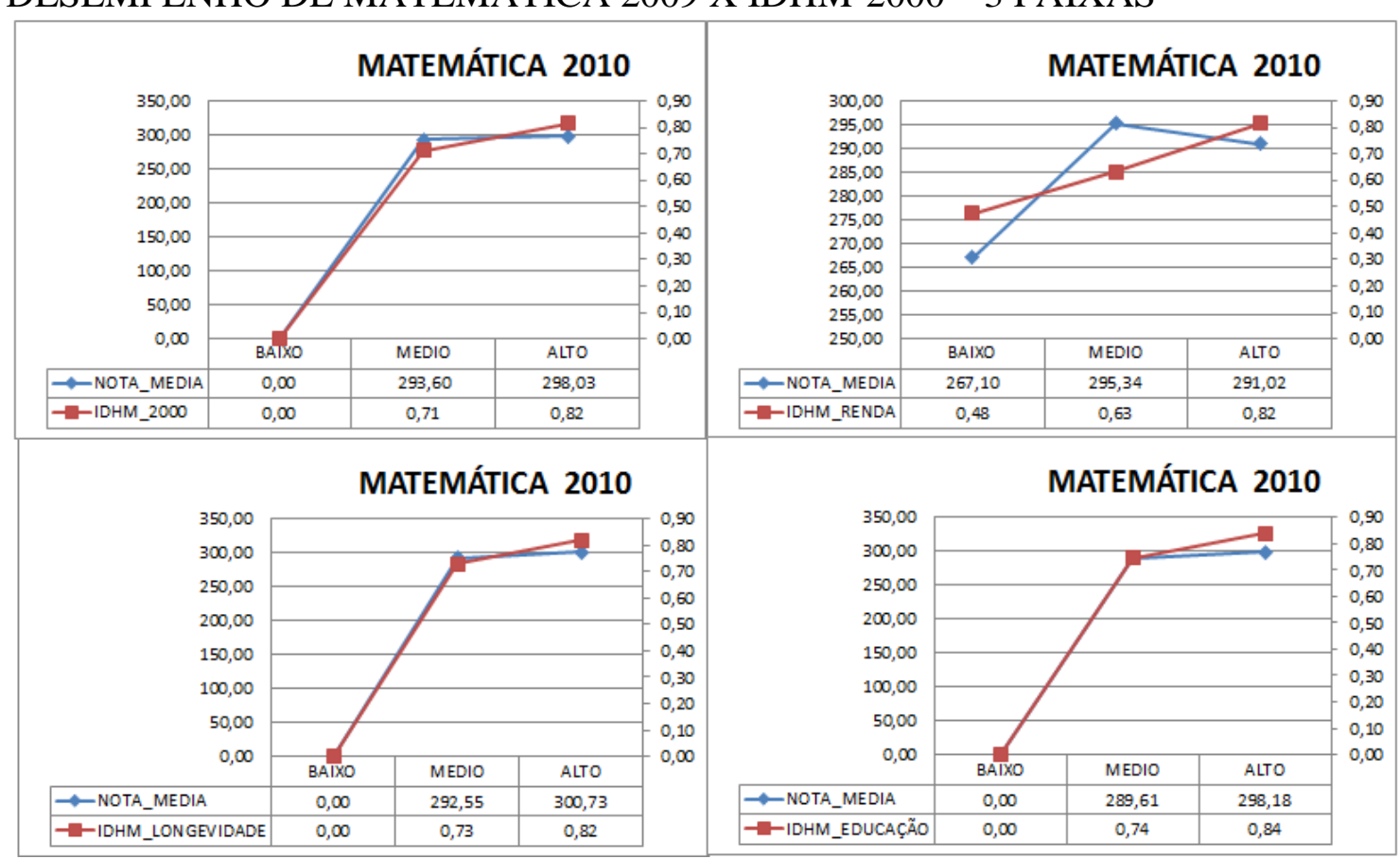

Fonte: Elaborado pelo autor. 
DESEMPENHO DE MATEMÁTICA 2010 X ÍNDICE DE GINI 2000 E 2010

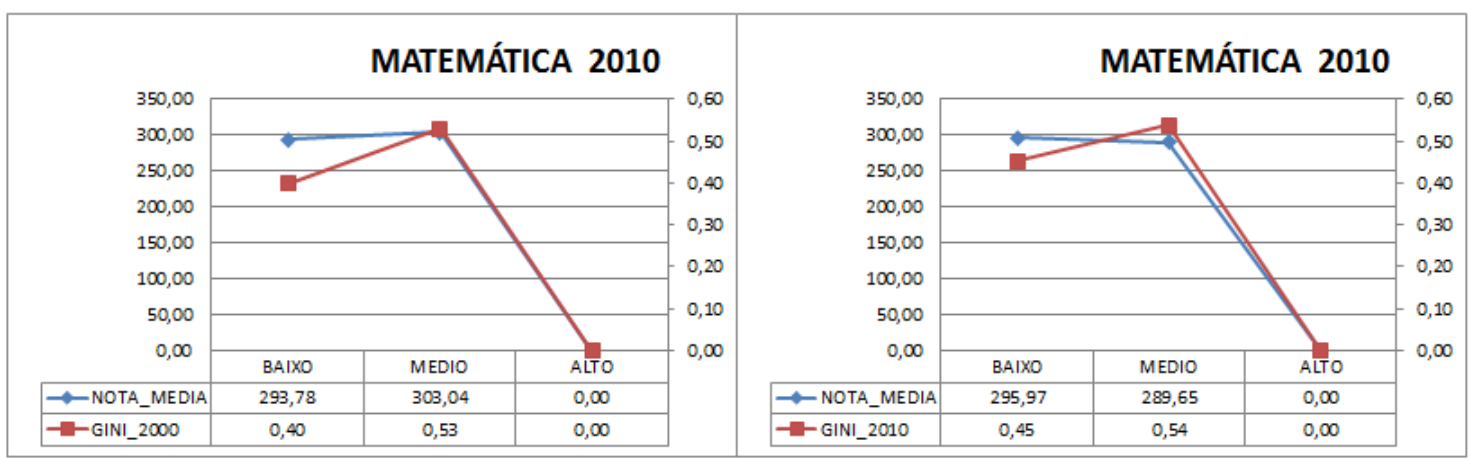

Fonte: Elaborado pelo autor.

DESEMPENHO DE MATEMÁTICA 2010 X IDHM E ÍNDICE DE GINI

\begin{tabular}{|c|c|c|c|c|c|c|}
\hline 2010 & IDHM_2000 & IDHM_RENDA & IDHM_LONGEVIDADE & IDHM_EDUCAÇÃO & GINI_2000 & GINI_2010 \\
\hline BAIXO & 0 & 46 & 0 & 0 & 845 & 556 \\
\hline MEDIO & 810 & 799 & 718 & 433 & 2 & 291 \\
\hline ALTO & 37 & 2 & 129 & 414 & 0 & 0 \\
\hline TOTAL & 847 & 847 & 847 & 847 & 847 & 847 \\
\hline
\end{tabular}

Fonte: Elaborado pelo autor.

DESEMPENHO DE MATEMÁTICA 2010 X IDHM E ÍNDICE DE GINI (\%)

\begin{tabular}{l|l|l|l|l|l|l}
\hline 2010 & IDHM_2000 & IDHM_RENDA & IDHM_LONGEVIDADE & IDHM_EDUCAÇÃO & GINI_2000 & GINI_2010 \\
\hline BAIXO & $0,0 \%$ & $5,4 \%$ & $0,0 \%$ & $0,0 \%$ & $99,8 \%$ & $65,6 \%$ \\
\hline MEDIO & $95,6 \%$ & $94,3 \%$ & $84,8 \%$ & $51,1 \%$ & $0,2 \%$ & $34,4 \%$ \\
\hline ALTO & $4,4 \%$ & $0,2 \%$ & $15,2 \%$ & $48,9 \%$ & $0,0 \%$ & $0,0 \%$ \\
\hline TOTAL & $100,0 \%$ & $100,0 \%$ & $100,0 \%$ & $100,0 \%$ & $100,0 \%$ & $100,0 \%$ \\
\hline
\end{tabular}

Fonte: Elaborado pelo autor.

No índice do IDHM, e da componente longevidade, e educação, há um acompanhamento perfeito, com exceção da renda, em que o nível alto não possui notas médias altas, mas uma queda, além disso, temos apenas duas cidades nesse nível: Belo Horizonte e São Gotardo. Já no índice de Gini, percebemos um acompanhamento do índice de 2000, mas não no de 2010, em que o nível médio apresenta queda em vez de acompanhamento. Outro fato que percebemos é que temos mais cidades na faixa média do índice Gini 2010 do que a concentração da faixa baixa do índice de Gini 2000, em que somente duas cidades estavam nesse nível médio: Carmesia e Morro do Pilar. Vale ressaltar que não há nenhuma cidade no nível alto. 
DESEMPENHO DE MATEMÁTICA 2010 X IDHM - 5 FAIXAS

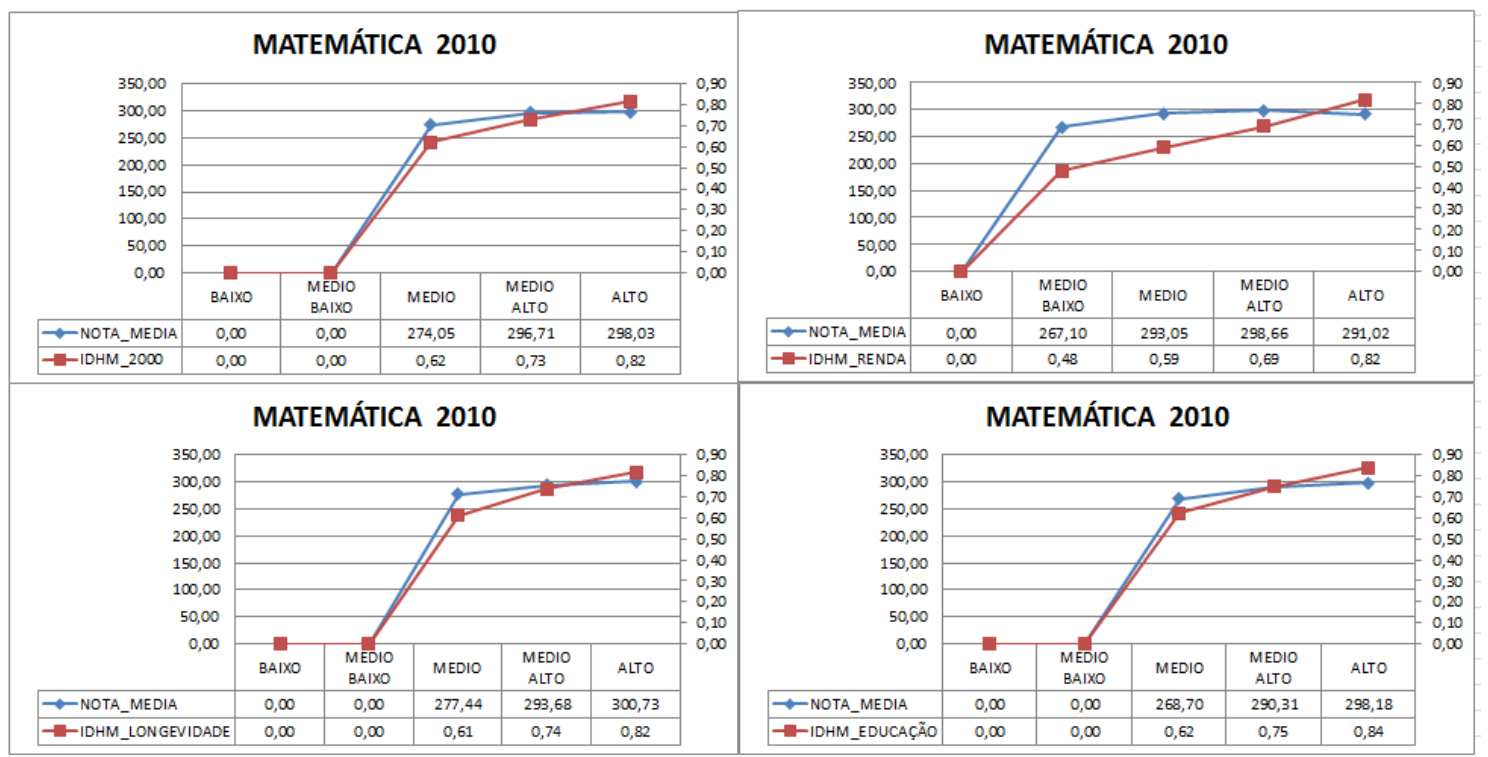

Fonte: Elaborado pelo autor.

DESEMPENHO DE MATEMÁTICA 2010 X IDHM - 5 FAIXAS

\begin{tabular}{l|l|l|l|l}
\hline 2010 & IDHM_2000 & IDHM_RENDA & IDHM_LONGEVIDADE & IDHM_EDUCAÇÃO \\
\hline BAIXO & 0 & 0 & 0 & 0 \\
\hline BAIXO MEDIO & 0 & 46 & 0 & 0 \\
\hline MEDIO & 111 & 473 & 50 & 14 \\
\hline MEDIO ALTO & 699 & 326 & 668 & 419 \\
\hline ALTO & 37 & 2 & 129 & 414 \\
\hline TOTAL & 847 & 847 & 847 & 847 \\
\hline
\end{tabular}

Fonte: Elaborado pelo autor.

DESEMPENHO DE MATEMÁTICA 2010 X IDHM - 5 FAIXAS (\%)

\begin{tabular}{l|l|l|l|l}
\hline 2010 & IDHM_2000 & IDHM_RENDA & IDHM_LONGEVIDADE & IDHM_EDUCAÇÃO \\
\hline BAIXO & $0,0 \%$ & $0,0 \%$ & $0,0 \%$ & $0,0 \%$ \\
\hline BAIXO MEDIO & $0,0 \%$ & $5,4 \%$ & $0,0 \%$ & $0,0 \%$ \\
\hline MEDIO & $13,1 \%$ & $55,8 \%$ & $5,9 \%$ & $1,7 \%$ \\
\hline MEDIO ALTO & $82,5 \%$ & $38,5 \%$ & $78,9 \%$ & $49,5 \%$ \\
\hline ALTO & $4,4 \%$ & $0,2 \%$ & $15,2 \%$ & $48,9 \%$ \\
\hline TOTAL & $100,0 \%$ & $100,0 \%$ & $100,0 \%$ & $100,0 \%$ \\
\hline
\end{tabular}

Fonte: Elaborado pelo autor.

Realizando uma nova divisão no IDHM, segmentando em 5 faixas, observamos o mesmo resultado da divisão em 3 faixas, a componente Renda novamente tem em seu nível alto, uma queda da nota média, e possui apenas duas cidades representando esse nível: Belo Horizonte e São Gotardo.

Português 2006. 
DESEMPENHO DE PORTUGUÊS 2006 X IFDM

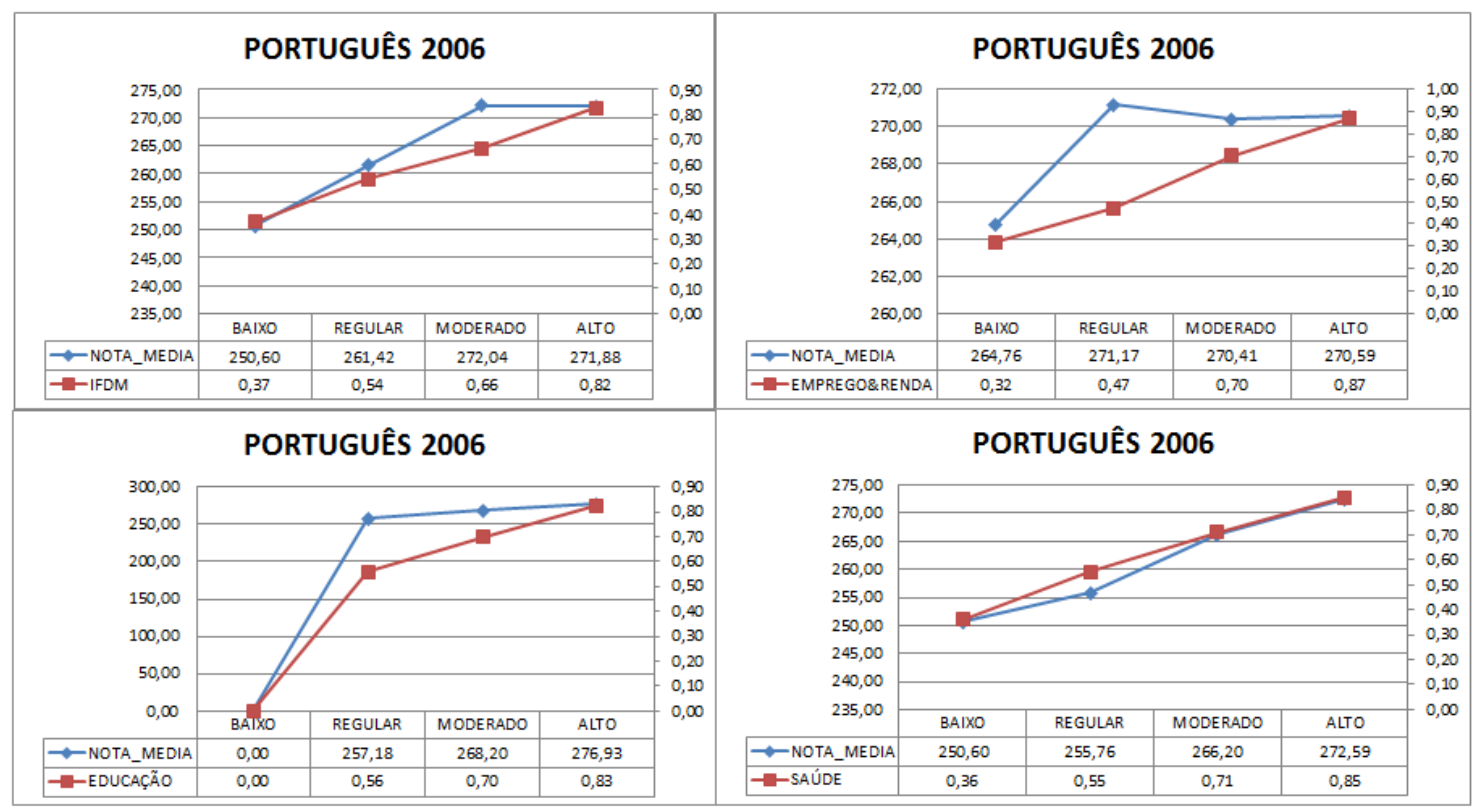

Fonte: Elaborado pelo autor.

DESEMPENHO DE PORTUGUÊS 2006 X IFDM

\begin{tabular}{l|l|l|l|l}
\hline 2006 & IFDM & EMPREGO\&RENDA & EDUCAÇ̃̃O & SAÚDE \\
\hline BAIXO & 1 & 507 & 0 & 1 \\
\hline REGULAR & 376 & 246 & 95 & 104 \\
\hline MODERADO & 428 & 50 & 705 & 422 \\
\hline ALTO & 16 & 18 & 21 & 294 \\
\hline TOTAL & 821 & 821 & 821 & 821 \\
\hline
\end{tabular}

Fonte: Elaborado pelo autor.

DESEMPENHO DE PORTUGUÊS 2006 X IFDM (\%)

\begin{tabular}{l|l|l|l|l}
\hline 2006 & IFDM & EMPREGO\&RENDA & EDUCAÇ̃̃O & SAÚDE \\
\hline BAIXO & $0,1 \%$ & $61,8 \%$ & $0,0 \%$ & $0,1 \%$ \\
\hline REGULAR & $45,8 \%$ & $30,0 \%$ & $11,6 \%$ & $12,7 \%$ \\
\hline MODERADO & $52,1 \%$ & $6,1 \%$ & $85,9 \%$ & $51,4 \%$ \\
\hline ALTO & $1,9 \%$ & $2,2 \%$ & $2,6 \%$ & $35,8 \%$ \\
\hline TOTAL & $100,0 \%$ & $100,0 \%$ & $100,0 \%$ & $100,0 \%$ \\
\hline
\end{tabular}

Fonte: Elaborado pelo autor.

No índice IFDM, as notas médias de 2006 acompanham bem até o nível moderado, no nível alto as notas médias sofrem uma queda, não refletindo melhores desempenhos para a faixa do alto índice do IFDM, para o componente Emprego \& Renda do IFDM, percebemos queda no nível moderado. Nas componentes educação e saúde, o comportamento foi crescente na medida que avançamos nas faixas do baixo até o alto. 
DESEMPENHO DE PORTUGUÊS 2006 X IDHM-2000 - 3 FAIXAS

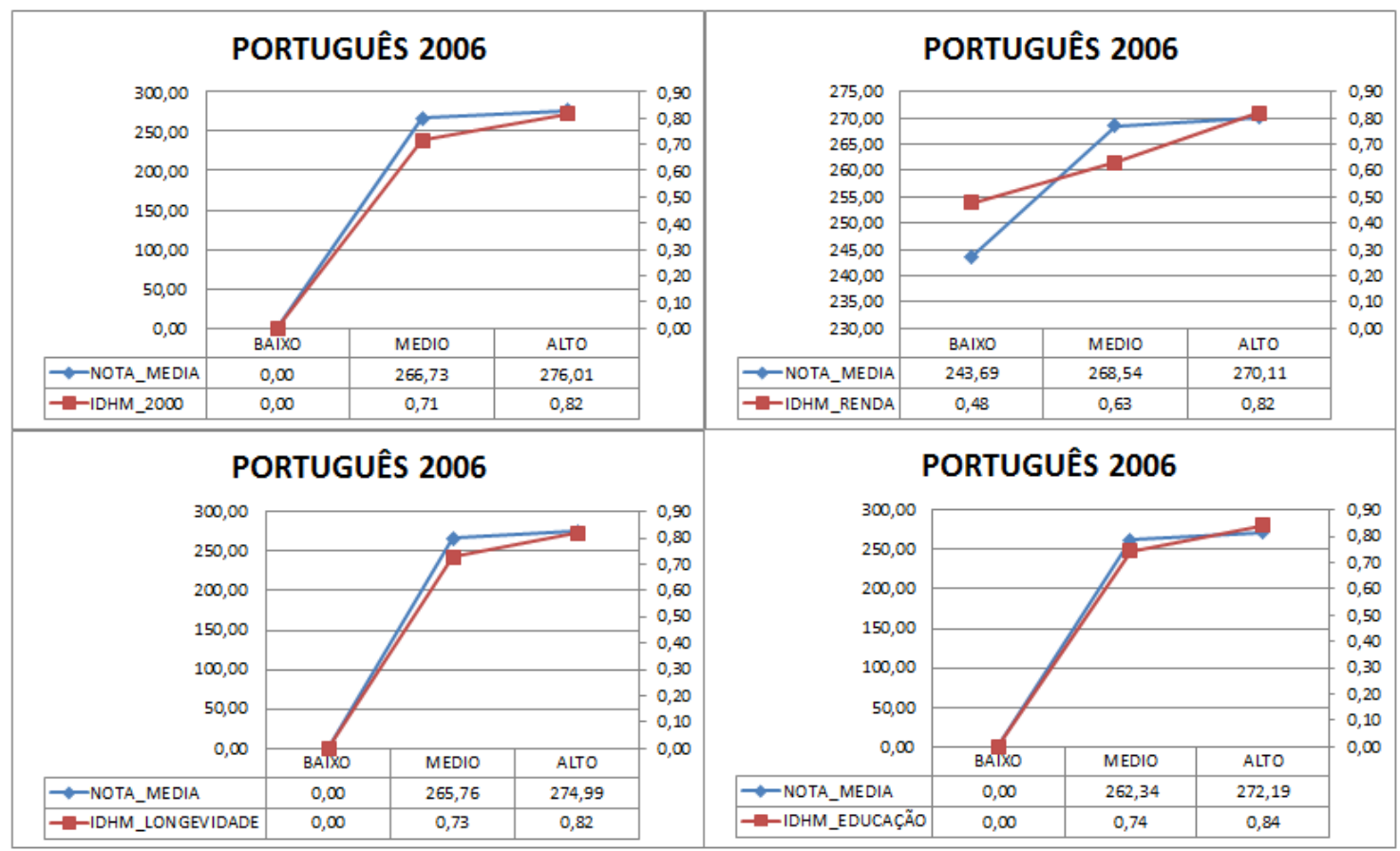

Fonte: Elaborado pelo autor.

DESEMPENHO DE PORTUGUÊS 2006 X ÍNDICE DE GINI 2000 E 2010

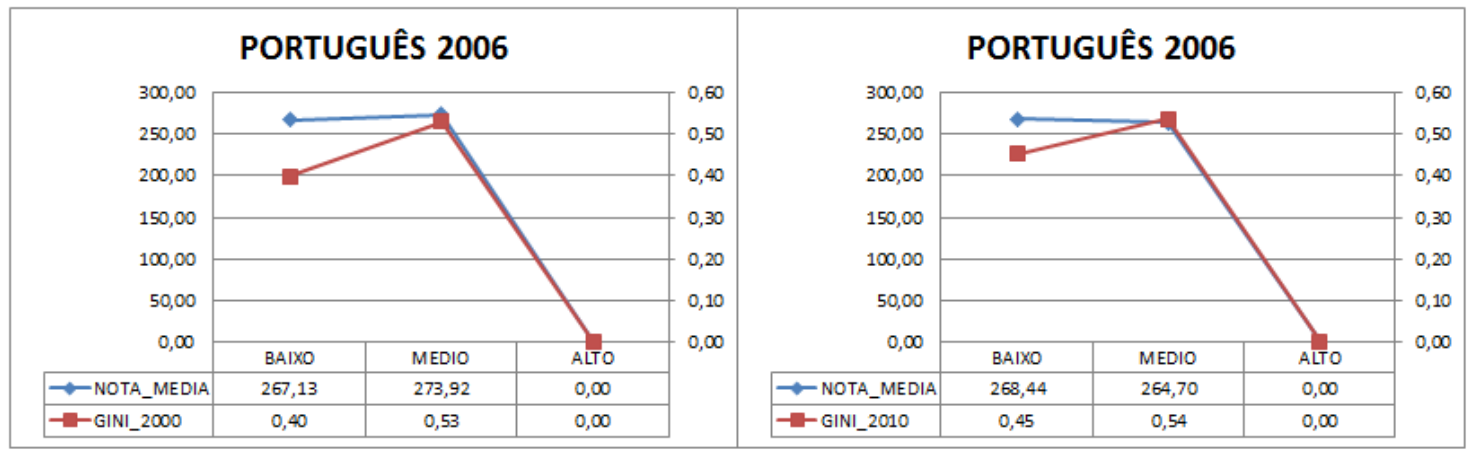

Fonte: Elaborado pelo autor.

DESEMPENHO DE PORTUGUÊS 2006 X IDHM E ÍNDICE DE GINI

\begin{tabular}{l|l|l|l|l|l|l}
\hline 2006 & IDHM_2000 & IDHM_RENDA & IDHM_LONGEVIDADE & IDHM_EDUCAÇÃO & GINI_2000 & GINI_2010 \\
\hline BAIXO & 0 & 46 & 0 & 0 & 819 & 538 \\
\hline MEDIO & 784 & 773 & 697 & 420 & 2 & 283 \\
\hline ALTO & 37 & 2 & 124 & 401 & 0 & 0 \\
\hline TOTAL & 821 & 821 & 821 & 821 & 821 & 821 \\
\hline
\end{tabular}

Fonte: Elaborado pelo autor.

DESEMPENHO DE PORTUGUÊS 2006 X IDHM E ÍNDICE DE GINI (\%)

\begin{tabular}{l|l|l|l|l|l|l}
\hline 2006 & IDHM_2000 & IDHM_RENDA & IDHM_LONGEVIDADE & IDHM_EDUCAÇÃO & GINI_2000 & GINI_2010 \\
\hline BAIXO & $0,0 \%$ & $5,6 \%$ & $0,0 \%$ & $0,0 \%$ & $99,8 \%$ & $65,5 \%$ \\
\hline MEDIO & $95,5 \%$ & $94,2 \%$ & $84,9 \%$ & $51,2 \%$ & $0,2 \%$ & $34,5 \%$ \\
\hline ALTO & $4,5 \%$ & $0,2 \%$ & $15,1 \%$ & $48,8 \%$ & $0,0 \%$ & $0,0 \%$ \\
\hline TOTAL & $100,0 \%$ & $100,0 \%$ & $100,0 \%$ & $100,0 \%$ & $100,0 \%$ & $100,0 \%$ \\
\hline
\end{tabular}

Fonte: Elaborado pelo autor. 
No índice do IDHM, e da componente longevidade, educação e renda, há um acompanhamento perfeito. Já no índice de Gini, percebemos um acompanhamento do índice de 2000, mas não no de 2010, em que o nível médio apresenta queda em vez de acompanhamento. Outro fato que percebemos é que temos mais cidades na faixa média do índice Gini 2010 do que a concentração da faixa baixa do índice de Gini 2000, em que somente duas cidades estavam nesse nível: Carmesia e Morro do Pilar. Vale ressaltar que não há nenhuma cidade no nível alto.

\section{DESEMPENHO DE PORTUGUÊS 2006 X IDHM-2000 - 5 FAIXAS}

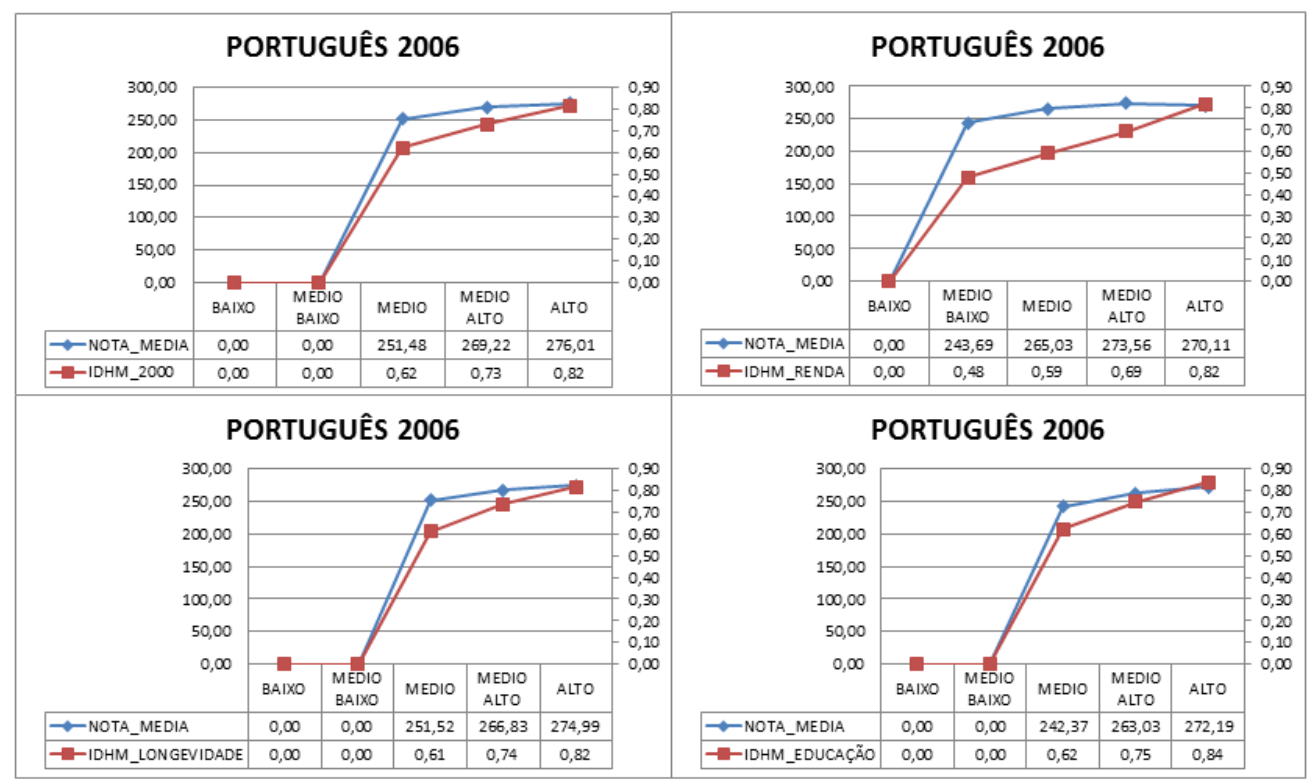

Fonte: Elaborado pelo autor.

DESEMPENHO DE PORTUGUÊS 2006 X IDHM - 5 FAIXAS

\begin{tabular}{l|l|l|l|l}
\hline 2006 & IDHM_2000 & IDHM_RENDA & IDHM_LONGEVIDADE & IDHM_EDUCAÇÃO \\
\hline BAIXO & 0 & 0 & 0 & 0 \\
\hline BAIXO MEDIO & 0 & 46 & 0 & 0 \\
\hline MEDIO & 110 & 455 & 49 & 14 \\
\hline MEDIO ALTO & 674 & 318 & 648 & 406 \\
\hline ALTO & 37 & 2 & 124 & 401 \\
\hline TOTAL & 821 & 821 & 821 & 821 \\
\hline
\end{tabular}

Fonte: Elaborado pelo autor. 
DESEMPENHO DE PORTUGUÊS 2006 X IDHM - 5 FAIXAS (\%)

\begin{tabular}{l|l|l|l|l}
\hline 2006 & IDHM_2000 & IDHM_RENDA & IDHM_LONGEVIDADE & IDHM_EDUCAÇÃO \\
\hline BAIXO & $0,0 \%$ & $0,0 \%$ & $0,0 \%$ & $0,0 \%$ \\
\hline BAIXO MEDIO & $0,0 \%$ & $5,6 \%$ & $0,0 \%$ & $0,0 \%$ \\
\hline MEDIO & $13,4 \%$ & $55,4 \%$ & $6,0 \%$ & $1,7 \%$ \\
\hline MEDIO ALTO & $82,1 \%$ & $38,7 \%$ & $78,9 \%$ & $49,5 \%$ \\
\hline ALTO & $4,5 \%$ & $0,2 \%$ & $15,1 \%$ & $48,8 \%$ \\
\hline TOTAL & $100,0 \%$ & $100,0 \%$ & $100,0 \%$ & $100,0 \%$ \\
\hline
\end{tabular}

Fonte: Elaborado pelo autor.

Realizando uma nova divisão no IDHM, segmentando em 5 faixas, observamos uma mudança do resultado da divisão em 3 faixas, a componente Renda tem em seu nível alto, uma queda da nota média, e possui apenas duas cidades representando esse nível: Belo Horizonte e São Gotardo.

Português 2007

\section{DESEMPENHO DE PORTUGUÊS 2007 X IFDM}

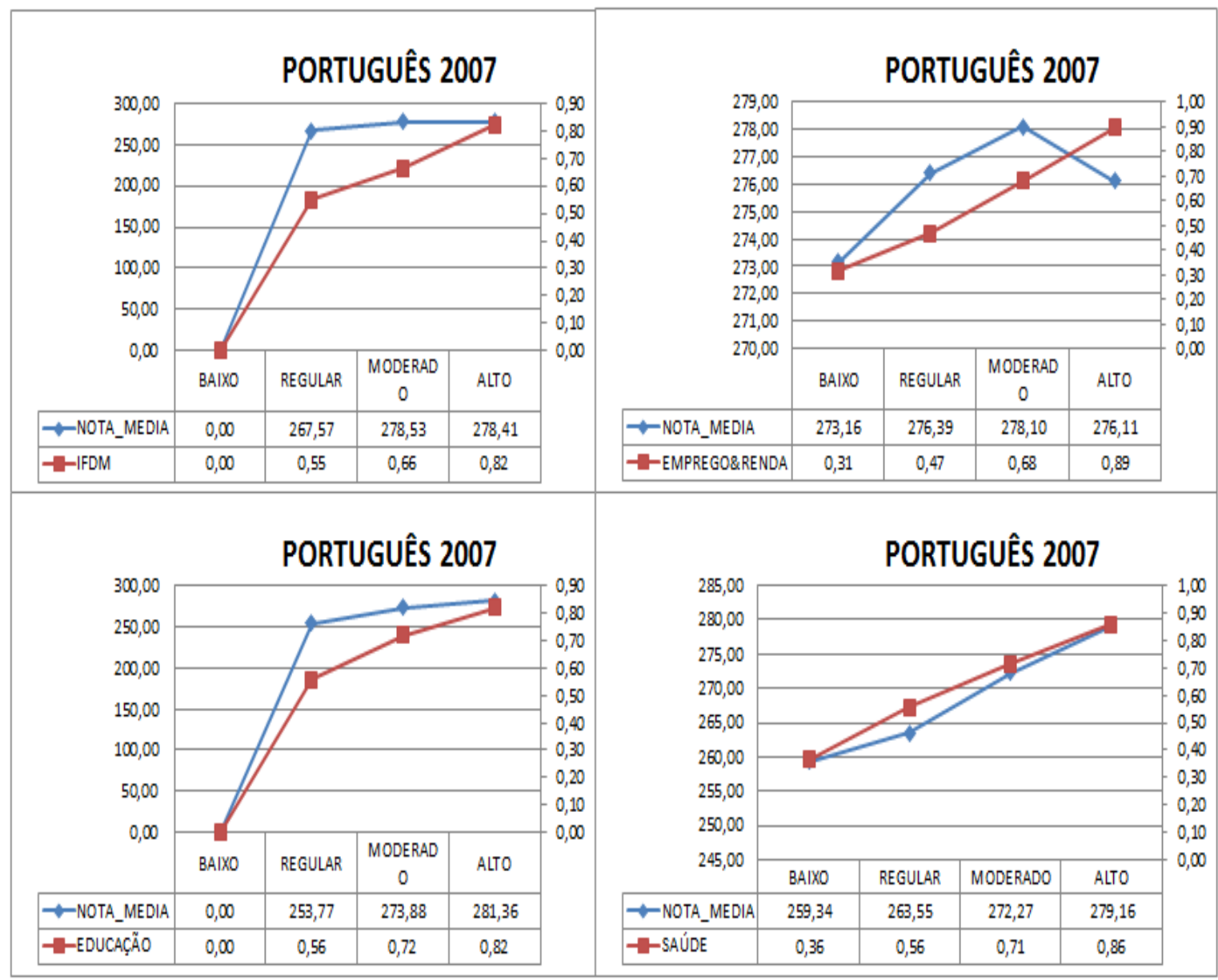

Fonte: Elaborado pelo autor. 
DESEMPENHO DE PORTUGUÊS 2007 X IFDM

\begin{tabular}{l|l|l|l|l}
\hline 2007 & IFDM & EMPREGO\&RENDA & EDUCAÇÃO & SAÚDE \\
\hline BAIXO & 0 & 568 & 0 & 1 \\
\hline REGULAR & 319 & 186 & 12 & 66 \\
\hline MODERADO & 489 & 57 & 734 & 430 \\
\hline ALTO & 14 & 11 & 76 & 325 \\
\hline TOTAL & 822 & 822 & 822 & 822 \\
\hline
\end{tabular}

Fonte: Elaborado pelo autor.

DESEMPENHO DE PORTUGUÊS 2007 X IFDM (\%)

\begin{tabular}{l|l|l|l|l}
\hline 2007 & IFDM & EMPREGO\&RENDA & EDUCAÇÃO & SAÚDE \\
\hline BAIXO & $0,0 \%$ & $69,1 \%$ & $0,0 \%$ & $0,1 \%$ \\
\hline REGULAR & $38,8 \%$ & $22,6 \%$ & $1,5 \%$ & $8,0 \%$ \\
\hline MODERADO & $59,5 \%$ & $6,9 \%$ & $89,3 \%$ & $52,3 \%$ \\
\hline ALTO & $1,7 \%$ & $1,3 \%$ & $9,2 \%$ & $39,5 \%$ \\
\hline TOTAL & $100,0 \%$ & $100,0 \%$ & $100,0 \%$ & $100,0 \%$ \\
\hline
\end{tabular}

Fonte: Elaborado pelo autor.

No índice IFDM, as notas médias de 2007 acompanham bem até o nível moderado, no nível alto as notas médias sofrem uma pequena queda, para o componente Emprego \& Renda do IFDM, percebemos queda no nível alto. Nas componentes educação e saúde, o comportamento foi crescente na medida que avançamos nas faixas do baixo até o alto.

DESEMPENHO DE PORTUGUÊS 2007 X IDHM-2000 - 3 FAIXAS

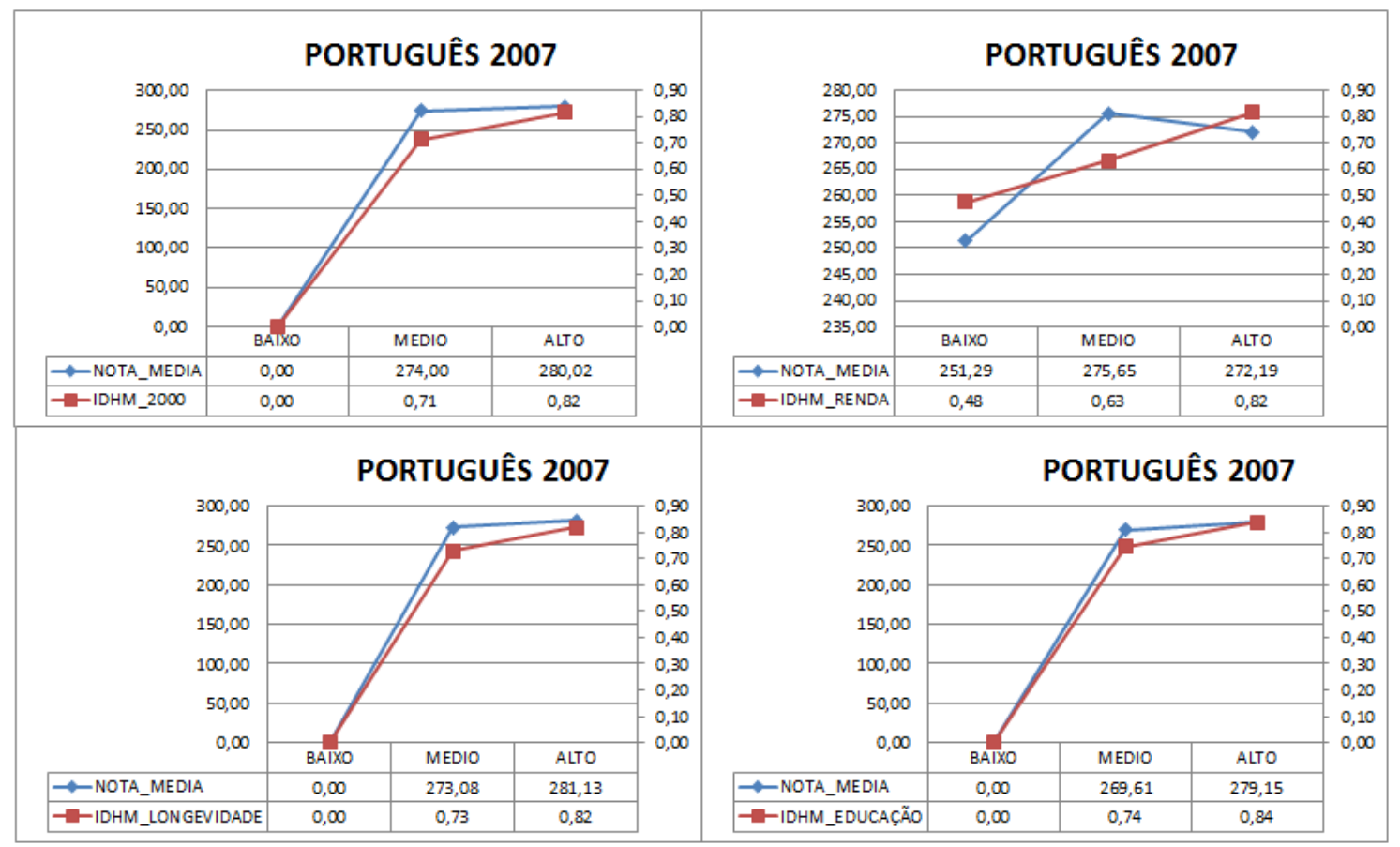

Fonte: Elaborado pelo autor. 
DESEMPENHO DE PORTUGUÊS 2007 X ÍNDICE DE GINI 2000 E 2010

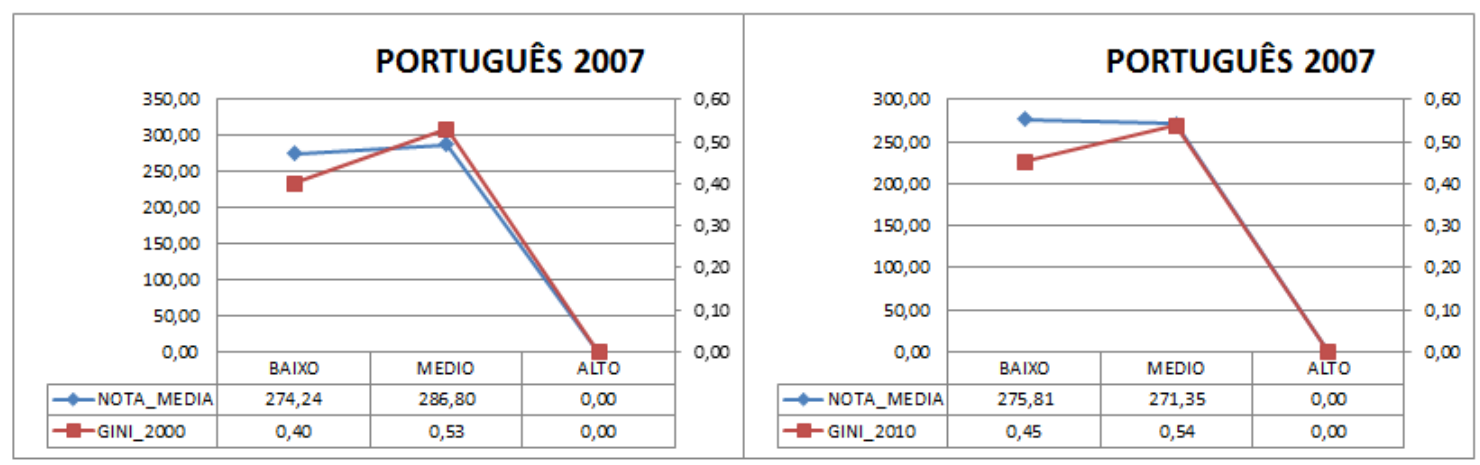

Fonte: Elaborado pelo autor.

DESEMPENHO DE PORTUGUÊS 2007 X IDHM E ÍNDICE DE GINI

\begin{tabular}{|c|c|c|c|c|c|c|}
\hline 2007 & IDHM_2000 & IDHM_RENDA & IDHM_LONGEVIDADE & IDHM_EDUCAÇÃO & GINI_2000 & GINI_2010 \\
\hline BAIXO & 0 & 46 & 0 & 0 & 820 & 539 \\
\hline MEDIO & 785 & 774 & 700 & 420 & 2 & 283 \\
\hline ALTO & 37 & 2 & 122 & 402 & 0 & 0 \\
\hline TOTAL & 822 & 822 & 822 & 822 & 822 & 822 \\
\hline
\end{tabular}

Fonte: Elaborado pelo autor.

DESEMPENHO DE PORTUGUÊS 2007 X IDHM E ÍNDICE DE GINI (\%)

\begin{tabular}{l|l|l|l|l|l|l}
\hline 2007 & IDHM_2000 & IDHM_RENDA & IDHM_LONGEVIDADE & IDHM_EDUCAÇÃO & GINI_2000 & GINI_2010 \\
\hline BAIXO & $0,0 \%$ & $5,6 \%$ & $0,0 \%$ & $0,0 \%$ & $99,8 \%$ & $65,6 \%$ \\
\hline MEDIO & $95,5 \%$ & $94,2 \%$ & $85,2 \%$ & $51,1 \%$ & $0,2 \%$ & $34,4 \%$ \\
\hline ALTO & $4,5 \%$ & $0,2 \%$ & $14,8 \%$ & $48,9 \%$ & $0,0 \%$ & $0,0 \%$ \\
\hline TOTAL & $100,0 \%$ & $100,0 \%$ & $100,0 \%$ & $100,0 \%$ & $100,0 \%$ & $100,0 \%$ \\
\hline
\end{tabular}

Fonte: Elaborado pelo autor.

No índice do IDHM, e da componente longevidade, e educação, há um acompanhamento perfeito, com exceção da renda, em que o nível alto não possui notas médias altas, mas uma queda, além disso, temos apenas duas cidades nesse nível: Belo Horizonte e São Gotardo. Já no índice de Gini, percebemos um acompanhamento do índice de 2000, mas não no de 2010, em que o nível médio apresenta queda em vez de acompanhamento. Outro fato que percebemos é que temos mais cidades na faixa média do índice Gini 2010 do que a concentração da faixa baixa do índice de Gini 2000, em que somente duas cidades estavam nesse nível: Carmesia e Morro do Pilar. Vale ressaltar que não há nenhuma cidade no nível alto. 


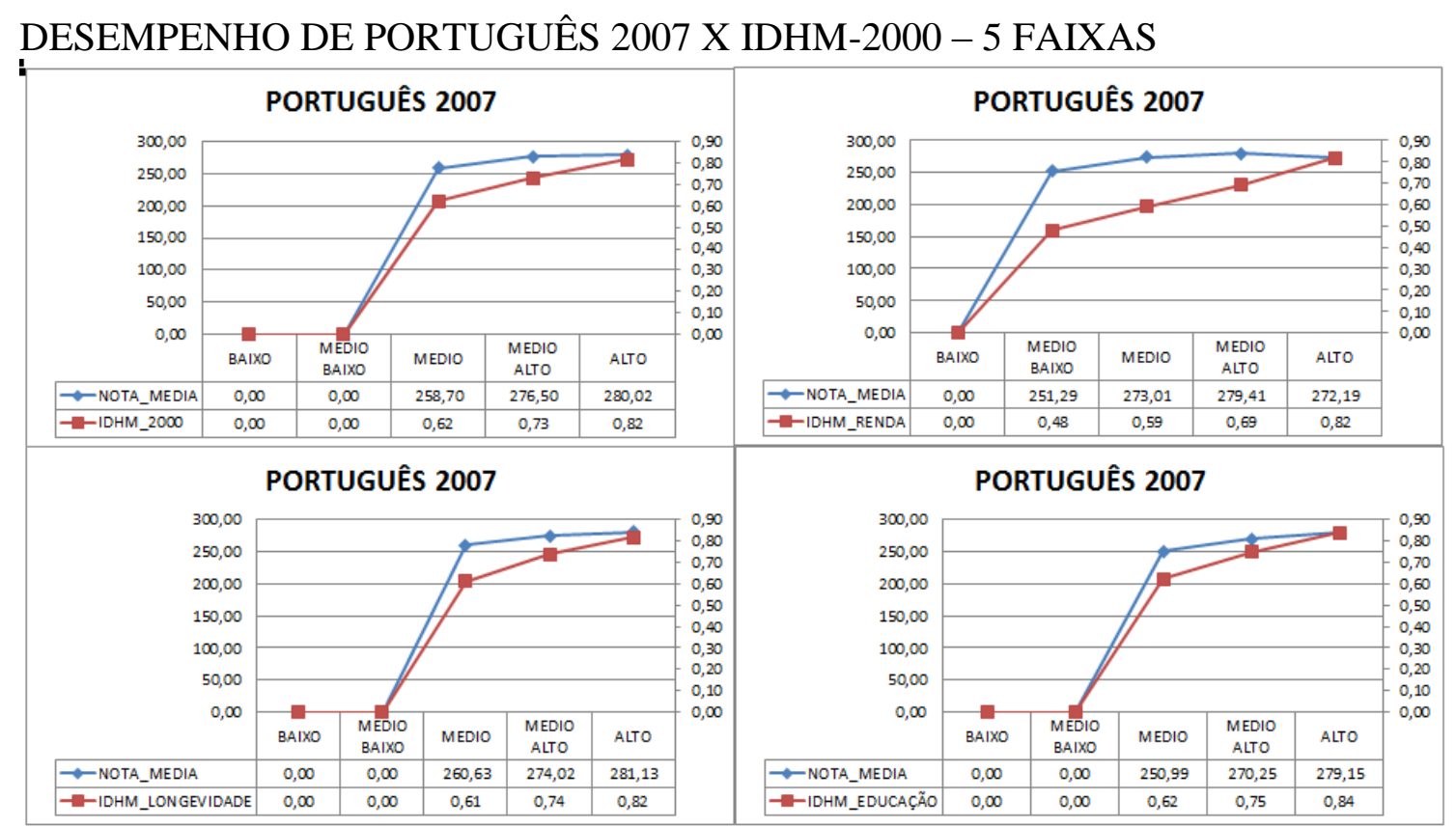

Fonte: Elaborado pelo autor.

DESEMPENHO DE PORTUGUÊS 2007 X IDHM - 5 FAIXAS

\begin{tabular}{l|l|l|l|l}
\hline 2007 & IDHM_2000 & IDHM_RENDA & IDHM_LONGEVIDADE & IDHM_EDUCAÇÃO \\
\hline BAIXO & 0 & 0 & 0 & 0 \\
\hline BAIXO MEDIO & 0 & 46 & 0 & 0 \\
\hline MEDIO & 110 & 455 & 49 & 14 \\
\hline MEDIO ALTO & 675 & 319 & 651 & 406 \\
\hline ALTO & 37 & 2 & 122 & 402 \\
\hline TOTAL & 822 & 822 & 822 & 822 \\
\hline
\end{tabular}

Fonte: Elaborado pelo autor.

DESEMPENHO DE PORTUGUÊS 2007 X IDHM - 5 FAIXAS (\%)

\begin{tabular}{l|l|l|l|l}
\hline 2007 & IDHM_2000 & IDHM_RENDA & IDHM_LONGEVIDADE & IDHM_EDUCAÇÃO \\
\hline BAIXO & $0,0 \%$ & $0,0 \%$ & $0,0 \%$ & $0,0 \%$ \\
\hline BAIXO MEDIO & $0,0 \%$ & $5,6 \%$ & $0,0 \%$ & $0,0 \%$ \\
\hline MEDIO & $13,4 \%$ & $55,4 \%$ & $6,0 \%$ & $1,7 \%$ \\
\hline MEDIO ALTO & $82,1 \%$ & $38,8 \%$ & $79,2 \%$ & $49,4 \%$ \\
\hline ALTO & $4,5 \%$ & $0,2 \%$ & $14,8 \%$ & $48,9 \%$ \\
\hline TOTAL & $100,0 \%$ & $100,0 \%$ & $100,0 \%$ & $100,0 \%$ \\
\hline
\end{tabular}

Fonte: Elaborado pelo autor.

Realizando uma nova divisão no IDHM, segmentando em 5 faixas, observamos o mesmo resultado da divisão em 3 faixas, a componente Renda novamente tem em seu nível alto, uma queda da nota média, e possui apenas duas cidades representando esse nível: Belo Horizonte e São Gotardo.

Português 2008 
DESEMPENHO DE PORTUGUÊS 2008 X IFDM

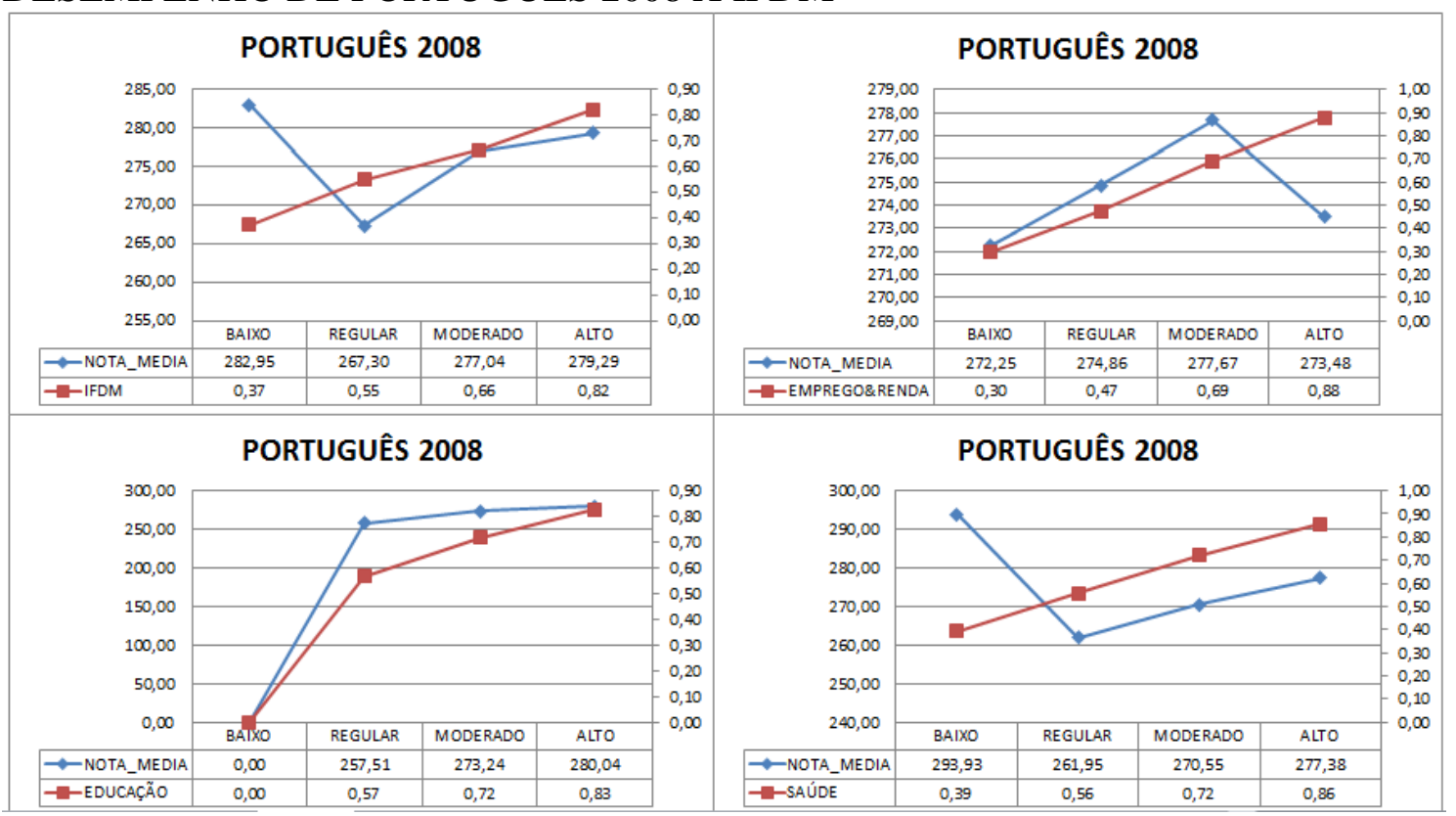

Fonte: Elaborado pelo autor.

DESEMPENHO DE PORTUGUÊS 2008 X IFDM

\begin{tabular}{l|l|l|l|l}
\hline 2008 & IFDM & EMPREGO\&RENDA & EDUCAÇÃO & SAÚDE \\
\hline BAIXO & 1 & 599 & 0 & 1 \\
\hline REGULAR & 342 & 183 & 38 & 46 \\
\hline MODERADO & 483 & 48 & 729 & 422 \\
\hline ALTO & 17 & 13 & 76 & 374 \\
\hline TOTAL & 843 & 843 & 843 & 843 \\
\hline
\end{tabular}

Fonte: Elaborado pelo autor.

DESEMPENHO DE PORTUGUÊS 2008 X IFDM $(\%)$

\begin{tabular}{l|l|l|l|l}
\hline 2008 & IFDM & EMPREGO\&RENDA & EDUCAÇ̃̃O & SAÚDE \\
\hline BAIXO & $0,1 \%$ & $71,1 \%$ & $0,0 \%$ & $0,1 \%$ \\
\hline REGULAR & $40,6 \%$ & $21,7 \%$ & $4,5 \%$ & $5,5 \%$ \\
\hline MODERADO & $57,3 \%$ & $5,7 \%$ & $86,5 \%$ & $50,1 \%$ \\
\hline ALTO & $2,0 \%$ & $1,5 \%$ & $9,0 \%$ & $44,4 \%$ \\
\hline TOTAL & $100,0 \%$ & $100,0 \%$ & $100,0 \%$ & $100,0 \%$ \\
\hline
\end{tabular}

Fonte: Elaborado pelo autor.

No índice IFDM, as notas médias de 2008 tem uma queda no nível regular, voltando a seguir o índice nos demais níveis seguintes, já para o componente Emprego \& Renda do IFDM, percebemos queda no nível alto e saúde teve queda no nível regular, voltando a seguir o crescimento do índice nos demais níveis. $\mathrm{Na}$ componentes educação, o comportamento foi crescente na medida que avançamos nas faixas do baixo até o alto. 
DESEMPENHO DE PORTUGUÊS 2008 X IDHM-2000 - 3 FAIXAS

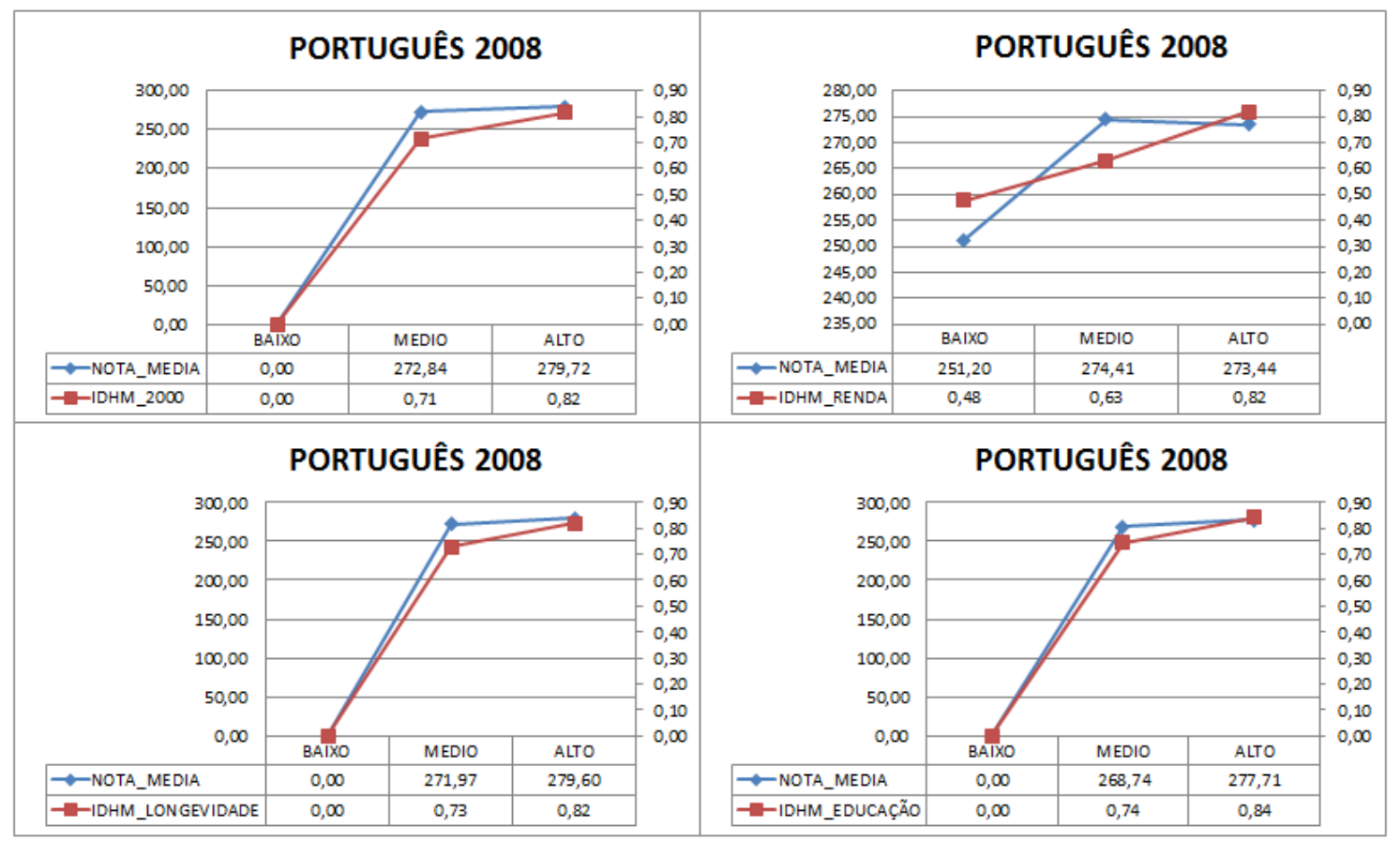

Fonte: Elaborado pelo autor.

\section{DESEMPENHO DE PORTUGUÊS 2008 X ÍNDICE DE GINI 2000 E 2010}

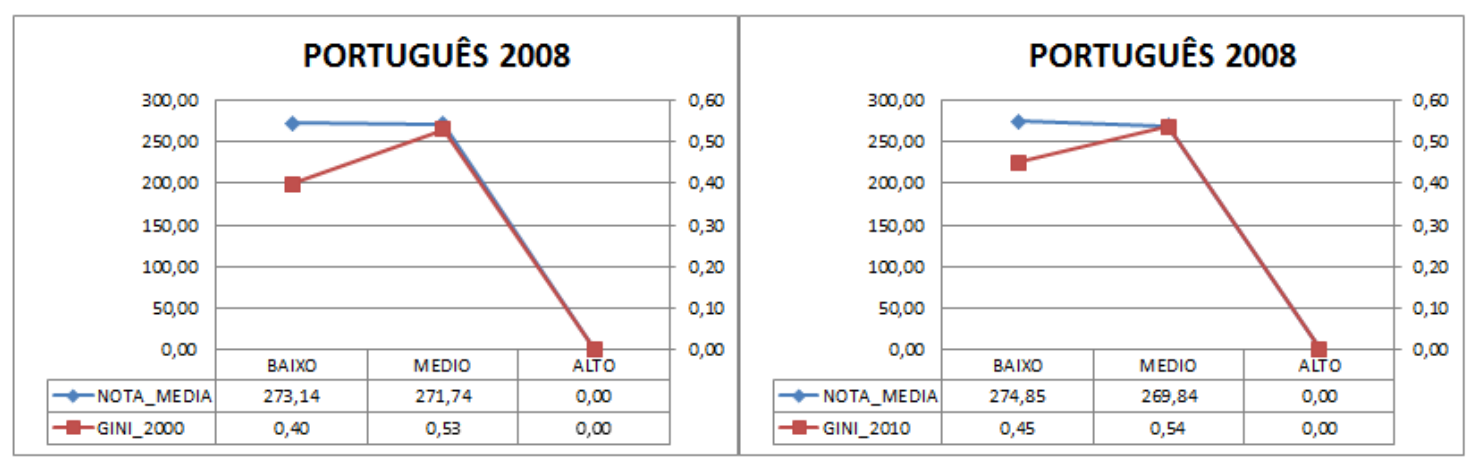

Fonte: Elaborado pelo autor.

DESEMPENHO DE PORTUGUÊS 2008 X IDHM E ÍNDICE DE GINI

\begin{tabular}{l|l|l|l|l|l|l}
\hline 2008 & IDHM_2000 & IDHM_RENDA & IDHM_LONGEVIDADE & IDHM_EDUCAÇÃO & GINI_2000 & GINI_2010 \\
\hline BAIXO & 0 & 46 & 0 & 0 & 841 & 555 \\
\hline MEDIO & 806 & 795 & 714 & 429 & 2 & 288 \\
\hline ALTO & 37 & 2 & 129 & 414 & 0 & 0 \\
\hline TOTAL & 843 & 843 & 843 & 843 & 843 & 843 \\
\hline
\end{tabular}

Fonte: Elaborado pelo autor.

DESEMPENHO DE PORTUGUÊS 2008 X IDHM E ÍNDICE DE GINI (\%)

\begin{tabular}{l|l|l|l|l|l|l}
\hline 2008 & IDHM_2000 & IDHM_RENDA & IDHM_LONGEVIDADE & IDHM_EDUCAÇÃO & GINI_2000 & GINI_2010 \\
\hline BAIXO & $0,0 \%$ & $5,5 \%$ & $0,0 \%$ & $0,0 \%$ & $99,8 \%$ & $65,8 \%$ \\
\hline MEDIO & $95,6 \%$ & $94,3 \%$ & $84,7 \%$ & $50,9 \%$ & $0,2 \%$ & $34,2 \%$ \\
\hline ALTO & $4,4 \%$ & $0,2 \%$ & $15,3 \%$ & $49,1 \%$ & $0,0 \%$ & $0,0 \%$ \\
\hline TOTAL & $100,0 \%$ & $100,0 \%$ & $100,0 \%$ & $100,0 \%$ & $100,0 \%$ & $100,0 \%$ \\
\hline
\end{tabular}

Fonte: Elaborado pelo autor. 
No índice do IDHM, e da componente longevidade, e educação, há um acompanhamento perfeito, com exceção da renda, em que o nível alto não possui notas médias altas, mas uma queda, além disso, temos apenas duas cidades nesse nível: Belo Horizonte e São Gotardo. Já no índice de Gini, percebemos queda tanto no ano de 2000 quanto no ano de 2010, em que o nível médio apresenta queda em vez de acompanhamento.

DESEMPENHO DE PORTUGUÊS 2008 X IDHM-2000 - 5 FAIXAS

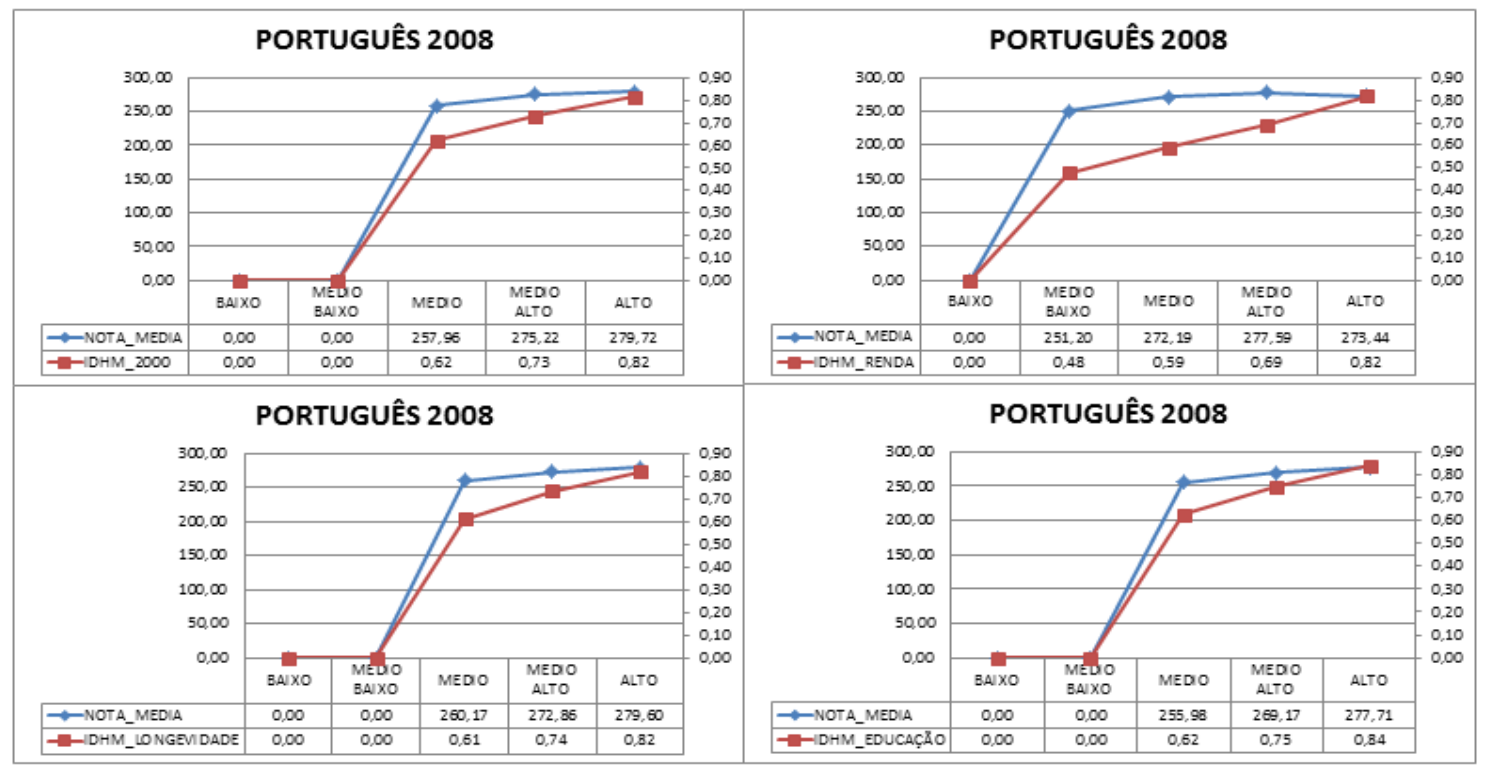

Fonte: Elaborado pelo autor.

DESEMPENHO DE PORTUGUÊS 2008 X IDHM - 5 FAIXAS

\begin{tabular}{l|l|l|l|l}
\hline 2008 & IDHM_2000 & IDHM_RENDA & IDHM_LONGEVIDADE & IDHM_EDUCAÇÃO \\
\hline BAIXO & 0 & 0 & 0 & 0 \\
\hline BAIXO MEDIO & 0 & 46 & 0 & 0 \\
\hline MEDIO & 111 & 468 & 50 & 14 \\
\hline MEDIO ALTO & 695 & 327 & 664 & 415 \\
\hline ALTO & 37 & 2 & 129 & 414 \\
\hline TOTAL & 843 & 843 & 843 & 843 \\
\hline
\end{tabular}

Fonte: Elaborado pelo autor.

DESEMPENHO DE PORTUGUÊS 2008 X IDHM - 5 FAIXAS (\%)

\begin{tabular}{l|l|l|l|l}
\hline 2008 & IDHM_2000 & IDHM_RENDA & IDHM_LONGEVIDADE & IDHM_EDUCAÇÃO \\
\hline BAIXO & $0,0 \%$ & $0,0 \%$ & $0,0 \%$ & $0,0 \%$ \\
\hline BAIXO MEDIO & $0,0 \%$ & $5,5 \%$ & $0,0 \%$ & $0,0 \%$ \\
\hline MEDIO & $13,2 \%$ & $55,5 \%$ & $5,9 \%$ & $1,7 \%$ \\
\hline MEDIO ALTO & $82,4 \%$ & $38,8 \%$ & $78,8 \%$ & $49,2 \%$ \\
\hline ALTO & $4,4 \%$ & $0,2 \%$ & $15,3 \%$ & $49,1 \%$ \\
\hline
\end{tabular}

Fonte: Elaborado pelo autor. 
Realizando uma nova divisão no IDHM, segmentando em 5 faixas, observamos o mesmo resultado da divisão em 3 faixas, a componente renda novamente tem em seu nível alto, uma queda da nota média, e possui apenas duas cidades representando esse nível: Belo Horizonte e São Gotardo.

Português 2009

\section{DESEMPENHO DE PORTUGUÊS 2009 X IFDM}

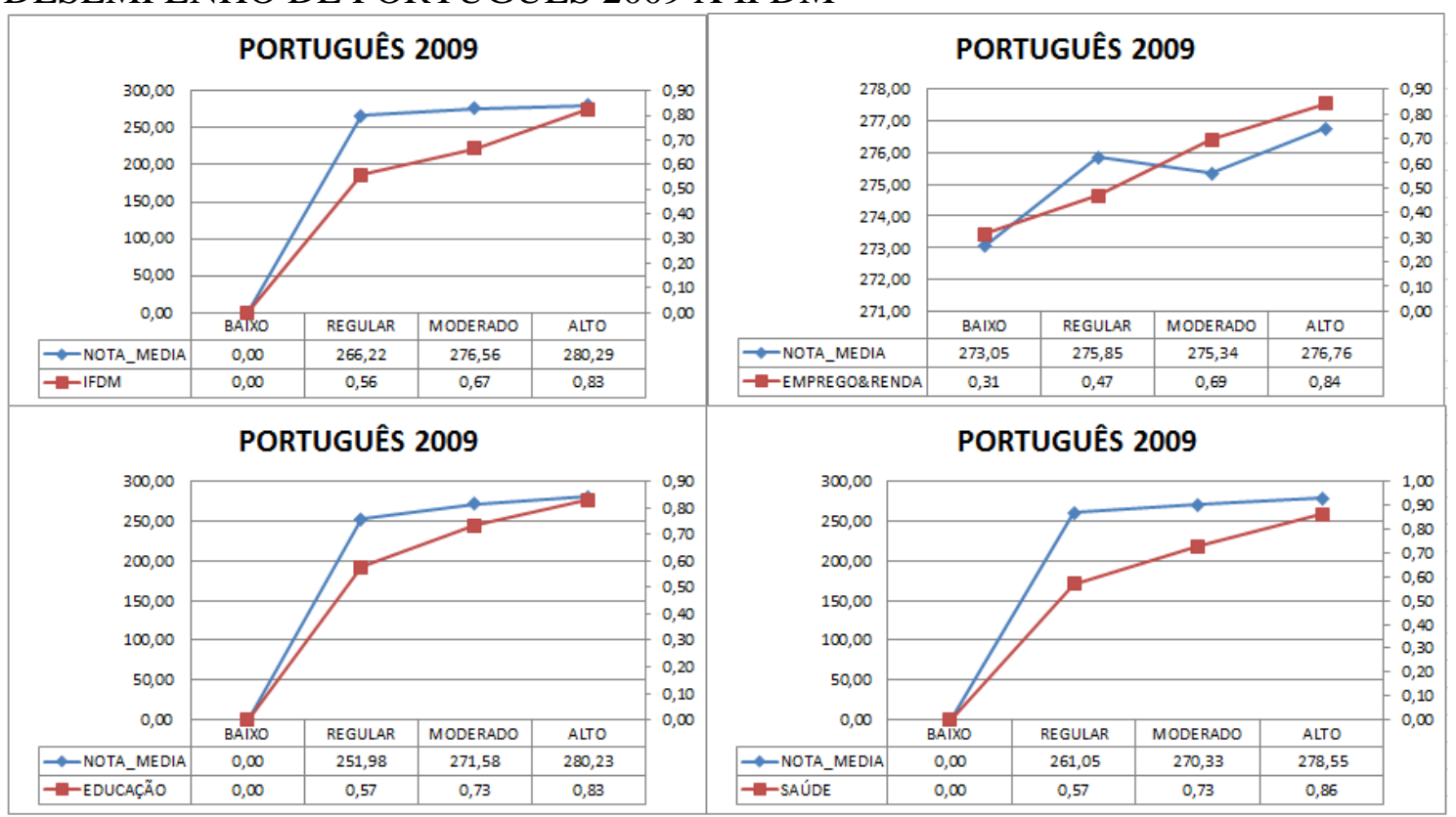

Fonte: Elaborado pelo autor.

DESEMPENHO DE PORTUGUÊS 2009 X IFDM

\begin{tabular}{l|l|l|l|l}
\hline 2009 & IFDM & EMPREGO\&RENDA & EDUCAÇÃO & SAÚDE \\
\hline BAIXO & 0 & 584 & 0 & 0 \\
\hline REGULAR & 224 & 211 & 11 & 34 \\
\hline MODERADO & 605 & 44 & 583 & 406 \\
\hline ALTO & 17 & 7 & 252 & 406 \\
\hline TOTAL & 846 & 846 & 846 & 846 \\
\hline
\end{tabular}

Fonte: Elaborado pelo autor.

DESEMPENHO DE PORTUGUÊS 2009 X IFDM (\%)

\begin{tabular}{l|l|l|l|l}
\hline 2009 & IFDM & EMPREGO\&RENDA & EDUCAÇ̃̃O & SAÚDE \\
\hline BAIXO & $0,0 \%$ & $69,0 \%$ & $0,0 \%$ & $0,0 \%$ \\
\hline REGULAR & $26,5 \%$ & $24,9 \%$ & $1,3 \%$ & $4,0 \%$ \\
\hline MODERADO & $71,5 \%$ & $5,2 \%$ & $68,9 \%$ & $48,0 \%$ \\
\hline ALTO & $2,0 \%$ & $0,8 \%$ & $29,8 \%$ & $48,0 \%$ \\
\hline TOTAL & $100,0 \%$ & $100,0 \%$ & $100,0 \%$ & $100,0 \%$ \\
\hline
\end{tabular}

Fonte: Elaborado pelo autor. 
No índice IFDM, as notas médias de 2009 acompanham bem, assim como os demais componentes, com exceção do Emprego \& Renda do IFDM, percebemos queda no nível moderado.

\section{DESEMPENHO DE PORTUGUÊS 2009 X IDHM-2000 - 3 FAIXAS}

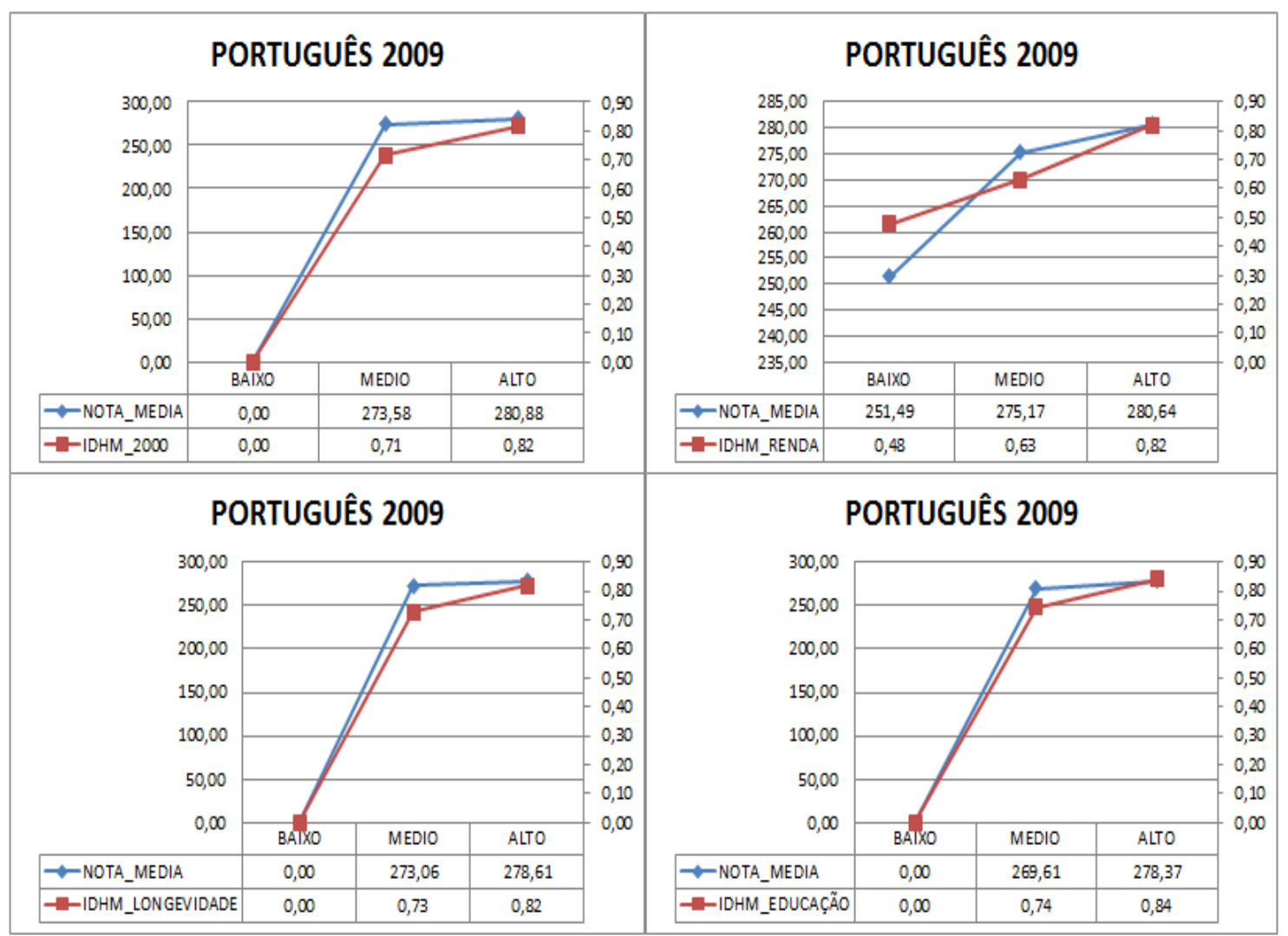

Fonte: Elaborado pelo autor.

DESEMPENHO DE PORTUGUÊS 2009 X ÍNDICE DE GINI 2000 E 2010

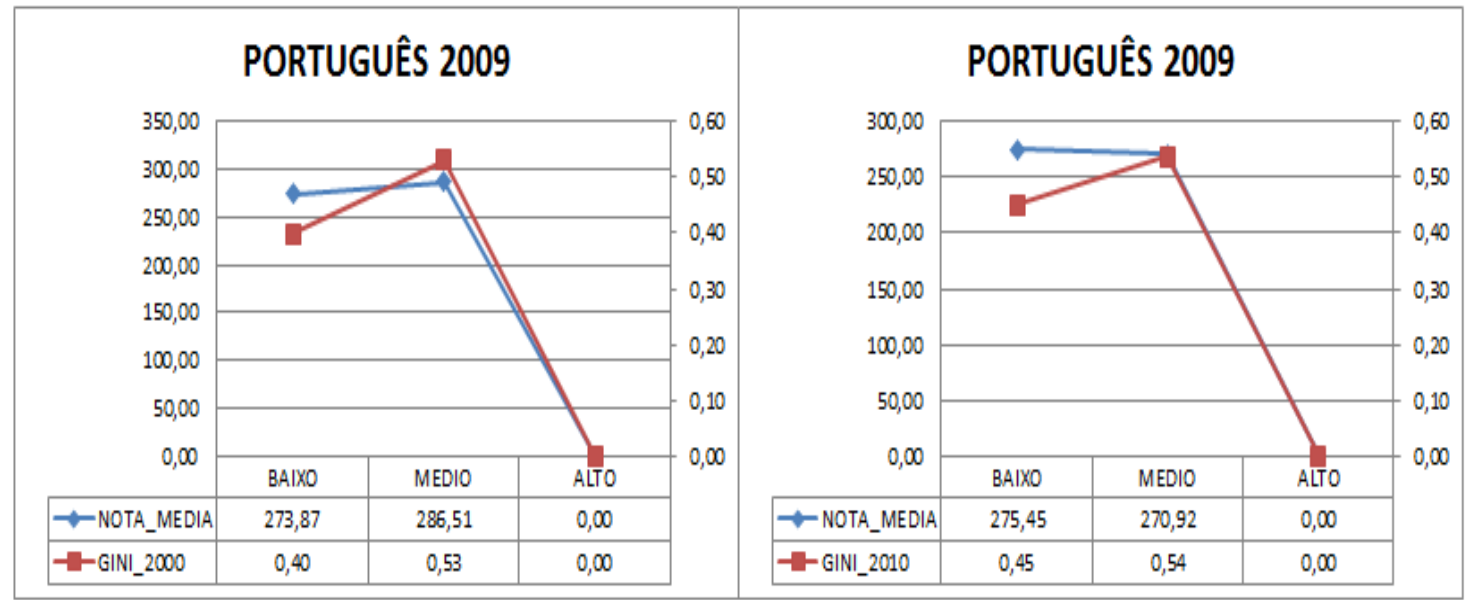

Fonte: Elaborado pelo autor. 
DESEMPENHO DE PORTUGUÊS 2009 X IDHM E ÍNDICE DE GINI

\begin{tabular}{l|l|l|l|l|l|l}
\hline 2009 & IDHM_2000 & IDHM_RENDA & IDHM_LONGEVIDADE & IDHM_EDUCAÇÃO & GINI_2000 & GINI_2010 \\
\hline BAIXO & 0 & 46 & 0 & 0 & 844 & 556 \\
\hline MEDIO & 809 & 798 & 718 & 432 & 2 & 290 \\
\hline ALTO & 37 & 2 & 128 & 414 & 0 & 0 \\
\hline TOTAL & 846 & 846 & 846 & 846 & 846 & 846 \\
\hline
\end{tabular}

Fonte: Elaborado pelo autor.

DESEMPENHO DE PORTUGUÊS 2009 X IDHM E ÍNDICE DE GINI (\%)

\begin{tabular}{l|l|l|l|l|l|l}
\hline 2009 & IDHM_2000 & IDHM_RENDA & IDHM_LONGEVIDADE & IDHM_EDUCAÇÃO & GINI_2000 & GINI_2010 \\
\hline BAIXO & $0,0 \%$ & $5,4 \%$ & $0,0 \%$ & $0,0 \%$ & $99,8 \%$ & $65,7 \%$ \\
\hline MEDIO & $95,6 \%$ & $94,3 \%$ & $84,9 \%$ & $51,1 \%$ & $0,2 \%$ & $34,3 \%$ \\
\hline ALTO & $4,4 \%$ & $0,2 \%$ & $15,1 \%$ & $48,9 \%$ & $0,0 \%$ & $0,0 \%$ \\
\hline TOTAL & $100,0 \%$ & $100,0 \%$ & $100,0 \%$ & $100,0 \%$ & $100,0 \%$ & $100,0 \%$ \\
\hline
\end{tabular}

Fonte: Elaborado pelo autor.

No índice do IDHM, e do componente longevidade, educação e renda há um acompanhamento perfeito. Já no índice de Gini, percebemos um acompanhamento do índice de 2000, mas não no de 2010, em que o nível médio apresenta queda em vez de acompanhamento. Outro fato que percebemos é que temos mais cidades na faixa média do índice Gini 2010 do que a concentração da faixa baixa do índice de Gini 2000, em que somente duas cidades estavam nesse nível: Carmesia e Morro do Pilar. Vale ressaltar que não há nenhuma cidade no nível alto.

DESEMPENHO DE PORTUGUÊS 2009 X IDHM-2000 - 5 FAIXAS

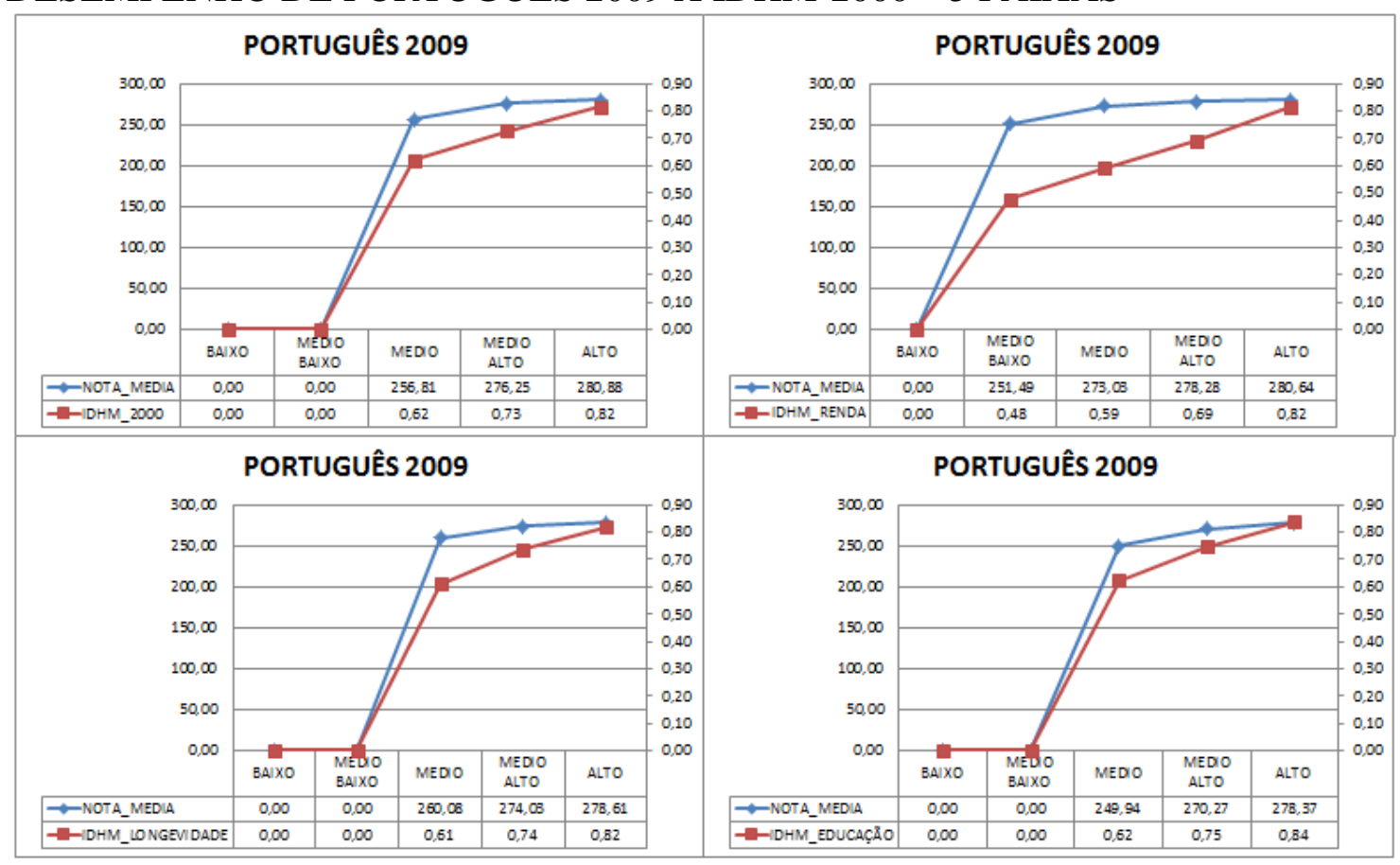

Fonte: Elaborado pelo autor. 
DESEMPENHO DE PORTUGUÊS 2009 X IDHM - 5 FAIXAS

\begin{tabular}{l|l|l|l|l}
\hline 2009 & IDHM_2000 & IDHM_RENDA & IDHM_LONGEVIDADE & IDHM_EDUCAÇ̃̃O \\
\hline BAIXO & 0 & 0 & 0 & 0 \\
\hline BAIXO MEDIO & 0 & 46 & 0 & 0 \\
\hline MEDIO & 111 & 472 & 50 & 14 \\
\hline MEDIO ALTO & 698 & 326 & 668 & 418 \\
\hline ALTO & 37 & 2 & 128 & 414 \\
\hline TOTAL & 846 & 846 & 846 & 846 \\
\hline
\end{tabular}

Fonte: Elaborado pelo autor.

DESEMPENHO DE PORTUGUÊS 2009 X IDHM - 5 FAIXAS (\%)

\begin{tabular}{l|l|l|l|l}
\hline 2009 & IDHM_2000 & IDHM_RENDA & IDHM_LONGEVIDADE & IDHM_EDUCAÇÃO \\
\hline BAIXO & $0,0 \%$ & $0,0 \%$ & $0,0 \%$ & $0,0 \%$ \\
\hline BAIXO MEDIO & $0,0 \%$ & $5,4 \%$ & $0,0 \%$ & $0,0 \%$ \\
\hline MEDIO & $13,1 \%$ & $55,8 \%$ & $5,9 \%$ & $1,7 \%$ \\
\hline MEDIO ALTO & $82,5 \%$ & $38,5 \%$ & $79,0 \%$ & $49,4 \%$ \\
\hline ALTO & $4,4 \%$ & $0,2 \%$ & $15,1 \%$ & $48,9 \%$ \\
\hline TOTAL & $100,0 \%$ & $100,0 \%$ & $100,0 \%$ & $100,0 \%$ \\
\hline
\end{tabular}

Fonte: Elaborado pelo autor.

Realizando uma nova divisão no IDHM, segmentando em 5 faixas, observamos o mesmo resultado da divisão em 3 faixas, uma aderência aos índices em cada nível.

2.3.10. Português 2010

DESEMPENHO DE PORTUGUÊS 2010 X IFDM

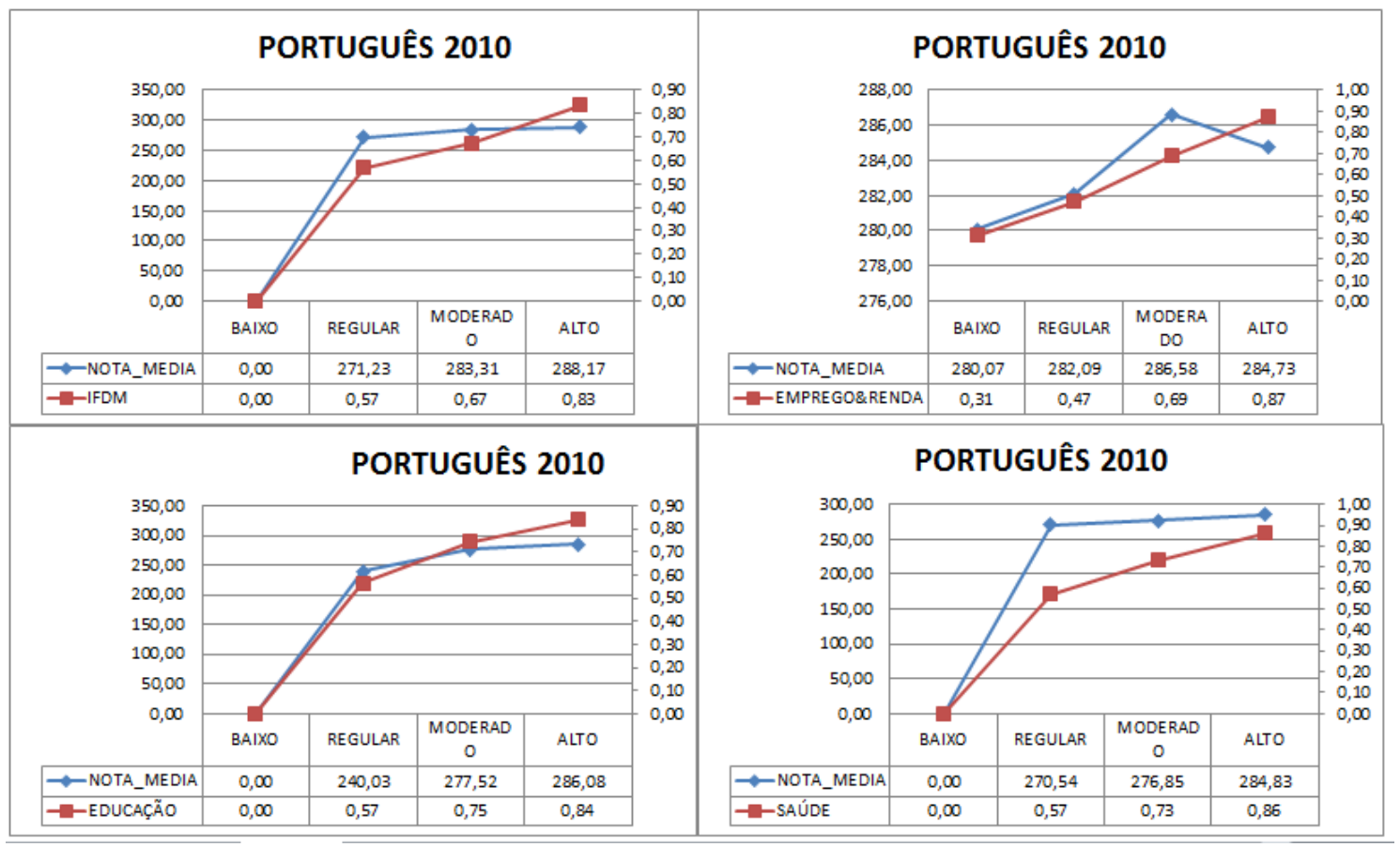

Fonte: Elaborado pelo autor. 
DESEMPENHO DE PORTUGUÊS 2010 X IFDM

\begin{tabular}{l|l|l|l|l}
\hline 2010 & IFDM & EMPREGO\&RENDA & EDUCAÇÃO & SAÚDE \\
\hline BAIXO & 0 & 566 & 0 & 0 \\
\hline REGULAR & 169 & 209 & 4 & 15 \\
\hline MODERADO & 645 & 56 & 472 & 370 \\
\hline ALTO & 33 & 16 & 371 & 462 \\
\hline TOTAL & 847 & 847 & 847 & 847 \\
\hline
\end{tabular}

Fonte: Elaborado pelo autor.

DESEMPENHO DE PORTUGUÊS 2010 X IFDM (\%)

\begin{tabular}{l|l|l|l|l}
\hline 2010 & IFDM & EMPREGO\&RENDA & EDUCAÇ̃̃O & SAÚDE \\
\hline BAIXO & $0,0 \%$ & $66,8 \%$ & $0,0 \%$ & $0,0 \%$ \\
\hline REGULAR & $20,0 \%$ & $24,7 \%$ & $0,5 \%$ & $1,8 \%$ \\
\hline MODERADO & $76,2 \%$ & $6,6 \%$ & $55,7 \%$ & $43,7 \%$ \\
\hline ALTO & $3,9 \%$ & $1,9 \%$ & $43,8 \%$ & $54,5 \%$ \\
\hline TOTAL & $100,0 \%$ & $100,0 \%$ & $100,0 \%$ & $100,0 \%$ \\
\hline
\end{tabular}

Fonte: Elaborado pelo autor.

No índice IFDM, as notas médias de 2010 acompanham bem, assim como os demais componentes com exceção do Emprego \& Renda do IFDM, percebemos queda no nível moderado.

\section{DESEMPENHO DE PORTUGUÊS 2010 X IDHM-2000 X 3 FAIXAS}

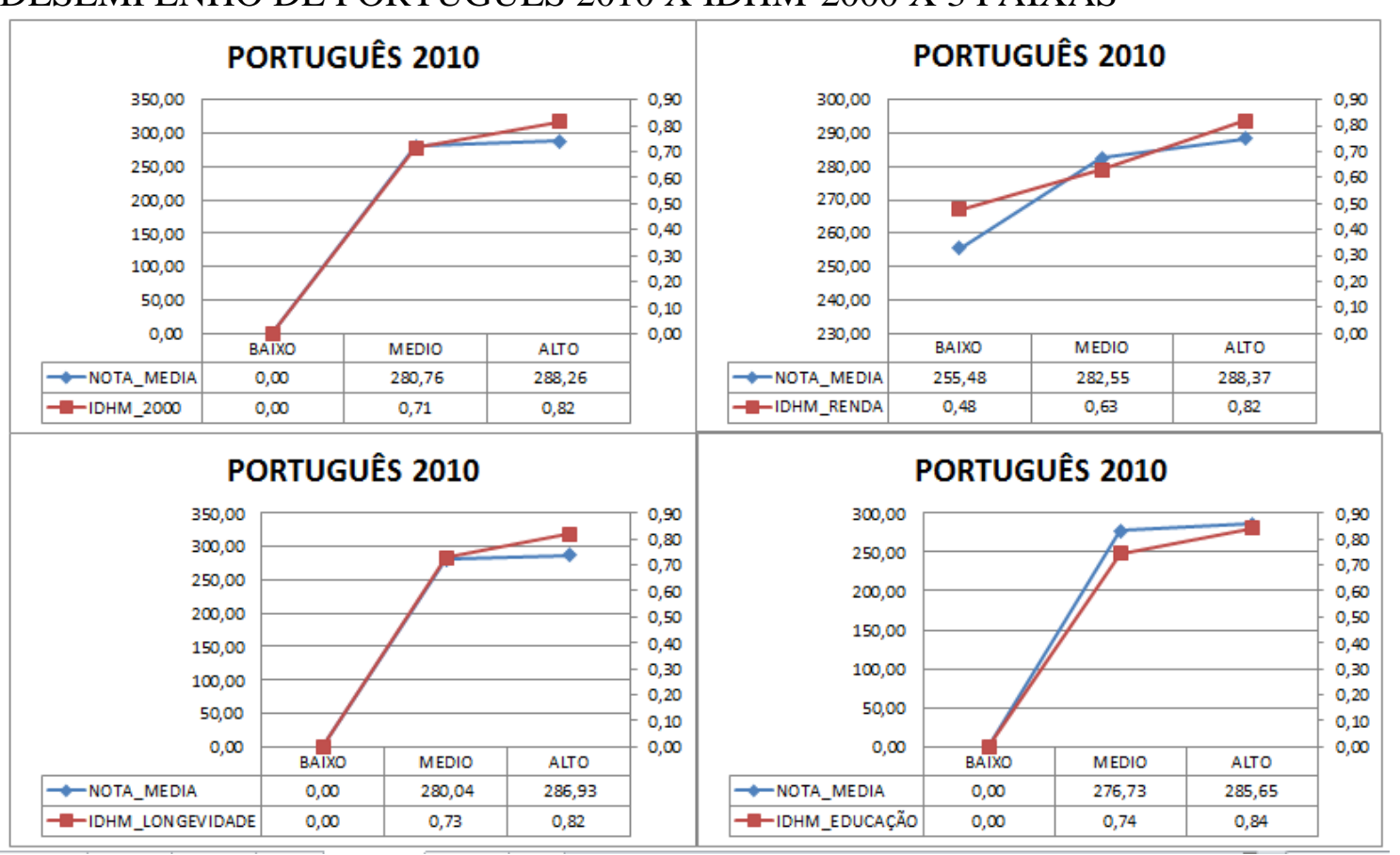

Fonte: Elaborado pelo autor. 
DESEMPENHO DE PORTUGUÊS 2010 X ÍNDICE DE GINI 2000 E 2010

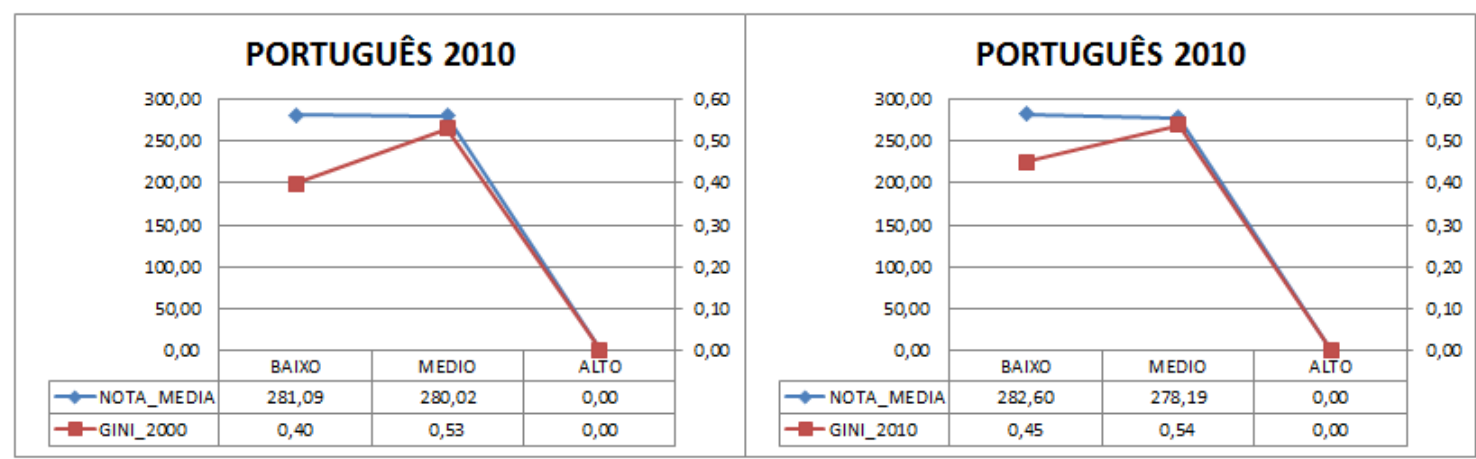

Fonte: Elaborado pelo autor.

DESEMPENHO DE PORTUGUÊS 2010 X IDHM E ÍNDICE DE GINI

\begin{tabular}{l|l|l|l|l|l|l}
\hline 2010 & IDHM_2000 & IDHM_RENDA & IDHM_LONGEVIDADE & IDHM_EDUCAÇÃO & GINI_2000 & GINI_2010 \\
\hline BAIXO & 0 & 46 & 0 & 0 & 845 & 556 \\
\hline MEDIO & 810 & 799 & 718 & 433 & 2 & 291 \\
\hline ALTO & 37 & 2 & 129 & 414 & 0 & 0 \\
\hline TOTAL & 847 & 847 & 847 & 847 & 847 & 847 \\
\hline
\end{tabular}

Fonte: Elaborado pelo autor.

DESEMPENHO DE PORTUGUÊS 2010 X IDHM E ÍNDICE DE GINI (\%)

\begin{tabular}{l|l|l|l|l|l|l}
\hline 2010 & IDHM_2000 & IDHM_RENDA & IDHM_LONGEVIDADE & IDHM_EDUCAÇÃO & GINI_2000 & GINI_2010 \\
\hline BAIXO & $0,0 \%$ & $5,4 \%$ & $0,0 \%$ & $0,0 \%$ & $99,8 \%$ & $65,6 \%$ \\
\hline MEDIO & $95,6 \%$ & $94,3 \%$ & $84,8 \%$ & $51,1 \%$ & $0,2 \%$ & $34,4 \%$ \\
\hline ALTO & $4,4 \%$ & $0,2 \%$ & $15,2 \%$ & $48,9 \%$ & $0,0 \%$ & $0,0 \%$ \\
\hline TOTAL & $100,0 \%$ & $100,0 \%$ & $100,0 \%$ & $100,0 \%$ & $100,0 \%$ & $100,0 \%$ \\
\hline \multicolumn{6}{c}{ Fonte: Elaborado pelo autor. }
\end{tabular}

No índice do IDHM, e da componente longevidade, educação e renda, há um acompanhamento perfeito. Já no índice de Gini, percebemos queda tanto no índice de 2000, quanto no de 2010, em que o nível médio apresenta queda em vez de acompanhamento. 
DESEMPENHO DE PORTUGUÊS 2010 X ÍNDICE DE IDHM-2000 - 5 FAIXAS

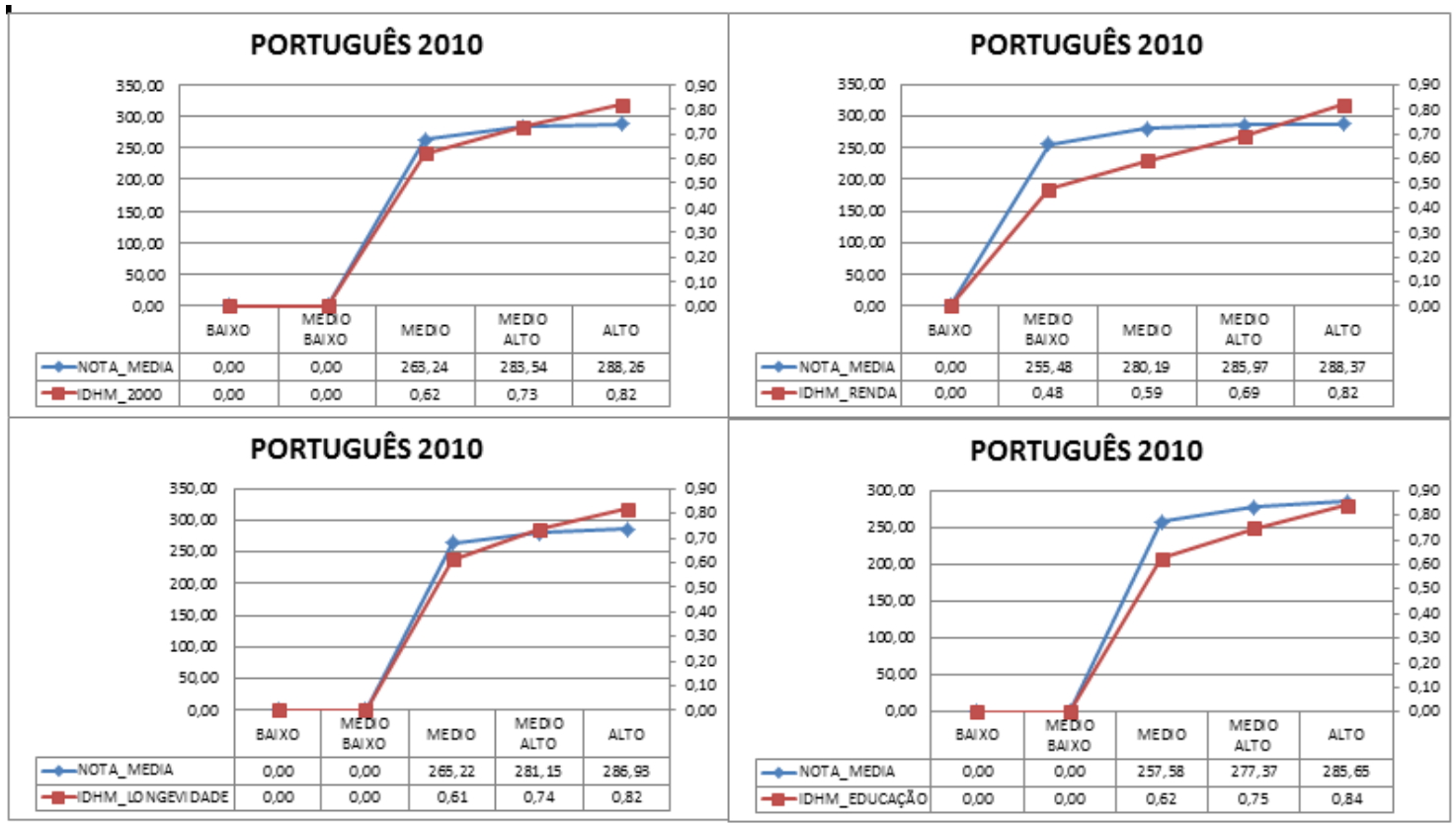

Fonte: Elaborado pelo autor.

DESEMPENHO DE PORTUGUÊS 2010 X IDHM - 5 FAIXAS

\begin{tabular}{l|l|l|l|l}
\hline 2010 & IDHM_2000 & IDHM_RENDA & IDHM_LONGEVIDADE & IDHM_EDUCAÇÃO \\
\hline BAIXO & 0 & 0 & 0 & 0 \\
\hline BAIXO MEDIO & 0 & 46 & 0 & 0 \\
\hline MEDIO & 111 & 473 & 50 & 14 \\
\hline MEDIO ALTO & 699 & 326 & 668 & 419 \\
\hline ALTO & 37 & 2 & 129 & 414 \\
\hline TOTAL & 847 & 847 & 847 & 847 \\
\hline
\end{tabular}

Fonte: Elaborado pelo autor.

DESEMPENHO DE PORTUGUÊS 2010 X IDHM - 5 FAIXAS (\%)

\begin{tabular}{l|l|l|l|l}
\hline 2010 & IDHM_2000 & IDHM_RENDA & IDHM_LONGEVIDADE & IDHM_EDUCAÇÃO \\
\hline BAIXO & $0,0 \%$ & $0,0 \%$ & $0,0 \%$ & $0,0 \%$ \\
\hline BAIXO MEDIO & $0,0 \%$ & $5,4 \%$ & $0,0 \%$ & $0,0 \%$ \\
\hline MEDIO & $13,1 \%$ & $55,8 \%$ & $5,9 \%$ & $1,7 \%$ \\
\hline MEDIO ALTO & $82,5 \%$ & $38,5 \%$ & $78,9 \%$ & $49,5 \%$ \\
\hline ALTO & $4,4 \%$ & $0,2 \%$ & $15,2 \%$ & $48,9 \%$ \\
\hline TOTAL & $100,0 \%$ & $100,0 \%$ & $100,0 \%$ & $100,0 \%$ \\
\hline
\end{tabular}

Fonte: Elaborado pelo autor.

Realizando uma nova divisão no IDHM, segmentando em 5 faixas, observamos o mesmo resultado da divisão em 3 faixas, uma aderência no comportamento dos índices. 


\section{5.}

\section{Desempenho das escolas contemplas com programas/políticas educacionais x Não contempladas}

Desempenho das escolas contemplas com programas/políticas educacionais x Não contempladas.

A seguir, analiso os indicadores por meio dos gráficos de barra. Alguns indicadores estarão ausentes em alguns anos em que não foram desenvolvidos da rede estadual mineira. $\mathrm{Na}$ análise o número " 1 " indica as escolas que foram contempladas com o programa e o número "0" as escolas não contempladas.

Português 2006.

DESEMPENHO MÉDIO EM PORTUGUÊS DAS ESCOLAS CONTEMPLADAS (1) E NÃO CONTEMPLADAS (0) COM O PROJETO "ESCOLAS REFERENCIA - ER" DA REDE ESTADUAL DE MINAS GERAIS - PROEB 2006

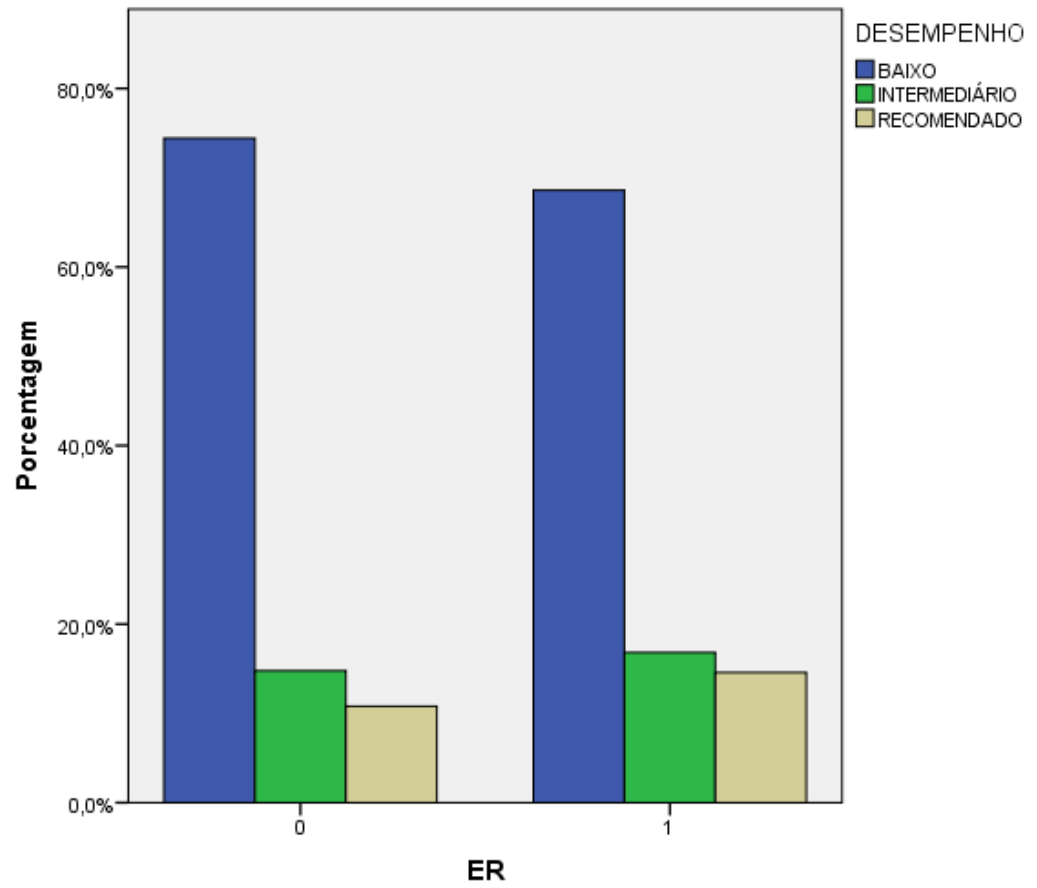

Fonte: Elaborado pelo autor. 
DESEMPENHO MÉDIO EM PORTUGUÊS DAS ESCOLAS CONTEMPLADAS (1) E NÃO CONTEMPLADAS (0) COM O PROJETO "ESCOLAS REFERÊNCIA - ER" DA REDE ESTADUAL DE MINAS GERAIS - PROEB 2006.

\begin{tabular}{|c|c|c|c|c|c|}
\hline & \multicolumn{4}{|c|}{ ER - Português - 2006} \\
\hline & & \multicolumn{2}{|l|}{0} & \multicolumn{2}{|c|}{1} \\
\hline & & total & $\%$ & total & $\%$ \\
\hline \multirow{4}{*}{ DESEMPENHO } & BAIXO & 75355 & $74,4 \%$ & 28862 & $268,6 \%$ \\
\hline & INTERMEDIÁRIO & 14955 & $14,8 \%$ & 7075 & $16,8 \%$ \\
\hline & RECOMENDADO & 10934 & $10,8 \%$ & 6136 & $14,6 \%$ \\
\hline & Total & 101244 & $100,0 \%$ & 42073 & $100,0 \%$ \\
\hline
\end{tabular}

Fonte: Elaborado pelo autor.

DESEMPENHO MÉDIO EM PORTUGUÊS DAS ESCOLAS CONTEMPLADAS (1) E NÃO CONTEMPLADAS (0) COM O "PROGRAMA DE DESENVOLVIMENTO PROFISSIONAL - PDP" DA REDE ESTADUAL DE MINAS GERAIS - PROEB 2006.

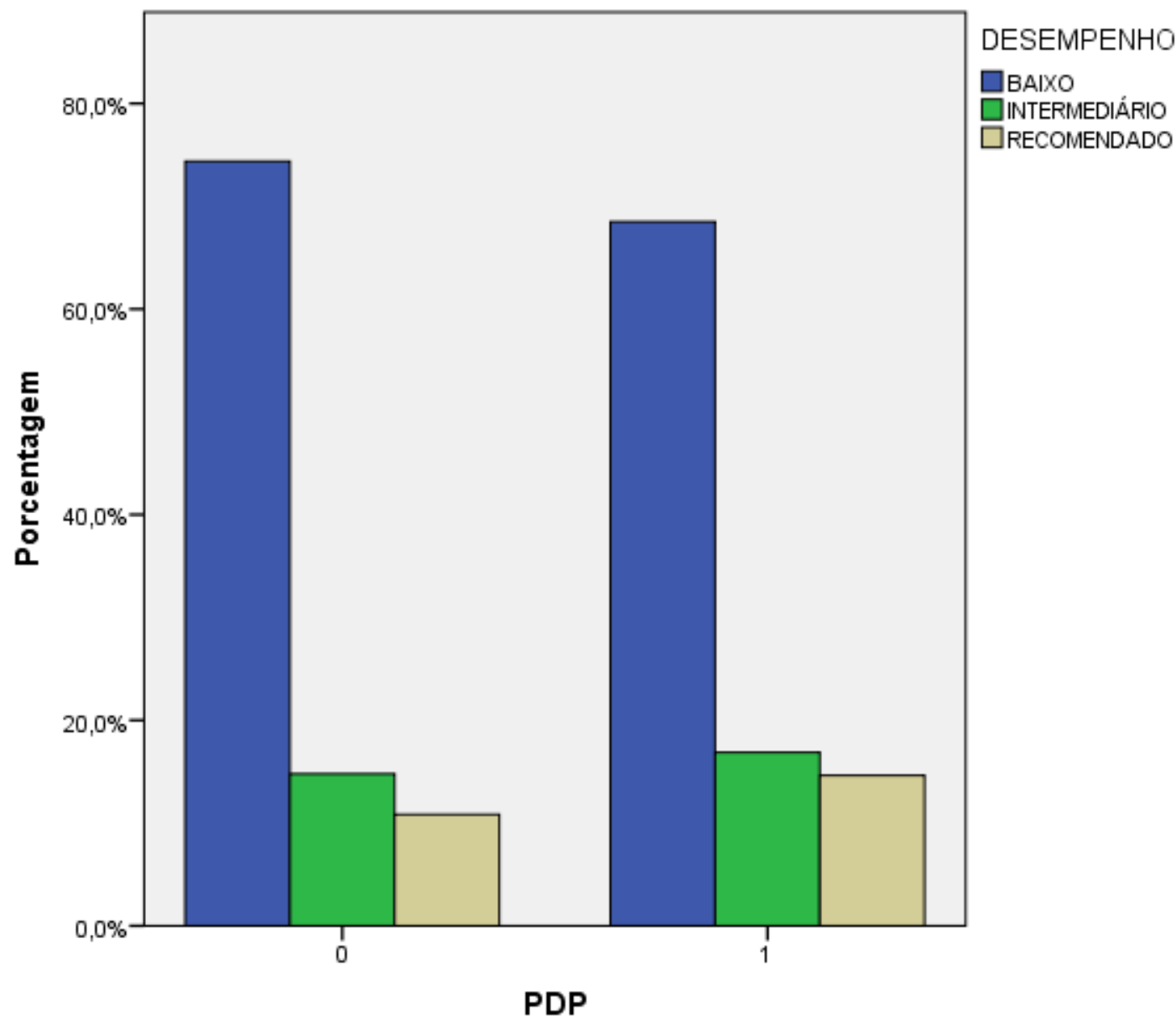

Fonte: Elaborado pelo autor. 
DESEMPENHO MÉDIO EM PORTUGUÊS DAS ESCOLAS CONTEMPLADAS (1) E NÃO CONTEMPLADAS (0) COM O "PROGRAMA DE ATENÇÃO AO JOVEM PEAS” DA REDE ESTADUAL DE MINAS GERAIS - PROEB 2006.

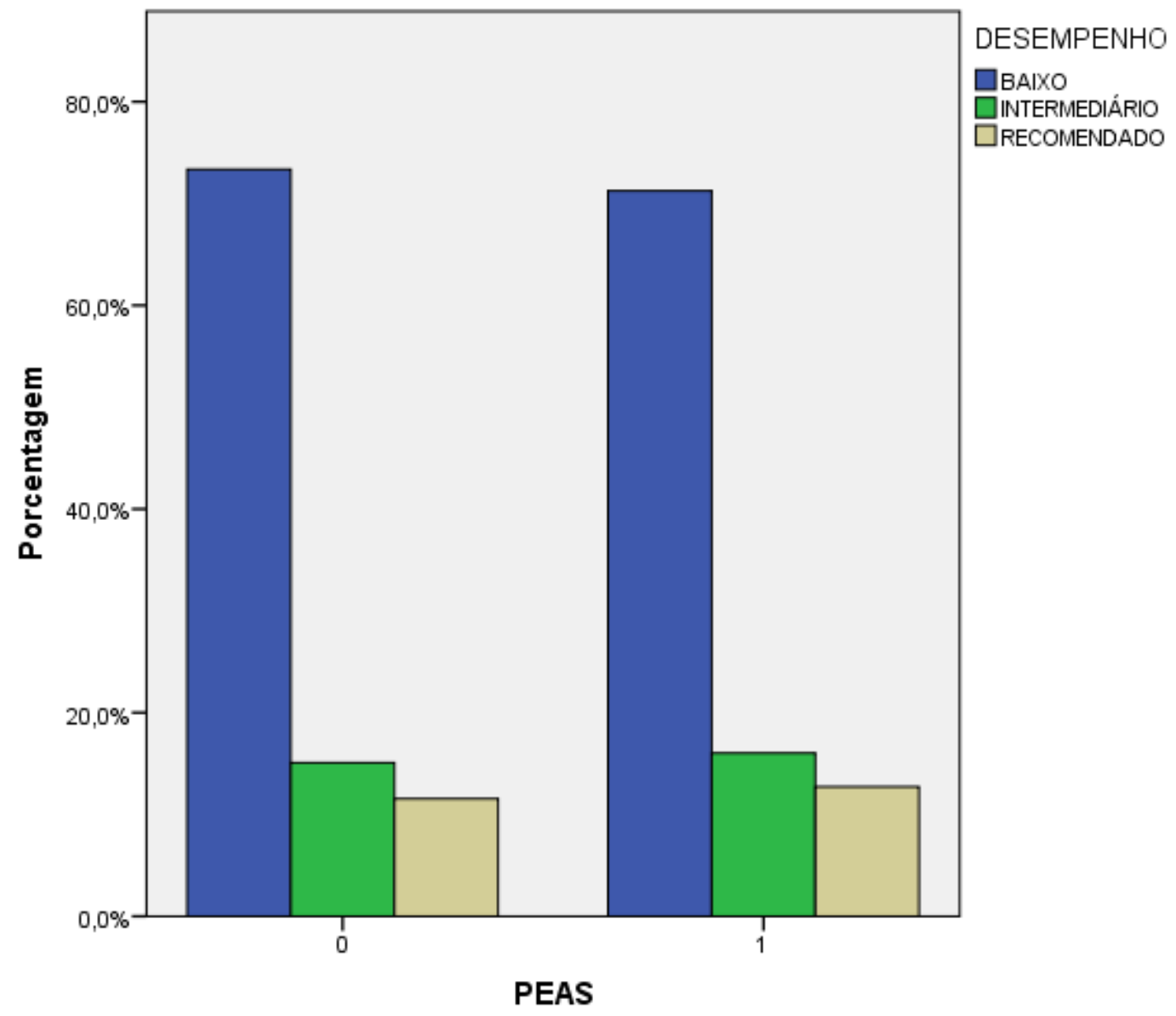

Fonte: Elaborado pelo autor.

DESEMPENHO MÉDIO EM PORTUGUÊS DAS ESCOLAS CONTEMPLADAS (1) E NÃO CONTEMPLADAS (0) COM O "PROGRAMA DE ATENÇÃO AO JOVEM PEAS” DA REDE ESTADUAL DE MINAS GERAIS - PROEB 2006.

\begin{tabular}{c|l|l|l|l}
\hline & \multicolumn{3}{|l|}{ PEAS - Português - 2006} \\
\cline { 2 - 5 } & 0 & \multicolumn{3}{l}{1} \\
\cline { 2 - 5 } & total & $\%$ & total & $\%$ \\
\hline BAIXO & 72893 & $73,4 \%$ & 31324 & $71,3 \%$ \\
DESEMPENHO INTERMEDIÁRIO & 14980 & $15,1 \%$ & 7050 & $16,0 \%$ \\
RECOMENDADO & 11483 & $11,6 \%$ & 5587 & $12,7 \%$ \\
Total & 99356 & $100,0 \%$ & 43961 & $100,0 \%$ \\
\hline
\end{tabular}

Fonte: Elaborado pelo autor. 
DESEMPENHO MÉDIO EM PORTUGUÊS DAS ESCOLAS CONTEMPLADAS (1) E NÃO CONTEMPLADAS (0) COM O PROJETO "ESCOLAS REFERÊNCIA - ER" DA REDE ESTADUAL DE MINAS GERAIS - PROEB 2007.

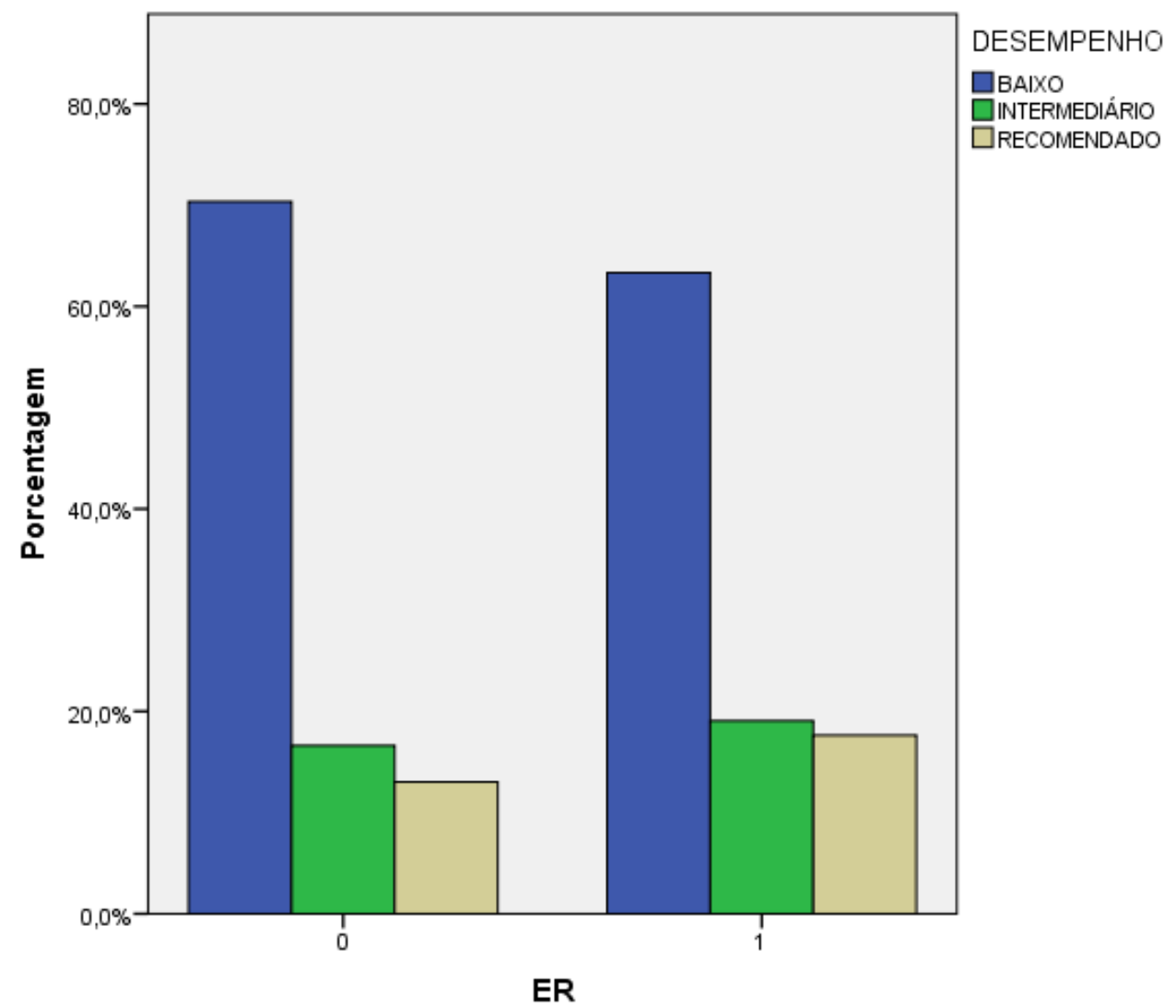

Fonte: Elaborado pelo autor.

DESEMPENHO MÉDIO EM PORTUGUÊS DAS ESCOLAS CONTEMPLADAS (1) E NÃO CONTEMPLADAS (0) COM O PROJETO "ESCOLAS REFERÊNCIA - ER" DA REDE ESTADUAL DE MINAS GERAIS - PROEB 2007.

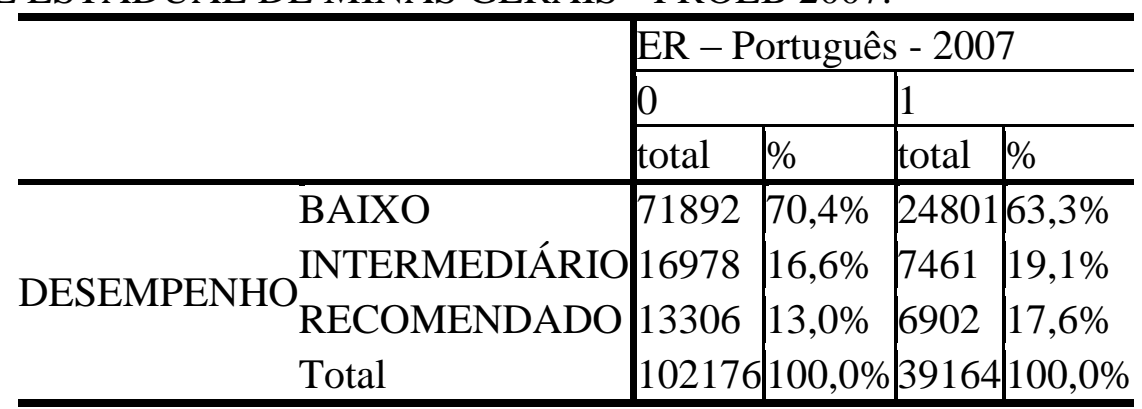

Fonte: Elaborado pelo autor. 
DESEMPENHO MÉDIO EM PORTUGUÊS DAS ESCOLAS CONTEMPLADAS (1) E NÃO CONTEMPLADAS (0) COM O "PROGRAMA DE DESENVOLVIMENTO PROFISSIONAL - PDP" DA REDE ESTADUAL DE MINAS GERAIS - PROEB 2007.

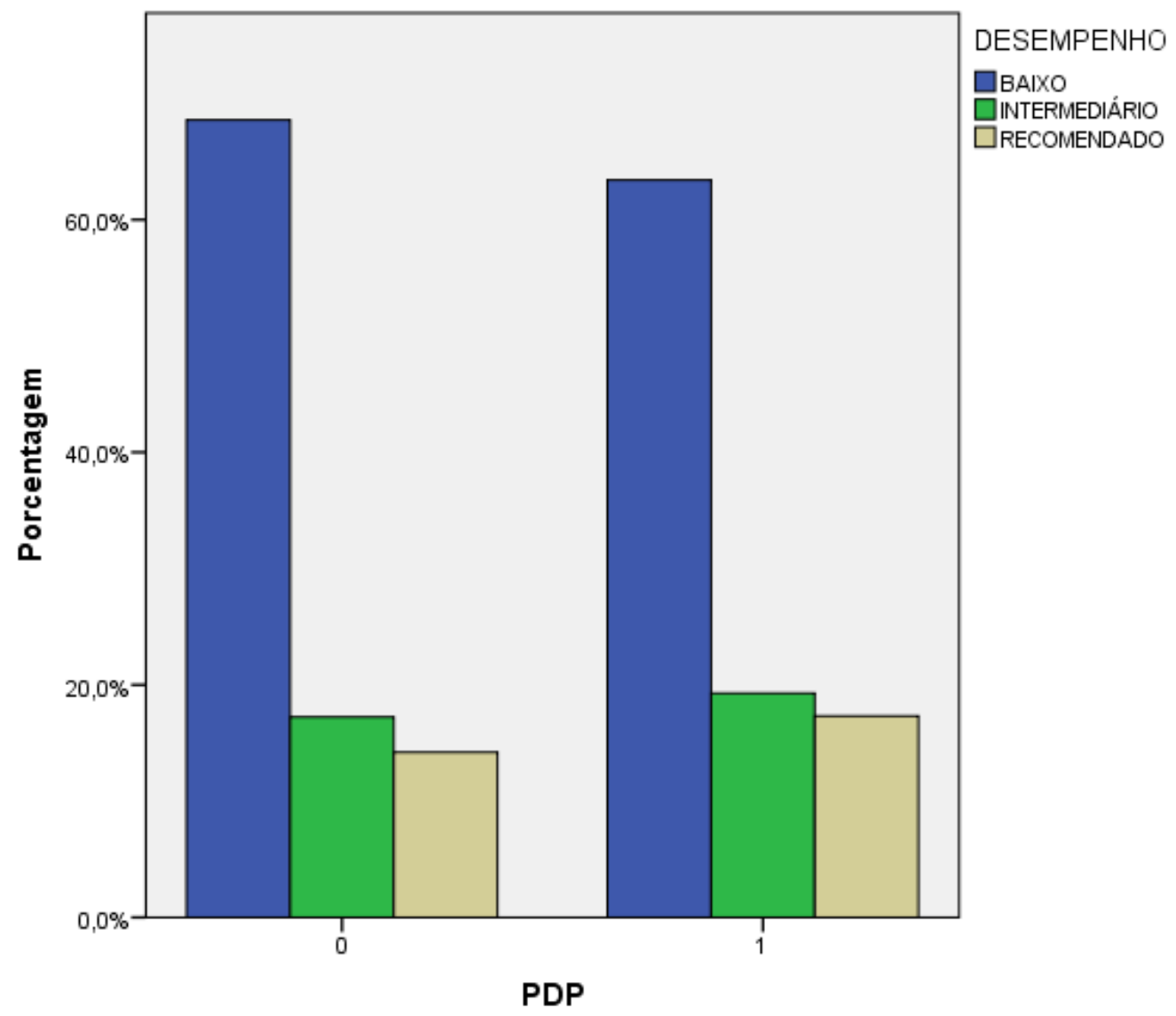

Fonte: Elaborado pelo autor.

DESEMPENHO MÉDIO EM PORTUGUÊS DAS ESCOLAS CONTEMPLADAS (1) E NÃO CONTEMPLADAS (0) COM O "PROGRAMA DE DESENVOLVIMENTO PROFISSIONAL - PDP" DA REDE ESTADUAL DE MINAS GERAIS - PROEB 2007.

\begin{tabular}{c|l|l|l|l}
\hline & \multicolumn{4}{|l}{ PDP - Português - 2007 } \\
\cline { 2 - 5 } & 0 & \multicolumn{3}{l}{1} \\
\cline { 2 - 5 } & total & $\%$ & total & $\%$ \\
\hline BAIXO & 93683 & $68,6 \%$ & 3010 & $63,4 \%$ \\
DESEMPENHO INTERMEDIÁRIO & 23524 & $17,2 \%$ & 915 & $19,3 \%$ \\
RECOMENDADO & 19386 & $14,2 \%$ & 822 & $17,3 \%$ \\
Total & 136593 & $100,0 \%$ & 4747 & $100,0 \%$ \\
\hline
\end{tabular}

Fonte: Elaborado pelo autor. 
DESEMPENHO MÉDIO EM PORTUGUÊS DAS ESCOLAS CONTEMPLADAS (1) E NÃO CONTEMPLADAS (0) COM O "PROGRAMA DE ATENÇÃO AO JOVEM PEAS” DA REDE ESTADUAL DE MINAS GERAIS - PROEB 2007.

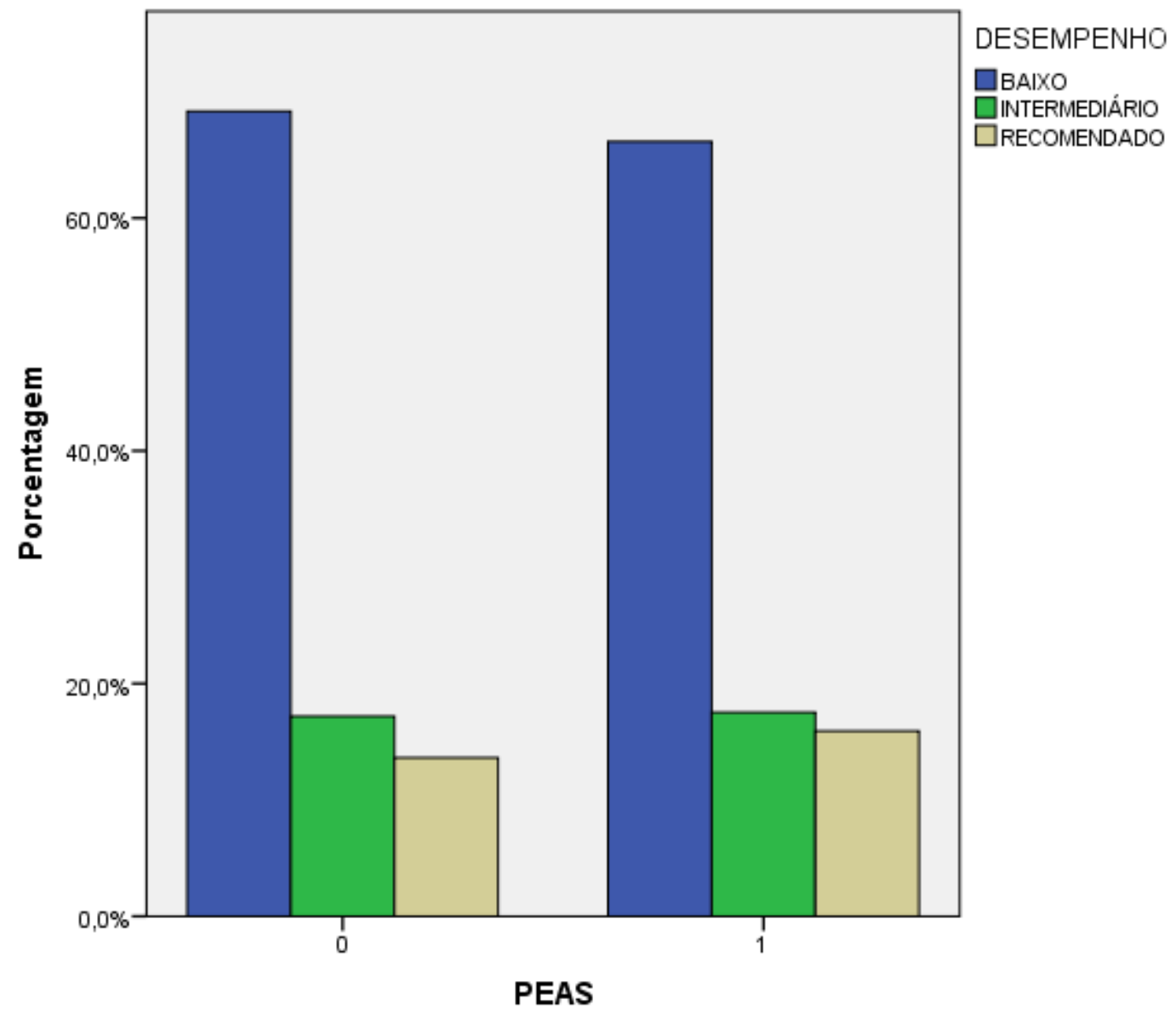

Fonte: Elaborado pelo autor.

DESEMPENHO MÉDIO EM PORTUGUÊS DAS ESCOLAS CONTEMPLADAS (1) E NÃO CONTEMPLADAS (0) COM O "PROGRAMA DE ATENÇÃO AO JOVEM PEAS" DA REDE ESTADUAL DE MINAS GERAIS - PROEB 2007.

\begin{tabular}{c|l|l|l|l}
\hline & \multicolumn{3}{|l}{ PEAS - Português - 2007 } \\
\cline { 2 - 5 } & 0 & \multicolumn{3}{l}{1} \\
\cline { 2 - 5 } & total & $\%$ & total & $\%$ \\
\hline BAIXO & 68902 & $69,2 \%$ & 27791 & $66,6 \%$ \\
DESEMPENHO INTERMEDIÁRIO & 17125 & $17,2 \%$ & 7314 & $17,5 \%$ \\
RECOMENDADO & 13565 & $13,6 \%$ & 6643 & $15,9 \%$ \\
Total & 99592 & $100,0 \%$ & 41748 & $100,0 \%$ \\
\hline
\end{tabular}

Fonte: Elaborado pelo autor. 
DESEMPENHO MÉDIO EM PORTUGUÊS DAS ESCOLAS CONTEMPLADAS (1) E NÃO CONTEMPLADAS (0) COM O "PROGRAMA DE EDUCAÇÃO PROFISSIONAL - PEP” DA REDE ESTADUAL DE MINAS GERAIS - PROEB 2007.

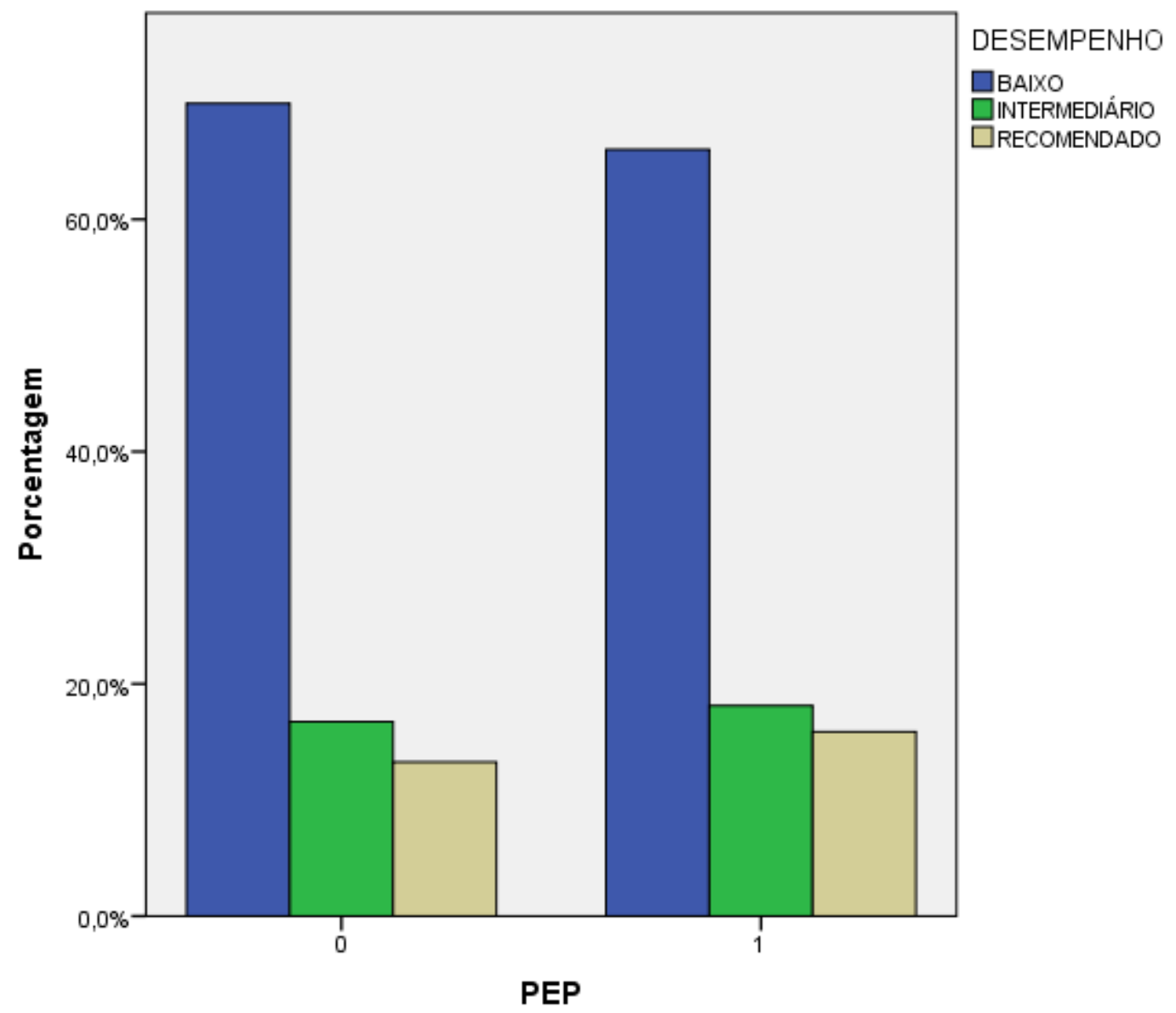

Fonte: Elaborado pelo autor.

DESEMPENHO MÉDIO EM PORTUGUÊS DAS ESCOLAS CONTEMPLADAS (1) E NÃO CONTEMPLADAS (0) COM O "PROGRAMA DE EDUCAÇÃO PROFISSIONAL - PEP” DA REDE ESTADUAL DE MINAS GERAIS - PROEB 2007.

\begin{tabular}{c|l|l|l|l|l}
\hline & \multicolumn{3}{|l|}{ PEP - Português - 2007 } \\
\cline { 2 - 5 } & 0 & \multicolumn{2}{l}{1} \\
\cline { 2 - 5 } & total & $\%$ & total & $\%$ \\
\hline BAIXO & 59716 & $70,0 \%$ & 36977 & $66,0 \%$ \\
INTERMEDIÁRIO & 14291 & $16,7 \%$ & 10148 & $18,1 \%$ \\
IESEMPENHO & RECOMENDADO & 11314 & $13,3 \%$ & 8894 & $15,9 \%$ \\
Total & 85321 & $100,0 \%$ & 56019 & $100,0 \%$ \\
\hline
\end{tabular}

Fonte: Elaborado pelo autor. 
DESEMPENHO MÉDIO EM PORTUGUÊS DAS ESCOLAS CONTEMPLADAS (1) E NÃO CONTEMPLADAS (0) COM O "PROGRAMA POUPANÇA JOVEM - PJ" DA REDE ESTADUAL DE MINAS GERAIS - PROEB 2007.

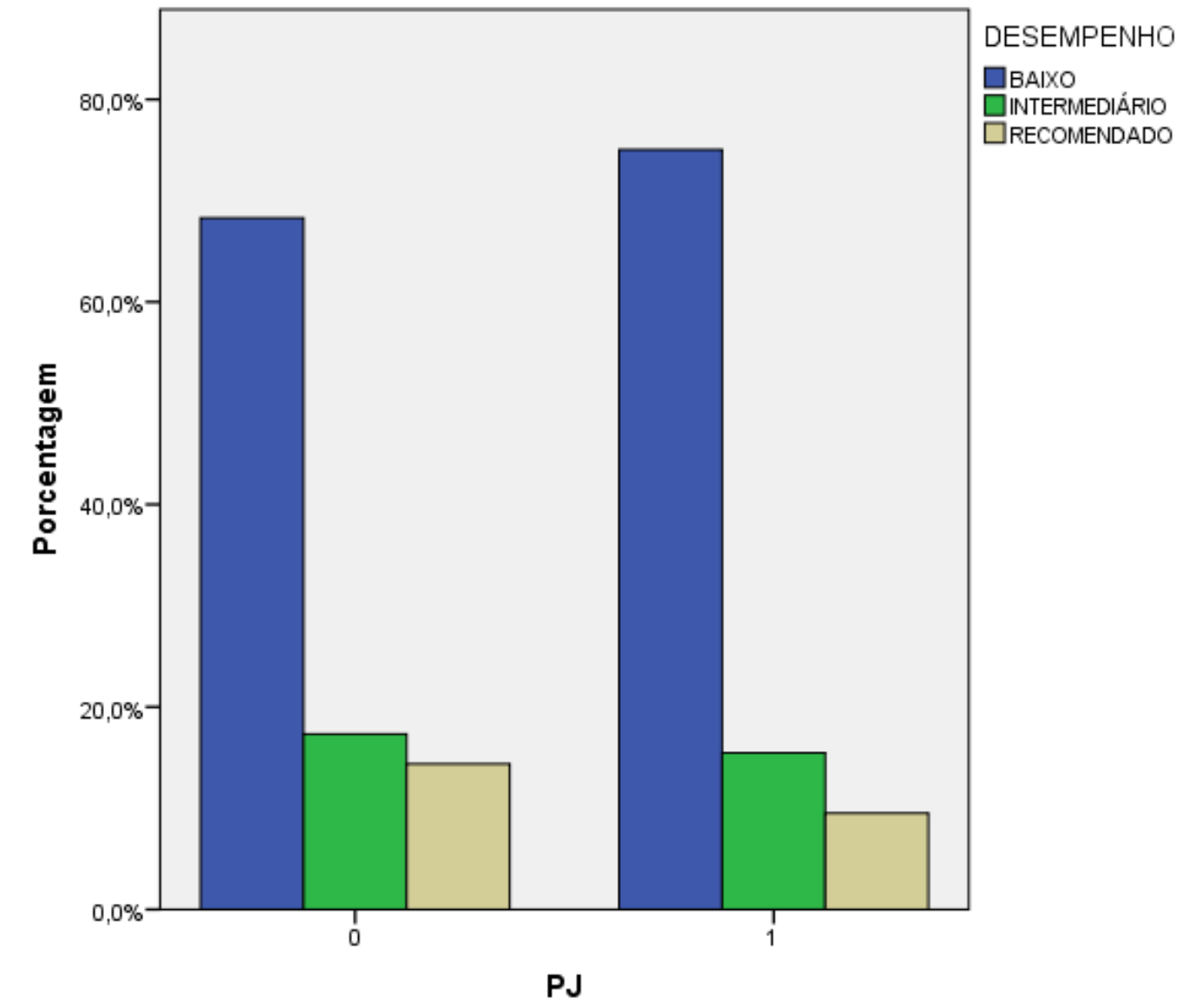

Fonte: Elaborado pelo autor.

DESEMPENHO MÉDIO EM PORTUGUÊS DAS ESCOLAS CONTEMPLADAS (1) E NÃO CONTEMPLADAS (0) COM O "PROGRAMA POUPANÇA JOVEM - PJ" DA REDE ESTADUAL DE MINAS GERAIS - PROEB 2007.

\begin{tabular}{c|l|l|l|l|l}
\hline \multirow{2}{*}{} & \multicolumn{4}{|l|}{ PJ - Português - 2007} \\
\cline { 2 - 6 } & 0 & \multicolumn{3}{l}{1} \\
\cline { 2 - 6 } & total & $\%$ & total & $\%$ \\
\hline BAIXO & 94994 & $68,3 \%$ & 1699 & $75,0 \%$ \\
INESEMPENHO & RECOMEDIÁRIO & 24089 & $17,3 \%$ & 350 & $15,5 \%$ \\
& RECOMENDADO & 19993 & $14,4 \%$ & 215 & $9,5 \%$ \\
Total & 139076 & $100,0 \%$ & 2264 & $100,0 \%$ \\
\hline
\end{tabular}

Fonte: Elaborado pelo autor. 
Português 2008

DESEMPENHO MÉDIO EM PORTUGUÊS DAS ESCOLAS CONTEMPLADAS (1) E NÃO CONTEMPLADAS (0) COM O PROJETO "ESCOLAS REFERÊNCIA - ER" DA REDE ESTADUAL DE MINAS GERAIS - PROEB 2008.

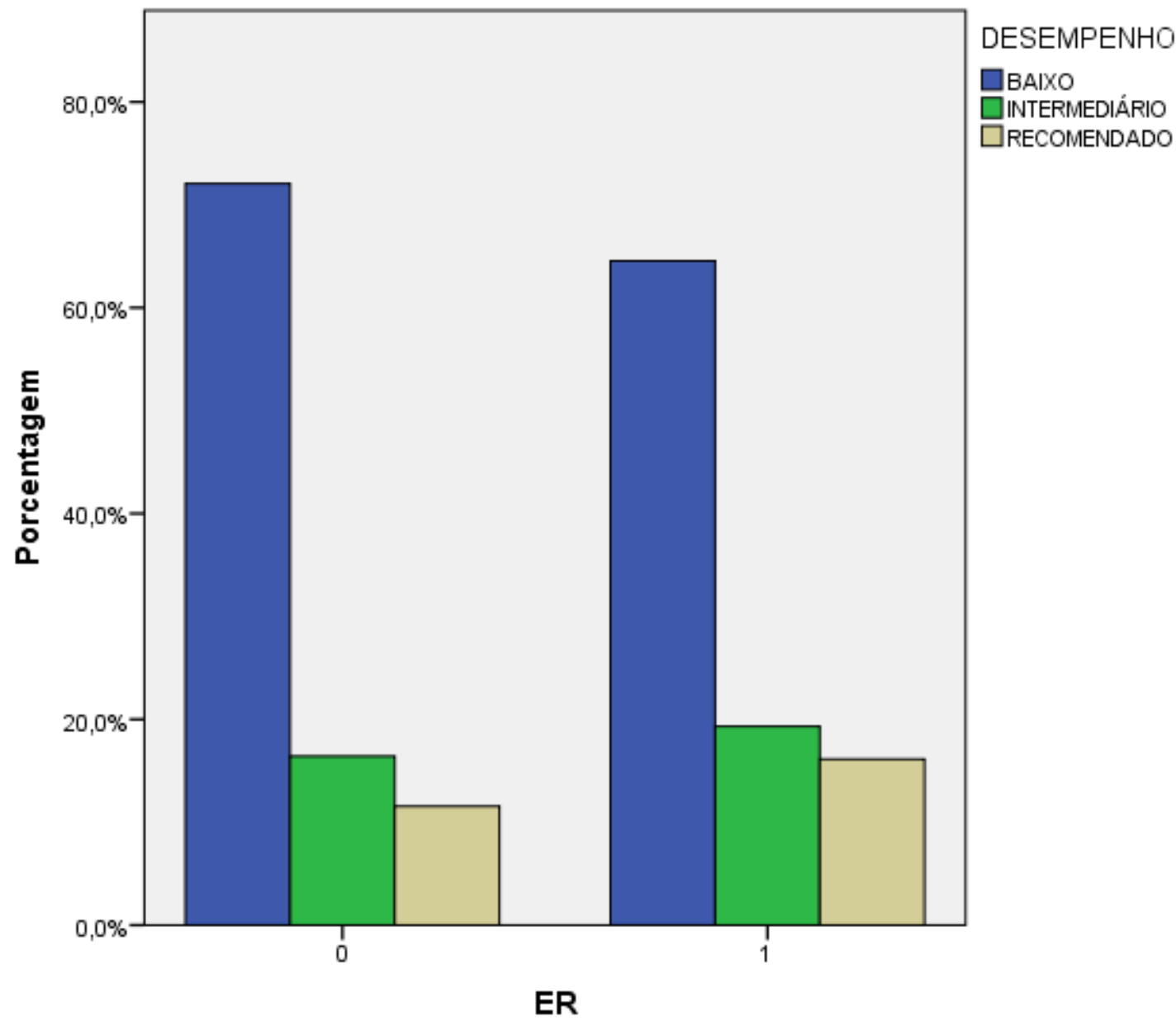

Fonte: Elaborado pelo autor.

DESEMPENHO MÉDIO EM PORTUGUÊS DAS ESCOLAS CONTEMPLADAS (1) E NÃO CONTEMPLADAS (0) COM O PROJETO "ESCOLAS REFERÊNCIA - ER" DA REDE ESTADUAL DE MINAS GERAIS - PROEB 2008.

\begin{tabular}{c|l|l|l|l}
\hline \multirow{2}{*}{} & \multicolumn{4}{|l|}{ ER - Português - 2008 } \\
\cline { 2 - 6 } & 0 & \multicolumn{3}{l}{1} \\
\cline { 2 - 6 } & total & $\%$ & total & $\%$ \\
\hline BAIXO & 72786 & $72,1 \%$ & 31317 & $64,6 \%$ \\
DESEMPENHO INTERMEDIÁRIO & 16561 & $16,4 \%$ & 9369 & $19,3 \%$ \\
RECOMENDADO & 11661 & $11,5 \%$ & 7829 & $16,1 \%$ \\
Total & 101008 & $100,0 \%$ & 48515 & $100,0 \%$ \\
\hline
\end{tabular}

Fonte: Elaborado pelo autor. 
DESEMPENHO MÉDIO EM PORTUGUÊS DAS ESCOLAS CONTEMPLADAS (1) E NÃO CONTEMPLADAS (0) COM O "PROGRAMA DE DESENVOLVIMENTO PROFISSIONAL - PDP" DA REDE ESTADUAL DE MINAS GERAIS - PROEB 2008.

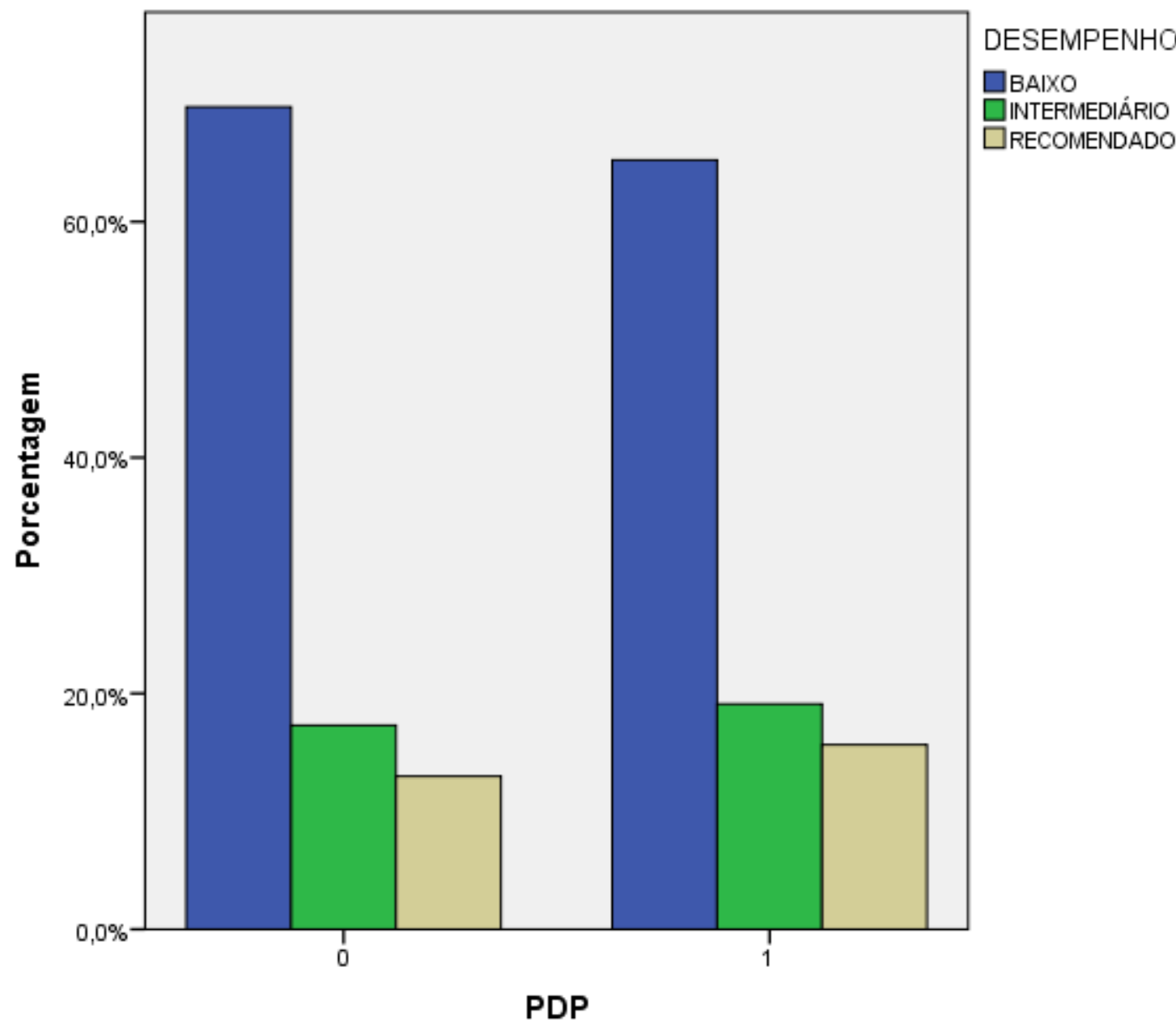

Fonte: Elaborado pelo autor.

DESEMPENHO MÉDIO EM PORTUGUÊS DAS ESCOLAS CONTEMPLADAS (1) E NÃO CONTEMPLADAS (0) COM O "PROGRAMA DE DESENVOLVIMENTO PROFISSIONAL - PDP" DA REDE ESTADUAL DE MINAS GERAIS - PROEB 2008.

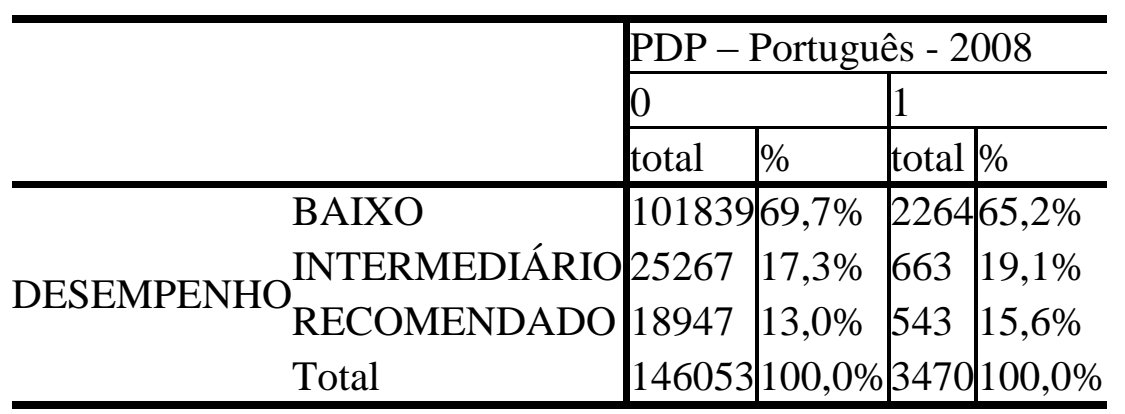

Fonte: Elaborado pelo autor. 
DESEMPENHO MÉDIO EM PORTUGUÊS DAS ESCOLAS CONTEMPLADAS (1) E NÃO CONTEMPLADAS (0) COM O "PROGRAMA DE ATENÇÃO AO JOVEM PEAS” DA REDE ESTADUAL DE MINAS GERAIS - PROEB 2008.

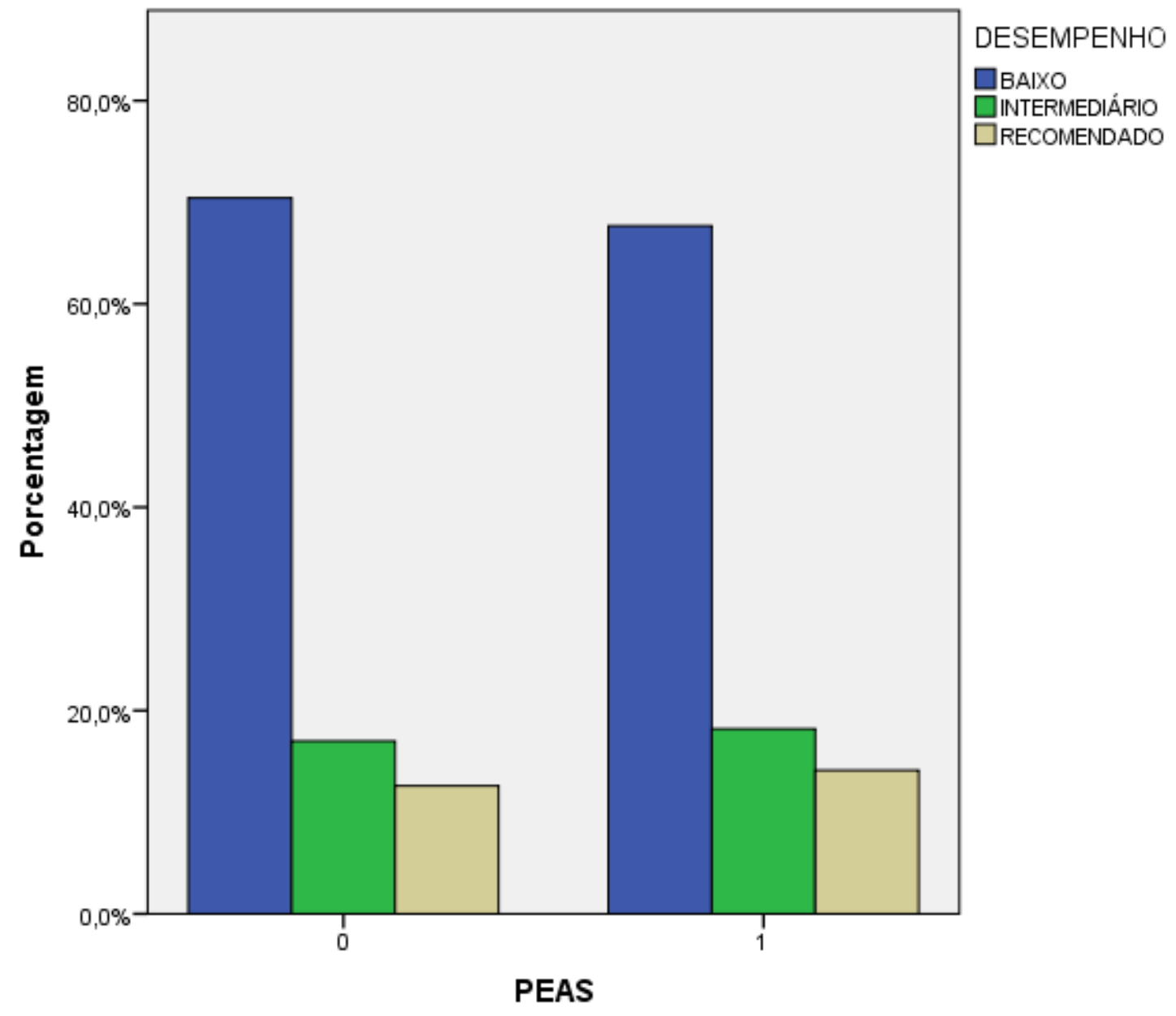

Fonte: Elaborado pelo autor.

DESEMPENHO MÉDIO EM PORTUGUÊS DAS ESCOLAS CONTEMPLADAS (1) E NÃO CONTEMPLADAS (0) COM O "PROGRAMA DE ATENÇÃO AO JOVEM PEAS” DA REDE ESTADUAL DE MINAS GERAIS - PROEB 2008.

\begin{tabular}{c|l|l|l|l}
\hline & \multicolumn{3}{|l}{ PEAS - Português - 2008 } \\
\cline { 2 - 5 } & 0 & \multicolumn{3}{l}{1} \\
\cline { 2 - 6 } & total & $\%$ & total & $\%$ \\
\hline BAIXO & 74408 & $70,4 \%$ & 29695 & $67,7 \%$ \\
DESEMPENHO INTERMEDIÁRIO & 17944 & $17,0 \%$ & 7986 & $18,2 \%$ \\
RECOMENDADO & 13299 & $12,6 \%$ & 6191 & $14,1 \%$ \\
Total & 105651 & $100,0 \%$ & 43872 & $100,0 \%$ \\
\hline
\end{tabular}

Fonte: Elaborado pelo autor. 
DESEMPENHO MÉDIO EM PORTUGUÊS DAS ESCOLAS CONTEMPLADAS (1) E NÃO CONTEMPLADAS (0) COM O PROGRAMA "FORMAÇÃO INICIAL PARA O TRABALHO - FIT" DA REDE ESTADUAL DE MINAS GERAIS - PROEB 2008.

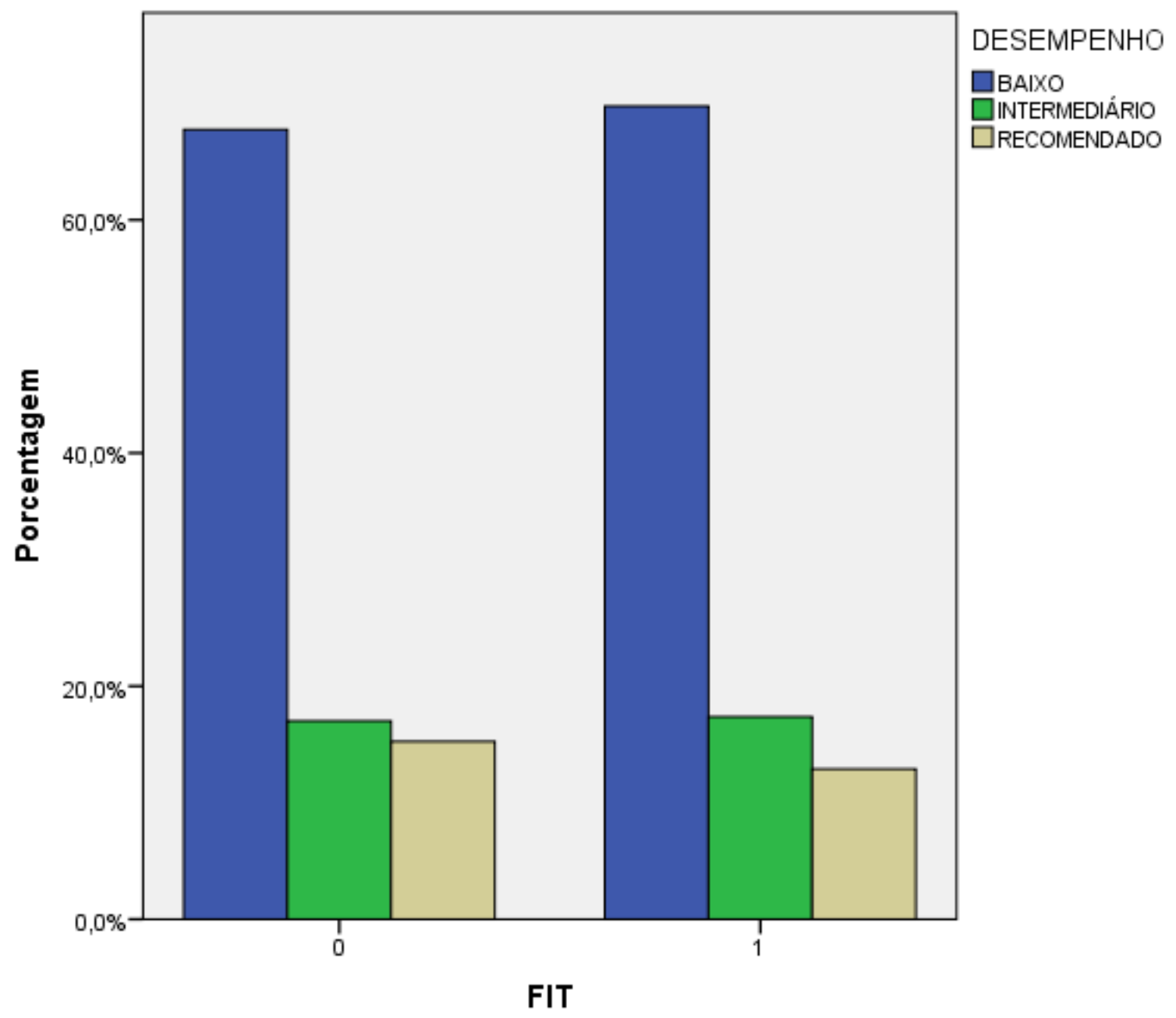

Fonte: Elaborado pelo autor.

DESEMPENHO MÉDIO EM PORTUGUÊS DAS ESCOLAS CONTEMPLADAS (1) E NÃO CONTEMPLADAS (0) COM O PROGRAMA "FORMAÇÃO INICIAL PARA O TRABALHO - FIT" DA REDE ESTADUAL DE MINAS GERAIS - PROEB 2008.

\begin{tabular}{c|l|l|l|l}
\hline & \multicolumn{3}{|l|}{ FIT - Português - 2008 } \\
\cline { 2 - 5 } & 0 & \multicolumn{3}{l}{1} \\
\cline { 2 - 5 } & total & $\%$ & total & $\%$ \\
\hline BAIXO & 6600 & $67,7 \%$ & 97503 & $69,8 \%$ \\
INESEMPENHO INTERMEDIÁRIO & 1657 & $17,0 \%$ & 24273 & $17,4 \%$ \\
RECOMENDADO & 1485 & $15,2 \%$ & 18005 & $12,9 \%$ \\
Total & 9742 & $100,0 \%$ & 139781 & $100,0 \%$ \\
\hline
\end{tabular}

Fonte: Elaborado pelo autor. 
DESEMPENHO MÉDIO EM PORTUGUÊS DAS ESCOLAS CONTEMPLADAS (1) E NÃO CONTEMPLADAS (0) COM O "PROGRAMA DE EDUCAÇÃO PROFISSIONAL - PEP” DA REDE ESTADUAL DE MINAS GERAIS - PROEB 2008.

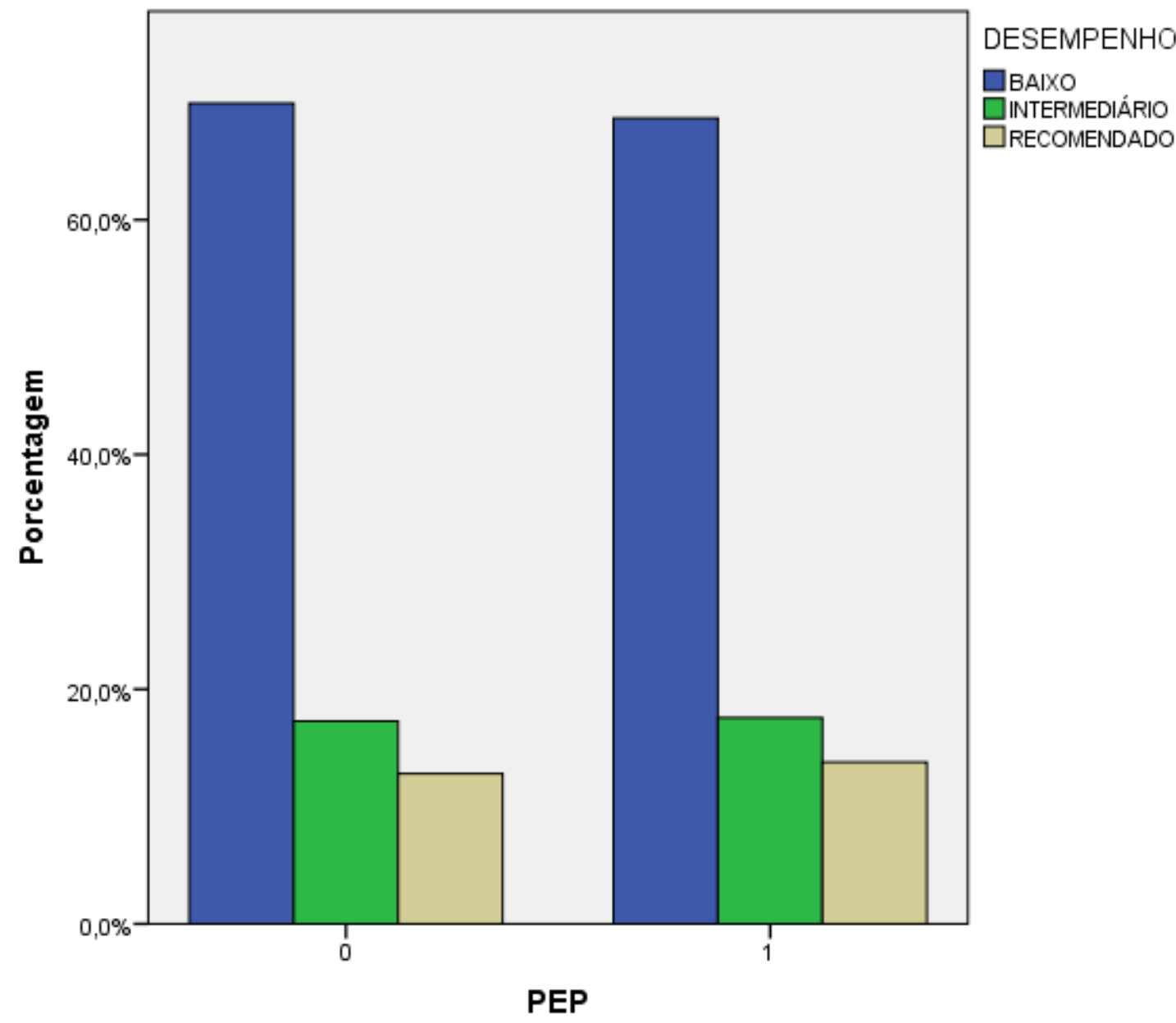

Fonte: Elaborado pelo autor.

DESEMPENHO MÉDIO EM PORTUGUÊS DAS ESCOLAS CONTEMPLADAS (1) E NÃO CONTEMPLADAS (0) COM O "PROGRAMA DE EDUCAÇÃO PROFISSIONAL - PEP” DA REDE ESTADUAL DE MINAS GERAIS - PROEB 2008.

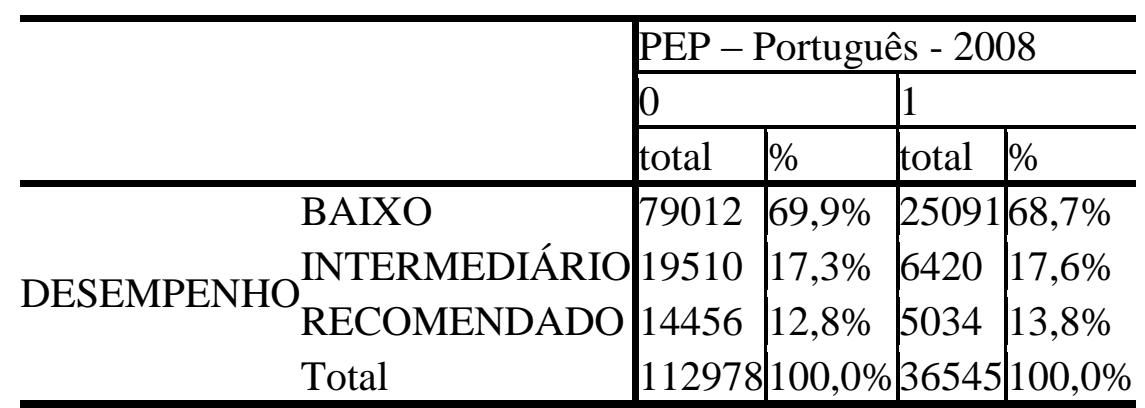

Fonte: Elaborado pelo autor. 
DESEMPENHO MÉDIO EM PORTUGUÊS DAS ESCOLAS CONTEMPLADAS (1) E NÃO CONTEMPLADAS (0) COM O "PROGRAMA POUPANÇA JOVEM - PJ" DA REDE ESTADUAL DE MINAS GERAIS - PROEB 2008.

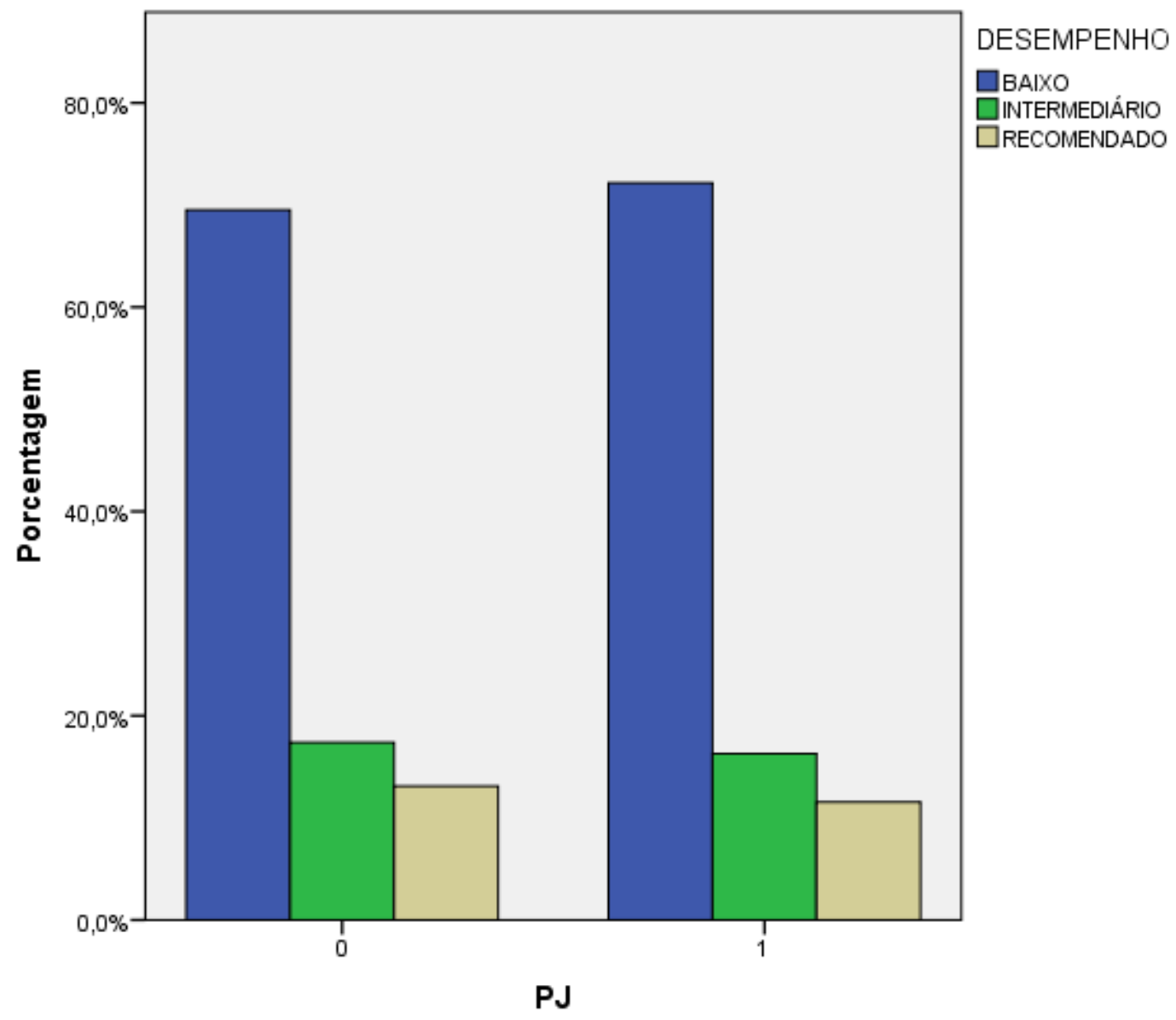

Fonte: Elaborado pelo autor.

DESEMPENHO MÉDIO EM PORTUGUÊS DAS ESCOLAS CONTEMPLADAS (1) E NÃO CONTEMPLADAS (0) COM O "PROGRAMA POUPANÇA JOVEM - PJ" DA REDE ESTADUAL DE MINAS GERAIS - PROEB 2008.

\begin{tabular}{|c|c|c|c|}
\hline & \multicolumn{3}{|c|}{ PJ - Português - 2008} \\
\hline & \multicolumn{2}{|l|}{0} & \multirow{2}{*}{$\left|\frac{1}{|l|}\right|$} \\
\hline & total & $\%$ & \\
\hline BAIXO & 99863 & $69,5 \%$ & $424072,2 \%$ \\
\hline IPENHO INTERMEDIÁRIC & 24973 & $17,4 \%$ & $957 \quad 16,3 \%$ \\
\hline RECOMENDADO & 18812 & $13,1 \%$ & $678 \quad 11,5 \%$ \\
\hline Total & 143648 & $100,0 \%$ & $5875100,0 \%$ \\
\hline
\end{tabular}

Fonte: Elaborado pelo autor. 
Português 2009

DESEMPENHO MÉDIO EM PORTUGUÊS DAS ESCOLAS CONTEMPLADAS (1) E NÃO CONTEMPLADAS (0) COM O PROJETO "ESCOLAS REFERÊNCIA - ER" DA REDE ESTADUAL DE MINAS GERAIS - PROEB 2009.

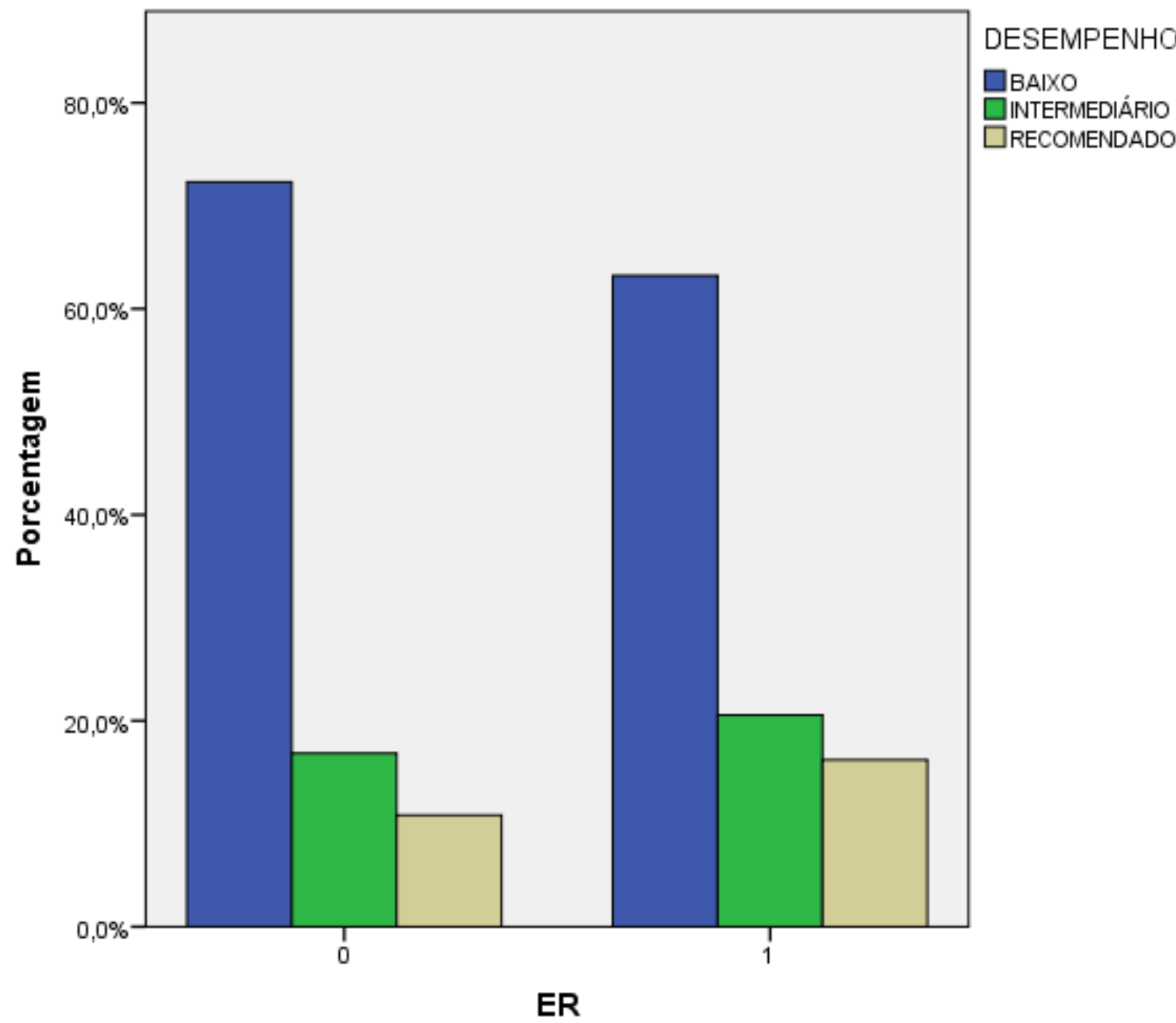

Fonte: Elaborado pelo autor.

DESEMPENHO MÉDIO EM PORTUGUÊS DAS ESCOLAS CONTEMPLADAS (1) E NÃO CONTEMPLADAS (0) COM O PROJETO "ESCOLAS REFERENNCIA - ER" DA REDE ESTADUAL DE MINAS GERAIS - PROEB 2009.

\begin{tabular}{|c|c|c|c|c|}
\hline & \multicolumn{4}{|c|}{ ER - Português - 2009} \\
\hline & \multicolumn{2}{|l|}{0} & \multicolumn{2}{|l|}{1} \\
\hline & total & $\%$ & total & $\%$ \\
\hline BAIXO & 77228 & $72,3 \%$ & 31150 & $63,2 \%$ \\
\hline INTERMEDIÁRIO & 17988 & $16,8 \%$ & 10135 & $20,6 \%$ \\
\hline RECOMENDADO & 11571 & $10,8 \%$ & 7984 & $16,2 \%$ \\
\hline Total & 106787 & $100,0 \%$ & 49269 & $100,0 \%$ \\
\hline
\end{tabular}

Fonte: Elaborado pelo autor. 
DESEMPENHO MÉDIO EM PORTUGUÊS DAS ESCOLAS CONTEMPLADAS (1) E NÃO CONTEMPLADAS (0) COM O "PROGRAMA DE DESENVOLVIMENTO PROFISSIONAL - PDP" DA REDE ESTADUAL DE MINAS GERAIS - PROEB 2009.

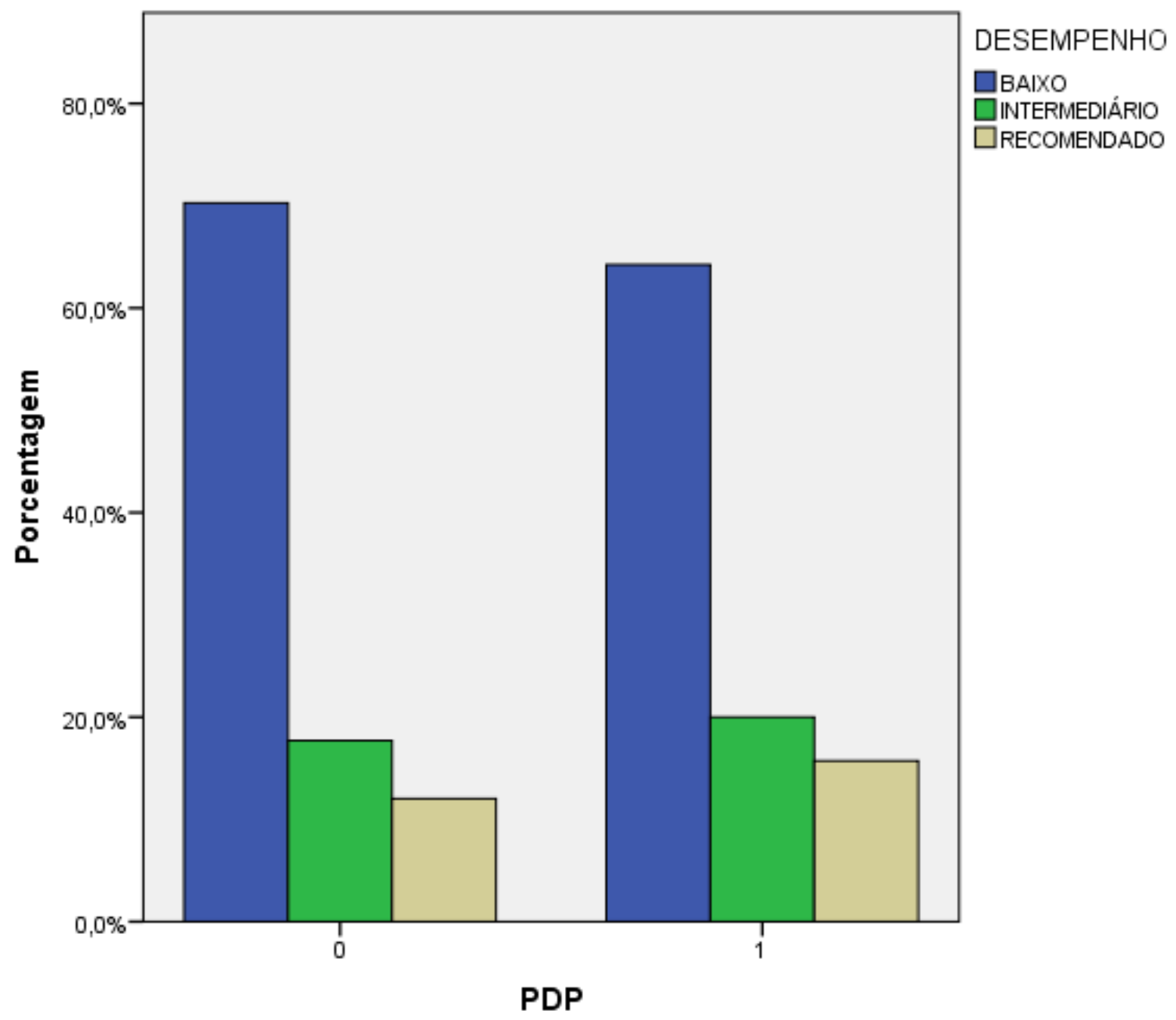

Fonte: Elaborado pelo autor.

DESEMPENHO MÉDIO EM PORTUGUÊS DAS ESCOLAS CONTEMPLADAS (1) E NÃO CONTEMPLADAS (0) COM O "PROGRAMA DE DESENVOLVIMENTO PROFISSIONAL - PDP" DA REDE ESTADUAL DE MINAS GERAIS - PROEB 2009.

\begin{tabular}{c|l|l|l|l}
\hline & \multicolumn{4}{|l}{ PDP - Português - 2009 } \\
\cline { 2 - 6 } & 0 & \multicolumn{3}{l}{1} \\
\cline { 2 - 6 } & total & $\%$ & total & $\%$ \\
\hline BAIXO & 94676 & $70,3 \%$ & 13702 & $64,3 \%$ \\
DESEMPENHO INTERMEDIÁRIO & 23856 & $17,7 \%$ & 4267 & $20,0 \%$ \\
RECOMENDADO & 16200 & $12,0 \%$ & 3355 & $15,7 \%$ \\
Total & 134732 & $100,0 \%$ & 21324 & $100,0 \%$ \\
\hline
\end{tabular}

Fonte: Elaborado pelo autor. 
DESEMPENHO MÉDIO EM PORTUGUÊS DAS ESCOLAS CONTEMPLADAS (1) E NÃO CONTEMPLADAS (0) COM O "PROGRAMA DE ATENÇÃO AO JOVEM PEAS” DA REDE ESTADUAL DE MINAS GERAIS - PROEB 2009.

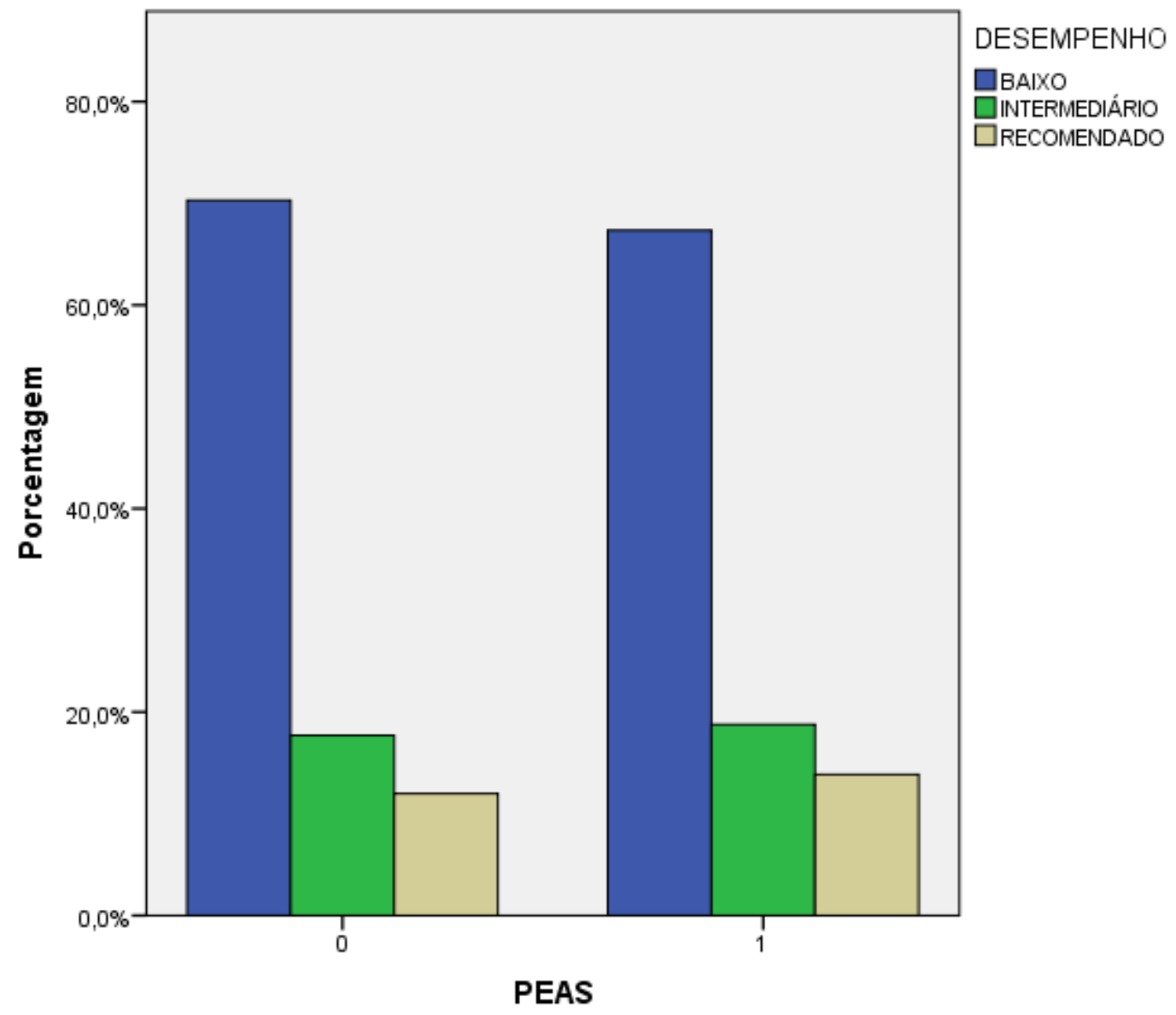

Fonte: Elaborado pelo autor.

DESEMPENHO MÉDIO EM PORTUGUÊS DAS ESCOLAS CONTEMPLADAS (1) E NÃO CONTEMPLADAS (0) COM O "PROGRAMA DE ATENÇÃO AO JOVEM PEAS” DA REDE ESTADUAL DE MINAS GERAIS - PROEB 2009.

\begin{tabular}{c|l|l|l|l}
\hline & \multicolumn{3}{|l|}{ PEAS - Português - 2009 } \\
\cline { 2 - 5 } & 0 & \multicolumn{3}{l}{} \\
\cline { 2 - 5 } & total & $\%$ & total & $\%$ \\
\hline BAIXO & 77626 & $70,3 \%$ & 30752 & $67,4 \%$ \\
DESEMPENHO INTERMEDIÁRIO & 19548 & $17,7 \%$ & 8575 & $18,8 \%$ \\
RECOMENDADO & 13228 & $12,0 \%$ & 6327 & $13,9 \%$ \\
Total & 110402 & $100,0 \%$ & 45654 & $100,0 \%$ \\
\hline
\end{tabular}

Fonte: Elaborado pelo autor. 
DESEMPENHO MÉDIO EM PORTUGUÊS DAS ESCOLAS CONTEMPLADAS (1) E NÃO CONTEMPLADAS (0) COM O PROGRAMA "FORMAÇÃO INICIAL PARA O TRABALHO - FIT" DA REDE ESTADUAL DE MINAS GERAIS - PROEB 2009.

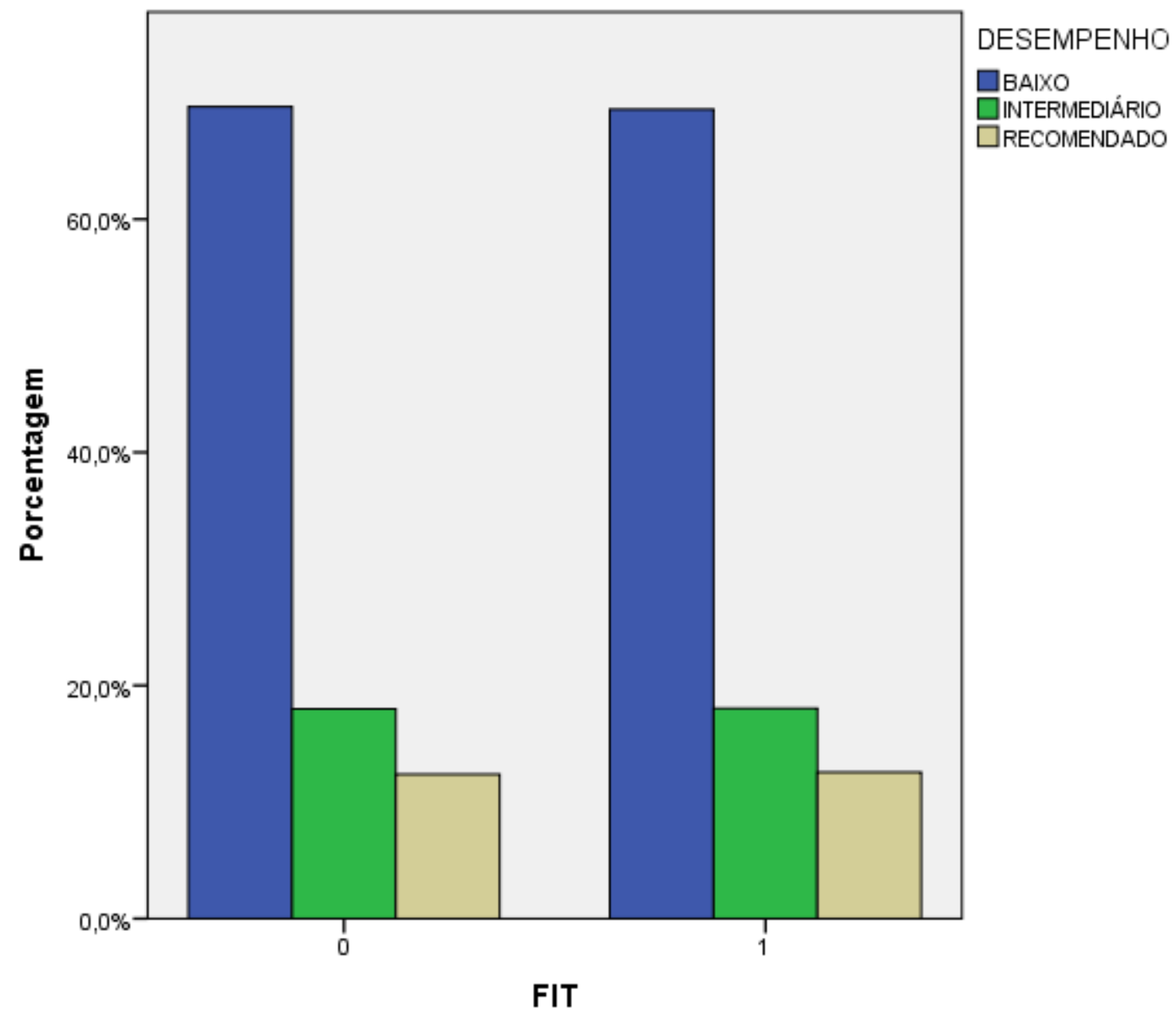

Fonte: Elaborado pelo autor.

DESEMPENHO MÉDIO EM PORTUGUÊS DAS ESCOLAS CONTEMPLADAS (1) E NÃO CONTEMPLADAS (0) COM O PROGRAMA "FORMAÇÃO INICIAL PARA O TRABALHO - FIT” DA REDE ESTADUAL DE MINAS GERAIS - PROEB 2009.

\begin{tabular}{c|l|l|l|l|l}
\hline & \multicolumn{4}{|l|}{ FIT - Português - 2009 } \\
\cline { 2 - 6 } & 0 & \multicolumn{3}{l}{} & \multicolumn{1}{l}{} \\
\cline { 2 - 5 } & total & $\%$ & total & $\%$ \\
\hline BAIXO & 7624 & $69,6 \%$ & 100754 & $69,4 \%$ \\
DESEMPENHO INTERMEDIÁRIO & 1968 & $18,0 \%$ & 26155 & $18,0 \%$ \\
RECOMENDADO & 1355 & $12,4 \%$ & 18200 & $12,5 \%$ \\
Total & 10947 & $100,0 \%$ & 145109 & $100,0 \%$ \\
\hline
\end{tabular}

Fonte: Elaborado pelo autor. 
DESEMPENHO MÉDIO EM PORTUGUÊS DAS ESCOLAS CONTEMPLADAS (1) E NÃO CONTEMPLADAS (0) COM O "PROGRAMA DE EDUCAÇÃO PROFISSIONAL - PEP" DA REDE ESTADUAL DE MINAS GERAIS - PROEB 2009.

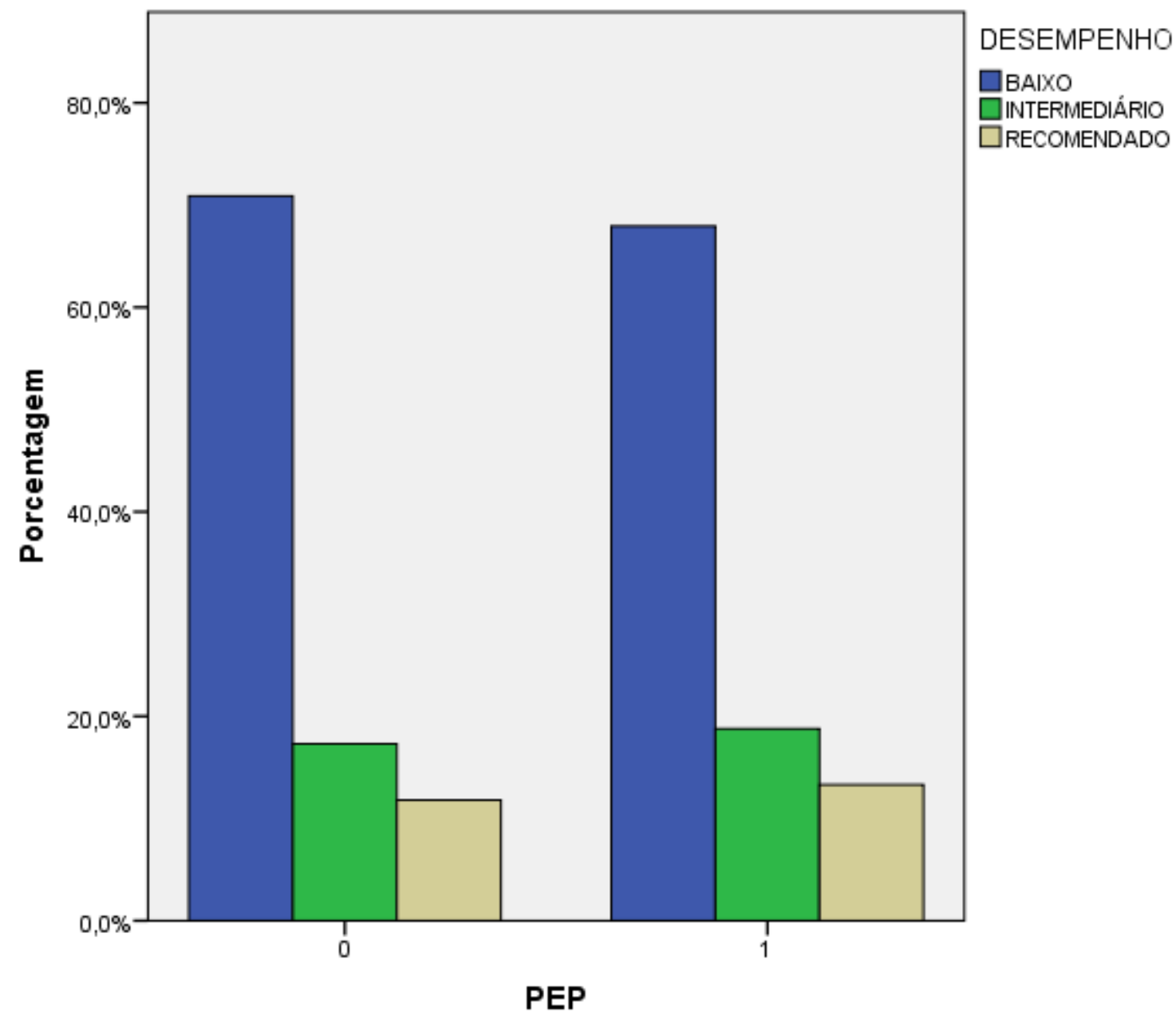

Fonte: Elaborado pelo autor.

DESEMPENHO MÉDIO EM PORTUGUÊS DAS ESCOLAS CONTEMPLADAS (1) E NÃO CONTEMPLADAS (0) COM O "PROGRAMA DE EDUCAÇÃO PROFISSIONAL - PEP” DA REDE ESTADUAL DE MINAS GERAIS - PROEB 2009.

\begin{tabular}{cc|l|l|l|l}
\hline \multirow{2}{*}{} & \multicolumn{4}{|l|}{ PEP - Português - 2009 } \\
\cline { 2 - 5 } & 0 & \multicolumn{3}{l}{1} \\
\cline { 2 - 5 } & total & $\%$ & total & $\%$ \\
\hline BAIXO & 56894 & $70,9 \%$ & 51484 & $67,9 \%$ \\
INESEMPENHO & INTERMEDIÁRIO & 13892 & $17,3 \%$ & 14231 & $18,8 \%$ \\
& RECOMENDADO & 9482 & $11,8 \%$ & 10073 & $13,3 \%$ \\
Total & 80268 & $100,0 \%$ & 75788 & $100,0 \%$ \\
\hline
\end{tabular}

Fonte: Elaborado pelo autor. 
DESEMPENHO MÉDIO EM PORTUGUÊS DAS ESCOLAS CONTEMPLADAS (1) E NÃO CONTEMPLADAS (0) COM O "PROGRAMA POUPANÇA JOVEM - PJ" DA REDE ESTADUAL DE MINAS GERAIS - PROEB 2009.

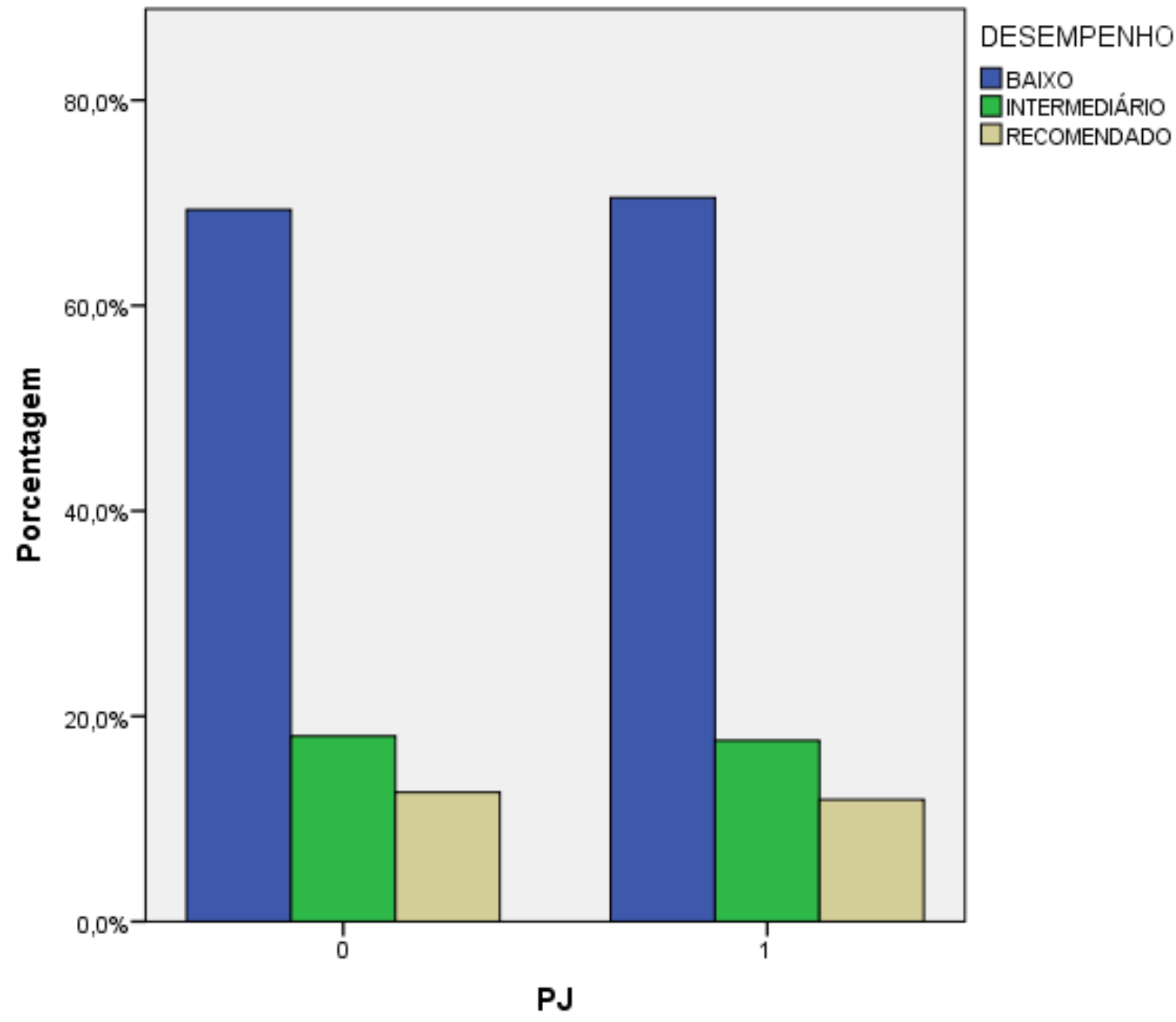

Fonte: Elaborado pelo autor.

DESEMPENHO MÉDIO EM PORTUGUÊS DAS ESCOLAS CONTEMPLADAS (1) E NÃO CONTEMPLADAS (0) COM O "PROGRAMA POUPANÇA JOVEM - PJ" DA REDE ESTADUAL DE MINAS GERAIS - PROEB 2009.

\begin{tabular}{|c|c|c|c|c|}
\hline & \multicolumn{4}{|c|}{ PJ - Português - 2009} \\
\hline & \multicolumn{2}{|l|}{0} & \multicolumn{2}{|l|}{$\sqrt{1}$} \\
\hline & total & $\%$ & total & $\%$ \\
\hline BAIXO & 98529 & $69,3 \%$ & 9849 & $70,5 \%$ \\
\hline DESEMPENHO ${ }^{\text {INTERMEDIÁRIC }}$ & 25662 & $18,1 \%$ & 2461 & $17,6 \%$ \\
\hline DESEIIPENHU RECOMENDADC & 17897 & $12,6 \%$ & 1658 & $11,9 \%$ \\
\hline Total & 142088 & $100,0 \%$ & 13968 & $100,0 \%$ \\
\hline
\end{tabular}

Fonte: Elaborado pelo autor. 
Português 2010

DESEMPENHO MÉDIO EM PORTUGUÊS DAS ESCOLAS CONTEMPLADAS (1) E NÃO CONTEMPLADAS (0) COM O PROJETO "ESCOLAS REFERÊNCIA - ER" DA REDE ESTADUAL DE MINAS GERAIS - PROEB 2010.

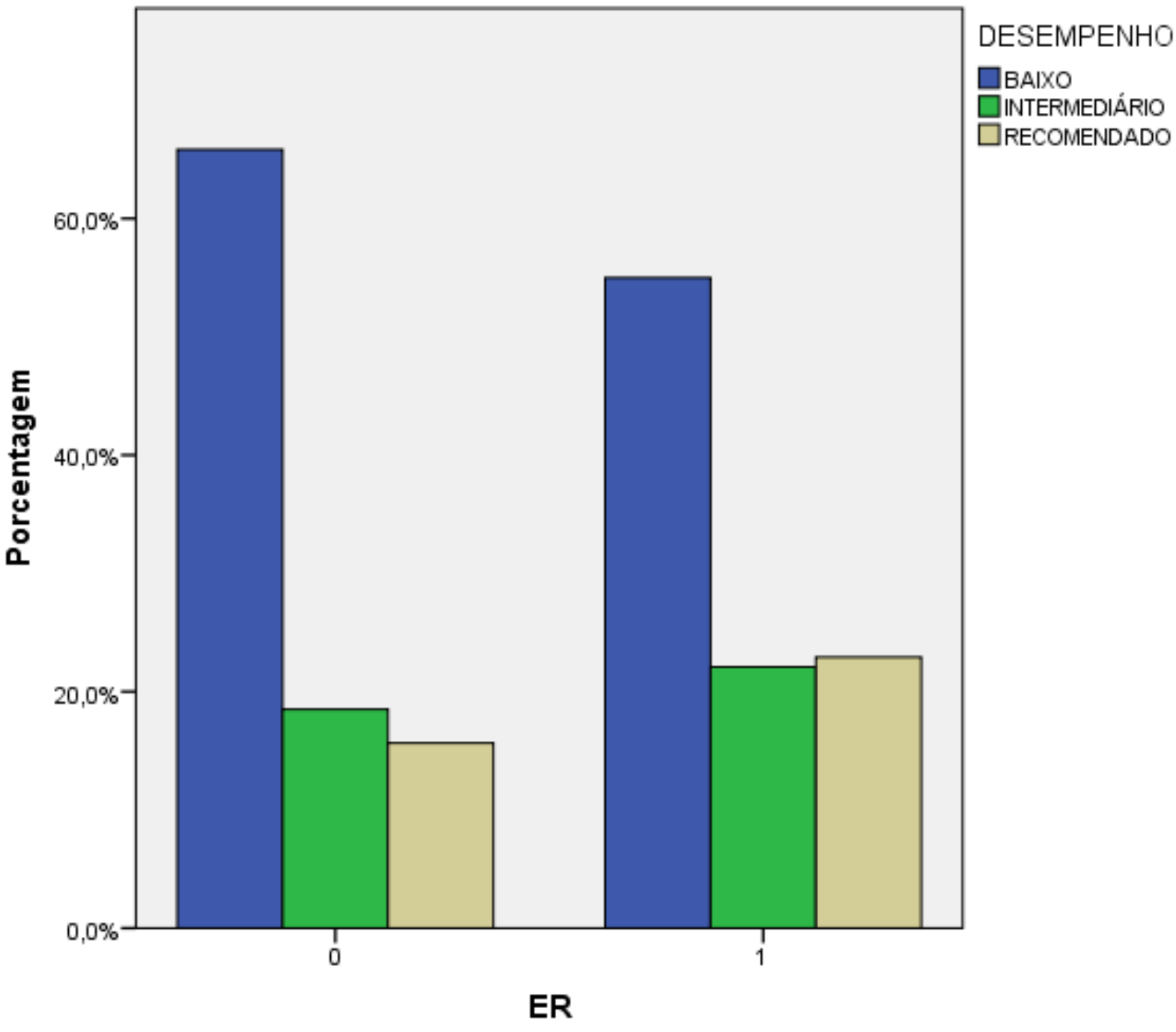

Fonte: Elaborado pelo autor.

DESEMPENHO MÉDIO EM PORTUGUÊS DAS ESCOLAS CONTEMPLADAS (1) E NÃO CONTEMPLADAS (0) COM O PROJETO "ESCOLAS REFERÊNCIA - ER" DA REDE ESTADUAL DE MINAS GERAIS - PROEB 2010.

\begin{tabular}{|c|c|c|c|}
\hline & \multicolumn{3}{|c|}{ ER - Português - 2010} \\
\hline & \multicolumn{2}{|l|}{0} & 1 \\
\hline & total & $\%$ & total $\%$ \\
\hline BAIXO & 69304 & $65,8 \%$ & $2581155,0 \%$ \\
\hline INTERMEDIÁRIO & 19479 & $18,5 \%$ & $1037022,1 \%$ \\
\hline RECOMENDADO & 16465 & $15,6 \%$ & $10756 \mid 22,9 \%$ \\
\hline Total & $10524 \varepsilon$ & $100,0 \%$ & $46937100,0 \%$ \\
\hline
\end{tabular}

Fonte: Elaborado pelo autor. 
DESEMPENHO MÉDIO EM PORTUGUÊS DAS ESCOLAS CONTEMPLADAS (1) E NÃO CONTEMPLADAS (0) COM O "PROGRAMA DE DESENVOLVIMENTO PROFISSIONAL - PDP" DA REDE ESTADUAL DE MINAS GERAIS - PROEB 2010.

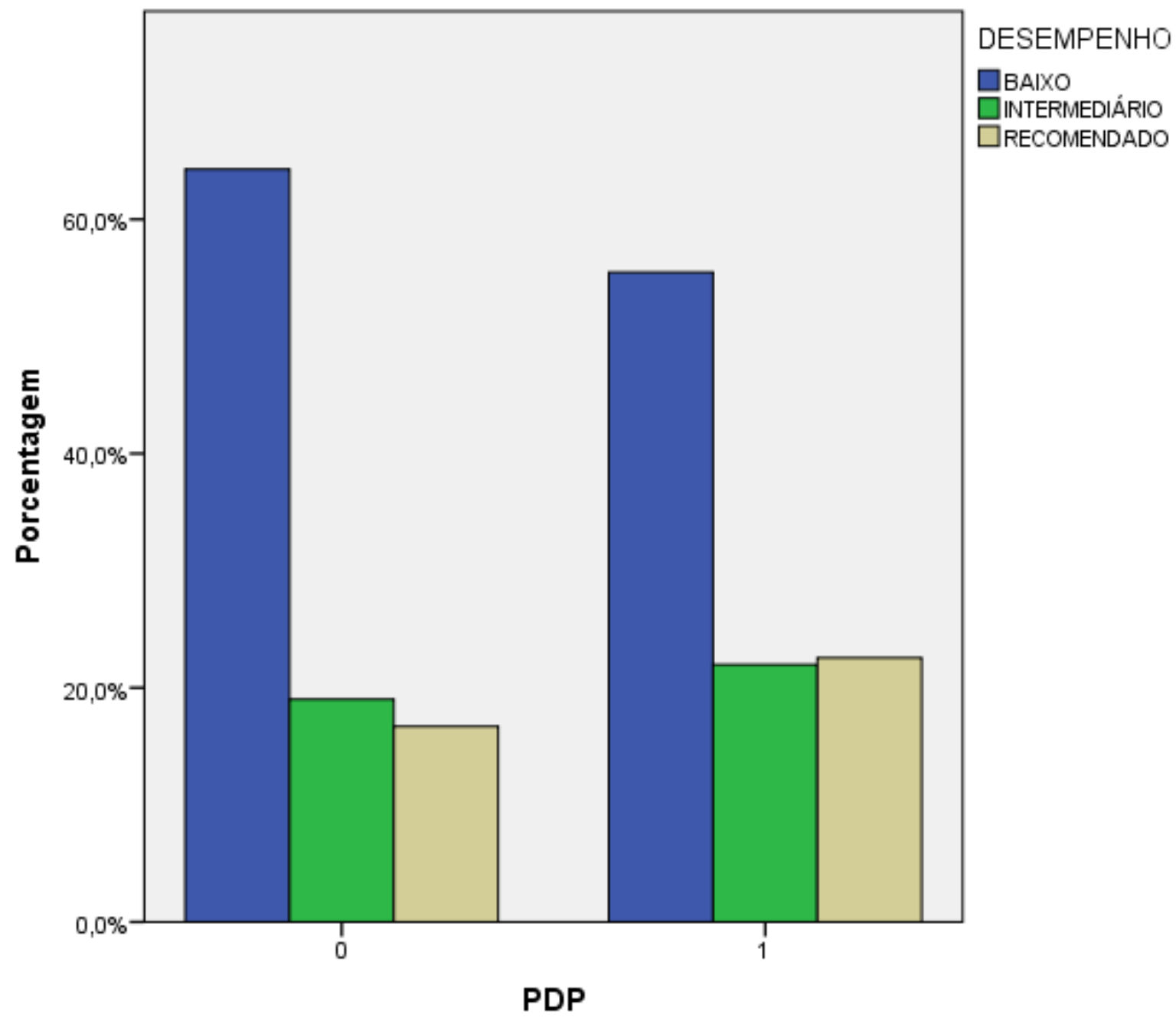

Fonte: Elaborado pelo autor.

DESEMPENHO MÉDIO EM PORTUGUÊS DAS ESCOLAS CONTEMPLADAS (1) E NÃO CONTEMPLADAS (0) COM O "PROGRAMA DE DESENVOLVIMENTO PROFISSIONAL - PDP" DA REDE ESTADUAL DE MINAS GERAIS - PROEB 2010.

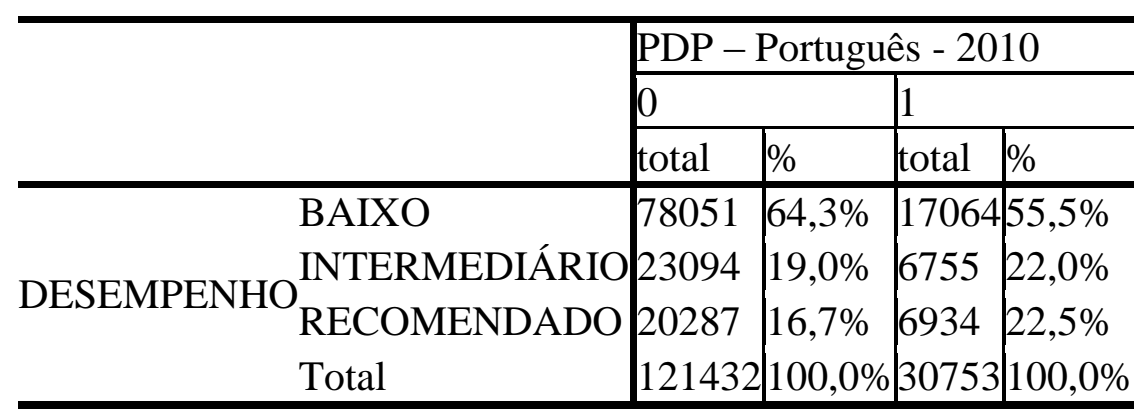

Fonte: Elaborado pelo autor. 
DESEMPENHO MÉDIO EM PORTUGUÊS DAS ESCOLAS CONTEMPLADAS (1) E NÃO CONTEMPLADAS (0) COM O "PROGRAMA DE EDUCAÇÃO PROFISSIONAL - PEP” DA REDE ESTADUAL DE MINAS GERAIS - PROEB 2010.

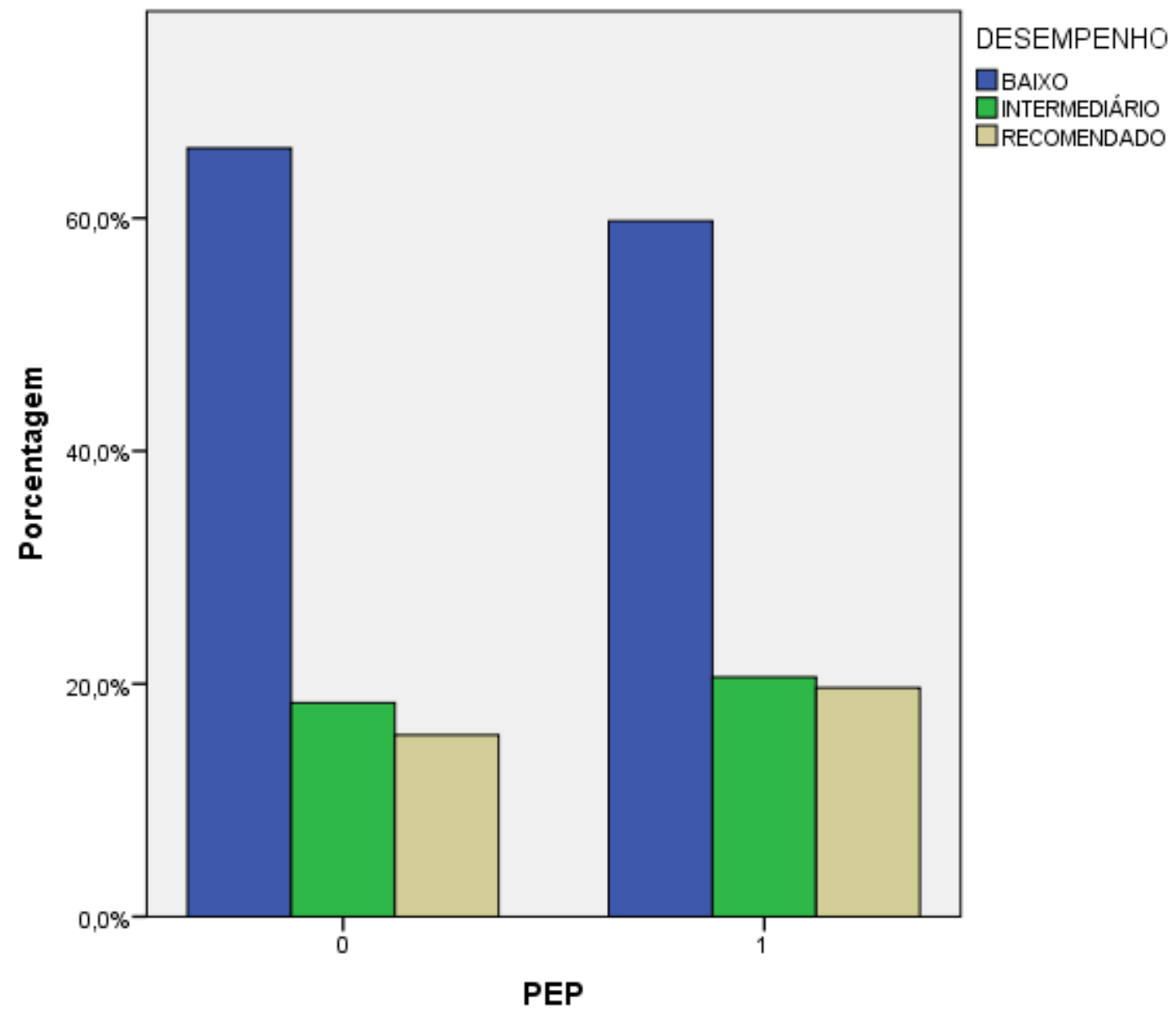

Fonte: Elaborado pelo autor.

DESEMPENHO MÉDIO EM PORTUGUÊS DAS ESCOLAS CONTEMPLADAS (1) E NÃO CONTEMPLADAS (0) COM O "PROGRAMA DE EDUCAÇÃO PROFISSIONAL - PEP” DA REDE ESTADUAL DE MINAS GERAIS - PROEB 2010.

\begin{tabular}{cc|l|l|l|l}
\hline & \multicolumn{4}{|l}{ PEP - Português - 2010 } \\
\cline { 2 - 5 } & 0 & \multicolumn{1}{l}{1} \\
\cline { 2 - 5 } & total & $\%$ & total & $\%$ \\
\hline BAIXO & 43941 & $66,0 \%$ & 51174 & $59,8 \%$ \\
DESEMPENHO INTERMEDIÁRIO & 12223 & $18,4 \%$ & 17626 & $20,6 \%$ \\
& RECOMENDADO & 10389 & $15,6 \%$ & 16832 & $19,7 \%$ \\
Total & 66553 & $100,0 \%$ & 85632 & $100,0 \%$ \\
\hline
\end{tabular}

Fonte: Elaborado pelo autor. 
DESEMPENHO MÉDIO EM PORTUGUÊS DAS ESCOLAS CONTEMPLADAS (1) E NÃO CONTEMPLADAS (0) COM O "PROGRAMA POUPANÇA JOVEM - PJ" DA REDE ESTADUAL DE MINAS GERAIS - PROEB 2010.

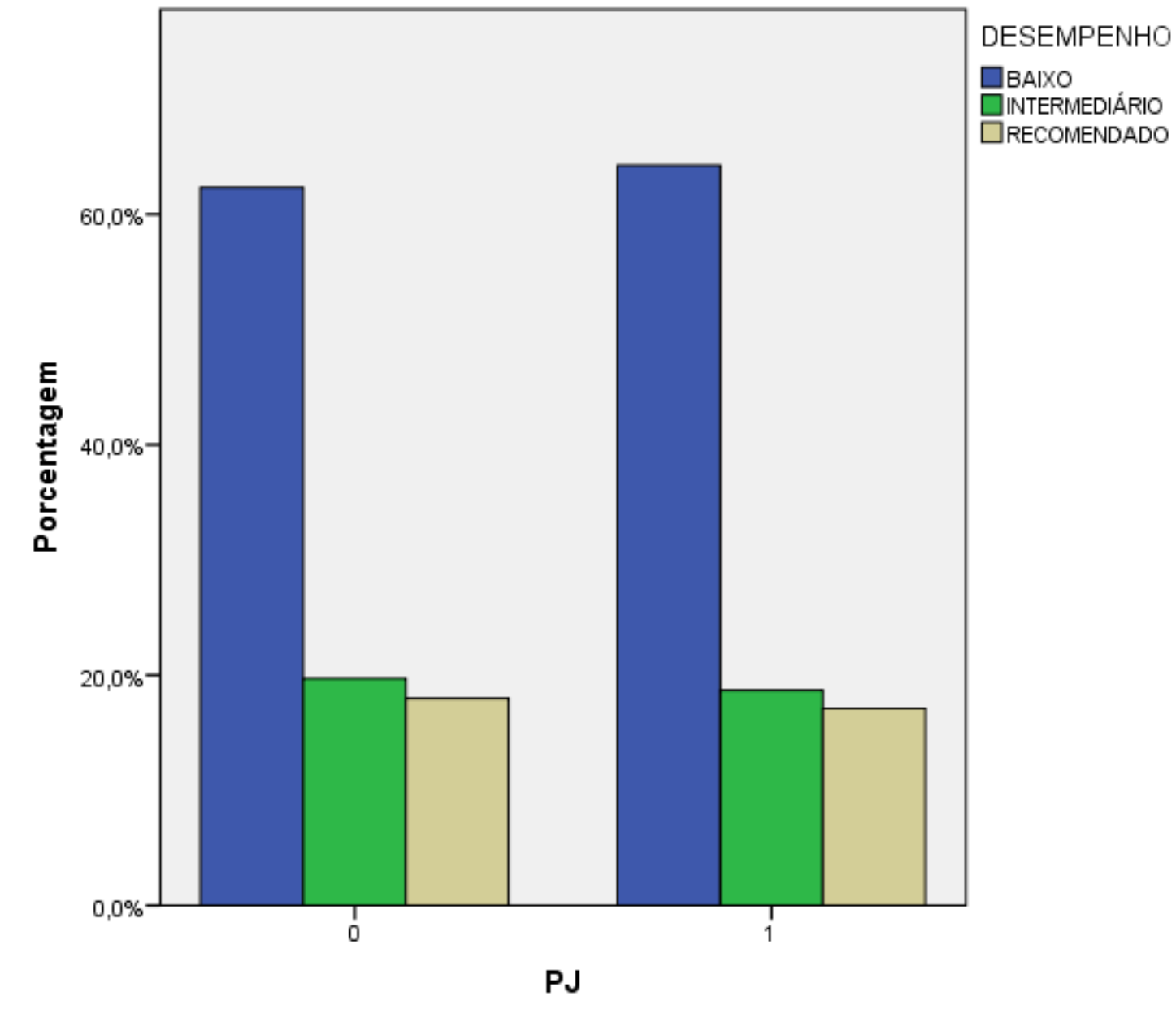

Fonte: Elaborado pelo autor.

DESEMPENHO MÉDIO EM PORTUGUÊS DAS ESCOLAS CONTEMPLADAS (1) E NÃO CONTEMPLADAS (0) COM O "PROGRAMA POUPANÇA JOVEM - PJ" DA REDE ESTADUAL DE MINAS GERAIS - PROEB 2010.

\begin{tabular}{|c|c|c|c|c|}
\hline & \multicolumn{4}{|c|}{ PJ - Português - 2010} \\
\hline & \multicolumn{2}{|l|}{0} & \multicolumn{2}{|l|}{1} \\
\hline & total & $\%$ & total & $\%$ \\
\hline BAIXO & 85990 & $62,3 \%$ & 9125 & $64,2 \%$ \\
\hline INTERMEDIÁRIO & 27196 & $19,7 \%$ & 2653 & $18,7 \%$ \\
\hline RECOMENDADO & 24793 & $18,0 \%$ & 2428 & $17,1 \%$ \\
\hline Total & 137979 & $100,0 \%$ & 14206 & $100,0 \%$ \\
\hline
\end{tabular}

Fonte: Elaborado pelo autor. 
Matemática - 2006

DESEMPENHO MÉDIO EM MATEMÁTICA DAS ESCOLAS CONTEMPLADAS (1) E NÃO CONTEMPLADAS (0) COM O PROJETO "ESCOLAS REFERÊNCIA ER" DA REDE ESTADUAL DE MINAS GERAIS - PROEB 2006.

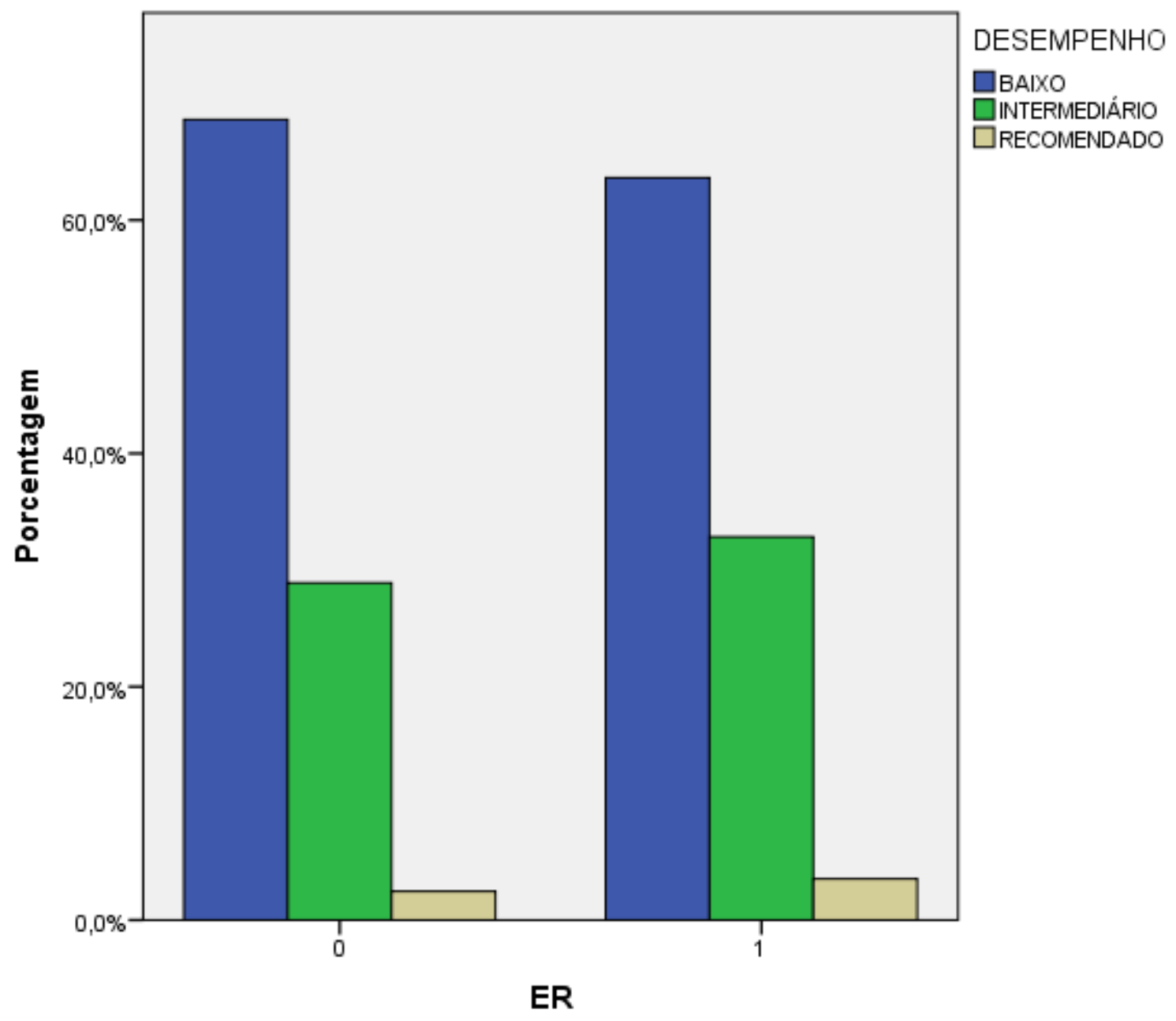

Fonte: Elaborado pelo autor.

DESEMPENHO MÉDIO EM MATEMÁTICA DAS ESCOLAS CONTEMPLADAS (1) E NÃO CONTEMPLADAS (0) COM O PROJETO "ESCOLAS REFERÊNCIA ER" DA REDE ESTADUAL DE MINAS GERAIS - PROEB 2006.

\begin{tabular}{|c|c|c|}
\hline & \multicolumn{2}{|c|}{ ER - Matemática - 2006} \\
\hline & 0 & 1 \\
\hline & total $\%$ & total $\%$ \\
\hline BAIXO & $6450768,6 \%$ & $2519963,6 \%$ \\
\hline DFSFMPFNHO INTERMEDIÁRIO & $27172 \mid 28,9 \%$ & $1300832,8 \%$ \\
\hline RECOMENDADO & $23112,5 \%$ & $13963,5 \%$ \\
\hline Total & $93990100,0 \%$ & $39603 \mid 100,0 \%$ \\
\hline
\end{tabular}

Fonte: Elaborado pelo autor. 
DESEMPENHO MÉDIO EM MATEMÁTICA DAS ESCOLAS CONTEMPLADAS (1) E NÃO CONTEMPLADAS (0) COM O "PROGRAMA DE DESENVOLVIMENTO PROFISSIONAL - PDP" DA REDE ESTADUAL DE MINAS GERAIS - PROEB 2006.

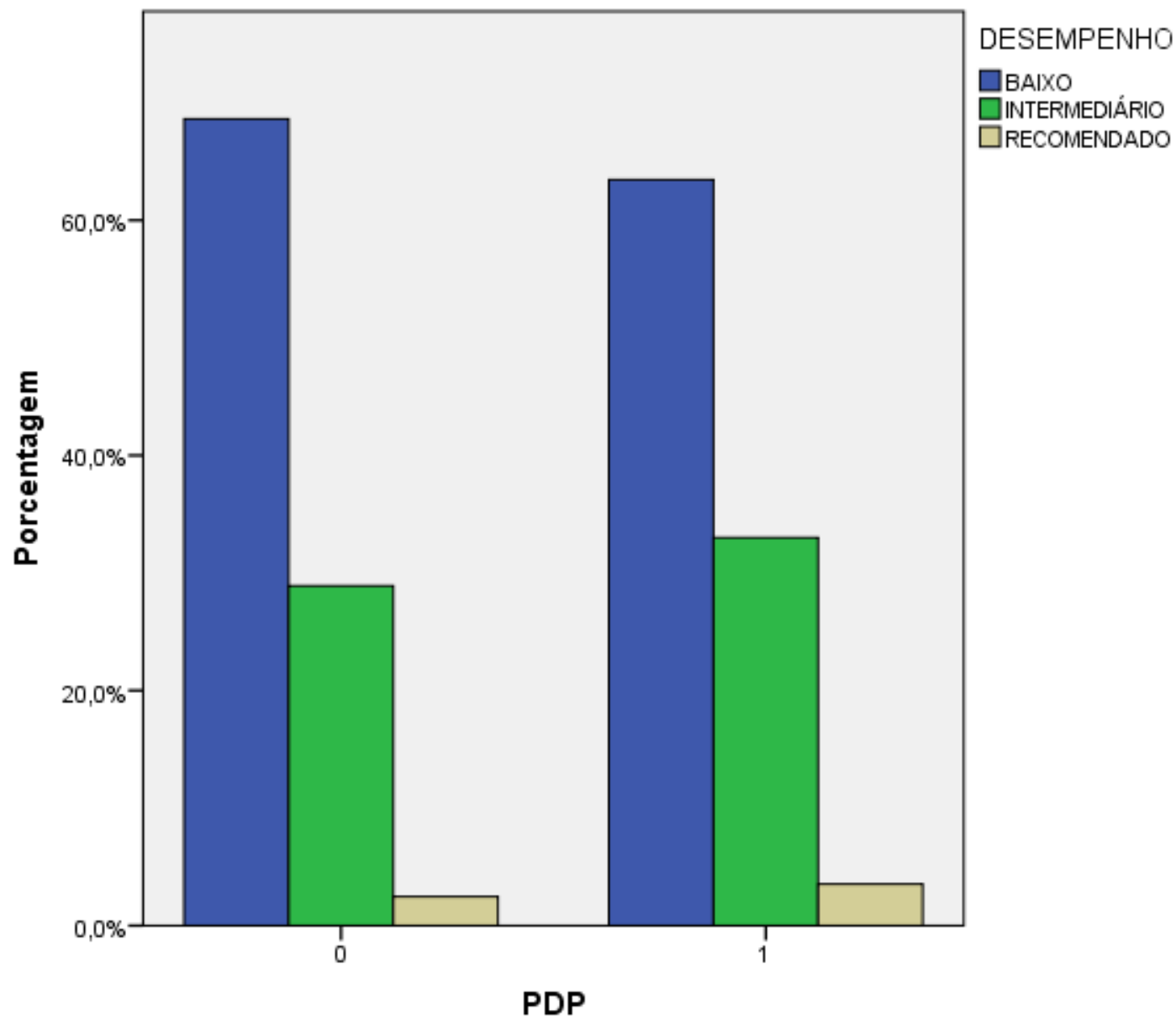

Fonte: Elaborado pelo autor.

DESEMPENHO MÉDIO EM MATEMÁTICA DAS ESCOLAS CONTEMPLADAS (1) E NÃO CONTEMPLADAS (0) COM O "PROGRAMA DE DESENVOLVIMENTO PROFISSIONAL - PDP" DA REDE ESTADUAL DE MINAS GERAIS - PROEB 2006.

\begin{tabular}{|c|c|c|}
\hline & \multicolumn{2}{|c|}{ PDP - Matemática - 2006} \\
\hline & 0 & 1 \\
\hline & total $\%$ & total $\%$ \\
\hline BAIXO & $6549868,6 \%$ & $2420863,5 \%$ \\
\hline INTERMEDIÁRIO & $2758728,9 \%$ & $1259333,0 \%$ \\
\hline RECOMENDADO & $23572,5 \%$ & $1350 \quad 3,5 \%$ \\
\hline Total & 95442 $100,0 \%$ & $38151 \mid 100,0 \%$ \\
\hline
\end{tabular}

Fonte: Elaborado pelo autor. 
DESEMPENHO MÉDIO EM MATEMÁTICA DAS ESCOLAS CONTEMPLADAS (1) E NÃO CONTEMPLADAS (0) COM O "PROGRAMA DE ATENÇÃO AO JOVEM - PEAS" DA REDE ESTADUAL DE MINAS GERAIS - PROEB 2006.

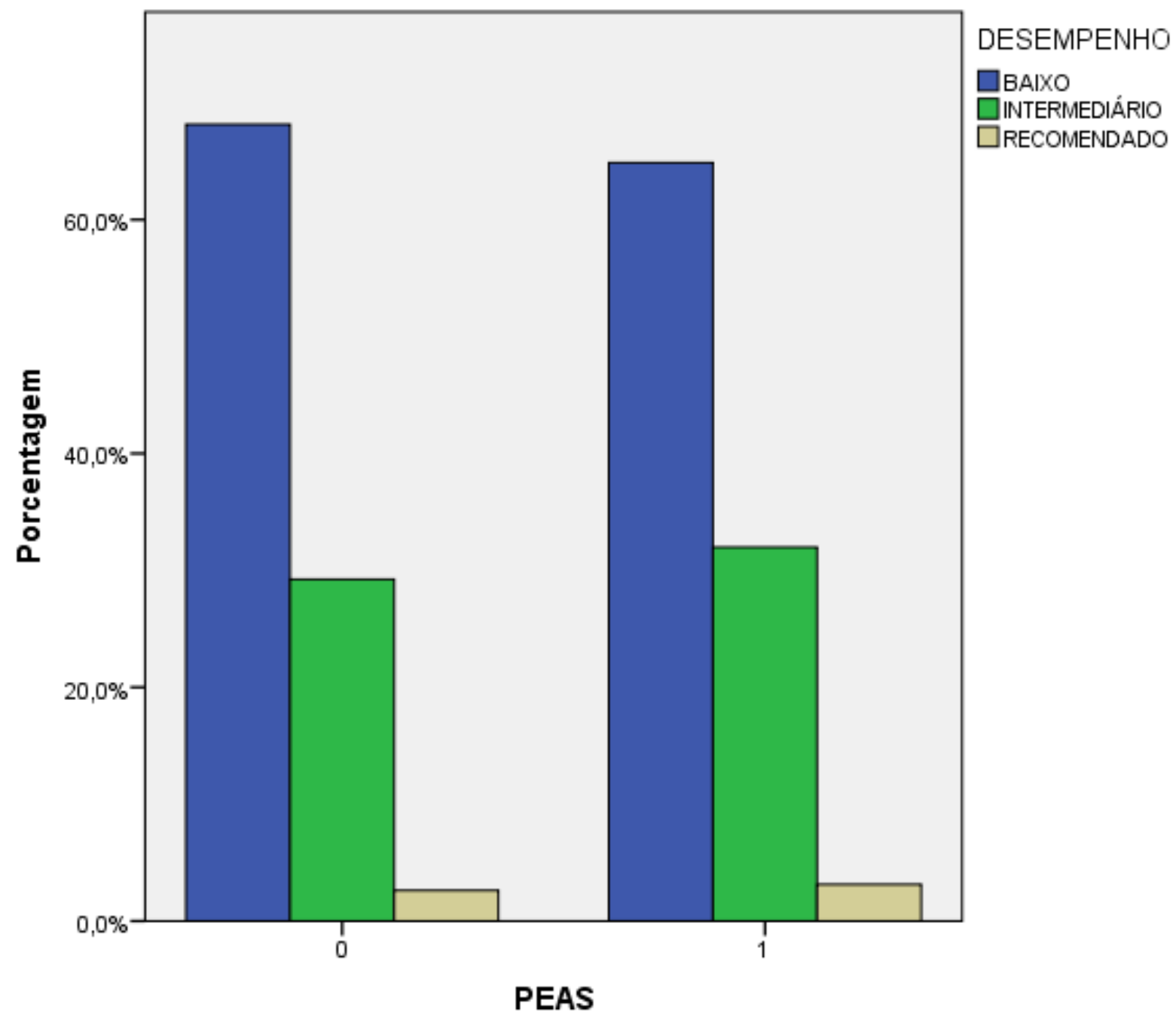

Fonte: Elaborado pelo autor.

DESEMPENHO MÉDIO EM MATEMÁTICA DAS ESCOLAS CONTEMPLADAS (1) E NÃO CONTEMPLADAS (0) COM O "PROGRAMA DE ATENÇÃO AO JOVEM - PEAS” DA REDE ESTADUAL DE MINAS GERAIS - PROEB 2006.

\begin{tabular}{c|l|l|l|l|l}
\hline \multirow{2}{*}{} & \multicolumn{4}{|l|}{ PEAS - Matemática - 2006 } \\
\cline { 2 - 6 } & 0 & \multicolumn{3}{l}{1} \\
\cline { 2 - 6 } & Botal & $\%$ & total & $\%$ \\
\hline BAIXO & 62967 & $68,2 \%$ & 26739 & $64,9 \%$ \\
\multirow{2}{*}{ DESEMPENHO INTERMEDIÁRIO } & 27002 & $29,2 \%$ & 13178 & $32,0 \%$ \\
& RECOMENDADO & 2415 & $2,6 \%$ & 1292 & $3,1 \%$ \\
& Total & 92384 & $100,0 \%$ & 41209 & $100,0 \%$ \\
\hline
\end{tabular}

Fonte: Elaborado pelo autor. 
DESEMPENHO MÉDIO EM MATEMÁTICA DAS ESCOLAS CONTEMPLADAS (1) E NÃO CONTEMPLADAS (0) COM O "PROGRAMA POUPANÇA JOVEM PJ" DA REDE ESTADUAL DE MINAS GERAIS - PROEB 2010.

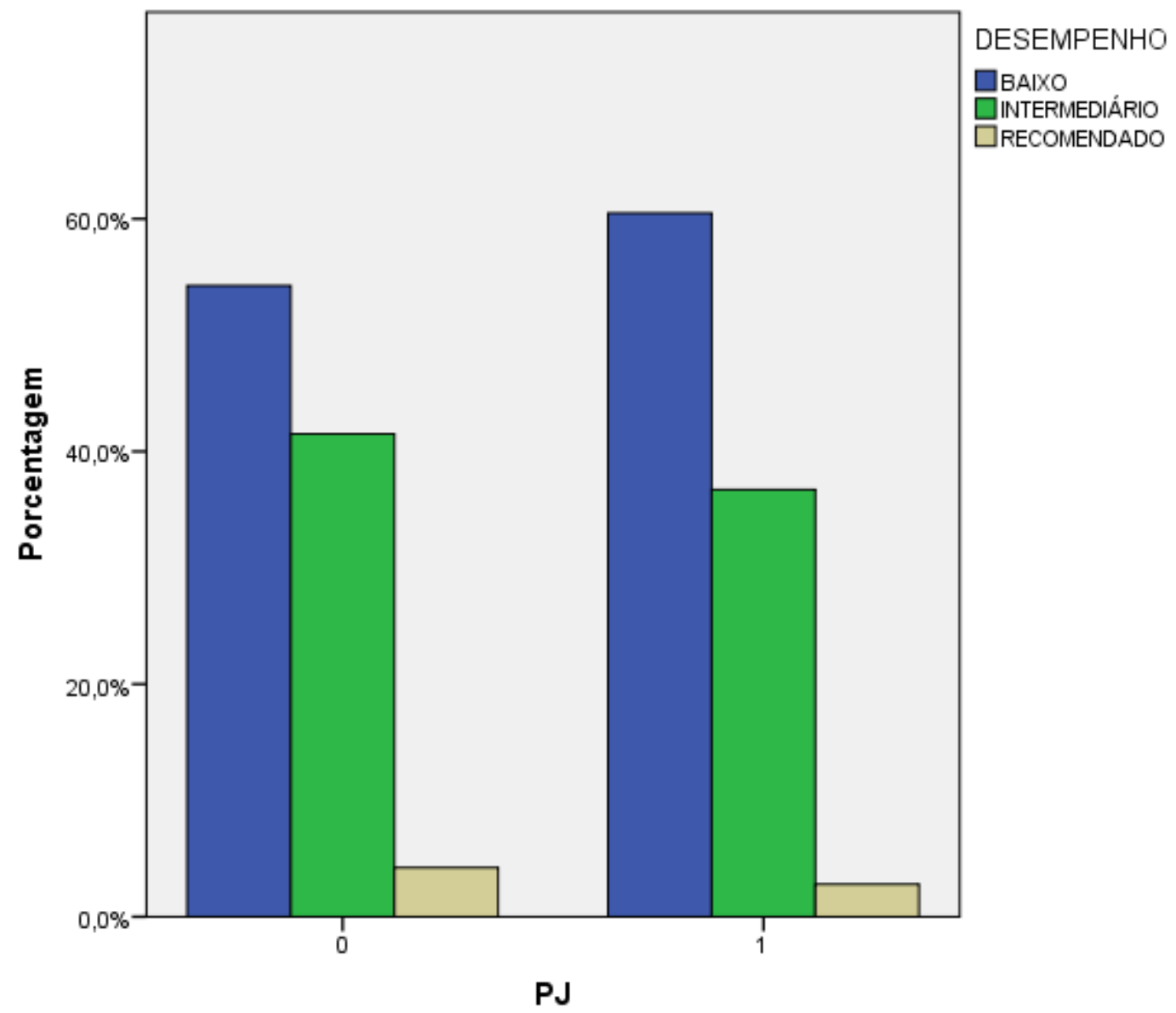

Fonte: Elaborado pelo autor.

DESEMPENHO MÉDIO EM MATEMÁTICA DAS ESCOLAS CONTEMPLADAS (1) E NÃO CONTEMPLADAS (0) COM O "PROGRAMA POUPANÇA JOVEM PJ" DA REDE ESTADUAL DE MINAS GERAIS - PROEB 2010.

\begin{tabular}{c|l|l|l|l}
\hline & \multicolumn{3}{|l}{ PJ - Matemática - 2010 } \\
\cline { 2 - 5 } & 0 & \multicolumn{3}{l}{1} \\
\cline { 2 - 6 } & total & $\%$ & total & $\%$ \\
\hline BAIXO & 73354 & $54,3 \%$ & 8528 & $60,5 \%$ \\
DESEMPENHO INTERMEDIÁRIO & 56140 & $41,5 \%$ & 5176 & $36,7 \%$ \\
RECOMENDADO & 5716 & $4,2 \%$ & 393 & $2,8 \%$ \\
Total & 135210 & $100,0 \%$ & 14097 & $100,0 \%$ \\
\hline
\end{tabular}

Fonte: Elaborado pelo autor. 
Matemática - 2007

DESEMPENHO MÉDIO EM MATEMÁTICA DAS ESCOLAS CONTEMPLADAS (1) E NÃO CONTEMPLADAS (0) COM O PROJETO "ESCOLAS REFERÊNCIA ER" DA REDE ESTADUAL DE MINAS GERAIS - PROEB 2007.

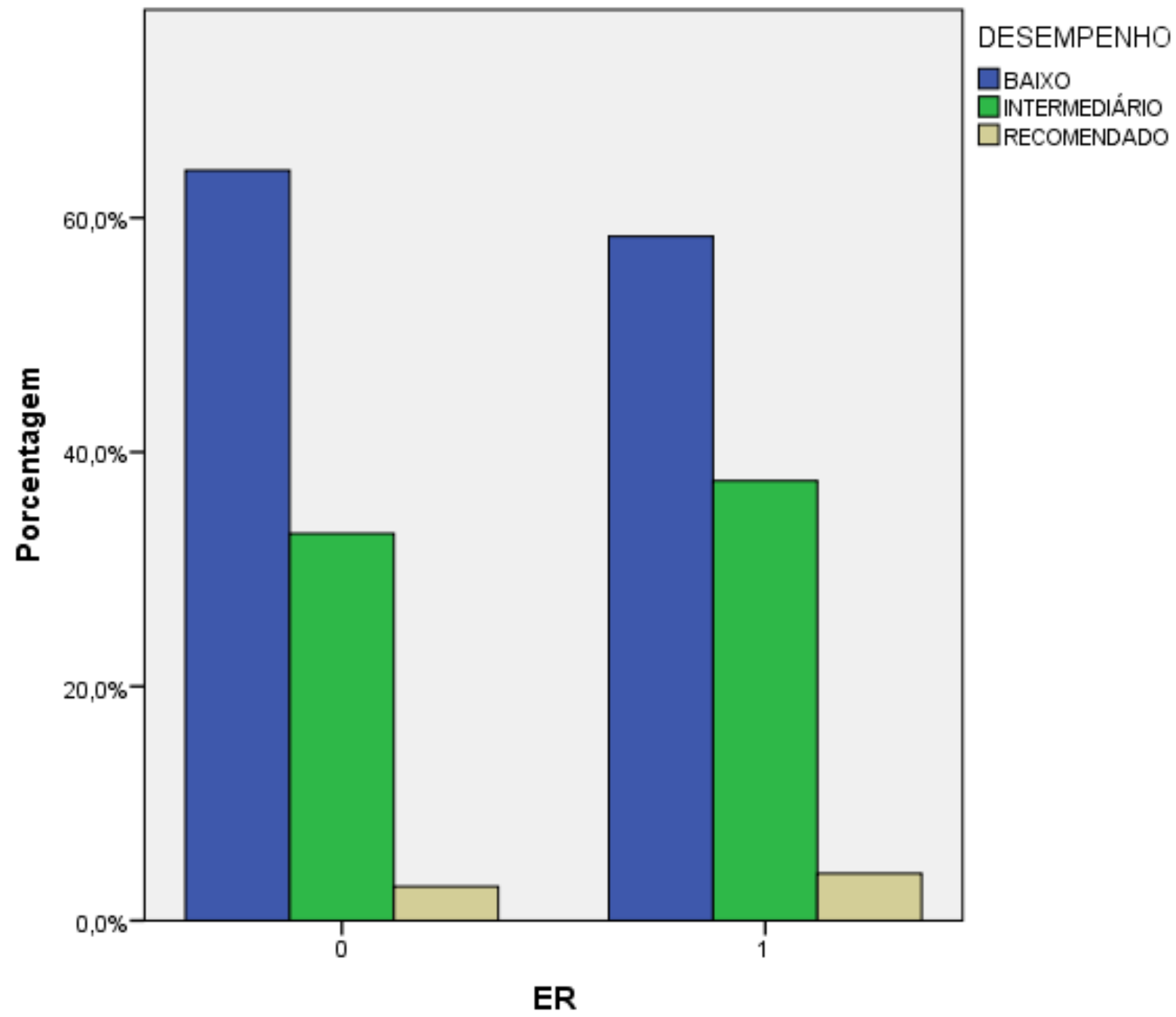

Fonte: Elaborado pelo autor.

DESEMPENHO MÉDIO EM MATEMÁTICA DAS ESCOLAS CONTEMPLADAS (1) E NÃO CONTEMPLADAS (0) COM O PROJETO "ESCOLAS REFERÊNCIA ER” DA REDE ESTADUAL DE MINAS GERAIS - PROEB 2007.

\begin{tabular}{|c|c|c|}
\hline & \multicolumn{2}{|c|}{ ER - Matemática - 2007} \\
\hline & 0 & 1 \\
\hline & total $\%$ & total $\%$ \\
\hline BAIXO & $6127464,1 \%$ & $2150158,4 \%$ \\
\hline DESEMPENHO INTERMEDIÁRIC & $3160633,0 \%$ & $1382337,6 \%$ \\
\hline RECOMENDADO & $27812,9 \%$ & $14844,0 \%$ \\
\hline Total & $95661100,0 \%$ & $36808100,0 \%$ \\
\hline
\end{tabular}

Fonte: Elaborado pelo autor. 
DESEMPENHO MÉDIO EM MATEMÁTICA DAS ESCOLAS CONTEMPLADAS

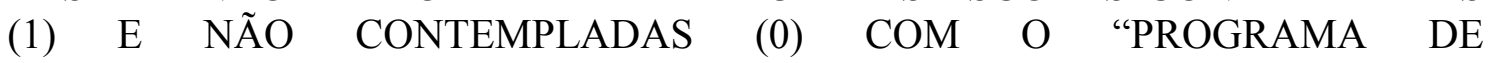
DESENVOLVIMENTO PROFISSIONAL - PDP" DA REDE ESTADUAL DE MINAS GERAIS - PROEB 2007.

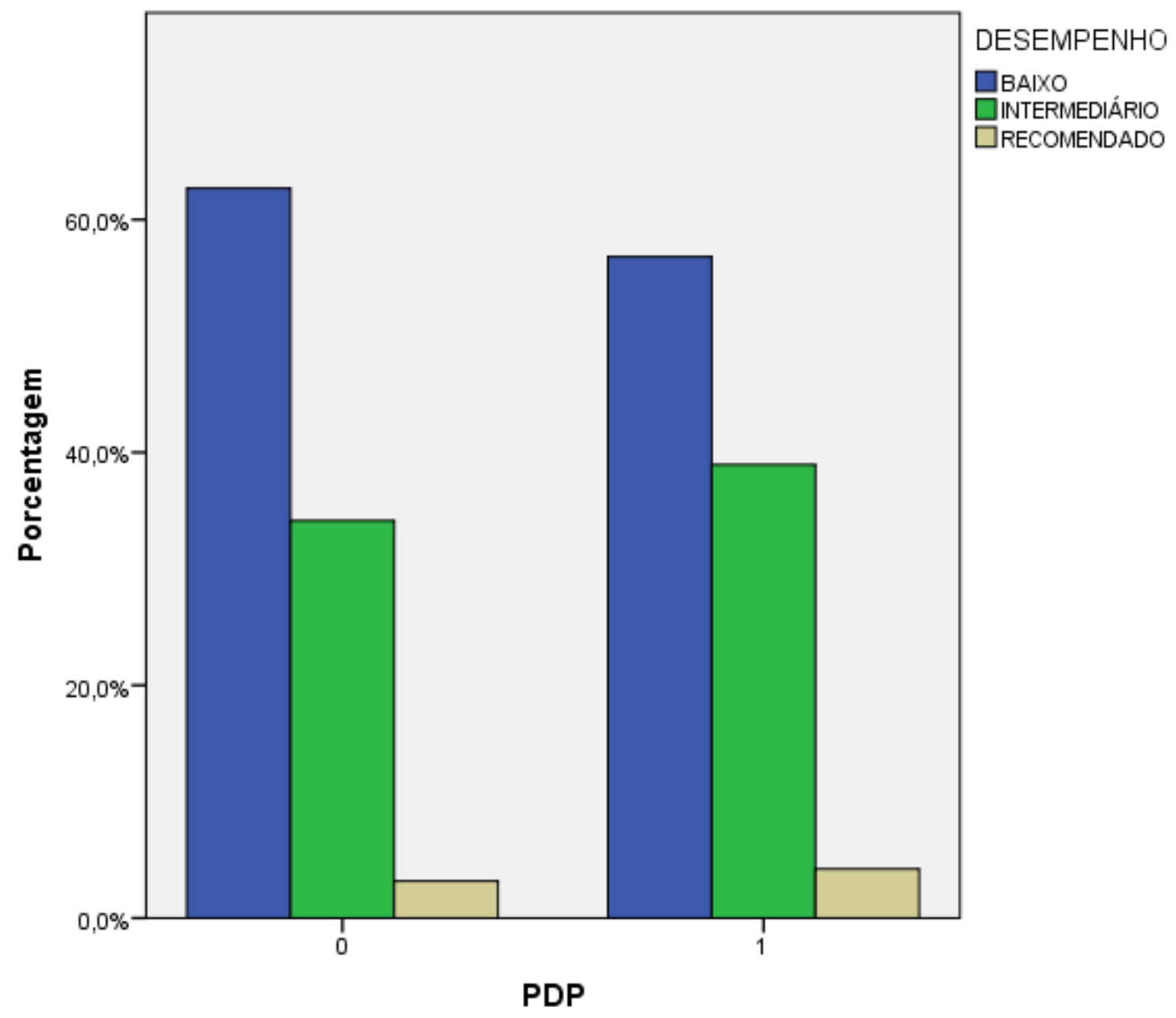

Fonte: Elaborado pelo autor.

DESEMPENHO MÉDIO EM MATEMÁTICA DAS ESCOLAS CONTEMPLADAS (1) E NÃO CONTEMPLADAS (0) COM O "PROGRAMA DE DESENVOLVIMENTO PROFISSIONAL - PDP" DA REDE ESTADUAL DE MINAS GERAIS - PROEB 2007

\begin{tabular}{c|l|l|l|l}
\hline & \multicolumn{3}{|l}{ PDP - Matemática - 2007 } \\
\cline { 2 - 5 } & 0 & \multicolumn{3}{l}{1} \\
\cline { 2 - 5 } & total & $\%$ & total & $\%$ \\
\hline BAIXO & 80197 & $62,7 \%$ & 2578 & $56,8 \%$ \\
DESEMPENHO INTERMEDIÁRIO & 43662 & $34,1 \%$ & 1767 & $38,9 \%$ \\
RECOMENDADO & 4073 & $3,2 \%$ & 192 & $4,2 \%$ \\
Total & 127932 & $100,0 \%$ & 4537 & $100,0 \%$ \\
\hline
\end{tabular}

Fonte: Elaborado pelo autor. 
DESEMPENHO MÉDIO EM MATEMÁTICA DAS ESCOLAS CONTEMPLADAS (1) E NÃO CONTEMPLADAS (0) COM O "PROGRAMA DE ATENÇÃO AO JOVEM - PEAS” DA REDE ESTADUAL DE MINAS GERAIS - PROEB 2007.

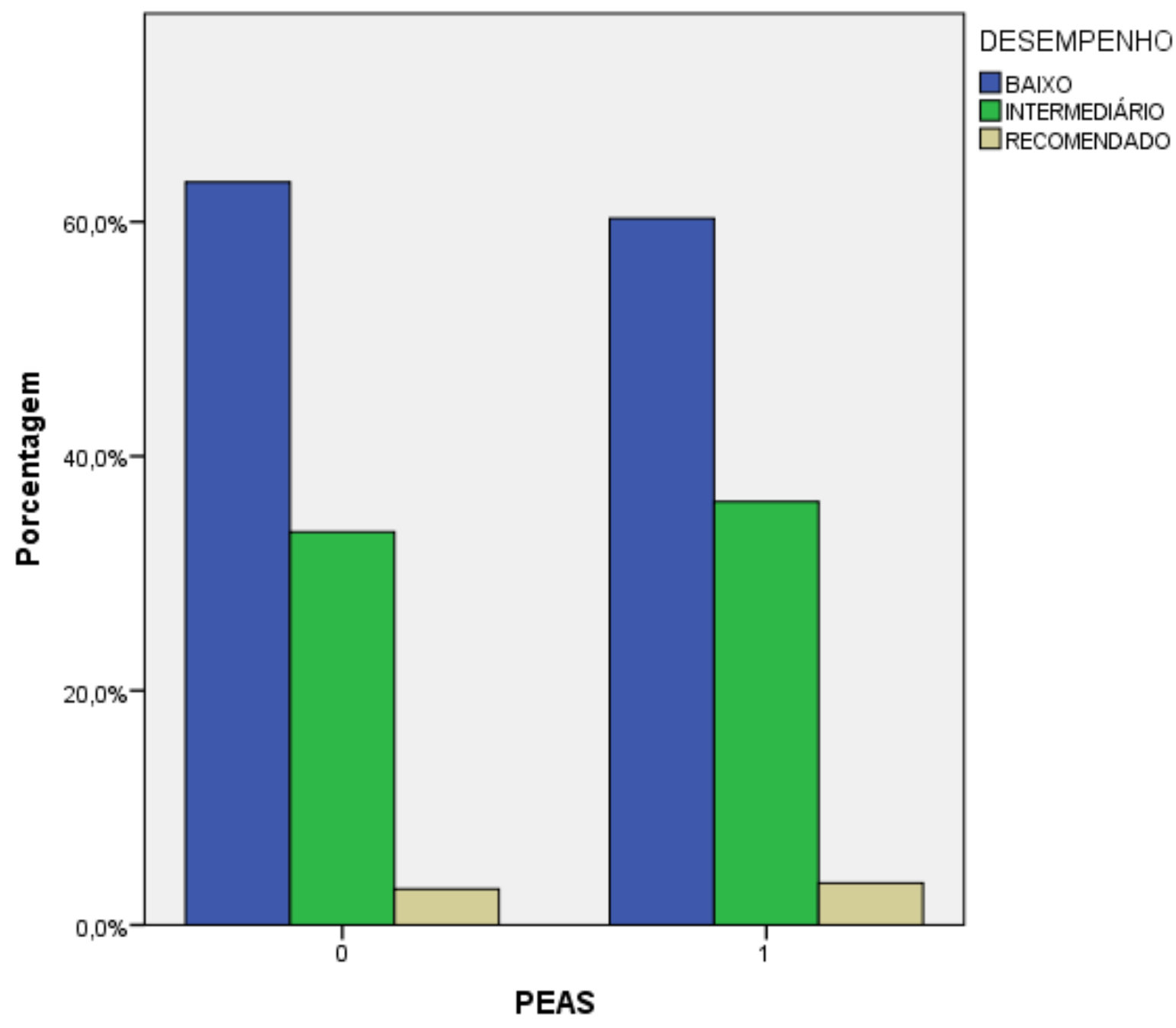

Fonte: Elaborado pelo autor.

DESEMPENHO MÉDIO EM MATEMÁTICA DAS ESCOLAS CONTEMPLADAS (1) E NÃO CONTEMPLADAS (0) COM O "PROGRAMA DE ATENÇÃO AO JOVEM - PEAS” DA REDE ESTADUAL DE MINAS GERAIS - PROEB 2007.

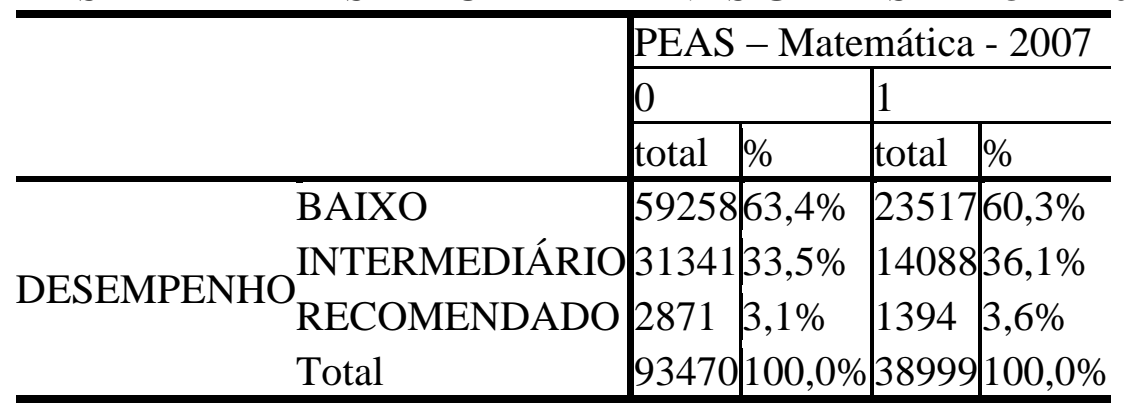

Fonte: Elaborado pelo autor. 
DESEMPENHO MÉDIO EM MATEMÁTICA DAS ESCOLAS CONTEMPLADAS (1) E NÃO CONTEMPLADAS (0) COM O "PROGRAMA DE EDUCAÇÃO PROFISSIONAL - PEP" DA REDE ESTADUAL DE MINAS GERAIS - PROEB 2007.

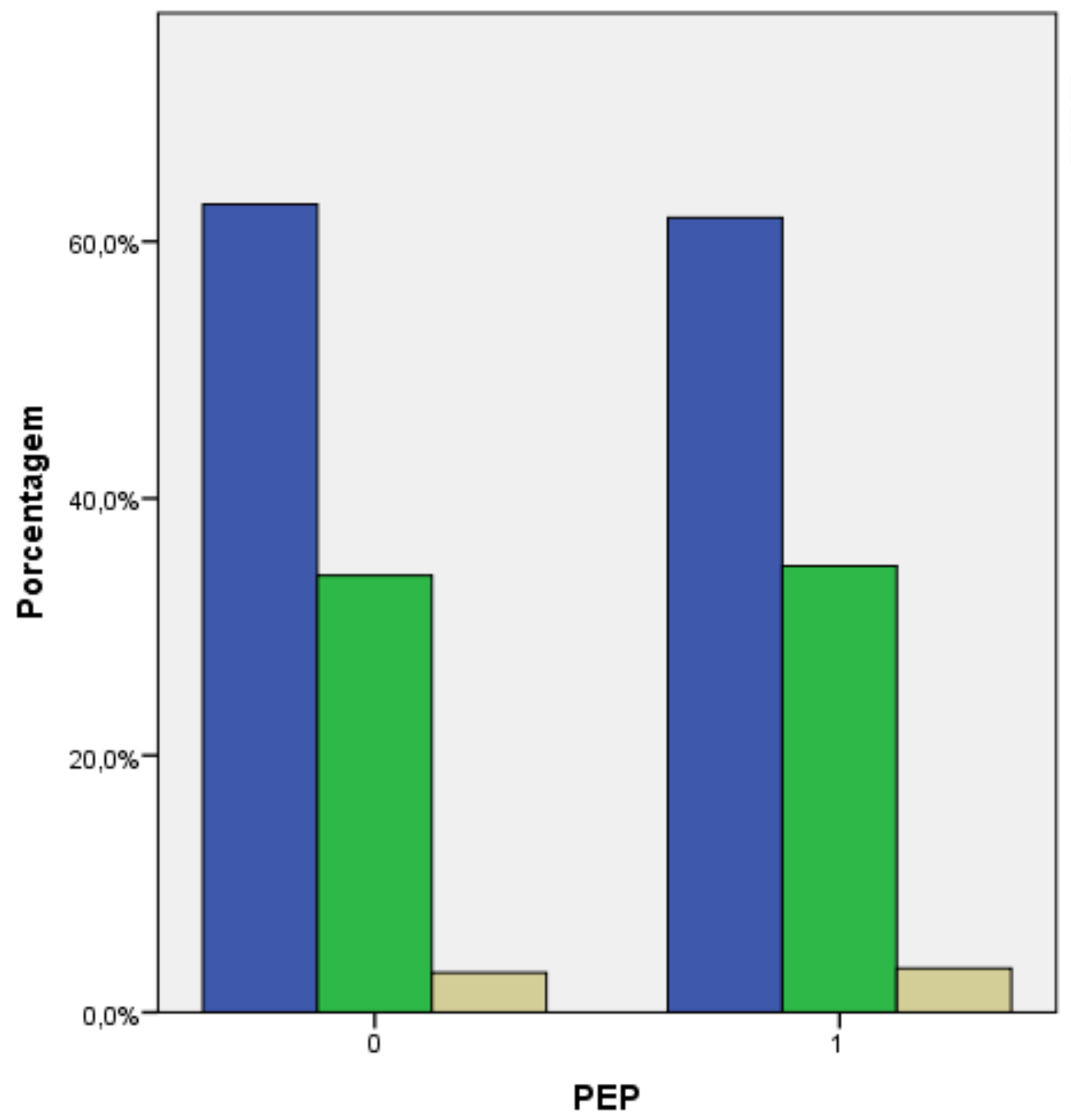

DESEMPENHO

口BAIXo

DINTERMEDIÁRIO

$\square$ RECOMENDADO

Fonte: Elaborado pelo autor.

DESEMPENHO MÉDIO EM MATEMÁTICA DAS ESCOLAS CONTEMPLADAS (1) E NÃO CONTEMPLADAS (0) COM O "PROGRAMA DE EDUCAÇÃO PROFISSIONAL - PEP” DA REDE ESTADUAL DE MINAS GERAIS - PROEB 2007.

\begin{tabular}{|c|c|c|}
\hline & \multicolumn{2}{|c|}{ PEP - Matemática - 2007} \\
\hline & 0 & 1 \\
\hline & total $\%$ & total $\%$ \\
\hline BAIXO & $5041862,9 \%$ & $3235761,8 \%$ \\
\hline INTERMEDIÁRIO & $2725734,0 \%$ & $1817234,7 \%$ \\
\hline RECOMENDADO & $24773,1 \%$ & $1788 \quad 3,4 \%$ \\
\hline Total & $80152100,0 \%$ & $52317100,0 \%$ \\
\hline
\end{tabular}

Fonte: Elaborado pelo autor. 
DESEMPENHO MÉDIO EM MATEMÁTICA DAS ESCOLAS CONTEMPLADAS (1) E NÃO CONTEMPLADAS (0) COM O "PROGRAMA POUPANÇA JOVEM PJ” DA REDE ESTADUAL DE MINAS GERAIS - PROEB 2007.

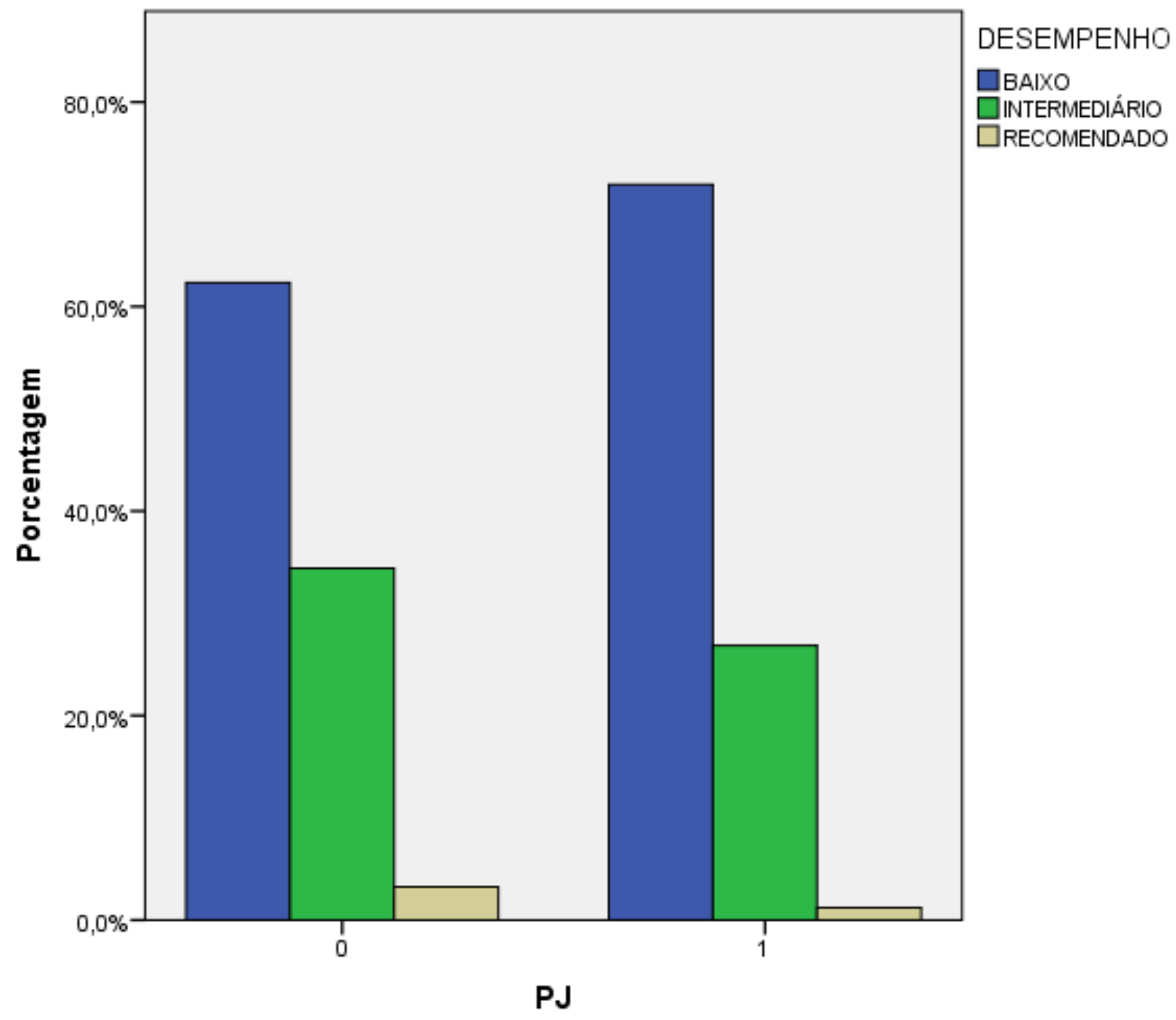

Fonte: Elaborado pelo autor.

DESEMPENHO MÉDIO EM MATEMÁTICA DAS ESCOLAS CONTEMPLADAS (1) E NÃO CONTEMPLADAS (0) COM O "PROGRAMA POUPANÇA JOVEM PJ” DA REDE ESTADUAL DE MINAS GERAIS - PROEB 2007.

\begin{tabular}{c|l|l|l|l}
\hline & \multicolumn{3}{|l|}{ PJ - Matemática - 2007 } \\
\cline { 2 - 6 } & 0 & \multicolumn{3}{l}{1} \\
\cline { 2 - 6 } & total & $\%$ & total & $\%$ \\
\hline BAIXO & 81224 & $62,3 \%$ & 1551 & $71,9 \%$ \\
DESEMPENHO INTERMEDIÁRIO & 44850 & $34,4 \%$ & 579 & $26,9 \%$ \\
RECOMENDADO & 4239 & $3,3 \%$ & 26 & $1,2 \%$ \\
Total & 130313 & $100,0 \%$ & 2156 & $100,0 \%$ \\
\hline
\end{tabular}

Fonte: Elaborado pelo autor. 
Matemática 2008

DESEMPENHO MÉDIO EM MATEMÁTICA DAS ESCOLAS CONTEMPLADAS (1) E NÃO CONTEMPLADAS (0) COM O PROJETO "ESCOLAS REFERÊNCIA ER" DA REDE ESTADUAL DE MINAS GERAIS - PROEB 2008.

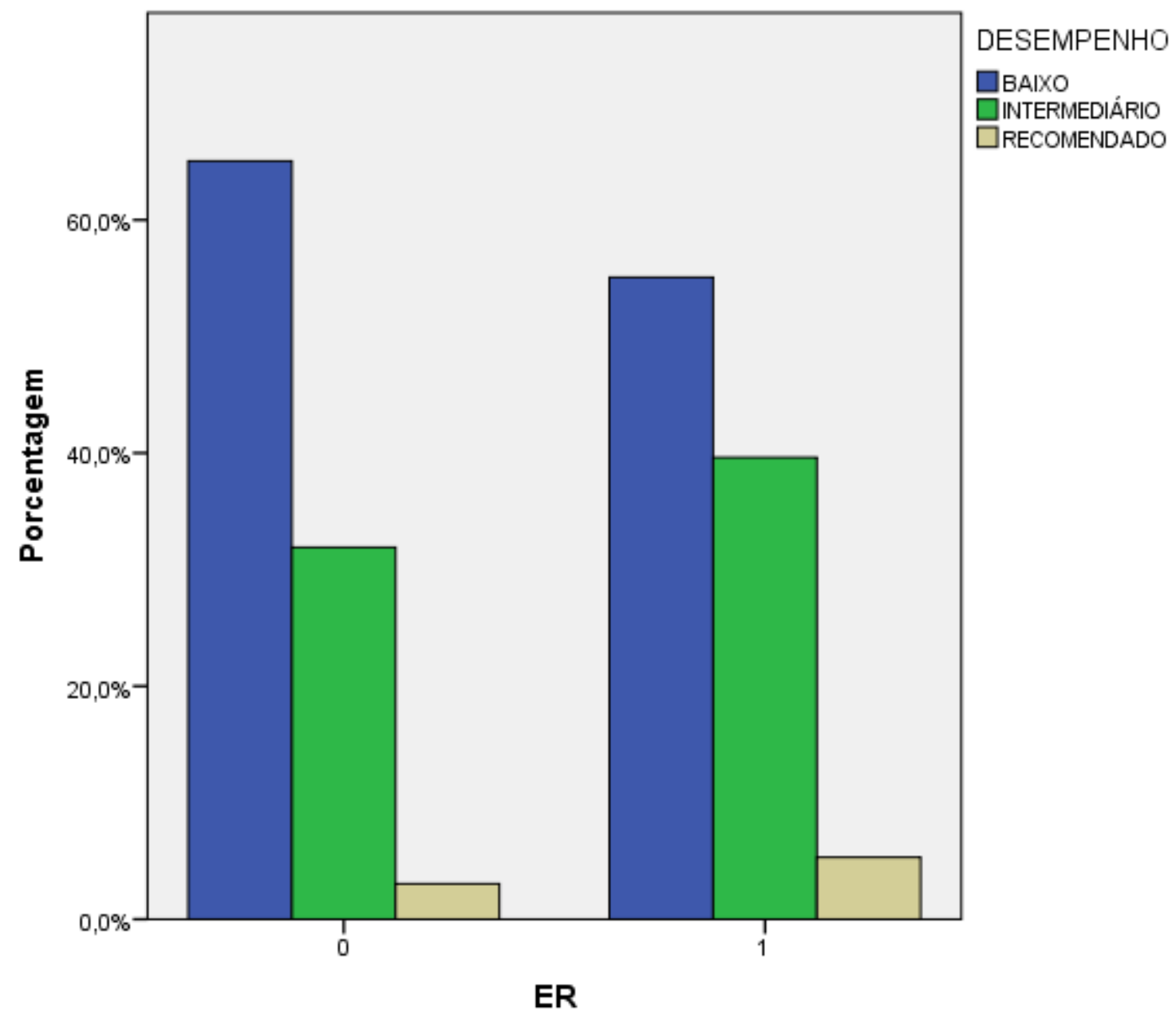

Fonte: Elaborado pelo autor.

DESEMPENHO MÉDIO EM MATEMÁTICA DAS ESCOLAS CONTEMPLADAS (1) E NÃO CONTEMPLADAS (0) COM O PROJETO "ESCOLAS REFERÊNCIA ER” DA REDE ESTADUAL DE MINAS GERAIS - PROEB 2008.

\begin{tabular}{|c|c|c|}
\hline & \multicolumn{2}{|c|}{ ER - Matemática - 2008} \\
\hline & 0 & 1 \\
\hline & \begin{tabular}{|l|l|} 
total & $\%$ \\
\end{tabular} & \begin{tabular}{|l|l|} 
total & $\%$ \\
\end{tabular} \\
\hline BAIXO & $6 1 9 5 4 \longdiv { 6 5 , 0 \% }$ & \begin{tabular}{|l|l}
25032 & $55,1 \%$
\end{tabular} \\
\hline DFSFMPFNHO INTERMEDIÁRIO & $3039031,9 \%$ & $1800239,6 \%$ \\
\hline RECOMENDADO & $29013,0 \%$ & $24145,3 \%$ \\
\hline Total & $95245100,0 \%$ & $45448100,0 \%$ \\
\hline
\end{tabular}

Fonte: Elaborado pelo autor. 
DESEMPENHO MÉDIO EM MATEMÁTICA DAS ESCOLAS CONTEMPLADAS (1) E NÃO CONTEMPLADAS (0) COM O "PROGRAMA DE DESENVOLVIMENTO PROFISSIONAL - PDP" DA REDE ESTADUAL DE MINAS GERAIS - PROEB 2008.

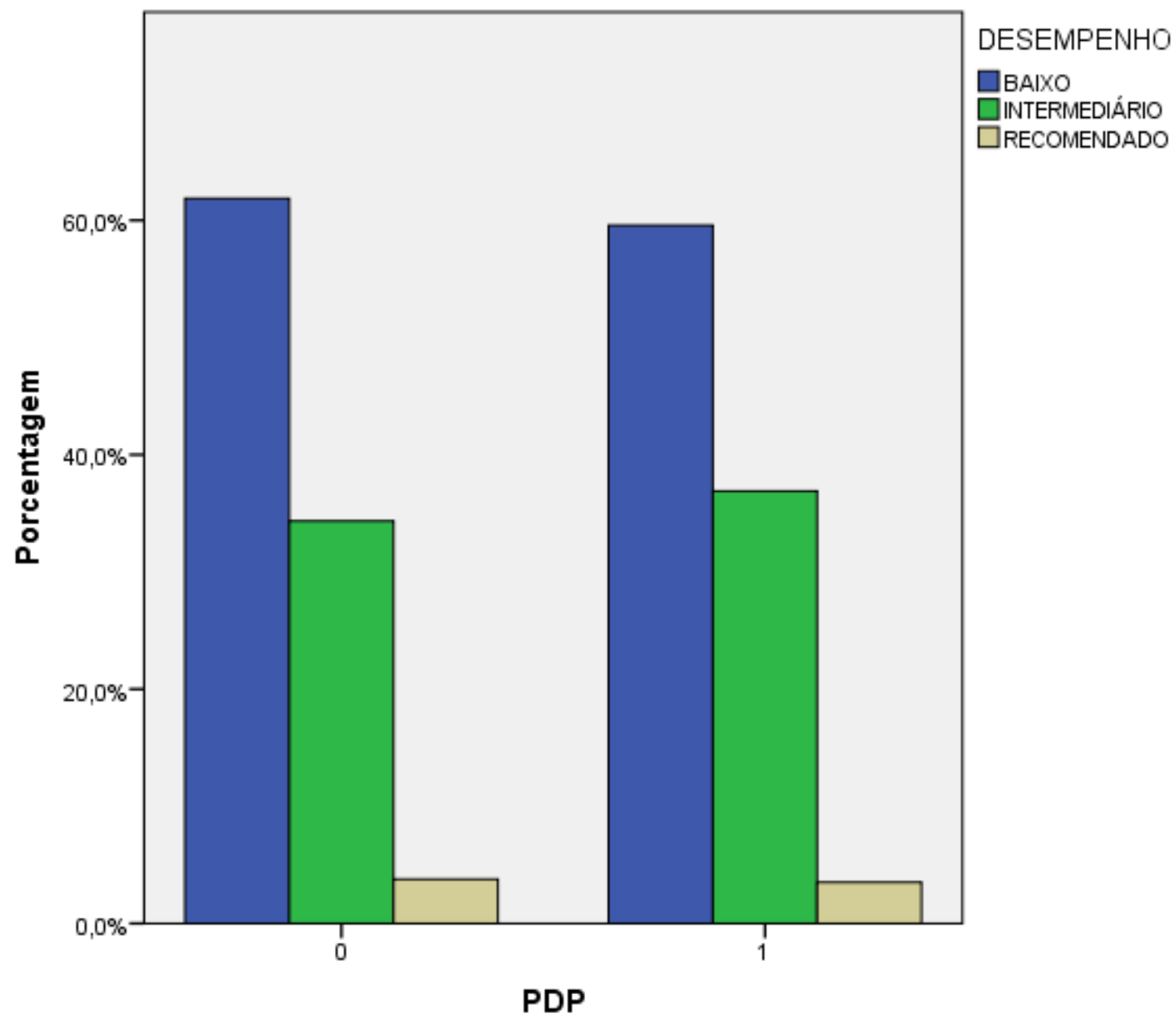

Fonte: Elaborado pelo autor.

DESEMPENHO MÉDIO EM MATEMÁTICA DAS ESCOLAS CONTEMPLADAS (1) E NÃO CONTEMPLADAS (0) COM O "PROGRAMA DE DESENVOLVIMENTO PROFISSIONAL - PDP” DA REDE ESTADUAL DE MINAS GERAIS - PROEB 2008.

\begin{tabular}{|c|c|c|c|}
\hline & \multicolumn{3}{|c|}{ PDP - Matemática - 2008} \\
\hline & \multicolumn{2}{|l|}{0} & \multirow{2}{*}{$\frac{1}{\text { total }} \%$} \\
\hline & total & $\%$ & \\
\hline BAIXO & 85050 & $61,9 \%$ & $1 9 3 6 \longdiv { 5 9 , 6 \% }$ \\
\hline DFSFMPFNHO INTERMEDIÁRIO & 47193 & $34,3 \%$ & $119936,9 \%$ \\
\hline RECOMENDADO & 5201 & $3,8 \%$ & $1143,5 \%$ \\
\hline Total & 13744 & $100,0 \%$ & $3249100,0 \%$ \\
\hline
\end{tabular}

Fonte: Elaborado pelo autor. 
DESEMPENHO MÉDIO EM MATEMÁTICA DAS ESCOLAS CONTEMPLADAS (1) E NÃO CONTEMPLADAS (0) COM O "PROGRAMA DE ATENÇÃO AO JOVEM - PEAS” DA REDE ESTADUAL DE MINAS GERAIS - PROEB 2008.

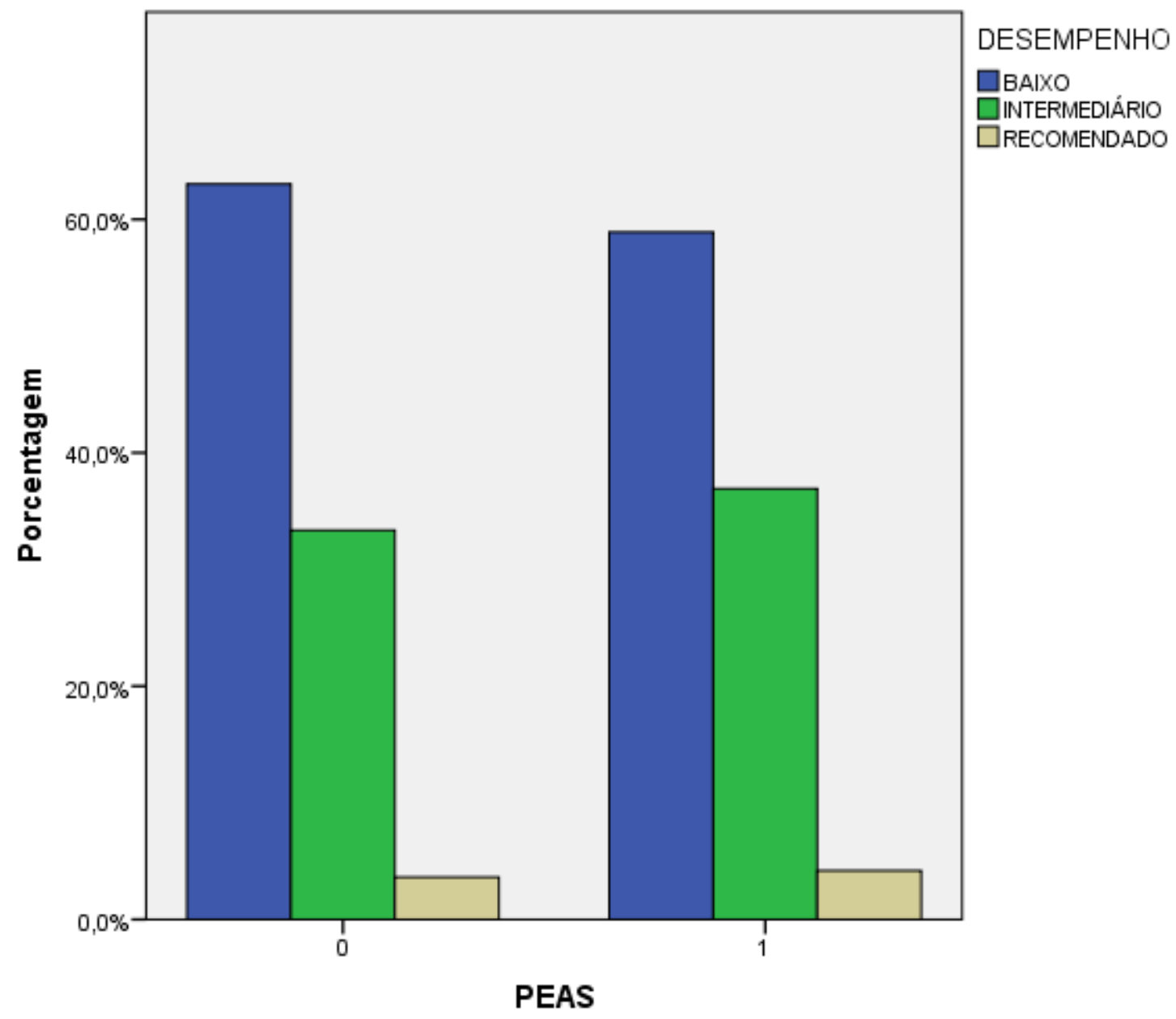

Fonte: Elaborado pelo autor.

DESEMPENHO MÉDIO EM MATEMÁTICA DAS ESCOLAS CONTEMPLADAS (1) E NÃO CONTEMPLADAS (0) COM O "PROGRAMA DE ATENÇÃO AO JOVEM - PEAS" DA REDE ESTADUAL DE MINAS GERAIS - PROEB 2008.

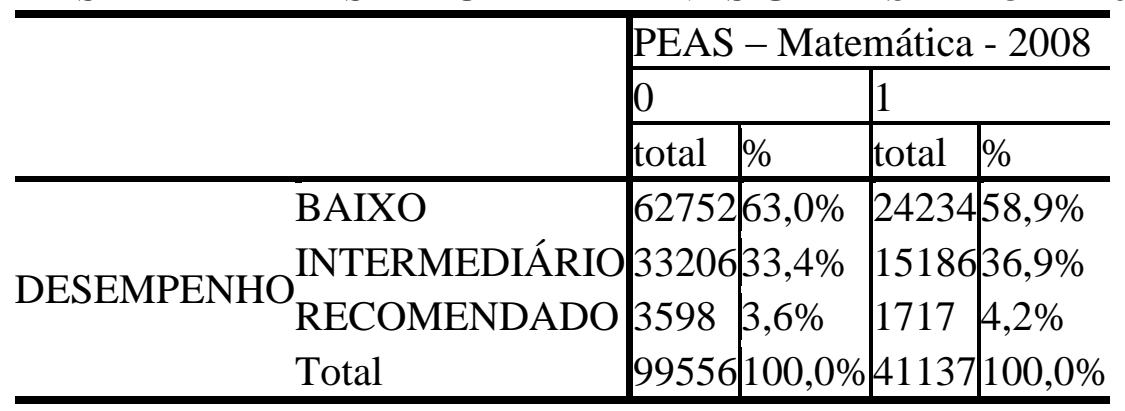

Fonte: Elaborado pelo autor. 
DESEMPENHO MÉDIO EM MATEMÁTICA DAS ESCOLAS CONTEMPLADAS (1) E NÃO CONTEMPLADAS (0) COM O PROGRAMA "FORMAÇÃO INICIAL PARA O TRABALHO - FIT" DA REDE ESTADUAL DE MINAS GERAIS - PROEB 2008.

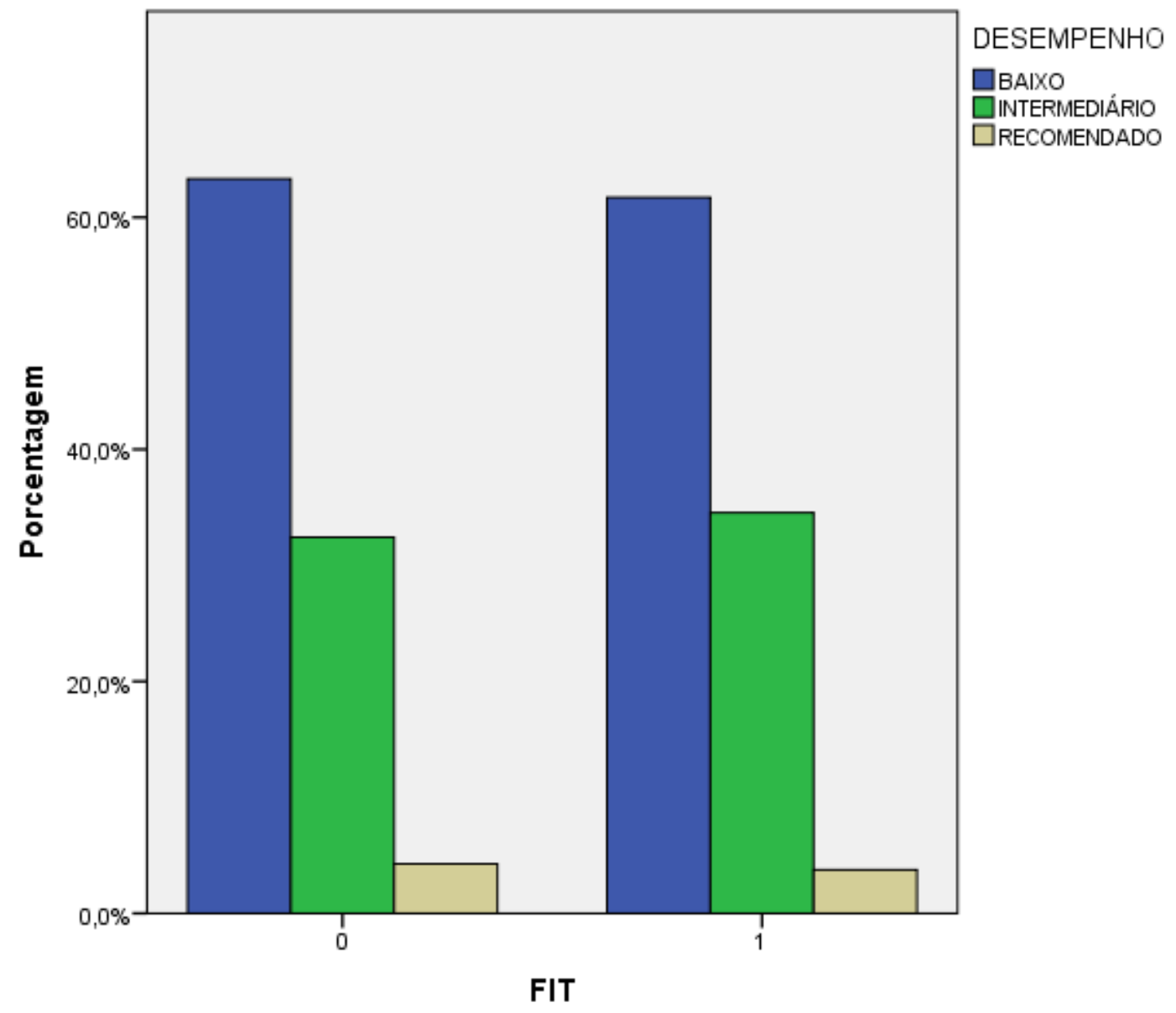

Fonte: Elaborado pelo autor.

DESEMPENHO MÉDIO EM MATEMÁTICA DAS ESCOLAS CONTEMPLADAS (1) E NÃO CONTEMPLADAS (0) COM O PROGRAMA "FORMAÇÃO INICIAL PARA O TRABALHO - FIT" DA REDE ESTADUAL DE MINAS GERAIS - PROEB 2008.

\begin{tabular}{c|l|l|l|l}
\hline & \multicolumn{3}{|l}{ FIT - Matemática - 2008 } \\
\cline { 2 - 5 } & 0 & \multicolumn{1}{l}{1} \\
\cline { 2 - 5 } & total & $\%$ & total & $\%$ \\
\hline BAIXO & 5827 & $63,3 \%$ & 81159 & $61,7 \%$ \\
DESEMPENHO INTERMEDIÁRIO & 2983 & $32,4 \%$ & 45409 & $34,5 \%$ \\
RECOMENDADO & 392 & $4,3 \%$ & 4923 & $3,7 \%$ \\
Total & 9202 & $100,0 \%$ & 131491 & $100,0 \%$ \\
\hline
\end{tabular}

Fonte: Elaborado pelo autor. 
DESEMPENHO MÉDIO EM MATEMÁTICA DAS ESCOLAS CONTEMPLADAS (1) E NÃO CONTEMPLADAS (0) COM O "PROGRAMA DE EDUCAÇÃO PROFISSIONAL - PEP” DA REDE ESTADUAL DE MINAS GERAIS - PROEB 2008.

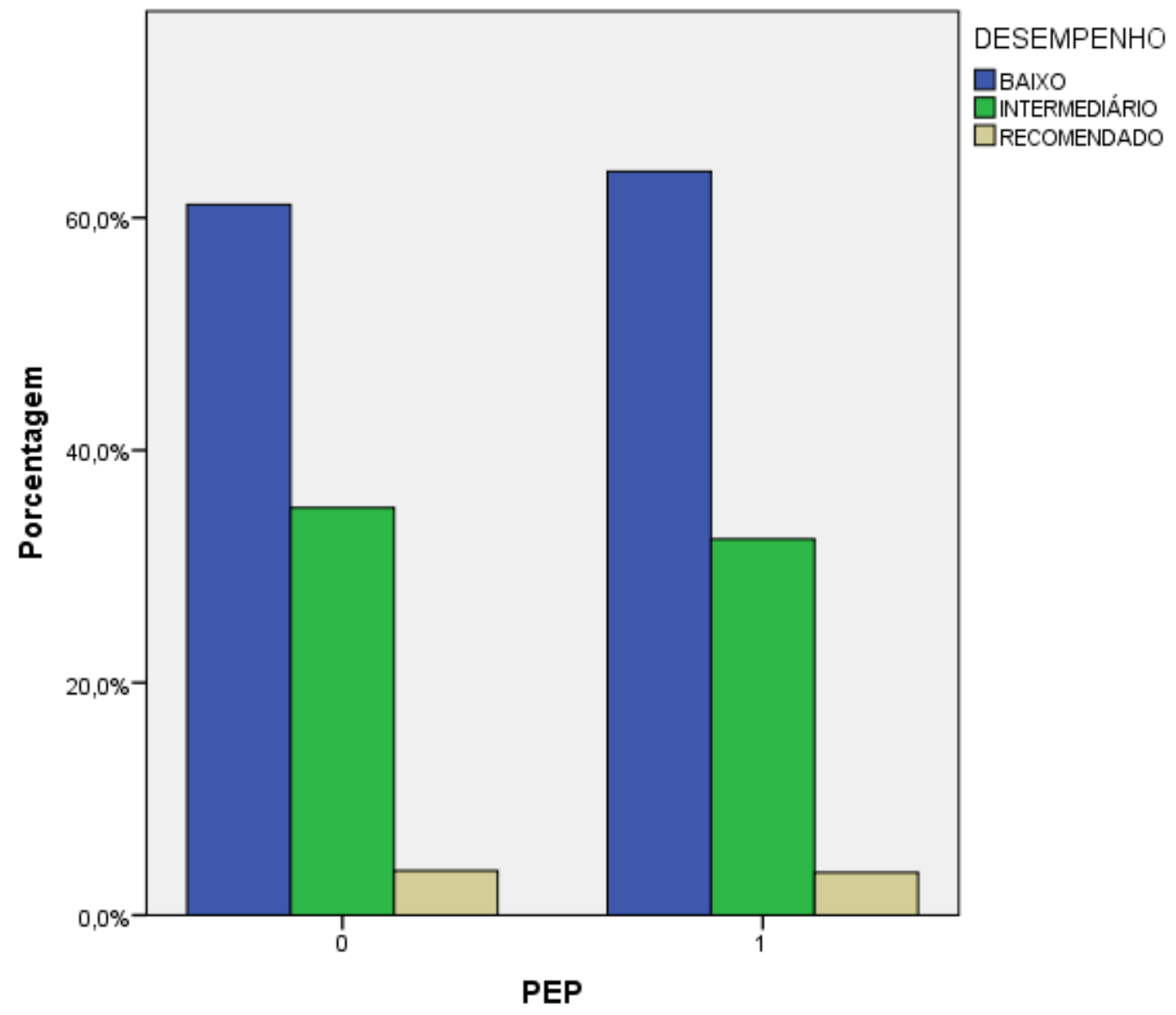

Fonte: Elaborado pelo autor.

DESEMPENHO MÉDIO EM MATEMÁTICA DAS ESCOLAS CONTEMPLADAS (1) E NÃO CONTEMPLADAS (0) COM O "PROGRAMA DE EDUCAÇ̃̃O PROFISSIONAL - PEP” DA REDE ESTADUAL DE MINAS GERAIS - PROEB 2008.

\begin{tabular}{c|l|l|l|l}
\hline & \multicolumn{3}{|l}{ PEP - Matemática - 2008 } \\
\cline { 2 - 5 } & 0 & \multicolumn{3}{l}{} \\
\cline { 2 - 5 } & total & $\%$ & total & $\%$ \\
\hline BAIXO & 65177 & $61,1 \%$ & 21809 & $64,0 \%$ \\
DESEMPENHO INTERMEDIÁRIO & 37365 & $35,0 \%$ & 11027 & $32,4 \%$ \\
RECOMENDADO & 4065 & $3,8 \%$ & 1250 & $3,7 \%$ \\
Total & 106607 & $100,0 \%$ & 34086 & $100,0 \%$ \\
\hline
\end{tabular}

Fonte: Elaborado pelo autor. 
DESEMPENHO MÉDIO EM MATEMÁTICA DAS ESCOLAS CONTEMPLADAS (1) E NÃO CONTEMPLADAS (0) COM O "PROGRAMA POUPANÇA JOVEM PJ” DA REDE ESTADUAL DE MINAS GERAIS - PROEB 2008.

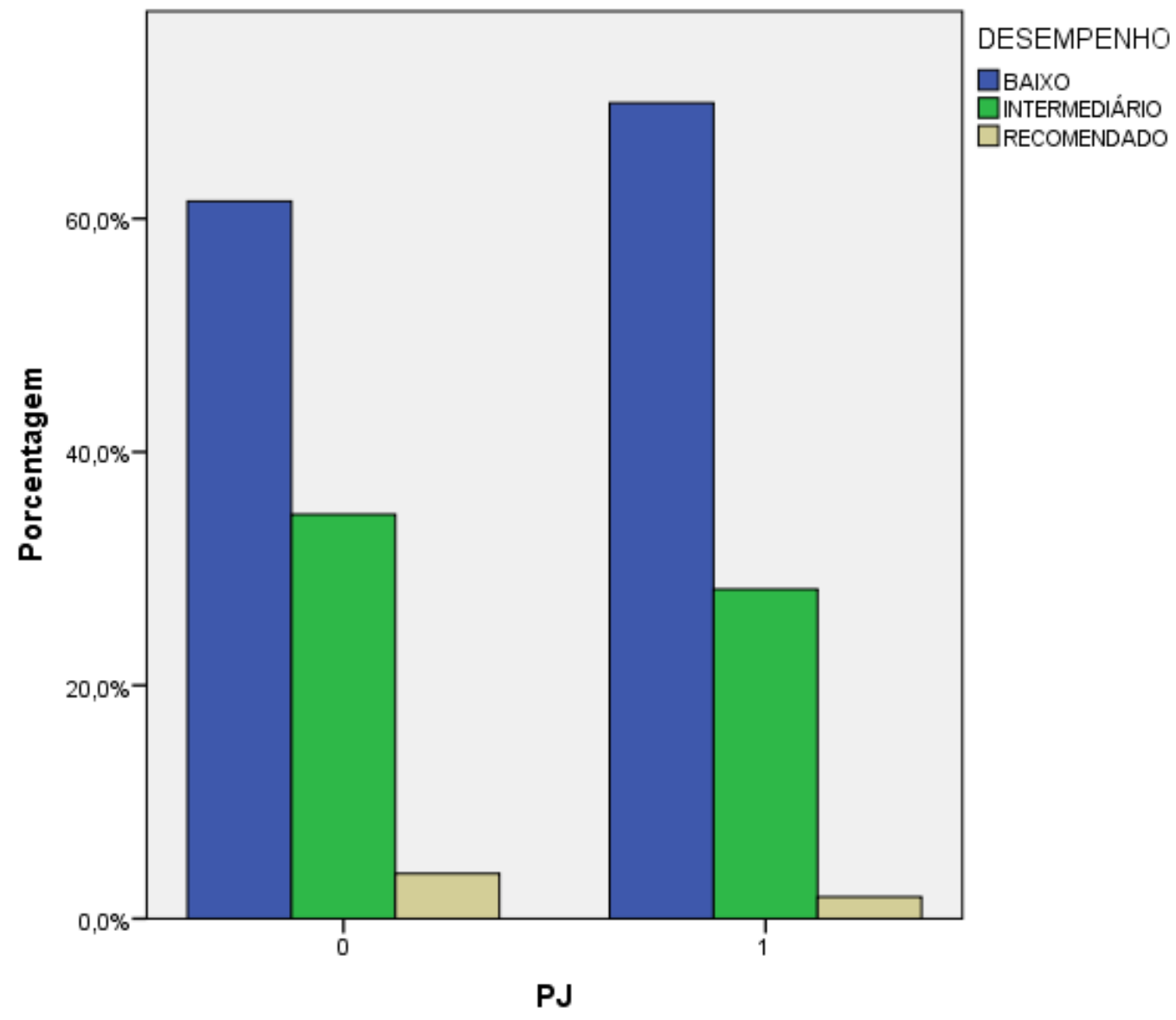

Fonte: Elaborado pelo autor.

DESEMPENHO MÉDIO EM MATEMÁTICA DAS ESCOLAS CONTEMPLADAS (1) E NÃO CONTEMPLADAS (0) COM O "PROGRAMA POUPANÇA JOVEM PJ" DA REDE ESTADUAL DE MINAS GERAIS - PROEB 2008.

\begin{tabular}{c|l|l|l|l}
\hline & \multicolumn{3}{|l}{ PJ - Matemática - 2008 } \\
\cline { 2 - 5 } & 0 & \multicolumn{3}{l}{1} \\
\cline { 2 - 5 } & total & $\%$ & total & $\%$ \\
\hline BAIXO & 83146 & $61,5 \%$ & 3840 & $69,9 \%$ \\
DESEMPENHO INTERMEDIÁRIO & 46841 & $34,6 \%$ & 1551 & $28,2 \%$ \\
RECOMENDADO & 5213 & $3,9 \%$ & 102 & $1,9 \%$ \\
Total & 135200 & $100,0 \%$ & 5493 & $100,0 \%$ \\
\hline
\end{tabular}

Fonte: Elaborado pelo autor. 
Matemática 2009

DESEMPENHO MÉDIO EM MATEMÁTICA DAS ESCOLAS CONTEMPLADAS (1) E NÃO CONTEMPLADAS (0) COM O PROJETO "ESCOLAS REFERÊNCIA ER” DA REDE ESTADUAL DE MINAS GERAIS - PROEB 2009.

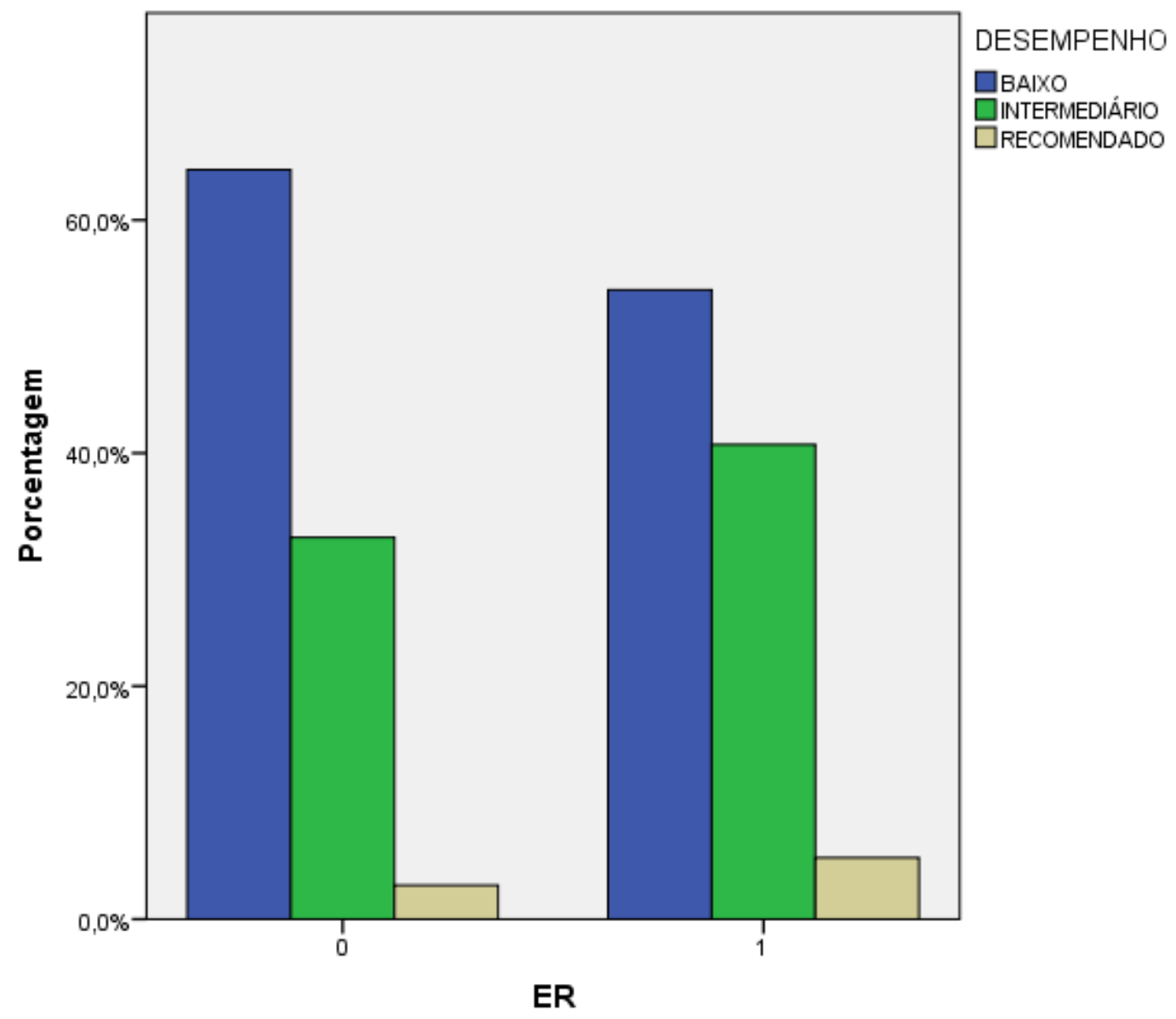

Fonte: Elaborado pelo autor.

DESEMPENHO MÉDIO EM MATEMÁTICA DAS ESCOLAS CONTEMPLADAS (1) E NÃO CONTEMPLADAS (0) COM O PROJETO "ESCOLAS REFERÊNCIA ER" DA REDE ESTADUAL DE MINAS GERAIS - PROEB 2009.

\begin{tabular}{c|l|l|l|l}
\hline & \multicolumn{3}{|l}{ ER - Matemática - 2009 } \\
\cline { 2 - 5 } & 0 & \multicolumn{3}{l}{1} \\
\cline { 2 - 5 } & total & $\%$ & total & $\%$ \\
\hline BAIXO & 66875 & $64,3 \%$ & 26020 & $54,0 \%$ \\
DESEMPENHO INTERMEDIÁRIO & 34048 & $32,8 \%$ & 19617 & $40,7 \%$ \\
RECOMENDADO & 3031 & $2,9 \%$ & 2535 & $5,3 \%$ \\
Total & 103954 & $100,0 \%$ & 48172 & $100,0 \%$ \\
\hline
\end{tabular}

Fonte: Elaborado pelo autor. 
DESEMPENHO MÉDIO EM MATEMÁTICA DAS ESCOLAS CONTEMPLADAS

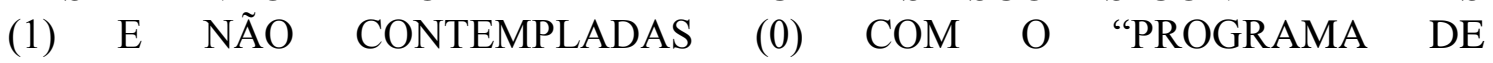
DESENVOLVIMENTO PROFISSIONAL - PDP" DA REDE ESTADUAL DE MINAS GERAIS - PROEB 2009.

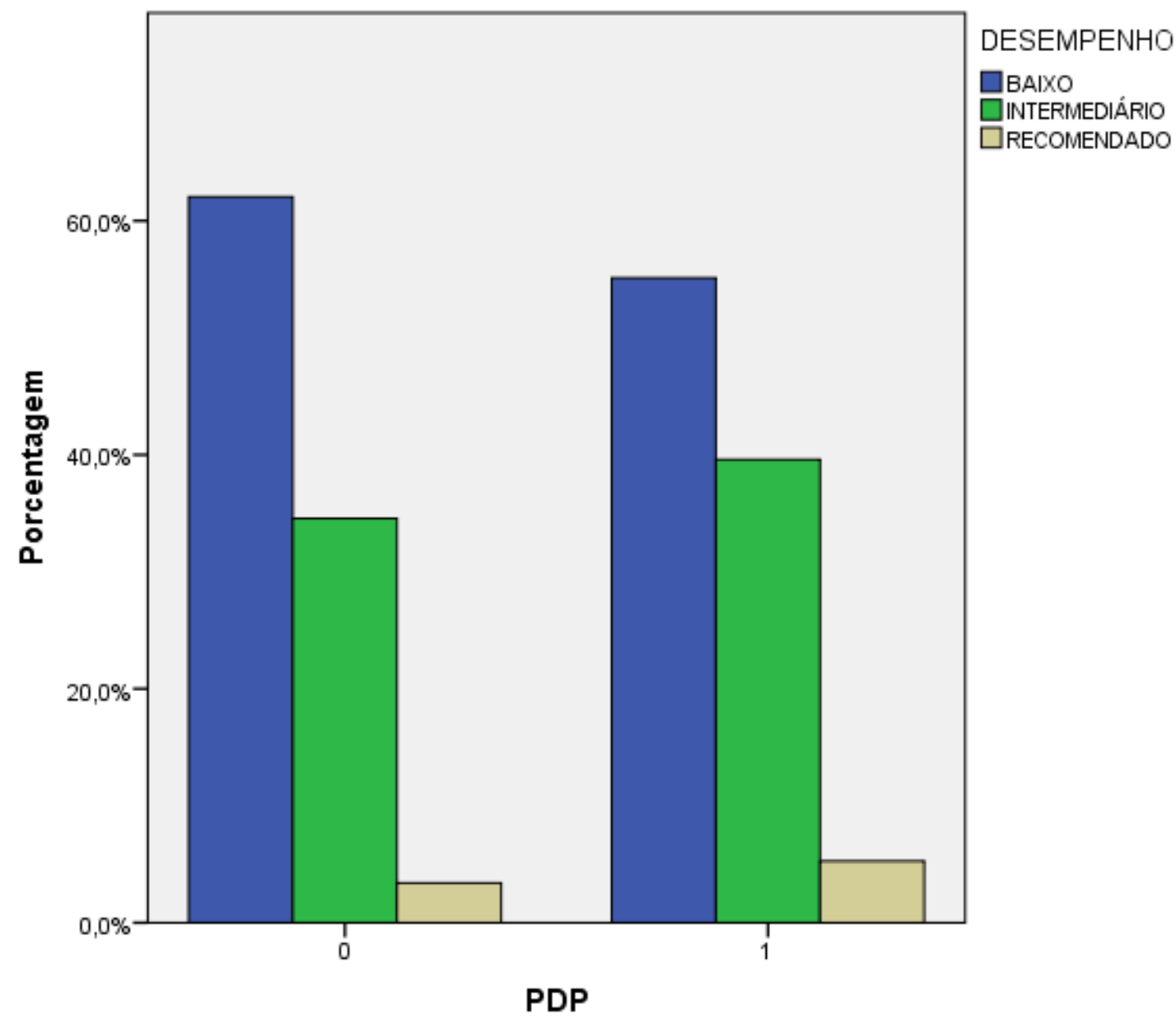

Fonte: Elaborado pelo autor.

DESEMPENHO MÉDIO EM MATEMÁTICA DAS ESCOLAS CONTEMPLADAS (1) E NÃO CONTEMPLADAS (0) COM O "PROGRAMA DE DESENVOLVIMENTO PROFISSIONAL - PDP" DA REDE ESTADUAL DE MINAS GERAIS - PROEB 2009.

\begin{tabular}{c|l|l|l|l}
\hline & \multicolumn{4}{|l}{ PDP - Matemática - 2009 } \\
\cline { 2 - 6 } & 0 & \multicolumn{3}{l}{1} \\
\cline { 2 - 6 } & total & $\%$ & total & $\%$ \\
\hline BAIXO & 81031 & $62,0 \%$ & 11864 & $55,1 \%$ \\
DESEMPENHO INTERMEDIÁRIO & 45143 & $34,6 \%$ & 8522 & $39,6 \%$ \\
RECOMENDADO & 4433 & $3,4 \%$ & 1133 & $5,3 \%$ \\
Total & 130607 & $100,0 \%$ & 21519 & $100,0 \%$ \\
\hline
\end{tabular}

Fonte: Elaborado pelo autor. 
DESEMPENHO MÉDIO EM MATEMÁTICA DAS ESCOLAS CONTEMPLADAS (1) E NÃO CONTEMPLADAS (0) COM O "PROGRAMA DE ATENÇÃO AO JOVEM - PEAS” DA REDE ESTADUAL DE MINAS GERAIS - PROEB 2009.

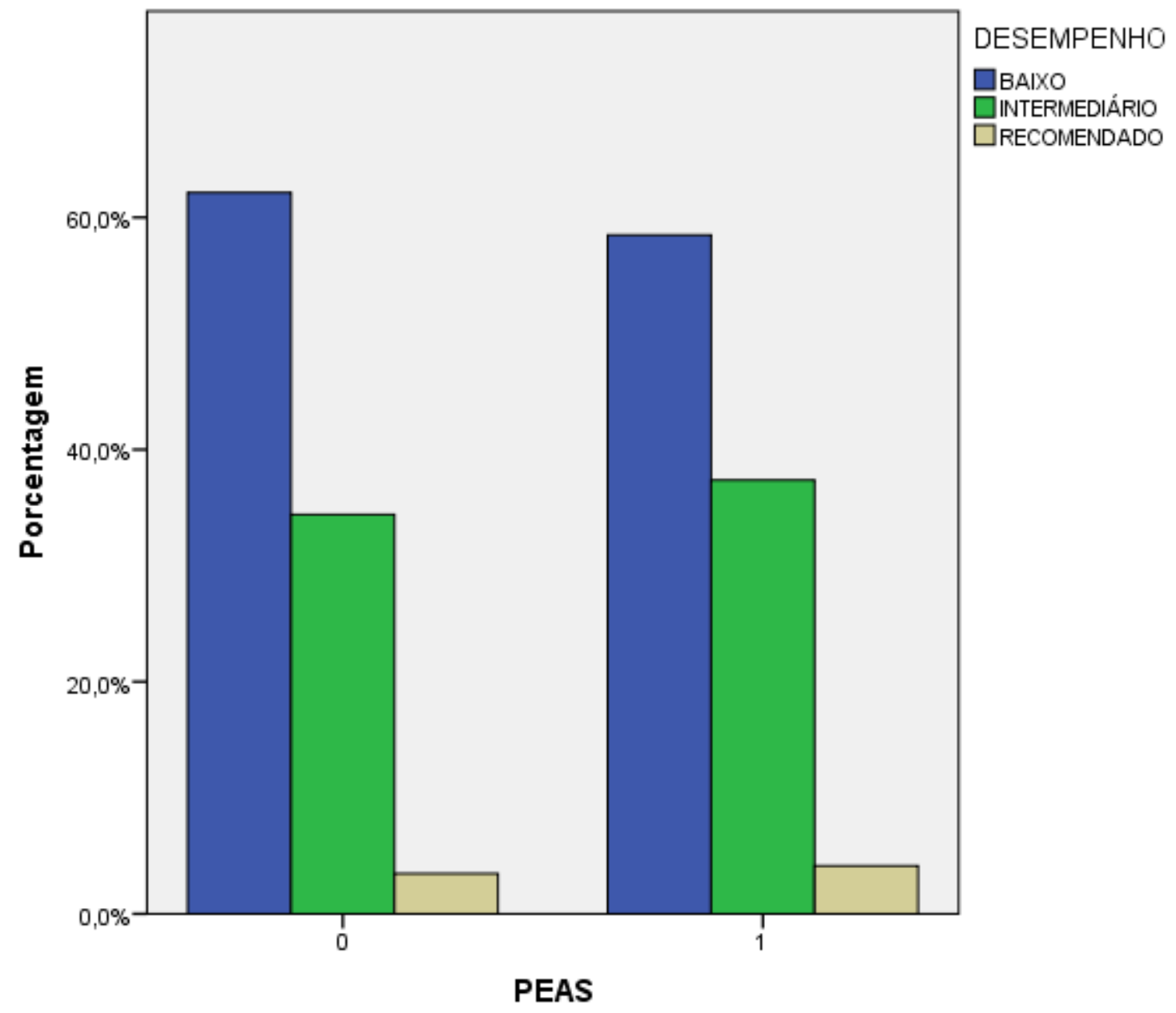

Fonte: Elaborado pelo autor.

DESEMPENHO MÉDIO EM MATEMÁTICA DAS ESCOLAS CONTEMPLADAS (1) E NÃO CONTEMPLADAS (0) COM O "PROGRAMA DE ATENÇÃO AO JOVEM - PEAS” DA REDE ESTADUAL DE MINAS GERAIS - PROEB 2009.

\begin{tabular}{c|l|l|l|l}
\hline \multirow{2}{*}{} & \multicolumn{4}{|l|}{ PEAS - Matemática - 2009 } \\
\cline { 2 - 5 } & 0 & \multicolumn{3}{l}{1} \\
\cline { 2 - 6 } & total & $\%$ & total & $\%$ \\
\hline BAIXO & 66719 & $62,1 \%$ & 26176 & $58,5 \%$ \\
DESEMPENHO INTERMEDIÁRIO & 36940 & $34,4 \%$ & 16725 & $37,4 \%$ \\
RECOMENDADO & 3718 & $3,5 \%$ & 1848 & $4,1 \%$ \\
Total & 107377 & $100,0 \%$ & 44749 & $100,0 \%$ \\
\hline
\end{tabular}

Fonte: Elaborado pelo autor. 
DESEMPENHO MÉDIO EM MATEMÁTICA DAS ESCOLAS CONTEMPLADAS (1) E NÃO CONTEMPLADAS (0) COM O PROGRAMA "FORMAÇÃO INICIAL PARA O TRABALHO - FIT” DA REDE ESTADUAL DE MINAS GERAIS - PROEB 2009.

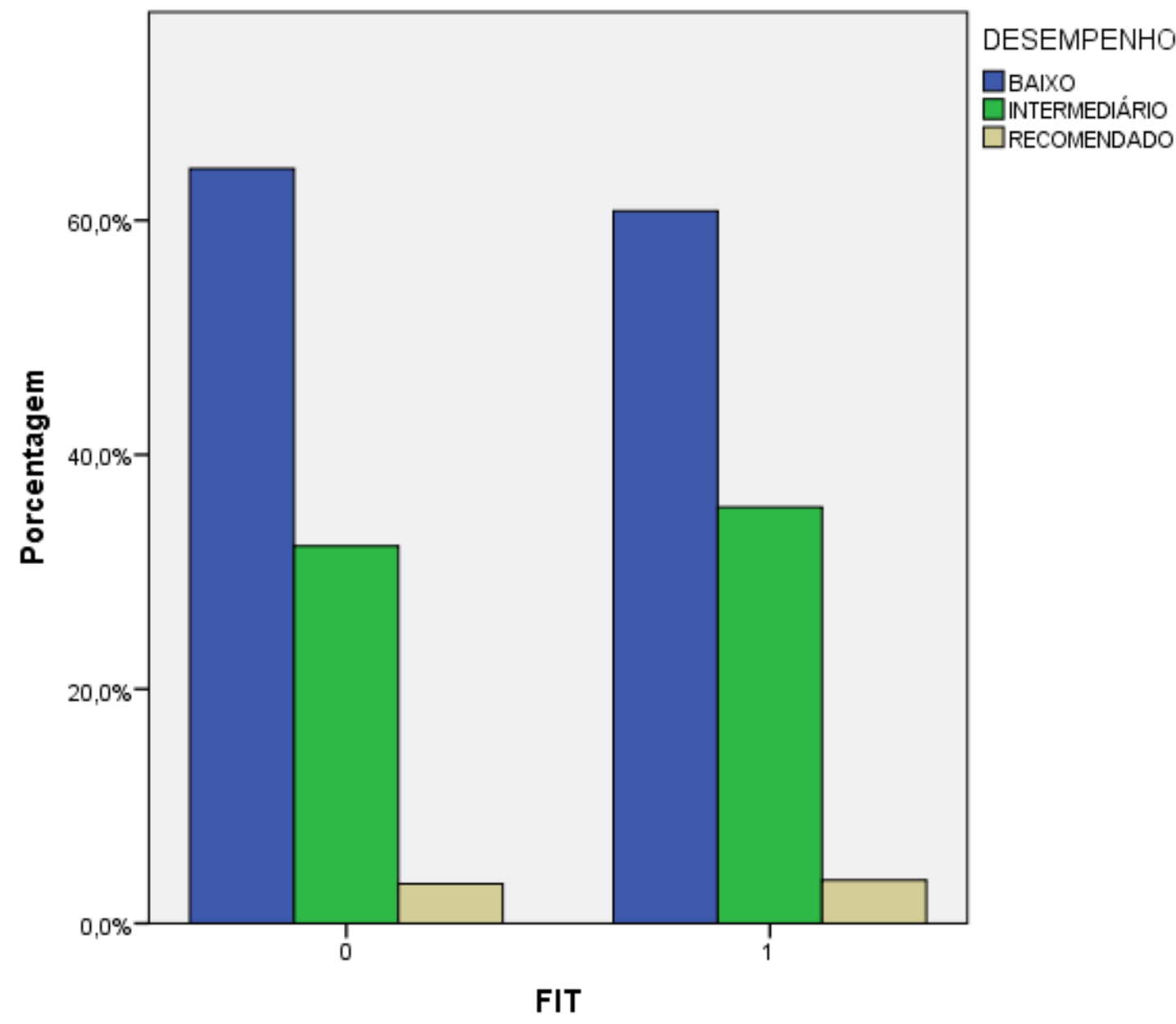

Fonte: Elaborado pelo autor.

DESEMPENHO MÉDIO EM MATEMÁTICA DAS ESCOLAS CONTEMPLADAS (1) E NÃO CONTEMPLADAS (0) COM O PROGRAMA "FORMAÇÃO INICIAL PARA O TRABALHO - FIT" DA REDE ESTADUAL DE MINAS GERAIS - PROEB 2009.

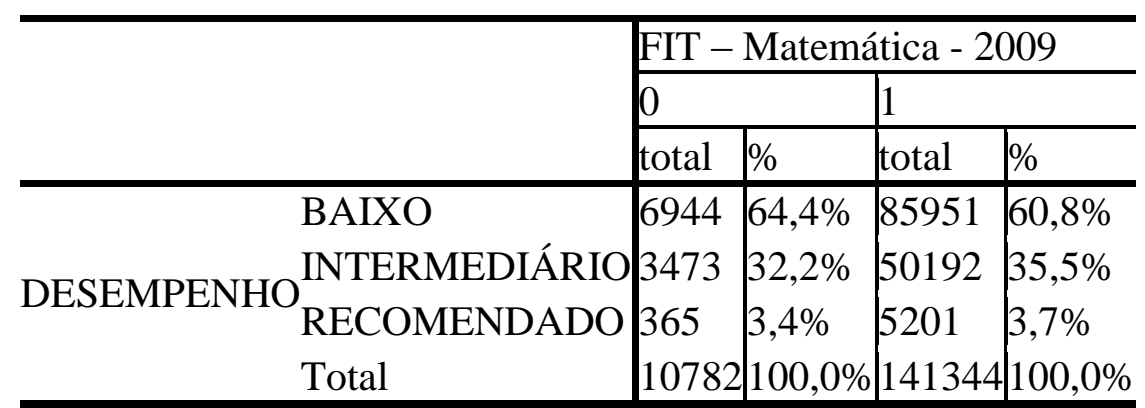

Fonte: Elaborado pelo autor. 
DESEMPENHO MÉDIO EM MATEMÁTICA DAS ESCOLAS CONTEMPLADAS (1) E NÃO CONTEMPLADAS (0) COM O "PROGRAMA DE EDUCAÇÃO PROFISSIONAL - PEP” DA REDE ESTADUAL DE MINAS GERAIS - PROEB 2009.

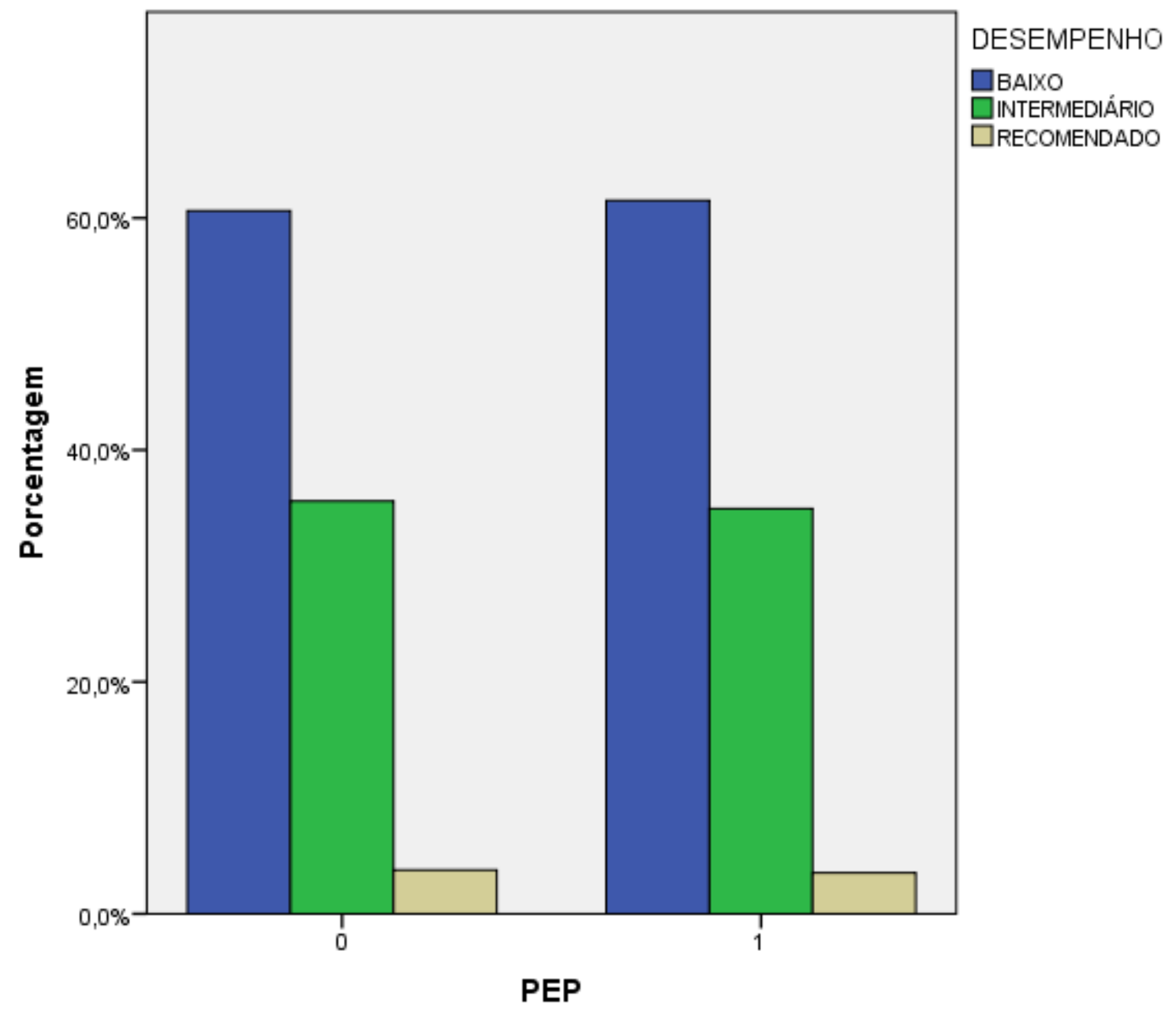

Fonte: Elaborado pelo autor.

DESEMPENHO MÉDIO EM MATEMÁTICA DAS ESCOLAS CONTEMPLADAS (1) E NÃO CONTEMPLADAS (0) COM O "PROGRAMA DE EDUCAÇÃO PROFISSIONAL - PEP” DA REDE ESTADUAL DE MINAS GERAIS - PROEB 2009.

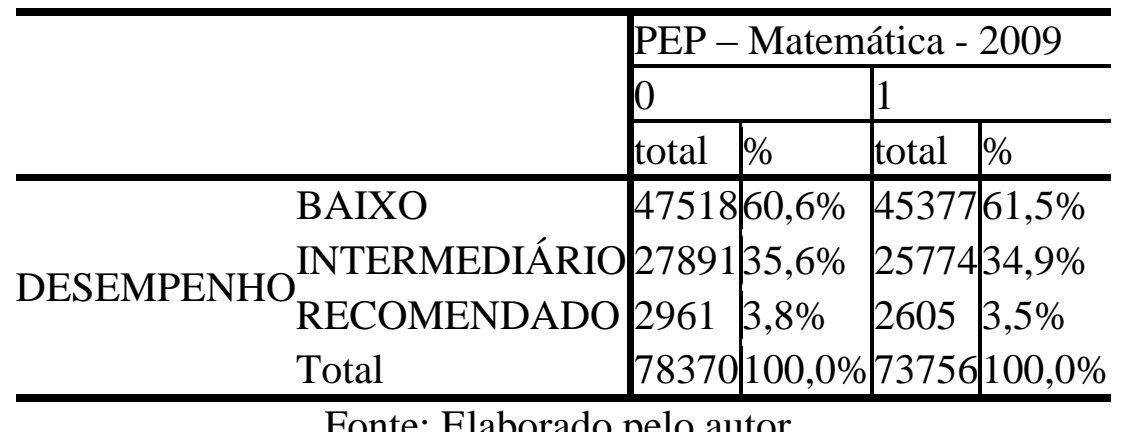

Fonte: Elaborado pelo autor. 
DESEMPENHO MÉDIO EM MATEMÁTICA DAS ESCOLAS CONTEMPLADAS (1) E NÃO CONTEMPLADAS (0) COM O "PROGRAMA POUPANÇA JOVEM PJ” DA REDE ESTADUAL DE MINAS GERAIS - PROEB 2009.

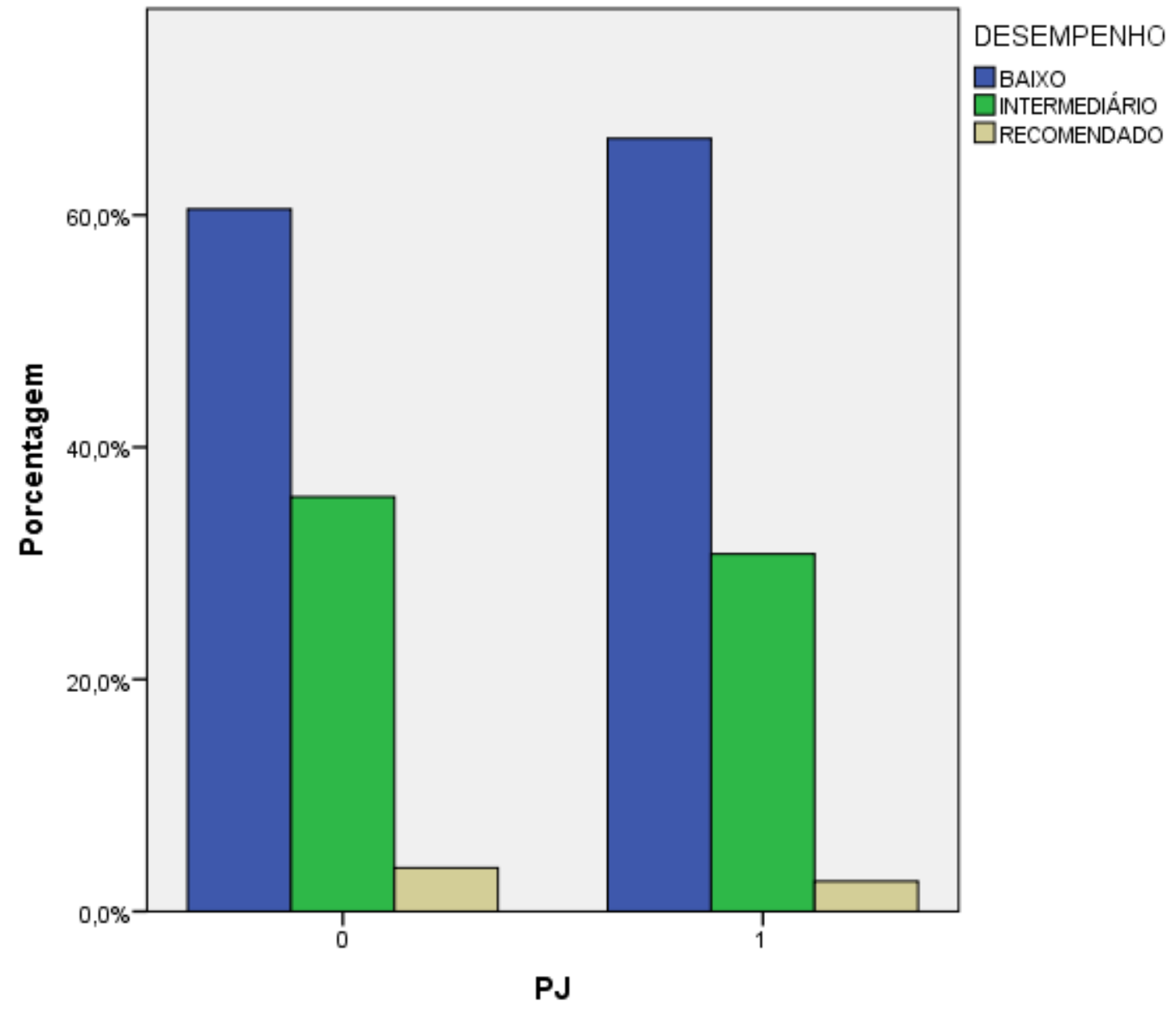

Fonte: Elaborado pelo autor.

DESEMPENHO MÉDIO EM MATEMÁTICA DAS ESCOLAS CONTEMPLADAS (1) E NÃO CONTEMPLADAS (0) COM O "PROGRAMA POUPANÇA JOVEM PJ" DA REDE ESTADUAL DE MINAS GERAIS - PROEB 2009.

\begin{tabular}{c|l|l|l|l}
\hline & \multicolumn{3}{|l}{ PJ - Matemática - 2009 } \\
\cline { 2 - 6 } & 0 & \multicolumn{3}{l}{1} \\
\cline { 2 - 6 } & total & $\%$ & total & $\%$ \\
\hline BAIXO & 83789 & $60,5 \%$ & 9106 & $66,6 \%$ \\
DESEMPENHO INTERMEDIÁRIO & 49455 & $35,7 \%$ & 4210 & $30,8 \%$ \\
RECOMENDADO & 5210 & $3,8 \%$ & 356 & $2,6 \%$ \\
Total & 138454 & $100,0 \%$ & 13672 & $100,0 \%$ \\
\hline
\end{tabular}

Fonte: Elaborado pelo autor. 
Matemática 2010

DESEMPENHO MÉDIO EM MATEMÁTICA DAS ESCOLAS CONTEMPLADAS (1) E NÃO CONTEMPLADAS (0) COM O PROJETO "ESCOLAS REFERÊNCIA ER" DA REDE ESTADUAL DE MINAS GERAIS - PROEB 2010.

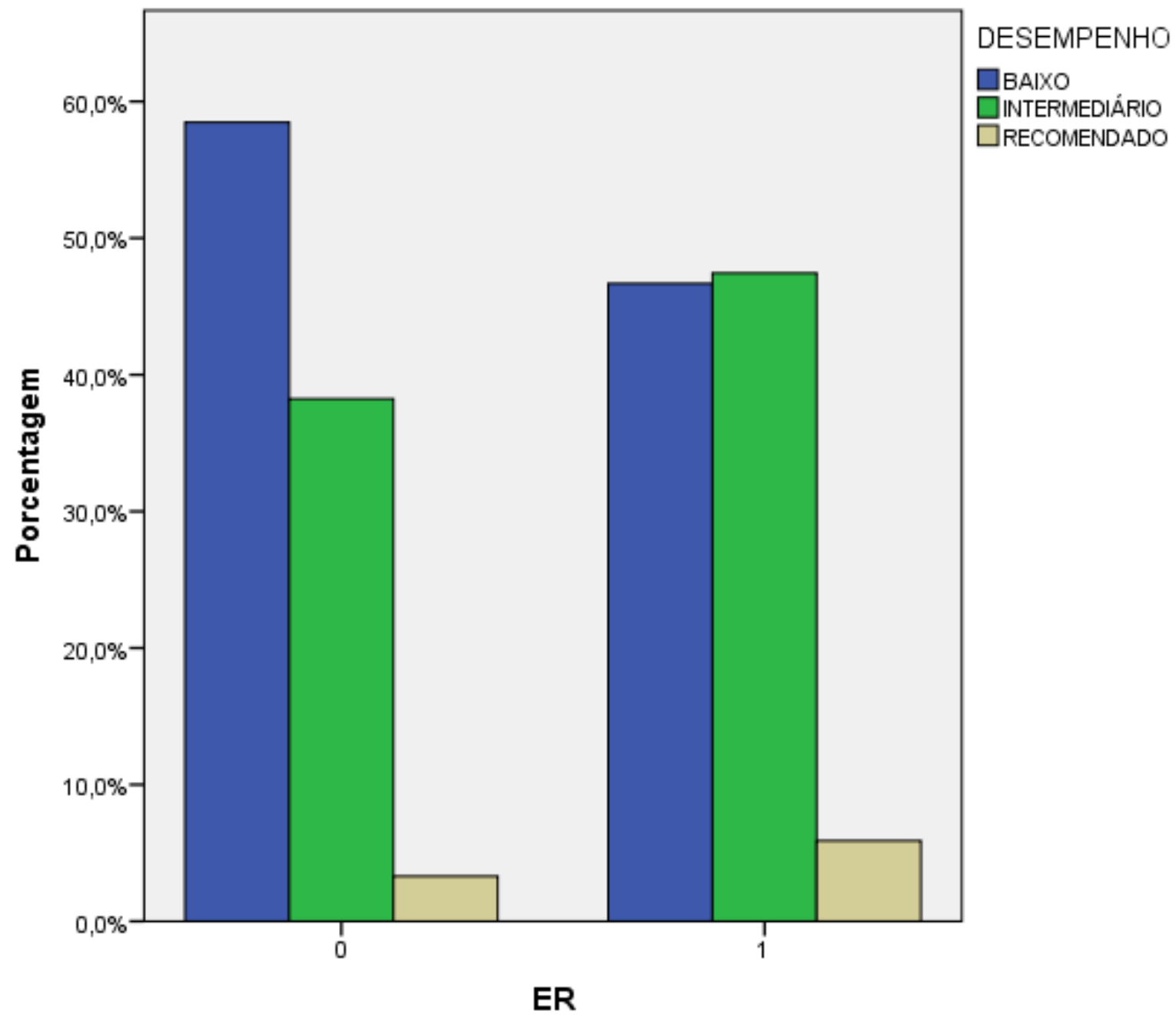

Fonte: Elaborado pelo autor.

DESEMPENHO MÉDIO EM MATEMÁTICA DAS ESCOLAS CONTEMPLADAS (1) E NÃO CONTEMPLADAS (0) COM O PROJETO "ESCOLAS REFERÊNCIA ER” DA REDE ESTADUAL DE MINAS GERAIS - PROEB 2010.

\begin{tabular}{c|l|l|l|l}
\hline \multirow{2}{*}{} & \multicolumn{3}{|l|}{ ER - Matemática - 2010 } \\
\cline { 2 - 5 } & 0 & \multicolumn{3}{l}{1} \\
\cline { 2 - 5 } & total & $\%$ & total & $\%$ \\
\hline BAIXO & 60395 & $58,5 \%$ & 21487 & $46,7 \%$ \\
DESEMPENHO INTERMEDIÁRIO & 39481 & $38,2 \%$ & 21835 & $47,4 \%$ \\
RECOMENDADO & 3400 & $3,3 \%$ & 2709 & $5,9 \%$ \\
Total & 103276 & $100,0 \%$ & 46031 & $100,0 \%$ \\
\hline
\end{tabular}

Fonte: Elaborado pelo autor. 
DESEMPENHO MÉDIO EM MATEMÁTICA DAS ESCOLAS CONTEMPLADAS

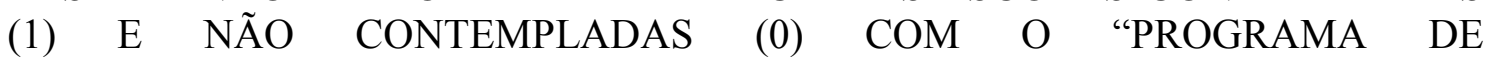
DESENVOLVIMENTO PROFISSIONAL - PDP" DA REDE ESTADUAL DE MINAS GERAIS - PROEB 2010.

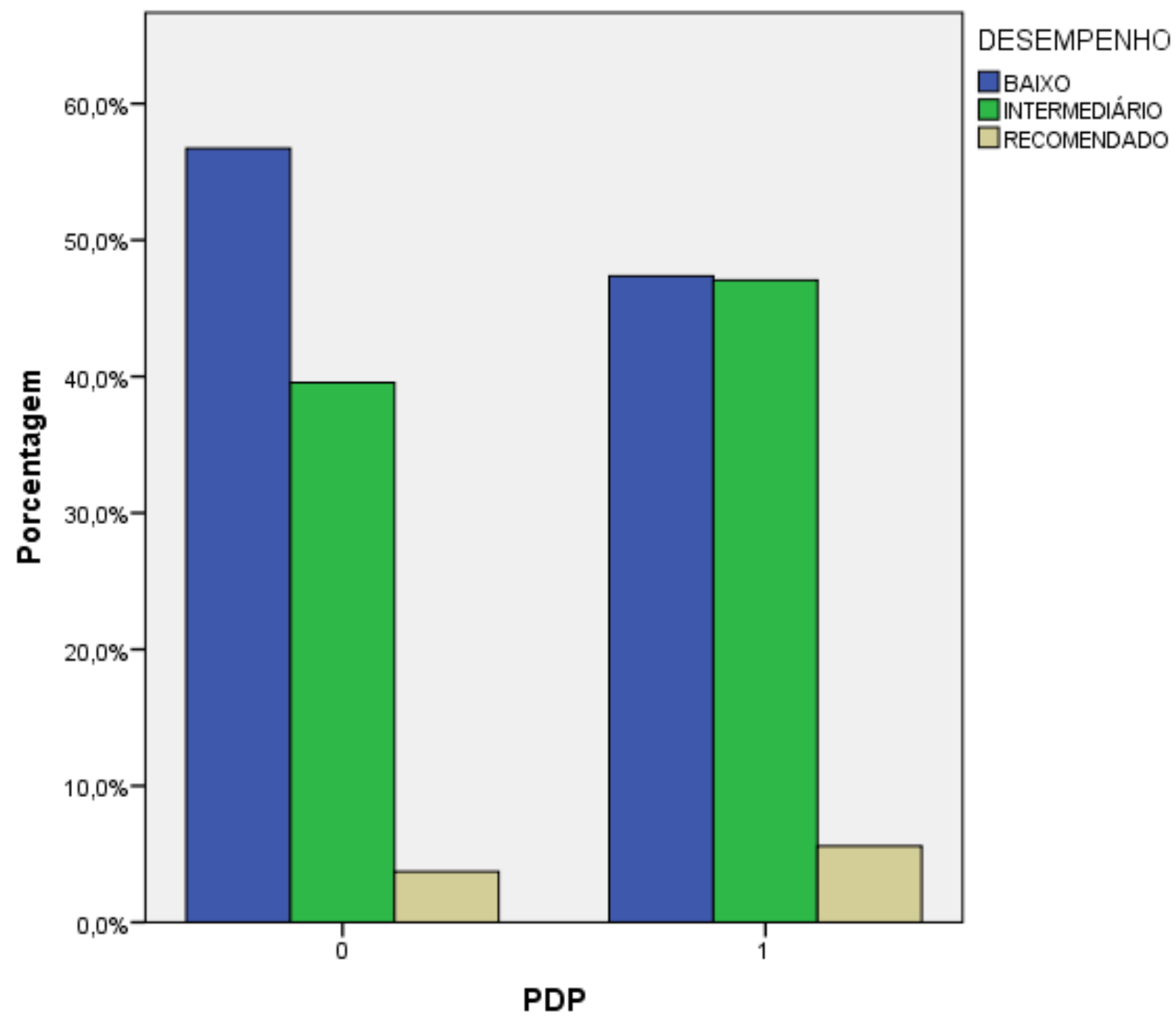

Fonte: Elaborado pelo autor.

DESEMPENHO MÉDIO EM MATEMÁTICA DAS ESCOLAS CONTEMPLADAS (1) E NÃO CONTEMPLADAS (0) COM O "PROGRAMA DE DESENVOLVIMENTO PROFISSIONAL - PDP" DA REDE ESTADUAL DE MINAS GERAIS - PROEB 2010.

\begin{tabular}{c|l|l|l|l}
\hline & \multicolumn{3}{|l}{ PDP - Matemática - 2010 } \\
\cline { 2 - 5 } & 0 & \multicolumn{3}{l}{1} \\
\cline { 2 - 5 } & total & $\%$ & total & $\%$ \\
\hline BAIXO & 67678 & $56,7 \%$ & 14204 & $47,4 \%$ \\
DESEMPENHO INTERMEDIÁRIO & 47201 & $39,6 \%$ & 14115 & $47,1 \%$ \\
RECOMENDADO & 4433 & $3,7 \%$ & 1676 & $5,6 \%$ \\
Total & 119312 & $100,0 \%$ & 29995 & $100,0 \%$ \\
\hline
\end{tabular}

Fonte: Elaborado pelo autor. 
DESEMPENHO MÉDIO EM MATEMÁTICA DAS ESCOLAS CONTEMPLADAS (1) E NÃO CONTEMPLADAS (0) COM O "PROGRAMA DE EDUCAÇÃO PROFISSIONAL - PEP" DA REDE ESTADUAL DE MINAS GERAIS - PROEB 2010.

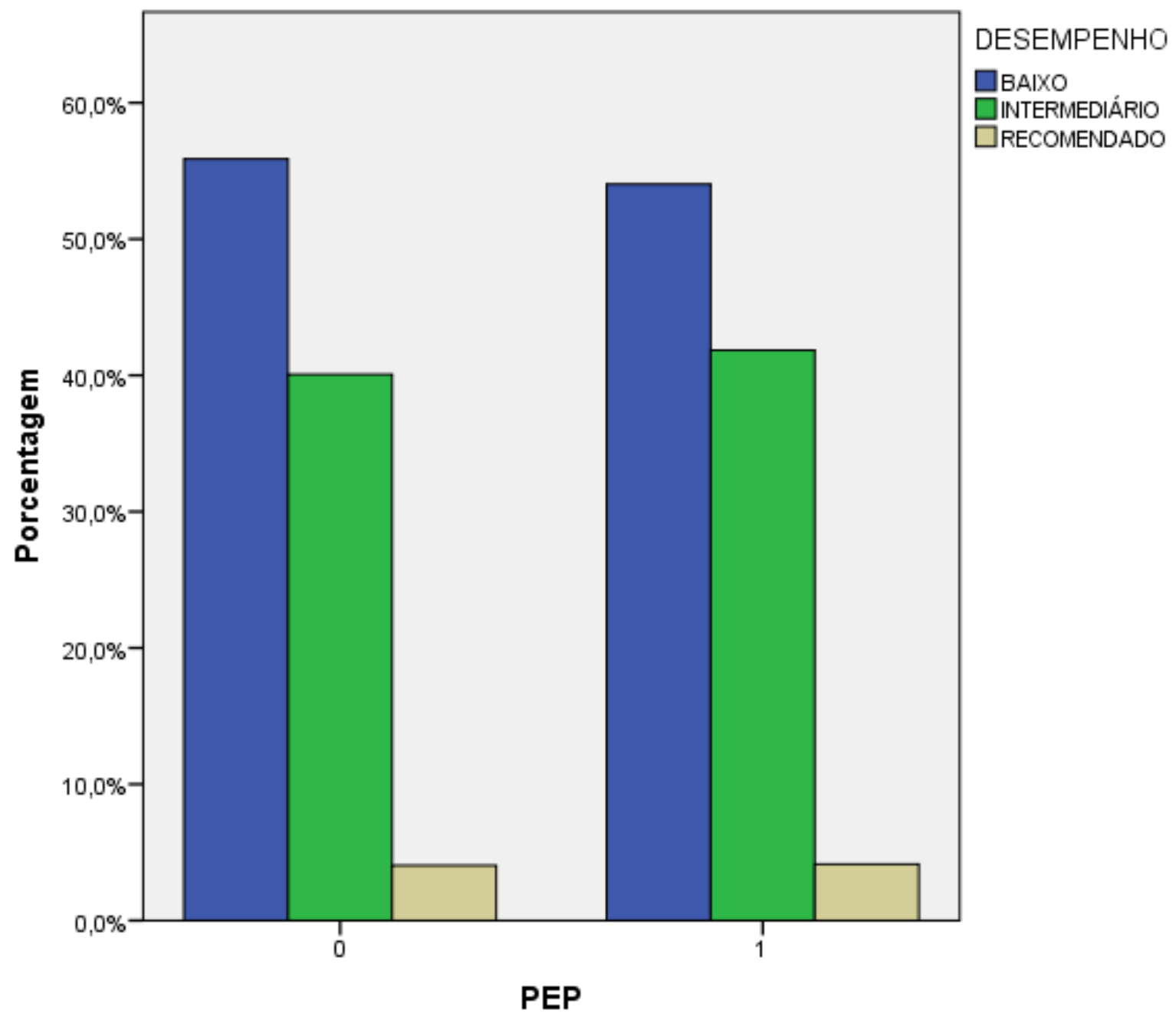

Fonte: Elaborado pelo autor.

DESEMPENHO MÉDIO EM MATEMÁTICA DAS ESCOLAS CONTEMPLADAS (1) E NÃO CONTEMPLADAS (0) COM O "PROGRAMA DE EDUCAÇÃO PROFISSIONAL - PEP" DA REDE ESTADUAL DE MINAS GERAIS - PROEB 2010.

\begin{tabular}{c|l|l|l|l}
\hline \multirow{2}{*}{} & \multicolumn{4}{|l}{ PEP - Matemática - 2010 } \\
\cline { 2 - 6 } & 0 & \multicolumn{1}{l}{1} \\
\cline { 2 - 6 } & total & $\%$ & total & $\%$ \\
\hline BAIXO & 36722 & $55,9 \%$ & 45160 & $54,0 \%$ \\
DESEMPENHO INTERMEDIÁRIO & 26332 & $40,1 \%$ & 34984 & $41,9 \%$ \\
RECOMENDADO & 2660 & $4,0 \%$ & 3449 & $4,1 \%$ \\
Total & 65714 & $100,0 \%$ & 83593 & $100,0 \%$ \\
\hline
\end{tabular}

Fonte: Elaborado pelo autor. 